BUDAPESTI CORVINUS EGYETEM

TÁJÉPÍTÉSZETI KAR

TÁJTERVEZÉSI ÉS TERÜLETFEJLESZTÉSI TANSZÉK

PhD ÉRTEKEZÉS

\title{
PASSZÍV KÉPALKOTÓ TÁVÉRZÉKELÉS A TÁJKARAKTER-ELEMZÉSBEN
}

JOMBACH SÁNDOR

TÉMAVEZETŐ:

KOLLÁNYI LÁSZLÓ CSc

BUDAPEST, 2014 
A doktori iskola

megnevezése: Budapesti Corvinus Egyetem

Tájépítészeti és Tájökológiai Doktori Iskola

tudományága: Agrármüszaki tudományok

vezetője: $\quad$ Csemez Attila DSc

egyetemi tanár

Budapesti Corvinus Egyetem

Tájtervezési és Területfejlesztési Tanszék

Témavezető: $\quad$ Kollányi László CSc

tanszékvezető, egyetemi docens, Budapesti Corvinus Egyetem

Tájtervezési és Területfejlesztési Tanszék

A jelölt a Budapesti Corvinus Egyetem Doktori Szabályzatában elöírt valamennyi feltételnek eleget tett, az értekezés műhelyvitájában elhangzott észrevételeket és javaslatokat az értekezés átdolgozásakor figyelembe vette, ezért az értekezés védési eljárásra bocsátható.

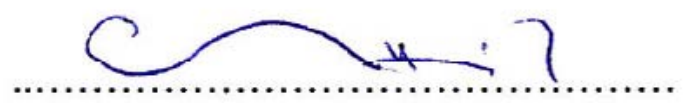

Az iskolavezető jóváhagyása

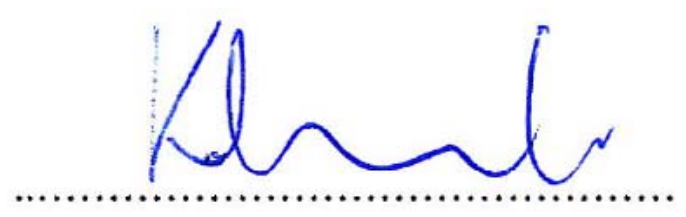

A témavezető jóváhagyása 
A Budapesti Corvinus Egyetem Élettudományi Területi Doktori Tanácsának (ÉTDT) 2014. március 18-i határozatában és az Egyetemi Doktori Tanács (EDT) 2014. április 2.-i határozatában a nyilvános vita lefolytatására az alábbi bíráló Bizottságot jelölte ki:

BÍRÁLÓ BIZOTTSÁG:

\title{
Elnöke:
}

Jámbor Imre CSc, DLA

\author{
Tagjai \\ Csima Péter CSc \\ Gerzánics Annamária CSc \\ Illyés Zsuzsanna CSc \\ Konkoly-Gyuró Éva CSc
}

Opponensek

Kabai Róbert PhD

Kristóf Dániel PhD

Titkár

Filepné Kovács Krisztina PhD 


\section{TARTALOMJEGYZÉK}

BEVEZETÉS

1. IRODALMI ÁTTEKINTÉS 9

1.1. Tájkarakter-elemzés 9

1.1.1. Tájkarakter 10

1.1.1.1. Táj és karakter 10

1.1.1.2. A táj karaktere 12

$\begin{array}{ll}\text { 1.1.1.3. Tájelemek, karakterjegyek, kulcsjellemzők } & 14\end{array}$

$\begin{array}{ll}\text { 1.1.1.4. Egyedi és típusos tájkarakter } & 15\end{array}$

$\begin{array}{lr}\text { 1.1.2. A tájkarakter szerepe } & 17\end{array}$

$\begin{array}{ll}\text { 1.1.2.1. A tájkarakter kezelésének jelentősége } & 17\end{array}$

$\begin{array}{ll}\text { 1.1.2.2. A tájkarakter kezelésének szükségessége } & 18\end{array}$

1.1.3. A tájkarakter-elemzés jelentösége 19

1.1.3.1. A tájkarakter-elemzés lényege, célja, szerepe 20

1.1.3.2. A tájkarakter-elemzés módszere 21

1.1.3.3. A tájkarakter-elemzés eszköztárának kialakulása 22

1.2. Passzív képalkotó távérzékelés

1.2.1. Távérzékelés $\quad 25$

1.2.1.1. Passzív és aktív távérzékelés 26

1.2.1.2. Passzív képalkotó távérzékelés jellemzői 27

1.2.2. Passzív képalkotó távérzékelési alapadatok 28

1.2.2.1. Földfelszíni, terepi fényképek 28

$\begin{array}{lr}\text { 1.2.2.2. Légifelvételek } & 29\end{array}$

1.2.2.3. Ürfelvételek 30

1.2.2.4. Származtatott digitális adatbázisok $\quad 32$

1.2.3. Passzív képalkotó távérzékelés feldolgozási eljárásai 34

1.2.3.1. Digitális számítógépes elöfeldolgozás $\quad 34$

1.2.3.2. Radiometriai korrekciók 35

1.2.3.3. Képjavítási eljárások $\quad 36$

1.2.3.4. Vizuális interpretáció $\quad 36$

$\begin{array}{ll}\text { 1.2.3.5. Indexek } & 37\end{array}$

$\begin{array}{ll}\text { 1.2.3.6. Képpont-osztályozás } & 39\end{array}$

1.2.3.7. Szegmentáció 41

1.2.3.8. Adatmodell konverziók és adat-elemzés 42

1.3. Passzív képalkotó távérzékelési alkalmazások a tájkarakter-elemzési gyakorlatban 43

1.3.1. Útmutatások passzív képalkotó távérzékelés alkalmazására 43

1.3.2. Tájkarakter-elemzési gyakorlatban elterjedt alkalmazások 46

1.3.3. Tájelemzési vagy tájkarakter-elem zési gyakorlatban elöforduló alátámasztó
jellegü alkalmazások

1.3.3.1. Domborzat-elemzés

1.3.3.2. Indexek $\quad 54$

$\begin{array}{ll}\text { 1.3.3.3. Változás-elemzés } & 57\end{array}$

$\begin{array}{ll}\text { 1.3.3.4. Láthatóság-elemzés } & 59\end{array}$

$\begin{array}{ll}\text { 1.3.3.5. Megjelenítés (Vizualizáció) } & 61\end{array}$

1.3.3.6. Jellemzés és határvonal-térképezés $\quad 65$

2. A MEGOLDANDÓ FELADATOK ISMERTETÉSE 67

2.1. A passzív képalkotó távérzékelés tájkarakter-elemzésbeli szerepének meghatározása 68

2.2. A domborzat-jellemzés lehetőségeinek meghatározása

2.3. Térbeli indexekkel történő tájkarakter-jellemzés lehetőségeinek meghatározása $\quad 69$

2.4. Változás-elemzés felhasználási lehetőségeinek meghatározása $\quad \mathbf{7 0}$

2.5. Láthatóság-elemzés lehetőségeinek meghatározása a karakter-elemzésben $\quad 71$

2.6. A megjelenítés (vizualizáció) szerepének meghatározása a karakter-elemzésben $\quad 72$

2.7. A tájkarakter-elemzésben használatos tájhatárvonalak térképezési lehetőségeinek meghatározása 
3.1. A kutatás anyaga $\quad 73$

3.2. A kutatás mintaterületei $\quad 75$

3.3. A kutatás módszerei $\quad 77$

4. EREDMÉNYEK $\quad 81$

4.1. A passzív képalkotó távérzékelés szerepe a tájkarakter-elemzésben 81

4.1.1. Tájelemek, tájelem-együttesek elemezhetősége 81

4.1.2. Felvételek és származtatott adatok lehetséges alkalmazása 82

4.1.3. Képfeldolgozási eljárások és térinformatikai elemzések a tájkarakter-elemzés lépéseiben $\quad 83$

4.2. A domborzat jellemzése passzív képalkotó távérzékelési adatokkal $\quad 84$

4.2.1. Digitális magassági modellek általános összehasonlítása 84

4.2.2. Domborzat-típusokra, és terepi alakzatokra vonatkozó következtetések 86

4.2.3. Domborzatmodellek pontosságának összefüggései felszínborítással és
kitettséggel

4.2.4. Domborzat-elemzési és -jellemzési módszerek a tájkarakter-elemzésben 90

4.3. A tájkarakter jellemzése térbeli indexekkel 91

4.3.1. Tájkarakter-elemzés céljára felhasználható indexek meghatározása 91

4.3.2. Indexek felhasználásának módszerei, feltételei, korlátai 92

4.3.3. Zöldfelület-intenzitás index és használata a tájkarakter jellemzésére 93

4.3.4. Származtatott adatbázisokra építhetö indexek a tájkarakter-jellemzésben 96

4.4. A tájkarakter-elemzést támogató változás-vizsgálatok 98

4.4.1. Változás-jelenségek vizsgálata automatikus változás-detektálással 98

4.4.2. Tájkarakter-változás vizsgálata automatikus eljárásokra épülö
változás-indikátorokkal

4.4.3. Változás-vizsgálat származtatott adatbázisok felhasználásával 100

4.4.4. A táj nyitottságának változása indikátor alkalmazása a tájkarakter jellemzésére 102

4.4.5. Tájjelleg-változás elem zése felvételek vizuális interpretációjával 103

$\begin{array}{ll}\text { 4.5. Láthatóság-elemzés a tájkarakter-elemzésben } & \mathbf{1 0 5}\end{array}$

$\begin{array}{lr}\text { 4.5.1. A táj láthatósága } & 105\end{array}$

4.5.2. Karakteradó tájelemek láthatósága 106

4.5.3. Láthatóság módosulásának vizsgálata 108

4.5.4. Tájkaraktert meghatározó kilátóhelyek és a fontos látványelemek elemzése 109

4.6. Megjelenítési (vizualizációs) megoldások a tájkarakter interpretálására 112

4.6.1. A táj jellegének bem utatása 112

4.6.2. A tájkarakter sajátosságainak megjelenitése 113

4.6.3. A tájjelleg-változás érzékeltetése 115

$\begin{array}{ll}\text { 4.6.4. A tájkarakter online 3D-megjelenitése } & 117\end{array}$

4.7. A tájkarakter jellemzése és lehatárolása $\quad 119$

5. KÖVETKEZTETÉSEK ÉS JAVASLATOK

6. ÚJ TUDOMÁNYOS EREDMÉNYEK

ÖSSZEFOGLALÁS / SUMMARY

FORRÁSJEGYZÉK $\quad 137$

TÁBLÁZATJEGYZÉK

ÁBRAJEGYZÉK $\quad 156$

MELLÉKLETEK

KÖSZÖNETNYILVÁNÍTÁS 


\section{BEVEZETÉS}

A tájkarakter-elemzés egy tájrendezési tevékenységet elökészítő elemzés, melynek angolszász eredetủ módszere (SWANWICK 2002, 13) nemzetközi szinten elfogadott, egyes elemeit térségi, országos és európai léptékben is alkalmazzák. Előnye, hogy a hazai gyakorlatban elterjedt tájrendezési folyamattal (CSEMEZ 1996, 140) (KONKOLYNÉ GYURÓ 2003, 159) összeegyeztethető. A tájkarakter-elemzés módszerével érzékelhetővé, érthetővé lehet tenni a táj karakteradó sajátosságait a fejlesztéssel, tervezéssel, védelemmel és rehabilitációval foglalkozó szakterületek számára. Segítségével bemutathatóak a táj jellegzetes értékei és kezelési útmutatások, előírások összeállítására nyílik lehetőség.

A tájkarakter-elemzés módszerét - akárcsak a tájrendezési folyamatot is - sok egyéb információ mellett képszerü anyagok, ábrák, térképek egészítik ki. Ezek alapadatként, munkaanyagként vagy illusztrációként, de mindenképpen eszközként jelennek meg az elemzésben. A tájkarakter-elemzésben napjainkban egyre nagyobb szerephez jut a képalkotó távérzékelés és a képfeldolgozás. A tájépítészek körében is terjed a fényképek, légifelvételek, ürfelvételek és a belőlük származtatott adatok alkalmazása. Fontos, hogy ezt a passzív képalkotó távérzékelési eszköztárat ismerjük és a tájkarakter bizonyos elemeinek meghatározására, valamint kezelésére hasznosítani tudjuk.

Talán észre sem vesszük, de digitális távérzékelési eljárások adnak új keretet mindennapjainknak a térbeli információszerzés és -kezelés terén. Számos szakterületen érvényesül ez a jelenség az orvostudománytól az üzleti életig. Ilyen távérzékelési eszközök és kapcsolódó térinformatikai megoldások gyorsítják fel, egyszerüsítik, terjesztik ki térben és időben tájaink megismerését, szakszerü bemutatását, elemzését.

A távérzékelés és a térinformatika kombinációja megkönnyítheti a tervezés megalapozását bármely térbeli léptékben. Fontos eszközzé válhat tájaink sajátosságainak elemzésében, ám ezek az eszközök a megoldandó tájkezelési teendőket nem ismerik fel, és nem is végzik el helyettünk. Mégis reális az esély arra, hogy feladataink néhány fáradságos elemét megoldják és látványos, a táj sajátosságait közérthetően bemutató eredményeket szolgáltassanak.

A témaválasztást indokolja, hogy tájaink egyre intenzívebben változnak. Átalakulásuk mértéke és jelentősége az elmúlt évtizedekben világszerte fokozatosan növekszik. A globálisan érzékelhető változási folyamatok tájainkat sokféleképpen formálják. Ezek a folyamatok helyenként homogenizálnak, néhol azonban az egyedi, nemzeti sajátosságok erősödését eredményezik. Gyakori változási jelenség egyes térségekben a müvelés felhagyása, a tájak funkcióvesztése, míg máshol a túlhasználat, a multifunkcionalitás erősödése jellemző. 
Mindkét esetben tájelemek, potenciális tájértékek átalakulásáról vagy eltűnéséről lehet szó, amit kezelni kell. A tájkarakter-elemzés egyik szerepe, hogy a táji sajátosságok kezelésére útmutatást adjon helyi, térségi vagy nemzeti sajátosságok és változási tendenciák figyelembevételével. Ebben a munkafolyamatban nagy segítséget jelenthet a passzív képalkotó távérzékelési eszköztár.

A tájkarakter-elemzés eszköztárának áttekintését az Európai Táj Egyezmény (COUNCIL OF EUROPE 2000) is indokolja, melyet számos európai ország aláírt. Az Európai Táj Egyezmény nyomán Magyarország is törvényt léptetett életbe (2007. évi CXI. törvény), melyben, mint az egyezményt aláíró ország egyebek mellett vállalta a tájak számbavételét, jellemző vonásaik és alakító hatásaik elemzését, változásaik monitorozását és a tájak értékelését. Mindezeket a feladatokat a törvény egy csupán föbb pontjaiban kidolgozott, a tájkarakter-elemzéshez hasonlatos folyamatban javasolja megvalósítani, de a digitális technikai eszköztárra vonatkozóan nem nyújt támpontokat.

$\mathrm{Az}$ értekezésben célom áttekintést adni, hogy a fényképekkel, légi- és ürfelvételekkel, valamint a belölük származtatott adatbázisokkal reprezentálható „passzív képalkotó távérzékelési” eszköztárnak milyen szerep jut a tájkarakter-elemzés folyamatában. Célom új tudományos eredményekkel igazolni, hogy a „passzív képalkotó távérzékelés” eszköztárának és eljárásainak bizonyos része hasznosítható a tájkarakter-elemzésben. Meglátásom szerint egyes alkalmazásokkal olyan karakteradó tájelemeket is feltárhatunk, melyeket eddig nem állt módunkban. A disszertációban célom meghatározni, hogy mely felvételek és adatok, milyen feldolgozási eljárásokkal hasznosíthatók annak érdekében, hogy a táj bizonyos karakteres alkotóelemeit megragadjuk, a táj sajátosságait leírjuk, jellemezzük és mindezzel a tájkarakterelemzés adta kereteken belül felkészüljünk egy eredményesebb tájkezelésre. 


\section{IRODALMI ÁTTEKINTÉS}

$\mathrm{Az}$ irodalmi áttekintés eredményét három nagyobb fejezetben ismertetem. Elsőként a tájkarakter-elemzés témakörét vizsgálom. Az értekezésben a karakter-elemzés, mint a tájrendezés (a tájvédelem a tájkezelés és a tájtervezés ${ }^{1}$ ) egyik lehetséges módszere kerül bemutatásra (1.1. fejezet). A passzív képalkotó távérzékelés témaköre - magában foglalva a légi- és egyes ürfelvételek, földfelszíni fényképek készítésének és feldolgozásának eljárásait mint tájértelmezési és tájelemzési segédeszköz kerül feldolgozásra (1.2. fejezet). Végül áttekintést adok a tájkarakter-elemzésekben elterjedt vagy kapcsolódó esettanulmányokban előforduló passzív képalkotó távérzékelési alkalmazásokról (1.3. fejezet).

$\mathrm{Az}$ irodalomkutatás elkészítése érdekében számos hazai és nemzetközi, nyomtatott és digitális irodalmat tekintettem át. Könyvekből, folyóiratokból valamint a tájkarakter-elemzés témaköréhez kapcsolódó gyakorlat-orientált tanulmányokból, előadásokból, munkaközi anyagokból, térképekből, projekt-összefoglalókból, útmutatókból és szükség esetén jogszabályokból dolgoztam. Irodalomkutatási módszeremet a 3.3. fejezetben ismertetem.

\subsection{Tájkarakter-elemzés}

A táj alakítását és ezáltal esetenként a táj jellegének, karakterének ${ }^{2}$ formálását sokan sokféleképpen végezzük, akár tudatosan akár tudattalanul. Tudatosan tervezzük, szabályozzuk, alakítjuk például terveink, jogszabályaink készítésével, oktatási, nevelési munkánkkal vagy éppen környezetalakító tevékenységünk által. Tudattalanul formáljuk mindennapi cselekedeteink során például élelmiszerfogyasztási, vásárlási szokásainkon és döntéseinken keresztül, vagy akár szabadidős és sportolási tevékenységeink eredményeként.

A tájkarakter-elemzés egyike azon kezelési lehetőségeknek, melyekkel tudatosan, a táj sajátosságait és az érintettek érdekeit figyelembe véve alakíthatjuk tájainkat. A tervező kezében a tájjelleg kezelését befolyásoló eszköznek is tekinthető. Módszertanát az európai szakirodalomban és az elterjedt nemzetközi gyakorlatban is egyre inkább a Carys Swanwick által az évezred elején kiadott tájkarakter-elemzési útmutató (SWANWICK 2002) mintája határozza meg.

\footnotetext{
${ }^{1}$ Táj védelme, tervezése, kezelése: A legfontosabb fogalmak és feladatok az Európai Táj Egyezményben (COUNCIL OF EUROPE 2000, Article 1 d, e, f,) melyeket tájrendezés gyüjtőnévvel használok az értekezésben, A védelem és tervezés jelentése egyértelmű. A táj kezelésének jelentése az egyezmény szerint: „A táj kezelése” a fenntartható fejlődés szempontjából olyan tevékenységet jelent, amelynek célja a táj rendszeres fenntartása. Célja, hogy a társadalmi, gazdasági és környezeti folyamatok által előidézett változásokat irányítsa és összhangba hozza.

${ }^{2}$ Az értekezésben a ,jelleg” és „karakter” szavakat - ahogy a legtöbb hazai szakirodalom - egymás szinonimáiként használom. A „tájjelleg” fogalom jelentése megegyezik a részben idegen eredetü „tájkarakter” fogalom jelentésével. (bővebben az 1.1.1.1. fejezetben)
} 


\subsubsection{Tájkarakter}

A tájkaraktert igen sokféleképpen értelmezik. A ,tájkarakter” fogalmát ennek megfelelöen a szakirodalomban is változatosan határozzák meg. Miután a „táj” és a „karakter” szavak jelentésére önmagában is többféle magyarázat található, ezért mindkét fogalom meghatározására külön kitérek (1.1.1.1. és 1.1.1.2. fejezetek).

\subsubsection{Táj és karakter}

A táj meghatározására számos kutató és tervező vállalkozott. A tájkarakter megértéséhez vezető úton több hazai és külföldi definíció is sorakozik, melyeket a mellékletekben (M1) részletesen, az alábbi táblázatban röviden ismertetek (1. táblázat $\left.(\mathrm{M} 2)^{3}\right)$. A ,táj” szó a magyar nyelvben oszthatatlan, mégis összetett jelentést hordoz, melyben az általános természeti tényezők mellett, egyedi humán lenyomatok, sajátos emberi tényezők is szerepet játszanak. Az európai nyelvek többségében a „táj” szó a „föld képének” egy „terület látványának” jelentéstartalmát hordozza. A magyar tájértelmezéshez - ahogy Drexler megállapította - a nagyobb európai népek közül a német fogalomértelmezés áll a legközelebb, mely a képi jelentéstartalom mellett erős tárgyi jelentéstartalommal is bír, miután a sokkal materiálisabb objektumot, a földfelszín egy részét is jelenti (DREXLER 2010, 29).

\section{1. táblázat (részlet $\left.{ }^{4}\right)$ Tájfogalmak (M2)}

\begin{tabular}{|c|c|c|}
\hline $\begin{array}{l}\text { A fogalom } \\
\text { szerzöje }\end{array}$ & Tájfogalmak & Forrás \\
\hline $\begin{array}{l}\text { Európai Táj } \\
\text { Egyezmény } \\
\text { I. Fejezet - } \\
\text { 1. Cikk (2000) }\end{array}$ & $\begin{array}{l}\text { "It means an area, as perceived by people, whose character is the result of the } \\
\text { action and interaction of natural and/or human factors." } \\
\text { (A disszertáció szerzőjének fordításában: Az ember által érzékelt terület, } \\
\text { melynek jellege természeti tényezők és/vagy emberi tevékenységek hatása és } \\
\text { kölcsönhatása eredményeként alakult ki.) }\end{array}$ & $\begin{array}{l}\text { COUNCIL OF } \\
\text { EUROPE 2000 } \\
\text { 2007. évi CXI. } \\
\text { törvény }\end{array}$ \\
\hline $\begin{array}{l}\text { Mőcsényi Mihály } \\
\text { (1968) }\end{array}$ & $\begin{array}{l}\text { A természet és a társadalom kölcsönhatásainak ellentmondásos, ezért } \\
\text { dialektikus egysége. }\end{array}$ & CSEMEZ 1996, 15 \\
\hline $\begin{array}{l}\text { Természetvédelmi } \\
\text { törvény (1996) }\end{array}$ & $\begin{array}{l}\text { A földfelszín térben lehatárolható, jellegzetes felépítésủ és sajátosságú része, a } \\
\text { rá jellemző természeti értékekkel és természeti rendszerekkel, valamint az } \\
\text { emberi kultúra jellegzetességeivel együtt, ahol kölcsönhatásban találhatók a } \\
\text { természeti erők és a mesterséges (ember által létrehozott) környezeti elemek. }\end{array}$ & $\begin{array}{l}\text { 1996. évi LIII. } \\
\text { törvény }\end{array}$ \\
\hline
\end{tabular}

A magyar jelentés tartalmában összetettebb. A „táj” szó jelentésébe nem csak a tájképét látjuk bele, de tárgyiasan beleértjük a tájat alakító, formáló valamennyi tényezőt is. A táj nem pusztán a föld képe, hanem egy komplex területi egység (CSEMEZ 1996, 278), melyet számos természeti és társadalmi tényező folyamatosan alakít. Ennek a folyamatnak az eredményeként értjük és kezeljük a tájat, nem csupán annak képét. Ez az alapvető kettősség, a képi és a tárgyias tájértelmezés érhető tetten akkor is, amikor a 14. századi Petrarca féle tájérzékelést vetjük össze a korai 19. századi Humboldt féle tudományos értelmezéssel. (WASCHER 2005,).

\footnotetext{
${ }^{3}$ Az (M2) jelzés számértéke a melléklet oldalszámát mutatja, ahol a táblázat teljes terjedelmében megtalálható.

${ }^{4} \mathrm{Az}$ 1. táblázat teljes terjedelmében a mellékletben található. A disszertáció szövegében csak egy-egy részletében megjelenő táblázatok és ábrák (pl.: 1. táblázat) a mellékletben teljes terjedelmükben megtalálhatók. A mellékletek kizárólag ábrákból és táblázatokból állnak, így azok sorszámozása szükségtelen, mert teljes mértékben egyezik az ábrák és táblázatok számozásával. A kereshetőség egyszerüsítésére a mellékletek oldalszámait tüntettem fel a szövegközben szereplő ábrák és táblázatok esetében (pl.: M1).
} 
Az Európai Táj Egyezmény és a Swanwick féle tájkarakter-elemzési útmutató hangulatában inkább az angolszász tájértelmezési hagyományok mentén definiálja a tájat, de a fogalomba beleérthető a materialista tájértelmezés is. Az egyezmény eredeti angol változata szerint egyértelmü, hogy a táj az ember által érzékelt terület, melynek jellege természeti tényezők és/vagy emberi tevékenységek hatásának és kölcsönhatásának eredménye (COUNCIL OF EUROPE 2000, Article 1, a) ${ }^{5}$. Az egyezmény úgy tekint a tájra és annak karakterére, mely a természet és a társadalom állandó kölcsönhatása során folyamatosan változik.

A történeti tájkarakter-elemzés útmutatójának készítői szerint sem mondható, hogy egy tájegység véglegesen kialakult (CLARK et al. 2004, 3). Az egyezmény szelleme azt sugallja, hogy a táj általában nem szabadtéri múzeum vagy skanzen, melyben konzerválni kell a kialakult állapotot annak minden jellegzetességével. A tájak karaktere is folyamatos változásban van, melynek kezelését az egyezmény több javaslatával, útmutatásként megfogalmazott tevékenységek sorával támogatja (COUNCIL OF EUROPE 2000, Article 6, C). Hangsúlyozom, hogy a disszertációban a tájat és annak kialakult karakterét nem pusztán látványként, látképként, tájképként értelmezem. A tájat komplex élettérnek tekintem, melynek szerepe, szerkezete, állapota és látványa sokféle szereplő változatos érdekének érvényesülésével, időben és térben eltérő ütemben és mértékben, folyamatosan alakul.

A „karakter” görög eredetü szó, magyar megfelelője a ,jelleg” (MTA NYELVTUDOMÁNYI INTÉZET 1986, 752) ,,jellegzetesség”, ,jellemző vonás” (BAKOS 1994, 382) kifejezések. A hétköznapi nyelvben általában egy-egy jelenség, tárgy, élölény vagy személy jellemzésére használatos. Megjelenhet a karakter szó egyének jellemének leírásában, egy színdarabban szereplő „karakter” külső vagy belső tulajdonságainak jellemzése során ${ }^{6}$. Egy színpadi „karakter” megformálása során a színészek arra is törekednek, hogy a szereplő egyértelműen megkülönböztethető legyen a darab többi, eltérő karakterrel rendelkező szereplőjétől. Ez a megkülönböztethetőség, elkülöníthetőség különösen nagy jelentőséget kap a tájkarakter fogalom értelmezése során is, ahol a tájak egymástól eltérő jellegét tartjuk fontosnak (SWANWICK 2002).

Figyelemre méltó, hogy a „karakter” szóval illetjük a nyomdai írásjeleket, melyek jelentésükben tartalmi, alakjukban pedig formai eltéréseket hordoznak. Egy tárgy, egy objektum vagy egy alkotás karakterét alapvető funkcionális, formai vagy ízbeli sajátosságai alapján határozzuk meg $^{7}\left(\right.$ INT-001) ${ }^{8}$. Beszélhetünk épületek, közterek vagy településrészek karakteréről is: „az országház sajátos karakterét a csúcsívek adják” (MTA NYELVTUDOMÁNYI INTÉZET 1986, 752). Egy körülöttünk zajló folyamat

\footnotetext{
5 "Landscape" means an area, as perceived by people, whose character is the result of the action and interaction of natural and/or human factors. (COUNCIL OF EUROPE 2000, Chapter I. Article 1.)

${ }^{6}$ Carmen féktelen, kihívó és lázító karaktere váltja ki Don José-ból a szabályoknak ellenszegülő viselkedést.

7 „A nyújtott, emelkedő vonalak optikailag megnyújtják az autót, még dinamikusabb karakterrel ruházva fel azt” (INT-001)

${ }^{8}$ Internetes hivatkozás: INT-001: N.R.T.M. BMW 20123-as Limousine járművet bemutató oldala (2012. 07. 12)
} 
sajátosságainak, jellemzőinek meghatározására alkalmazott a karakter kifejezés például a következő szövegkörnyezetben: A 20. század második felében a dinamikus területi fejlődés karakteréhez ${ }^{9}$ tartozott a tájkép jelentős változása és az ökológiai folyosók eltűnése. A fentiekböl is levezethetö, de a tájépítészeti szakirodalomban is tapasztalható, hogy a táj esetében a táj egyedi vagy tipikus jellemzőinek leírásához használjuk a karakter kifejezést.

\subsubsection{A táj karaktere}

A tájkarakter témájával több száz szakirodalmi kiadvány foglalkozik, de csak töredékük definiálja magát a fogalmat (2. táblázat(M3)). Néhány nagyobb formátumú munka ismerteti a tájkarakter jelentését, de olyan is akad, mely - bár címében tartalmazza a tájkaraktert - már bevezetésként elörebocsájtja, hogy nem egyszerü azt megfogalmazni (AHERN 2004, 8). A fogalmak többsége egységes annak vonatkozásában, hogy a tájkarakter bizonyos tájelemek vagy azok együttese által kialakuló, érzékelhető sajátos jelleg. A leginkább hivatkozott, Európában egyre elfogadottabb és terjedő, fogalom ${ }^{10}$ szerint „,a tájkarakter a tájelemek megkülönböztethető, felismerhető mintázata, ami az egyik tájat megkülönbözteti a másiktól, nem pedig jobb vagy rosszabb minősítéssel fémjelzi azokat"11 (SWANWICK 2002, 8).

\section{2. táblázat (részlet (M3)) Tájkarakter fogalmak}

\begin{tabular}{|c|c|c|}
\hline Szerző & Tájkarakter / tájjelleg fogalmak & Források \\
\hline Csemez Attila & $\begin{array}{l}\text { A sajátos természeti elemekből a gazdálkodás és a népi kultúra együtteséből } \\
\text { kialakult karakter (jelleg). }\end{array}$ & $\begin{array}{l}\text { CSEMEZ 1996, } \\
279\end{array}$ \\
\hline Csima Péter & $\begin{array}{l}\text { A tájkarakter a tájkép mellett a történelmileg kialakult tájszerkezet, valamint } \\
\text { az adott tájhoz kötődő érzelmek és hagyományok együttesen határozzák meg. }\end{array}$ & $\begin{array}{l}\text { CSIMA 2008, } \\
\quad 405\end{array}$ \\
\hline Jack Ahern & $\begin{array}{l}\text { Landscape "character" includes physiographic structure of the land, patterns } \\
\text { of vegetation, spatial experiences and sequences, and the means of moving } \\
\text { through the landscape. Landscape character derives from cultural features } \\
\text { and particular ways of life, as well as geology and topography; it combines } \\
\text { patterns of human activity and the physical patterns of the places that are } \\
\text { shaped by those activities, or conversely that have shaped them. }\end{array}$ & AHERN 2004, 8 \\
\hline $\begin{array}{l}\text { Konkoly Gyuró Éva } \\
\text { (Swanwick nyomán) }\end{array}$ & $\begin{array}{l}\text { A természeti és antropogén tájalkotó elemek elkülöníthető, felismerhető, } \\
\text { konzisztens rendszeréből, sajátos együtteséből kialakult jellemzők } \\
\text { összessége, mely a tájat egyedivé, megkülönböztethetővé teszi. }\end{array}$ & $\begin{array}{l}\text { KONKOLY } \\
\text { GYURÓ 2006, } \\
18\end{array}$ \\
\hline $\begin{array}{l}\text { The Landscape } \\
\text { Institute }\end{array}$ & $\begin{array}{l}\text { The distinct and recognisable pattern of elements that occurs consistently in a } \\
\text { particular type of landscape, and how this is perceived by people. It reflects } \\
\text { particular combinations of geology, landform, soils, vegetation, land use and } \\
\text { human settlement. It creates the particular sense of place of different areas of } \\
\text { the landscape }\end{array}$ & $\begin{array}{l}\text { THE } \\
\text { LANDSCAPE } \\
\text { INSTITUTE } \\
2002,12\end{array}$ \\
\hline $\begin{array}{l}\text { Jombach Sándor } \\
\text { (Swanwick és Konkoly } \\
\text { Gyuró nyomán) }\end{array}$ & $\begin{array}{c}\text { A tájelemek elkülöníthető, felismerhető egyedinek vagy tipikusnak } \\
\text { tekinthető rendszere és / vagy mintázata, mely a táj kezelése céljából az } \\
\text { egyik tájat megkülönbözteti a másiktól, nem pedig jóként vagy rosszként } \\
\text { minősíti azokat }\end{array}$ & $\begin{array}{c}\text { a disszertáció } \\
\text { szerzöjének } \\
\text { adaptációja, annak } \\
\text { érdekében, hogy a } \\
\text { passzív távérzékelési } \\
\text { adatok térinformatikai } \\
\text { alkalmazási } \\
\text { lehetőségét érthetöbbé } \\
\text { tegye } \\
\end{array}$ \\
\hline
\end{tabular}

\footnotetext{
9 A tájkép változása a területi fejlődés karakteréhez tartozott, tehát annak jellemzőjeként, sajátosságaként értelmezzük.

10 „A distinct recognisable pattern of elements in the landscape that makes one landscape different from another, rather than better or worse." (SWANWICK 2002, 8)

${ }^{11}$ A disszertáció szerzőjének értelmezésében.
} 
A Swanwick féle megfogalmazás összhangban áll az Európai Táj Egyezmény szellemével. A tájakat elemei szerint nem pusztán jóként vagy rosszként azonosítja. Nem hasznosíthatóként vagy haszontalanként, müvelhetőként vagy müvelhetetlenként kívánja azokat besorolni. Az egyezmény annak megfelelően javasolja minősíteni a tájakat, hogy az érdekeltek és érintettek $^{12}$ milyen jelentőséget és értéket tulajdonítanak nekik (COUNCIL OF EUROPE 2000, Article 6, C/1b). Ebben az értelmezésben a táj rendezése is természetesen az értékek figyelembevételével kell történjen. A tájkarakter definícióban szereplő megkülönböztetés célja az egyezmény szellemét figyelembe véve egyértelmü. Az adott fejlődési stádiumban lévő, meghatározható karakterrel rendelkező táj számára, az érintettek érdekeinek és értékrendjének megfelelő specifikált kezelést kell biztosítani.

Természetesen emellett létezik olyan hazai tájkarakter megfogalmazás is mely a természet, a gazdaság és a társadalom hármasságára koncentráltan fogalmaz (CSEMEZ 1996, 279). Van olyan hazai értelmezés, mely a táj karakterét meghatározó tényezők közé tapasztalati alapon az objektív és szubjektív karaktert meghatározó tényezőket négy föbb csoportba rendezve természeti, törtneti, tájhasznosítási és tájszerkezeti, valamint tájképi és érzelmi - tárgyalja (CSIMA és MÓDOSNÉ BUGYI 2010, 201). Létezik olyan megközelítés is, amely az angolszász és a terjedő nemzetközi gyakorlathoz hasonlóan, azzal párhuzamosan értelmezi a tájkaraktert és adaptálja kezelésének módszerét (KONKOLY GYURÓ 2006, 18). Ezeket nem egymásnak ellentmondó megfogalmazásoknak, hanem a tájkarakter lényegéből más-más elemet hangsúlyozó, egymást kiegészítő megközelítéseknek tekintem.

Az értekezésemben használt tájkarakter fogalom kialakításánál az alábbi elvárásokat támasztottam és érvényesítettem.

- A nemzetközi szakirodalomban és gyakorlatban tapasztalható trendeknek megfeleljen.

- Az Európai Táj Egyezmény tájrendezés-központú szellemisége érvényesüljön.

- A magyar szakirodalomban meglévő sajátosságok, nézőpontok integrálhatók legyenek.

- A passzív képalkotó távérzékelési és részben térinformatikai eszköztár alkalmazását leginkább alátámasztó szempontoknak megfeleltethető legyen ${ }^{13}$.

Az értekezés témájához illeszkedően a továbbiakban a tájkarakter a tájelemek elkülöníthető, felismerhető, egyedinek vagy tipikusnak tekinthető rendszere és / vagy mintázata, mely a táj kezelése céljából az egyik tájat megkülönbözteti a másiktól, nem pedig jóként vagy rosszként minősíti azokat. A definícióból egyértelmüen látszik, hogy a tájelemeknek kiemelt jelentőségük van a karakter megformálásában. A fogalom hangsúlyozza az egyedi és típusos jelleg szétválasztását is. Ezekkel a tájkarakter értelmezését meghatározó tényezőkkel behatóbban a következő két fejezet (1.1.1.3., és 1.1.1.4.) foglalkozik.

\footnotetext{
${ }^{12}$ Érdekeltek és érintettek körébe tartoznak a szakemberek, helybéliek, gazdálkodók, döntéshozók, látogatók stb.

${ }^{13}$ Ilyen szempont például a tájelemek felismerhetösége; tájegységek vagy tájtípusok elkülöníthetösége és térképezhetősége
} 


\subsubsection{Tájelemek, karakterjegyek, kulcsjellemzők}

A tájelemek a táj alkotóelemei, melyekből a táj „felépül”. Swanwick 2002-ben publikált ábrája a táj alkotóelmeinek sokféleségét illusztrálja. Több európai tanulmányban használják, átveszik, fordítják (1. ábra (M3)). Az ábra bemutatja, mi minden alkotja és részese, vagy közvetítője annak, amit részben szubjektíven, részben objektíven tájként értelmezünk (SWANWICK 2002, 2). Nehezen összemérhetö, összetett elemek szerepelnek rajta, adott esetben azonban mind egy-egy konkrét tájelemen keresztül érvényesülhetnek. Tájelemek útján válhat érzékelhetővé a táj a látványtól az érintésig, az emlékektől a területhasználatokig. A táj elemeinek, elem-együtteseinek köre - az ábra alapján is látható - igen szerteágazó.

\section{A karakterelemek körébe bármi beletartozhat, ami a táj jellegzetes vonásaihoz hozzájárul.}

A természeti és antropogén elemek kézzel tapintható, vagy megfoghatatlan, láthatatlan tájelemek is lehetnek. Ide tartozhat a geológia tudományterületéhez kapcsolódó ,alapkőzet”, a társadalomtudomány területéhez tartozó ,,jelentős nemzeti kisebbségek részaránya”, a gazdaság tudományterületén fontos „foglalkoztatottság” és számtalan olyan elem, mely a vizsgált táj meghatározója lehet. Az elemek száma olyannyira végtelennek tünik, hogy teljes körü, a világ bármely pontján alkalmazható potenciális tájelem listát készíteni belölük lehetetlen. A tájelemeket csoportosító táblázat (3. táblázat (M4)) egy olyan minta, melyben a tájelemek a teljesség igénye nélkül, csak példaként szerepelnek típusokba rendezve. A példákat úgy válogattam, hogy sokféleképpen reprezentálják a tájelemek potenciális halmazát. A tájelemek kérdésköre és a minta tájelem-lista azért fontos, mert a távérzékelés és a térinformatika a tájat a tájelemek oldaláról közelíti meg.

A hagyományos értelemben vett, konkrét fizikai hellyel rendelkező megfogható tájelemek mellett a táblázatban szerepelnek „érinthetetlen"14 tájelemek is. Ezek nem kézzelfogható objektumok vagy élőlények, hanem olyan folyamatok, társadalmi vagy gazdasági jellemzők, melyek a táj karakterét befolyásolhatják. A tájelemek felismerése minden esetben a tájépítész, vagy a tájkezelést tudatosan végző szereplők, érintettek feladata. Az adott tájegységre vonatkozó tájkaraktert meghatározó tájelemek listájának elkészítése is az ő felelősségük.

Ahogy a tájkarakter definíció is kiemelte, a táj jellegének kialakulásához „bizonyos” tájelemek járulnak hozzá. Olyan elemek, melyek jól felismerhetők és az adott tájat megkülönböztetik a szomszédos tájaktól. Az ilyen tájelemeket, vagy elemek kombinációit melyek a megkülönböztethető karakter kialakulásához vezetnek - nevezhetjük a táj karakteradó elemeinek (KONKOLY GYURÓ 2006, 19) vagy karakterelemeknek ${ }^{15}$. Egy táj esetében - adott szituációban - bármely tájelem lehet karakteradó elem. Meglátásom szerint nincsenek eleve karakteradónak kikiáltandó tájelemek. A táj kezelőjének feladata felismerni, hogy melyek az adott táj karakterének kialakulásához hozzájáruló tájelemek.

\footnotetext{
${ }^{14}$ Az angol ,intangible” azaz megfoghatatlan, érinthetetlen kifejezés alapján. Örökség-elemekre használatos.

${ }^{15}$ A karakterelem angol eredetije: ,characteristics” (SWANWICK 2002, 8)
} 
Az alapvető karakterformáló elemek kulcsfontosságú karakterjegyként, vagy a tájkarakter kulcsjellemzőiként említhetők. Ezek olyan elemek, melyek jelenléte, száma, elhelyezkedése, története alapvető jelentőségü a tájkarakter meghatározásakor vagy lehatárolásakor (KONKOLY GYURÓ 2006, 19). Változásukkal, eltűnésükkel vagy megjelenésükkel a tájkarakter átalakulásáról tanúskodnak.

A tájelemeknek, a karakterjegyeknek és a tájkarakter kulcsjellemzőinek egy része látható, fényképezhető, távérzékeléssel detektálható, térképezhető, elemezhető, de minősítésükhöz, besorolásukhoz a helyismeret általában elengedhetetlen. Elhelyezkedésük, tájszerkezetben betöltött szerepük, mintázatuk, a távérzékeléssel készült felvételeken sokszor felismerhető. Ilyenek például a földfelszíni épített létesítmények, a növénytakaró, a vízfelület, a felszínmozgalmasság és még számos egyéb elem, melyekre az 1.3.3.-as fejezetben térek ki. A tájelemek egy része távérzékelési módszerekkel nem detektálható. Térinformatikai adatbázisban, ábrán vagy táblázatban csak terepi mérések, kérdőíves felmérések, kutatások, statisztikai elemzések eredményeként jeleníthetők meg. Köztük olyan jellemzők is szerepelhetnek, mint a gasztronómiai sajátosságok vagy a szállodai férőhelyek száma.

A karakterelemek beazonosítása, megnevezése, csoportosítása, leírása, jellemzése, elhelyezkedésének meghatározása, nagyban hozzásegít a tájkarakter felismeréséhez. A tájelemek tipikus jellege, mintázata, rendszere, a táj szemlélőjében esetenként azt az érzetet kelti, hogy egy bizonyos típusú, a Föld más területén is elképzelhető tájat lát. Máskor a tájelemek egyedisége, egyedi elhelyezkedése vagy története olyan unikális jelleget biztosít a tájnak, hogy a szemlélő úgy érzékeli, nincs még egy ilyen tájegység a földön. A két alapvető megközelítést a tájjelleg azonosítására a következő fejezetben ismertetem.

\subsubsection{Egyedi és típusos tájkarakter}

A tájkarakter meghatározásához a fent tárgyalt tájelemek, karakterelemek, kulcsjellemzők elhelyezkedése, megjelenése, mintázata mellett az elemek egyedisége vagy típusossága is hozzájárulhat. Arra a kérdésre, hogy a tájkarakter miként azonosítható és nevezhető, kétféle válasz létezik. Az egyik a tájak egyediségét emeli ki és alkalmazza nevezéktanában, a másik a tájak egymáshoz hasonlatos, tipikus vonásai alapján nevezi meg a karaktert. A Swanwick féle tájkarakter-elemzésre támaszkodó irodalom az egyedit „tájkarakter területnek”, a típusost pedig „tájkarakter típusnak" nevezi ${ }^{16}$. A magyar nyelvben a hasonló értelmű „tájegység” és „tájtípus” kifejezések terjedtek el. A köznyelvben ezek a szavak egyértelmü jelentéstartalmat hordoznak, ismertebbek, érthetőbbek, mint az angol nyelvből fordítottak. „Tájtípusok” és „,egyes táj” kifejezések már Teleki Pál 1917-ben megjelent művében is használatosak (TELEKI 1996, 139). Ezért a „tájegység” és a „tájtípus” szavakat helyenként a „tájkarakter terület” és „,tájkarakter típus” szinonimáiként használom.

\footnotetext{
${ }^{16}$ A tájkarakter terület és tájkarakter típus angol eredetije: landscape character area, landscape character type (SWANWICK 2002, 9) fordítás: KONKOLY GYURÓ 2006, 19 szerint
} 
A tájkarakter területek (pl.: 2.(a) ábra (M4)) és a hasonló jelentésü tájegységek egyedi területként, önálló térségként kerülnek meghatározásra. Sajátos, egyéni, sőt egyedi karakterük, identitásuk van, amit általában a helyi lakosság elnevezéseinek, a kulturális, történelmi eseményeknek, vagy az épített létesítmények dominanciájának köszönhetnek. Ez a megkülönböztetés megjelenik a megnevezésben is, és ahogy Teleki írta „a táj individualitása kidomborodik" (TELEKI 1996, 139). A tájkarakter területek általában egyedi helynevet viselnek. (SWANWICK 2002, 9) Hazánk kistájai ${ }^{17}$ többnyire ilyen egyedi beazonosítás általában földrajzi egység vagy település alapján - kerültek meghatározásra ${ }^{18}$.

A tájkarakter típusok (pl.: 2.(b) ábra (M4)) és a hasonló jelentésủ tájtípusok olyan térségek, melyek a Föld számos vidékén, több földrészén vagy országában, esetleg országrészében, több foltban is előfordulhatnak. Karakterük a meghatározás alapján típusonként egymáshoz hasonlatos, tehát bárhol legyenek is a Földön, mindenütt ugyanazokat a föbb általános jellegzetességeket hordozzák (SWANWICK 2002, 9 és KONKOLY GYURÓ 2006, 19-20 alapján). Legtöbbször alapvető tájhasználati funkciók, vagy természettudományos sajátosságok mentén kerülnek besorolásra a felszínborítás, a tájhasználat, a táblamintázat, a településszerkezet, a vegetáció, a geológiai, a talajtani, a vízrajzi vagy a domborzati adottságok hasonlatossága alapján ${ }^{19}$. Tájkarakter típusokra az egyszerű tájtípusoktól (lakótáj, üdülőtáj, termelőtáj stb.) (CSEMEZ 1996, 100) az összetettebbekig találhatunk példát ${ }^{20}$.

\section{A tájegységek és tájtípusok hétköznapjainkban általában hierarchikus rendszerekben,} több szinten, de sokszor eltérő szempontok szerint kerültek megnevezésre szerte a világon ${ }^{21}$. A legtöbb európai országban létezik saját tájbeosztási rendszer, mely a tájakat egységekbe, vagy típusokba sorolja (WASCHER 2005). Magyarországon a tájegységek három szintjeként a nagytájak, a középtájak és a kistájak hierarchikus szintjét tekintjük mértékadónak (MAROSI és SOMOGYI 1990, DÖVÉNYI 2010). Tájtípusok példái a karakter-meghatározás szempontjától függően szerteágazóak. Koncentrálhatnak a felszínborításra, a tájhasználatra, a természetes növénytakaróra, a geológiai adottságokra és még számos egyéb tényezőre, vagy mindezek valamilyen kombinációjára ${ }^{22}$.

${ }^{17}$ pl.: Tétényi-fennsík, Keleti-Gerecse (MAROSI és SOMOGYI 1990, 726, és 707)

${ }^{18}$ A tájegységekre koncentráló karakter-elemzés hasznosítása általában a humán és művészeti tudományokban (építészet, zene, néprajz), vagy a szolgáltató ágazatban, mint a turizmusban, kereskedelemben, élelmiszergazdaságban történhet meg (borkultúra, gasztronómia, turizmus). A tervezésben valamivel indokoltabb az objektum-szinthez közelebbi ágakban, de térségi szinten is használatos.

19 A tájkarakter típusokra koncentráló karakter-elemzés hasznosítása inkább a természettudományokban (földrajz, biológia), vagy a gazdaságtudományok termelő jellegü ágaiban (mezőgazdaság, erdőgazdaság, energiatermelés, építőipar, bányamüvelés) történhet meg. A tervezésben valamivel nagyobb a relevanciája térségi és regionális szinten, de objektum-szinten is használatos lehet.

20 Összetettebb tájtípus példák: „déli kitettséggel rendelkező dombvidéki sziklakopáros táj településperemen”, vagy „erdőgazdasági, raktár-logisztikai és lakó foltokkal mozaikos síkvidék”

${ }^{21}$ A Szahara és az Andok vagy Európában az Alpok és a Kárpát-medence - melyek egyedi sajátosságokkal, egyedi földrajzi helynévvel rendelkeznek - országhatárokon átívelö, hatalmas kiterjedésü, a bennük élő népek történelmi korában elnevezett óriási tájegységek példái.

22 Ezekben az esetekben azonos fötípusba kerülhetnek a magashegységek (pl.: a fent tájegységekként meghatározott Alpok és Andok), a sivatagok (pl.: Atacama, Szahara), vagy a mérsékelt éghajlati övi medencék (pl.: Kárpát-medence, Cseh-medence). 
A tájkarakter-elemzés készítésekor a tájkezelés célja (4. táblázat (M4)) és egyéb paraméterei ${ }^{23}$ határozhatják meg, hogy az elemzést készítő tájegy ségekben vagy tájtípusokban gondolkodik. A feladat léptékéhez igazodva érdemes kiválasztani a hierarchiarendszerben a megfelelő szintet. A legtöbb esetben több szint együttes figyelembevétele indokolt. Az elemzés készítőjének mérlegelnie kell, hogy a táj karaktere milyen szerepet tölt be a térségben, milyen veszélyek fenyegetik és milyen potenciállal rendelkezik.

\subsubsection{A tájkarakter szerepe}

Tájaink eltérő karaktere, sokfélesége a különbözö természeti adottságok, és az ezekhez eltérő módon alkalmazkodó emberi tevékenység (hasznosítás, termelés, hagyományok stb.) révén alakult ki. Ezt a változatosságot napjainkban is természeti folyamatok és emberi tevékenységek módosítják, vagy tartják fenn az egész világon. Ez a sokféleség azonban folyamatosan változik. A jellegbéli átalakulást korunk globális folyamatai rendkívül módon felgyorsítják és helyenként domináns mértéküvé fokozzák. A következő két fejezetben azzal foglalkozom, hogy várhatóan mi lesz a tájkarakter szerepe és jelentősége a 21. században. Milyen tájjelleg-változási folyamatokkal szembesülhetünk, és mi indokolja, hogy a tájkarakter kezelésére, a kezelés módjára és eszközeire gondot fordítsunk.

\subsubsection{A tájkarakter kezelésének jelentősége}

A tájkarakter meghatározása, elemzése és kezelése több szempontból is indokolt. Különösen az európai országokban, ahol a tájak sokféleségét a természeti mellett az antropogén tájformáló tényezők jelentősen befolyásolták és befolyásolják ma is. A tájkarakter kezelésének természeti, gazdasági és társadalmi hasznosságát, melyet több tanulmány is alátámasztott (SWANWICK 2002) (WASHER 2005, IX) (CSORBA és BODNÁR 2007, 7), az alábbi felsorolásban összegzem.

\section{Az európai tájak változatos természeti karakterének megőrzése}

- elősegítheti a kulcsfontosságú természetes élőhelyek megőrzését,

- megerősítheti a természetes tájalakulási folyamatok érvényesülését,

- támogathatja a természetkímélő gazdálkodás elterjedését,

- lehetővé teheti az ökoszisztéma szolgáltatásainak kedvezőbb kihasználását,

- fokozhatja a társadalom természet-tudatosságát.

\section{A táj sajátosságához alkalmazkodó gazdasági tevékenység}

- elősegítheti a fenntartható területhasználat helyes megválasztását,

- lehetőséget adhat a racionálisabb, „tartamos” gazdasági hasznosításra,

- támpontot adhat anyag-, energia- és erőforrás-takarékos termelés kialakítására,

- erösítheti a helyi szinten jövedelmező gazdasági tevékenységeket,

- útmutatást adhat az agrártermelés és az élelmiszeripar specializálására.

\footnotetext{
${ }^{23}$ A tájkezelés egyéb paraméterei természetszerüleg adódhatnak a kezelendő tájváltozás jellegéből, függhetnek a megbízó szándékától, a táji sajátosságoktól, a területi kiterjedéstől, stb.
} 


\section{A megfelelően „tálalt” tájkarakter igen fontos tényező lehet}

- a turisztikai bevételek növelésében,

- helybéliek identitásának, nemzeti vagy nemzetiségi hovatartozásának erősítésében,

- a hagyományos tájgazdálkodási módok („,know how”), hagyományok, szokások

kialakulásának dokumentálásában és átörökítésében,

- a kultúrtörténeti és eszmei tájértékek megőrzésében, a tájtörténet megértetésében,

- az „érzelmek fagyhalála” és ,,versenyfutás” halálos bűnének (LORENZ 2002, 36, 44) elkerülésében, az életminőség megőrzésében, javításában (CSEMEZ 1996, 11-12).

A fenti „opciósokaság” csupán a lehetőségeket, az elérhető ,jövőképeket” vázolja. Azt sugallja, hogy a tájkarakter tudatos kezelésével tegyünk lépéseket a hagyományokat értő, mégis innovatív, a racionális gazdaságfejlesztést adaptáló, de ugyanakkor a természetkímélő és fenntarthatósági célkitüzésekhez is közelítő tájhasználat irányába. A sikeres kezeléshez valamennyi érintett aktív közremüködésére van szükség, különösen olyan időszakban, amikor a tájkarakter tudatos kezelését alapvető tájváltozási folyamatok indokolják világszerte.

\subsubsection{A tájkarakter kezelésének szükségessége}

A tájkarakter kezelésére általában a táji sajátosságoknak megfelelő hasznosítás elérése érdekében, vagy a veszélyben lévő értékes, védendő jelleg megőrzése céljából van igény. A karakter kezelése tehát mind a tájtervezésben, mind a tájvédelemben fontos szerepet kaphat és hozzájárulhat az 1.1.2.1.-es fejezetben listába szedett lehetséges eredmények eléréséhez. A tájjelleg különösen akkor kerül a figyelem középpontjába, amikor egy-egy szélsőséges természeti jelenség, vagy markáns emberi tevékenység hatására rövid idő alatt, a hétköznapi ember számára is érzékelhető a változás.

A tájjelleg megváltozhat bizonyos tájelemek eltủnése, illetve megjelenése esetén, például egyes területhasználatok változása következtében. A ma közismert és nagy területre kiterjedő változásokat ${ }^{24}$ többnyire globális folyamatok részeként éljük meg. Tájjellegváltozást eredményezhet az is, ha minőségi, jelentésbéli átalakulás megy végbe. Ilyen jellegbéli változás számos tényezőből adódhat ${ }^{25}$. Az elmúlt néhány évtizedben tájaink Európában is rendkívül dinamikusan változtak (ANTROP 2004, FERANEC et al. 2010, SCHNEEBERGER et al. 2007). A változások sok esetben a táj jellegét, karakterét is átformálták. A jelentősebb, tájkarakterre is kiható tájváltozási folyamatokat csoportokba gyüjtve mutatom be (5. táblázat (M5))

\footnotetext{
${ }^{24}$ Nagy területre kiterjedő változás lehet például.: sivatagosodás, az esőerdők és a sarki jégsapkák kiterjedésének csökkenése, népességnövekedés, urbanizáció, a tenger vízs zintjének emelkedése, stb.

${ }^{25}$ Minőségi átalakulás eredhet például a mezőgazdasági művelés módjából (kézi, vagy gépi), a termesztett növény- vagy tartott állatállomány fajtaösszetételéből, a növénytelepítés módjából, irányából, a müemlékek állapotából, ismertségéből, stb. Társadalmi változások, szokásbéli, vagy hagyománybéli változások, értékrendváltozás, a tájhoz kötődő emlékek elfeledése is eredményezheti a tájkarakter jelentős átalakulását.
} 
5. táblázat. (részlet (M5)) Jelentősebb, tájkarakterre is kiható tájváltozási folyamatok

\begin{tabular}{|c|c|c|}
\hline Változási folyamatok & Példák & Források \\
\hline $\begin{array}{c}\text { Épített vonalas } \\
\text { infrastruktúra területi } \\
\text { fejlődése }\end{array}$ & $\begin{array}{l}\text { autópálya, vasúthálózat, energia és } \\
\text { információs hálózatok }\end{array}$ & $\begin{array}{l}\text { GARRÉ, MEEUS és GULINCK 2009, } 125 \\
\text { ANTONSON 2009, } 169\end{array}$ \\
\hline $\begin{array}{l}\text { Erőmüvek építése, } \\
\text { bővítése, terjedése }\end{array}$ & $\begin{array}{l}\text { szél-, víz-, atom-, illetve bioenergia } \\
\text { erömüvek }\end{array}$ & $\begin{array}{c}\text { MÖLLER 2010 } \\
\text { FRANTÁL és KUNC } 2010 \\
\text { DUERKSEN és GOEBEL 1999, } 143 \\
\text { STEINITZ et al. 2003, XII } \\
\end{array}$ \\
\hline $\begin{array}{c}\text { Energiaültetvények } \\
\text { telepítése }\end{array}$ & erdők, gabonák, füvek, repce & $\begin{array}{c}\text { FISCHER et al. 2010 } \\
\text { SKÄRBÄCK és BECHT 2005, 151-159 }\end{array}$ \\
\hline Gyepterület csökkenése & $\begin{array}{c}\text { legelők és kaszálók csökkenése, legelő } \\
\text { állatok eltünése }\end{array}$ & $\begin{array}{c}\text { FERANEC et al. } 2010 \\
\text { HUNZIKER 1995, } \\
\text { SKÅNES és BUNCE 1997, } 61 \\
\end{array}$ \\
\hline $\begin{array}{l}\text { Vidéki mezőgazdasági } \\
\text { tájhasználat } \\
\text { területhasználatainak } \\
\text { változása }\end{array}$ & $\begin{array}{l}\text { szölők, gyümölcsösök, kertek, } \\
\text { szántóterületek felhagyása, erdősülése, } \\
\text { extenzifikáció, beépülés, helyenként } \\
\text { intenzitás növekedése }\end{array}$ & $\begin{array}{c}\text { VERBURG et al. 2006 } \\
\text { HUNZIKER 1995, } \\
\text { VEJRE, PRIMDAHL és BRANDT 2007, 311.323 } \\
\text { MAKHZOUMI 1997, 115-122 } \\
\text { MOTTET et al. 2006, 304 } \\
\text { YEH és HUANG 2009, 151-162 }\end{array}$ \\
\hline $\begin{array}{l}\text { Csökkenő élőhelyek és } \\
\text { biodiverzitás, helyenként } \\
\text { élőhely-rehabilitáció }\end{array}$ & $\begin{array}{c}\text { féltermészetes és vizenyős területek } \\
\text { növekedése }\end{array}$ & $\begin{array}{l}\text { KIM és PAULEIT 2007, 264, } 271 \\
\text { BAILEY, LEE és THOMPSON 2006, 227-243 } \\
\text { APAN, RAINE és PATERSON 2002, 55 } \\
\text { BAILEY, LEE és THOMPSON 2006, 227-243 }\end{array}$ \\
\hline $\begin{array}{c}\text { Városi és elővárosi } \\
\text { zöldfelületek szerepének } \\
\text { változása, } \\
\text { multifunkcionalitásának } \\
\text { erősödése }\end{array}$ & $\begin{array}{l}\text { véderdők, zöld övek, parkerdők, } \\
\text { zöldutak létesítése / megőrzése }\end{array}$ & $\begin{array}{c}\text { VEJRE, PRIMDAHL és BRANDT } 2007 \\
\text { FÁBOS et al. 2010 } \\
\text { ARENDT 2004, 241-269 } \\
\text { SHANNON, SMARDON és KNUDSON } 1995\end{array}$ \\
\hline Tájidenditás változása & $\begin{array}{l}\text { nemzeti vagy regionális identitás } \\
\text { elvesztése, uniformi zálódás }\end{array}$ & $\begin{array}{c}\text { NOHL 2001, 225 } \\
\text { ANTROP 2005, } 21 \\
\text { SALEH 2001, } 965 \\
\text { PEDROLI et al. 2007, 11-12 } \\
\end{array}$ \\
\hline
\end{tabular}

A felsorolt változások jelentősen befolyásolhatják a táj karakterét, ezért kezelése szükségszerü. A kutatási mintaterületeimen jellemző változásokat a 3.2.-es fejezetben tárom fel. Az Európai Táj Egyezmény a tájak számbavételére és értékelésére vonatkozóan fogalmaz meg olyan elvárásokat, melyek a fenti változások dokumentálására, elemzésére terjednek ki (COUNCIL OF EUROPE 2000, Article 6, C/1/a/iii). Eszközöket a feladatok elvégzésére nem nevez meg, de az aláíró felek számára lényegében a tájkarakter-elemzés módszertanához illeszthető tevékenység-sorozatot sugall. Kabai az egyezmény e pontja alapján tájkarakterfelmérések készítését látja indokoltnak (KABAI 2011, 65). A tájkarakter-elemzéssel kapcsolatos irodalomkutatási eredményeimet a következő fejezetben mutatom be.

\subsubsection{A tájkarakter-elemzés jelentősége}

A tájkarakter kezelésére a fenti 1.1.2.1. fejezetben vázolt kedvező jövőkép elérése érdekében és különösen az 1.1.2.2. fejezetben sorolt változási folyamatok miatt van szükség. A tájkarakter-elemzés egy komplex eljárás, melynek során Swanwick szerint elsőként bizonyos táji sajátosságok leírását, dokumentálását végezzük, majd a sajátosságok kezelését irányozzuk elő útmutatásokkal, javaslatokkal (3. ábra (M5)). Az elemzés során meghatározásra kerül a tájkarakter, és értékelésre kerül a helyzet, a szituáció, a tájfejlődési folyamat, melyben a karaktert a továbbiakban kezelni kell. 
Napjainkban a tájkarakter-elemzésnek nagyon fontos gyakorlati alapvetései vannak. A tájegységek jellegét leírja, kataszterezi és értékeli, de mindemellett gyakorlatba átültethető, hasznosítható tanácsokat kell adnia a tájkarakter és a karakterjegyek kezelésére egy konkrét szituációban. Ennek megértése érdekében fontos ismertetni a tájkarakter-elemzés lényegét és változatos céljait, módszereit, elkészítésének lépéseit. Különös hangsúllyal ki kell térni az elemzések eszközrendszerére, illetve azok történeti fejlődésére is.

\subsubsection{A tájkarakter-elemzés lényege, célja, szerepe}

A tájkarakter-elemzés lényege, hogy a táj jellegét vizsgáljuk, meghatározzuk, leírjuk, majd egy adott tájfejlődési folyamatban szerepét értékeljük annak érdekében, hogy optimálisan kezelni tudjuk. Ez a folyamat igen hasonlatos a hazánkban többek által felvázolt tájrendezési folyamathoz (CSEMEZ 1996, 140; KONKOLYNÉ GYURÓ 2003, 159), de itt a tájat egyértelmúen a más tájaktól elkülönítő karakterjegyek és azok rendszere alapján vizsgáljuk. Az értékelést a sajátosságok, vagy az őket formáló tényezők kezelése kapcsán végezzük. A tájkarakter kezelésének több célja is lehet, ez pedig a karakter-elemzés célját is meghatározhatja.

A karakter-elemzéssel kapcsolatosan Swanwick azt állítja, hogy elemzésünk célja lehet:

- a kialakult tájjelleg fenntartása, megörzése, védelme,

- a kialakult tájjelleg erősítése, fejlesztése, tudatosítása,

- egy korábbi tájjelleg helyreállítása, rehabilitálása,

- egy új tájjelleg kialakítása, megalkotása, tervezése,

- a megőrzés, erősítés, helyreállítás és kialakítás céljainak valamilyen kombinációja. (SWANWICK 2002, 53 alapján, részletesen az 4. táblázatban (M4))

Mindemellett az elemzések készítésének elsődleges és általános célja, hogy megalapozza a különböző tervek, akár ágazati tervek készítését. Swanwick szerint általános cél, hogy döntéshelyzetekben alátámasztásként szolgáljon, támpontot adjon tervezők, fejlesztők, beruházók, döntéshozók, hatóságok és helybéliek számára egyaránt. Jelenleg a hazai tervezési rendszerben a tájkarakter-elemzésnek, mint önálló tervfajtának nincs jogszabályokban meghatározott helye. Szerepkörét részben a tájrendezési és területrendezési tervek vagy esetenként más tervek, programok, koncepciók tölthetik be. A karakter-elemzés szerepe, hogy hivatkozási alapot biztosítson az érintett felek számára az elemzésben előirányzott optimális kezelés érvényesítésére pl. civil szervezeteken keresztül, helyi közösségek érdekének érvényesítésére is. Mindez feltételezi, egy igen erős, aktív érdekérvényesítésre képes, az elemzésbe bevonható civil közremüködési demokrácia müködését az adott területen (SWANWICK et al. 2002 TP3). 


\subsubsection{A tájkarakter-elemzés módszere}

Tájkarakter-elemzést világszerte különféle módszerekkel készítettek, de a nemzetközi gyakorlatban leginkább használt és az áttekintett irodalomban leggyakrabban hivatkozott módszertani útmutatót a karakter-elemzés készítésére Carys Swanwick dolgozta ki és publikálta 2002-ben. A tájkarakter-elemzés Swanwick által leírt módszere hat egymást követő lépésen alapul (3. ábra (M5)) (SWANWICK 2002, 13). A lépéseket a hazai tájrendezési folyamathoz illesztve, hazai tájrendezési hagyományokhoz igazítva a hazai adottságokhoz adaptálva a következőképpen fordítom:

1. Témamegjelölés - tartalmazza az egész tájkarakter-elemzés céljának meghatározását, a táj megismerését és a terület lehatárolását, a közremüködők és érintettek megnevezését és bevonásuk célját, a munka léptékének, részletességének és a leendő értékelés típusának meghatározását.

2. „Irodai” tájvizsgálat ${ }^{26}$ - magában foglalja a korábbi elemzések, térképek, adatbázisok, egyéb segédanyagok összeállítását, térinformatikai fedvényekké alakítását, alaptérkép kiválasztását, a tájtörténet és a tájfejlödés vizsgálatát, a területre vonatkozó irodalom és statisztikai adatok áttekintését.

3. Terepi felmérés - terepi adatgyüjtést, fényképezést, térképezést, szabadkézi rajzok készítését, interjúkészítést, kérdőívezést, jelenlegi állapot felmérését és változási tendenciák feltárását jelenti.

4. Osztályozás és leírás - a tájegységek, vagy tájtípusok megnevezésére, lehatárolására, és leírására kerül sor a tájelemeket és a táji adottságokat csoportosító, szintetizáló folyamat eredményeként. A lépés során párhuzamosan folytatandó tevékenység
a. a tájak felosztása („lebontása” tájelemekre, tájrészletekre),
b. a tájelemek, tájrészletek csoportosítása, osztályozása,
c. a megnevezés (,identifikáció”),
d. a térképezés: tájegységek vagy tájtípusok határvonalainak meghúzása,
e. és a jellemzés.

5. Értékelés ${ }^{27}$ - a táj értékelése történik meg a karakter-meghatározás (1-4 lépés), az aktuális fejlesztési célok, és a tájalakulási tendenciák összevetése alapján.

6. Döntéshozás - a tájkarakter kezelésére vonatkozó döntések, javaslatok meghozatalát jelenti az értékelés nyomán. Tájkezelési útmutató és stratégia születik meg eredményképpen (SWANWICK 2002, 14 alapján, a szerző értelmezése).

A tájkarakter-elemzés Swanwick féle módszere a hazánkban és az Európában többnyire elterjedt tájrendezési folyamathoz (vizsgálat, értékelés, javaslat) igazítható. Bár angolszász eredete következtében tájképi jellege dominál, meglátásom szerint a hazai tárgyiasabb, objektívebb, teljesítőképesség-orientált tájrendezési gyakorlatba adaptálható.

\footnotetext{
${ }^{26} \mathrm{Az}$,irodai” tájvizsgálat lépést Swanwick eredetileg „Desk study” névvel illeti, melynek magyar megfelelője az irodai tevékenységre helyezi a hangsúlyt.

${ }^{27}$ Az „értékelés” lépést Swanwick eredetileg a következőént nevezi: „Defining the approach to judgements” Ez Swanwick módszertanának legkevésbé kidolgozott lépése. Gyakorlatilag a hazai tájrendezési folyamat értékelési feladatát végzi el, amikor egy-egy tájalkotó tényező jelentőségének megítéléséről, tájértékek szerepéről, a tájelemek érvényesüléséről végez értékelést, vagy amikor a tevékenységek döntést előkészítő szerepét hangsúlyozza.
} 
Egy karakter-elemzés attól függően, hogy a módszertan mely elemeiből indul ki, illetve, hogy eszköztárának mely elemét részesíti előnyben, készülhet „felülről lefelé indító”, vagy „alulról felfelé építkező” megközelítéssel (SWANWICK 2002, 37) ${ }^{28}$. A felülről lefelé indító megközelítés általában irodában végzett térinformatikával támogatott tevékenységet takar, nagy kiterjedésü tájegységek információinak számítógépes feldolgozásán alapul. Az alulról felfelé építkező megközelítés részletes terepbejárásra, helyiek megkérdezésére hagyatkozik és inkább a táj kisebb egységeinek megismerésével, a hely szellemének feltárásával indít.

Tájkarakter-elemzést hazai jogszabály nem ír elő, semmiféle módszer alkalmazását nem teszi kötelezővé, azonban az Európai Táj Egyezmény melyet törvénnyel iktattak a hazai jogrendszerbe (2007. évi CXI. törvény), nemzeti szintü intézkedések közé sorolja a tájak identifikációját és értékelését. Az egyezmény 6. cikkében kijelenti, hogy egyedi intézkedésekre van szükség a tájak kezeléséhez. Tájak megnevezése, meghatározása ${ }^{29}$, számbavétele és értékelése ezek közül csupán egy-egy szelet. Az egyezmény szerint a fogékonyság növelésén, a képzésen és oktatáson túl - melyekre szintén kitér - szükséges:

— a tájak számbavétele (meghatározása) az egyes országok területén;

— a jellemző vonások, azaz a tájak sajátosságainak elemzése;

— a tájat és sajátosságait alakító tényezők és hatások elemzése;

- a változások számon tartása, feljegyzése;

- a számba vett tájak értékelése, figyelembe véve azokat az értékeket, melyeket az érdekelt felek (gazdálkodók, vállalkozók, döntéshozók) és az érintett lakosság a tájnak tulajdonítanak (COUNCIL OF EUROPE 2000, II. Fejezet, 6. cikk, C/1).

Miután az egyezmény által előirányzott és az aláírók által vállalt feladatok lépései hasonlatosak a tájkarakter-elemzés módszertanához, indokoltnak látom, hogy a számbavétel alkalmával, a vonások leírása során, valamint a tájváltozás kezelésében a tájkarakterelemzés módszere és eszköztára markáns szerepet töltsön be. A disszertációnak nem célja, hogy a karakter-elemzési módszert fejlessze, vagy az Európai Táj Egyezmény elvárásainak megfelelően alakítsa azt. Ellenben a passziv képalkotó távérzékelés releváns alkalmazásainak bővítésével kíván hozzájárulni a módszert segítő technikai eszköztár kiegészítéséhez.

\subsubsection{A tájkarakter-elemzés eszköztárának kialakulása}

A technikai eszköztár nem meghatározója, de általában fontos kiegészítője a tájelemzési módszereknek. Az eszköztárba beletartozhat a szabadkézi rajztól a digitális térinformatikai szoftverekig bármi, ami hozzájárul az elemzés érthetőségének és eredményességének növeléséhez. Értekezésemben mindent eszköznek tekintek, ami a tájakról gyüjtött információk mérésében, rögzítésében, dokumentálásában, leírásában, térképezésében, vizsgálatában, elemzésében, megjelenítésében, kommunikálásában szerepet játszhat.

\footnotetext{
28 SWANWICK 2002, 37 A „top down” és „bottom up” kifejezéseket Swanwick egyértelműen az eszközrendszer elemeire és kifejezetten a 4. lépésre, az „osztályozás és leírás” lépésére használja.

${ }^{29}$ Az Európai Táj Egyezmény angol eredetije az „identification” azaz „meghatározás” kifejezést használja, nem a számbavételt, mint a magyar fordítás, vagy a 2007. évi CXI. törvény.
} 
A hatékony tájkarakter-elemzés gyakorlatilag megvalósíthatatlan illusztrációk, fényképes, térképes vagy egyéb ábraszerű megjelenítés nélkül. Az eszköztár - főként az elmúlt kétszáz év technikai fejlödésének köszönhetően - folyamatosan fejlődött. A fejlödés megállapításom szerint nyomon követhető a 18-19. sz.-i úti leírásoktól, a 20 század közepén divatos tájmonográfiákon át a 20 . sz. végi tájkataszterekig, tájérték-leltárakig, tájérték-kataszterekig.

A tájkarakter-elemzés módszertanának és eszköztárának egyes elemei néhány száz éves fejlődési folyamat eredményei. Konkolyné Gyuró megállapítja, hogy a földrajzi leírások és tájleírások, egyebek mellett főként a tájkarakterről és annak változásáról szolgáltathatnak adatokat (KONKOLYNÉ GYURÓ 2003, 87). Kutatásom szerint a 18.-19. századi útleírásokban már megtalálhatjuk a tájegységek sajátosságainak jellemzését, az eltéréseket és hasonlóságokat összevető fejtegetéseket. Ezek alapján állítom, hogy a tájjelleggel kapcsolatos elemzési tevékenységek egyes módszerei és eszközei, részben a földrajzi felfedező utazások során készült úti leírásokból vagy tájleírásokból eredeztethetők (6. táblázat (M6-7)) ${ }^{30}$.

Már ebben a korszakban megjelentek a szubjektív és objektív tájjelleget leíró stílus elemei. Ismeretes olyan magyar tájkarakter-kezelési útmutatás is, mely a táj egyedi jellegének megfelelő hasznosítási formára, pl. védettségre adott javaslatot (HORÁNYI 2004, 28-31) 31 . Térképek, rajzok, ábrák készültek a honi tájaktól eltérő tájegységek sajátosságainak megörökítésére. Ez az eszköztár akkoriban a karakteradó sajátosságok szemléltetésére szolgált helyrajzként vagy látványrajzként.

A karakter-elemzés alapvető módszertani elemei és eszközei - különös tekintettel a leírás objektív, tudományos módjára, egyes tájelemek és tájformáló tényezők alapos számbavételére, és megjelenítésére - fellelhetők a 20. sz. derekának természetföldrajzi leírásaiban és tájmonográfiáiban. A korszakban a földtörténeti, földtani, vagy általánosabb földrajzi témájú monográfiák mellett olyan is akadt, mely a tájak sajátosságaira, vagy konkrétan egy-egy tájegység ismertetésére készült. Az ekkori leírások célja a tájegységek természetföldrajzi vagy társadalmi jellegének tudományos ismertetése, oktatási tananyagként történő hasznosítása, a honi tájak népszerüsítése, a nemzeti identitást hordozó tájak szépségének hangsúlyozása, a kárpát-medencei tájak együvé tartozásának kiemelése volt. Eszközei a fényképek, tematikus térképek, rajzok, táblázatok, metszetek, diagramok voltak, melyek célja a szemléltetés, egyes információk kiemelése, összefoglalása volt (GAÁL 1944) (BULLA és MENDÖL 1947), (SZABÓ 1954), (PÉCSI és SÁRFALVI 1960).

A 20-21. század fordulójára elterjedt tájkataszterekben, a tájak jellemzését egy tudatosan kialakított, hierarchikus rendszerbe illesztve, az elérhető legtöbb statisztikai adattal vagy

\footnotetext{
${ }^{30}$ Nem kifejezetten a szépirodalmi művek tájleírásai a jelentősek, hanem elsősorban a földrajzi felfedezők azon írásai figyelemre méltók, melyek a bejárt tájegységek sajátosságainak dokumentálására, a tájtípusok jellegzetességeinek összevetésére, az ott élő népek eltérő szokásainak, hagyományainak feltárására törekedtek.

${ }^{31}$ Czárán Gyula az egyik legjobb példa azokra a magyar utazókra, akik tájleírásokat, összevetéseket készítettek a 19. század végén. Az első olyan „kutató”, aki a tájak sajátosságainak feltárása során kalauzt készített túrázóknak és védelmi javaslatot is tett. Lehetséges nemzeti parkok közé a Bihar-hegységet javasolta.
} 
természetföldrajzi jellemzővel igyekeznek bemutatni (MAROSI és SOMOGYI 1990) (PÉCSI 1989, 90-91). Magyarország Kistájainak Katasztere domborzati, földtani-talajtani, éghajlati, vízrajzi, flóra- és fauna-jellemzők valamint területhasználati, települési alapinformációkat is felhasznál a tájak meghatározásához, térképezéséhez. Már ez a változat is alkalmazott indexeket (pl. ariditási index) (MAROSI és SOMOGYI 1990, 21), de a felújított kiadás ürfelvételekböl előállított felszínborítás adatok feldolgozásával, társadalmi, gazdasági információkkal és tájértékek felsorolásával is bővült (DÖVÉNYI 2010, 19-21). Térképi eszköztárában és szemléletességében azonban a felújított kiadvány elmarad a kor elvárásaitól, még az egyszerübb topográfiai térképek igényességét sem hozza.

A tájérték-leltárakban, tájérték-kataszterekben a tájak, tájelemek, tájértékek jellegét elemző módszerek egyszerüek, az eszköztár pedig a digitális térinformatika és a távérzékelés alkalmazásával kibővítésre, helyenként túlsúlyba is került INT-002 ${ }^{32}$, INT-003 ${ }^{33}$ ). Az alkalmazott módszerek viszont egyre összetettebb eszközrendszerrel egészültek ki, a természet- és társadalomtudományos megközelítés helyenként már értékelemző szemlélettel jelent meg (GATE és ÖKOPLAN 1984). Már használnak távérzékeléssel készített felvételeket, a táj szemléltetésére (INT-002, INT-003) és a Tájérték-Katasztert tájkarakterelemzések megalapozására is alkalmasnak tartják (KOLLÁNYI 2010, KOLLÁNYI et al. 2012). Infravörös légifelvételek tartalmi értékelésével zöldfelületi típusokat is lehatároló digitális kataszter is készült. Az Ökoplan Kft. Budapest Digitális Zöldfelületi Katasztere projektjében megvalósult a fóváros egyfajta finkcionális és minőségi zöldfelületi karakterjellemzését összegző digitális térképezése (ÖKOPLAN 1994).

A 21. századra kialakult tájkarakter-elemzési eszköztárba a fenti tájelemzési eszközök szinte mindegyike beletartozik, a szabadkézi ábrázolástól az ürfelvételekig, a történeti fényképektől a digitális térképi adatbázisokig. A legcélszerübb tájkarakter-elemzési eszköztár azonban minden adatot, képszerü információt, térképet egy térinformatikai rendszerbe táplál, ahonnan bármikor elérhető, elemezhető, az értékelés és a döntések eredménye ebbe integrálható (PORTER és AHERN 2002, 2).

A Swanwick féle karakter-elemzés eszköztárát a módszertani lépéseket erősítő technikai megoldások sokasága képezi, melyeket a szerző csak részben nevesít. Ide sorolok minden technikai megoldást, mely hozzájárulhat az elemzés érthetőségének növeléséhez, eredményességéhez a szabadkézi rajztól a digitális térképkészítésig és az erre alkalmas szoftverekig (7. táblázat (M8)). Ezek az eszközök általában bevonásra kerülnek a tájkezelési folyamatba annak érdekében, hogy megjelenítsék a tájat és annak változását, illetve azért, hogy pusztán térbeli referenciát biztosítsanak. Napjainkban a tájjelleg esetenként oly nagymértékben és oly rövid idő alatt változik, hogy a folyamat monitorozására, érzékeltetésére, előrejelzésére a képalkotó távérzékelés és a térinformatika kombinált alkalmazásával lehet képes a tájrendező.

\footnotetext{
${ }^{32}$ INT-002: Az ÖKOPLAN Kft Alsó-Duna-völgyi Tájérték Leltára az 1997-es Duna-felméréssel (2004. 11. 05.)

${ }^{33}$ INT-003: A Tájérték-kataszter Projekt honlapja (2014. 01. 17.)
} 


\subsection{Passzív képalkotó távérzékelés}

A tájelemzés során elkerülhetetlen valamilyen vizuális, térképi vagy egyéb grafikus információt vizsgálni, vagy szemléltetésül közölni a kezelendő tájról. Ezek a képi információk gyakran kulcsfontosságúak a tájjelleg megértésében. Ahogy ezt az újszerü, látványos, magyarázó szerepet az útleírások idején a rajzok és térképek, a tájmonográfiák, földrajzi tájleírások korszakában a metszetek, ábrák és fényképek, a tájkataszterek korszakában a statisztikai adatok, az érték-leltárak és értéktárak korszakában a digitális térképek, fényképek, térinformatikai adatbázisok biztosították, úgy válhatnak a tájkarakterelemzés újabb hatékony eszközévé a passzív képalkotó távérzékelés felvételei és az azokból levezetett digitális térinformatikai adatok.

Napjainkra a passzív képalkotó távérzékelés rendszeresen frissülö, hatalmas mennyiségü légi-, űr- és egyéb felvételeket, valamint feldolgozási eljárásokat biztosít világszerte. Ez a halmaz a tájrendező számára sokféle, releváns vizuális információt jelent többféle témában és léptékben (OLÁH 2012; EGYED 2012, 61, 71; FIRNIGL 2012, 121; MOLNÁR 2013, 103; FILEPNÉ KOVÁCS 2013, 89; BOROMISZA 2012, 54, 57; EPLÉNYI 2012, 130). Ennek megfelelően a távérzékelésre a táji adatok forrástáraként tekintek a disszertációban.

A távérzékeléssel készült felvételek és felhasználásuk célja szakterülettől függően eltérő és feldolgozásának módja is igen speciális lehet. Az elmúlt években a távérzékelés felvételeit felhasználó doktori értekezés készült a környezettudomány (KRISTÓF 2005), a geokörnyezettudomány (JANCSÓ 2006), a felszínvizsgálatok (PETRIK 2007), a hadtörténeti folyamatok rekonstrukciója (JUHÁSZ 2008), az árvíz-detektálás (KUGLER 2008), a precíziós mezőgazdaság (MILICS 2008), a növénytermesztés (GYULAI 2009), a városklimatológia (GÁL 2009), a vegetáció-rekonstrukciós vizsgálatok (CSERHALMI 2009) és a táji hatások vizsgálata (TIRÁSZI 2011) területén. A képfeldolgozás eljárásait pedig alkalmazták a gömbgrafitos öntöttvasak szövetszerkezetének jellemzésére (KARDOS 2009) és az üvegházi és szabadföldi kísérletek kiértékelésénél (GRÓSZ 2010) is.

Meglátásom szerint a tájkarakter-elemzésben elsősorban a passzív képalkotó technikával készített felvételek és feldolgozási eljárásaik hasznosíthatók. Ezek csak a természetes forrásból származó sugárzás detektálásával képként rögzített felvételeket és a képfeldolgozást jelentik. Ezért szükségesnek tartom a következő fejezetekben ismertetni a távérzékelés témakörét, aktív és passzív változatának elkülönítését, a passzív képalkotó távérzékelés jellemzőinek, alapadatainak és fontosabb feldolgozási eljárásainak ismertetését.

\subsubsection{Távérzékelés}

A távérzékelés fogalmát - müszaki tudományról lévén szó - sokan egymáshoz meglehetősen hasonlatosan, objektívan definiálták (8. táblázat (M9)). Lényege, hogy úgy szerez információt különféle objektumokról (például fénykép készítésével), hogy azokkal nem lép közvetlen 
kapcsolatba. A távérzékelés számos forrásból táplálkozó és a tájkarakter-elemzés sajátosságait szem előtt tartó definíciója, melyet a disszertációban használok, a következő: „Tárgyakról, területekröl, jelenségekröl és folyamatokról (pl.: tájakról, azok elemeiröl és mindezek változásáról) távolról, közvetett módon, az elektromágneses sugárzás közvetítésével nyerhető adat-, és információszerzés, illetve -feldolgozás tudománya." (döntően Engler definícióját kiegészítve ENGLER 2000,4)

Elektromágneses sugárzáson mindenféle direkt vagy visszavert sugárzást ${ }^{34}$, a körülöttünk lévő tárgyakból érkező sugárzást ${ }^{35}$, valamint a mesterséges forrásokból kibocsájtott sugárzást ${ }^{36}$ értünk. A napfény a teljes elektromágneses spektrum csak egy kisebb, nyilvánvalóbb, közismertebb, szabad szemmel is érzékelhető része „a látható fény tartománya" (HAGGETT 2006, 701). Ugyanígy csak egy szeletet jelentenek az elektromágneses spektrum emberi szemmel nem érzékelhető részei, például az infravörös sugárzás, a hősugárzás, vagy a rádiósugárzás tartományai is (BAKOS és HEREDEA 1987,).

A képalkotó távérzékelési szenzorok ezeket a sugárzásokat tudják felvételeken rögzíteni. Termékeik közé így például a földfelszíni fényképek, légifényképek, ürfelvételek mellett a hőképek és számos egyéb képszerű végtermék, mint a radar-, és lidarfelvételek is beletartoznak. A tájkarakter-elemzés szempontjából azonban a természetes és a mesterséges sugárforrásokra építő passzív és aktív távérzékelést érdemes elkülöníteni, mert jelenleg az utóbbira - nagyobb költségvonzata miatt - a tájkarakter-elemzésben nincs reális igény.

\subsubsection{Passzív és aktív távérzékelés}

A távérzékelés tudományterületén belül, a felhasznált elektromágneses sugárzás forrásától függően kétféle távérzékelési technika létezik. Amennyiben a sugárzás természetes forrásból származik $^{37}$, úgy passzív távérzékelésről beszélünk, míg a mesterségesen kibocsátott elektromágneses sugárzást felhasználó változatot aktív távérzékelésnek nevezzük ${ }^{38}$ (ENGLER 2000, 12). A különbségeket a 9. táblázat (M10) szemlélteti.

A tájelemzések eszköztárában az aktív távérzékelés két szempontból lehet figyelemre méltó. Az egyik a domborzati adatgyüjtés és modellezés, a másik a különböző tájelemek ${ }^{39}$ térbeli adatainak (helyzetének, formájának) detektálása és archiválása, melynek modellezési és megjelenítési lehetôségeit érdemes lehet kihasználni. Az aktív távérzékelés domborzat- és felületmodell készítési potenciálja a RADAR és a LIDAR alkalmazásoknál is igen erős és a tájkarakter-elemzés szempontjából is hasznosítható lehet.

\footnotetext{
${ }^{34}$ mint például a napfény

${ }^{35}$ mint például a testek saját hője

${ }^{36}$ mint például a mesterséges mi krohullámok

${ }^{37}$ például fényképkészítés esetén napsugárzás rögzítése történik

${ }^{38}$ például mi krohullámú távérzékelés radar felvételek esetén

39 építmények, épületek, szobrok, sziklaformációk, növényegyedek
} 
A radarfelvételekböl generálható domborzati modellek gyakran használatosak a 2,5-dimenziós tájmodellezésben. Feltétlenül igaz ez az SRTM adatbázisra (INT-004 ${ }^{40}$ ), mely ingyenesen letölthető adatbázisként hasznosítható a Föld nagy részére (INT-005 ${ }^{41}$ ). Az SRTM adatoknak a tájkarakter-elemzéseket meghatározó léptékben azonban létezik passzív képalkotó távérzékelési technikával készülő, világszerte ingyenesen elérhető, nagyobb részletességü alternatívája, az ASTER GDEM (INT-006 ${ }^{42}$ ). Kutatásom egyik célja, két domborzatmodell vizsgálata, és annak megállapítása, hogy melyik alkalmasabb a karakterelemzésben történő hasznosításra. Az eredményeket a 4.2. fejezetben ismertetem.

\subsubsection{Passzív képalkotó távérzékelés jellemzői}

Disszertációmban a „passzív képalkotó távérzékelést” a tájakról, tájelemekről és mindezek változásáról a természetes sugárzás közvetítésével végzett képalkotással nyerhető adat-, és információszerzés, illetve -feldolgozás tevékenységeként értelmezem (ENGLER 2000, 4). A passzív képalkotó távérzékelési technikával készült felvételek számos előnnyel rendelkeznek $^{43}$. Az előnyöket azonban ki is kell tudni használni, az optimális áron beszerzett adathalmazt fel is kell tudni dolgozni megfelelő szoftverállománnyal, szakembergárdával és tudatában kell lenni a hasznosítás legfontosabb korlátainak ${ }^{44}$ (KUN és MOLNÁR 1999, 29; ENGLER 2000; DETREKÖI és SZABÓ 2002).

A geometriai és spektrális felbontás a felvételek legfontosabb tulajdonságai, melyeket további lényeges paraméterekkel együtt a fogalomtárban ismertetek 10. táblázat (M11). A karakter-elemzés számára többféle passzív képalkotó távérzékelési technikával készített felvétel is fontos lehet, készüljön az bárikor, bármilyen érzékelővel. Éppúgy fontos adalékkal szolgálhat egy fekete-fehér terepi fénykép a 20. sz. elejéről, mint egy műhold által készített ürfelvétel. A leggyakrabban használt adatok a látható tartományban $(0,45-0,69 \mu \mathrm{m})$, a közeli és középső infra $(0,76-0,9$ és 1,55-1,75 $\mu \mathrm{m})$ vagy a termális infra (10,4-12,5 $\mu \mathrm{m})$ hullámhossz-tartományban rögzítettek (a TM szenzor csatornái alapján, MUCSI 2004, 100).

\footnotetext{
${ }^{40}$ INT-004: A NASA SRTM felmérését bemutató oldala (2014. 01. 18.)

${ }^{41}$ INT-005: SRTM adatok letöltésére szolgáló oldal (2014. 01. 18)

${ }^{42}$ INT-006: ASTER GDEM adatokat ismertető oldal (2014. 01. 18)

${ }^{43}$ Elönyök:
}

- Nagy területre, a felbontástól függően viszonylag olcsón beszerezhetők,

- Bizonyos formátumban és minőségben ingyenesen elérhető változataik is böngészhetők a világhálón,

- Gyors információszerzést biztosítanak, digitális adatfeldolgozást tesznek lehetővé, a tájkarakter-elemzés szintjéhez elegendő részletességgel,

- Feldolgozásuk nyílt forráskódú ingyenes szoftverekkel, online alkalmazásokkal is megvalósítható,

- A tájrészletek többségükön jól felismerhetők, viszonylag gyorsan áttekinthetők,

- Jó térbeli és időbeli mintavételezést biztosítanak,

- A tájat homogén módon reprezentáló adatrendszert biztosítanak (KUN és MOLNÁR 1999, 29; ${ }^{44}$ Korlátok: ENGLER 2000; DETREKÖI és SZABÓ 2002 alapján).

- Erősen időjárásfüggő a felvételek hasznosíthatósága,

- Egy-egy felvétel csak pillanatnyi állapotot tükröz,

- Minőségi feldolgozásuk nagy területre jelenleg drága hardvert, szoftvert és szakértelmet igényel.

- Terepi bejárást, terepi kiegészítő mérést igényel a felvételek értelmezése, (KUN és MOLNÁR 1999, 29; ENGLER 2000; DETREKÖI és SZABÓ 2002 alapján) 
A passzív képalkotó távérzékelés felvételeit - melyekre a karakter-elemzés szempontjából alapadatként tekintek - három nagyobb csoportba soroltam, a belölük származtatott adatokkal együtt az 1.2.2.-es fejezetben tárgyalom. A feldolgozásuk módszereivel a 1.2.3.-as fejezetben foglalkozom.

\subsubsection{Passzív képalkotó távérzékelési alapadatok}

A passzív képalkotó távérzékelés körébe tartoznak a legismertebb távérzékeléssel készült felvételek $^{45}$. Feldolgozásuk, használhatóságuk változatos tulajdonságaiktól függ, ezért három nagyobb csoportban - földfelszíni fényképek, légifelvételek, müholdfelvételek - tárgyalom ezeket. Ezt követően a felvételekből származtatott adatbázisokat (pl. CLC adatbázis) ismertetem, melyeket a tájkutatásban ma már szintén alapadatnak tekintenek.

\subsubsection{Földfelszíni, terepi fényképek}

A földfelszínen készített felvételek technikai és fejlödéstörténeti szempontból nem különböznek a légifelvételektől, készüljenek filmre vagy digitálisan. Azért tárgyalom őket külön fejezetben, mert mindennapjainkban a tájjelleget ebből a szögből tapasztaljuk meg, tehát a földfelszíni képek a karakter-elemzés során nézőpontjukból fakadóan meghatározóak.

Fényképek készítésével a tudomány már a 19. század közepétől kezdve foglalkozott. A legtöbb használható, a tájat is dokumentáló fénykép hazánkban azonban csak a 20. század elejétől áll rendelkezésünkre. A század végétől pedig a tömeges polgári hasznosítás fokozatos terjedése jellemző. Mennyiségükből és egyszerü kezelhetőségükből következően kiemelkedő szerepük lehet a történeti tájkarakter-elemzés során.

A fényképek készülhetnek fotografikus úton, a fényképezési spektrum bármely tartományára érzékenyített filmre $(0,3-1 \mu \mathrm{m})$, (ENGLER 2007, 66) vagy digitális szenzorral. A feketefehér film esetén csak egyetlen fényérzékeny réteget alkalmaztak. Ezzel a módszerrel készítették a 20. század első hét évtizedében a fényképek többségét. Készülhetett fekete-fehér kép a látható és a közeli infravörös tartományra érzékenyítet filmre is (ENGLER 2007, 65).

A digitális fényképek megjelenésével (INT-007 ${ }^{46}$ ) és különösen az ezredfordulótól folyamatosan terjed a digitális polgári alkalmazás. Többségük a látható tartományban érkező

\footnotetext{
${ }^{45}$ A felvételek készülhetnek:

- hagyományos fotográfiai eljárással, adott tartományra érzékenyített film felhasználásával, melyek sajátosságát Engler összegzi (ENGLER 2007, 57-70)

- digitális mérökamerákkal vagy amatőr kamerákkal (BUSICS et al. 2009, 100),

- légi digitális szenzorokkal (BUSICS et al. 2009, 101),

- az ürben dolgozó müholdas szenzorokkal, (MUCSI 2004, 43-172)

- közvetve, analóg felvételek lefényképezésével vagy aktív módon „letapogatással” síkágyas szkennerrel, vagy fotogrammetriai szkennerrel. (BUSICS et al. 2009, 102).

${ }^{46}$ INT-007: A fényképezésről szóló Wikipédia oldal (2014. 01. 18.)
} 
sugárzás valós színes vagy fekete-fehér rögzítését végzi. A kisebbséget jelentik azok a digitális kézi kamerák, melyek a termális (INT- $008^{47}$ ) vagy a közeli infra tartományra érzékenyítettek (INT-009 $\left.9^{48}\right)^{49}$. A közeli infravörös tartományban készített terepi képek hasznosítása a zöldfelület látványban betöltött szerepének elemzése szempontból figyelemre méltó (HAGGETT 2006, 702), azonban szerepük a tájkarakter-elemzésben ismeretlen.

A digitalizált történeti fényképeket, régi képeket gyakran használják a tájkarakterelemzésben (TIRÁSZI, TERPÓ és KONKOLY-GYURÓ 2013, NAGY és CSIMA 2010). Hazánkban ehhez hozzájárulhat több múzeum képanyagának digitális archiválása. Tájképek szempontjából a Magyar Múzeumi Képeslap Katalógus oldala erre a jó példa (INT-010 ${ }^{50}$ ).

A földfelszíni fényképek előnye, hogy készítésük egyénileg, minimális képfeldolgozói szaktudással szervezhető, a szükséges eszközök olcsón beszerezhetők. A készítés földrajzi helyzete meghatározható, sőt egyes kamerák esetében már beépített GPS-szel a fénykép maga tárolja készítésének helyét. Felbontásuk a néhány megapixeltől akár a több tíz megapixelig terjedhet, mégis, tájelemzéshez a közepes méretü, 5-10 megapixeles képek javasolhatók.

\subsubsection{Légifelvételek}

Légifelvételnek tekinthető bármely a levegőből készített fénykép, vagy digitális felvétel. A kép rögzítése történhet filmre, digitális szkennerrel, vagy a felvételek fényképezésével, szkennelésével. A tájelemzésben a látható és az infravörös tartományban rögzített felvételek használata terjedt el, bár léteznek légi termális szkennerek is, melyeket elsősorban a városklíma és hő-szennyezés térképezésében használatosak. A légifelvételeket, ortofotókat általában nemzeti archívumokban tárolják és orszá gos vetületi rendszerben forgalmazzák.

Fotogrammetriai eljárás kifejlesztésével már az 1860-as években történt térképészeti hasznosítás (NAGY 1998, 5). Magyarországon katonai célból készített légifelvételek az 1920 as 1940-es évekből állnak rendelkezésre, de országos lefedettséget csak az 1950-es években elsősorban térképezési céllal készített felvételek biztosítanak. A Hadtörténeti Intézet és Múzeumban folytatott kutatásaim során megállapítottam, hogy az évtized elejéröl (1950-55) főként „téli”, az évtized második feléből (56-58) „nyári” felvételek állnak rendelkezésre. Ezek egy része megvásárolható a HM Térképészeti Közhasznú Nonprofit Korlátolt Felelősségű Társaságtól (INT-011 ${ }^{51}$ ), vagy megtekinthető és költségtérítés ellenében lefényképezhető a Hadtörténeti Intézet és Múzeumban, a Hadtörténeti Térképtárban. Itt további történeti jelentőségü felvételek vannak az 1960-as évekből Budapest környékéröl.

\footnotetext{
${ }^{47}$ INT-008: A bruel.hu hőkamerákat bemutató oldala (2014. 01. 18.)

${ }^{48}$ INT-009: A PIXINFO.com infravörös fényképezést bemutató oldala (2014. 01. 18.)

${ }^{49}$ Ezek használata például az orvostudomány és az épületdiagnosztika területén terjedt el.

${ }^{50}$ INT-010: Magyar Múzeumi Képeslap Katalógus oldala (2014. 01. 18.)

${ }^{51}$ INT-011: A HM Zrínyi Térképészeti és Kommunikációs Szolgáltató Közhasznú Nonprofit Kft oldala (2014. 01. 18.)
} 
Országos lefedettséget biztosító felvételek 1978-1979-ből a Hadtörténeti Térképtárban fellelhetők vagy a Földmérési és Távérzékelési Intézetnél megvásárolhatók. 1986-87-es, majd 1992-es felvételek is tömegesen készültek Budapest környékére és a két intézet valamelyikénél fellelhetők. A felvételek a domborzati és egyéb torzító hatástól nem mentesek, ezért felhasználásuk során geometriai korrekcióra feltétlenül szükség van.

Az ország teljes területéről 2000. évtől legritkábban ötévente rendszeresen készül ortofotó a MADOP $^{52}$-on belül. Az ortofotó már nem hordozza a domborzati és egyéb tényezőkből fakadó képtorzításokat, térképként is használható. A Földmérési és Távérzékelési Intézet honlapján (INT-012 ${ }^{53}$ ) megtekinthető, hogy mely években milyen területekre készült felmérés, és milyen áron lehet beszerezni. Az infravörös légifelvételek és infra ortofotók a vegetáció térképezése szempontjából hasznosak, miután az élő, egészséges zöldfelület intenzív vörös színnel jelenik meg rajtuk ${ }^{54}$.

A légifelvételek térbeli felbontása változó. A történeti felvételek szkennelés esetén optimálisan legfeljebb 2-3m-es felbontást érnek el, de ez újbóli elöhívás és nagyítás esetén javítható. Az ortofotók többféle felbontásban (0,5m-2m) és formátumban (tiff, jpg) elérhetők. Egyéni célú és idejü repülést és fényképezést lehet szervezni, de kis területen legfeljebb pilótanélküli eszközökkel lesz költséghatékony. A mérőkamarás légifényképezés feltételeit a 21/1997-es FM-HM együttes rendelet, a légi távérzékelési engedélyeztetési eljárást a 399/2012-es Korm. rendelet szabályozza.

Bizonyos esetekben a madártávlati légifényképek, úgynevezett ferde tengelyü képek készítése is indokolt lehet, különösen a tájkarakter jellemzésére. Egyes alkalmazások egy-egy nagykiterjedésű épített létesítmény bemutatását célozzák (INT-012 ${ }^{55}$ ). Az ilyen felvételek készítéséhez gyakran siklóernyőt, sárkányrepülőt, helikoptert, távirányítású pilóta nélküli repülőeszközöket (UAV) is használnak. Készítésük akkor indokolt, ha megadott objektumot, területet, egyedi irányból, látószögből vagy útvonalon kell fényképezni.

\subsubsection{3. Ürfelvételek}

Ürfelvételek a Föld felszíne felett több száz km-rel keringő müholdakra telepített érzékelőkkel ${ }^{56}$ készített felvételek. Ezek a felvételek érzékelöik paraméterei alapján többfélék lehetnek. Általános, hogy a szenzorok az elektromágneses spektrum több tartományában egyidejüleg rögzítenek. Így egy müholdfelvétellel szerezhetünk információt a földfelszín hőmérsékletéről, a növényállomány egészségi állapotáról, vagy az aktuális felhőborításról.

\footnotetext{
${ }^{52}$ Magyarország Digitális Ortofotó Programja

${ }^{53}$ INT-012: A FÖMI honlapjának légifelvételeket bemutató oldala: (2014. 01. 18.)

${ }^{54}$ A szín intenzitása a klorofiltartalomtól, részben a vegetáció vitalitásától, életképességétől függően, változik.

${ }^{55}$ INT-013: Az Interspect Kft. Ferde tengelyü légifotókat bemutató oldala (2014. 01. 19.)

${ }^{56}$ Az érzékelő és szenzor szavakat szinonimaként, azonos jelentéssel használom a müholdak esetén
} 
A műholdas távérzékelés a 20. század második felében terjedt el, és mára már több száz mühold kering Föld körüli pályán (HAGGETT 2006, 700). Az ürfelvételeket alapvetően három-négy kategóriába sorolják térbeli felbontásuk alapján. Az alacsony felbontású felvételek képpontjai ${ }^{57}$ akár több száz méter oldalhosszúságúak, míg a nagyon nagyfelbontású felvételeknél ez az érték már méter alatti szám is lehet.

Az alacsony felbontású ürfelvételek köréből az időjárás-megfigyelő, vagy óceán- és földmegfigyelö, esetenként vegetáció-térképezésre is használatos felvételek a legjelentősebbek. Az egyik legismertebb, légköri és óceáni jelenségek megfigyelésére alkalmas mühold a NOAA ${ }^{58}$, melynek AVHRR ${ }^{59}$ érzékelője (INT-014 ${ }^{60}$ ) kb. 1,1 km-es térbeli felbontással rendelkezik (MUCSI 2004, 69). A Terra és az Aqua müholdakon található MODIS érzékelő által készített kb. 250 m-es felbontású felvételek pedig a földfelszín és a vegetációs borítottság térképezésére is alkalmasak (LILLESAND, KIEFER és CHIPMAN 2004, 478-480). Mindkét felvételtípus térítésmentesen hozzáférhető, igényelhető oktatási, kutatási célokra. Felbontásából fakadóan meglátásom szerint legfeljebb a több $10000 \mathrm{~km}^{2}$-es országrészre vagy nagyobb területre készülő karakter-elemzés használhatja eredményesen.

Közepes és nagyfelbontású ürfelvételek müholdjai közül a Landsat és a SPOT müholdcsalád tagjai a legismertebbek Európában. A felszínborítás térképezéséhez mindkét mühold felvételei nagymértékben hozzájárultak az elmúlt évtizedekben. Tájelemzők számára leginkább a települési, kistérségi vagy regionális munkák esetében használatosak. Térbeli felbontásuk 30m (pl.: Landsat legtöbb csatornája), 10m (pl. 1-3 csatornák SPOT5), illetve 2,5-5m (pankromatikus csatorna SPOT5) között változik (MATHER 2004, 44). A felvételek alkalmazhatóak vegetáció települési szintű térképezésére, a településhálózat és az úthálózat elemzésére. A Landsat felvételek többsége (INT-015 ${ }^{61}$ ) a Landsat-archívumból térítésmentesen letölthető, míg a SPOT adatok megvásárolhatók (INT-16 ${ }^{62}$ ). Mindkét müholdfelvétel rendelkezik közeli infravörös csatornával ${ }^{63}$. A Landsat archívum a hosszú történeti idősor miatt lehet fontos a tájkarakter-elemzés számára. A kategóriába tartoznak még az IRS, a RapidEye (5m), az ASTER (15m), valamint a CBERS, a FORMOSAT, a Cartosat, a KOMPSAT és számos egyéb műhold bizonyos érzékelőivel készített felvételei.

$\mathrm{A}$,nagyon nagy felbontású”, úgynevezett $\mathrm{VHR}^{64}$ ürfelvételek képminőségben $1 \mathrm{~m}$ alatti felbontásukkal gyakorlatilag a légifelvételekkel kelnek versenyre. Ezek a felvételek egy tájrendező kertépítő mérnök számára már lakótömbökön belüli térképezési munkára is használhatóak. Épületek, növényegyedek, gépjárművek, járdafelületek, utcabútorok egyedi beazonosítására is lehetőség van. Ilyen felvételeket az IKONOS, a QuickBird, a GeoEye-1, a

\footnotetext{
${ }^{57}$ képpont: a felvételek legkisebb képegysége, (pixel)

${ }^{58}$ National Oceanic \& Atmospheric Administration

${ }^{59}$ Advanced Very High Resolution Radiometer

${ }^{60}$ INT-014: Az Európai Ürügynökség (ESA) NOAA AVHRR-t ismertető honlapja (2014. 01. 19.)

${ }^{61}$ INT-015a: Az amerikai Nemzeti Repülési és Ürhajózási Hivatal (NASA) Landsat Programot ismertető oldala (2014. 01. 19.)

${ }^{62}$ INT-016 A Satellite Imaging Corporation SPOT müholdakat bemutató oldala (2014. 01. 19.)

${ }^{63}$ A Landsat5 mühold TM érzékelője még termális infra csatornával is rendelkezik

${ }^{64}$ Very High Resolution (VHR)
} 
WorldView-1 és 2, a Pleiades-1A és B müholdak készítenek (INT-017 ${ }^{65}$ ). Legtöbbjük közeli infravörös tartományban is rögzít, mely a vegetációs indexek számításához hasznos. A felvételek a látható színtartományra készült változatát tömörített formátumban általában láthatjuk a GoogleEarth felületén is. Bővebb ismertetést és megvásárlásukhoz szükséges információkat a Satellite Imaging Corporation honlapja (INT-017) ad.

Az 1996. évi LXXVI. törvényt 2013. jan. 1-ével jórészt felváltó 2012. évi XLVI. törvény a földmérési és térképészeti tevékenységről 16. pontja kimondja, hogy állami távérzékelési adatbázist kell létrehozni, melynek részei az analóg és digitális légifényképek, ürfelvételek, földi távérzékelési felvételek is. A törvény erre vonatkozó szövegét pontosan a 11. táblázat (M11) tartalmazza. Törvényi garancia adott a felvételek digitális adatbázisba rendezésére.

\subsubsection{Származtatott digitális adatbázisok}

Számos olyan adatbázis készült, vagy készül rendszeresen a felvételek feldolgozásával, melyek ma már tömegesen és ingyenesen alapadatként használhatók. Ezek közé tartozik

- az IMAGE 2000 és 2006: Landsat ürfelvételek legjobbjainak mozaikja,

- a CORINE Felszínborítási Adatbázis (CLC): a Landsat és Spot felvételek vizuális interpretációjával készülő térinformatikai adatbázis több változata és évjárata.

- az Európai Városi Atlasz: Európa nagyvárosi agglomerációinak térképi adatbázisa

- a MODIS szenzor felvételeiből előállított, felszínborítás, hő és vegetációs adatok

- ASTER GDEM: Az ASTER szenzor felvételeiből készített domborzati adatbázis

Az IMAGE 2000 Projekt Európa 29 államának területére a 2000. év körül készült Landsat 7 ETM+ felvételek legjobbjaiból készített geokorrigált és orto-helyesbített mozaikokat (INT$018^{66}$ ). A mozaikok többféle változatban és vetületben (nemzeti és európai) már az újabb IMAGE 2006 projekt eredményeire is elérhető ${ }^{67}$.

A CORINE Felszínborítás Adatbázis egy vektoros adatmodellre építő térinformatikai adatbázis, mely ma már több mint 30 európai ország területét felszínborítási kategóriák szerint tartalmazza (INT-019 ${ }^{68}$ ). Az adatbázis ürfelvételek (Landsat, Spot) vizuális interpretációjával készült el több időpontban, de egységes európai módszertan szerint. Több változata is létezik. A térítésmentesen változata az 1990, 2000 és 2006 időpontokra készült el eddig, és továbbiak készítése várható 5-6 évente (INT- $020^{69}$ ). Kategóriarendszere 3-szintes és összesen 44 felszínborítás kategóriát tartalmaz, melyből Magyarországon 27 fordul elő (INT-021 ${ }^{70}$ ). Az adatbázis letölthető és kutatási, oktatási célra felhasználható az Európai Környezetvédelmi Ügynökség (European Environment Agency) honlapjáról (INT-022 ${ }^{71}$ ).

\footnotetext{
${ }^{65}$ INT-017 A Satellite Imaging Corporation müholdakat bemutató oldala (2014. 01. 19.)

${ }^{66}$ INT-018 A JRC IMAGE 2000 projektet bemutató honlapja (2014. 01. 19.)

${ }^{67}$ A felvételek mindegyike regisztráció után ingyenesen, korlátozásmentesen elérhető, oktatási, kutatási és egyéb célokra, kivéve a kereskedést. Az EEA és a JRC közös projektjében a cél az volt, elkészüljön a CLC 2000 is.

${ }^{68}$ INT-019 A JRC CLC 2000 projektet bemutató honlapja (2014. 01. 19.)

${ }^{69}$ INT-020 Az Európai Környezetvédelmi Ügynökség CLC-t bemutató oldala (2014. 01. 19.)

${ }^{70}$ INT-021 A FÖMI CORINE Felszínborítási Adatokat bemutató oldala (2014. 01. 19.)

${ }^{71}$ INT-022 Az Európai Környezetvédelmi Ügynökség (EEA) CLC2000 letöltését biztosító oldala (2014. 01. 19)
} 
A CLC100-as adatbázis készítése során minden alkalommal létrejön a CORINE

Felsźnborítási Változás-adatbázis, mely már 5 hektáros térképezési egységekkel dolgozik, és folyamatosan frissíti a CLC adatbázisokat (INT-023 ${ }^{72}$ ). Potenciálja a térségi változások elemzésében és a tájkarakter változására utaló jelek feltárásában igen nagy.

A CLC50 2000 Magyarország területére készült el egy 5-szintes, összesen 79 felszínborítást tartalmazó kategóriarendszerrel. Méretaránya 1:50 000 és a legkisebb térképezési egység 4 hektár, a minimális vonalas elem szélesség pedig már csak 50 méter. Az adatbázis a Földmérési és Távérzékelési Intézettől megvásárolható (INT-24 ${ }^{73}$ ). Valamennyi CLC adatbázis elsősorban több településre, kistérségre készülő elemzésekre lehet alkalmas.

Az Európai Városi Atlasz (European Urban Atlas) 305 nagyvárosi agglomeráció részletes térképezése eredményeként elöálló vektoros térinformatikai adatbázis (INT-025 ${ }^{74}$ ). A programban az Európai Unió minden 100 ezer fönél nagyobb települése agglomerációjával együtt, funkcionálisan eltérő területhasználatával került térképezésre ${ }^{75}$.

A Terra és az Aqua müholdak MODIS szenzorának felvételeiből több olyan terméket állítanak elő, mely ugyan alacsony felbontású, de sürün, nagy számban készített 36 csatornás felvételek feldolgozása eredményeként készül (INT-026 ${ }^{76}$ ). Az adatbázisok közül elsősorban a felszínborítás, a vegetációs indexek és a felszínhőmérséklet tekinthető olyan terméknek, mely a térbeli és időbeli összehasonlításokra lehetőséget biztosíthat.

Az ASTER GDEM a Terra mühold ASTER érzékelőjének felvételeiből a japán METI $^{77}$ és a NASA által készített domborzati magassági adatok (INT-027 $7^{78}$. Ezek az adatok passzív képalkotó távérzékeléssel detektált, eredetileg $15 \mathrm{~m}$-es felbontású felvételekből sztereoszkópos $^{79}$ módszerrel készültek. Az ASTER GDEMv2 változata jelenleg területi korlátozás nélkül, ingyenesen elérhető domborzati adatbázis a Föld szinte teljes területére kb. 30m-es felbontással. Ez a változat jelentős módosításokkal, sokkal pontosabb (MEYER 2011), mint az első. Karakter-elemzés esetén domborzatmodellezési, vizualizációs célra, de domborzat jellegbeli elemzésére is használható lehet. Érdemes lenne összevetni az SRTM modellek pontosságával, melyre hazai kutatások már hoztak bizonyos eredményeket a kitettség összefüggésében is (SZABÓ és SZABÓ 2010; SZABÓ 2011).

\footnotetext{
${ }^{72}$ INT-023 Az EEA CLC változásadatok letöltésére alkalmas oldala (2014. 01. 19.)

${ }^{73}$ INT-024 A FÖMI CLC50 adatbázist ismertető oldala (2014. 01. 19.)

${ }^{74}$ INT-025 Az Európai Környezetvédelmi Ügynökség European Urban Atlas-t ismertető oldala (2014. 01. 19.)

${ }^{75}$ Magyarország 9 legnagyobb települése esik ebbe a kategóriába. Az elsődleges cél az volt, hogy Európa nagyvárosainak területhasználati adatai és a térszerkezet térképesen is összehasonlítható legyen. Az út és vasúthálózat mellett többek között megkülönböztetésre kerülnek a városi zöldfelületek, a sport és szabadidő funkcióval rendelkező területek, és az erdők is. Az adatbázis letölthető az EEA honlapjáról.

${ }^{76}$ INT-026 A NASA MODIS termékeket bemutató oldala (2014. 01. 19.)

${ }^{77}$ Ministry of Economy, Trade and Industry (Japán Gazdasági, Kereskedelmi és Ipari Minisztérium)

${ }^{78}$ INT-027 A japán J-spacesystems honlapjának ASTERGDEM adatbázist bemutató oldala (2014. 01. 19.)

${ }^{79}$ Sztereoszkópos eljárás során több felvétel együttes felhasználásával, összevetésével készült magassági modell. Sztereoszkópos eljárás során egyébként 3D épületmodelleket is lehet nyerni, de az ilyen modellek hasznosítása a tájkarakter-elemzésben csak kis területen volna lehetséges.
} 


\subsubsection{Passzív képalkotó távérzékelés feldolgozási eljárásai}

A felvételekből történő információszerzés eljárásait évtizedek óta számos területen folyamatosan fejlesztik a mezőgazdaságtól az orvostudományig. Azt a folyamatot, melynek során a képbéli adatokból információt nyerünk, interpretációnak nevezzük (LILLESAND, KIEFER és CHIPMAN 2004, 193). A megelőző feldolgozó lépéseknek (igazítás, korrekció stb.) fel kell készíteniük a felvételeket a helyes interpretációra. Ebben az alfejezetben áttekintem, hogy a tájhoz köthető tudományterületeken milyen feldolgozási eljárásokkal és interpretációs módszerekkel lehetséges a felvételekből információt szerezni.

\subsubsection{Digitális számítógépes előfeldolgozás}

Első felhasználói lépésként ${ }^{80}$ történik meg a digitális számítógépes elő-feldolgozás. A vizsgálati területre rendelkezésre álló felvételeket át kell tekinteni, a használható ${ }^{81}$ felvételeket ki kell választani a nyilvántartó meta-adatbázisokból. Miután beszerzésre, vagy letöltésre kerülnek a felvételek, megkezdődik a felhasználó térinformatikai rendszerébe illesztésének folyamata. Történeti felvételek esetén, mindez akár a film újbóli előhívását, az analóg felvételek szkennelését és georeferálását is igényelheti.

A digitális felvételt méretei vagy terjedelme miatt gyakran kell mozaikolni, kivágni, szelvényezni, de előfordulhat, hogy forgatásra, átméretezésre, nyújtásra is szükség van. Egyes multispektrális felvételeket akár csatornánként egy fájlba kell összerakni. A felhasználó térinformatikai rendszerébe integrálásakor file-formátumváltás, vetületváltás történhet, melynek során a kép tartalmi tulajdonságai módosulhatnak.

A geometriai igazítások egy részét ${ }^{82}$ a felvételeket forgalmazók általában elvégzik (KRISTÓF 2005, 37). A felhasználó által preferált koordinátarendszerbe transzformálás során (geokorrekció, georeferálás) a felvételek újra-mintavételezésével a felvételt a referenciakoordinátarendszerbe illeszthetővé alakítjuk. A geokorrekció történhet illesztő-pontok segítségével, melyeket a felhasználó azonosít és jelöl meg manuálisan, de Kristóf beszámol olyan automatizált mozgóablakos módszerről is, melynek alapja a felvételek részletei közötti hasonlóság mérése (Blanc 1999 in KRISTÓF 2005, 37).

A felvételek hibajavításának két tipikus esete a csíkhiba javítás a felhők és árnyékuk javítása. Ezeket a legegyszerübb egy másik közeli időszakban készült felvételből származó csíkhiba-mentes, vagy felhő- és árnyékmentes értékekkel helyettesíteni.

\footnotetext{
${ }^{80}$ A felvételek detektálása, rögzítése, tárolása és meta-adatbázisuk kiegészítése nem felhasználói lépés.

${ }^{81}$ Kiválasztáskor fontos szempont, hogy alacsony felhőborítással rendelkezzen és a teljes területet lefedje a kép.

${ }^{82} \mathrm{Pl}$.: szögtorzulás, egynemü légköri hatások, stb.
} 
A következő fejezetekben a felvételeken található egyéb hibák, jellemző torzítások javítására, vagy a kép értelmezhetőségének fokozására szolgáló müveleteket ismertetek. A radiometriai korrekciók (1.2.3.2. fejezet) akkor indokoltak, ha a felvétel kvantitatív, azaz mennyiségi jellegü vizsgálaton esik át. Itt kulcsfontosságú jelentősége van a sugárzási értékeknek, valamint az azokból számított tartalomnak ${ }^{83}$. A képjavítási eljárásokat (1.2.3.3. fejezet) általában azokban az esetekben alkalmazzuk, amikor a felvételeket vizuális interpretáció alá vetjük, tehát egy minőségi jellegü, tematikus értelmezést célzó, ún. kvalitatív elemzésen esik át a felvétel (KRISTÓF 2005, 39 alapján). A két módszer közötti lényegi különbség, hogy a kvantitatív esetében a képpontok számértékeit számításokra használjuk fel, a kvalitatív esetében pedig a felvétel képszerüségéből a vizuális tartalmat minősítve értelmezünk.

\subsubsection{Radiometriai korrekciók}

A távérzékeléssel készített felvételeket számos radiometriai torzító hatás terheli. A megvilágítás sajátosságai, a légkör jellemzői, az érzékelők tulajdonságai és egyéb tényezők oly mértékben módosíthatják a felvételeket, hogy indokolt lehet korrekciójuk (ARONOFF 2005, 289 alapján). Egyes korrekciókat maguk a felvételek elöállítói is elvégeznek és a felhasználónak már nincs vele gondja ${ }^{84}$.

A mennyiségi elemzések világában a radiometriai korrekciók végrehajtása során beszélünk abszolút és relatív korrekcióról. Az abszolút korrekció esetén célunk a digitális számértékekből kiszámítani a földfelszínről visszavert sugárzás jellemzőjét, mint például a felszínhőmérséklet számítása során (CHEN et al. 2006). Ezzel szemben a relatív korrekció lényege éppen az, hogy nincs szükségünk abszolút számértékekre, hanem megelégszünk viszonyszámokkal ${ }^{85}$.

Egyes módszerek több-időpontú főkomponens-analízissel kiválasztják azokat a felvételrészleteket, melyek lényegében változatlanok (invariánsok) és ezekre építik a radiometriai korrekciót (DU et al. 2002, in KRISTÓF 2005). Az MNSK korrekcióo ${ }^{86}$ egy ilyen többidőpontú elemzést segítő relatív korrekció, melyet Kristóf főként a légköri hatások relatív korrekciójára vezetett be. A korrekció első lépéseként kiválasztásra kerülnek az invariánsok, majd ezek statisztikái alapján meghatározhatók a normalizáláshoz szükséges lineáris transzformáció együtthatói (KRISTÓF 2005, 84-90).

\footnotetext{
${ }^{83}$ Például spektrális indexek alkalmazása esetén.

84 Bizonyos esetekben fontos lehet a napmagasság korrekciója, vagy a Nap-Föld távolság korrekciója (LILLESAND, KIEFER és CHIPMAN 2004, 501). Több olyan korrekciós eljárás létezik, mely a légköri hatások korrekciójára szolgál, és alkalmazza a különféle megfigyelések és energiaáramlás modellezésének tapasztalatait (ARONOFF, 2005, 289).

${ }^{85}$ Változásvizs gálatok során, vagy két terület összevetésekor is igen praktikus lehet pusztán a relatív korrekció eredményeit felhasználni. A relatív módszer lényege, hogy felvételeken a radiometriai torzító hatások eredőjét lineáris jellegünek tételezi fel, mely a linearitás alapján korrigálható.

${ }^{86}$ MNSK korrekció: Multitemporális Normalizált Sáv-Különbség értéken alapuló korrekció
} 
Bármilyen nem kívánt zavaró jelenség, mely a távérzékelés érzékelési és rögzítési fázisában előáll, zajnak nevezhető. Ez lehet pontszerü, foltszerü hibajelenség, torzulás, adathiány, csíkosság, melynek megszüntetésére zajszürési módszereket (noise removal) vezettek be (LILLESAND, KIEFER és CHIPMAN 2004, 504). A csíkosság - az egyik legjellemzőbb zaj - megszüntetésére csíkmentesítési (destriping) eljárásokat dolgoztak ki, de akad automatikus módszer a csíkban megjelenő hiány (line drop) jelenségének korrekciójára is.

\subsubsection{Képjavítási eljárások}

Azokat a müveleteket melyek a felvételek vizuális interpretálhatóságát fokozzák, képjavítási eljárásoknak $^{87}$ nevezzük (ARONOFF 2005, 292). A képjavítási eljárásokat, mint pl. a világosság vagy a kontraszt módosítása, a vizuális interpretáció előkésźtésére használják. A képpont-osztályozás során viszont a javítás-mentes képeket favorizálják, mert az eredeti értékek hủen reprezentálják a földfelszíni visszaverődést (ARONOFF 2005, 293). A képjavítási eljáráson átesett felvétel könnyebben értelmezhető, mert bizonyos eltérések kiemelésre kerültek (ARONOFF 2005, 293), ezáltal lehetővé válik, hogy egyes tájelemeket vagy jelenségeket felismerjünk.

Számos képfeldolgozó szoftverben találhatók képjavítási megoldások. Ilyenek a világosság (brightness) beállítására, a kontraszt növelésére (contrast) vagy az élesség (sharpness) fokozására alkalmas funkciók, melyek az egyszerübb képkezelő szoftverek eszköztárában is szerepelnek. A világosítás gyakorlatilag a digitális értékek emelését jelenti, míg a kontraszt és az élesség kezelése összetettebb eljárás, melyekről a 12. táblázat (M12) ad ismertetést.

\subsubsection{Vizuális interpretáció}

A vizuális interpretáció a felvétel látványa alapján szemmel történő képértelmezési,

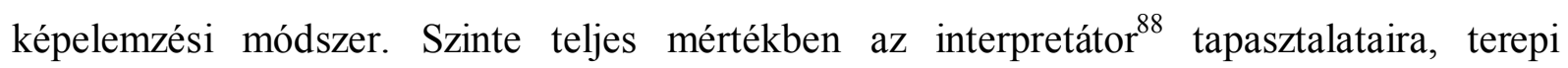
ismereteire, kognitív és asszociatív képességeire épít. A képek, szükség esetén - annak érdekében, hogy könnyebben értelmezhetők legyenek - ekkorra már átesnek az 1.2.3.3. fejezetben említett feldolgozási folyamaton. Vizuális interpretáció során az elemzendő felvételek mellett használatosak eltérő időpontban készült kiegészítő adatok, térképek is.

Összevetve más képelemzési módszerekkel, Kristóf megállapítása szerint nagy gyakorlatot és élőmunkát igényel a módszer, továbbá jelentős szubjektivitás érvényesül a képek értelmezése során (KRISTÓF 2005, 44). A multispektrális felvételek esetében már vizuális interpretációs eljárásnak tekinthető a megfelelő szín-kompozitok előállítása is. A valós színeket az RGB csatornák (321 sorrend) összeállítása eredményeként kapjuk, míg az infravörös sáv interpretációjához a 453-as sorrend javasolt pl. egy Landsat felvétel esetében.

\footnotetext{
${ }^{87}$ Image enhancement

${ }^{88}$ Interpretátor: a képet értelmező szakember
} 
Képinterpretáció során tudatosan vagy tudattalanul a képértelmezés elemeit alkalmazzuk (LLOYD et al 2002 in JENSEN 2007, 131). Ilyen elemek az alak, méret, szín, árnyék, mintázat, szerkezet stb. A szakirodalom egymástól helyenként eltérően nyolc (ARONOFF 2005, 265), kilenc (BUITEN 1993 in KRISTÓF 2005, 44), tíz (KRISTÓF 2005, 44), tizenegy (LILLESAND et al. 2004 195-200), vagy tizenkét (JENSEN 2007, 133) interpretációs elemet sorol fel, melyek jó része tartalmilag átfed. Az irodalomkutatás eredményeként készített 13. táblázat (M12) több szerző munkáját összegzi annak érdekében, hogy áttekintést adjon az interpretációs elemekről, valamint megmagyarázza azok jelentőségét.

13. táblázat. (részlet (M12)) A távérzékelés interpretációs elemei. A táblázat több szerző munkájának feldolgozásával készülit ${ }^{89}$

\begin{tabular}{|c|c|c|c|}
\hline & $\begin{array}{l}\text { Interpretációs elem } \\
\text { (angol megfelelője) }\end{array}$ & $\begin{array}{c}\text { Az elem leírása, magyarázata: Mi alapján történik a } \\
\text { felismerés / beazonosítás / besorolás / mérés? }\end{array}$ & $\begin{array}{c}\text { Az elemet } \\
\text { megnevezők }\end{array}$ \\
\hline 1 & Alak (shape) & $\begin{array}{l}\text { A vizsgált földfelszíni tájelem jellegzetes körvonala, formája, } \\
\text { alakja, elemei alapján }\end{array}$ & $\begin{array}{l}\text { BUITEN in KRISTÓF, } \\
\text { ARONOFF, JENSEN }\end{array}$ \\
\hline 6 & Mintázat (pattern) & $\begin{array}{l}\text { A földfelszín és domborzatának elemei vagy a rajta elhelyezkedő } \\
\text { tájelemek elhelyezkedéséből, elrendezéséből látható vagy } \\
\text { kiolvasható formák, alakzatok alapján }\end{array}$ & $\begin{array}{l}\text { BUITEN in KRISTÓF, } \\
\text { LILLESAND et al. } \\
\text { ARONOFF, JENSEN }\end{array}$ \\
\hline 7 & $\begin{array}{l}\text { Szerkezet / textúra } \\
\text { (texture) }\end{array}$ & $\begin{array}{l}\text { A földfelszín, vagy egyes elemei felületeinek szerkezete, texturája, } \\
\text { anyagának jellege alapján }\end{array}$ & $\begin{array}{l}\text { BUITEN in KRISTÓF, } \\
\text { LILLESAND et al. } \\
\text { ARONOFF, JENSEN }\end{array}$ \\
\hline 10 & $\begin{array}{l}\text { Asszociáció } \\
\text { (association) }\end{array}$ & $\begin{array}{l}\text { Tájelemek egymás közötti kapcsolatainak értelmezése, elemzése } \\
\text { alapján }\end{array}$ & $\begin{array}{l}\text { BUITEN in KRISTÓF, } \\
\text { ARONOFF, JENSEN }\end{array}$ \\
\hline 11 & Szituáció (situation) & $\begin{array}{l}\text { Tájelemek egymáshoz viszonyított helyzete (bezárt szög, } \\
\text { párhuzamosság) alapján }\end{array}$ & JENSEN \\
\hline 14 & $\begin{array}{l}\text { Időbeliség } \\
\text { (time scale) }\end{array}$ & $\begin{array}{l}\text { Több időpontból származó felvételen látható tájelemek } \\
\text { fejlődéstörténetének összeállítása alapján }\end{array}$ & KRISTÓF \\
\hline 15 & $\begin{array}{l}\text { Térbeli eltérés } \\
\text { (spatial difference) }\end{array}$ & $\begin{array}{l}\text { Több tájkarakter területből vagy tájkarakter típusból származó } \\
\text { felvételen látható jellegzetes különbségek összevetése alapján }\end{array}$ & $\begin{array}{l}\text { A disszertáció szerzőjének } \\
\text { megállapitása, a tájak } \\
\text { összevetése során alkalmazott } \\
\text { interpretációs elemröl }\end{array}$ \\
\hline
\end{tabular}

A gyakorlatban ezeket az interpretációs elemeket együttesen alkalmazzuk (ARONOFF 2005, 265), és gyakran csak egymást kiegészítve vezetnek helyes képértelmezéshez. Szakterületenként eltérő lehet, hogy az egyes elemekre az interpretátor milyen arányban támaszkodik. Különösen igaz az utolsó elem, a térbeli eltérés vonatkozásában. Itt a tájkarakter szempontjából kulcsfontosságú, hogy az interpretátor az egyik tájtípus vagy tájegység sajátossá gait a másiktól elkülönítse, a tájakat elhatárolja, identifikálja és jellemezze.

\subsubsection{Indexek}

Azokat az eljárásokat, matematikai képleteket, függvényeket, melyekkel a felvételek képpontjaiban rögzített sugárzási értékek alapján a földfelszín valamilyen jellegzetes

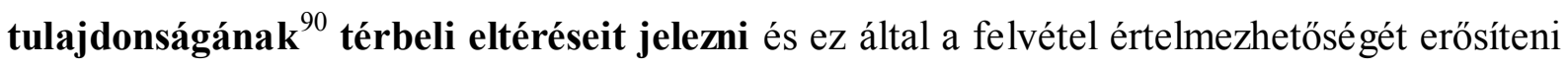
tudjuk, indexeknek nevezzük (ARONOFF 2005, 298 alapján).

\footnotetext{
${ }^{89}$ (BUITEN 1993 in KRISTÓF 2005, 44; LILLESAND et al. 2004, 306-310; ARONOFF 2005, 262-266; 39-40; JENSEN 2007, 133)

${ }^{90}$ pl. vegetáció-borítás, vízfelszín stb.
} 
A távérzékelési gyakorlatban legismertebb index - a vegetációs indexek egyike az NDVI ${ }^{91}$, mely a növényzet jelenlétéről és állapotáról szolgáltat információt. A vegetáció életképességét, vitalitását, fotoszintetizáló-képességét mutatja meg döntően a klorofilltartalom alapján (INT-028 $8^{92}$ ). Bevezetését a hatvanas évek végén Kriegler javasolta (GIBSON \& POWER 2000, 117). Az index a látható fénytartomány vörös $(0,63-0,69 \mu \mathrm{m})$ sávjában és az elektromágneses spektrum közeli infravörös $(0,7-1,1 \mu \mathrm{m})$ sávjában rögzített adatokat használja $\mathrm{fel}^{93}$. Ezekben a tartományokban a vegetáció jellegzetes módon nyeli el, illetve veri vissza a sugárzást. A vörös tartományban érkező sugárzásnak mindössze 8\%-át, míg az infravörös tartományban érkező sugarak 50\%-át veri vissza az egészséges növényzet (INT-027).

Az NDVI mellett más vegetációs index is létezik, mint a $\mathrm{PVI}^{94}$, a $\mathrm{DVI}^{95}$, $\mathrm{WDVI}^{96}$, de olyan változatok is, melyek a talajfelszín vegetációs indexre tett hatását mérséklik, mint a SAVI ${ }^{97}$, a TSAVI $^{98}$, a MSAVI ${ }^{99}$ (GIBSON \& POWER 2000, 117-119). Az NDVI képletére épít az alacsony felbontású NOAA AVHRR GVI terméke ${ }^{100}$. Ennek előnye, hogy napjában több felvétel is készül, így könnyen előállíthatók felhőmentes mozaikok és a vegetáció évszakról évszakra történő változása is monitorozható (GIBSON and POWER 2000, 120, 135).

A Terra és az Aqua müholdon lévő MODIS szenzor adatainak megjelenésével az ezredfordulótól számos újabb vegetációs index fejlődött ki folyamatosan. Ezek közül az EVI ${ }^{101}$ vált legismertebbé, mely a talaj és az atmoszféra torzító hatását mérséklő elemeket integrált az NDVI képletébe (LILLESAND et al. 2004, 545). A vegetációs indexeken kívül még számos egyéb index használatos a távérzékelésben. Ilyen, a vízfelület kimutatására McFeeters által 1996-ban javasolt NDWI ${ }^{102}$, és a Xu által 2005-ben módosított MNDWI ${ }^{103}$, mely a zöld és közeli infra, valamint a zöld és középső infra tartományokat használja fel (in XU 2007, 1384). A beépített területek és a csupasz felszín detektálására pedig alkalmazhatók olyan indexek, mint a Zha, Gao és Ni által 2003-ban publikált NDBI ${ }^{104}$ (CHEN et al. 2006, 134) és a Zhao és Chen által bevezetett NDBaI ${ }^{105}$ (CHEN et al. 2006, 137).

\footnotetext{
${ }^{91}$ Normalized Difference Vegetation Index (NIR - VISR) / (NIR + VISR)

${ }^{92}$ INT-028: A NASA NDVI-t ismertetö honlapja

93 Az NDVI képlete: (közeli infravörös - látható vörös) / (közeli infravörös + látható vörös). A képlet lefuttatása eredményeként -1 és +1 közötti számértékeket kapunk, melyből a hazai távérzékelési tapasztalatok 0 érték alatt a vegetáció hiányát, 0,5 érték felett dús, életerős vegetációval borított felszíneket igazolják vissza. Képlet alacsony, közepes, nagy és nagyon nagyfelbontású felvételeknél is használatos, így alkalmazása a globális növénytakaró változásainak (pl.: az esőerdők monitorozásától a városi zöldfelületek állapotfelméréséig) számos szakterületre kiterjed. A vegetációs indexek általában mérőeszközként szolgálnak a növényzet mennyiségének, elhelyezkedésének / szerkezetének és állapotának feltárására.

${ }^{94}$ Perpendicular Vegetation Index

${ }^{95}$ Difference Vegetation Index

${ }^{96}$ Weighted Difference Vegetation Index

${ }^{97}$ Soil Adjusted Vegetation Index

98 Transformed Soil Adjusted Vegetation Index

${ }^{99}$ Modified Soil Adjusted Vegetation Index

${ }^{100}$ Global Vegetation Index

${ }^{101}$ Enhanced Vegetation Index

${ }^{102}$ Normalized Difference Water Index (GREEN - NIR) / (GREEN + NIR)

${ }^{103}$ Modified Normalized Difference Water Index (GREEN - MIR) / (GREEN - MIR)

${ }^{104}$ Normalized Difference Build-up Index $(M I R-N I R) /(M I R+M I R)$

${ }^{105}$ Normalized Difference Bareness Index $(M I R-T h I R) /(M I R+$ ThIR $)$
} 


\subsubsection{Képpont-osztályozás}

A képpont-osztályozás a digitális felvételek részben automatizált elemzésének egyik módszere, mely a hasonló spektrális tulajdonságokkal rendelkező képpontok csoportosításán alapszik. Lényege Piwowar szerint, hogy a „világ” alkotóelemeit, illetve ezek képi elemeit hasznosítható osztályokba soroljuk, így az könnyebben megérthető (ARONOFF 2004, 305). Az osztályozás két fontos lépésből áll Mather interpretációja szerint. Az elsőben fel kell ismerni a valós világ objektumainak kategóriáit (pl.: erdő, vízfelszín, gyepes területek stb.). Esetenként ezt a lépést önmagában is osztályozásnak hívják. A második lépés a kategóriák megnevezéséből áll. Esetenként ezt a lépést identifikációnak, vagy címkézésnek hívják (MATHER 2004, 203). Ennek érdekében a felhasználónak két lépésben meg kell határoznia:

- a kategóriák számát és jellegét annak függvényében, hogy milyen felszínborítási kategóriák azonosíthatók be az adott felvételen.

- a kategóriák nevét a kapcsolt képrészletek sajátosságai alapján. (MATHER 2004, 203) E két lépés hasonlatossága a tájkarakter-elemzés „osztályozás” és „identifikáció” lépéseihez a kutatásban feltétlen tisztázandó. A képpont-osztályozás számos képfeldolgozó szoftverben müködő alapvető funkció és igen elterjedt módszer például bizonyos területhasználatok lehatárolására. Alapvetően kétféleképpen, irányítatlanul és irányítottan lehet végezni.

\subsection{Irányítatlan képpont-osztályozás}

Az irányítatlan osztályozást hívják automatikus, vagy nem-felügyelt ${ }^{106}$ osztályozásnak is. Lényege, hogy a képpontok csoportba sorolásakor a program csak a felvétel pixeleinek sokasága mögött rejlő adathalmazra épít, és az elemző utólagosan próbálja értelmezni az automatikusan létrejött osztályokat és igyekszik kapcsolni őket a valóságban megtalálható tájelemekhez. Kristóf szerint akkor alkalmazzuk, amikor kevés információval rendelkezünk a területről (KRISTÓF 2005, 45). Ez pusztán az adathalmaz statisztikai elemzésén nyugvó módszer, miszerint minden pixelt több körben a legközelebbi osztályhoz ${ }^{107}$ sorolja a szoftver, úgy, hogy közben az osztályok közötti „,választóvonalat” folyamatosan körről-körre módosítja (GIBSON és POWER 2000, 86). A folyamat kezdetén az elemző meghatározhatja:

- az osztályok számát,

- a maximális iterációk számát (a pixelek újracsoportosítási köreinek számát),

- az ismételt pixelbesorolások során más osztályba kerülő pixelek arányára vonatkozó határértéket, mely kedvezően alacsony szintjén befejezettnek tekintendő a folyamat.

Eredményképpen a gyorsan létrejött képen a kívánt mennyiségü osztályba sorolt képpontok sokasága látható. Az osztályok mindegyikéről az elemzőnek kell megadnia, hogy milyen valóságos területhez kapcsolható. Az osztályozott felvétel vektoros adattá átalakítható. Az egyes jellegzetes területhasználatok (vízfelszín, erdőterület) lehatárolásához, tematikus térképezéséhez a legtöbb közepes felbontású felvétel esetében jól használható ez a módszer.

\footnotetext{
${ }^{106}$ Non-supervised classification / Unsupervised classification

${ }^{107}$ A legközelebbi osztály esetén például a leginkább hasonló értékekkel rendelkező csoportot érthetjük.
} 


\subsection{Irányított képpont-osztályozás}

Az irányított osztályozást hívják felügyelt, ellenörzött vagy tanulóterületes osztályozásnak is ${ }^{108}$. Alapját azok a mintaterületek jelentik, melyeket az elemzést végző személy jól ismer, osztályokba tud sorolni, továbbá segítségével meg tudja tanítani a szoftvert a hasonló területek felismerésére. Ezek a mintaterületek az úgynevezett tanulóterületek, melyeket az osztályozást irányító személy kiválaszt vizuális felismeréssel, helyszíni ismeretei alapján, vagy egyéb térképi forrásokat felhasználva. A mintaterületeket az osztályozást megelőzően kategóriákba sorolja ${ }^{109}$, majd a tanulóterületek alapján szerzett tudást a szoftver kiterjeszti a kép egészére (KRISTÓF 2005, 47; GIBSON és POWER 2000, 72 ismertetése alapján).

Az irányított osztályozás lényege, Kristóf szerint, hogy a tanulóterületekkel olyan pixelcsoportokat, érték-csoportokat definiálunk, melyek jellemzik, elkülönítik egymástól a tanuló-területrészeket és ennek mentén később az osztályokat is (KRISTÓF 2005, 47). A tanulóterületek nyomán - az adott szituációhoz választható döntési szabályoknak megfelelően - minden pixel bekerül valamelyik osztályba. A szabályok valójában döntési algoritmusok (decision rules), melyek a képpontok értékei alapján eldöntik osztály-hovatartozásukat. A leginkább elterjedt fajtáikat ${ }^{110}$ számos szerző ismerteti (LILLESAND, KIEFER és CHIPMAN 2004, 556-562; GIBSON és POWER 2000, 78-81; ARONOFF 2005, 310-313; MATHER és KOCH 2011, 246-248; ENGLER 2000, 63-64; BUSICS et al. 2009, 165-168; CHUVIECO és HUETE 2010, 287-289; LÓKI 2002, 85-90; TAMÁS 2000, 46-48).

Az eredményben azok az osztályok szerepelnek, melyekre a tanulóterületek megalkotása során koncentrált az elemző, és melyekbe az elemzés az adott felvétel minden képpontját besorolta. Ez a módszer alaposabb előzetes ismereteket igényel. A felszínborítás elemzésének, a területhasználatok térképezésének egyik igen elterjedt módszere. Alkalmazása a karakter-elemzésben különösen a tájtípusok lehatárolásánál lehet indokolt. Érdekes megoldás a több forrásból származó adatok osztályozása („Multisource classification”), mely valamennyi felhasználni kívánt adatot egyetlen file-ba von össze, és az összes rétegen létező adatot egyszerre figyelembe véve végzi el az osztályozást, vagy szegmentálást (TSO és MATHER 2001, 271). Ez az eljárás a tájkarakter-elemzés sok szempontot integráló tájakat, tájelemeket, tájrészleteket osztályozó elemzéséhez járulhat hozzá.

\footnotetext{
${ }^{108}$ Irányított os ztályozás angol neve: Supervised classification

${ }^{109}$ például az adott terület felszínborításának megfelelő kategóriákba

${ }^{110}$ Osztályozás ismertebb, gyakran alkalmazott fajtái Engler szerint:

- „Minimum distance to means” osztályozó A pixel abba az osztályba kerül, amihez az értéke alapján a legközelebb áll. A módszert Engler a „legközelebbi középpont osztályozásnak” nevezi.

- „Gaussian maximum likelihood” osztályozó: A pixel abba az osztályba kerül, ahova a legnagyobb valószínüséggel tartozik.

- „Parallelepiped” osztályozó esetén a pixel abba az osztályba kerül, amelynek a minimum és maximum értékei közé esik. Ezt a módszert Engler „doboz-módszernek” hívja (ENGLER 2000, 63-64).
} 


\subsubsection{Szegmentáció}

A képszegmentáció egy olyan képelemzési módszer, melynek során a képet felosztjuk nagyjából azonos méretü, összefüggő homogén foltokat alkotó, szomszédos foltoktól elkülönülő területekre. A műveletet a felhasználó vezérli, de bizonyos szabályok megalkotása után $^{111}$ a képértelmező szoftver automatikusan hajtja végre a müveletet, és eredményként egy régióknak, vagy szegmenseknek nevezett foltokból álló térképet kapunk (BELÉNYESI 2008, 68 és KRISTÓF 2005, 52 alapján).

A szegmentált elem fogalmát „képobjektumnak” (image object) (TRIMBLE 2010, 2) és ennek kapcsán a szegmentálás folyamatát objektum-alapú képelemzésnek OBIA-nak ${ }^{112}$ is nevezik a távérzékelési szakirodalomban (BLASCHKE, LANG és HAY 2008). A módszer alapja, hogy a szegmensek olyan képrészleteket határolnak le, melyek valamilyen tényleges „objektumot” takarnak a valóságban, legyen az egy erdőfolt vagy tisztás például egy közepes felbontású felvételen, egy épület egy nagyfelbontású felvételen, vagy akár egy élő szövet része, mint egy anyajegy.

Engler már 2000-ben megállapította, hogy a szegmentálás sikere döntően az elemző által előre kialakított „definíciókon” múlik. Az összes olyan paramétert ugyanis előzetesen meg kell adni, amely a szegmentálás folyamatában a döntésekben szerepet játszik" (ENGLER 2000, 59). A szegmentálás során a szegmensek méretére, a beletartozó képrészlet jellegére vonatkozóan a felhasználó ad meghatározást, a felhasználó definiálja azokat a szabályokat, melyek mentén a szegmentálás megtörténik. A kívánt foltok nagyságát is például az elemző adja meg a pixelek számának meghatározásával (BELÉNYESI 2008, 68).

Attól függően, hogy a figyelembe vett sajátosságok hasonlósági, vagy különbözőségi jellemzőket mérnek (azaz homogén részeket vagy határvonalakat keresnek) foltokat vagy határvonal-éleket kapunk a kétféle szegmentálási módszer eredményeként (BUSICS ET AL 2009, 162). A folttérképen minden egyes folt címkét kap, melyet a beletartozó képpontok megörökölnek, míg a határvonalas térképen az élek határpixeleket jelentenek, melyek 1-es értéket kapnak, míg azok, melyek nem határpixelek 0 értékkel szerepelnek (KRISTÓF 2005, 52). Ez az eljárás néhány elemében emlékeztethet a tájkarakter-elemzés osztályozó, lehatároló és térképező lépésére, ezért érdemes lehet a szegmentációs alkalmazásokat az irodalomkutatásban kiemelten kezelni.

\footnotetext{
111 Szabályok: sajátságvektorok, távolságfüggvény, döntésfüggvény, eredmény-jellemzők, mintasajátságvektorok (ENGLER 2000, 59-60)

${ }^{112}$ Object-Based Image Analysis: Objektum-alapú képelemzés
} 


\subsubsection{Adatmodell konverziók és adat-elemzés}

A képfeldolgozási eljárások eredményeként többségében raszteres adatok születnek, ám a tájkarakter-elemzéshez sok esetben a vektoros térinformatikai adatokra is szükség lehet. Fontos, hogy bármilyen elemzést is végzünk raszteres adatokkal, ügyeljünk arra, hogy az értelmezhető vektoros adatmodellbe alakíthatóság lehetősége megmaradjon. Ezt az igényt

- esetenként az egyszerübb adatkezelés,

- a kis fájlmérethez illeszkedő kisebb tárhely-szükséglet,

- a többféle szoftverbe importálhatóság és használhatóság,

- a látványos, adatmennyiség-takarékos megjelenítés,

- a vektoros térinformatikai elemzési eszköztár lehetőségei indokolják.

A raszter-vektor konverziók előnyét azért érdemes kihasználni, mert, bár léteznek raszteres tájelemzésre kifejlesztett megoldások ${ }^{113}$ (BOTEQUILHA LEITÃO et al. 2006), számos karakter-elemzéshez fontos térinformatikai elemzést vektoros adatmodellel egyszerübb megoldani, mint raszteres adatokkal. Az ilyen müveletek potenciális körét Longley és szerzőtársai 2011-ben megjelent könyvükben ismertetik (LONGLEY et al. 2011). A könyv a térinformatikai adatfeldolgozás mellett, példákat hoz a vizualizáció, térbeli adatelemzés és modellezés, sőt a GIS management és kezelés témaköreivel kapcsolatosan is. Számos egyéb szakirodalom (CHOU 1997; ELEK 2007, 88-100; GYENIZSE és NAGYVÁRADI 2008, 113-124;) foglalkozik részletesen a vektoros térinformatikai elemző eszköztárral, mely kiegészítheti az 1.2.3.1.-1.2.3.6. alfejezetekben részletezett raszteres elemzéseket.

Akad olyan szerkesztési megoldás is, amit kizárólag vektoros adatmodellben lehet megvalósítani (pl.: snapping). Általában egyszerübb a térbeli adatok kapcsolása egy másik vektoros réteg objektumaihoz (pl.: spatial join), így a területek jellemzése, a területi arányok számítása is. Egyes fedvények közötti müveleteknél például metszésnél és leválogatásnál praktikusabb lehet vektoros adatmodellel dolgozni, különösen, ha más forrásból származó vektoros adatokkal is össze kell vetnünk eredményeinket.

A legtöbb térinformatikai képfeldolgozó szoftverben lehetőség van raszter-vektor konverziókra. Az elemzések eredményeként született raszteres állományokat (pl.: osztályozott kép) lehetőség van sokszög, vagy vonalsokaság formájában is exportálni. Egyes távérzékelési adatok (pl.: felszínmodell) esetén indokolt lehet a képpontokat vektoros pontfedvénnyé exportálni. A vektoros adatmodellekre specializálódott térinformatikai müveleteket ${ }^{\vee}$ LATE szoftverrel Lang publikációi ismertetik (LANG és TEIDE 2003, LANG és BLASCHKE 2007). A vektoros adatokon végzett térinformatikai elemzés eredményeit további elemzések esetén szükséges lehet ismét raszteres adatmodellbe integrálni. Ezek a konverziós és elemzési müveletek kulcsfontosságúak lehetnek a tájkarakter jellemzése során.

113 például a FRAGSTATS szoftverrel 


\subsection{Passzív képalkotó távérzékelési alkalmazások a tájkarakter-elemzési gyakorlatban}

Áttekintettem azokat a hazai és nemzetközi forrásokat, melyek érintik a tájkarakter és a passzív képalkotó távérzékelés témakörét is. Vizsgáltam azokat, melyek a táj jellegének elemzéséhez lehetséges eszközként javasolják, vagy gyakorlatban is alkalmazzák a passzív képalkotó távérzékelés egyes felvételeit vagy képfeldolgozási eljárásait.

\subsection{1. Útmutatások passzív képalkotó távérzékelés alkalmazására}

A feltárt források között kevés olyan publikációt találtam, melyben konkrét utalás történt arra, hogy passzív képalkotó távérzékelési felvételeket, képfeldolgozási eljárásokat, vagy akár csak térinformatikai eszközöket hogyan használjunk a tájkarakter-elemzés során. A kivételek egyike a Swanwick féle karakter-elemzési útmutató (SWANWICK 2002) és annak negyedik függeléke (PORTER és AHERN 2002), „Térinformatikai rendszerek és számítógépes eljárások használata” címmel, melyek a témában útmutatásokat adnak.

A tájkarakter-elemzési útmutató kiemeli, hogy Swanwick a karakter-elemzés folyamatát hat lépésre bontja (3. ábra (M5)) (SWANWICK 2002, 6-7), ezek közül is kulcslépésként különös hangsúllyal kezeli a tájkarakter-meghatározáson („characterisation”) belül az osztályozás, térképezés, leírás rész-lépéseket (SWANWICK 2002, 9). A térinformatikát - beleértve a passzív képalkotó távérzékelést is - eszköznek tekinti. Kijelenti, hogy eszközként (,as tools”) kell használni a tájkarakter-elemzésben, a jövőben pedig egyre gyakrabban az elemzés különbözö lépéseiben is. Említi a lépték, a GIS-kezelési készségek, a szoftverek, a hardverek, és az elérhető alapadatok jelentőségét (SWANWICK 2002, 18). Hangsúlyozza, hogy az eszközök nem vonhatják el a figyelmet az érintettek integrálásától, nem használhatók esztétikai vagy percepciós tényezők rovására a karakter-elemzésben (SWANWICK 2002, 19).

Több karakter-elemzés módszertanát ismertető anyagban elökerül a területhasználatok és a települési mintázatok szerepe (SWANWICK 2002, 21-22, 24, 31, 37, DEANWOOD et al 2002, 1). A szerzők részletezik a „vegetation, landform, tree cover, rivers” témákat, (SWANWICK 2002, 23-26). Elemzésüket térinformatikai és távérzékelési alkalmazásokkal javasolják, de konkrétan nem határozzák meg a felhasználás módszertanát. A terepen a kommentálható, megjegyzések felvitelére alkalmas térképek használata - terepi fényképekkel kiegészítve - javasolt (SWANWICK 2002, 32).

Swanwick a tájak csoportosításáról, határvonalak meghúzásáról, tájak leírásáról, jellemzésről ad útmutatást (SWANWICK 2002, 37-40) és ezekhez kapcsolódóan említi általánosságban a térinformatikát, mint hasznos eszközt, de nem részletezi a lehetséges alkalmazás módszereit. Néhányszor felhozza a „számítógépes osztályozási technikákat”, amit főként a különféle mintázatok beazonosítására, csoportosítására javasol (SWANWICK 2002, 37-38, 50), (SWANWICK 2002 TP1, 3,5). Megemlíti, hogy akár önállóan, vagy kézi módszerekkel kombináltan is lehetséges az osztályozás. Gyakran használja a „GIS data manipulation” vagy 
a „map manipulation” kifejezéseket (SWANWICK 2002, 37-38). A GIS alkalmazásokat föként a nagyobb területekre kiterjedő elemzéseknél tartja indokoltak (SWANWICK 2002, 50). Az útmutató és függelékei olyan kulcsszavakat, témákat, említenek, melyek kifejezetten indokolják a passzív képalkotó távérzékelés felvételeinek alkalmazását. Ezeket a 14. táblázatban (M13) foglaltam össze a felvételek alkalmazását indokoló magyarázattal együtt.

A térinfor matika és a tájkarakter-elemzés kapcsolatát legrészletesebben feltáró szakirodalom szerzői szerint a térinformatikát az adattárolási, adat-elemzési és megjelenítési képességeik teszik alkalmassá a hasznosításra (PORTER és AHERN 2002, 1). Állításuk szerint a térinformatikai eszközrendszer minden karakter-elemzési lépéshez hozzá tud járulni, mert a terepi felmérés adatai integrálhatók a megjelenítésben és az eredményhasznosításban is. Az adatok módosíthatók és így a döntések következményeinek tesztelésére is használhatók (PORTER és AHERN 2002, 1). Kiemelik, hogy az adatok alkalmasak lehetnek arra, hogy mintázatokat felfedezzünk, beazonosítsunk, megnevezzünk, a felvételek értelmezésével a tájjellegről leírást készítsünk és elemezzük ezeket (PORTER és AHERN 2002, 10).

A szerzők hangsúlyozzák, hogy a térinformatikát és értelemszerüen a passzív képalkotó távérzékelést is arra használjuk a karakter-elemzésben, hogy tájelemeket reprezentáljunk térbeli adatokkal (PORTER és AHERN 2002, 2). A tipikus raszteres adatok sorában a légifényképeket, szkennelt fényképeket említik és a képpontok értékének elemzését, mint lehetséges műveletet. A vektoros adatmodell alapelemeit (pont, vonal, sokszög) pedig egyértelmüen a karakterelemzésben fontos tájelemekkel azonosítják be (élölények, müemlékek, határvonalak, patakok, erdők stb.) (PORTER és AHERN 2002, 2).

A karakter-elemzésben használható távérzékeléssel összefüggő adatokra több példát hoznak táblázatosan (PORTER és AHERN 2002, 3). Megemlítik a müholdfelvételeket, mint a területhasználatok feltárásához alkalmas eszközt (PORTER és AHERN 2002, 13). A felszínborítás adatbázis is szerepel a javasolt adatok között, de a légifelvételekről csak annyit írnak, hogy sokfélék. A domborzati és hidrológiai adatoknál digitális felszínmodellek és digitális domborzatmodellek használhatósá gát nem említik (PORTER és AHERN 2002, 3).

Porter és Ahern ismerteti a „Landscape Description Unit” fogalmát, ami a vizsgált terület elhatárolható, egyjellegü, homogén egysége ${ }^{114}$. (PORTER és AHERN 2002, 5). Konkrét módszerként a vizuális értékelést, interpretációt és térbeli elemzést említi, melyek többféle adat kombinálásával megvalósíthatók, annak érdekében, hogy egyjellegü karakterrel rendelkező foltokat lehatároljunk. A terepen időjárásálló laptop, és mobil internet alkalmazását javasolta a folttérképek igazításához már 2002-ben is (PORTER és AHERN 2002, 7).

\footnotetext{
${ }^{114}$ Határaiként a domborzati, a geológiai és talajtani egységek, a települési és vidéki területhasználatok határait hozza mintaként. Világossá teszi, hogy ezek az adatok külön térinformatikai rétegekröl származhatnak. Javaslata szerint a természeti dimenziót kell elsőként térképezni, és ezeknek kell adni a főbb határoló elemeket, míg a társadalmi tényezők csak alábonthatják (subdivide) ezeket, ott ahol jelentősek. (PORTER és AHERN 2002, 5) Derbyshire tájkarakter-elemzése során a terepi bejárás során véglegesítették az irodai tájvizsgálat során feltárt határokat. (PORTER és AHERN 2002, 8-9) nem részletezi a módszerét, GIS elemzésből álltak elő a határok.
} 
A terepi fényképekre a jelenlegi vagy a jövőbeli változások szcenárióinak bemutatására alkalmas vizualizációs eszközként tekintenek (PORTER és AHERN 2002, 8). Megemlítik, hogy azonos helyszínen különböző időpontokban készített fényképekkel a karakterelemzésben használható felvételsorozatot lehet készíteni (PORTER és AHERN 2002,8) és ilyen esetben az időjárási körülményekre, a kamera adataira, beállításaira oda kell figyelni.

A karakter-elemzés osztályozás lépésének alátámasztására szolgálhat a digitális adatok „kézi”, vagy „számítógépes” csoportosítása. E kettő közötti különbséget Porter és Ahern részletezik. A kézi csoportosítást a vizuális összevetés és interpretáció eredményeként, míg a számítógépest a rétegenkénti statisztikai és térbeli adatok alapján elvégezhető digitális osztályozás módszereként értelmezik. Utóbbi szerintük nagyban függ a bemeneti adatok minőségétől, típusától ${ }^{15}$, és a megfelelő osztályozási módszer megválasztásától. Hangsúlyozzák, hogy igen hasznos tud lenni a számítógépes módszerrel végzett osztályozás a foltok feltárásához ${ }^{116}$, de az eredmények értelmezése és felhasználása tájelemzői szakismerettel kell megtörténjen. (PORTER és AHERN 2002, 10).

Mind a „kézi”, mind a „gépi” módszer esetében javasolják importálni az érintettek nézőpontjait is, hogy az eredmények elfogadottak és érthetőek legyenek. (PORTER és AHERN 2002, 10). Megemlítik, hogy az érintettek maguk is használhatják a térinformatikai rendszerekben bemutatható karakter-elemzési eredményeket workshopokon vagy online térképeken (PORTER és AHERN 2002, 10-11). Ezeknek egyszerűen használhatóknak kell lenniük. A megjelenítés (vizualizáció) esetében, mely eseteket maga Swanwick is támogat (SWANWICK et al. 2002 TP3, 8) Porter és Ahern kiemelik a 3D modellek szerepét és a digitális képeket is integráló változatok jelentőségét (PORTER és AHERN 2002, 12) ${ }^{117}$.

A történeti tájkarakter-elemzés föként egy GIS alapú elemzés, melyben foltokkal, polygonokkal tárjuk fel és emeljük ki a jelentős tájelembeli változásokat, „veszteségeket” (FAIRCLOUGH és MACINNES 2002, 7). Kiemelkedőnek bizonyul a térinformatikai adatok szerepe a tájkarakter érzékenység és alkalmasság tanulmányok készítése során is ${ }^{118}$, mert átláthatóságot, adattárolást, fedvények közötti műveleteket és hatásos térképi megjelenítést nyújtanak (SWANWICK 2002 TP6, 17). A tájkarakter és a fenntarthatóság összefüggései témakörben a legtöbb gondolat a tájjelleg-változás monitorozása, minőség-indikátorok kidolgozása körül zajlik (COLE 2002, 2), melyhez a távérzékelés felvételei és származtatott adatbázisai alapadatként szolgálhatnak. A klíma- és tájjelleg-változás összefüggéseinek elemzése során a területhasználatok változása indokolhatja a felvételek és felszínborítási adatbázisok integrálását a változás monitorozása céljából (DEANWOOD et al 2002, 9-10).

${ }^{115}$ Felhívják a figyelmet, hogy bármilyen témájú információhalmazból lehet térbeli adatot előállítani (pl. meghatározó építőanyagok elterjedéséből). Az ilyen adatok is hozzájárulhatnak mind a „kézi”, mind a „gépi” osztályozás sikerességéhez, de ennek módszereit nem részletezik (PORTER és AHERN 2002, 10).

${ }^{116}$ Nem derül ki milyen módszerrel, de vélhetőleg képpont-osztályozásra gondolhat.

${ }^{117}$ Kiemelik az épületek és a cserjék megjeleníthetőségének, érzékeltethetőségének fontosságát is.

${ }^{118}$ Durham megye tájkarakter-elemzése során a térinformatikai eszköztárat a táj alkalmasságának modellezésére használták a szélenergia és lakóterületi bővítés és erdőtelepítés esetében. (PORTER és AHERN 2002, 14). 


\subsubsection{Tájkarakter-elemzési gyakorlatban elterjedt alkalmazások}

A magyarországi tanulmányok és cikkek sokasága említi a táj karakterét, a tájjelleget, vizsgál karakteradó tájelemeket, jellemzi egy-egy terület karakterét, de kevés olyan található, mely karakter-elemzési céllal született. Azokat a forrásokat tekintettem át, ahol a tájkarakterelemzés legalább részcél volt, a tájkarakter többször, hangsúlyosan elöfordult, vagy a tájkarakter jellemzése megtörtént. Vizsgáltam az elkészült hazai tanulmányok eszköztárát, de a karakter-elemzés módszerére csak akkor tértem ki, ha az eszköztárat is érintette.

Glauser 1993-ban írt munkája nyomán készített ábrában Konkolyné Gyuró az integrált tájmegfigyelés adatforrásainak tekinti a légifelvételeket és a földi fényképeket. Megállapítja, hogy a légifényképek jelentősége elsősorban a tájökológia (élőhelyek, tájhasználat) vonatkozásában, míg a földi fényképek föként a tájjelleg, területi identitás azonosításában érvényesíthetők jobban (4. ábra (M13)). (KONKOLYNÉ GYURÓ 2003, 161). A felvételek készítésének nézőpontjaiból, nevezetesen a felülnézetből és az oldalnézetből feltáruló táj látványa alapján is logikus megállapítás ez, ezért indokoltnak tartom a felvételek alkalmazás-kutatását nézőpont és távolság alapján is elkülöníteni.

Általánosan megállapítható, hogy szinte valamennyi tájkarakter témában született forrás felhasznált fényképeket, vagy a fényképek alkalmazását alapvetőnek tekinti. Az földfelszíni fényképek alkalmazása a tanulmányokban elsősorban illusztrációra szolgál, de a szerzők terepi bejárásaik, kutatási eredményeik dokumentálásra, elemzésre, vizuális képértelmezésre is felhasználták azokat ${ }^{119}$.

A legtöbb tájkarakterről szóló cikk vagy tanulmány fényképek használatának szükségességét említi ((KABAI 2010, 101)), vagy fényképekkel illusztrál (KONKOLYNÉ GYURÓ 2006a 26-32) (CSIMA és MÓDOSNÉ BUGYI 2010, 201-210) (DUBLINSZKI-BODA 2010, 215, 217) (NAGY és CSIMA 2010, 237). Akad olyan alkalmazás, mely komplex tájelemző munkaként - különös tekintettel a tájkarakterre - tartalmaz fényképeket a terepfelvételek helyzetének bemutatására (KONKOLYNÉ GYURÓ 2006b, 6).

Néhány tanulmány kifejezetten sok terepi fényképet használ, hogy a lehető legtöbb nézőpontból bemutassa a tájat és annak bizonyos elemeit (KONKOLYNÉ GYURÓ 2007, 27), és megnevezésükkel illusztrálja a tájkarakter-elemzési tevékenység eredményeként lehatárolt tájkarakter-típusokat. (KONKOLY-GYURÓ 2010, 11-13) Több szerző is, de Konkolyné Gyuró különösen gyakran használ panoráma fényképet is a szélesebb látószög biztosítása érdekében (KONKOLYNÉ GYURÓ 2007, 24). Bemutat $360^{\circ}$-os panorámafényképeket (KONKOLYNÉ GYURÓ 2006b, 51-52) és részben ezekre építi vizuális értékelését.

\footnotetext{
${ }^{119}$ Hangsúlyozom, hogy az áttekintés elsősorban a passzív képalkotó távérzékelés alkalmazására vonatkozott, és megállapításai nem terjednek ki a térképes alkalmazásokra, tehát nem lehet olyan következtetést levonni, hogy a hazai tájkarakter-elemzések ne használnának fel egyéb térképes (topográfiai, tematikus) alapadatokat, vagy egyáltalán a térbeli referenciát tájkarakter-kutatásaik, elemzéseik során.
} 
Légifelvételek és ortofotók használata a tájkarakterrel foglalkozó forrásokban ritkábban fordul elő. Troll szerint a légifényképes kutatás a különböző módszerekkel dolgozó tudományokat a tájháztartás szintjén hozza össze (KERTÉSZ 2003, 14), Kertész pedig a táj elemzése kapcsán a térbeli szerkezet, „mintázat” jelentőségét hangsúlyozza (KERTÉSZ 2003, 25), melynek elemzéséhez nagyban hozzájárulnak ezek a felvételek, még akkor is, ha hazánkban ez a folyamat részben intuitíve történik és sokszor nem kerül dokumentálásra.

A tájjelleg légifénykép alapú elemzése gyakori tevékenység, de hazánkban ritkán kerül akár módszertanában vagy térképes feldolgozásával dokumentálásra és bemutatásra. Elvétve akad olyan tanulmány, mely bizonyos tájelemek illusztrációjaként alkalmaz infravörös felvételeket (KONKOLYNÉ GYURÓ 2007, 26, 40, 67). Gyakori a felvételek vizuális interpretációja, de alig fordul elő vektoros digitalizálás a karaktert meghatározó tájelemek helyzetének, felülnézeti formájának, vagy a tájkarakter-típusok térképezésének érdekében.

Ürfelvételek alkalmazására a hazai gyakorlatban szinte csak illusztrációs céllal és csak kivételes esetben került sor $^{120}$. Illusztrációs céllal alaptérképként infravörös csatornáival jelenített meg közepes vagy nagy felbontású ürfelvételt (Landsat vagy SPOT) a Zemplénihegység és peremvidékéről készült tanulmány, annak érdekében, hogy közigazgatási határvonalakat mutasson be (KONKOLYNÉ GYURÓ 2006b, 63), vagy terepi felvételi pontok helyét jelölje be (KONKOLYNÉ GYURÓ 2007, 21).

A források egy része illusztrációra használ ferde tengelyü madártávlati képet, vagy 2,5D3D tájmodellt is ${ }^{121}$, de csak egy olyat találtam, mely a kutatásba is bevonja ezeket és vizuális kérdőívezés útján kívánja meghatározni a tájjelleg változásának percepcióját (TIRÁSZI 2011). Tirászi 2011-es doktori értekezésében ismerteti kutatását, melyben a tájmodellek feldolgozásával illusztrált tájváltozási folyamatokat vizuális kérdőívezésbe integrálta. Ezzel a táj jelentős változásának küszöbértékét kívánta meghatározni ${ }^{122}$. A kutatásban résztvevő 20 szakértő és 300 laikus értékelése alapján a markáns tájváltozási küszöböt az erdőterület növekedése esetén átlagosan a teljes terület $20 \%$-át érintő, a vízfelület esetén $10 \%$-át érintő, a beépített területeknél 15\%-át érintő szintnél állapította meg (TIRÁSZI 2011, 38-39).

${ }^{120}$ Csorba Landsat és SPOT adatok felhasználását javasolja a tájökológiában, a különböző élőhelyfoltok térképszerü lehatárolására. (CSORBA 2006, 71-72) és 2008-as cikkében ehhez hasonló módszerrel lehatárolt ökotopok továbbgondolásával javasolja a tájhatárok pontosítását (CSORBA 2006, 83-89). Konkoly-Guró alaptérképként közepes vagy nagy felbontású infravörös ürfelvételt (Landsat vagy SPOT) használ, mind a 13 tájegység bemutatásakor áttekintő és részletes térképként is, hogy terepi felvételi pontokat jelöljön rajta. (KONKOLY-GYURÓ 2010) A Fertő-Hanság térségére készített két anyagban jelöli a lehatárolt tájkarakter típusokat is, mert nagyon jól illeszkedik a lehatárolás a felszínborítás foltokhoz (KONKOLYNÉ GYURÓ 2007, (KONKOLY-GYURÓ 2010) Feltételezhető, hogy a típusok határvonalát is a felszínborítás-foltok mentén vizuális interpretációs eljárást alkalmazva határozta meg.

121 Illusztráció egyik példája domborzatmodellre helyezett infravörös légifelvétellel tájmodellt készít és tájkarakter típusonként más-más részletét kivágva, helyenként magyarázó grafikus és szöveges elemekkel mutatja be (KONKOLYNÉ GYURÓ 2007, 24, 66).

122 Ehhez a kutatócsoport 2,5D-s digitális tájmodelleket használt, melyek különböző területhasználati változásokat jelenítettek meg hat lépésben, ahol minden egyes lépésben 5\%-kal növekedett egy területhasználat egy másik területhasznált rovására. 
A származtatott adatbázisok alkalmazása esetenként szintén előfordul. A CORINE Felszínborítás Adatbázis alkalmazásán kívül más példát (Urban Atlas, ASTERGDEM) nem találtam. A CLC100 és CLC50 alkalmazása is megvalósul. Előbbi esetében változás-elemzés céljából is. Hazánk kistáj-kataszterének második, átdolgozott bővített kiadásban a területhasznosítás jellemzéséhez, felhasználták a CLC50 adatbázist. Az adatbázis kategóriarendszeréhez területhasználatokat párosítottak és az adatbázist elmetszették a kistájhatárokkal, „majd a területek újraszámításával és összegzésével kinyerhető állapotba kerültek a kistájakhoz tartozó területhasználati értékek" (DÖVÉNYI 2010, 11-12).

Konkolyné CLC50 adatbázis felszínborítás foltjait használja a felszínborítás természetességének és a tájhasználat intenzitásának elemzésére, továbbá egyes élőhelyek veszélyeztetettségének feltárására. A CLC50 adatbázis tartalma alapján minősíti a terület jellegét KONKOLYNÉ GYURÓ 2006b, 7-11). A CLC50 kategóriáit bizonyos szempontok (pl. természetesség) alapján összevonja, kategóriákat alkot ${ }^{123}$. Természetességi kategóriákat hoz létre KONKOLYNÉ GYURÓ 2006b, 17), valamint lehatárolásokat (magterület, pufferzóna) tesz meg ezek alapján (KONKOLYNÉ GYURÓ 2006b, 19).

Konkolyné Gyuró 2007-es tanulmányában a CLC50-es felszínborítás adatbázisból következtet a földhasználat megoszlására (KONKOLYNÉ GYURÓ 2007, 28) és táblázatos földhasználati és egyéb nagyobb felszínborítási kategória-csoportok szerint is készít területi kimutatást (KONKOLYNÉ GYURÓ 2007, 119). A szerző használ egy úgynevezett felszínborítás természetessége mutatót, amit a felszínborítási adatbázisra épít ${ }^{124}$. Az ökológiai hálózat rehabilitációs tervének alátámasztásához nem csak a természetesség, hanem a használat intenzitásának mértékét is részben a CLC50-es adatbázis alapján, részben szakmai tapasztalatok alapján határozza meg. (KONKOLYNÉ GYURÓ 2007, 116-119). Tirászi doktori értekezésében több, a tájkarakter-jellemzésére alkalmas indikátort képzett a CLC adatok alapján (TIRÁSZI 2011), melynek eredményeit az 1.3.3.3. fejezetben ismertetem.

Konkolyné Gyuró 2007-es tanulmányában a térszerkezet feltárását, az élőhely-együttesek mérete, eloszlása alapján kirajzolódó felszíni mintázatot vélhetően vizuális interpretáció eszközével ürfelvételek, légifelvételek illetve a CLC50 adatbázis együttes használata alapján határozta meg ${ }^{125}$ (KONKOLYNÉ GYURÓ 2007, 121). Egy másik tanulmányban a tájra vonatkozó információkat már a térinformatikai rendszerben lévő fedvények attribútumtáblájába építette be, de a térképezés módszerét nem publikálta. Az ezt követő elemzőlehatároló munkafázisban elkerülhetetlennek tartja a szakértői ítéletalkotást és a megelőző terepi bejárást (KONKOLY-GYURÓ 2010, 13). A háromféle információ kombinációjából 63 típus született, melyet 13 tájkarakter típussá vont össze. Ezt szükséges lépésnek tekintette és közben a területek egyediségét is figyelembe vette.

\footnotetext{
${ }^{123} \mathrm{pl}$.: mozaikos élőhely-együttesek, elszigetelt természetes élőhely-együttesek, zárvány mesterséges élőhelyek

${ }^{124}$ gyakorlatilag az adatbázis kategóriáival „modellezi” a területre a természetesség fokát minden típusnál

${ }^{125}$ A teljesség igénye nélkül sorolom, hogy milyen kategóriák születtek, melyeket a szerző korábbi munkájában részben már definiált (KONKOLYNÉ GYURÓ 2003, 201-203): Felszabdalt természetes élöhely-együttesek, Elszigetelt töredék természetközeli és átmeneti élőhelyek, Mozaikos szerkezetű élőhely-együttesek
} 
Digitális domborzatmodell-elemzést a hazai gyakorlatban elvétve találtam. Ezek a DDM100-as, vagy az aktív távérzékelési SRTM modellt használták fel szintvonalas térképgenerálásra, lejtőkategória-térkép, kitettség-térkép (KONKOLYNÉ GYURÓ 2006b, 7), reliefenergia térkép készítésére (KOLLÁNYI és CSEMEZ 2006, 8), vagy a tájhasználat összefüggésében erózió- és deflációveszély megállapításához (KONKOLYNÉ GYURÓ 2006b, 7). Egyes tanulmányok, melyek pl. a középső-ipoly-völgyi települések és a kőszegi szőlőtermesztő táj karakterének vizsgálata során a terepi bejárás mellet bizonyosan felhasználtak domborzati adatokat, az elemzés technikáját azonban nem részletezik (CSIMA és MÓDOSNÉ BUGYI 2010, 208-210), (NAGY és CSIMA 2010, 327-240), véleményem szerint azért, mert nem tartják fontosnak a cikk üzenetének megértetéséhez.

A külföldi példákban a karakter-elemzés eszközeként, vagy a tájkarakter illusztrálása érdekében természetesen szintén használtak terepi fényképeket (US FOREST SERVICE 1989) (DUERKSEN és GOEBEL 1999, 15), légifelvételeket (PEONEER VALLEY PLANNING COMMISION 1997, 27-31), (FABOS és CASWELL 1977, 31-58), ürfelvételeket (LYON 2001), CLC vagy egyéb származtatott adatokat (CULLOTTA és BARBERA 2011) (VAN EETVELDE és ANTROP 2009b) (BOHNET és SMITH 2007), (STRAND 2011), ferde tengelyü madártávlati felvételeket és számítógéppel generált tájmodelleket vagy ezek kombinációit (BELL 1999) (AHERN 2004) (CLARK, DARLINGTON és FAIRCLOUGH 2004, 10) (JASMINKA, VASILJEVIC és TUTUNDŽIĆ 2007) (BERIATOS és GOSPODINI 2004) (GOSPODINI 2006).

A nemzetközi szakirodalmat annak érdekében tekintettem át, hogy megállapítsam, melyek azok a tájkarakter-elemzések, ahol a passzív képalkotó távérzékelési eszköztár több elemét, vagy eljárását alkalmazzák, mint a hazai gyakorlatban. Természetesen Európában sem hétköznapi a távérzékelési adatok tömeges alkalmazása a tájkarakter-elemzésben. A Julie Martin Associates tanulmánya az írországi tájkarakter-elemzések felülvizsgálata és értékelése kiadványában felhívja a figyelmet arra, hogy az áttekintett karakter-elemzésekben a térképezés általában sematikus, nem digitális és csak a megyék harmadában történt térinformatikai felhasználás (JULIE MARTIN ASSOCIATES 2006, 4).

A tanulmány említi az ELCAI projektet, mely több ország (14 résztvevő) tájkaraktertérképeit, -katasztereit vetette össze. A vizsgált országok közül Belgium, Németország, Norvégia, Skócia, Spanyolország és Wales is használt térinformatikát a karakter-elemzési rendszerében. Belgium ürfelvételeket, Németország különböző CLC adatokat, Norvégia és Portugália nemzeti adatbázisokat használt és a tájra vonatkozó információk sokaságát tárolta térinformatikai rendszerben. Skócia és Spanyolország a térképezést (határvonal-húzást) végezte térinformatikai eszközökkel, és utóbbi ebben a rendszerben használt fel sok egyéb vizuális információt is (JULIE MARTIN ASSOCIATES 2006, 69). 
Az ELCAI Projekt „Európai Tájkarakter Területek” című kiadványa széleskörű áttekintést ad a résztvevő országok tájkarakter-elemzési gyakorlatáról és technikájáról, elemzi az iránymutatások és résztvevők szerepét a különböző szinteken. Áttekintett 51 példát, különös tekintettel a tájkarakter-elemzéshez kapcsolódó tevékenységekre, az eredmények térbeli jellemzőire és a módszerekre (WASCHER 2005, VIII). A projekt megállapította, hogy a térinformatikával támogatott megoldások életképes segítséget nyújthatnak a karakterelemzéshez, de eredményeik terepi bejárással, vitamühelyekkel (workshopokkal) támogatott interaktív szakértői finomítására szükség van (WASCHER 2005, VIII).

A nyolc európai kiterjedésű tájjelleg-térkép közül kettőnél derül ki egyértelműen, hogy közvetlenül felhasználtak a számos térképes input adat mellett távérzékelési adatokat ${ }^{126} . \mathrm{Az}$ ENVIP-Nature tájtipológia térképe, mely természetvédelmi indikátorok érdekében állt elö, SPOT, Landsat, IRS adatokat használ fel az indikátorok elöállításához, különös hangsúllyal a biodiverzitás értékeléséhez. Az Európai Környezeti Ügynökség (Dominant Landscape Types) térképéhez felszínborítás adatokat használtak fel (INT-029 ${ }^{127}$ ) (WASCHER 2005, 11-12).

Az 51 táj karakter-elemzési jellegü példa rövid jellemzéseit (WASCHER 2005) átolvasva a távérzékelés szempontjából fontos megállapításaim a következők:

- Az igen gyakori terepi fényképek mellett ürfelvételek és ortofotók, történeti légifelvételek elemzése is előfordul, de a CLC adatok használata jóval rendszeresebb.

- Nem mindenhol került megemlítésre, de az esetek kétharmadában vektoros, egyharmadában raszteres adatfeldolgozási dominanciát lehet érzékelni ${ }^{128}$.

- Az eszköztárat a következő nem távérzékelési jellegű elemek egészítik ki az előfordulás gyakoriságának sorrendjében: változatos forrásból származó térképek, topográfiai, történeti és tematikus térképek irodalmi adatok, statisztikai adatok.

A kiadványban nagy hangsúlyt kapott a tájkarakter térképezések áttekintése, és az osztályozás, mint tájkarakter-elemzési lépés jelentősége (WASCHER 2005, VIII). Wascher és Mücher úgy mutatja be a LANMAP-et, mint az európai tájtípus térképet, mely azért jött létre, hogy egy egységes osztályozási rendszert biztosítson (MÜCHER és WASCHER 2007, 37). A LANMAP2 a tájosztályozás új módszere 2003-ban azért született, hogy tájkaraktertípus térképet készítsen teljes Európára. Mücher annak érdekében fejlesztette ki, hogy lehetőséget adjon a nemzetközi elemzésekre, melyet a nemzeti karakter-elemzések változatos módszertana és a térképek sokféle jelmagyarázata nem tett lehetővé (WASCHER 2005, 26).

A LANMAP2 módszer négy fontos tájjelleg-meghatározó tényezőre ${ }^{129}$ és annak digitális térinformatikai adatbázisára (5. ábra (M14)), valamint a képfeldolgozás szegmentációs módszerére alapoz (6. ábra (M14)). A négy tényező adatbázisait generalizálták,

\footnotetext{
${ }^{126}$ A többi esetben csak meglévő térképek újbóli feldolgozására lehet következtetni.

${ }^{127}$ INT-029 Az EEA Európai Tájtípus térképét bemutató oldala (2014. 01. 25.)

${ }^{128}$ A megállapítást az alapján tettem, hogy polygonokkal, vagy raszterekkel példálózott-e az áttekintés.

${ }^{129}$ Négy tájjelleget meghatározó tényező: domborzat, alapkőzet, klímaövek, felszínborítás
} 
egyszerüsítették, majd az eCognition szoftver szegmentáló és osztályozó funkcióival félautomatikusan készítették (MÜCHER et al. 2010). Wascher leírja, hogy a tematikus adatokat egy fájl több rétegeként, mint egy ürfelvétel sávjaiként összevonták és így történt meg a „felvétel” szegmentációja és „objektum alapú” osztályozása több lépésben és több szinten (7. ábra (M15)). Az osztályozás során az azonos, vagy hasonló jellemzőkkel rendelkező lehatárolt képszegmensek kategóriákba csoportosítása történt meg (WASCHER 2005, 28).

Domborzati alapnak a GTOPO30-at, felszínborításhoz a CLC2000-et, néhol a Global Land Cover 2000-et használták fel (MÜCHER et al. 2010, 91). A létrejött folttérképnek annyi kategóriája lett, hogy értelmezése és megjelenítése is nehézkessé vált ${ }^{130}$. A neveket az alapadatok vonatkozó kategóriáiból generálták (8. ábra (M15)). Szükség volt olyan további kiegészítésekre, mint a domináns városi területek kiigazítása, a kis kiterjedésü foltok összevonása nagyobbakkal (WASCHER 2005, 30).

A LANMAP2 módszeréhez hasonló a Chuman és Romportl módszere mely 8 tényezőt ${ }^{131}$ figyelembe véve készítette el Csehország tájtípusainak térképét (9. ábra (M16)) (CHUMAN és ROMPORTL 2010, 200-209). Leírásuk szerint az adatokat egy folytonos skálából nominális skálába újraosztályozták és hierarchikus elválasztó klaszteranalízist használtak egy úgynevezett módosított TWINSPAN algoritmus felhasználásával, JUICE 7.0 szoftver segítségével több lépésben. Így végül 11 osztályra bontották az ország területét (CHUMAN és ROMPORTL 2010, 202). A 11 osztályban, akárcsak a LANMAP2 esetén, fơként a klimatikus jellemzők, azaz az első bemeneti paraméterek a meghatározók és a térkép tematikus értelmezését is ez jellemzi (CHUMAN és ROMPORTL 2010, 205-208).

Van Eetvelte és Antrop tájkarakter-térképük készítése során domborzatmodellek, ürfelvételek és felszínborítás-térképek alkalmazását is integrálják az elemzésbe és egy többlépéses folyamat során javasolják felhasználni valamennyi térképszerü alapadatot. Az első lépésben a tájtípusokat kategorizálják még raszteres adatmodellben és erre épül a tájrészletek lehatárolása, majd a tájtípus-információk hozzárendelésével a tájegységek identifikációja következik (10. ábra (M17)) (VAN EETVELDE és ANTROP 2009a, 162-163).

Soto és Pintó tájkarakter-térképezést végzett Porto Rico teljes területére. Első körben tájtípusokat határoltak le természeti sajátosságok alapján (11. ábra (M18)). A természettudományos adatokat egy-egy fedvény ${ }^{132}$ reprezentálta. Kilenc tájtípust definiáltak $^{133}$, majd ezekből tájegységeket generáltak. (SOTO és PINTÓ 2010, 720, 722).

\footnotetext{
13014 ezer polygon és 375 féle tájtípus született. A foltok láthatóan követik az $1 \mathrm{~km}$-es rácsháló szerkezetét. A módszer előnye, hogy a tájtípusokat elhatároló jellemzőket az alapadatok és azok csoportosításával az elemző maga adhatja meg, ugyanakkor a munkaigényes számítást és térképezést a szoftver végzi.

131 Tényezők: csapadék, hőmérséklet, tengerszint feletti magasság, lejtőmeredekség, kitettség, talajtípus, felszínborítás, rekonstruált természetes vegetáció. Meglátásom szerint ezek a paraméterek rétegenként egyesével is egymásnak megfeleltethető azonos jellegü típusokra osztanák a cseh tájat, tehát nincs nagy ellentmondás tartalma szerint, és vélhetőleg sok Európai országban alkalmazható lehet.

${ }^{132}$ Fedvények: tengerszint feletti magasság, lejtőmeredekség, földtani adottságok, potenciális vegetáció

${ }^{133}$ Nem lineáris (kategorikus) főkomponens-elemzést és k-means klaszterezést hajtottak végre.
} 
Jellema és társai a régió-növesztés (region-growing) eszközét javasolják a tájkarakterelemzésekhez. A módszer szerintük alkalmas arra, hogy meghatározzák a tájak karakterét, elkülönítsék, jellemezzék és értékeljék azokat. Új-zélandi mintaterületükön a régiónövesztés technikájával dolgoztak és határoltak le tájtípus foltokat. Az eredményt összevetették szakértői térképezéssel és azt találták, hogy a hasonlatosság a kétféle osztályozás között 34 és $100 \%$ között váltakozott. A régiónövesztés technikájával született eredményt ellentmondásmentesebbnek találták, mint a szakértői elemzést ${ }^{134}$ (JELLEMA et al. 2009, S161).

Több példa van az ökológiai, tájökológiai célú karakter-meghatározásra, ahol a táj veszélyeztetett ökológiai karakterének megőrzése érdekében folyik térképezés és karakterelemzés ${ }^{135}$ (GRIFFITHS et al. 2011). Akad olyan is, amely csak a táj elemei változásának mérésével, vektoros tájelem-adatbázis, vagy raszteres adatok elemzésével hoz következtetést a táj ökológiai karakterével kapcsolatban (GROOT, JELLEMA és ROSSINGA 2009,).

A vizenyős tájak karakter-meghatározásával foglalkozó könyvében Lyon vizuális interpretációs elemzéseinek tanulságairól ad számot (LYON 2001). Pozitívan nyilatkozik az irányítatlan képpont-osztályozás módszerének eredményeiről, de nem mélyed technikai részletekbe (LYON 2001, 56-87). Kutatásából egyértelmüen kiderül, hogy vizenyős élőhelyek esetében kifejezetten csak több felvételből lehet kiindulni és folyamatos monitorozás szükséges az élőhelyek meghatározásához is (LYON 2001, 39-46).

Antonson a tájkarakter-elemzés szerepét az infrastruktúra-tervezés szemszögéből járja körbe (ANTONSON 2009, 169-177) és a tájkarakter-térkép hatásvizsgálati alkalmazását javasolja. Egyszerű eszköztár-elemző módszere a „legnagyobb elemtől” (,grand features”) indít és tart a kisebb elemek felé, vizsgálja a domborzati elemeket, a vízhálózatot és a fontosabb felszínborítás foltokat, mintázatokat is (ANTONSON 2009, 174-1755) (12. ábra (M19)) ${ }^{136}$.

Cullotta és Barbera tájkarakter-terület jellemzésére használt fel felszínborítás adatokat. A CLC100 adatbázis alapján az Etna környéki hagyományos tájhasználatot térképezték, számos egyéb térképes információt (pl.: teraszos mezőgazdasági művelés adatbázist) is felhasználtak, és a feldolgozás folyamatát, szintjeit és lépéseit ábrán is megjelenítették (13. ábra (M13)) (CULLOTTA és BARBERA 2011, 103-104). A sokféle adatot egységes térinformatikai rendszerben dolgozták fel és a területen belül további tájtípusokat határoltak le (CULLOTTA és BARBERA 2011, 98-108).

\footnotetext{
${ }^{134}$ A régió-növesztés egy szegmentációs technika, mely a szegmenseket több körben osztályba sorolja. Minden körben a leginkább hasonló tulajdonsággal rendelkező szomszédos szegmenseket olvasztja össze. (JELLEMA et al. 2009, S162) Eredményét fel lehet használni arra is, hogy jellemezzük a lehatárolt területet, mert attribútum adatok a lehatárolt területek jellemzőjeként tovább használhatók (JELLEMA et al. 2009, S161-S174).

135 Ilyen példák általában természeti adottságokat vesznek figyelembe az identifikáció során, így a megnevezésben is ezek a jellemzők szerepelnek, és dominánsan típusokat határolnak le

${ }^{136}$ A 37 régiót definiáló térkép elkészítésekor a mintázatok elemzésekor figyelembe vették a természeti adottságokat, a lakónépesség sürüségét, a lakott területek mintázatát, a közlekedési hálózatok mintázatát is.
} 
A karakter-elemzést hazai és nemzetközi gyakorlatban közvetlenül kiegészítő passzív képalkotó távérzékelési eszköztárat és a kapcsolódó eljárásokat áttekintettem. Meglátásom szerint eszközhasználatukban is eröteljesen elválnak a gyakorlati és a tudományos jellegü munkák. A gyakorlatias karakter-elemzés célja általában egy konkrét tájkezelési feladat előkészítése, míg a tudományos jellegü elemzés inkább az eszköztárat korszerüsíti, újabb adatfeldolgozási eljárásokat keres, de mindezt csak távlati célok elérése érdekében, pl. egy általánosan használható tájkarakter-térkép elkészítése érdekében teszi. Utóbbiaknál kiemelkedik a karaktert automatikusan értékelő megoldások iránti igény, amelyek képfeldolgozási, vagy térinformatikai eljárásokat alkalmaznak. További kutatásomban fontosnak tartom, hogy a gyakorlatias és tudományos jellegü karakter-elemzési eljárások között a tájkezelési cél figyelembevételével az egyensúly megtartására törekedjek.

\subsubsection{Tájelemzési vagy tájkarakter-elemzési gyakorlatban elöforduló alátámasztó jellegü alkalmazások}

A tájkarakter-elemzést közvetlenül kiegészítő passzív képalkotó távérzékelési eszköztár és a kapcsolódó feldolgozási eljárások irodalmát az 1.3.2. fejezetben áttekintettem. A megoldandó kutatási feladatok megfogalmazásához azonban további publikációk kutatását tartottam szükségesnek. Hat lényeges témakör különlegességeit az alábbi fejezetekben tárgyalom:

- Domborzat-elemzés (1.3.3.1.) ～- Láthatóság-elemzés (1.3.3.4.)

- Indexek (1.3.3.2.)

- Megjelenítés (vizualizáció) (1.3.3.5.)

- Változás-elemzés (1.3.3.3.)

- Jellemzés és határvonal-térképezés (1.3.3.6.)

Ezekben a fejezetekben azokat az általános tájelemzési érdekességeket is figyelembe vettem, melyek a passzív távérzékelési eszköztár és feldolgozási eljárásaik újszerüen továbbfejleszthető alkalmazásával a hozzájárulhatnak a tájkarakter-elemzéshez.

\subsubsection{Domborzat-elemzés}

A domborzat a táj alapvető sajátossága. Az ELCAI projekt által áttekintett 51 tájkarakterelemzési példát megvizsgáltam (WASCHER 2005), és megállapítottam, hogy a leggyakrabban felhasznált ,jellemzo" a domborzat. Kertész is kiemelten kezeli a domborzat szerepét az tájalkotó tényezők között. Több olyan alapvető geomorfológiai formát sorol fel, melyet évtizedek óta különböző módszerekkel térképen ábrázolunk ${ }^{137}$ (KERTÉSZ 2003, 60). A német geomorfológiai térképpel példálózik, mely tartalmazza a domborzati elemek lejtését, görbületi íveit, kúpjait, mélyedéseit, völgyvonalakat (KERTÉSZ 2003, 64).

Csima és Göncz a táj terhelhetősége szempontjából a legfontosabb domborzati adottságoknak tartja a felszínformák, a lejtésviszonyok, az égtáji kitettség és a reliefenergia vizsgálatát és a terhelhetőség esetében ezeket tartja leginkább elemzendőnek (CSIMA és GÖNCZ 2002, 1819). Csima több karakter-elemzése során is alapvetőnek tekinti a domborzatot és az általa

\footnotetext{
${ }^{137}$ lejtőkategória, a lejtők átlaga, a hegy-idomtani formák (fennsíkok, sasbércek, hegygerincek) medrek, völgyek
} 
meghatározható karakter-jegyeket (CSIMA és MÓDOSNÉ BUGYI 2010), (CSIMA és MÓDOSNÉ BUGYI 2010, 208-210). A domborzat legfontosabb jellemzője, a tengerszint feletti magasság jelenik meg Kollányi kistáj-határos térképén (KOLLÁNYI 2006, 19). Az OTRT tájképvédelmi övezetével kapcsolatos tanulmányában publikált reliefenergia-térkép a terület-egységen belüli magasságkülönbség mértékét jelzi (KOLLÁNYI 2004, 8). Kalotaszeg tájkarakter-elemzéséről szóló értekezésének harmadik tézisében Eplényi a jellegzetes felszínformákat (pl. agroteraszoltság) a kalotaszegi táj karakterének legerősebb mintázataként határozza meg, mely elkülöníti a szomszédos tájrészletektől (EPLÉNYI 2012).

A domborzat-elemzéshez hozzátartozik a vízrajz elemzése is. Használatos a digitális domborzatmodellek azon képessége, mely térinformatikai elemzőszoftverek többségében található hidrológiai elemző funkcióval lehetőséget ad a vízhálózati elemek potenciális helyének kirajzolására, vízlefolyás-vizsgálatok készítésére (COROZA, EVANS és BISHOP 1997, 13-23). Egyes kutatásokban célszerü lehet a vízgyüjtő-területek lehatárolása is (APAN, RAINE és PATERSON 2002, 47), mely ma már online is elérhető alkalmazás (INT-030 ${ }^{138}$ ).

A domborzati formák osztályozásával foglalkozott Drăguţ és Blaschke (14. ábra (M21)). Kutatásukban egy romániai (15. ábra (M22)) és egy németországi mintaterületen, eCognition szoftverrel digitális terepmodellt használtak és objektum-alapú képelemzés módszerével lejtőformák típusait határozták meg (DRĂGUŢ és BLASCHKE 2006, 334) ${ }^{139}$.

Konkolyné SRTM domborzatmodellt alkalmazott szintvonalas térkép-generálásra, lejtőkategória- és kitettség-térképet készített, melyeket a tájhasználat elemzéséhez, erózió- és deflációveszély megállapításához használt KONKOLYNÉ GYURÓ 2006b, 7). A feltárt tanulmányok között nem találtam a passzív képalkotó távérzékelésből származó ASTER GDEMv2 modell használatát leíró publikációt, ezért indokoltnak tartom az adatbázis domborzat-elemzési alkalmasságának kutatását.

\subsubsection{Indexek}

A tájkutatásban elterjedt indexek térbeli mutatóként is értelmezhetők. Alkalmasak arra, hogy segítségükkel térbeli eltéréseket és időbeli változásokat tárjunk fel. Ebben a fejezetben a térbeli indexekkel foglalkozom. A térbeli mutatók alkalmazásával tájak területi sajátosságait tudjuk összevetni, mely fontos adalék lehet a tájkarakter-elemzéshez. A passzív képalkotó távérzékelés fontos kimeneti adatait jelentő indexek legnagyobb csoportja a tájkutatásban és különösen a tájökológiában, a felszínborítási adatokkal kapcsolatos.

\footnotetext{
${ }^{138}$ INT-030: A DEM Explorer honlapja (2014. 02. 05.)

139 Olyan formákat neveznek meg Dikau alapján mint „flat slope”, „nose slope”, „head slope”, „side slope”, „peak”, „toeslope” „shoulder” és „,negative contact”. A módszer előnye, hogy nem abszolút magasságokkal, hanem relatív magasságokkal dolgozik, így a világ bármely más területén adaptálható és a geomorfológiai kutatások egy fontos eszközének tekintik (DRĂGUȚ és BLASCHKE 2006, 330-344)
} 
$\mathrm{Az}$ Európában alkalmazott tájindikátorok áttekintése során Kollányi három nagyobb csoportot nevezett $\operatorname{meg}^{140}$ (KOLLÁNYI 2004, 19), Tirászi pedig öt fó csoportot különített el $^{141}$ (TIRÁSZI 2008, 104). Tirászi megállapítja, hogy az utóbbi évtizedben jelentek meg a tájak látványára és a táj komplex értékelésére törekvő kezdeményezések, ahol az antropogén és természeti tényezők egyaránt meghatározó szerepét elismerik (TIRÁSZI 2008, 104).

Az esztétikai indikátorok több évtizedes múltra tekintenek vissza. Fábos és Caswell például az 1970-es években légifelvételeket javasolt „visual landscape complexity” és „visual landscape compatibility" néven a látvány összetettségének és összeférhetőségének elemzésére (FABOS és CASWELL 1977, 101-102). Ezeket a mutatókat részben más szerzők 1960-as és 1970-es években megjelent munkáira (Zube, Brush, Berlyne, Vitz, Day, Terwillinger) alapozták. A tájban kontrasztosan megjelenő szegélyeket jelentősnek tartják ${ }^{142}$.

Az ELCAI Projekt tanúsága szerint Európában a domborzat után a felszínborítás a leggyakrabban figyelembe vett tájkaraktert potenciálisan meghatározó tényező (WASCHER 2005, 12-26). A projekt több tájkarakterrel összefüggésbe hozható tájindikátort bemutat (WASCHER 2005, 88, 91, 92), melyek közül sok a felszínborításra épít. Kollányi, Kerényi és Tirászi különböző munkáiban összesen több mint 40 tájindikátort sorol fel (KOLLÁNYI 2004) (KOLLÁNYI 2006 39-43) (KERÉNYI 2007, 145, 174-175) (TIRÁSZI 2011). Kollányi az $\mathrm{OTRT}^{143}$ tájképvédelmi övezetének lehatárolásához és a környezetállapot értékeléshez készült munkáiban indikátorok segítségével térképesen jellemezte Magyarország tájait. Részletes bemutatást és térképezést végzett a szegélysűrüség indikátor, a Shannonféle diverzitás index, a látvány mutató, és „az értékesebb szegélytípus” mutató kapcsán ${ }^{144}$ (KOLLÁNYI 2004), (KOLLÁNYI és CSEMEZ 2006).

A tájjal összefüggő politikák hatásainak vizsgálatára alkalmazható indikátorok közül a legfontosabbak a tájhasználatot és annak intenzitását jelzők, a történetiséget és az esztétikai jellemzőket kifejezők. Tirászi szerint ezek a felszínborításból levezethetők. Az indikátortípusok kipróbálásához szükséges adatbázisokat összegyüjtötte és foglalkozott alkalmazásuk korlátaival (TIRÁSZI 2011 6. tézis). A javasolt indikátorok közül többet mintaterületen is tesztelt. Mintaterületi tájkarakter elemzései során megállapította, hogy a meghatározott kulcsjellemzők jó alapot jelentenek az indikátorképzéshez (TIRÁSZI 20114.2 tézis).

Az indexek többféle tudományos kutatáshoz könnyen adaptálhatók. Sokan hivatkoznak olyan módszerekre, melyek alkalmazásával gyorsan, egyszerüen tudják jellemezni a tájat. Ez a tájökológiai kutatásokban igen gyakori. Több tanulmány használja és hivatkozza McGarigal

\footnotetext{
${ }^{140} 1$. biológiai, fizikai vagy biodiverzitás mutatók, 2. szocio-ökonómiai mutatók, 3. tájesztétikai mutatók

141 1. fizikai megjelenés, 2. ökológiai állapot, 3. tájgazdálkodás, -védelem és -megőrzés, 4. kulturális értékek, 5. látvány

${ }^{142}$ meredek hegyoldalak, vízfelszín és vegetáció (erdő, legelő) vagy mesterséges felszínek szegélye

${ }^{143}$ OTRT: Országos Területrendezési Terv

144 A látvány mutató, és „az értékesebb szegélytípus” mutató lényege, hogy bizonyos területhasználatokhoz, vagy azok szegélyéhez magasabb értéket társít az elemző és ennek megfelelően a felszínborítás adatbázis alapján modellezi és egyben minősíti is a táj esztétikai értékét.
} 
Fragstats alkalmazását és a népszerü tájökológiai indexeket (BLASCHKE 2006, 209), VAN EETVELDE és ANTROP 2009b, 901-910) (JI et al. 2006, 869-879), (DE LA FUENTE DE VAL, ATAURI és DE LUCIO 2005, 393-407) (YEH és HUANG 2009, 151-162) (APAN, RAINE és PATERSON 2002, 46). 2006 óta útmutató ismerteti a témában a használható megoldásokat (BOTEQUILHA LEITÃO et al. 2006). Ismert olyan kutatás is mely a tájkarakter-elemzés módszerét a tájökológiai elemzés módszerével egészítette ki (16. ábra (M23)) (KIM és PAULEIT 2007, 264-274). Ezek a kutatások rendszeresen használnak felszínborítás adatokat, mint a táj ökológiai sajátosságainak jellemzésére.

Brabyn új-zélandi mintaterületének természetességét elemezte (BRABYN 2005, 23-34). Három fontos mutatójára (felszínborítás, infrastruktúra és telekméret) három távérzékelési képfeldolgozási elemzést alkalmazott egy $100 \mathrm{~m}$-es felbontású raszteres adatbázison ${ }^{145}$. Minden réteget öt osztályba sorolt (17. ábra (M24)) és természetességi fokok szerint úgynevezett ,aggregáló ostályozást” végzett (BRABYN 2005, 23-34).

Az ELCAI projektben három ENRISK (nyitottság, koherencia, sokféleség) és két IRENA (állapot és sokféleség) indikátor áttekintése történt meg. A felelösök a CLC adatbázist és változás-adatbázist az ENRISK indikátoroknál alkalmasnak és technikailag is lehetségesnek találták a vizsgálatra (WASCHER 2005, IX). Az egyik ilyen indikátor a „,nyitottság”, melynek vizsgálatát a résztvevők elvégezték. Ez az egyetlen indikátor, melyről valamennyi aktív résztvevő megállapította, hogy használata országában és a LANMAP2 keretek között akár európai léptékben is ésszerü és technikailag is megvalósítható (WASCHER 2005, 96).

Hazánkban több területen foglalkoznak a táj- vagy településkép nyitottságával (TIRÁSZI 2011, 83-89), (KOLLÁNYI 2004, 13), (BENKÖ 2010), de külföldön is gyakran említik potenciális tájindikátorként (TVEIT 2009, 2882-2888), (COLLINS és KEARNS 2010, 435446). Egyes területeken (vízpartokon, nyitott legelökön) bizonyos kutatások még a fejlesztés mozgatójaként is azonosították (COLLINS és KEARNS 2010, 440). A nyitottságot úgy is vizsgálták, hogy fényképes kérdőívezés eredményeit összevetették a holland táj nyitottságának térbeli modellezésével (PALMER és LANKHORST 1998, 71-73) és eredményeik igazolták, hogy a nyitottság érzete összefügg azzal, hogy milyen mértékben „telített” a táj fákkal vagy épületekkel (PALMER és LANKHORST 1998, 65).

Norvég is kutatók részletesen foglalkoztak a táj nyitottságával (ODE, TVEIT és FRY 2010, 24-31). A földfelszíni elemek ,áteresztő” mértéke alapján a légifelvételek interpretációja során három osztályt alkalmaztak ${ }^{146}$ (ODE, TVEIT és FRY 2010, 26-27). Tirászi doktori

145 1. felszínborítás mintázatát „majority” (többség) filtert használva egyszerüsítette, hogy meghatározza a domináns foltokat, mert nagyon szabdalt volt a felszínborítás térkép ( $1 \mathrm{~km}$-es sugárral). 2. vonalas infrastruktúra-hálózat sürüségét $\left(\mathrm{m} / \mathrm{km}^{2}\right)$ „,density” sürüség filterrel „,keni el” egy raszteres topográfiai térkép feldolgozásával. 3. telekméret elemzés során „mean” filtert majd „minimum filtert” (focal neighbourhood, mean és minimum filterek) alkalmazott az átlagos és a legkisebb telekméret jellemzésére (1km-es sugárral).

146 1. nyitott (nincs, vagy alig van növényzet), 2. félig nyitott (átlátni helyenként a növényegyedek között), 3. zárt (már nem láts zik felülnézetből a földfelszín) 
értekezésében tesz javaslatot a zártság és nyitottság CLC adatbázis alapján történő kimutatására, a felszínborítás kategóriák nyitott, félig zárt és zárt kategóriába történő besorolásra (TIRÁSZI 2011, 83-89). A felszínborítás-adatbázis nagy foltméretei miatt térségi szinten a zöldsávok sürüségének vizsgálatát is indokoltnak látja.

Dramstad és szerzőtársai az agrártáj változásának vizsgálatát kívánták megalapozni a $3 Q$ programban a politikák és egyéb intézkedések hatásaként az agrártájban érzékelhető eltérések meghatározására (DRAMSTAD et al. 2001, 257-268). Ennek érdekében Norvégiában számos indikátort és $1474 \mathrm{db}$, egy négyzetkilométernyi mintaterületet jelöltek ki (18. ábra (M25)). Módszerük a légifelvételek interpretációja és az indikátorok témájának megfelelő tájelemek térképezése volt ${ }^{147}$. Az 5-évente elkészülő ortofotó sorozat felhasználásával változási folyamat monitorozását tüzték ki célul (DRAMSTAD et al. 2001, 258).

\subsubsection{Változás-elemzés}

A tájkutatásban általában is javasolt, hogy több időpontban vizsgálódjunk, mert a táj csak változásában érthető meg. Különösen igaz ez, ha magát a változási folyamatot kívánjuk feltárni, melyhez legtöbbször nem elegendő két vagy három időpont állapotának vizsgálata, hanem hosszabb idősorok elemzésére is szükség lehet. A táj változása bekövetkezhet természetes folyamat eredményeként például szukcesszió során, melyet Kerényi a legjellemzőbb folyamatként említ (KERÉNYI 2007, 99), de gyakori a természeti katasztrófák hatására, a felhagyott müvelés, vagy jelentős emberi beavatkozások (bányászat, beépítés, lecsapolás stb.) következményeként megvalósuló jelenség is.

A tájváltozás térképezésére, elemzésére irodalomkutatásom eredményei szerint kiválóan alkalmasak a felszínborítást reprezentáló adatok. Ilyen adatok tájkarakter-történeti témájú anyagban is használatosak az erdőterület és a beépített terület alakulásának térképezésére (AHERN 2004, 4, 3, 48, 76, 96). A legegyszerübb tájváltozás-vizsgálati megoldás a különböző korokból származó terepi fényképek összevetése, melyekkel a táj egyes minőségi, látványbeli változásai feltárhatók (TIRÁSZI, TERPÓ és KONKOLY-GYURÓ 2013, 325333), vagy egyedi tájértékek fennmaradása vizsgálható (NAGY és CSIMA 2010, 237).

Gyakran felmerül a táj ugyanabból a nézőpontból történő fényképezésének szükségessége. Pedroli példája egy több évtizedes különbségekkel fényképezett út történetét mutatja be úgy, hogy a fényképeket egymás mellé rendezi (PEDROLI et al. 2007, 13). Többen nem csak terepi, hanem történeti légifénykép-tárak áttekintését javasolják (ODE, TVEIT és FRY 2010,

\footnotetext{
${ }^{147}$ Indikátorok: 1 mezőgazdasági és nem mezőgazdasági területek kiterjedése, 2. élőhely-foltok átlagos mérete, és a foltok száma, 3. különféle területhasználati szegélyek hossza, 4. Shannon féle diverzitás index, 5. Sokféleség, 6. Pontszerü elemek száma (sziklakibúvások, szoliter fák, medencék, élőhely-szigetek), 7. Vonalas elemek száma (folyók, árkok, cserjesávok), 8. Vízszegély hossza, 9. Utak, ösvények hossza. 10. Kőfalak és kerítések hossza, 11. A szabadon elérhető, bejárható mezőgazdasági terület aránya, 12. Az úthálózat folyamatossága, 13. Az utak 100 m-es környezetében lévő területek kiterjedése, 14. Történeti jelentőségü épületek száma (1900 előttiek) 15. Sírhelyek, romok, kőhalmok, korábbi művelés nyomai (DRAMSTAD et al. 2001, 260).
} 
26), vagy alkalmazzák tájtörténeti sajátosságok feltárására (PECCOL, BIRD és BREWER 1996, 355-367). Peccol és társai egy légifotó-interpretációs módszert is alkalmaztak, melyben osztályozták a légifotóról leolvasható tájelemeket (PECCOL, BIRD és BREWER 1996, 360).

Skånes és Bunce bizonyos dél-svédországi mezőgazdasági területek erdősülését vizsgáló történeti karakter-elemzést folytattak. Ábrájuk illusztrálja, hogy számos egyéb adat mellett történeti légifelvételekkel egészítették ki vizsgálatukat (19. ábra (M26)) (SKÅNES és BUNCE 1997, 65). A félig nyitott tájakból a zárt tájakba való átalakulás folyamatát tárták fel az erdősülés folyamatának vizsgálatával. Igazolták, hogy a gyepes-erdős vidékies tájak zárt erdős „nem vidékies” vadonná alakulnak át ${ }^{148}$ (SKÅNES és BUNCE 1997, 61-75).

Ode és szerzőtársai norvégiai mintaterületükön történeti légifelvételek elemzésével tapasztalták a tájkép záródása és nyílása jelenségeit (ODE, TVEIT és FRY 2010, 27). A VisuLands projekt eredményeként tájindikátor-képzéshez és tájváltozás-vizsgálathoz többféle típusú adatot javasolnak. Ábrájukon indikátor-készletet javasolnak a vizuális tájkarakter elemzésére (ODE, TVEIT és FRY 2010, 24-31). Ebben kiemelt szerep jut a terepi fényképeknek, a légifelvételeknek és a felszínborítás adatoknak (20. ábra (M27)).

Számos forrásban találtam nyomát annak, hogy légi-, vagy ortofotó alapján készített felszínborítás adatokat használtak fel a hagyományos tájhasználat változásainak detektálására (VAN EETVELDE és ANTROP 2009b, 904). Ezek azt igazolták, hogy a szőlőkkel, olajfaligetekkel, legelőkkel, kaszálókkal jellemzett mezőgazdasági táj minőségi változása is interpretálható (SERRA, PONS és SAURÍ 2008, 189-209) (ZOMENI, TZANOPOULOS és PANTIS 2008, 38-46) (TAILLEFUMIER és PIÉGAY 2003, 267-296), (VAN EETVELDE és ANTROP 2004, 79-95) (MOTTET et al. 2006, 296-310).

A táj időbeli változásának kifejezésére elterjedt az előző fejezetben (1.3.3.2.) ismertetett térbeli indexek alkalmazása. A tájkutatással foglalkozó szakirodalomban az ilyen mutatókat tömegesen alkalmazzák tájváltozás jellemzésére. Dibari többször is használja ezeket ${ }^{149}$ müholdfelvételekből készített felszínborítás adatbázisaira épülő kutatásaiban, például városi területek terjedésének (DIBARI 2007, 308-313), vagy a Yellowstone Nemzeti Park területén 1988-ban esett tűzesetek hatására változó tájjelleg elemzésére (DIBARI 2003, 275-284).

Yeh és Huang a tájban található foltok sokféleségének változás-elemzésével a tájdiverzitás térbeli és időbeli mintázatát tanulmányozta Tajvanon, Taipei térségében. (YEH és HUANG 2009, 151-162). Légifelvételekből digitalizált felszínborítás adatokat használtak fel. Shannon féle diverzitás-elemzést végeztek mozgóablakos elemzéssel Fragstats használatával 1971-es és 2005-ös időpontokra. Térképes ábrákkal és a diverzitás-elemzéssel is igazolták, hogy nem

148 Annak érdekében, hogy az öt felszínborítási osztály egymáshoz viszonyított változását meghatározzák főkomponens-analízist használtak. Alkalmasnak találták arra, hogy összefoglalják és illusztrálják a tájváltozás folyamatában feltárt különbségeket és mennyiségeket (SKÅNES és BUNCE 1997, 70, 73).

149 pl.: largest patch index (LPI), fractal dimension index, euclidean nearest neighbour (ENN), interspersion and juxtaposition index, (DIBARI 2007, 305) 
egyszerüen csak a felszínborítás változott (beépített területek növekedése, erdősülés), hanem a mezőgazdasági müvelés alatt álló apró területek „eltünésével” a tájdiverzitás is jelentősen csökkent (21. ábra (M28)), a táj homogénebbé vált (YEH és HUANG 2009, 151-162).

A Landsat müholdfelvételek használata és a képpont-osztályozási eljárások alkalmazása igen bevett gyakorlat a markáns tájváltozási folyamatok feltárására. Ji és társai Kansas város területi változásait elemezték a Jensen féle supervised maximum likelihood osztályozási módszerével $^{150}$ (JI et al. 2006, 865). Apan és szerzőtársai egy ausztráliai mintaterületen a vízparti területek változásait elemezték NDVI index, irányított képpont-osztályozás és change detection funkciók alkalmazásával (APAN, RAINE és PATERSON 2002, 46).

Jat és társai egy indiai város növekedését vizsgálták 1977 és 2001 között (JAT, GARG és KHARE 2008, 26-43), míg Wu és társai kínai városok terjeszkedését tanulmányozták 19862001 időszakban (WU et al 2006, 322-333), majd a várható fejlődést modellezték. A szcenárióépítés és területhasználati modellezés a tájváltozás-vizsgálat egy speciális változata mely a jövőre vonatkozik. Meyer mezőgazdasági térségben modellezi és elemzi a várható tájváltozást, amihez ASTER és Landsat felvételeket javasol (MEYER 2006, 86, 106). Számos egyéb példa is akad modellezésre, melyek felszínborítás adatok mellett domborzatot (BOHNET és SMITH 2007, 139) és vízrajzi adatokat (STEINITZ et al. 2003, 40-129), (HULSE, GREGORY, és BAKER 2002, 82, 109, 147) használnak fel.

A szcenáriókészítés interjúkészítéssel kombinálva, workshopokon is alkalmas eszköz a tájjelleg-változás értékelésére (SOUTHERN et al. 2011, 179-189). Pedroli szerint ugyan vannak módszerek arra, hogy a szcenáriókat, mint egy időutazó hajó fedélzetén érintettekkel közösen értékeljük, de arra, hogy a tájváltozás élményét teljességgel éljük át úgy, hogy a hagyományokat, értékeket egyaránt megtapasztaljuk, nincsen (PEDROLI et al. 2007, 14).

\subsubsection{Láthatóság-elemzés}

A táj és elemeinek láthatósága alapvető tényező a táj jellegének megítélésében. Egyes elemek láthatósága karakteresen meghatározhatja a tájképet pozitív és negatív értelemben is. A Landscape Institute kiadványa több eset kapcsán is hatásvizsgálati nézőpontból foglalkozik a láthatósággal. A láthatóság-elemzést a vizuális hatások kommunikálására az egyik legalkalmasabb eszköznek tartja (THE LANDSCAPE INSTITUTE 2002, 101).

Láthatóság-elemzési tapasztalat a technikai alkalmazások körében az esettanulmányok áttekintésével szerezhető. A Landscape Institute útmutatójában hulladék-kezelő üzem láthatósága jelenik meg térképen, ahol a látótávolságot különbözö sugarú koncentrikus körökkel érzékeltetik (THE LANDSCAPE INSTITUTE 2002, 54-55, 74, 106), míg Garré és

\footnotetext{
${ }^{150}$ Négy nagyobb osztályt határoltak le: beépített terület, erdő, nem erdős zöldfelület (mezőgazdasági területek is), és a vízfelszín. Ezt követően Frags tats programmal tájmetriai vizs gálatokat folytattak annak érdekében, hogy foltsürüséget (PD) legnagyobb foltméretet (LPI) és egyéb mutatókat számítsanak a területre (JI et al. 2006, 866).
} 
szerzőtársai a látótávolsággal arányosan eltérő színeket használ (GARRÉ, MEEUS és GULINCK 2009, 130). Egy harmadik tanulmányban a színskála, a vizsgálat fókuszában lévő látható építményterülettel arányosan sötétül (ROGGE, NEVENS és GULINCK 2008, 80-81).

A tájkarakter-elemzés feladatának tekinti, hogy a beruházások esetén megvizsgálja az új létesítmények láthatóságát. A vizsgálathoz a domborzat kézi vagy számítógépes elemzése javasolt (THE LANDSCAPE INSTITUTE 2002, 73). Ilyen esetben meg kell határozni:

- a vizuális hatás valószínűsíthető zónáját (terület, ahonnan látható a létesítmény)

- az elsődleges szerepü nézőpontokat (kilátóhelyek, fontosabb útvonalak stb.)

- a potenciálisan érintett szemlélök körét (lakosok, látogatók, gazdálkodók stb.) (THE LANDSCAPE INSTITUTE 2002, 75)

Landscape Institute útmutatója felsorolja azokat a tényezőket is, melyek a puszta láthatóságon túl fokozzák a tájban megjelenő változás hatását. Ide sorolja számos tényező mellett a közvetett változások hatását, az összegződő hatásokat, a táj érzékenységét, a hatás erősségét és jelentőségét, a szemlélők érzékenységét (THE LANDSCAPE INSTITUTE 2002, 84-95).

Kollányi és Csemez a tájképvédelmi övezettel kapcsolatos módosító javaslatában többször említi a tájkarakter megörzésének fontosságát. A települések rendezési terveiben javasolja kijelölni a kilátás- és látványvédelmi övezet határát, amely a tájképi értéket képező kulturális örökségi területeket, a helyi védelem alatt álló természetvédelmi területeket, azok környezetét, valamint a település arculatát, karakterét meghatározó fontos területeket kell tartalmazza. (KOLLÁNYI és CSEMEZ 2006, 21) A javaslat lényegét a törvény 21. § (5) pontjában is tartalmazza (2003. évi XXVI. Törvény jelenleg hatályos változata).

A tanulmányok többsége láthatóság esetében épített létesítménnyel vagy épülettel foglalkozik. Rogge és szerzőtársai már létező és tervezett üvegházak láthatóságát vizsgálták három változatban $^{151}$ (ROGGE, NEVENS és GULINCK 2008, 80-81). Javaslataikat az alapján adták meg, hogy a láthatóság-fedvényeket egyesével megvizsgálták és kiválasztották a változatok legjobb kombinációját. Épületek láthatóságát vizsgálták Sztejn és társai is. Szerintük meg kell vizsgálni az észleléskor keletkező szubjektív értékítéletet is, és ezt egyeztetni szükséges a láthatóság-térképekkel ((SZTEJN, ŁABĘDŹ és OZIMEK 2012, 234). Akad olyan alkalmazás is, mely a terepen készült fényképeket láthatóság-fedvények alapján térinformatikai rendszerbe illeszti és jellemezi (BRABYN és MARK 2011,1120).

Ode és társai sokat foglalkoznak a táj nyitottságának kérdésével és ezen belül a látványában nyitott területek arányával, foltjaival, a foltok kiterjedésével, alakjával és mindezek változásának jelentőségével ${ }^{152}$ (ODE, TVEIT és FRY 2010, 25). Többféle szoftver alkalmas arra, hogy domborzat, vagy felszínmodell alkalmazásával láthatóság-fedvényeket készítsen.

\footnotetext{
${ }^{151}$ Három változat: 1. jelen állapotban, 2. a tervek teljesülése esetén, 3. alternatív megoldás esetén, ahol több takarónövény telepítése javasolt.

${ }^{152}$ Kutatásukban láthatóság-indikátorokat is javasolnak, mint: 1. a látható terület, 2. a látható terület kerülete, 3. a látósugár hossza (ODE, TVEIT és FRY 2010, 28).
} 
Ismert olyan elemzés is, ahol ArcGIS-t (ROGGE, NEVENS és GULINCK 2008, 78) de olyan is melyben AutoCAD Civil3D-t alkalmaztak (SZTEJN, ŁABĘDŹ és OZIMEK 2012, 234). A domborzatmodellek száma növekszik, és bár a Landscape Institute sztereoszkópikus úton nyert magassági adatokat (THE LANDSCAPE INSTITUTE 2002, 150) és térinformatikai elemzést javasol, nem találtam olyan kutatást, ami ASTER GDEMv2 modellt használta volna.

Garré és társai egy Belgiumban készült kutatásban vizsgálták, hogy milyen kilátás nyílik az utakról és az automatikusan végzett kilátás-értékelés hogyan illeszkedik a kilátás látványát felmérő „vizuális kérőívezés” eredményeihez (GARRÉ, MEEUS és GULINCK 2009). Az elemzéshez légifotókból készített felszínborítás-térképet használtak és egy komplex módszert alkalmaztak a térképes és a terepi fényképi adatok összevetésére ${ }^{153}$ (22. ábra (M29)) (GARRÉ, MEEUS és GULINCK 2009, 128).

\subsubsection{Megjelenítés (Vizualizáció)}

Látvány-megjelenítést évezredek óta azért használ az ember, hogy megértse környezetét, tanulmányozhassa és összevethesse egyes elemeit, sajátosságait. Bishop és Lange megfogalmazásában a vizualizációt azért is használjuk, mert megadja a lehetőséget, hogy megtapasztaljuk a körülöttünk zajló változásokat még az előtt, hogy megtörténnének (BISHOP és LANGE, 2005, 3). Alapvető cél, hogy megjelenítsük a táj múltbéli és jövőbeli változásait, annak érdekében, hogy a táj kezelésében közös jövőképet alkossunk.

A táj a passzív képalkotó távérzékelés felvételein ismertetve önmagában is vizualizációnak tekinthető. A fényképeken, légi- vagy ürfelvételeken a tájjelleg bizonyos képi vonatkozásai feltárulnak. A tájkezelésben éppen a táj közérthető megjelenítése miatt fontos a vizualizáció szerepe. Fjellstad kutatásában volt olyan kérdőívezett, aki levelében fényképet küldött, hogy elmagyarázza a tájkezelési kérdésre adott válaszát (FJELLSTAD et al. 2009, 1146). Bell egy terepi fényképen mutatja be, hogy milyen érdekes lehet a szabadkézi rajz (szkeccs) és a digitálisan feldolgozott képek ${ }^{154}$ összevetése (BELL 1999, 48-50).

A tájkezelésbe bevonni szánt érintettek részvételét, megkérdezését több gyakorlati szakember is fontosnak tartja (SOUTHERN et al. 2011, 179-189), (BOHNET és SMITH 2007, 137-152). Ennek érdekében a 20. század utolsó éveiben egyre többen javasolták a

153 A kutatócsoport első körben az utakról nyíló kilátás értékelését végezte el az alapján, hogy milyen paraméterek jellemzik:

- a látótávolságot („,view”), (az utakról nyíló látósugarak hossza alapján),

- a látható terület alakját („shape”), (a látható terület összetettsége, azaz a látósugarak végpontjainak távolsága alapján),

- a látóhatárt („,sky”), (a házfalnak ütköző látósugarak száma alapján)

Második lépésben egy online vizuális kérdőívezést készítettek fényképek alapján arról, hogy milyen mértékben kedvelik a feltáruló látványt a megkérdezettek. A fényképeken a kérdöívezéstől függetlenül vizuálisan interpretálták és osztályozták a legfontosabb tájelemeket és ez alapján vetették össze a preferenciavizsgálat eredményeit a kilátás vizsgálat eredményeivel (GARRÉ, MEEUS és GULINCK 2009, 133).

${ }^{154}$ Bell példája egy élkeresés („Find Edges”) művelettel elemzett tájkép, mely szerinte segíti a látvány értékelését. 
digitális látvány-megjelenítési eszközöket, annak érdekében, hogy a közösség a számára kedvező javaslatokat mutassa be a tervező (DUERKSEN és GOEBEL 1999, 33), (SCHMID 2001, 213-221), (THE LANDSCAPE INSTITUTE 2002, 33-34), (LEWIS és SHEPPARD 2006), (BOHNET és SMITH 2007, 137-152), (SHEPPARD és CIZEK 2009).

Igen gyakori táj-elemzési módszer a tájat fényképekkel bemutató „vizuális kérdőívezés”. Egyszerüsége miatt rengeteg tanulmány használja tájpreferencia felmérésre. Többségében terepi fényképeket alkalmaznak. A tájértékelés mellett elterjedt a környezet-pszichológiában (OHTA 2001, 387-403) és a turizmusban is (FAIRWEATHER és SWAFFIELD 2001, 219228). Egyes kutatások igyekeznek különböző csoportokra fókuszálni ${ }^{155}$, csoportvéleményt felmérni és közöttük érzékelhető eltéréseket meghatározni (KEARNEY et al. 2008, 117-128) (ROGGE, NEVENS és GULINCK 2007, 174).

A fényképes tájpreferencia-felméréseket használják fejlesztések előkészitési fázisában is, hogy megtudják, hogyan viszonyulnak a helybéliek a tervezett fejlesztésekhez (KEARNEY et al. 2008, 117-128), a környezeti hatásokhoz (CLOQUELL-BALLESTER et al. 2011) vagy egy védettség kibővítéséhez (LOKOCZ, RYAN és SADLER 2011, 65-76). A módszert arra is alkalmazzák, hogy igazoljanak olyan korábbi területi elemzéseket, mint például egy láthatóság-elemzés (22. ábra (M29)) (GARRÉ, MEEUS és GULINCK 2009, 127), eredményeit összevessék korábbi becslésekkel (FRANCO et al 2003, 119-138), vizsgálják a vizuális és ökológiai indikátorok közötti kapcsolatot. (FRY et al. 2009, 944), vagy feltárják, milyen összefüggés lehet a szép tájkép és a térbeli mintázat között (DE LA FUENTE DE VAL, ATAURI és DE LUCIO 2005, 393-407).

A legtöbb esetben azonban csak egyszerü preferencia-felmérésről van szó. Szeretnék megtudni, hogy egy különleges tájjelleghez a kérdöívezettek hogyan viszonyulnak, mennyire kedvelik a látott tájrészleteket (WALKER és RYAN 2008, 141-152) (SEVENANT és ANTROP 2009, 2889-2899) (KENT és ELLIOT 1995, 341-355) (TVEIT 2009, 2882-2888). A nagymintás látványpreferencia-vizsgálatokban azonban félrevezető lehet, ha a megkérdezettek csak azt tudják elmondani, hogy tetszik, vagy nem tetszik nekik a látvány. Palmer és Hoffman vizsgálja az ilyen felmérések megbízhatóságát a tájak esetében és a fényképes megjelenítés érvényességét ${ }^{156}$ (PALMER és HOFFMAN, 2001, 149-161).

Bishop és Lange tanulmánya sokoldalúan mutatja be a különféle megjelenítési technikákat a fotomontázstól a 2,5D és 3D modelleken át a virtuális valóság rendszerekig (BISHOP és LANGE 2005, 10-13), és kiemeli ezek szerepét a változások bemutatásában. A továbbiakban ennek megfelelő bontásban tárgyalom a passzív képalkotó távérzékelési alkalmazásokat.

\footnotetext{
${ }^{155}$ turisták, háztulajdonosok, gazdálkodók, tájjal foglalkozó vagy környezet-tudatos szakértők

${ }^{156}$ Felvetik a kérdést, hogy hány fényképre van szükség ahhoz, hogy egy tájat megfelelően érzékeltessünk a kérdőívezett számára, hogy a felmérések hány éven belül tekinthetők elavultnak (PALMER és HOFFMAN, 2001, 150-152). Véleményük szerint a 60 fokos látószögben látható fénykép nem ugyanazt a térélményt adja, mint a 120 fokos valóságos látószög a terepen.
} 
A fotomontázs alapú vizualizációk a kép szerkesztésére építenek, többféle nézőpont látványát is felhasználhatják. Gyengeségük, hogy az apró részletek (szerkezet, szín, anyag) nehezen módosíthatók. (DOCKERTY ET AL. 2006) (SOLIVA és HUNZIKER 2009) (TRESS és TRESS 2003). Ahern karakter-elemzési tanulmányában a fotomontázst használta a partközeli beépítés változás-jelenségének érzékeltetésére (AHERN 2004, 13). Egy másik kutatás hatásvizsgálathoz végzett percepció vizsgálatot kérdőívezéssel, melybe a módosított fényképeket vonta be (CLOQUELL-BALLESTER et al. 2011). A Landscape Institute is ezt a technikát javasolja az épített létesítmények megjelenítésére terepi, vagy madártávlati fényképek felhasználásával (THE LANDSCAPE INSTITUTE 2002, 61, 79, 103).

A 2,5 dimenziós tájmodellek alkalmazása a térségi szintű vizualizációkban gyakori. A San Pedro völgy jövő-forgatókönyveit különböző témákban ${ }^{157}$, domborzatmodellen megjelenített folttérképekkel valósították meg 2,5D-ben, ferde-tengelyü madártávlati látószögben (STEINITZ et al. 2003, 156-163), World Construction Set vizualizációs szoftverrel. Egy hasonló esetben a szintén USA-beli Willamente folyóvölgy jellegét és tájhasználatát tárták fel. A tájalakulási forgatókönyvek változatonként feldolgozott légifelvételek domborzatmodellre helyezésével elsősorban az erdő- és a településterület, valamint a vízfolyás-ágak változását illusztrálták (HULSE, GREGORY, és BAKER 2002, 78-82, 109, 147).

Az utóbbi évtizedekben a digitális fényképezést és terepmodellezést kiegészítették a CAD objektumok, melyek realisztikusan megjeleníthetők többféle térinformatikai rendszerben (JUDE 2003), (DONALDSON-SELBY 2007). Gyengeségük, hogy a hely szellemét általában nem tudják hitelesen visszaadni, modelljeik neutrálisnak, sterilnek tünhetnek. Általában renderelő szoftverrel tehetők foto-realisztikussá, és referencia pontokkal illeszthetők az eredeti fényképbe (KRETZLER 2002), (THE LANDSCAPE INSTITUTE 2002, 76-77). Ebben az esetben csak korlátozott számú nézőpontot használhatunk. A Landscape Institute az „elötte és utána” típusú képeknél a jelen állapotot ábrázoló fényképpel megegyező nézőpontot és látószöget javasolja 3D-modell esetében is (THE LANDSCAPE INSTITUTE 2002, 152).

Néhány példa kombinálja a fényképezést és a 3D CAD modellek alkalmazását és lehetőséget ad fényképekkel textúrázott tájelem-modellek (épületek, növényegyedek stb.) beillesztésére. Egy ilyen kutatásban Appleton és Lovett a terepen légifelvételeket használtak, a házak oldalára terepi fényképeket raktak, és több tájkép-párt is elkészítettek. A párok közül az egyik mindig elnagyoltabb, míg a másik az előtérben sokkal részletgazdagabb volt (APPLETON és LOVETT 2003, 130). Internetes preferencia-felmérés során megállapították, a részletek segítenek a szemlélő tájékozódásában és abban, hogy valódi tájat képzeljenek el.

Lange és Hehl-Lange több lépésben bemutatott tájalakítási folyamat foto-realisztikus 3D-megjelenítését végezte el az angliai Alport völgy területén (23. ábra (M30)). Céljuk az

\footnotetext{
157 Témák: vegetáció változása, a vízmennyiség változása, az ökológiai hálózat és mintázat elemeinek változása, a potenciális élőhelyek változása, a vizuális vonzerő változása
} 
volt, hogy a döntéshozás fázisában látványos jövőképet fessenek a Peak District Nemzeti Park érintettjei elé, amint az idősödő tülevelü erdőt lépésről lépésre felváltja a tölgyes-nyíres ligetes erdőtípus a dombtetőkön (LANGE és HEHL-LANGE 2010, 696). A vizualizációhoz domborzatmodellt és ortofotót használtak fel a Simmetry 3D szoftverben valamint SketchUp szoftvert alkalmaztak a házmodellek elkészítésére (LANGE és HEHL-LANGE 2010, 695).

Egy hasonló kutatás számítógépes 3D-vizualizációkat használt, a tájkép kedveltségének felmérésére, figyelemmel a természetességre. (ODE et al 2009, 375-383). A képeken számítógépes vizualizációval változtatták a természetesség jellemzőit. Az elképzelt tájakat egy térinformatikai rendszerben, Visual Nature Studio alkalmazásával jelenítették meg, európai tájakról készült fényképek felhasználásával (ODE et al 2009, 377). A szukcesszió folyamatát illusztrálták az ábrák és eredményképpen megállapították, hogy mintaterületükön a természetesség indikátoroknak haszna lehet a tájképi minőség megítélésében is.

Egy kanadai mintaterületen végzett kutatás szerint a 3D megjelenítés sokkal kedvezőbb fogadtatásra lelt a zárt közösségekben élő hegyvidéki bennszülöttek körében is, mint az egyszerü térképek, még akkor is, ha újdonságnak számítottak. A térképeken könnyen félreorientálták magukat, míg a 3D-vizualizációval nem (LEWIS és SHEPPARD 2006). Igazi 3D-vizualizációs különlegesség Sanderson könyve Mannhattanről (SANDERSON 2009). Látványos foto-realisztikus vizualizációk jelennek meg benne New York leginkább átalakított városrészének történeti tájképéről, melyek az egykori természeti karaktert az úgynevezett „Mannahatta” tájkaraktert tükrözik (24. ábra (M31) ${ }^{158}$.

Egyes vizualizációs megoldásoknak vannak navigációs lehetőségei is (FALCÃO et al. 2006), (THE LANDSCAPE INSTITUTE 2002, 153-154). Az ilyen alkalmazásokat arra használják, hogy egy helyszínt a maga komplexitásában, környezetével ábrázoljanak. Ezekben általában a tervezett változtatások is megtekinthetők. Legnagyobb előnyük az egyéni navigáció lehetősége a vizsgált területen belül, és így a térbeli elhelyezkedés érzékelése, a tervezett tájelemek különböző, változtatható nézőpontból feltáruló látványa.

A ,virtuális földgolyó” (virtual globe) alkalmazások legismertebbje a Google Earth, egy sokak által használt, vagy javasolt vizualizációs megoldás. Nagy előnye az elérhetőség és az interaktivitás, ezért fontos szerepe lehet a környezettudatosság növelésében (SHEPPARD és CIZEK 2009). A Google Earth mindemellett igen sok alapadattal, felvétellel, a felhasználók által hozzávetőlegesen georeferált terepi fényképtárral rendelkező „táj-böngésző”. Schmid 2001-ben azt feltételezte, hogy a területi tervezési döntéshozásban nagy szerepe lesz a 3D-nek (SCHMID 2001, 213-221) és egy napon szerinte a térrel kapcsolatos tervezési folyamat már teljesen 3D-ben fog megtörténni, közvetlenül számítógépen (SCHMID 2001, 221). A bemutatott példák igazolják, hogy egyes területeken ez már részben megvalósult.

\footnotetext{
158 Több nézőpontból készített foto-realisztikus vizualizációk rendre párban mutatják be a mai és az egykori állapotot. A vizualizációk alapjául több passzív képalkotó távérzékeléssel készített felvétel került felhasználásra. Domborzatmodell alapján (SANDERSON 2009, 83) vázolták fel a víz egykor vélhetö jelenlétét, a különbözö élőhelyek előfordulását és egyes fajok, pl. hódok előfordulását térképezték (SANDERSON 2009, 139, 202-203).
} 


\subsubsection{Jellemzés és határvonal-térképezés}

A tájak jellemzése, és a jellemzés alapján történő elhatárolás a tájkarakter-elemzés egyik fontos lépése. Az irodalomkutatásban eddig számos olyan tényezőt vettem figyelembe, melyek alapján mind a jellemzés, mind a tájkarakter típusok és területek elhatárolása megtehető. Az ELCAI projekt alapján megállapítottam, hogy a jellemzésben leggyakrabban felhasznált jellemzők az előfordulás gyakoriságának sorrendjében: a domborzat, a felszínborítás, a talaj vagy alapkőzet, a klíma, a vízrajz, a tájszerkezet, a percepciós és kulturális tényezők, a mintázat (települési, vagy területhasználati), a potenciális természetes vegetáció, a természeti területek vagy biodiverzitás és a népesség (WASCHER 2005, 12-26).

Mintaterületi munkák során magyar tanulmányok is meghatározták, melyek a fontosabb jellemzők és támpontok a lehatárolásnál. Nagy és Csima egy Köszeg környéki mintaterületen fö meghatározónak a domborzatot és a növényborítottságot tekintette (NAGY és CSIMA 2010, 238). Konkoly-Gyuró Fertő-Hanság térségében három fö jellemzőt határozott meg, mely a tájkarakter kialakulásáért felelős ${ }^{159}$ (KONKOLY-GYURÓ 2010, 1113). Eplényi Kalotaszeg környékén végzett karakter-elemzés témájú disszertációjának negyedik tézisében prioritási sorrendet állított fel ${ }^{160}$ (EPLÉNYI 2012). A jellemzők nagy többsége a passzív képalkotó távérzékelés felvételein vagy származtatott adatbázisain láthatók, térképezhetők, térbeli eltéréseik, és időbeli változásaik elemezhető.

Lóczy foglalkozik a tájak hasonlósága és különbözősége kérdéssel, melynek során a „tájtípus vagy tájegység” kérdést is boncolgatja (LÓCZY 2002, 14). A „lágy határok” témakörével szimpatizál, amit a „lágy halmazok” matematikai elméletéből eredeztet. Ez alapján a tájat is egy hozzátartozási függvénnyel lehetne leírni, hogy miként kapcsolódik egy nagyobb egységhez, vagy típushoz. A tájbeosztás-térképek tájhatárai a gyakorlatban sokkal elmosódottabbak (LÓCZY 2002, 25), de javaslatára ez a probléma átmeneti sávok közbeiktatásával feloldható, de szerinte ez rontja az áttekinthetőséget (LÓCZY 2002, 26).

Csorba szerint csak 2-3 km-es pontossággal lehet tájhatárokat kijelölni, mert a tájalkotó tényezők (domborzat, éghajlat, vízrajz stb.) csak ilyen térbeli „ütemben” váltakoznak (CSORBA 2008, 83) Jelzi, tudatában van annak, hogy a geográfia olyan pontossággal tudja megadni a tájak térképi határait, amely a gyakorlati tudományok (tájtervezés, tájvédelem) számra csak korlátozottan használható. Ennél a kijelentésnél Csima 2004-es cikkét veszi figyelembe. A gyakorlati szakemberek számára a méterre pontos tájhatár lenne kívánatos, míg a tájföldrajzos számára mindez „szőrszálhasogatásnak” minősül (CSORBA 2008, 84). Megoldásként CLC felszínborítás adatokat és a tájökológiában használatos tájszerkezeti grádiensek („gradient concept of landscape structure” McGarigal alapján) és tájszintü ökotonok (átmeneti sávok) térképezését tartja lehetségesnek (CSORBA 2008, 83-89).

159 1. domborzat, 2. emberi hatás mértéke (részben mennyiségi, részben minőségi) 3. felszínborítás dominancia

160 1. felszínmorfológiai, domborzati jellemzők, 2. ligetesen-szórványosan erdősült felszínek, 3. alaktanimintázati jegyek szerepeltek, 4. a karaktert befolyásoló pontszerü objektumok 
Kertész általános tértudományi, ezen belül földrajzi metodikai problémának tekinti a határok meghúzását. Szerinte a tájhatárok meghúzását önkényesen végezzük, egy sávon belül bárhol megtehetjük (KERTÉSZ 2003, 31). Ez nyilván nem tájkezelési célszerüségi alapon végzett tájhatárolás, hanem egy elvi álláspont alapján történő határvonal-meghúzás (KERTÉSZ 2003, 31). Tájbeosztást bármilyen méretarányban elkészíthetünk, attól függően, hogy milyen nagyságrendü egységig „megyünk le”. (KERTÉSZ 2003, 107).

A tájegységek vagy tájtípusok összevethetőségét és lehatárolásának megértését segítheti, ha a jellemzőket egyetlen térinformatikai rendszerben fedvényenként áttekinthetjük, mint a MÉTA és CLC50-es adatok esetében (KONKOLYNÉ GYURÓ 2006b, 10. Melléklete), és ha a lehatárolt tájegységek jellemzése egységes rendszerben, azonos szempontokat figyelembe véve történik meg ${ }^{161}$ (KONKOLYNÉ GYURÓ 2007).

Norvégia területére készített tájhatár-kutatásában Strand azt vizsgálta, hogy melyek azok a területek, amelyek a legnagyobb valószínűséggel esnek bele egy már meglévő tájkarakterbeosztás előre definiált egységeibe (STRAND 2011, 1150-1157). Számos alapadatot használt fel raszteres adatmodellben. A Farming Landscape Regions 1999-ben készített kategóriarendszer szerint az országot 10-féle típusba sorolta. Strand annak módszerét kutatta, hogy milyen valószínüséggel esnek bele a tájrészletek egyik, vagy másik kategóriába (25. ábra (M32)). A tájrészleteket $25 \mathrm{~km}^{2}$-es négyzetekkel reprezentálta (STRAND 2011, 1151). Kutatásához 16 tényezőt vett figyelembe ${ }^{162}$. Térképei azt mutatják, hogy az ország $5 * 5 \mathrm{~km}$-es tájrészletei milyen valószínüséggel esnek egy kiválasztott tájtípusba, figyelembe véve azok sajátosságait leíró adatokat (25. ábra (a) (M32)) (STRAND 2011, 1153).

A tájkezelést célként szem előtt tartó tájkarakter-elemzés igyekszik minél pontosabb, a gyakorlatban is használható határvonalakat húzni. Van olyan megoldás, amely vízgyüjtőkben gondolkodik (SOUTHERN et al. 2011, 179-189) és olyan is, amelyik felszínborítás foltok mentén, pl. ürfelvétel interpretálásának útján húzza meg a tájhatárokat (KONKOLYNÉ GYURÓ 2007). Mindkét esetben van lehetőség a passzív képalkotó távérzékelési eszköztár használatára. Konkolyné Gyuró 2006-os tanulmánya szerint fontos szempont a munka illeszthetősége az igazgatási egységekhez is, de ennek lényegét egyáltalán nem a tájhatárok közigazgatási határhoz illesztésében keresi, hanem az elemzés eredményeinek térbeli referenciájával biztosítja (KONKOLYNÉ GYURÓ 2006b, 4). Ez az igény is indokolja a felvételek térinformatikai felhasználását a tájkarakter-elemzésben.

${ }^{161}$ 1. Elhelyezkedés, határok, kulcsjellemzők, 2. Tájkaraktert formáló tényezők (természeti adottságok, történeti folyamatok, tájhasználat,), 3. A tájkarakter összetevői (felszínborítás és élőhelyek; települések, infrastruktúra; örökség, egyedi tájértékek), 4. Percepcionális jellemzők (vizuális vonások, látványjellemzők), 5. Tájkarakter értékelés és tájkarakter-védelmi javaslatok (védendő és veszélyeztetett tájkarakter-elemek, és ezeket megőrző folyamatok, tevékenységek; degradációk, tájsebek) (KONKOLYNÉ GYURÓ 2007)

162 1. az északra esés mértéke $(\mathrm{km}), 2$. legnagyobb tengerszint feletti magasság $(\mathrm{m})$, 3.tengerszint feletti magasságkülönbség $(\mathrm{m}), 4$. tengerparttól mért távolság $(\mathrm{km}), 5$. mezőgazdasági terület aránya $(\%), 6$. legelők $(\%)$, 7. erdök aránya $(\%), 8$. fahatár alatti vizek $(\%), 9$. fahatár feletti területek aránya $(\%), 10$. épületekkel borított területek $(\mathrm{m} 2), 11$. népesség (fö), 12. gabonatermesztés területe $(\%), 13$. gyepgazdálkodás területe $(\%), 14$. szarvasmarha $(\mathrm{db}), 15$. bárány $(\mathrm{db}), 16$. nyári gazdaságok $(\mathrm{db})$ (STRAND 2011, 1152) 


\section{A MEGOLDANDÓ FELADATOK ISMERTETÉSE}

A doktori értekezés célja, hogy meghatározza és kutatási eredményeivel bővítse a passzív távérzékeléssel készített felvételek felhasználási lehetőségeit valamint a felvételek feldolgozási eljárásait a tájkarakter-elemzésben (26. ábra (M33)). A kutatás részcéljai:

1. A „passzív képalkotó távérzékelési merítés” tájkarakter-elemzési szerepének erôsítése.

2. A tájelemek minél nagyobb része érzékelhető legyen passzív képalkotó távérzékeléssel.

3. A tájelemek érzékelése minél több távérzékelési eszközalkalmazásával történjen meg.

4. Az eljárások és elemzések kiegészítése a karakteradó jelleget meghatározása, megnevezése, lehatárolása és értékelése érdekében.

A célkitűzéseket az alábbi távlati célok megközelítése érdekében határoztam meg.

(a) Az Európai Táj Egyezményben rögzített feladatoknak megfelelően (COUNCIL OF EUROPE 2000. II. Fejezet, 6. cikk C rész) a „tájak számbavétele és értékelése” során passzív képalkotó távérzékelési alkalmazásokkal kiegészített tájkarakter-elemzés térinformatikai rendszerben, nagy területen tájegységekre vagy bármely kisebb tájrészletre vonatkozóan megvalósítható legyen.

(b) A tájkarakter-elemzéssel könnyen értelmezhetö, tájrészlet szint felé is nyitott, területi és közösségi értelmezési lehetőséget biztosítsunk az érintettek számára.

(c) A tájkarakter-elemzéssel gyorsan, látványosan és eredményesen hozzájáruljunk a hazai és európai tájak egyedi vagy tipikus sajátossá gainak felméréséhez. Az elemzés aktív döntésalátámasztó szerepet tölthessen be a tervezés elökészítésében.

(d) A tájkarakter-elemzés eredményei integrálhatóak legyenek a tervezési rendszer egyes elemeibe, ezáltal több tervezési szinten hozzájárulhassanak a fenntartható tájtervezéshez és tájvédelemhez a hazai és a nemzetközi gyakorlatban.
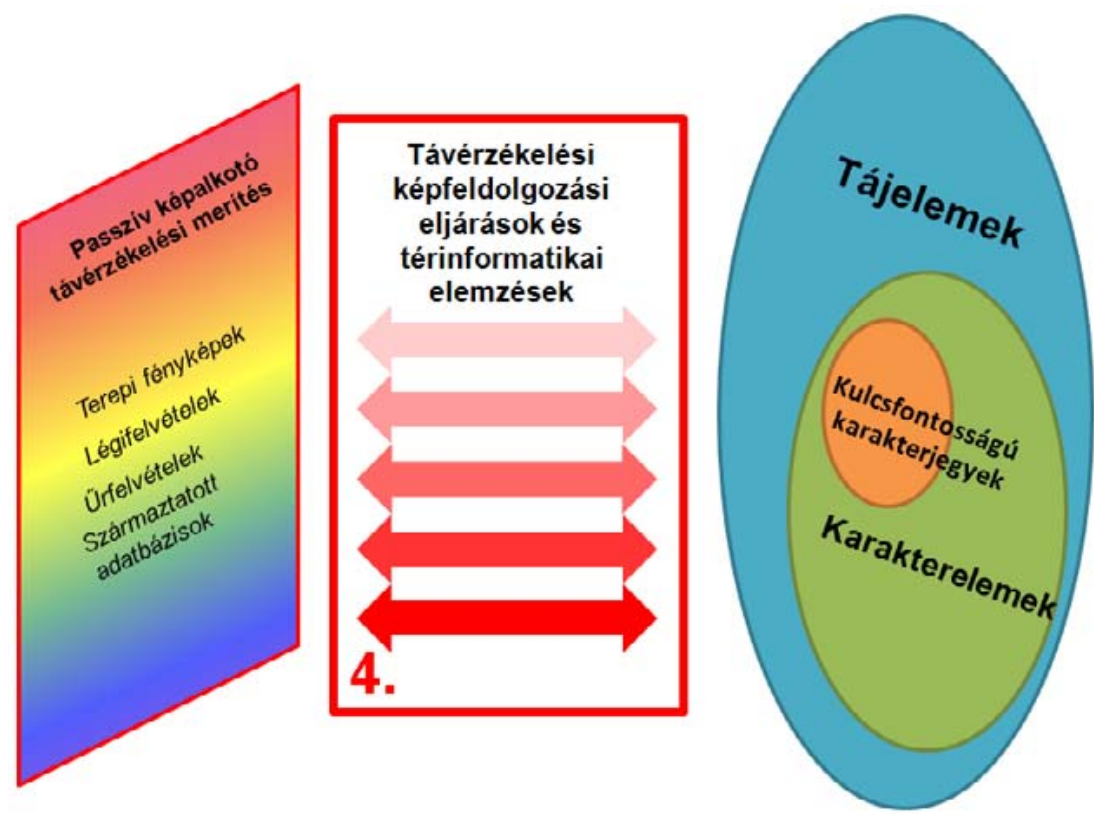

26. ábra (részlet (M33)) A kutatás célja a passzív képalkotó távérzékelés alkalmazási lehetőségeinek bővítése a tájkarakter-elemzésben 


\subsection{A paszív képalkotó távérzékelés tájkarakter-elemzésbeli szerepének meghatározása}

A doktori értekezés céljának eléréséhez fontos meghatározni, hogy mi a passzív képalkotó távérzékelés szerepe a karakter-elemzésben. Ennek érdekében végeztem el az irodalomkutatást, melynek eredményei alapján az alábbi kérdésekre lehet megadni a választ:

1. Milyen tájelemek, tájelem-együttesek detektálhatók és elemezhetők a passzív képalkotó távérzékeléssel készült adatokkal?

2. Milyen felvételek és származtatott adatbázisok alkalmasak erre a különböző léptékü tájkarakter-elemzések keretében?

3. Mely képfeldolgozási eljárások és térinformatikai elemzések használhatók a tájkarakter-elemzés során?

Feltételezésem szerint a sokféle tájelem, felvétel és származtatott adatbázis, valamint többféle képfeldolgozási eljárás alkalmazható a tájkarakter-elemzésben. A földfelszíni tájelemeket (növényzet, épített létesítmények) tartalmazó adatoknak kiemelkedő szerepe van jelenleg is, de hasznosításukban további potenciál rejlik. Kutatásom kezdetéig publikált gyakorlati és tudományos irodalom áttekintésének eredményeként adható válaszokat a 4.1.-es fejezetben ismertetem.

\subsection{A domborzat-jellemzés lehetőségeinek meghatározása}

A domborzat a tájkarakter egyik legfontosabb meghatározója. Számos tanulmány - melyet irodalomkutatásomban feltártam - igazolja, hogy vizsgálata, értékelése, megjelenítése különösen fontos a tájkarakter-elemzésekben. Digitális domborzatmodelleket passzív (pl. sztereo-fotogrammetriai kiértékelés), és aktív (pl.: radar vagy lidar mérések) távérzékeléssel egyaránt, valamint képalkotó (felvételkészítés) és nem képalkotó (pl.: hagyományos geodéziai mérések) távérzékeléssel egyaránt készítenek.

A nemzetközi tájkutatási és tájépítészeti gyakorlatban egyre inkább teret nyernek a digitális domborzatmodellek és egyre gyakrabban helyettesítik korábban használatos analóg (szintvonalas, hagyományos színezéssel ellátott) papír alapú elődeiket, vagy azok szkennelt változatait. A digitális domborzatmodellek - különböző részletezettségük, adatformátumuk, pontosságuk következtében - eltérő módon használhatók fel a karakter-elemzésben, ezért elsőként egy „,ár-felbontás-pontosság” összevetést készítettem (15. táblázat (M34)).

Az összevetésből egyértelmüen kiderül, hogy a részletes topográfiai térképekből származtatott hazai adatok térségi szintre igen költségesek, beszerzésük napokat vesz igénybe, de nagy felbontással és pontossággal rendelkeznek. míg a különféle távérzékelési módszerekkel készített domborzati modellek nagy területre, gyorsan, ingyenesen beszerezhetők, ám minden esetben valamilyen pontatlansággal kell számolnunk.

A passzív képalkotó távérzékelésből származó ASTER GDEM modellek és SRTM modellek valós terepi magassági pontokkal történő összevetésével több irodalmi forrás is 
felszínborításra és általános eltérésekre vonatkozó megállapításokat tett (METI/ERSDAC NASA/LPDAAC - USGS/EROS 2009, MEYER 2011, 2). Hazai kutatások kimutatták az SRTM és az ASTER GDEMv1 eltéréseinek összefüggését a kitettséggel (SZABÓ és SZABÓ 2010; SZABÓ 2011). Megállapították, hogy az SRTM modell pontossága az északkeleti és délnyugati kitettségek esetén a legnagyobb. Az ASTER GDEMv1 modell esetében is a legnagyobb eltérést az északkeleti lejtők mutatták. Ezekből azonban nem lehet a jelenségek területi megoszlására, magyarországi, vagy európai sajátosságaira, és a tájkarakter szempontjából egyértelmủen fontos információkra következtetni. Ezért fontosnak tartom a különféle magassági modellek domborzati típusonként történő összevetését és elemzését is.

A tájkarakter-elemzés szempontjából meg kell határozni, hogy a különböző magassági modellek, hogyan, milyen léptékben, milyen mértékben és milyen várható eredménnyel használhatók fel a karakter szempontjából fontos domborzati sajátosságok elemzéséhez. Ennek meghatározása érdekében mintaterületi elemzések lefolytatása szükséges, melynek eredményeit a 4.2. fejezetben mutatom be. Indokoltnak tartom, hogy a domborzati elemzés témában a kutatás terjedjen ki és adjon válaszokat a következő kérdésekre:

1. Melyek a jellemző különbségek a távérzékeléssel készített magassági modellek (különösen az ASTER GDEM) és a valósághoz legközelebb álló tízezres topográfiai térképek alapján elöállított modellek (pl.: DDM5), vagy egyéb domborzati modellek (SRTM) között?

2. A jellegzetes domborzat-típusokra (síkvidékek, dombvidékek, hegyvidékek), terepi alakzatokra (medencék, völgyek, hegygerincek, csúcsok, szakadékok, falak, sziklák, stb.) vonatkozóan lehet-e általános következtetéseket levonni? Milyen mértékben tükröződnek ezek a formációk a modellekben?

3. A felsźnborítás és a kitettség milyen módon befolyásolja a magassági adatok pontosságát?

4. Milyen domborzat-elemzési és domborzat-jellemzési módszerek illeszkedhetnek a tájkarakter-elemzés folyamatába?

Feltételezésem szerint az ASTER GDEMv2 magassági modell - nagyobb felbontásának köszönhetően - bizonyos esetekben pontosabb adatokhoz juthatunk és releváns domborzati karakter-jellemzést készíthetünk, mint bármely más, ingyenes modellel. Kutatási eredményeimet a 4.2. fejezetben ismertetem.

\subsection{Térbeli indexekkel történő tájkarakter-jellemzés lehetőségeinek meghatározása}

A tájkarakter fogalom-meghatározásban és az elemzés gyakorlatában is hangsúlyosak a „sajátos”, vagy „típusos” jellemzők, melyek ,az egyik tájat megkülönböztetik a másiktól". Ezek a jellemzők különösképpen indokolják a térbeli eltéréseket feltáró indexek alkalmazását. Tájrészletek egymáshoz viszonyított eltéréseit igen jól tükrözik a különféle felszínborítási mutatók ${ }^{163}$. Azokat a spektrális indexeket, melyeket egyes felvételek

\footnotetext{
${ }^{163}$ Bizonyos tájegységek jellegét például döntően meghatározza az erdőborítás aránya, a nyílt vízfelület területe, vagy a felszínborítások foltjainak alakja, szegélyének hossza stb.
} 
tartalmának automatikus értelmezésére fejlesztettek ki - például a zöldfelület vitalitásának, a vízfelszín dominanciájának, vagy egyéb jellegzetes felszínek detektálására - az irodalom szintén összefüggésbe hozza táj jellegbeli eltéréseinek leírásával.

Az irodalomkutatás eredményeiből azonban nem egyértelmü, hogy konkrétan mely passzív képalkotó távérzékelési adatokra és eljárásokra épülő indexek, milyen módszerrel hasznosíthatók a tájkarakter-elemzésben. Az indexek és mutatók kutatása során ki kell térni és válaszokat kell adni a következő kérdésekre:

1. Mely felvételekre vagy származtatott adatbázisokra épülő indexek alkalmazhatók tájak karakterének jellemzésére?

2. A legelterjedtebb indexek milyen módszerekkel, milyen feltételekkel, milyen korlátok között hasznosíthatók karakter-jellemzési célra?

3. Milyen passzív képalkotó távérzékelési adatokra épülő új index kidolgozása indokolt és valósítható meg a táj növényborítottságának jellemzése érdekében?

4. Milyen eredmények érhetők el a származtatott adatbázisokra épülő indexekkel?

Feltételezésem szerint a tájelemzésben már használatos indexek bizonyos módosításával a tájkarakter-elemzésben is hasznosítható, a lehatárolt tájegységek jellemzésére alkalmas mutatókat lehet képezni, melyek egyértelműen jellemzik felszínborítási, zöldfelületi vagy egyéb sajátosságokat. Kutatási eredményeimet a 4.3.-as fejezetben ismertetem.

\subsection{Változás-elemzés felhasználási lehetőségeinek meghatározása}

A tájkarakter-elemzés során fontos a tájjelleg átalakulását eredményező domináns tájváltozási folyamatokat felismerése. A tájváltozások detektálásáról, elemzéséről számos publikáció született, de kevés közöttük, amely a karakterre vonatkozóan vonna le következtetéseket, vagy kifejezetten a karakter-elemzés céljából készítette volna a változásvizsgálatot. Több forrás enged következtetni arra, hogy a passzív távérzékelési felvételek és feldolgozási módszereik alkalmasak lehetnek:

- a táj domináns, karaktert befolyásoló változásfolyamatainak meghatározására

- a táj változásfolyamatokkal történő jellemzésére (pl.: nyitottság és szegélyek változása)

- a tájat érintő változás mértékének számszerüsítő meghatározására.

A passzív képalkotó távérzékelés felvételei és technológiái többféle megoldást kínálnak, de alapvetően kétféle módon teszik lehetővé a tájváltozás vizsgálatát:

- a felszínborítás változásának elemzésével, amit döntően közepes esetleg alacsony felbontású ürfelvételek, vagy származtatott adatbázisok feldolgozásával végezhetünk,

- egyéb karakteradó tájelemek megjelenésének, átalakulásának, vagy eltünésének elemzésével, amit igen nagy felbontású ürfelvételek, légi- és ortofotók, vagy terepi fényképek felhasználásával tudunk megoldani. 
Ezért fontos, hogy a tájkarakter-változás témában a kutatás terjedjen ki és válaszolja meg a következő kérdéseket:

1. Milyen változás jelezhető automatikus változás-detektáló megoldásokkal, milyen léptékben, milyen mintaterületi eredményekkel, lehetőségekkel és korlátokkal?

2. Milyen újszerü, a táj karakterének változásának detektálására is alkalmas automatikus módszerre építő változás-indikátor képezhető?

3. Passzív távérzékelési adatokból származtatott adatbázisok felhasználásával (CLC) milyen tájjelleg-változás vizsgálata végezhető el, milyen léptékben, milyen mintaterületi eredményekkel, lehetőségekkel és korlátokkal?

4. Milyen újszerü, származtatott adatbázisokra építő változás indikátorok képezhetőek és állíthatóak a tájkarakter-elemzés szolgálatába?

5. Milyen tájkarakter-változást alátámasztó felszínborítás-változás, tájelem-változás elemzése végezhető el vizuális interpretációval, milyen léptékben, milyen várható mintaterületi eredményekkel, lehetőségekkel és korlátokkal?

\subsection{Láthatóság-elemzés lehetőségeinek meghatározása a karakter-elemzésben}

A táj karakterét jelentősen meghatározhatják a láthatósági viszonyok. Swanwick szerint a láthatóság a tájkarakter érzékenységéhez nagyban hozzájárul (SWANWICK 2002 TP6, 8-9). A tájváltozás vizuális jelentősége például nagyban függ a terület láthatóságának mértékétől, amit részben a domborzati viszonyok, részben a felszínborítás tájelemei határoznak meg. Ezek vizsgálata a terepi felmérések és megfigyelések mellett térinformatikai elemzéssel is történhet. Több tanulmány áttekintése alapján (1.3.3.4. fejezet) feltételezem, hogy a passzív képalkotó távérzékelési adatok közül a domborzati és a felszínborítási adatok is eredményesen használhatók térségi mintaterületi munkák során.

Ezért fontos, hogy a láthatóság és kilátás elemzése témában a kutatás terjedjen ki, adjon válaszokat a következő kérdésekre:

1. Milyen módon lehet a tájjelleg szempontjából számottevő láthatóságot vizsgálni, elemezni, jellemezni, a tájegységek közötti és tájegységeken belüli sajátos eltéréseket bemutatni?

2. Hogyan lehetséges meglévő vagy tervezett tájelemek láthatóságát meghatározni?

3. Hogyan lehetséges a tájkaraktert jelentősen módosító láthatósági változást meghatározni?

4. Hogyan lehetséges a láthatóságon túl, a tájkarakter szempontjából fontos, kilátóhelyekről feltáruló látványbeli tényezők meghatározása? 


\subsection{A megjelenítés (vizualizáció) szerepének meghatározása a karakter-elemzésben}

A tájkarakter megértését nagyban szolgálhatják a különböző tájat bemutató látványos digitális megjelenítési lehetőségek. A passzív távérzékelés felvételei képalkotó jellegüknél fogva alkalmasak 2,5-, vagy 3-dimenziós digitális vizualizációkra. A feltárt irodalom egy része foglalkozik a táj megjelenítésével, a tájkarakter megértetése, vagy az elemzés eredményének megjelenítése céljából.

Az irodalomkutatás alapján feltételezem, hogy a passzív képalkotó távérzékelés felvételei képfeldolgozó térinformatikai szoftver-környezetben megjelenítve, vagy feldolgozva alkalmasak a tájjelleg sokrétű illusztrálására, bemutatására, a változások jelentőségének érzékeltetésére. Ezért fontosnak tartom, hogy a tájkarakter bemutatása témában a vizualizációs megoldások kutatása terjedjen ki és adjon válaszokat a következő kérdésekre:

1. Milyen passzív képalkotó távérzékelési adatokkal, milyen léptékben, milyen megoldásokkal és eredményekkel lehetséges a táj jellegének bemutatása?

2. Felvételek felhasználásával milyen módon érzékelhető, és érzékeltethető a táj karaktere a hétköznapi emberek számára?

3. Milyen technikai és módszertani megoldásokkal lehetséges a tájjelleg-változás érzékeltetése és monitorozása?

4. Hogyan, milyen megoldásokkal lehetséges és milyen „környezetben” javasolható a tájkarakterrel kapcsolatos információk háromdimenziós megjelenítése?

\subsection{A tájkarakter-elemzésben használatos tájhatárvonalak térképezési lehetőségeinek meghatározása}

A tájegységek és tájtípusok sajátosságait összevető megoldások és a lehatárolás technikai módszerei fontos elemei a tájkarakter-elemzésnek. A témával több, a 1.3.3.7. fejezetben bemutatott irodalom is foglalkozott. Feltételezésem szerint a passziv képalkotó távérzékelés hozzájárulhat a karakter-elemzés sikerességéhez a tájhatár-vonalak meghúzása érdekében, az eredmények térinformatikai rendszerben történő összesítése és együttes áttekintése során.

Ezért fontos, hogy az alkalmazhatóságot támogató kérdések elemzése témában a kutatás adjon válaszokat a következő kérdésekre:

1. Milyen adatok, milyen módszerrel történő feldolgozása támogathatja a tájhatárvonalak meghúzását?

2. Milyen újfajta tájhatár-térképezési eljárások kidolgozása lehetséges? 


\section{ANYAG, MINTATERÜLET ÉS MÓDSZER}

Az értekezésben tárgyalt kutatásom jellege eszköz alkalmazás-kutatás, melynek célja a tájkarakter-elemzési módszertan kiegészítése. A kutatás anyagát ezért különbözö adatok, felvételek, térképek, térképi adatbázisok képezik. A mintaterületek a kutatás fontos elemei, melyeken a technikai eszköztár alkalmazását tesztelem. Kutatásom módszerei az irodalmi áttekintés, a terepi felmérés, a kérdőívezés, az interjúkészítés, a távérzékelési képfeldolgozási eljárások valamint a térinformatikai adatfeldolgozás.

\subsection{A kutatás anyaga}

A disszertáció témájából következően a tájkarakter elemzését a tájról információval rendelkező anyagok vizsgálata útján végzem. Ezeket a felvételeket, térképeket, adatokat és térképi adatbázisokat a következő fejezetben a kutatás anyagaként ismertetem.

\subsubsection{Felvételek}

A kutatás anyagaként számos távérzékeléssel készített légi- és ürfelvételt, valamint egyéb digitális, vagy digitalizált fényképet használtam fel. A felhasznált terepi felvételek passzív képalkotó távérzékeléssel készültek. A terepi fényképek többsége saját készítésü, a madártávlati ferde tengelyü felvételek pedig az általam tervezett útvonalak mentén, motoros siklóernyős repülések során készültek. A disszertáció kutatási eredményeinek elkészítéséhez felhasznált felvételek listáját a 16. táblázat (M35), típusaikat a következő felsorolás tartalmazza:

- Müholdfelvételek (Landsat TM5, ETM+)

- Nagyon nagy felbontású felvételek látható tartományban rögzített tömörített változata (Google Earth)

- Ortofotók (2000, 2005, 2008, 2010) (FÖMI)

- Történeti légifelvételek 1927-től 1992-ig (Hadtörténeti Múzeum, FÖMI)

- Saját terepi fényképfelvételek

- Ferde tengelyü madártávlati felvételek (A Pillangó Siklóernyős Iskola archívumából)

\subsubsection{Térképek}

A kutatásban digitális és digitalizált térképeket, referencia- és tematikus térképeket egyaránt használtam. Topográfiai térképeket tájrészletek, tájelemek egyedi megnevezésére, valamint referenciaként, egyes geokorrekciós műveletekhez használtam. Katonai felmérések térképeit tájváltozás-vizsgálatok alátámasztására alkalmaztam. A felhasznált térképek pontos megnevezését és területi kiterjedését a 17. táblázat (M36), típusait a következő felsorolás tartalmazza. 


\subsubsection{Térképi adatbázisok}

A kutatás során többféle digitális térképi adatbázist használtam. A legtöbb adatbázis passzív képalkotó távérzékelés felvételeiből származtatott adat (pl.: CLC100), de akadt olyan adatbázis is, amit a kutatási eredmények szemléltetésére alkalmaztam (pl.: Magyarország kistájai). Az ASTER GDEMv2 magassági modell tájelemzési alkalmasságának meghatározása érdekében referenciaként és viszonyítási alapként hazai digitális domborzati adatokat (DDM) és aktív távérzékelésből származó SRTM magassági adatokat is felhasználtam. A digitális térképi adatbázisokat részletesen a 18. táblázat (M36), típusait a következő felsorolás tartalmazza:

- CLC100 (1990, 2000, 2006) (EEA ${ }^{164}$ és FÖMI)

- CLC50 (2000) (FÖMI)

- European Urban Atlas (EEA)

- ASTERGDEMv1 és v2 (NASA és METI)

- SRTM domborzatmodell (NASA)

- DDM5 és DDM100 (FÖMI)

- ETOPO05 (EEA)

- GLSDEM (FOMI)

- Egyéb vektoros alapadatok

- TM World Borders: Orszá ghatár-térkép (Bjorn Sandvik)

- NUTS0 és NUTSX (NUTS2-3) (EUROSTAT) ${ }^{165}$

- Településhatáros térkép (FÖMI)

- Kistájhatáros térkép (MTA TAKI GIS Labor ${ }^{166}$ )

○ DTA 50 (HM TÉHI)

\subsubsection{Statisztikai és saját felmérési adatok}

A kutatás anyagaként különféle forrásból származó statisztikai adatok mellett számos saját felmérésből származó adatot használtam fel. A saját felmérésből származó adatok döntően kérdőívezés, interjúkészítés útján álltak elő. A felhasznált statisztikai adatok megnevezését és forrását az irodalomjegyzékben elhelyezett internetes hivatkozások tartalmazzák, ezért itt csak a fontosabb témaköröket emelem ki:

- KSH statisztikai adatok (a KSH honlapjáról)

- Eurostat statisztikai adatok (az Eurostat honlapjáról)

- TEIR statisztikai adatok (a TEIR honlapjáról)

- Saját felmérésekből nyert adatok (kérdőívek és interjúk eredményei)

${ }^{164}$ EEA: European Environment Agency (Európai Környezetvédelmi Ügynökség). A fejezetben található betüszavakat melyek többségében adatok elérhetőségét biztosító intézetek nevének rövidítései a Passzív képalkotó távérzékelési alapadatok alfejezetben (1.2.2.) már ismertettem.

${ }^{165}$ NUTS: Statisztikai Célú Területi Egységek Nómenklatúrája az az egész Európai Uniót lefedő rendszer része, amelyet az Eurostat fejlesztett ki.

${ }^{166}$ MTA TAKI GIS Labor: MAROSI és SOMOGYI 1990 mellékleteként jelent meg, amelynek térinformatikai feldolgozását az MTA TAKI GIS Labor munkatársai készítették el 


\subsection{A kutatás mintaterületei}

A felvételek sokaságának és feldolgozási eszköztárának alkalmazását a tájkarakterelemzésben több mintaterületen kutattam. Ezeket a mintaként kiválasztott területeket az eszköz-alkalmazás „kísérleti laboratóriumainak” tekintem. Négy eltérő kiterjedésű és változatos táji adottságokkal rendelkező mintaterületet választottam különböző karakterelemzési feladatokhoz (19. táblázat (M37)). A következő alfejezetekben - kutatási eredményeim bemutatása érdekében - indokolom a területválastást, ismertetem a mintaterületek legfontosabb sajátosságait és jellemzem a domináns tájváltozási folyamatokat.

A tájkarakter-elemzésben alapvető a domináns tájváltozási folyamatok feltárása. A változási folyamat kezelésére is javaslatokat, útmutatásokat adhatunk elemzésünk utolsó döntéshozást segítő lépésében. Ezért fontosnak tartottam a mintaterületek tájváltozásáról szóló forrásokat áttekinteni, terepi tapasztalatokat gyüjteni és a változási tendenciákat ismertetni. A mintaterületeken érvényesülő, aktuális és jövőben várható változásokat a 20 . táblázat (M38) foglalja össze.

\subsubsection{Európai Unió 28 tagállama +3 állam $^{167}$}

Európa tájainak sokfélesége a legnyomósabb érv arra, hogy tájkarakter-elemzést támogató technikai megoldásokat keressek a félkontinensnyi mintaterületen (27. ábra (M39)). A kutatás eredményei így nagyobb nemzetközi érdeklődésre is számot tarthatnak. A mintaterületkijelölés egyéb okai a következők voltak:

- Az Európai Táj Egyezmény (COUNCIL OF EUROPE 2000) európai szinten, az aláíró országok területén, egységes keretekbe foglalva törekszik a tájkezelési alapvetések összefogására. A tájkarakter-elemzés szellemét idéző, módszertanához és megvalósítási lépéseihez hasonlatos megoldásokat javasol.

- A térítésmentesen beszerezhető, vagy böngészhető passzív képalkotó távérzékelési adatok (MODIS, Landsat) és egyéb származtatott térképi adatbázisok (CLC100, ASTER GDEM, Urban Atlas stb.) bizonyos táji sajátosságokat akár „félkontinensnyi” területen is jól kutathatóvá tesznek, némelyik kifejezetten ebben a léptékben alkalmas a tájkarakter egyes meghatározó elemeinek jellemzésére.

- Személyes közremüködésem és tapasztalataim az EU államai és további országok területére kiterjedő SENSOR Projektben, 2006-2008 között (INT-031 ${ }^{168}$ ). A projektben végzett tevékenységem igazolta, hogy távérzékelési adatok térinformatikai feldolgozásával, a táj eltérő sajátosságinak jellemzése, a tagállamok tájértelmezési és tájkezelési sokféleségéből származó nehézségeket áthidalhatja. (KONKOLY GYURÓ, JOMBACH és TATAI 2008, 52-59).

\footnotetext{
${ }^{167}$ Az EU 28 tagállamán túli három államot (Izland, Norvégia, Svájc) természeti szempontból indokolt a mintaterület részének tekinteni

${ }^{168}$ INT-031: A SENSOR projekt honlapja (2014. 01. 28.)
} 


\subsubsection{Magyarország}

Magyarország általános táji adottságai - természetes és épített elemei -jól ismertek a hazai tájépítész szakma és a társ-szakmák számára. Annak érdekében, hogy kutatásom eredményeit a „legismertebb tájegység-sokaságon” mutassam be, indokoltnak tartottam országos mintaterületi kutatást is végezni (28. ábra (M39)). A teljes ország mintaterületté választásának egyéb okai a következők voltak:

- Az Európai Táj Egyezmény - mint a tájkarakter-elemzés témaköréhez erősen és aktuálisan kapcsolódó irányadó anyag - országok szintjén írja elő a tájak kezelését. A kapcsolódó törvény is ezen a szinten indítványozza a tájak számbavételét, ezért az alkalmazásokat célszerü országosan is bemutatni, tesztelni.

- A jelenleg térítésmentesen beszerezhető, vagy böngészhető passzív képalkotó távérzékelési adatok (Landsat, MODIS, Orto2000, stb.) és egyéb származtatott térképi adatbázisok (CLC100, Urban Atlas, ASTER GDEM stb.) a táji adottságokat olyan felbontásban, részletezettségben tartalmazzák, hogy elemezhetőségük napjainkban országos szintű tájkarakter-elemzésekben hasznosítható leginkább.

\subsubsection{Nagyberek térsége}

A Nagyberek térsége egy alapvetően síkvidéki, tóparti, vizenyős, erdő- és agrárgazdasági térség, veszélyeztetett természeti értékekkel a Balaton Üdülökörzet perifériáján szezonálisan megjelenő jelentős számú üdülőnépességgel. A terület lehatárolását a 29. ábra (M40) tartalmazza. Mintaterületté választásának és lehatárolásának egyéb okai az alábbiak voltak:

- A Budapesti Corvinus Egyetem Tájtervezési és Területfejlesztési Tanszékének Vital Landscapes (Élő Tájak) Central Europe Interreg projektje a térséget választotta mintaterületnek, így a projektben folytatott kutatások egy része integrálhatóvá vált a disszertációba.

- Változatos tájhasználat jellemző a térségben, várhatóan jelentős tájváltozási potenciállal, hazai és nemzetközi rekreációs és üdülési igénnyel.

- Többféle távérzékelési és térképes adat (ortofotó, DDM, topográfiai térképek) beszerzése történt meg erre a mintaterületre az elmúlt években a BCE Tájtervezési és Területfejlesztési Tanszékén.

- Az igen nagyfelbontású ürfelvételek és légi- és ortofotók alkalmazásának léptéke térségi, települési vagy tájrészlet szintű mintaterületi alkalmazásokat is indokol.

- Közremüködésem projektvezető-helyettesként a Vital Landscapes (Élő Tájak projektben) indokolta a projekt mintaterületi eredményeinek integrálását a disszertációba. 


\subsubsection{Délnyugat-Budakörnyék}

A Délnyugat-Budakörnyék egy alapvetően dombvidéki, folyó-menti, nagyvárosias és elővárosias térség a főváros és jórészt a Budapesti Agglomeráció területén jelentős számú lakónépességgel. Táji adottságai jól ismertek a hazai tájépítészek körében. A terület lehatárolását a 30. ábra (M40) tartalmazza. Mintaterületté választásának egyéb okai az alábbiak voltak:

- A Budapesti Corvinus Egyetem (BCE) Budai Campusa ebben a térségben található. Kutatásomban megkezdett terepi munkák a későbbiekben folytathatók, bővíthetők ebben a térségben. További kutatási projekteket lehet erre a közeli, hallgatókkal és társ-kutatókkal is egyszerüen, költségkímélően bejárható térségre építeni.

- Változatos táji sajátosságok jellemzőek, kis területen jelentős hétköznapi és hétvégi rekreációs igénnyel, nemzetközi turisztikai jelentőséggel.

- A legváltozatosabb passzív távérzékelési adatok (Valós színes és infra ortofotók, légifotók) beszerzése és ingyenesen hozzáférhető felvételek gyüjtése erre a területre történt meg az elmúlt években a BCE Tájtervezési és Területfejlesztési Tanszéken.

- A nagyon nagy felbontású ürfelvételek, légi- és ortofotók alkalmazásának léptéke térségi, települési vagy település-rész szintü mintaterületi alkalmazásokat is indokol.

- Személyes lakókörnyezetem ebben a térségben található.

\subsection{A kutatás módszerei}

Kutatási munkám többféle módszerre alapozott. Az irodalomkutatás módszere az eddigi alkalmazások, eredmények és az elterjedt gyakorlat megismerését szolgálta. A terepi bejárás és felmérés során a mintaterületek tájairól, azok jellegéröl gyüjtöttem személyes tapasztalatokat, készítettem felméréseket. A kérdőívezés és interjú-készítés módszerével a távérzékelési felvételek és származtatott adatbázisok használhatóságát határoztam meg, továbbá a tájjellegről, a tájjelleg változásáról és megjelenítéséröl alkotott véleményeket tártam fel. A távérzékelési képfeldolgozási eljárások és térinformatikai elemzések módszereivel a felvételek és származtatott adatbázisok felhasználásával tájkarakter-elemzést alátámasztó kutatást végeztem.

\subsubsection{Irodalomkutatás módszere}

Irodalmi áttekintést a témára vonatkozó nyomtatott és digitális irodalom felkutatásával, értelmezésével, rendszeres, többszöri átolvasásával és iteráló elemzésével végeztem 2006 és 2014 között. Kutatásom támaszkodott a BCE Entz Ferenc Könyvtár és Levéltár (INT032) ${ }^{169}$, a BOKU ${ }^{170}$ (INT-033) $^{171}$, a Belgrádi Egyetem Erdészeti Karának ${ }^{172}$ (INT-034) $^{173}$,

${ }^{169}$ INT-032: Budapesti Corvinus Egyetem Entz Ferenc Könyvtár és Levéltár honlapja (2013. 06. 16.) 
valamint a Massachusettsi Állami Egyetem (UMASS) ${ }^{174}$ (INT-035) ${ }^{175}$ könyvtárának anyagaira. Állományaikhoz részben $\mathrm{PhD}$ tanulmányaim, részben a Nyugat-Magyarországi Egyetem SENSOR projektjében végzett kutatási tevékenységem, részben külföldi ösztöndíjaim során fértem hozzá. A fent említett intézmények digitális könyvtárában is számos, releváns publikációt találtam. Többségük elérhetőségét az EISZ honlapja (INT036) ${ }^{176}$ és a UMASS digitális könyvtára biztosította (INT-035).

\subsubsection{Kulcsszó-keresés}

A kutatási témához köthető írott forrásokat kulcsszó-keresés módszerével tártam fel. Első körben meghatároztam a kutatás témakörébe tartozó legfontosabb kulcsszavakat ${ }^{177}$. A kulcsszavak alapján a témához leginkább illeszkedö több mint 500 forrást tártam fel. Többségük folyóiratcikk, de 200-nál több nyomtatott kiadványt vagy könyvet is találtam, mely a témát érinti, vagy a mintaterület tájleírását egészíti ki.

\subsubsection{Kulcsszavak kontextus-elemzése}

A feltárt nyomtatott forrásokat első körben áttekintő jelleggel tanulmányoztam, a fontos kulcsszavakat szöveg-környezetükkel együtt értelmeztem. A digitális irodalom esetében az automatikus keresést használtam. A kulcsszavak környezetének tartalmi vizsgálata alapján határoztam meg, hogy milyen irányban, mely forrásoknál érdemes kibővítenem az irodalomkutatást, vagy alaposabban elmélyülni egy-egy anyagban. Már ezen a szinten meghatároztam a karakter-elemzés jelenleg elterjedt passzív képalkotó távérzékelési eszköztár-készletét.

\subsubsection{Részletes irodalmi áttekintés}

A kifejezetten tájkarakter-elemzési, vagy tájkaraktert érintő irodalom elemzését a legjelentősebb nemzetközi, majd hazai források részletes áttekintésével végeztem. Ebbe a körbe tartozott a karakter-elemzés szempontjából útmutatásokat megfogalmazó módszertani irodalom és a gyakorlati alkalmazásokat esettanulmány szinten ismertető irodalom is.

\footnotetext{
${ }^{170}$ BOKU: Universität für Bodenkultur Wien, University of Natural Resources and Life Sciences, Vienna

${ }^{171}$ INT-033: BOKU könyvtárának honlapja (2013. 06. 16.)

${ }^{172}$ Univerzitet u Beogradu, Šumarski Fakultet

${ }^{173}$ INT-034: Belgrádi Egyetem könyvtárának honlapja (2013. 06. 16.)

${ }^{174}$ University of Massachusetts, Amherst

${ }^{175}$ INT-035: UMASS Amherst könyvtárának honlapja (2013. 06. 16.)

${ }^{176}$ INT-036: Elektronikus Információszol gáltatás honlapja (2014. 02. 11.)

${ }^{177}$ tájkarakter (landscape character), távérzékelés (remote sensing), térinformatika (GIS), karakter (character), táj (landscape), tájkép (landscape scenery), tájindikátor (landscape indicator), tájmetria (landscape metrics), tájesztétika (landscape aesthetics), tájidentitás (landscape identity), fénykép (photo), légifotó (aerial photo), ortofotó (orthophoto), ürfelvétel (satellite image), magassági modell (elevation model) stb.
} 
Meghatároztam az eszköztár-készlet alkalmazási gyakorlatát és a gyakorlat átalakulásának irányaira, az eszköztár-készlet folyamatos bővülésére koncentráltam. Ebben a lépésben körvonalazódott a tájkarakter-elemzés módszertanához kapcsolható passzív képalkotó távérzékelési eszköztár-készlet és ennek alapján vázoltam fel a bővítési lehetőségeket.

\subsubsection{Eszköztár-tematikus áttekintés}

Az utolsó körben az eszköztár-készlet bővítésének lehetőségeit érintő témát feldolgozó forrásokra koncentráltam. Az ilyen források még akkor is hasznosnak bizonyultak, ha nem egyértelműen a tájkarakter témában születtek. Ezen a szinten az irodalom-kutatás célja a társszakmákban megjelenő változatos alkalmazások megismerése volt. Ezt a kutatást annak érdekében végeztem, hogy ötletet merítsek a karakter-elemzési eszköztár kibővítéséhez. Itt hat nagyobb témakörben folytattam az áttekintést ${ }^{178}$.

\subsubsection{Kérdőivezés és interjúkészítés}

A kérdőívezés módszerét a feldolgozott irodalomban gyakran használt vizuális kérdőívezésre alapoztam. A kérdőívezetteknek passzív képalkotó távérzékeléssel készült felvételeket mutattam tájrészletekről. A kérdések arra irányultak, hogy felismerik-e a szükebb vagy tágabb lakókörnyezetükbe tartozó tájakat, be tudják-e azonosítani azok elemeit, az ábrázolt tájrészletek között felfedeznek-e eltéréseket és ezek közül melyiket tartják jelentős, karakteres eltérésnek.

A kérdések egy része arra irányult, hogy mely felvételeket vagy tájmodelleket látná szívesebben egy jövőbeli fejlesztés bemutatásának alapjául egy látványtervben és melyik az, amelyikért még „fizetni” is hajlandó lenne. A vizuális kérdőívezést egy 40 fős csoporton személyes kérdőívezéssel teszteltem 2012-2013 időszakban. 2014 elején pedig egy 215 fôs felmérést végeztem csoportos vetítéses módszerrel, feleletválasztós kérdésekkel. A felvételeket és tájmodelleket ${ }^{179}$ a Délnyugat-Budakörnyéki és Nagyberek térségi mintaterületekről válogattam össze. Vizuális kérdőívezés során összesen 400 képet mutattam meg, melyeket a nagymintás felmérés során 120 képre szükítettem. Két kép összevetése esetén először a 2,5D vagy 3D tájmodell képét láthatták, és csak később az azonos nézőpontból készült valós madártávlati fényképet. A kérdőívezettek döntő többsége 20 és 30 év közötti diák volt. A felvételekből és kérdésekből néhányat a 31-33. ábrák (M41-M43) mutatnak be.

\footnotetext{
${ }^{178}$ domborzat-elemzés, indexek, változás-vizsgálat, láthatóság-elemzés, vizualizáció, jellemzés és lehatárolás,

${ }^{179}$ A kérdőívekben és interjúkban felhasznált anyagok: terepi fényképek, madártávlati ferde tengelyü fényképek, $2,5 \mathrm{D}$ vagy $3 \mathrm{D}$ tájmodellek képei, ortofotók és ürfelvételek
} 
Az interjúkészítés során a kérdőívezés felvételeit használtam. Olyan kérdéseket tettem fel, melyek a kérdőívezésben kapott válaszok lényegére, miértjére céloztak. Az interjúk átlagosan 60 percig tartottak. A tájrészleteket ábrázoló felvételek megtekintése során az interjúalany kifejthette véleményét a különböző felvételek használhatóságáról, illetve arról, hogy milyen tájjelleg érzékelhető számára, milyen elemek alapján vél ráismerni a területre, vagy sorolja be azt valamilyen típusba, tájegységbe. Az interjúalanyoknak lehetőségük volt megjegyzéseket tenni, döntéseiket, képválasztásaikat részletesen indokolni. A 40 fövel folytatott beszélgetés során a képeket nyomtatott A4-es formában jelenítettem meg. A megkérdezettek életkora 17 és 72 év között volt.

\subsubsection{Terepi bejárás és felmérés}

A mintaterületek tájainak megismeréséhez terepi bejárásaim alapvetően hozzájárultak. A mintaterületek mindegyikén számos alkalommal tájkutatási, felmérési céllal jártam. Magyarország és Európa több államának tájait természetesen lehetetlenség megismerni, mégis minden bejárásom során törekedtem arra, hogy ne csak a sokak által látogatott városi, vagy beépített területeket járjam be, hanem a vidéki, lakott területen kívüli tájrészletekkel is megismerkedhessek. Ezért gyakran választottam a repülőutak helyett a vonatot, személygépjármüvet, kerékpárt vagy a tömegközlekedéssel kombinált gyaloglást. Terepi felméréseim további szakmai eszközeiként alkalmaztam

- a különféle térképek, felvételek alapján történő tájékozódás módszereit,

- a GPS-szel történő helymeghatározást

- a digitális fényképezést és dokumentálást.

A legtöbb eredménycsomag elkészítéséhez felhasznált Délnyugat-Budakörnyéki mintaterületen több mint 13 éve végzek folyamatos terepi bejárást és felmérést. A legtöbb terepi felmérést ezen a mintaterületen 2010-2011 időszakban, a Nagyberek térségében 20102013 időszakban végeztem.

\subsubsection{Képfeldolgozási eljárások és térinformatikai elemzések}

A felvételek, térképek, térbeli adatok feldolgozásához többféle térinformatikai és képfeldolgozó szoftvert használtam (Erdas Imagine 8.7, ArcMap 9.3, eCognition Developer 8.7). A legfontosabb funkciók közé a geokorrekció, a képpont-osztályozás, az indexek, a térbeli kapcsolás ${ }^{180}$ a vizuális interpretáció és a láthatóság-elemzés tartoztak. Ezeket a módszereket az irodalomkutatásban ismertettem. Továbbá használtam 3D megjelenítő és szerkesztő alkalmazásokat a GoogleEarthPro, és a GoogleSketchUp szoftverrel, valamint képszerkesztési müveleteket a Photoshop és GIMP programokkal.

180 „spatial join” parancs (ArcMap) 


\section{EREDMÉNYEK}

A kutatási tevékenységemet - mely a második fejezetben (a 2.1.-2.7. alfejezetekben) vázolt feladatok megoldásából áll - az ott kialakított nagyobb témacsoportok szerint végeztem. Kutatási eredményeimet a témacsoportoknak megfelelő csomagokban, a 4.1.-4.7. alfejezetekben ismertetem. A második fejezetben megfogalmazott feltételezések kapcsán született téziseimet az 5. fejezetben, az új tudományos eredmények fejezetben összegzem.

\subsection{Passzív képalkotó tá vér zékelés szerepe a tájkarakter-elemzésben}

A passzív képalkotó távérzékelés szerepét a tájkarakter-elemzésekben irodalomkutatási eredményeim összefoglalásaként három szemszögből határoztam meg:

1. Milyen tájelemek, tájelem-együttesek detektálhatók és elemezhetők a passzív képalkotó távérzékeléssel készült adatokkal?

2. Milyen felvételek és szár maztatott adatbázisok alkalmasak erre a különböző léptékü tájkarakter-elemzések keretében?

3. Mely képfeldolgozási eljárások és térinformatikai elemzések használhatók a tájkarakter-elemzés során?

\subsubsection{Tájelemek, tájelem-együttesek elemezhetősége}

Az irodalomkutatás során megállapítottam, hogy a tájkarakter-elemzés számára potenciálisan számba vehető tájelemek száma végtelen, de típusaik meghatározhatók. Az is egyértelmüvé vált, hogy néhány tájelem-csoport, vagy más néven tájelem-együttes a legtöbb tájkarakterelemzésben fontos szerepet játszik és bármelyik válhat a táj karakteradó elemévé. Ilyen elem, vagy elem-együttes a domborzat, a felszínborítás, az éghajlat, a földtan és talajtan, a tájszerkezet, a mintázat, növényállomány, a látványelemek stb.

A 21. táblázatban (M44) közlöm, hogy melyek azok az elemek, vagy elem-együttesek, amelyeket passzív képalkotó távérzékelési adatok útján interpretáltak vagy elemeztek bármely tájkarakter-elemzési témájú irodalom tanúsága szerint. Az eredményből látszik, hogy

- leggyakrabban a felszínborítás és a növényzet elemzése történik meg valamilyen passzív képalkotó távérzékelési adat felhasználásával,

- ezt követi a különböző látvány elemek, percepcionális tényezők, tájszerkezet, és mintázat szerepe,

- a domborzat és vízrajz esetében nagy a kihasználatlan passzív képalkotó távérzékelési potenciál,

- több fontos természeti tényező esetében (pl.: földtan, talajtan és éghajlat) és a gazdasági tényezők esetében a távérzékelési adatok nem kerültek hasznosításra. 
21. táblázat (részlet (M44)) Tájelemek interpretálhatósága, elemezhetősége passzív képalkotó távérzékelés eszközeivel az irodalmi áttekintés eredményei alapján.

\begin{tabular}{|c|c|c|c|c|c|c|c|c|c|}
\hline Inte & $\begin{array}{l}\text { Tájelem-csoportok } \\
\text { rpretációs elemek }\end{array}$ & $\begin{array}{l}\text { Földtan } \\
\text { talajtan, } \\
\text { éghajlat }\end{array}$ & $\begin{array}{l}\text { Dom- } \\
\text { borzat }\end{array}$ & Vízrajz & $\begin{array}{l}\text { Növény- } \\
\text { takaró }\end{array}$ & $\begin{array}{l}\text { Felszín- } \\
\text { borítás }\end{array}$ & $\begin{array}{l}\text { Látvány- } \\
\text { elemek, } \\
\text { (percepció) }\end{array}$ & $\begin{array}{c}\text { Táj- } \\
\text { szerkezet }\end{array} \mid$ & Mintázat \\
\hline 1 & Alak (shape) & & volt & volt & volt & volt & volt & volt & volt \\
\hline 2 & Méret (size) & & lehetne & volt & volt & volt & volt & volt & volt \\
\hline 6 & Mintázat (pattern) & & volt & volt & volt & volt & volt & & volt \\
\hline 7 & $\begin{array}{l}\text { Szerkezet / textúra } \\
\text { (texture) }\end{array}$ & & volt & volt & volt & volt & volt & volt & \\
\hline 14 & $\begin{array}{l}\text { Időbeliség } \\
\text { (time scale) }\end{array}$ & & lehetne & lehetne & volt & volt & volt & volt & volt \\
\hline 15 & $\begin{array}{l}\text { Térbeli eltérés } \\
\text { (spatial difference) }\end{array}$ & & lehetne & lehetne & volt & volt & volt & volt & volt \\
\hline
\end{tabular}

\subsubsection{Felvételek és származtatott adatok lehetséges alkalmazása}

Az irodalomkutatás alapján meghatároztam mely felvételek és származtatott adatbázisok milyen léptékben kerültek hasznosításra a tájkarakter-elemzésben. Az ASTER GDEM modellek felhasználása tájkarakter-elemzésekben az áttekintett irodalomban nem szerepelt, de jellemzői alapján alkalmazható lehet a karakter-elemzésben szükséges domborzat-elemzési és láthatóság-elemzési feladatok során domborzati alapadatként (22. táblázat).

22. táblázat Passzív képalkotó távérzékeléssel nyert adatok felhasználásának gyakorlata léptéktől függően (figyelembe véve a feldolgozhatóság, áttekinthetőség, adatmennyiség optimalizálása szempontokat)

\begin{tabular}{|c|c|c|c|c|}
\hline Felvétel & \multirow{2}{*}{ Ürfelvétel } & \multirow{2}{*}{$\begin{array}{l}\text { Légifelvétel vagy } \\
\text { földfelszíni felvétel }^{181}\end{array}$} & \multirow{2}{*}{$\begin{array}{c}\text { Származtatott } \\
\text { adatbázis }\end{array}$} & \multirow{2}{*}{$\begin{array}{c}\begin{array}{c}\text { Domborzatmodell } \\
\text { vagy }\end{array} \\
\text { felszínmodell }^{182} \\
\end{array}$} \\
\hline Lépték & & & & \\
\hline $\begin{array}{l}\text { Kontinens - } \\
\text { ország }\end{array}$ & $\begin{array}{l}\text { Alacsony felbontás } \\
\text { (pl. Modis) }\end{array}$ & $\begin{array}{c}\text { Csak pilot projekt szinten, kis } \\
\text { mintaterületre }\left(10-100 \mathrm{~km}^{2}\right) \\
\text { javasolt }\end{array}$ & $\begin{array}{c}\text { CLC100, } \\
\text { European Urban } \\
\text { Atlas (utóbbi csak } \\
\text { mintaterületeken) } \\
\end{array}$ & $\begin{array}{l}\text { ASTER GDEMv1-v2 } \\
\text { (javasolható térbeli } \\
\text { felbontás: } 1 \mathrm{~km} \text { ) }\end{array}$ \\
\hline $\begin{array}{l}\text { Ország - } \\
\text { országrész, } \\
\text { régió, megye }\end{array}$ & $\begin{array}{l}\text { Közepes felbontás } \\
\text { (pl. Landsat) }\end{array}$ & $\begin{array}{l}\text { Csak pilot projekt szinten, kis } \\
\text { mintaterületre }\left(10-100 \mathrm{~km}^{2}\right) \\
\text { javasolt }\end{array}$ & $\begin{array}{c}\text { CLC100, } \\
\text { CLC50, European } \\
\text { Urban Atlas } \\
\text { (utóbbi csak } \\
\text { mintaterületeken) }\end{array}$ & $\begin{array}{l}\text { ASTER GDEMv1-v2 } \\
\text { (javasolható térbeli } \\
\text { felbontás: } 0,1 \mathrm{~km} \text { ) }\end{array}$ \\
\hline $\begin{array}{l}\text { Térség, } \\
\text { település }\end{array}$ & $\begin{array}{l}\text { Közepes vagy nagyfelbontás, } \\
\text { esetleg igen nagy felbontás } \\
\text { (pl.: Worldview2, Ikonos) }\end{array}$ & $\begin{array}{c}\text { Ortofotó, történeti } \\
\text { légifelvételek, madártávlati } \\
\text { ferde tengelyü és földfelszíni } \\
\text { fénykép javasolt }\end{array}$ & $\begin{array}{c}\text { CLC50, } \\
\text { CLC100, } \\
\text { European Urban } \\
\text { Atlas }\end{array}$ & $\begin{array}{l}\text { ASTER GDEMv1-v2 } \\
\text { (javasolható térbeli } \\
\text { felbontás: } 25 \mathrm{~m} \text { ) }\end{array}$ \\
\hline $\begin{array}{l}\text { Tájrészletek, } \\
\text { településrész }\end{array}$ & $\begin{array}{l}\text { Nagyfelbontású ürfelvétel } \\
\text { (pl.: Worldview2, Ikonos) }\end{array}$ & $\begin{array}{l}\text { Ortofotó, történeti } \\
\text { légifelvételek, madártávlati } \\
\text { ferde tengelyủ és földfelszíni } \\
\text { fénykép javasolt }\end{array}$ & $\begin{array}{c}\text { CLC50, CLC100, } \\
\text { European Urban } \\
\text { Atlas, } \\
\text { saját szerkesztés }\end{array}$ & $\begin{array}{l}\text { ASTER GDEMv1-v2 } \\
\text { (javasolható térbeli } \\
\text { felbontás: } 25 \mathrm{~m} \text { ) }\end{array}$ \\
\hline $\begin{array}{l}\text { Bizonyosan } \\
\text { feltárható } \\
\text { tájelem- } \\
\text { csoportok }\end{array}$ & $\begin{array}{l}\text { felszínborítás, növénytakaró, } \\
\text { vízhálózat, a tájszerkezet egyes } \\
\text { elemei és mindezek térbeli és } \\
\text { időbeli eltérései }\end{array}$ & $\begin{array}{l}\text { felszínborítás, növénytakaró, } \\
\text { vízhálózat, tájszerkezet, mintázat, } \\
\text { egyes elemei, látványelemek és } \\
\text { mindezek térbeli és időbeli } \\
\text { eltérései, (földfelszíni fényképnél } \\
\text { domborzati vagy geomorfológiai } \\
\text { elemek is) } \\
\end{array}$ & $\begin{array}{l}\text { felszínborítás, } \\
\text { vízhálózat, } \\
\text { tájszerkezet egyes } \\
\text { elemei és mindezek } \\
\text { térbeli és időbeli } \\
\text { eltérései } \\
\end{array}$ & $\begin{array}{l}\text { domborzati jellemzők, } \\
\text { láthatósági viszonyok }\end{array}$ \\
\hline
\end{tabular}

${ }^{181}$ Terepi és madártávlati fényképek természetesen minden léptékben kiegészíthetik a felhasználható felvételek sokaságát, mert mindössze illusztrációként szolgálnak, egy-egy tájrészletet reprezentálnak.

${ }^{182}$ ASTER GDEM modellek használatáról tájkarakter-elemzésben nincs információm, de valószínűnek tartom, hogy 2009 és 2011 óta használták már karakter-elemzési a célra valamelyik változatot. 


\subsubsection{Képfeldolgozási eljárások és térinformatikai elemzések a tájkarakter-elemzés lépéseiben}

$\mathrm{Az}$ irodalomkutatatás alapján meghatároztam, hogy a passzív képalkotó távérzékelés felvételei, származtatott adatbázisai és ezek feldolgozási eljárásai hogyan illeszkednek a tájkarakter-elemzés folyamatához (3. ábra (M5)) és annak egyes lépéseihez. Az eredményeket a 23. és 24. táblázatban (M45) foglaltam össze. A teljes folyamatot több helyen ki tudja egészíteni a passzív képalkotó távérzékelés, de a legnagyobb potenciálja a tájkarakter-elemzés 4. lépésében van. Ebben a lépésben valamennyi típusú felvétel feldolgozása, a lehető legtöbb tájelem beazonosítása érdekében szükséges lehet, ugyanakkor nagy szerepe van a felvételek és adatok képfeldolgozási és térinformatikai elemzési eljárásainak is (24. táblázat (M45)).

23. táblázat (részlet (M45)) Tájkarakter-elemzés folyamatához illeszkedő képfelhasználási javaslatok és képfeldolgozási eljárások

\begin{tabular}{|c|c|c|c|}
\hline & $\begin{array}{l}\text { Tájkarakter-elemzés } \\
\text { lépései } \\
\text { (SWANwick 2002, } 13 \text { alapján) }\end{array}$ & $\begin{array}{l}\text { Alkalmas passzív távérzékelési } \\
\text { képfelhasználási } \\
\text { és képfeldolgozási eljárások } \\
\text { (a disszertáció szerzójének megállapítása) }\end{array}$ & \\
\hline $\begin{array}{c}0 \\
0 \\
0 \\
0 \\
0 \\
0 \\
0 \\
0 \\
0 \\
0 \\
0 \\
0 \\
0 \\
0 \\
0 \\
0 \\
0\end{array}$ & $\begin{array}{l}\text { 2. „Irodai” tájvizsgálat } \\
\text { „Desk study” } \\
\text { Feladata: Irodalom, a lapadatok } \\
\text { és alaptérképek gyüjtésével és } \\
\text { áttekintésével a tájról szerezhető } \\
\text { információk elemzése }\end{array}$ & $\begin{array}{l}\text { Táji GIS a datbázis felállítása a téma kutatásához } \\
\text { szükséges különféle távérzékeléssel készített } \\
\text { felvételekből: ürfelvételek, ortofotók, ferde } \\
\text { tengelyü madártávlati és méröképes légifelvételek, } \\
\text { korábbi v. archív terepi földfelszíni fényképek } \\
\text { (kiegészítve aktuális térképi adatbázisokkal, } \\
\text { tematikus térképekkel, alaptérképekkel, történeti } \\
\text { térképekkel). } \\
\text { Eredmény: Tájtörténet, tájváltozás elemzése, a } \\
\text { jellegbeli tájalakulás feltárása, a jelenben zajló } \\
\text { domináns tájfejlödési folyamat meghatározása, } \\
\text { felkészülés a terepi bejárásra }\end{array}$ & \\
\hline : & $\begin{array}{l}\text { 3. Terepi felmérés } \\
\text { „Field survey” } \\
\text { Feladat: Terepbejárás, terepi } \\
\text { adatgyüjtés, felvételkészítés, } \\
\text { térbeli adatbázisba rendezés }\end{array}$ & $\begin{array}{l}\text { Terepi be járási térképlap vagy felmérési ív } \\
\text { nyomtatása a táji GIS adatbázisban rendelkezésre } \\
\text { álló felvételekből és származtatott térképi } \\
\text { adatbázisok kombinációjából. Ezek alapján a } \\
\text { terepi tájékozódás biztosítható, az érzékelés egyes } \\
\text { tényezőit konkrét helyhez, tájrészlethez, } \\
\text { tájelemekhez lehet kötni. Ezekre jelöléseket, } \\
\text { megjegyzéseket fel lehet vezetni. Fényképkészítés } \\
\text { vagy madártávlati légifényképezés a terepen. } \\
\text { Eredmény: Terepbejárás felvételeinek és egyéb } \\
\text { eredményeinek beemelése a táji GIS adatbázisba. }\end{array}$ & \\
\hline 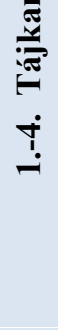 & $\begin{array}{l}\text { 4. Osztályozás és leírás } \\
\text { „Classification and } \\
\text { description” } \\
\text { Feladat: A tájrészletek } \\
\text { felismerése, osztályozása, } \\
\text { tájhatárok meghúzása, tájak } \\
\text { megnevezése, leírása }\end{array}$ & $\begin{array}{l}\text { Felvételek többféle fajtája és a felvételek } \\
\text { elemzésének különbözö formája használható: } \\
\text { vizuális interpretáció, irányítatlan és irányított } \\
\text { képpont-osztályozás, raszter-vektor konverziók } \\
\text { (másodlagos képadat-nyerés feldolgozási } \\
\text { módszerei), szegmentáció, index-elemzés, } \\
\text { domborzat-elemzés, (vízgyüjtő-lehatárolás, } \\
\text { vízfolyás-meghatározás, maximális lejtés } \\
\text { meghatározás), láthatóság-elemzés, stb. } \\
\text { Eredmény: A tájkarakter meghatározása }\end{array}$ & \\
\hline
\end{tabular}




\subsection{A domborzat jellemzése passzív képalkotó távérzékelési adatokkal}

Kutatásom során vizsgáltam és meghatároztam a passzív képalkotó távérzékelés felvételeiből készített digitális magassági modellek és feldolgozási technikáik alkalmazhatóságát a tájkarakter-elemzésben. Külön kitértem a 2.2. fejezetben megoldandó feladatként felsorolt magassági modellek (SRTM, GLSDEM, DDM5 és DDM100) összevetésére, pontosságuk vizsgálatára, az egyes terepi alakzatokra, a felszínborításra, a kitettségre, valamint a különféle térinformatikai domborzat-elemzési módszerekre.

\subsubsection{Digitális magassági modellek általános összehasonlítása}

Kutatásomban összevetettem a passzív képalkotó távérzékelés eredményeképpen készült ASTER GDEMv1 és ASTER GDEMv2 domborzati adatokat a hazai legrészletesebb és legpontosabb domborzatmodellekkel (FÖMI által készített DDM100 és DDM5), továbbá más európai mintaterületen egyéb, térítésmentesen elérhető domborzatmodellekkel (SRTM, GLSDEM). Célom meghatározni, milyen eltérések jellemzőek, milyen használhatóságot korlátozó hibák tárhatók fel és hibakorrekcióra vonatkozó javaslatok adhatók. Terepi geodéziai, vagy GPS alapú méréseket a pontosság meghatározása céljából nem végeztem, mert nem a domborzatmodell ismételt validálása, hanem a hazai gyakorlatban terjedő különféle magassági modellek használhatóságának vizsgálata és tájtípus-specifikus - a pontatlanság minimalizálását eredményező - javaslatok megfogalmazása volt a célom.

Az összevetés eredményeként megállapítható, hogy az aktív távérzékeléssel készített SRTM modell a DDM100 és a DDM5-ös adatbázishoz mérten is átlagosan a legpontosabb mind az ország területén, mind a mintaterületeken vételezett adatok vonatkozásában. A passzív távérzékelési ASTER GDEM változatok ebben az összevetésben kicsivel elmaradnak mögötte. Ez azért is figyelemre méltó, mert mindezzel cáfolom azt a feltételezést, hogy a nagyobb felbontással rendelkező ASTERGDEM adatbázis átlagosan sokkal pontosabb lenne az alacsonyabb felbontású SRTM domborzati adatoknál. Az összevetés eredményeit a 34. és 35. ábra (M46) foglalja össze és további ábrák egészítik ki.

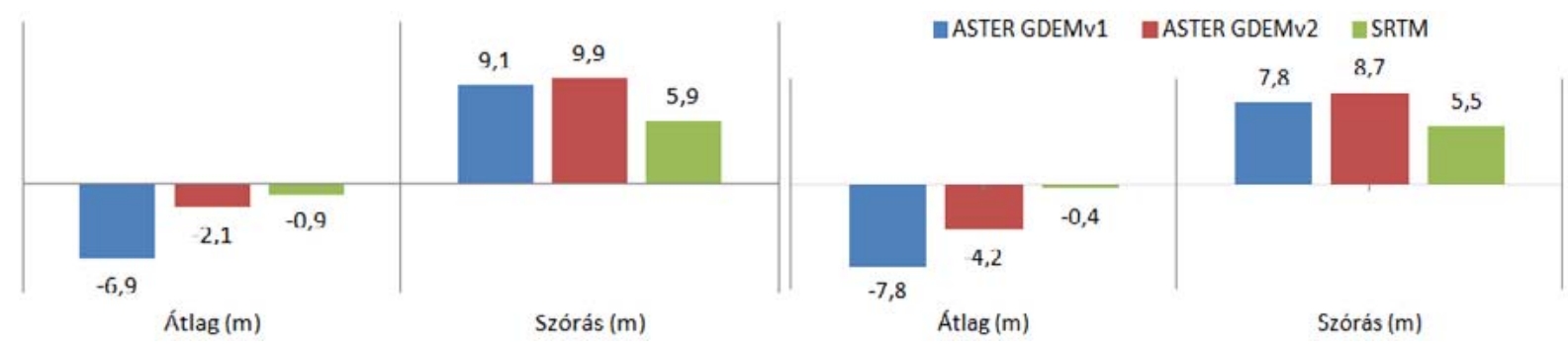

34. és 35. ábra (részletek (M46)) Magassági modellek DDM100-hoz és DDM5-höz viszonyított eltérései. 
Az ASTER GDEM adatok felbontásukból eredően a 60-as szélességtől északra már szemrevételezés alapján is sokkal részletgazdagabbak, mint a GLS DEM adatok. A térképes összevetés szemléletesen igazolta, hogy a GLS DEM és az SRTM adatok között Magyarország területén többnyire semmi eltérés nincs, helyenként viszont néhány tíz méteres, akár 30-40m-es eltérések is adódnak. A domborzati adatok vizuális összevetése alapján kijelenthető, hogy Magyarországon ez az eltérés lényegében csupán vízszintes geometriai pontatlanságból adódik, mert az eltérés legfeljebb ott kimutatható, ahol a domborzat meredek (36. ábra (M46))). A GLSDEM és a DDM-ek közötti eltérések vizsgálatát ezért nem tartottam indokoltnak, a továbbiakban a GLS DEM adataira nem térek ki.

A térképes összevetésböl derült ki, hogy az ASTER GDEM verziók esetében enyhén északkelet-délnyugat irányú, $60-70 \mathrm{~km}$ szélességü sávokban hullámzóan változó a magassági modellek közötti eltérés a v1 és a v2 esetében, is amennyiben a DDM adatokkal vetjük össze. Az SRTM adatoknál ilyen jelenség nem tapasztalható (37. ábra).
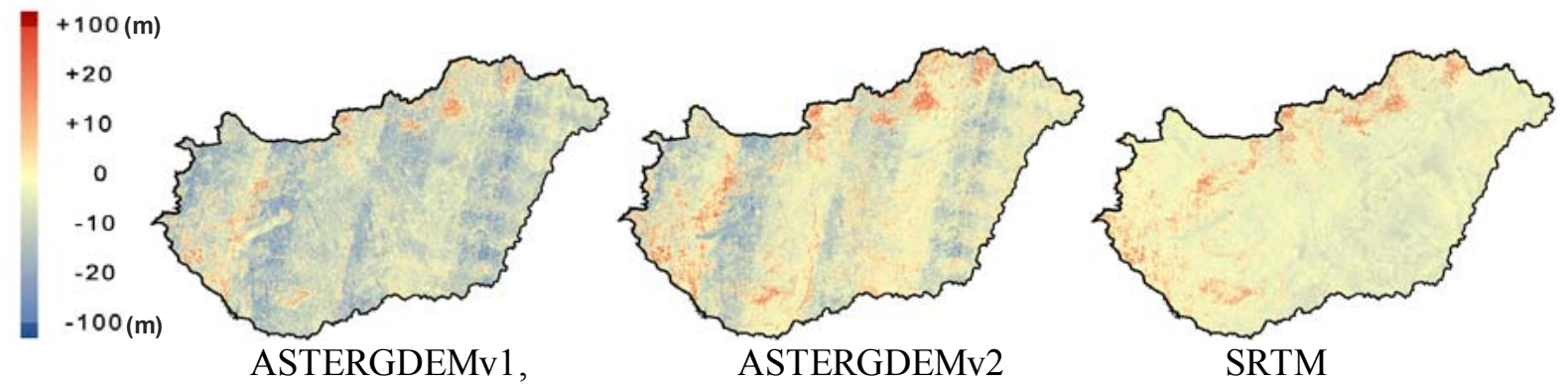

37. ábra Magassági modellek eltérései a valóságos tengerszintfeletti magasságot leginkább tükröző DDM100-hoz képest.

A kutatás eredményeként kijelenthető, hogy az ASTER GDEMv2 adatok mintaterületi vizsgálatok alapján a valósághoz vélhetőleg legközelebbi DDM5-höz képest átlagosan 4,2mrel terepszint alatti értékeket mutatnak. Fontos megjegyezni, hogy az eltérések adódhatnak:

- abból, hogy a sztereo-fotogrammetriai módszernek megfelelöen a felszínborítás (növényzet, épület) felső részének / tetejének magassági adatait hordozza az ASTER GDEM adatbázis, és abból, hogy az irodalom szerint is igen nagy a földfelszíni elemek és a kitettség eltéréseket befolyásoló hatása.

- abból, hogy tényleges terepmagasság-változás is történhetett két felmérés időpontja között (pl.: bánya-rekultiváció során bányagödör-feltöltés, vagy bányászati tevékenység során bányagödör mélyítése, hulladékdepónia emelése, tárolt iszap szintjének emelkedése, autópálya bevágás kialakítása vagy töltés építése, nagyobb építmény vagy épületegyüttes létesítése, stb. (38. ábra (M46)),

- abból, hogy a domborzatmodellek térbeli felbontása eltérö, a valós domborzatot különböző térbeli részletességgel képezik le. Nagyobb felbontásnál több információ, apróbb részletek, pl. sziklák, szakadékok is feltünhetnek, melyek az alacsonyabb felbontás esetén egy értékként átlagolódnak. 


\subsubsection{Domborzat-típusokra és terepi alakzatokra vonatkozó következtetések}

A magassági modellek (ASTER GDEMv1, ASTER GDEMv2, SRTM) esetében kimutattam, hogy a tényleges magasságot legjobban tükröző DDM100 és DDM5 adatokhoz képest az eltérés síkvidéken negatív elöjelü, hegyvidéken pozitív előjelü, dombvidéken pedig mindkettő előfordul, de nullához közelebbi értékekkel (39. és 41. ábra (M47)). Ez azt jelenti, hogy a vizsgált domborzatmodellek hazánkban síkvidéken nagyobb eséllyel mutatnak a valóságnál alacsonyabb értéket, míg hegyvidéken a valóságnál magasabb értékeket.

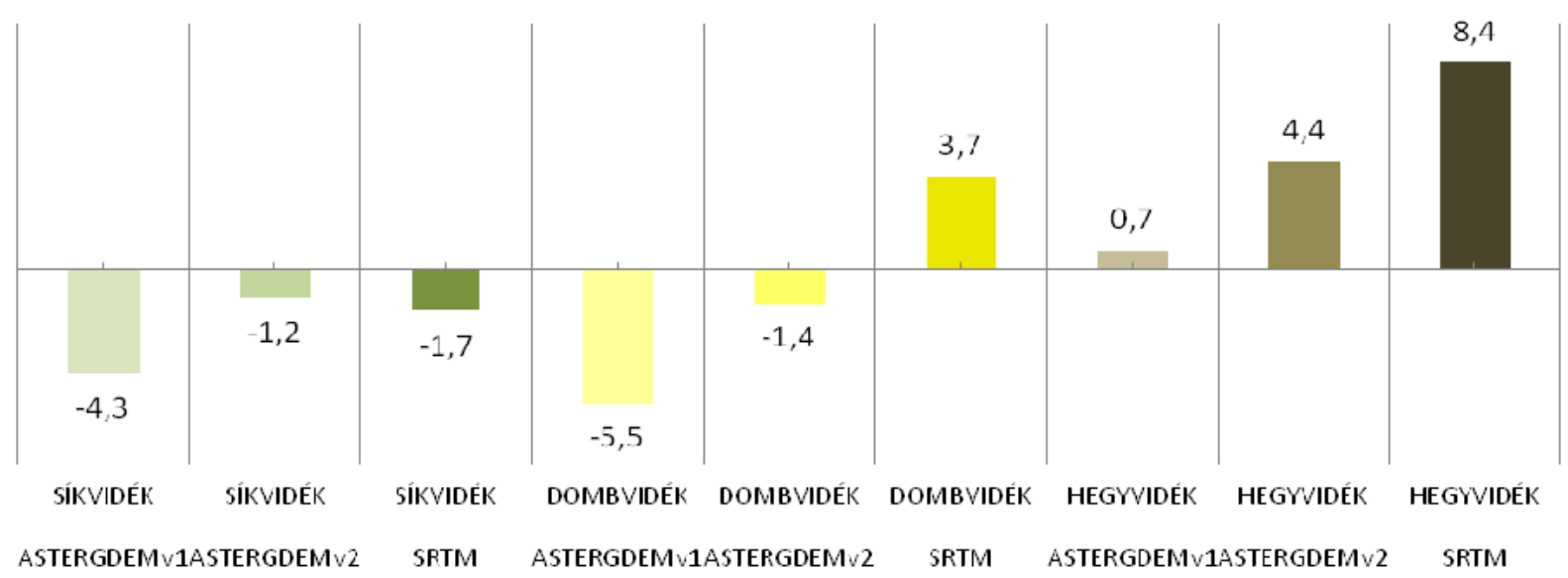

41. ábra (részlet (M47)) Magassági modellek DDM5-höz viszonyított eltéréseinek átlaga (m) magyarországi mintaterületeken, különböző domborzati típusok esetén.

Az SRTM a domborzat-típusonkénti elemzésben, a hasonló felbontással rendelkező DDM100 adatokkal történő összevetésben mutat nagyobb egyezést (40. ábra (M47)), míg az ASTERGDEMv2 a DDM5 esetén szolgál jobb eredményekkel (42. ábra (M47)). Ez az eredmény erősíti a feltételezést, hogy a térbeli felbontásnak lehet szerepe a domborzatmodell pontosságában. Mindettől függetlenül megállapítható, hogy az SRTM adatok domborzati típusonkénti mutatói még az 5 m-es felbontással való összevetésben sem jelentősen rosszabbak a nagyobb felbontású modellekhez képest (42. ábra (M47)).

A síkvidéki területeken a domborzatmodellek többsége nagyobb arányban egyezik meg a valóságos tengerszint feletti magassággal, mint dombvidéken és hegyvidéken. Az adatok legalább 40\%-a síkvidéken nem tér el +/- 3,5 méterrel a valós magasságtól, de az SRTM esetében ez az érték a 87\%-ot is eléri, ám hegyvidéken akár 20\%-ra is csökkenhet (42. ábra (M47)).

A tájkarakter domborzati tényezőjét vizsgáló összehasonlító elemzésemből kiderült, hogy az ASTER GDEMv2 magassági modell különösen hegyvidéki területen alkalmas a domborzati tájjelleg meghatározására. Az SRTM magassági modell alacsonyabb felbontása ellenére síkvidéken pontosabb. Dombvidéki területen a két modell pontossága között nincs jelentős eltérés (39-42. ábra (M47)). 
A térképeken és a felvett metszeteken jól látható, hogy:

- az ASTER GDEM és az SRTM modellen a völgyfenék magasabb, a hegyek laposabbak $^{183}$ mint a DDM5-ön, egyes kisebb dombok alig kivehetőek ${ }^{184}$,

- az ASTER GDEMv2, de még inkább a v1 és az SRTM modellek esetében a hegygerinc vonala nem rajzolódik ki élesen, a szakadékok, falak kevésbé érzékelhetők ${ }^{185}$, helyenként környezetük egyéb hibáktól is terhelt, és ez zavaró lehet az elemzések során,

- az ASTER GDEMv2 modellen a terepfelszín egyenetlenebb, mint a v1 vagy az SRTM esetében, ez föként a síkvidéki területeken szembetűnő,

- az ASTER GDEM modellekben a hozzávetőlegesen 20x30m-es cellaméret miatt a kb. $600 \mathrm{~m}^{2}$ alatti domborzati földfelszíni formákról nincs olyan érdemi információ, ami egy tájkarakter-elemzésben szerepelhetne. A szemléletesség kedvéért jelzem, hogy a Budaörsi Kálváriadomb kevéssel e határ felett van és alig valami észlelhető belőle az ASTER GDEM modell második változatában (43. ábra).

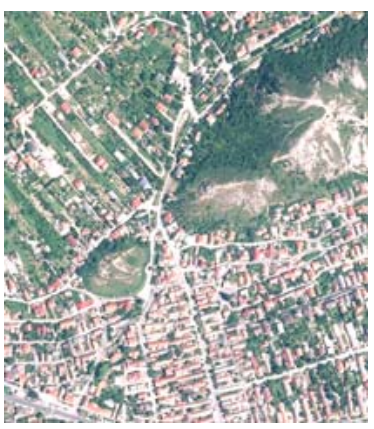

Ortofotó 2010 (FÖMI)

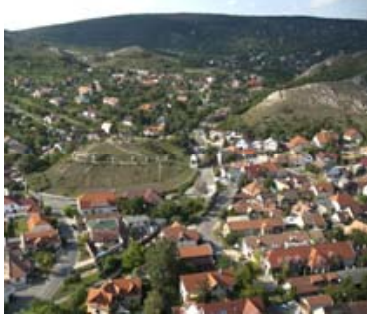

Madártávlat 2012 (Pillangó)

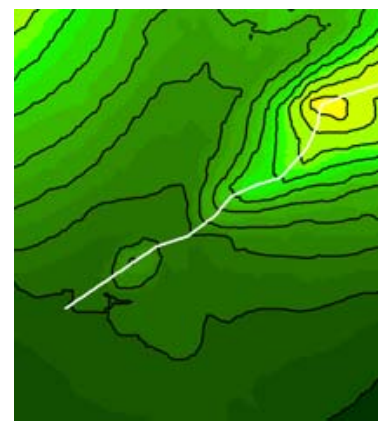

DDM5 (5m) (FÖMI)
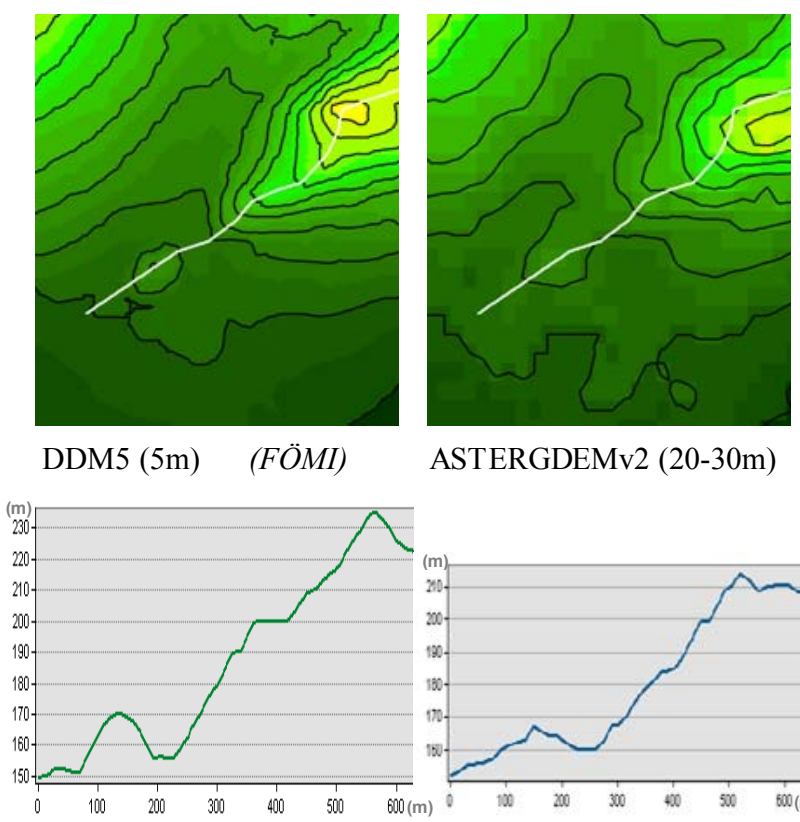

DDM5 (5m)
ASTERGDEMv2 (20-30m)

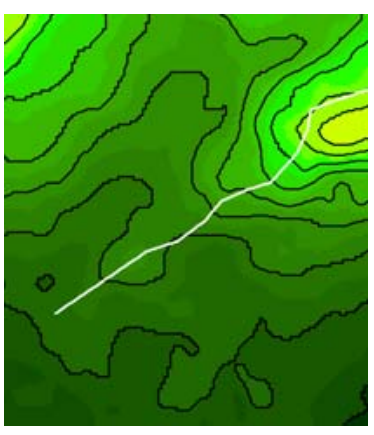

ASTERGDEMv2 (5m)
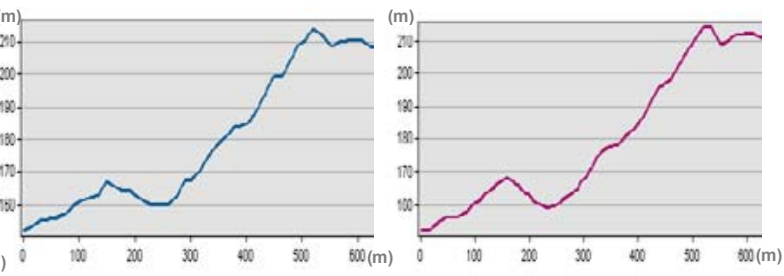

ASTERGDEMv2 (20-30m) ASTERGDEMv2 (5m)

43. ábra Felvételek, domborzatmodellek és metszetek a Budaörsi Kálváriadomb és Kő-hegy környékére. ASTERGDEMv2 eredeti felbontással és $5 \mathrm{~m}$-es felbontásra mintavételezett változatban is (felső sor), valamint madártávlati kép és a páronként megfeleltethető domborzatmodellekből a fehér színü gerincvonal mentén felvett metszetek (alsó sor).

\footnotetext{
${ }^{183}$ Részben az alacsonyabb felbontásnak köszönhetően

${ }^{184}$ P1.: Kálváriadomb Budaörsön (43. ábra az ASTER GDEMv2 esetében mutatja ezt)

${ }^{185} \mathrm{Pl}$.: fonyódi löszfal, budaörsi Törökugrató-hegy
} 
A meghatározott eltérések a térbeli felbontás növelésével sem csökkenthetők jelentősen az ASTER GDEM adatok esetében (44 ábra (M47)). A kis eltéréstartományokba eső terepi magassági adatok gyakorisága a DDM5 adatokkal akkor sem javult jelentősen, ha a modell adatait 5m-es felbontással, ERDAS Imagine szoftver „bilinear spline” módszerrel újramintavételeztem. A felbontás növelésével elérhető eredményeket a 44-45. ábrák (M47) mutatják.

A DDM100 adatainak DDM5-tel történö összevetése eredményeként már természetesen közel 40\%-kal nagyobb gyakoriságot kaptam a +/-3,5m-es eltérés-kategóriában, miután 5m-es felbontással történő újra-mintavételezésen ment át a DDM100 adathalmaz. Megállapítottam, hogy SRTM-nél mindenképpen érdemes nagyobb térbeli felbontással rendelkező háló mentén újra-mintavételezni, mert 9\%-os javulás is elérhető. Az ASTER GDEM esetében azonban alig 2-3\%-os javulás várható (45. ábra (M47)), ami azt a feltételezést támasztja alá, hogy a DDM5-höz viszonyított különbségei csak kis mértékben magyarázhatók a térbeli felbontással.

\subsubsection{Domborzatmodellek pontosságának összefüggései felszínborítással és kitettséggel}

A domborzatmodellek felszínborításonkénti elemzését a vízfelsźn vizsgálatával kezdtem. Több forrás alapján az alapvető hibajelenségek - mint a hullámzás eredményeként érkező bizonytalan jelek miatti nagymértékü eltéréseket - már a hazai online irodalom is megemlíti (INT-037 $\left.{ }^{186}\right)$. Az ASTER GDEMv1-röl a METI-NASA-USGS intézet-hármas által készített validálás eredményei kimutatták, hogy a vízfelszín átlagosan csak 1,32m-rel alacsonyabb a nemzeti domborzatmodelleknél, de a felszínborítások közül a legmagasabb szórást (15.71) épp a vízfelszín mutatta (METI/ERSDAC - NASA/LPDAAC - USGS/EROS 2009, 5-6). Az ASTER GDEMv2-ről készült validálás jelzi a vízfelszínek maszkolása eredményeként előállt javított magassági adatokat (MEYER 2011,2) is, de a táj szempontjából nem értékeli azokat.

Kutatási eredményeim egyértelműen kimutatták, hogy az eltérés mértéke változó. A vizsgált európai nagy tavak partoktól távol eső nyílt vízfelülete esetén is jelentős szélsőértékkülönbségek tapasztalhatók az SRTM és az ASTER GDEMv2 modell esetén. Az ASTER adatoknál ez egyértelmüen azt jelzi, hogy a maszkolás sikeressége megkérdőjelezhető (46. ábra (M48)). A térképes megjelenítés alapján feltételezhető, hogy a vízfelületek hibás lehatárolása, vagy hiányos maszkolása okán lehet az eltérés terjedelme egy-egy vízfelszín esetén akár 50m-t meghaladó (47. ábra (M48)). Ezt a feltételezést megerősíti az a diagram is mely megmutatja, hogy egyes tavaknál viszont nulla a szélsőérték-különbség, ami a maszkolás teljes sikeréröl tanúskodik.

${ }^{186}$ INT-037: Az ELTE földkutatás oldalán összegzett SRTM kutatás összefoglalója (2014. 02. 12.) 
A felszínborításokkal összefüggésben történő elemzésemből látható, hogy minél kevesebb a vertikális tájelem, annál inkább a negatív tartományba csúszik az ASTER GDEM modell DDM5-höz mért relatív magassága (48. ábra (M49)). Ez azonban nem biztos, hogy a vertikális elemek okozta hibát jelentenek, hanem mindössze azt, hogy az ASTER GDEM modelleket nem abszolút domborzatmodellként, hanem felszínmodellként kell értelmezni ${ }^{187}$.

Megfigyelhető ugyanis, hogy az egyes feszínborítási kategóriák egymáshoz viszonyított magassága hozzávetőlegesen megfelel a tájban ténylegesen tapasztalható magasságkülönbségeknek. A csupasz szántóföldnél 1-2 méterrel magasabb a gyepes, vagy cserjésedő gyepes, 3-4 méterrel a lakott és 8-9 méterrel az erdők lombkoronaszintje. Feltételezhető, hogy az ASTERGDEMv2 magassági modell relatíve pontosabb, mint abszolútértékben, de a terepszintet jól reprezentáló pontjai alacsonyabbak a tényleges terepi tengerszint feletti magasságnál.

Hazai kutatások kimutatták az SRTM és az ASTER GDEMv1 eltéréseinek összefüggését a kitettséggel (SZABÓ és SZABÓ 2010, SZABÓ 2011). Megállapították, hogy az ASTER GDEMv1 modell pontatlanságában a fátlan területeken is jelentős eltérések vannak a különbözö égtájak szerint a tokaj-hegyi mintaterületen. Kutatásomban meghatároztam, hogy van összefüggés a ASTER GDEM v2 magassági modell esetében is pontossága és a kitettség között. Szabó és társaihoz hasonló hullámzási jelenség itt is tapasztalható. ASTER GDEMv2 modellel egy $100 \mathrm{~km}^{2}$-es központi-gerecsei hegyvidéki erdőterületen, és egy azonos területü keleti-gerecsei dombvidéki mezőgazdasági területen végzett elemezésem eredményét a 49. ábra (M49) foglalja össze. Megállapítottam, hogy a legnagyobb pozitív irányú eltérés a keleti és délkeleti erdős lejtőkön, míg a legnagyobb negatív irányú eltérés a nyugati alacsony vegetációval jellemezhető nyugati lejtőkön tapasztalható.

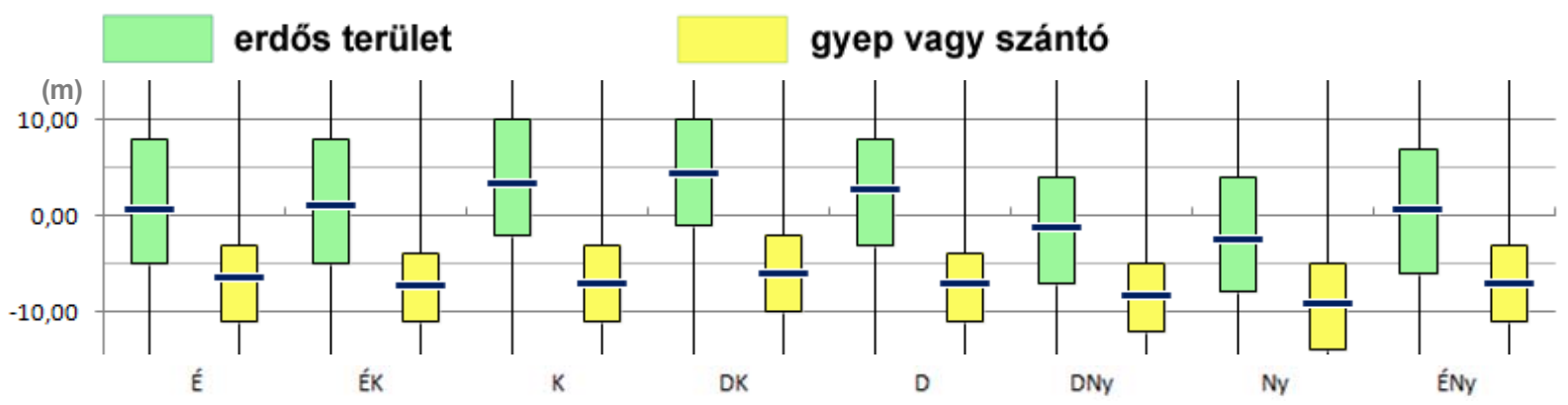

49. ábra (részlet M49) Az ASTER GDEMv2 magassági modell eltérései a DDM5-höz képest, lejtőkitettség kategóriánként a gerecsei mintaterületen. Az ábrán kitettség kategóriánkénti átlag értékek mellett (fekete vízszintes vonal) Szabó publikációjához hasonlóan feltüntettem az interkvartilis (adatsokaság középső két negyedének) értéktartományát is.

\footnotetext{
${ }^{187}$ Vizualizációs vagy láthatóság-elemzési célú felhasználás esetén megfontolandó a domborzat 6,8 méterrel történő „megemelése”.
} 


\subsubsection{Domborzat-elemzési és -jellemzési módszerek a tájkarakter-elemzésben}

A domborzat-elemzés hagyományos, térképes elemző módszerei ${ }^{188}$ a távérzékelési adatokból elöállított magassági modelleken térinformatikai feldolgozással is alkalmazhatók a táji adottságok jellemzésére. Ezek a módszerek gyorsan, egyszerúen és objektíven hozzájárulhatnak domborzati sajátosságok jellemzéséhez, leírásához, a különböző tájrészletek domborzati jellegének összevetéséhez. A jellemzés megtörténhet az adatok automatizált feldolgozásával, tájegységekre történő térinformatikai aggregálásával ${ }^{189}$.

Az elemzések többsége a passzív képalkotó távérzékelésből származó modelleken lefuttatható többféle térinformatikai szoftverrel is (ArcGIS, ERDAS Imagine, Surfer, QuantumGIS). Az ASTER GDEMv2 modellt a 4.2.1.-4.2.3. alfejezetekben megfogalmazott pontatlanságok figyelembevételével ajánlott ilyen elemzésekhez alkalmazni. Kutatásom során az ASTER GDEMv2 domborzatmodellt dolgoztam fel országos léptékben, $1 \mathrm{~km}^{2}$-es felbontással (50-56 ábra (M50-M51)). A felhasználás legegyszerübb módja és lépései a következők:

1. A választott domborzatmodell-elemzés (pl. kitettség) automatikus lefuttatása egy térinformatikai képfeldolgozó szoftverrel (pl.: ERDAS Imagine / Aspect).

2. Az elemzés eredményének pontszerü vektoros állománnyá alakítása (Raster to point).

3. A pontok összekapcsolása a lehatárolt tájegységekkel/tájtípusokkal térbeli elhelyezkedésük alapján (pl.: ArcGIS-join by spatial location), közben értékük összegzése (igény szerint átlag, minimum, maximum számítása).

Az 56. ábra (M51) a kitettség karakteradó szerepét emeli ki a kistájak területére. A kitettség-értékeket bemutató diagramok akkor jelennek meg a térképen, ha a kistájban meghatározó a lejtőmeredekség. Minél nagyobb a meredekség annál nagyobb a kördiagram és benne a domináns égtáj körcikke. A térkép elöállításához az ASTER GDEMv2 modellel készített kistájankénti átlagos lejtőmeredekség és részletes kitettség adatokat használtam fel.

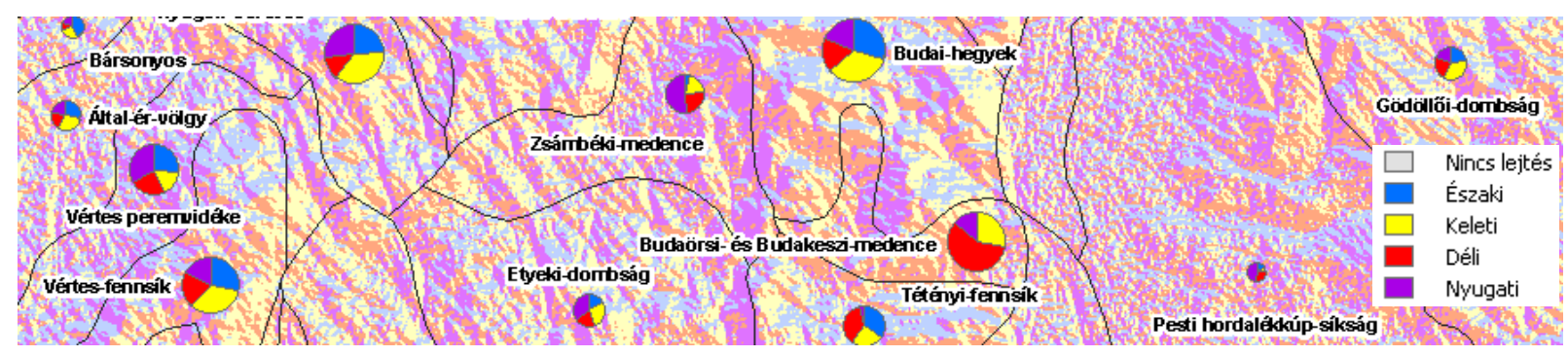

\section{6. ábra (részlet (M51)) Kitettség karakteradó szerepe}

A domborzat-elemzések azonban nem csak a tájak jellemzésében, hanem a határvonalak meghúzásában, a táji sajátosságok vizualizációjában és a láthatóság-elemzésben is fontosak. E három témában nyert kutatási eredményeimet a 4.5-4.7. fejezetekben ismertetem.

\footnotetext{
${ }^{188}$ tengerszint feletti magasság, lejtőmeredekség-, kitettség-, felszínmozgalmasság-elemzés

${ }^{189}$ A tájkarakter jellemzésre használható, egyéb elemzések és mutatók: 1. terep-változatosság 2. benapozottság, 3. lehetséges vízfolyások teljes hossza, 4. potenciális vízgyüjtők száma, 5. láthatóság-elemzések
} 


\subsection{A tájkarakter jellemzése térbeli indexekkel}

Áttekintettem a passzív távérzékelési képfeldolgozásban használatos indexeket és alkalmazásukat a környezet-, természet- és tájtudomány terén. Ezek az indexek szinte kivétel nélkül a felszínborítással kapcsolatosak. Szakirodalmi áttekintésből kirajzolódik, hogy használatuk többnyire egy egyszeri, néhány ezer $\mathbf{k m}^{2}$-es területre koncentráló, térképezési célú alkalmazás. Többségük a felvételekből jól interpretálható, elemezhető. Kutatással igazoltam, hogy egyes indexek átalakítással tájak jellemzésére is felhasználhatók.

\subsubsection{Tájkarakter-elemzés céljára felhasználható indexek meghatározása}

Passzív képalkotó távérzékelés adatainak feldolgozása során alapvetően kétféle indexcsoportot érdemes megkülönböztetni:

1. Felvételek spektrális sajátosságaira automatikusan építő indexek ${ }^{190}$

2. Felvételekből származtatott adatbázisokra épülő indexek ${ }^{191}$

Mindkét csoportba tartozó indexek többféle alapadat feldolgozásával (alacsony, közepes vagy nagyfelbontású felvételek) eltérő léptékben (országos, térségi vagy település szinten) is alkalmasak arra, hogy tájrészletek felszínborításának egymáshoz viszonyított térbeli eltéréseit jellemezzék. Az indexek számításának módszere - ahogy az a szakirodalmi áttekintés során is nyilvánvaló vált - igen sokféle, a müholdas érzékelők fejlödésével folyamatosan változik, megújul, kiegészül, egyedi alkalmazások során a gyakorlatban sokszor bővítik, esetenként kombinálják is ezeket. Tájak jellemzésére ezek közül több változat is felhasználható lehet. A teljesség igénye nélkül, a hazai vagy európai tájak jellemzésére általam leghasznosabbnak vélt index-változatokat táblázatban gyüjtöttem össze (25. táblázat (M52)).

25. a, b, c táblázat (részletek (M52-M54)) Passzív távérzékelési adatok feldolgozásához használható indexek és térbeli mutatók

\begin{tabular}{|c|c|c|c|}
\hline $\begin{array}{c}\text { Index rövid } \\
\text { neve }\end{array}$ & $\begin{array}{l}\text { Index / mutató teljes neve } \\
\text { (angol v. magyar) }\end{array}$ & Az index / mutató jelzi & $\begin{array}{c}\text { Képlet } \\
\text { (pl.: mühold, szenzor) }\end{array}$ \\
\hline NDVI & $\begin{array}{l}\text { Normalized Difference } \\
\text { Vegetation Index }\end{array}$ & $\begin{array}{c}\text { Zöldfelület jelenlétét és } \\
\text { egészségi állapotát }\end{array}$ & $\begin{array}{c}(4-3) /(4+3)(\text { LandsatTM, } \\
\text { ETM }+)\end{array}$ \\
\hline GSI (ZFI) & Green Space Intensity & Zöldfelület-intenzitását & $\begin{array}{c}\text { ZFI }= \\
0, \text { ha } 200 * \text { NDVI }<0 \\
200 * \text { NDVI egyébként } \\
100, \text { ha } 200 * \text { NDVI }>100\end{array}$ \\
\hline $\begin{array}{l}\text { CLCRI- } \\
\text { WAT }\end{array}$ & $\begin{array}{c}\text { Corine Land Cover Ratio Index } \\
\text { Water }\end{array}$ & Vízfelület-arányt & $\begin{array}{c}\text { (AreaCLC511+AreaCLC512) / } \\
\text { AreaCLCall*100 }\end{array}$ \\
\hline ED FOR & Edge Density Forest & Erdőszegély sürüségét & $\begin{array}{c}\text { TotalPerimeter(Unio CLC311, } \\
\text { CLC312, CLC313) / } 2 / \\
\text { TotalArea }\end{array}$ \\
\hline OPEN & Openness & A táj nyi tottságát & $\begin{array}{c}\text { CLC kategóriák nyitottsági } \\
\text { besorolása szerint }\end{array}$ \\
\hline GSI in URB & $\begin{array}{l}\text { Green Space Intensity in } \\
\text { Urbanized areas }\end{array}$ & $\begin{array}{c}\text { Tájegységben vagy } \\
\text { tájtípusban elöforduló } \\
\text { településszerkezetre jellemző } \\
\text { zöldfelület-intenzitást }\end{array}$ & $\begin{array}{c}\text { GSI Sum in (CLC111 and } \\
\text { CLC112 and CLC142) / } \\
\text { (AreaCLC111 + Area CLC112 } \\
+ \text { Area CLC142) }\end{array}$ \\
\hline
\end{tabular}

\footnotetext{
${ }^{190}$ Spektrális indexek: vegetációs indexek, víz-indexek stb. pl. Landsat vagy MODIS felvételek felhasználásával

${ }^{191}$ Felszínborítás arányainak, felszínborítás szerkezetének jellemzői pl. CLC adatbázis felhasználásával
} 


\subsubsection{Indexek felhasználásának módszerei, feltételei, korlátai a tájkarakter jellemzésére}

Kutatásom eredményeként elkészült a Magyarország Kistájainak Kataszterében (MAROSISOMOGYI 1990) lehatárolt kistájak vegetáció vitalitása szerinti jellemzése az egész országra, az NDVI index alkalmazásával és IMAGE2000 mozaikok felhasználásával (57. ábra (M55)). Az eredményeket bemutató térkép így azonban mindössze egyetlen időpont vegetációs állapotát tükrözi és pusztán NDVI adatok átlagoló összegzésével készült. A térkép és az eredeti felvételek áttekintésével és mintaterületeken végzett „look and feel” elemzés, ortofotóval történő vizuális összevetés eredményeként a következő két megállapítást tettem:

1. NDVI index pozitív értékei jelzik a vegetáció jelenlétét, de negatív értékei nem jellemzik a földfelszín zöldfelület-borítását, ellenben a számításokat jelentősen torzíthatják, így ezeket sem térben sem időben átlagolni nem célszerü.

2. Az IMAGE2000 adatokra épülő NDVI elemzés hiányossága, hogy pusztán egyetlen pillanatnyi állapot kerül feldolgozásra, mely a vegetáció esetében általában problémás. A mezőgazdasági területek és az erdőterületek jellemzésénél az időjárási tényezőktől (csapadékmennyiség, hőmérséklet stb.) függően évente, de esetenként akár havonta is eltérő lehet a vegetáció jelenléte vagy vitalitása. Ez azt eredményezheti, hogy nem a táj állandósult karaktervonásainak megfelelően történik a tájegységek jellemzése.

A megállapítások alapján kijelenthető, hogy - már a vegetációs állapot meghatározásához és jellemzéséhez is - mindenképpen több időpont NDVI értékeit ajánlott figyelembe venni, pl. több időpont Landsat felvételeinek átlaga alapján. A kistájak karakter-jellemzése céljából Image2000 adatok felhasználásával végzett MNDWI „vízfelület index” alkalmazása esetén „look and feel” módszerrel szintén a fenti két megállapításra jutottam (58. ábra (M55)).

Országos elemzéshez indokolt lehet az alacsonyabb felbontású müholdak sürübben készített felvételeit (pl. MODIS) használni és átlagolni. Térségi szinten a közepes felbontású Landsat és SPOT müholdfelvételek, míg települési szint alatt, tájrészlet szinten már nagyfelbontású felvételek (pl.: WorldView) feldolgozása lehet indokolt ${ }^{192}$. Ugyanakkor tájkarakter-jellemzés céljára az NDVI indexnél a területi összesítésre és összevetésre sokkal alkalmasabb zöldfelület-intenzitás mutató (ZFI, 25. táblázat (Mxxx)) kifejlesztését tartottam indokoltnak. Erre tettem javaslatot és folytattam kutatásokat, melynek eredményeit a 4.3.3. fejezetben ismertetem.

A passzív távérzékelési adatokból származtatott adatbázisokra építhető egyszerü (CLC alapú) felsźnborítási mutatók képezhetők, melyekkel a tájkarakter jellemezhető. A kistájak országos jellemzését néhány kulcsfontosságú felszínborítás esetében elvégeztem, az eredményeket térképes formában a mellékletek 59-66. ábrái (M56-M57) tartalmazzák.

\footnotetext{
${ }^{192}$ Az egyre részletesebb alapadatok, a felvétel-készítési időpontok megnövelt száma, kezelendő adatmennyiség, az anyagi erőforrás és időbeli ráfordítás növekedésével is jár az elemzést végző számára.
} 
Az indexek alapján történő tájkarakter jellemzés technikai módszere többféle lehet:

1. Raszteres adatok exportálása (Raster to ASCII) szöveges állományba tájanként.

2. Raszteres adatok ponttá alakítása (Raster to point) és térbeli elhelyezkedés alapján tájakhoz kapcsolása (Spatial join).

3. Raszteres adatok sokszöggé, vagy sokszögvonallá alakítása (Raster to polygon) és metszése tájakkal (Intersect), majd területarány-számítás, szegélyhossz-számítás.

4. Származtatott vektoros adatok (vonal vagy sokszög) esetén metszés tájakkal (Intersect) és abszolút vagy relatív területarány-számítás, hossz-számítás attribútum adatok és geometriai adatok alapján.

Az indexek felhasználásának feltétele, hogy

1. az értékek egyértelmüen és közérthetően jellemezzék a földfelszín bármely területrészét (NDVI, NDWI, NDBI, és NDBaI esetében ez nem mondható el),

2. a jellemző értékek térbeli és időbeli összesítése, átlagolása során az értékek ne torzuljanak (NDVI, NDWI, NDBI, és NDBaI esetében ez nem mondható el),

3. az elérhető legtöbb időpontra készült felvétel figyelembevételével készüljenek,

4. legyen terepi ellenőrzési lehetőség, helyismeret, kiegészítő felvétel vagy referenciaadatbázis.

Az indexek felhasználásának korlátai a következők:

1. A felvételek hibáit (felhők, felhőárnyékok, adathiányos csíkok stb.) korrigálni kell.

2. Az egységes módszerrel, vagy hasonló érzékelőkkel készített adatok összehasonlítása indokolt. Amennyiben változik a CLC készítés módszertana, vagy jelentősebben módosul egyes csatornák érzékelési tartománya, akkor az időbeli átlagok számítása, a területi aggregálás csak körültekintéssel, korlátozottan lehetséges.

3. Ürfelvételek képértelmező indexekkel történő elemzése során, közel azonos időben készített nagyfelbontású ürfelvételen, vagy ortofotón, érdemes vizuális interpretációval ellenőrizni, validálni és indokolt esetben korrigálni az index-szel végzett elemzés eredményét.

\subsubsection{Zöldfelület-intenzitás index és használata a tájkarakter jellemzésére}

A Normalized Difference Vegetation Index (NDVI) felhasználásával, a mára ingyenesen hozzáférhető Landsat müholdfelvételek feldolgozásával több éves kutatás során kidolgoztam a Zöldfelület Intenzitás (ZFI) mutatót és számításának módszerét. A zöldfelület intenzitás ugyan az NDVI-re épít, de annál érthetőbben mutatja meg, jellemzi, teszi térképezhetővé és átlagolhatóvá a tájegy ségek zöldfelület-borítását, amire az NDVI csak korlátozottan alkalmas. A zöldfelület intenzitás (ZFI) nullától százig terjedő értékekkel mutatja meg, hogy mekkora az adott területrészre (tájrészletre, településrészre) eső zöldfelület területi aránya és egészségi állapota. A ZFI egy olyan számérték az NDVI adatokból előállított digitális adatbázisban, mely jellemzi a zöldfelület intenzitását tetszőlegesen lehatárolható foltokban. 
Számításának módszerét publikáltam a TÁMOP projektben végzett kutatásom eredményeként (JOMBACH 2012, 219-232), melyet LandsatTM5 felvételekre és kiegészítésképpen valós és infra színes ortofotók mintaterületi feldolgozására alapoztam Délnyugat-Budakörnyék térségére (67 ábra (M58)). Megállapítottam és számításokkal igazoltam, hogy „,zöldfelületintenzitás" mutató egyetlen átlagos jelzőszámmal is képes összevethetővé tenni a tájegységek vagy tájtípusok karakterét a zöldfelület-borítottság szempontjából.

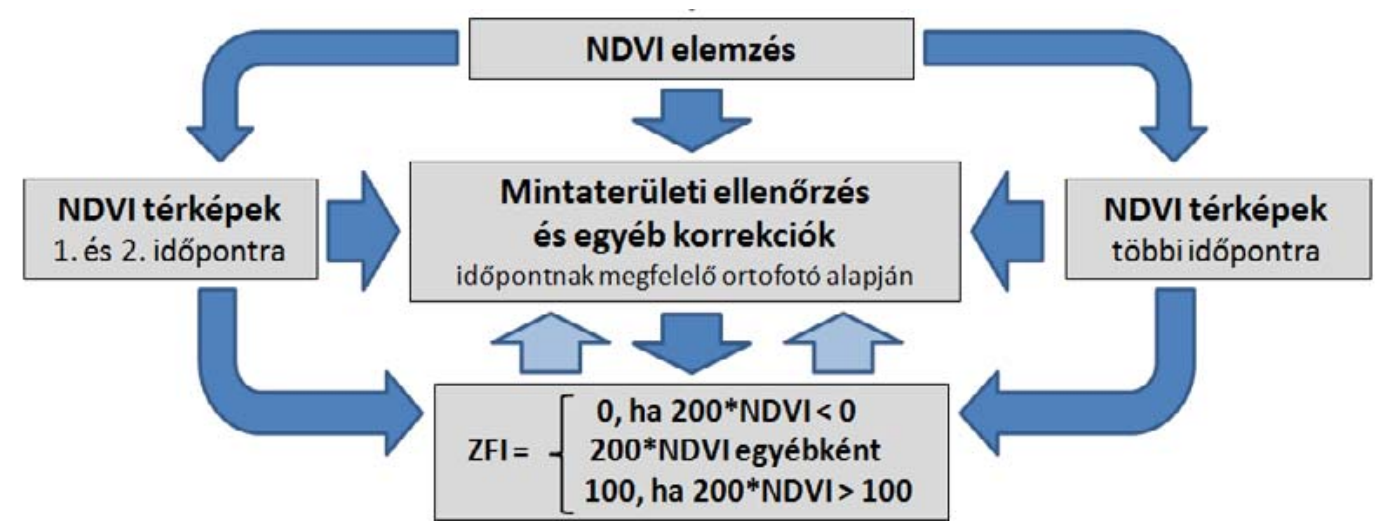

\section{7. ábra (részlet (M58)) A Zöldfelület Intenzitás (ZFI) index számítási módszere}

Az ZFI adatok jelmagyarázatát a 68. ábra (M58)) és a felhasználás technikai sokféleségét a lehatárolt területek jellemzésére a 69. ábra (M59) mutatja meg. Az adatok helyességét még különféle geometriai és radiometriai hibakorrekciók ${ }^{193}$ után is mintaterületeken ellenőrizni és pontosítani indokolt. Ennek legegyszerübb módja az azonos időpontban (évben) készített - lehetőleg infravörös tartományban rögzített - ortofotóval történő összevetés és igazítás. A 70. ábrán (M60) a mintaterületi ellenőrzés részletei figyelhetők meg. A 2010. júliusi ZFI adatok esetében az ellenőrzés mintanégyzetekben történt, melynek 255 négyzetes eleme egy 2,5km-es sürüségű rácsháló mentén automatikusan került kijelölésre Budapest területén. A mintanégyzetek 1, 9 illetve 25 képpont nagyságúak voltak (70. ábra (M60)).

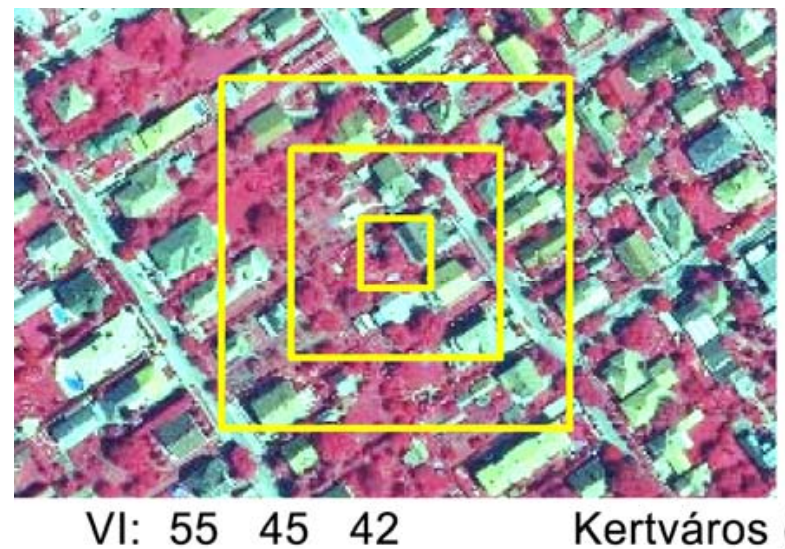

\begin{tabular}{l|l|l|l|l|l|l|l|l|l|l}
\hline 23 & 51 & 46 & 25 & 12 & 21 & 44 & 55 & 46 & 29 & 34 \\
\hline 38 & 65 & 77 & 64 & 43 & 27 & 33 & 42 & 38 & 30 & 32 \\
\hline 27 & 21 & 57 & 80 & 63 & 39 & 40 & 42 & 37 & 35 & 19 \\
\hline 21 & 14 & 32 & 62 & 64 & 41 & 19 & 23 & 28 & 27 & 11 \\
\hline 34 & 13 & 21 & 43 & 73 & 56 & 19 & 13 & 23 & 25 & 8 \\
\hline 45 & 8 & 5 & 19 & 72 & 78 & 38 & 15 & 25 & 37 & 42 \\
\hline 49 & 25 & 18 & 20 & 64 & 89 & 65 & 38 & 38 & 48 & 49 \\
\hline (XVI. ker.) & SZ: 40,8 & 46 & 44,4 &
\end{tabular}

70. ábra (részlet (M60)) A zöldfelület-intenzitás mintaterületi ellenőrzése. Vizuális interpretáció (VI) és számítás (SZ) eredményei (\%) a ZFI ellenőrzése során (Felhasznált alapadat Infra orto 2010, FÖMI).

\footnotetext{
${ }^{193}$ korrekciókról részletesen a 4.4.2. fejezetben
} 
Valamennyi mintanégyzet területére az infravörös ortofotó vizuális interpretációjával (VI) becslést készítettem a zöldfelület intenzitásáról, majd a zöldfelület intenzitás Landsat müholdfelvételböl számított értékek (SZ) összevetésre kerültek a vizuális becsléssel. Az „eltérések abszolút értékének átlaga" a $625 \mathrm{~m}^{2}$-es mintanégyzetekben nem haladta meg a 8,6\%-ot, míg a nagyobb, másfél hektáros négyzetek esetén ez az érték csak 7,4\% volt. Ha a változó zöldfelület intenzitással rendelkező szántóterületet kivettem az ellenőrzésből, akkor ezek az értékek 8,5-re és 6,7-re változtak. Hasonló, bár kisebb mértékü csökkenés volt megfigyelhetö, amikor a gyepterületek kerültek kivonásra (71. ábra).

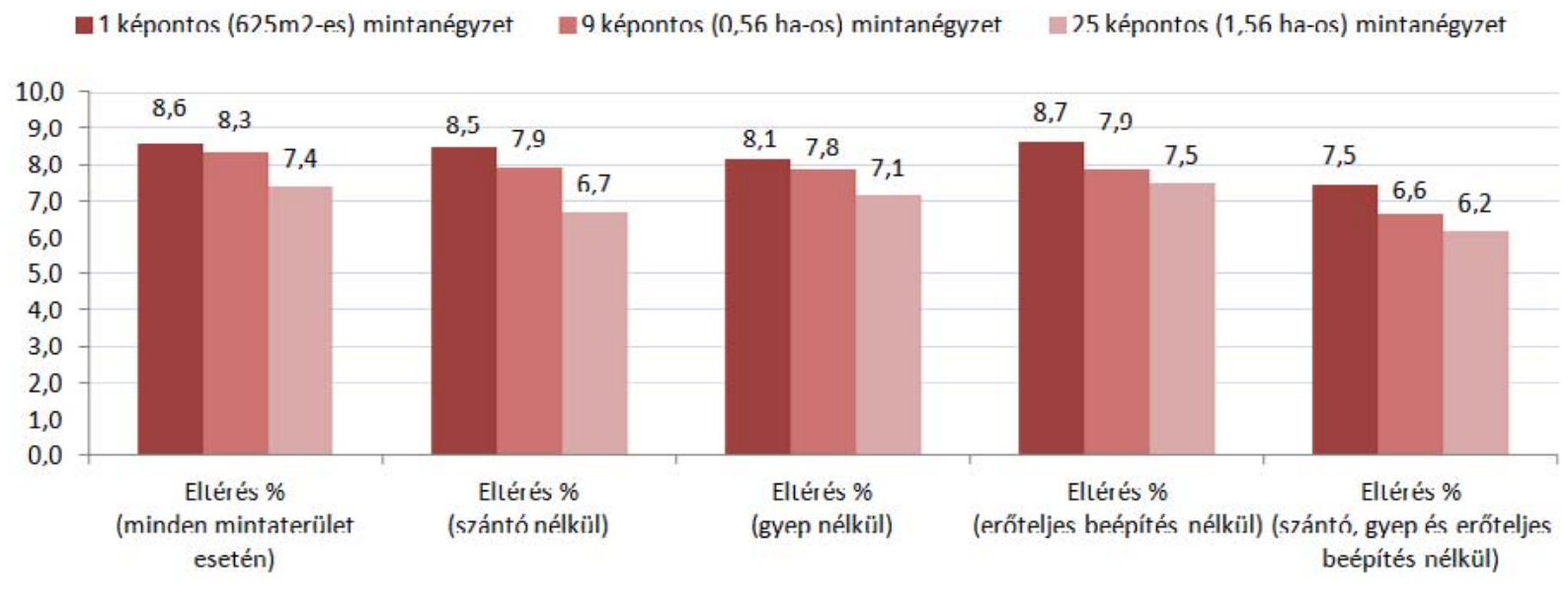

71. ábra A ZFI adatbázis mintaterületi ellenőrzése során tapasztalt eltérések (\%) abszolút értéke, különböző típusú mintanégyzetekben. Az eltérés mértéke az ortofotó vizuális interpretációja során becsült és a ZFI számított értéke között fellépő „eltérések abszolút értékeinek átlaga”.

Az abszolút eltérés mellett az úgynevezett „nem elfogadható eltérés” mértékét is vizsgáltam. Itt a vizuális interpretáció után a számított érték ismeretében újbóli vizuális interpretációval került meghatározására, hogy mekkora a biztosan hibának tekinthető eltérés. A vizuális interpretáció és az automatikus ZFI számítás eredményeinek utólagos összevetésével meghatározható volt, hogy mekkora az olyan eltérés, mely már semmiképp nem a vizuális becslés hozzávetőlegességéből, hanem a képfeldolgozási módszer pontatlanságából, a képanyag ki nem szürt torzulásaiból, vagy az eltérő időpont sajátosságaiból fakad. A 2010-es időpontra a nem elfogadható eltérés abszolút értékben a szántós mintaterületek kihagyásával csak 2,6\% volt (72. ábra (M61)).

A zöldfelület intenzitás adatbázisban azokat a mezőgazdasági jellegű területeket, melyeken a rendszeres müvelés (szántás, vetés, aratás, kaszálás stb.), vagy a csapadékvíz gyepet üdítő hatása azt eredményezheti, hogy a zöldfelület intenzitása egy éven belül, sőt egyik hónapról a másikra is jelentősen változik, érdemes egy kategóriánként átlagosan jellemző zöldfelület intenzitás értékekkel szerepeltetni az adatbázisban. Az általánosan jellemző zöldfelületintenzitás értékeket kutatásom során egy kibővített $15000 \mathrm{~km}^{2}$-es Délnyugat-Budakörnyék központú mintaterületen, 25 év Landsat felvételeiből (1986-2011, 26. táblázat (M61)) generált ZFI adatok hónaponként arányos átlagolásával határoztam meg. Ezeket a zöldfelületi intenzitás értékeket a 27. táblázat tartalmazza a gyakran változó intenzitású mezőgazdasági 
jellegü felszínborítás kategóriákra. Az ilyen területek lehatárolását a CLC50 2000. évi adatbázis felújított foltjai alapján végeztem el. A ZFI értékek meghatározására ezt követő elemzéseimben a Délnyugat-Budakörnyéki területre (73. ábra (M62)) a kutatási célnak megfelelően azokat az átlagértékeket alkalmaztam, melyeket a 27. táblázat tartalmaz.

27. táblázat Zöldfelület-intenzitás átlagértékek 1986 és 2011 közötti időszak 25 Landsat TM és ETM+ felvétele alapján. Javasolt zöldfelület intenzitás értékek mezőgazdasági területekre 50-ezres CORINE Felszínborítási Adatbázis alapján a Délnyugat-Budakörnyéki térség 60km-es környezetében lehatárolt $15000 \mathrm{~km}^{2}$-es térségében.

\begin{tabular}{|c|c|c|c|c|}
\hline $\begin{array}{c}\text { CLC50 kód } \\
\mathbf{( 2 0 0 0 )}\end{array}$ & Megnevezés (felszínborítás kategória) & $\begin{array}{c}\text { ZFI átlag } \\
\mathbf{1 2} \text { hónap } \\
\text { (jan-dec) }\end{array}$ & $\begin{array}{c}\text { ZFI átlag } \\
\mathbf{7} \text { hónap } \\
\text { (ápr-okt) }\end{array}$ & $\begin{array}{c}\text { ZFI átlag } \\
\mathbf{6} \text { hónap } \\
\text { (ápr-szept) }\end{array}$ \\
\hline 2111 & Nagytáblás szántóterület & 32,5 & 48,2 & 52 \\
\hline 2112 & Kistáblás szántó & 32,7 & 50 & 53 \\
\hline 2421 & Komplex múvelésben nagyarányú szántó & 34,2 & 54,1 & 56,4 \\
\hline 2431 & Mezőgazdasági terület nagyarányú szántóval & 38,4 & 60,9 & 63,3 \\
\hline 24221 & Komplex müvelésben kis szántó & 35,3 & 55,8 & 57,9 \\
\hline 2311 & Intenzív gyep fák bokrok nélkül & 38,3 & 58,6 & 60,6 \\
\hline 3212 & Természetes gyep fákkal és cserjékkel & 39,6 & 63,4 & 66 \\
\hline 1241 vagy & Repterek gyepfelülete & 29,6 & 44,9 & 46,7 \\
\hline 1242 & Intenzív gyep fákkal és bokrokkal & 38,5 & 60,9 & 63,3 \\
\hline 2312 & & &
\end{tabular}

\subsubsection{Származtatott adatbázisokra építhető indexek a tájkarakter-jellemzésben}

Passzív képalkotó távérzékelésből származtatott adatbázisok (CLC100, CLC50, European Urban Atlas) feldolgozásával is lehet részletes, újszerü tájkarakter-jellemzést végezni. A fejezet célja, hogy a mutató-képzés lehetőségeit igazolja.

A CLC100 2006-os adatai alapján meghatároztam Magyarország kistájainak jellegét egy természetszerúség-mesterségesség skálán. Az ember által jelentősen meghatározott, átalakított felszínborítás-foltokat (CLC111-244) a mesterséges kategóriába, a kevésbé átalakítottakat (CLC311-523) a természetszerübe soroltam, és minden kistájra kiszámítottam a kategóriák területi arányát. Az eredmények szerint az ország tájainak közel kétharmadán a mesterséges felszínek vannak jelentős területi túlsúlyban (74. és 75. ábra (M63)).

A hazai tájakon tájképi szempontból egyes térségekben igen jelentősek a vertikális elemek (épületek, fák, cserjék). Fontosnak tartottam, a kistájak nyitottságának elemzését felszínborítások alapján. A táj nyitottságát - az emberi szem magasságához viszonyítottan a felszínborítás jellemző tájelemeinek magassága alapján - háromféleképpen érdemes jellemezni CLC adatokkal (28. táblázat (M64)). A jelentősebb épületállománnyal, magas faegyedekkel domináló területek ,zártak”, a csupasz, mezőgazdasági, vízfelszínnel jellemzett területek „nyitottak”, míg a cserjés területek, városi parkok, szabadidő eltöltésére alkalmas területek, ,átmenetiek”. Ennek megfelelően a 2006-os CLC adatok alapján készítettem el az ország tájainak felszínborítással meghatározott nyitottság-térképét (76. ábra (M64)). 
Nagyvárosokban különösen fontos mutató a természetszerü foltok szabdaltsága. A kisebb, keskenyebb természet-közeli felszínborítás foltok - az élővilág bizonyos tagjai számára kedvezőtlenebb élőhelyet biztosítanak, mint a nagyobb összefüggő kompakt foltok. Az Urban Atlas adatbázis alapján hat Közép-Európai nagyváros (köztük Budapest) természetszerü területeinek arányát és szabdaltságát jellemeztem. A jól ismert kerület-terület arány index (erdők, parkok, vízfelszínek esetén) azt mutatja, hogy jelentős eltérések adódnak a KözépEurópai nagyvárosok között. Bécs e mutató és a területarány alapján is a lista előkelő helyén áll, főként a zöldfelületek vonatkozásában. Budapest, Varsó és Prága a középmezőnyben, Krakkó és München azonban mind területarányban, mind szabdaltságban a leggyengébb számokkal jellemezhető (77. ábra (M65)). Megállapíthatók olyan karakteres eltérések is, mint hogy Prágát a városi parkok nagy területi aránya, de apró sokasága határozza meg, Budapesten alacsonyabb a parkterület aránya, de kompaktabb parkok jellemzik.

Tájkarakter-jellemzésre - kutatásaim szerint - a zöldfelület-intenzitás mutató és származtatott vektoros adatbázisok kombinált alkalmazásával is sort keríthetünk. Nem csak a többnyire ingyenesen elérhető származtatott adatokkal történő összekapcsolás és aggregálás oldható meg egyszerüen, mint a ZFI adatok lakótömbönkénti leválogatása Urban Atlas adatok szerint (78. ábra (M66)), de olyan komplex index is képezhetö, mellyel egyes tájrészletek növényborítottsági sajátossága jellemezhető. Ilyen a „Településszerkezetre jellemző zöldfelületintenzitás" mutató, mely a lakó jellegü települési szövet zöldfelületének intenzitását jellemzi. Nem a teljes tájegység (járás, település) sokféle területhasználat (erdő, rét, szántó, stb.) zöldfelület intenzitását átlagolja, csak a lakó vagy üdülő jellegü településszerkezet területére koncentrál és annak átlagos zöldfelület-intenzitását jelzi (79. ábra (M67)). Az indexképzés során itt a ZFI indexet és a CLC50-es adatbázis egyes lakóterületi és üdülöterületi jellegü kategóriáit (CLC50 kód: 1111, 1112, 1121, 1122, 1423) használtam fel.
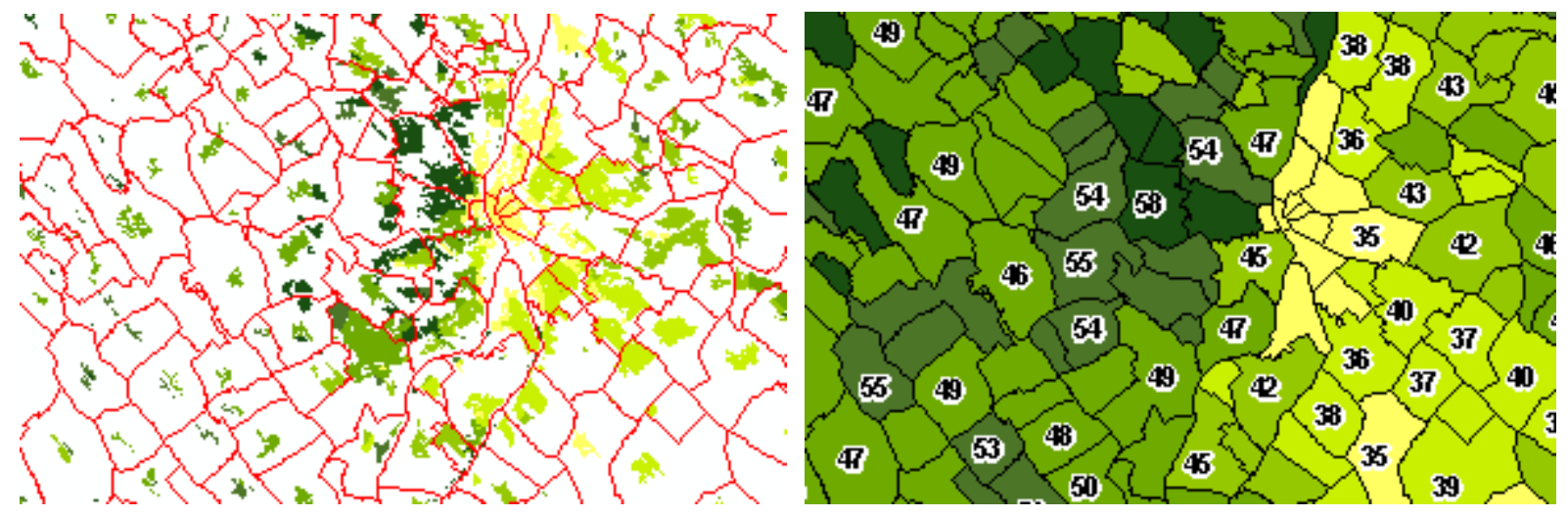

79. ábra (részlet (M67)) Településszerkezetre jellemző zöldfelület-intenzitás (\%) (felhasznált alapadatok CLC 50 és ZFI Landsat 1986-2011) 


\subsection{A tájkarakter-elemzést támogató változás-vizsgálatok}

Az irodalmi áttekintés eredményei alapján a passzív képalkotó távérzékelési eszköztár azokban az esetekben is hasznosulhat, ahol a tájváltozás kulcsfontosságú tényező. A változások detektálása, dokumentálása, leírása, a tájban zajló domináns változás-folyamatok meghatározása, valamint a módosító változások számszerű mértékének meghatározása is ebbe a körbe tartozik. A tájkarakter-elemzésben alapvető a helyes tájváltozási tendenciák feltárása. Kutatásaim megerősítettek az eszköztár tájváltozás-elemzésben betöltött lényegi jelentőségével kapcsolatban.

\subsubsection{Változás-jelenségek vizsgálata automatikus változás-detektálással}

Automatikus változás-detektálással ${ }^{194}$ kettő, vagy több felvétel eltéréseit lehet szoftverekkel felismerni a felvételben szereplő digitális számértékek különbsége alapján. Az eltérés számos forrásból származhat, de közepes és nagy felbontású Landsat vagy SPOT felvételeken alapvetően a felsźnborítási változásokat lehet meghatározni ${ }^{195}$. Ezzel a módszerrel általában nagy, közepes és alacsony felbontású felvételeken, főként térségi, vagy regionális léptékben lehetséges a változások hatékony kimutatása.

Az automatikus változás-detektálás eszközével térképezhetők a „gyakran változó felszínü területek". Az eszköz alkalmas arra, hogy valamennyi felvétel párba állításával a digitális számértékek különbségértékeinek számításával meghatározható legyen, melyek azok a tájrészletek, melyeknek karaktere, jellemvonása a gyakori és intenzív felszínváltozás, és ezért változásaik csak nagy körültekintéssel minősíthetők. Legtöbbször az intenzív mezőgazdasági területek (szántók, kaszálók) tartoznak ebbe a kategóriába. Ezeket a rendszeres változásokat mindenképpen el kell különíteni a markáns tájkarakter-változástól.

Mintaterületi kutatásom során több felvétel összevetésével ${ }^{196}$ olyan térképi adatbázist hoztam létre Délnyugat-Budakörnyék térségére, mely megmutatja a változó karakterü területeket 1986-2011 közötti korszakban. A kutatás a nyári időszakban készült felvételek digitális számértékei közötti különbség abszolút értékének átlagára épített. Természetesen négy-öt éves időszakokra szükítve, akár az építési tevékenység földfelszíni jelenségei is kerülhetnek a folyamatosan változó kategóriába. Ilyen eseteket a mintaterületen is tapasztaltam ${ }^{197}$. Elemezésem során ezért indokoltnak láttam a huszonöt éves korszak idősorának rövidebb időszakokra bontását, a változások rövid időszakon belüli detektálását - ettől elkülönítve - a néhány éves időszakok közötti változások vizsgálatát is.

\footnotetext{
${ }^{194}$ felvételek tartalma közötti eltérések automatikus felismerésével pl.: ERDAS Imagine / Change detection

${ }^{195}$ A módszert felszínborítás-változások szempontjából eredményesen csak azonos, vagy igen hasonló spektrális és térbeli felbontással rendelkező érzékelőkkel készített felvételeken lehet végrehajtani. De az így detektált változás sem jelent feltétlenül tájváltozást. Ezt terepi ismerettel rendelkező szakértőnek kell meghatároznia.

${ }^{196}$ ERDAS Imagine / Modeler / Model Maker

${ }^{197}$ kezdetben „zöldmező”, majd csupasz talajfelszín, majd építési munkahely, végül épített létesítmény pl.: Sasad Resort lakópark a 2005-2007 korszakban, Bp.11.ker., M0 délnyugati szektor autópálya-építés és szélesítés 1986-1994 és 2009-2011 időszakokban Törökbálint, Diósd, Bp.22.ker.)
} 
Különösen fontos ez az időbeli elválasztás, amikor a rendszeresen változó mezőgazdasági területektől kell elkülöníteni a karaktert ténylegesen megváltoztató jelenségeket. A térképi adatbázis (80. ábra (M68)) azt jelzi, hogy melyek azok a tájrészletek, amelyeknek „sajátja”, „karaktere” a folyamatos változás. Ezeken a területeken a megjelenő változásokat nem szabad - a változásfoltok láttán - automatikusan tájkarakter-változásként értékelni.

Mintaterületi kutatásaim során egyértelmüvé vált, hogy a sokféle feltárható változás közül, a tájkarakter szempontjából fontos tájalakulás csak kettőnél több időpontban készített felvételek elemzésével határozhatók meg. Lényeges, hogy a megállapított karakter-változás, az elemzett felvételekhez hasonló időpontban készített, nagyobb felbontású légi-, vagy ürfelvételeken végzett ellenőrzésekkel igazolható legyen. Ortofotók felhasználásával végzett kutatásaim alapján állítom, hogy nagyon nagy felbontású felvételekkel, akár VHR ürfelvételekkel is végezhető automatikus változás-detektálás, de tájkarakter-változás feltárására nem célszerü. Jelentős nehézséget okoz ugyanis a tényleges tájelem-béli változások és a fény-árnyék változások elkülönítése és nem egyszerü a sok detektált változás közül a tájkarakter szempontjából számottevő megtalálása.

\subsubsection{Tájkarakter-változás vizsgálata automatikus eljárásokra épülö változás- indikátorokkal}

A zöldfelület-intenzitás mutató ${ }^{198}$ alkalmazható a zöldfelület-változás vizsgálatára is. Több felvételen történő alkalmazásával az NDVI indexnél hatékonyabb a zöldfelületi jellegü változások meghatározása. Azokat az átalakulásokat, melyek hosszú időn át, egy irányú zöldfelületi változásként ${ }^{199}$ jelennek meg a felvételeken, indokolt lehet tájkaraktermódosítónak minősíteni, de ehhez természetesen szakértői felügyelet és ellenőrzés szükséges.

A Délnyugat-Budakörnyéki mintaterületen számos zöldfelület-intenzitás változást tártam fel. Ezek olyan folyamatokról tanúskodnak, amelyek jellegében is megváltoztatták a Tétényifennsík és a Budaörsi-medence tájegységeket. A következő három markáns, a tájkaraktert is befolyásoló változási folyamat volt feltárható a térség több területén:

- Zöldmezős beruházások hatására a zöld felületek nagy területen történő megszünése.

- Felhagyott területek „zöldülése” (a vegetáció spontán növekedésével).

- A lakóterületi zöldfelületek „születése, érése és öregedése” folyamat egyes fázisai.

Az ilyen jellegü változások az elővárosi térségben helyenként jócskán meghaladják a 15\%-os területi arányt, ami Tirászi 2011-ben publikált eredményei szerint már a tájváltozás mértékét is elérik (TIRÁSZI 2011, 39). A Landsat felvételekre építő zöldfelület-intenzitás változáselemzés elvégzése előtt is indokolt az „MNSK” korrekció (KRISTÓF 2005), annak érdekében, hogy kiküszöböljük a különböző időpontban készült felvételek eltérő légköri és sugárzási viszonyaiból következő potenciális hibákat.

\footnotetext{
${ }^{198}$ A 4.3.3. fejezetben ismertetetett módon, az NDVI index felhasználásával állítottam elő Landsat felvételekből

${ }^{199}$ Lehet csökkenő vagy növekvő tendencia, de lehet intenzitásbeli vagy kiterjedésbeli változás is.
} 
A zöldfelület intenzitás mutatóhoz hasonlóan az MNDWI indexből képzett vízfelületintenzitás mutató (25.a táblázat alapján (M52)) is jelezhet tájjelleg-változást. A DélnyugatBudakörnyéki térségben folytatott kutatásom során figyeltem fel arra a dél-pesti területre, ahol a vízfelszín 25 év leforgása alatt a többszörösére növekedett. Kiskunlacháza térségében kavicsbányászati tevékenység eredményeképpen egyes települések 4-5\%-án jelent meg új vízfelszín (Bugyi, Délegyháza, Dunavarsány, Majosháza), ami jelentős tájjelleg-változást eredményezett (81. ábra (M69)).

\subsubsection{Változás-vizsgálat származtatott adatbázisok felhasználásával}

A passzív képalkotó távérzékeléssel készült felvételek feldolgozásából származó adatbázisok közül a Corine Felszínborítási Adatbázis készült el több időpontra és alkalmazható tájváltozás vizsgálatra. Az adatbázist a tájidentitás-változás jellemzése céljára elsőként 2006 és 2008 között a SENSOR projektben, a Nyugat-Magyarországi Egyetemen folytatott kutatásaim során használtam. A kutatócsoportban két összetett tájváltozás-indikátort állítottunk fel (KONKOLY GYURÓ, JOMBACH és TATAI 2008). Mindkettő a jövőben Európa régióiban várható területhasználati változások hatását volt hivatott jelezni. $\mathrm{Az}$ indikátorok kifejlesztése során tesztekre használtuk a CLC100 (1990-2000) változásadatbázist. A „vizuális vonzerő” indikátor a tájképben jelentős szegélyek (víz, erdő, település, mezőgazdasági és vegyes) változását mutatta. Az indikátorba integráltuk a domborzat mozgalmasságát jellemző adatokat is, melyek a szegélyek jelentőségét emelték ki azokon a területeken, ahol nagyobb rálátás nyílt a tájra. A kutatás tapasztalatai nyomán az egyik legfontosabb vizuális szegély, az erdőszegély európai szintű elemzését végeztem el.

Az erdők szegélye meghatározó a tájjelleg szempontjából. A CLC 2000-2006 változásadatbázisa szerint az erdő a leggyakrabban változó terület szerte Európában (29. táblázat, 82. ábra (M70)). Az erdők szegélye markáns vertikális elem, így a típusos tájjelleget a síkvidéki, és a dombvidéki területeken is meghatározhatja. Ezért tartottam indokoltnak az erdőszegélyváltozást elemezni a tájjelleg-változás meghatározása céljából, európai mintaterületen és Magyarországon is. Az általam CLC 100 adatokra kidolgozott szegélyváltozás-mutató jelzi, hogy a vizsgált tájegységben található szegélyek a korábbi időpont értékéhez képest hány százalékkal csökkentek, vagy növekedtek (83. ábra (M70)).

A kutatás eredményeképpen megállapítottam, hogy a tájjelleg megváltozásában az erdőszegélyek alakulása régiónként/megyénként (NUTS2/NUTS3) eltérő mértékben játszhatott szerepet az ezredforduló utáni időszakban (2000-2006) (83. ábra (M70)). Angliában 14 régióban történt 15\%-nál jelentősebb erdő-szegélycsökkenés, de a Mediterráneum több országának (Portugália, Görögország, Spanyolország) egyes régiói is $10 \%$ körüli szegélycsökkenést szenvedtek hat év alatt. Az erdőszegély növekedését legintenzívebben Nyugat-Ausztriában, Skóciában és Dél-Svédországban mutattam ki. 
Fontos megemlíteni, hogy ezek a változások csak átlagolt összesítések. A helyben, lokálisan mért csökkenés egy részét kioltja az ugyanabban a térségben mért növekedés. Amennyiben Nagy-Britanniában az erdőszegélyt összesítjük, úgy az erdőszegély mérsékelt növekedését tapasztalhatjuk. A regionális elemzés azonban kimutatja, hogy a dél-angliai területek erdőszegély-csökkenését (mely Európában a legjelentősebb) az Egyesült Királyság szintjén elfedi a Skócia területén tapasztalt intenzív erdőszegély-növekedés (83. ábra (M70)).

Bár az összesített értékek EU28+3 államban regionális, vagy országos léptékben alacsonyak, és elsőre nem tűnnek jelentősnek, egyes térségekben csupán néhány százalékosak, helyi szinten, kistájakra, vagy településekre vetítve komoly tájjelleg változást jelenthetnek, melyeket érdemes a vizsgált területet leszükítve, nagyfelbontású ürfelvételekre építő térképezéssel részletesebben megvizsgálni és a változás hatásait is felmérni. Megállapítottam, hogy az erdőszegély-változás és az erdők területének változása a táj változás egyértelmüen két különféle jellemzőjeként értelmezhető a gyakorlatban is. Ez az EU28+3 állam területén $^{200}$ végzett kutatásom eredményeként jól látható (84.-86 ábra (M71)).
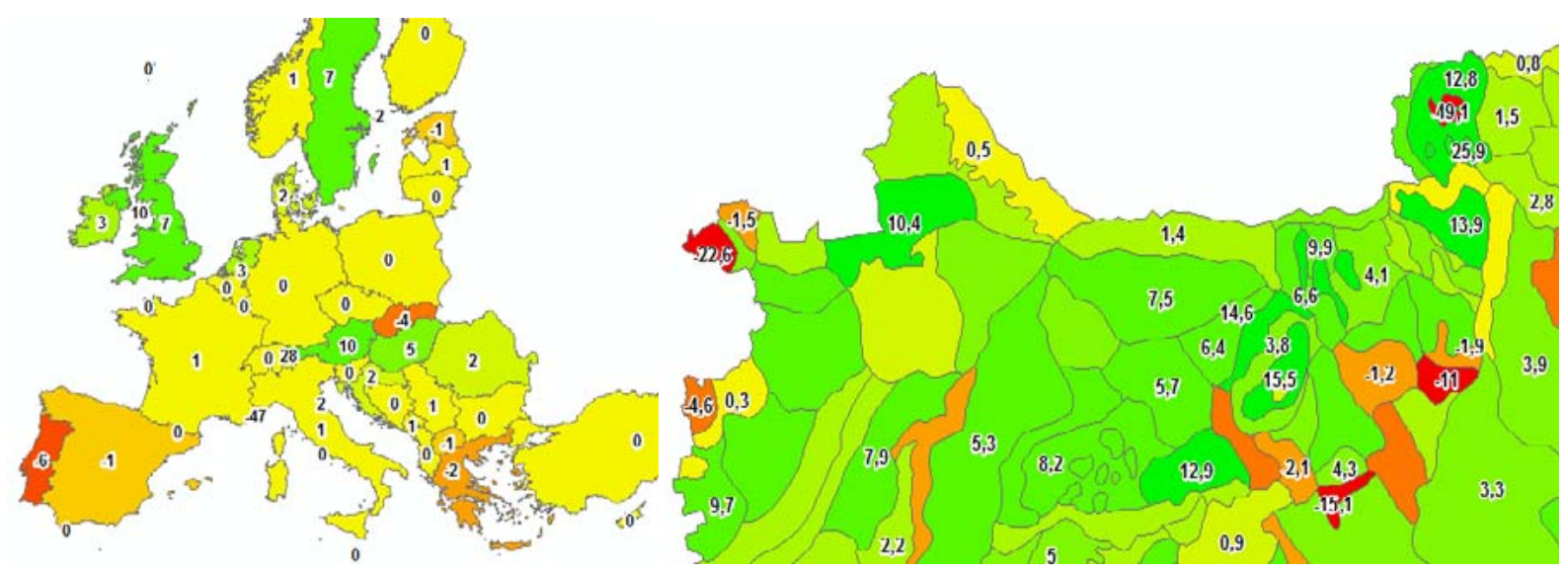

84. ábra és 85. ábra (részletek (M71)) Erdőszegély változása a korábbi értékhez képest (\%) (CLC100 2000 és 2006 Adatbázis alapján, Görögország területén 1990-2000 időszakra)

A CLC adatbázis felhasználásával, további tájváltozás-mutatók alkalmazásával, felszínborítás térképek összevetésével jellemeztem Magyarország tájait (87-90. ábra (M72-M73)). A felszínborítások területi arányával is számító változás-mutatók közül néhány valóban releváns a tájkarakter szempontjából. Hazánkban ilyenek a beépített területekhez, a mezőgazdasági területekhez, az erdőkhöz, a vizenyős területekhez és a vízfelületekhez kapcsolódó változás indikátorok. Kutatásom azt igazolja, hogy 1990-2006 közötti időszakban Magyarországon volt olyan jelentős, 15\%-nál magasabb felszínborítás-változás a mesterséges felszínek irányába, ami 16 éves távlatban már karakter-változásnak minősül (88. ábra (M72)).

\footnotetext{
${ }^{200}$ Míg Svédországban és Ausztriában úgy csökken az erdőterület, hogy az erdőszegély egyértelmüen növekszik, addig Portugáliában, Görögországban és Spanyolországban az erdőterület csökkenése egyben az erdőszegély csökkenésével jár. Míg Finnországban az erdőterületek kiterjedése és szegélyhossza szinte változatlan, addig Lengyelországban és Csehországban az erdőterület növekszik, de az erdőszegély összesítve változatlan. Magyarországon és Nagy-Britanniában erdőszegély úgy növekedett jelentősen, hogy a terület csak kis mértékben gyarapodott, Szlovákiában pedig úgy növekedett az erdőterület, hogy a szegélyek hossza jelentősen csökkent (84. ábra (M71)).
} 
Figyelembe véve, hogy a CLC egy Európai léptékhez fejlesztett „elnagyolt”, több hektáros foltokkal dolgozó adatbázis, mely csak a legmarkánsabb változásokat tartalmazza, szinte biztosak lehetünk abban, hogy tájegység, vagy megye szintjén kicsiny (5-10\%-os) területi változások lokálisan, a táj szempontból jelentősek, karakterformálóak. A CLC adatbázis előnye az országos és nemzetközi összevetés lehetőségében rejlik. Térségi szinten a CLC adatbázisnál sokkal részletesebb, finomabb, kisebb minimális térképezési egységgel dolgozó származtatott vektoros adatbázist indokolt készíteni vizuális interpretációval, vagy előállítani irányított képpont-osztályozással. Ezek a táj helyi sajátosságait figyelembe véve hitelesebbek lehetnek egy térségi tájkarakter-elemzés során, mint az európai szinten egységes kategóriákra és módszertanra épített CLC adatbázis.

\subsubsection{A táj nyitottságának változása indikátor alkalmazása a tájkarakter jellemzésére}

A tájkarakter egyik fontos jellemzője a táj nyitottsága, melyet leginkább a tájképben meghatározó elemek magasságával és a vertikálisan jelentős kiterjedésű tájelemek sürüségével tudunk jellemezni, mérhetővé tenni ${ }^{201}$. A „táj nyitottságának változása” a tájkarakter változásának fontos mutatója lehet. Megmutatja, hogy a táj egy vizsgált időszakban milyen mértékben nyílt vagy záródott. A gyep cserjésedésének, a településszövet terjedésének folyamata egyértelműen a záródás irányába, míg az erdők kivágása, a szőlők, vagy gyümölcsösök szántóvá alakítása egyértelmúen a nyitás irányába módosítják a tájképet. A változásmutatót országos vagy európai elemzésekhez felszínborítási adatokra érdemes építeni.

A mutatót CLC 2000-2006 változásadataival több mintaterületen teszteltem. Számítását a korábbi publikációkhoz képest (pl.: TIRÁSZI 2011) egyszerüsítettem, egyértelmüsítettem és segítségével értékeltem Magyarország és az EU28+3 állam tájainak nyitottság-változásait. A „táj nyitottságának változása” mutató számítási módszerét a 30. táblázat (M75) ismerteti. Lényege, hogy háromféle nyitottság állapotot alkalmaz, melyből a teljesen nyitott (pl. szántó, gyep) 1-es értéket, míg a zárt (pl. településszövet, erdő) 0 értéket, a szemmagasságig terjedő elemekkel jellemzett köztes kategóriák (pl.: szőlők, cserjések, gyümölcsösök stb.) 0,5 értéket kapnak. Felszínborítás-változás során a mutató így területarányosan jelzi, hogy egy tájegység milyen arányban záródott, vagy nyílt. Amennyiben például egy $1000 \mathrm{~km}^{2}$-es kistájon 100 $\mathrm{km}^{2}$-en erdő létesült korábbi gyepterületen, akkor az a táj $10 \%$-os záródását jelenti.

A mintaterületi elemzések eredményei azt mutatják, hogy egyes európai térségekben a táj nyitottsága jelentősen változott a 2000-2006 időszakban. Hat év alatt összesen kilenc portugál, svéd, lett és francia régióban történt meg a tájkép nyitottságának növekedése 1,5\%-nál nagyobb mértékben. A táj nyitottságának csökkenése négy régióban (két magyar, egy spanyol és egy ír) is meghaladta a 1,5\%-ot. Ez az érték a tájegységek szintjén még

\footnotetext{
${ }^{201}$ A táj nyitottsága indexet, mely megmutatja a vertikálisan nyitott (pl.: legelő, szántó), átmeneti jellegü (pl.: cserjés, kert) és zárt (pl.: erdő, településszövet) felszínborítás-foltok területi arányát, és ezáltal jellemzi a táj nyitottságát a 4.3.4. fejezetben ismertettem.
} 
magasabb lehet. Amennyiben egy 25 éves időszakra vetítem ki ezt a változásfolyamatot, akkor két régió/megye esetében a nyitottság növekedése (Kronobergs län. (SE), Centro (PT)), két régióban/megyében pedig a nyitottság csökkenése (Dublin (IE), Szabolcs-Szatmár-Bereg (HU)) mindenképpen megközelítené a tájváltozás szempontjából Tirászi által leírt, átlagosan 17,5\%-os küszöböt ${ }^{202}$ (91. ábra (M74)).
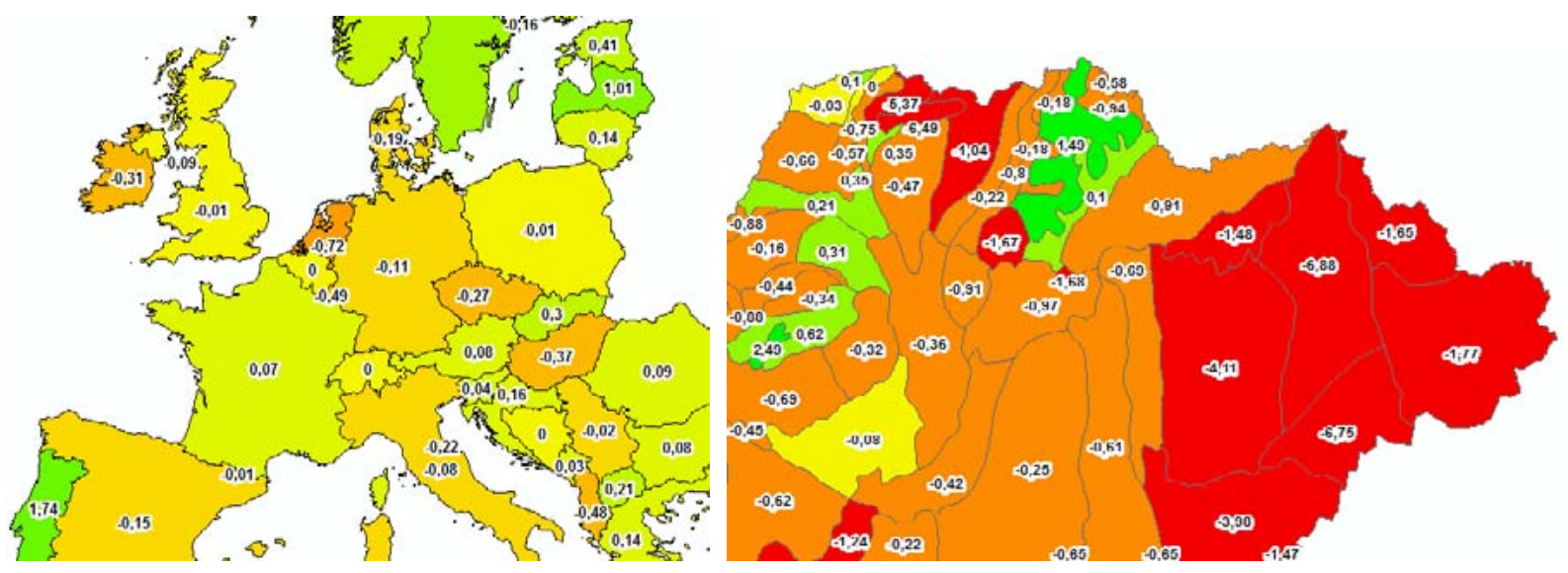

91. és 92. ábra (részletek (M74-M75) a Táj nyitottságának változása a korábbi értékhez képest 2000 és 2006 időpontok között Európában, 1990 és 2006 időpontok között Magyarországon.

Magyarországi kutatásaim eredményei igazolják a feltételezést, hogy lokálisan a táj nyitottságának változása jelentősebb lehet a tájkarakter szempontjából. A regionális/megyei szintű európai áttekintés Magyarországon kistáj szintre részletezett formában már két kistáj esetében is közel 5\%-os nyitottság csökkenést mutat 6 évre. Ez 16 évre készült elemzésem alapján (1990-2006) már közelíti a 7\%-ot (Délkelet-Nyírség, Északkelet-Nyírség) (92. ábra (M75)). Megállapítottam, hogy Magyarországon a tájkép „záródása” tendencia érvényesül, és a változás mértéke 16 év alatt a CLC adatbázis által igazoltan négy település esetében (Nyírpilis, Pilisjászfalu, Tornabarakony, Üröm) már meghaladta a 15\%-ot és tájkarakterváltozást eredményezett.

\subsubsection{Tájjelleg-változás elemzése felvételek vizuális interpretációjával}

A vizuális interpretáció a változás-vizsgálatok leginkább munka- és időigényes formája. Egy-egy változási jelenséget alátámasztó légifelvétel, vagy nagyfelbontású ürfelvétel sorozat felhasználásával akár tájelem szintű változás is dokumentálható. A Délnyugat-Budakörnyéki területen végzett kutatásomban öt év alatt - az 1920-as évektől napjainkig 12 különböző időpontban készült - több mint 1000 történeti jelentőségű légifelvételt tekintettem át és szkenneltem be a Hadtörténeti Múzeum Térképtárában, vagy vásároltam a Földmérési és Távérzékelési Intézet archívumából. Az ezekből válogatott közel 100 légifelvételt a térség tájváltozásának részletesebb elemzésére használtam fel. Az eredmények az agglomerációban

${ }^{202}$ Ez azt jelenti, hogy az EU28+3 állam területén több olyan régió is található, melynek tájegységeiről még egy „elnagyolt” európai adatbázis elemzése szerint, rövid időszak vizsgálata alapján is azt lehet alappal feltételezni, hogy negyed évszázad alatt jelentős tájkarakter-változáson mehetnek át. 
jellemző elővárosiasodás tendenciát igazolják. A terület településeinek kétharmadában területi arányban is meghatározó volt ${ }^{203}$ az elővárosi jellegü területhasználatok és tájelemek megjelenése hat évtized alatt. Budapest délnyugati szomszédságában lévő településeken jellemzően az 1950-es évektől figyelhető meg a vidéki tájelemek folyamatos csökkenése és a városi tájelemek terjedése. A jelenséget angol nyelven szezőtársaimmal közösen publikáltam (SALLAY, JOMBACH és FILEPNÉ KOVÁCS 2011) (93. ábra és 31. táblázat (M76-M77)).

Kutatásaim azt mutatják, hogy a térségben feltárt változások nem csak szakértők, hanem hétköznapi emberek számára madártávlati felvételek alapján is egyértelmüek lehetnek ${ }^{204}$. Kérdöívezés során kiderült hogy a válaszadók 97\%-a úgy gondolja a 94. ábra láttán (M78), a helyszín és időpontok ismerete hiányában is, hogy a Kamaraerdő és a Budaörsi-medence térségében $^{205}$ a táj karaktere megváltozott az 1920-as évekhez képest. A kérdőívezettek 92\%-a a változás jellegét ${ }^{206}$ helyesen meg tudta ítélni, azonban abban már bizonytalanabb volt, hogy ez a változás milyen időtávban következett be. A válaszok a „néhány év”-től a „100 év”-ig skálán szórnak, a többség azonban a tényleges időtávnál jóval rövidebb időszakra, 30-40 évre becsüli a felvételek közötti különbséget (94. ábra (M78)).

${ }^{203} 20 \%$-os változást meghaladta (TIRÁSZI 2011 alapján ez tájváltozást jelent)

${ }^{204}$ A tájkarakter-változáshoz alkal mazott vizuális interpretáció sikerességét nagymértékben fokozza:

- a felvételek digitális feldolgozása és dokumentálása

- az elérhető legnagyobb pontosságú geometriai korrekció biztosítása

- a georeferencia adatok hiányában a történeti jelentőségü felvételek időben visszafelé (napjainktól folyamatosan a közelmúlt, majd a régmúlt irányába), az idősorban legközelebbi referecia-felvételekről származó illesztőpontokkal végzett geokorrekciója

- a geokorrekció és a változások értelmezésének többszöri iterációja már a geokorrekció módszerének alkalmazása során

- kontraszt és fényerő módosítása

- a lehető legtöbb felvétel áttekintése, évszakok szerinti rendezése és összevetése

- az állandósult karaktervonások, és változásaik lehető legtöbb felvétel alapján történő meghatározása (egy felvétel alapján nem lehet állandósult karakter-vonást, vagy annak változását nagy biztonsággal megállapítani)

- az idősorba rendezett felvételek animálása, animációba rendezése

- az idősoros felvételek különféle szakértőkkel közös értékelése, elemzése

- a helyismeret

- a többszöri és módszeres terepi ellenőrzés

${ }^{205}$ Erre a területre terjedtek ki a legkorábbi madártávlati légifelvételek

${ }^{206}$ A változás jellege a felvételek szerint: beépítés, mezögazdasági területek csökkenése 


\subsection{Láthatóság-elemzés a tájkarakter-elemzésben}

A táj láthatóságának vizsgálatát az ország területére többféle szempont ${ }^{207}$ alapján végeztem ASTER GDEMv2 adatok felhasználásával. Két nagyobb beruházáshoz kapcsolódó hatásvizsgálati témában elvégzett láthatóság-elemzési munkám tájkarakter-elemzésben is hasznosítható tanulságait összefoglaltam. Kutatást folytattam a láthatóság módosulása, és a kilátóhelyekről jellegzetesen feltáruló terepfelszínek meghatározása témakörében.

\subsubsection{A táj láthatósága}

A táj láthatóságát a tájelemek láthatóságával lehet jellemezni. A passzív képalkotó távérzékelésből származó ASTER GDEMv2 magassági adatok nem a terepfelszín magasságát, hanem pontosan ezt a „tájelem-felszínt” modellezik ${ }^{208}$. Kutatásomban az ASTER GDEMv2 felszínmodell különböző felbontású változatait használtam fel a tájelemek és tájegységek láthatóságának elemzésére Magyarország területén. Bevezettem egy elméleti láthatósági mutatót, mely nem csak egy viszonyszámmal, hanem egy egyértelmü számértékkel jelzi, hogy az adott terület milyen százalékban látható a környező területek nézőpontjaiból. A mutató lényege, hogy a „látó” nézőpontokat százalékos arányban mutatja az összes nézőponthoz képest, minden vizsgált tájrészlet esetében (95-96. ábra (M79-M80)).

Az elemzést országos szinten készítettem elés kimutattam hogy:

- melyek az országos léptékben közeltérben $(0-5 \mathrm{~km})$, köztestérben $(5-10 \mathrm{~km})$ és távoltérben (10-20km) ${ }^{209}$ gyakran látható tájrészletek, tájegységek (97. ábra (M80)),

- melyek azok a tájrészletek, amelyekre felfelé látunk rá nagymértékben (98. ábra (M81)), illetve melyek azok, amelyekre letekintve nagy a rálátás (99. ábra (M81)).

A távoltérben igen gyakran látható tájrészletek közé tartoznak a síkvidéki környezetből kimagasló markáns elemek, mint a tanúhegyek, vagy magányos röghegységek, esetenként gejźrkúpok, vulkanikus kúpok, várhegyek. Ezek - terepi megfigyeléseim szerint valóban karakteres elemei a hazai tájaknak, amit láthatóságuk magas aránya is megerősít. A Badacsony például $20 \mathrm{~km}$-es környezetének $61 \%$-áról látható ${ }^{210}$. Hasonló elemek a Somló, a Ság, a Pannonhalma környéki sokorói hátak, a Marcali-hát kimagasló pontjai, a Mecsek egyes csúcsai, melyek az országos szintü $1 \mathrm{~km}^{2}$-es felbontású elemzésen az esetek kb. kétharmadában láthatóak $20 \mathrm{~km}$-es környezetükből (95. ábra (M79)). A legnagyobb átlagos láthatósággal rendelkező kistájak a Tokaji-hegy (37\%), a Villányi-hegység (32\%) és a Balatoni Riviéra (28\%) (96. ábra (M80)).

\footnotetext{
${ }^{207}$ letekintés, feltekintés, eltérő látótávolság

${ }^{208}$ Az adatbázis előállításának módszere és a 4.2. fejezetben elemzett adattartalma is azt igazolja, hogy a táj földfelszíni elemeinek magasságát reprezentálják. A tájelemek felszínének vizsgálata indokol tabb a tájkarakter szempontjából jelentős láthatóság elemzés esetében, mint a „csupasz” terepszint láthatósága.

${ }^{209}$ A közeltér, köztestér, távoltér fogalma nem azonos az elötér, középtér, háttér fogalmával. Utóbbi három esetében a látványban betöltött szerep a meghatározó a távolságtól függetlenül, míg a közeltér, köztestér és távoltér esetében csupán a nézőponttól mért távolság a meghatározó.

${ }^{210} 1 \mathrm{~km}^{2}$-es térbeli felbontású felszínmodell-változat használata esetén
} 
A 20km-es körzetre vizsgálva természetesen a legkevésbé láthatóak a kis kiterjedésü, mély fekvésü medencék ${ }^{211}$, de alacsony a láthatósági mutató a síkvidéki tájakon is (6-8\%). Magyarország felülről jól látható tájegységei a Balaton és környéke (19\%), a Vác-PestiDuna-völgy (15\%), a Borsodi-Mezőség (12\%) (98. ábra). A felfelé nyíló rálátás esetén főként a síkvidéki környezetből kiemelkedő középhegy ségek ${ }^{212}$ dominálnak (99. ábra(M81)).

Hangsúlyozom, hogy az elméleti láthatóság nem veszi figyelembe az erdőterület, a településszövet, vagy egyéb tájelemek látképet takaró hatását a nézöpontok esetén, és azt sem, hogy a tájat általában a frekventáltabb nézőpontokról szemléljük, és az itt megszerezhető tájélmény a meghatározó. A ,gyakorlati láthatóság” meghatározásához egy tájkarakterelemzés esetén természetesen nem csak a közeltér, köztestér, távoltér tényezők, a lefelé, vagy a felfelé tekintő rálátás, vagy a felszínborítás figyelembe vétele lehet érdekes, hanem a felszíni tájelemek láthatóságot módosító szerepe is. Általános tapasztalat, hogy a tájelemek digitalizálhatók a térinformatikai láthatóság-elemzést befolyásoló tényezők közé, de a terepi bejárások során szerzett tapasztalatokat, melyek a láthatóság-fedvények értelmezéséhez szükségesek, nem helyettesíthetik.
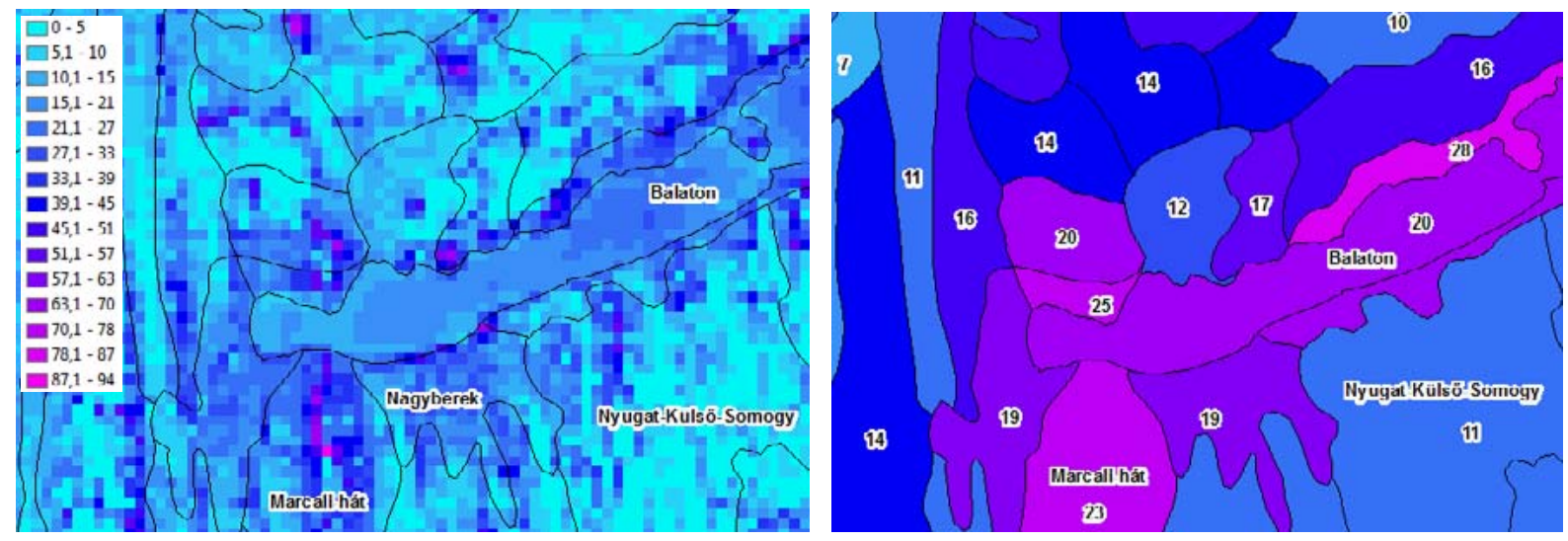

95. ábra (részlet (M79)) Tájrészletek láthatósága a Nagyberek térségében az elméleti láthatósági mutató alapján (\%). Az elméleti láthatósági mutató kifejezi, hogy a vizsgált tájrészletek milyen arányban (\%-ban) láthatóak a környező területekről. (Felhasznált alapadat: ASTER GDEMv2)

\subsubsection{Karakteradó tájelemek láthatósága}

Egyes karakteradó tájelemek láthatósága különösen fontos a karakter megítélésében. Legyenek ezek különleges felszínek (vízfelület, zöldfelület), területhasználatok (gyep, szőlő erdő stb), markáns szegélyek, nagy vertikális, vagy horizontális kiterjedésü objektumok, szokatlan, vagy éppen tradicionális örökség-elemek, a táj karakterét jelentősen meg tudják határozni, ezért láthatóságuk meghatározó lehet. Kutatásom során tapasztalatot szereztem a jelentős tájelemre koncentráló láthatóság-elemzésekben. Két konkrét esetben a beruházók szándékainak megfelelően tervezett építmények láthatóságát vizsgáltam.

\footnotetext{
${ }^{211}$ Gánti-medence a Vértesben (4\%), vagy a Tárkányi-medence a Bükkben $(6 \%)$

${ }^{212}$ Kőszegi-hegység (20\%), Magas-Mátra (19\%), a Vértes-fennsík (19\%), a Központi-Gerecse (18\%), a Hegyalja (17\%), és a Keszthelyi-fennsík (17\%)
} 
A tervezett nyergesújfalui cementgyár és kapcsolódó szállítószalag példájának érdekessége, hogy egy nagy területre kiterjedő és igen hosszan elnyúló keskeny, tervezett objektum nyilvánvalóan karakteradó láthatóságát kellett megvizsgálni (CSIMA et al. 2008). A 2008-ban indított, a Budapesti Corvinus Egyetem Tájvédelmi és Tájrehabilitációs Tanszékével részben közösen folytatott kutatásomból levont tanulságok a következők:

- Kilátópontokról készített kilátás-fedvények és a tájelemek láthatóságát mutató láthatóság-fedvények együttes, egymást kiegészítő alkalmazása indokolt a táj karakteradó elemeinek vizsgálatánál, a főbb láthatósági irányok meghatározásához.

- A nagykiterjedésü, vagy hosszan elnyúló objektumok esetén a láthatóságot, az objektum több, jellegzetes pontjával érdemes elemezni (100. ábra (M82)).

- A felszínborítás (főként erdő és beépített terület) jelentősen befolyásolhatja a tervezett létesítmények láthatóságát és érvényesülését a tájképben, ezért ezeknek a felszíneknek a feltüntetése minden láthatóság-térképen az elérhető legnagyobb részletességgel (legalább CLC50-es adatbázis aktualizált változata) indokolt (KOLLÁNYI és JOMBACH 2008).

- A „gyakorlati láthatóság”, azaz a terepen is tapasztalható láthatósági viszonyok elemzéséhez a Magyarországon elérhető legpontosabb DDM5 adatbázist indokolt kiegészíteni ASTER GDEMv2 felszínmodellel.

A perenyei szélerőfarmhoz kapcsolódó kutatás érdekessége, hogy több igen nagy függőleges kiterjedésü, tervezett szélerőtorony láthatóságát kellett elemezni (DREXLER, SALLAY és JOMBACH 2010). A tizenegy magas torony és a rajtuk elhelyezkedő turbinák láthatóságát három eltérő magasságban, több torony esetében együttesen és külön-külön is vizsgáltam (JOMBACH, DREXLER és SALLAY 2010). A 2009-ben indított kutatásom eredményeként levont legfontosabb tanulságok a következők:

- $\mathrm{Az}$ erdő és a beépített terület felszínborítás foltok „láthatósági árnyéka"213 kutatásom szerint több hektáros területet mentesít a szélerőfarm egyes elemeinek látványától, ezért indokolt a felsźnmodell (ASTER GDEMv2) alkalmazása, mely a tájelemek felszínének magassági adatait is tartalmazza.

- A legrészletesebb hazai DDM felszínborítás-foltok alapján történő módosítása helyett, a felsźnmodellhez viszonyított ,relatív" magassági pontok ${ }^{214}$ megadását tartom indokoltnak a valós láthatósági viszonyok elemzésére.

- A hatásmérséklést szolgáló takarás, növénytelepítés (pl. a fókuszterületként meghatározott fontosabb utak, vasutak mentén) csak akkor vezet eredményre, ha más, egyébként kedvező hatású karakteradó elem láthatóságát nem csökkenti. Ennek lehetőségét szintén elemezni kell.

- A szélerőtornyok áthelyezésével nyerhető láthatóság-csökkenés érdekében érdemes a tervezőnek alacsonyabb tengerszint feletti magasságra telepíthető alternatívát is javasolni (101. ábra (M83)).

\footnotetext{
${ }^{213}$ A „láthatósági árnyék” azt a területet jelenti, ahol a tervezett épített létesítmény nem lesz látható markáns vertikális tájelemek (erdő, vagy épület) vizuális takarásának köszönhetően.

${ }^{214}$ ArcMap programban akár felszíni, akár felszín alatti nézőpontok is megadhatók.
} 


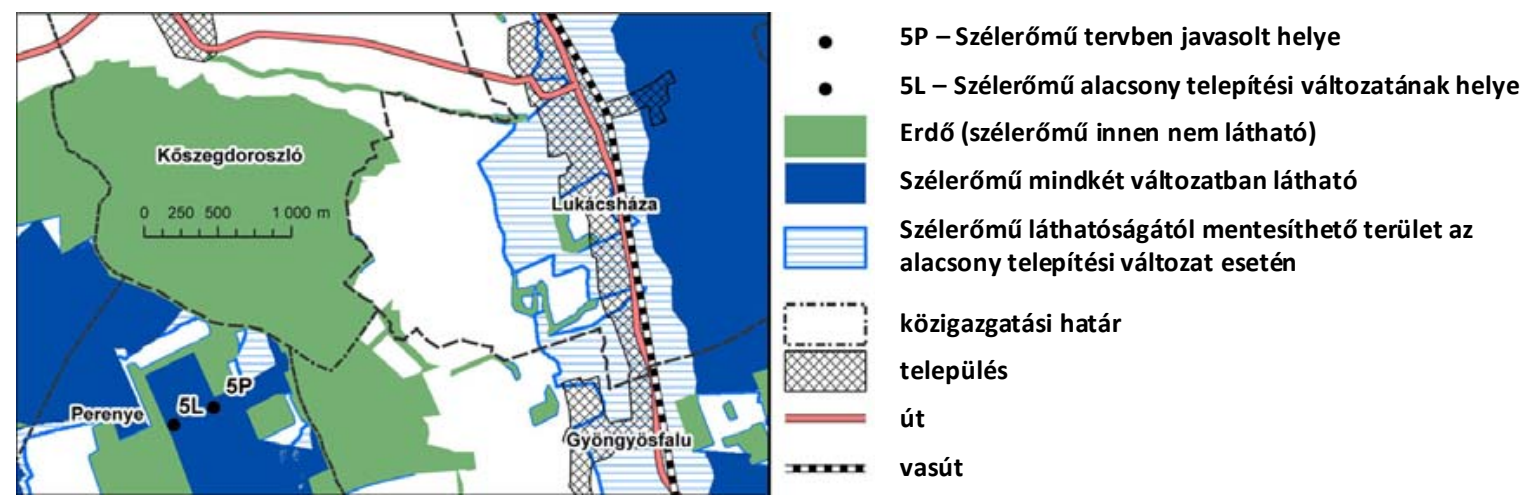

101. ábra (részlet (M83)) A Perenyére tervezett szélerőmüvek láthatóságának-elemzése

\subsubsection{Láthatóság módosulásának vizsgálata}

A táj láthatósága egyes esetekben pl. erdősülés, beépítés stb. következtében oly mértékben módosulhat, hogy ez által a tájjelleg is változik, pusztán egy-egy markáns karakteradó látványelem eltakarásával. A Lágymányosi-öbölböl nyíló láthatósági viszonyokat a tervek szerinti várható fejlesztések figyelembevételével vizsgáltam. Jelenleg a terület jó részéröl feltárul a Széchényi-hegy és Televízió-adótorony, valamint a Gellért-hegy, Citadella és Szabadság-szobor tájelem-együttesek markáns látványa. Ezek a karakteradó elemek azonban a kerületi szabályozási tervben meghatározott beépíthetőségi paraméterek figyelembevételével szinte biztosan veszítenek látványbeli jelentőségükből az Öböl-park közelében várható többszintes fejlesztés (lakó-, iroda- és szállodaépületek) következtében.

A Lágymányosi öböl területén és környezetében elhelyezkedő telkeken a jövőben nagymértékü beépítés várható. A XI. kerületi $\mathrm{KVSZ}^{215}$ övezeti térképe szerint (102. ábra (M84)) „Közepes intenzitású vegyes beépítésű intézményterület” van a közpark északi felétől nyugatra. A KVSZ szerint (102 ábra és 32. táblázat (M84)) a telkek többnyire 40\%-ban szabadonálló módban beépíthetők. Az I-XI/K-5 övezet (Közepes intenzitású intézményi övezet az Infopark déli részén), mely a terület nagy részét lefedi, 6-22 m magasságú épületeket enged nagyvárosias jellegű 3-as szintterületi mutató mellett. A szabályzat szerint az övezetben kivételesen megengedhető a 45 méteres építmény-magasság is a park közvetlen szomszédságában, két megjelölt helyen. Az öböl északi peremén az IZ-XI/1-es övezetben 35\%-os beépítettséggel és 2,4 maximális szintterületi mutatóval beépíthető, magasház építési lehetőséggel az övezet nyugati oldalán (103. ábra (M84)). Ezek a magasházak egyértelmüen korlátozhatják a Széchényi-hegy és/vagy a Gellért-hegy látványát.

Kutatásomban meghatároztam, hogy milyen építménymagasság esetén csökken jelentősen a két tájelem-együttes láthatósága (104. ábra (M85)). Topográfiai térképek alapján korrigáltam az ASTERGDEMv2 magassági adatait és ezután készítettem el a felszínmodell módosítását és a láthatóság-elemzést. A Gellért-hegy esetében a 12-16m magasság között húzódik a határérték, míg a Széchényi-hegy esetében a 10-14m magasság lehet mértékadó, ha az elem-együttesek karakteradó látványát szeretnénk megőrizni. A 22 m-es épületmagasság

${ }^{215}$ KVSZ: Kerületi Városrendezési és építési Szabályzat 
nem csak az elem-együttesek karakteradó szerepét „törölné”, hanem a láthatóságát is teljes mértékben megszüntetné, szinte az egész park területén.

\subsubsection{Tájkaraktert meghatározó kilátóhelyek és a fontos látványelemek elemzése}

A tájkaraktert jelentősen meghatározhatja, egy-egy közkedvelt kilátóhelyről ${ }^{216}$ feltáruló látvány. Ezért is fontos elemezni, hogy mely tájrészletek láthatóak a vizsgált tájegység kilátóiból. A digitális domborzatmodelleken alapuló kilátópontokból végzett láthatóságelemzés ${ }^{217}$ azonban többnyire csak a látható terület lehatárolására használatos. Meglátásom szerint a tájkarakter-elemzés esetében több láthatósági paraméter alkalmazása is indokolt. A Délnyugat-Budakörnyéki mintaterületen a vizsgált kilenc kilátópont esetében (33. táblázat, 105. ábra (M86)) ASTER GDEMv2 felszínmodellel végzett elemzések során számos objektív paramétert határoztam $\operatorname{meg}^{218}$.

Mindezek a láthatósági paraméterek a térinformatikai szoftverekkel, magassági modellek felhasználásával mérhetők. A tájkarakter jellemzéséhez azonban egyéb tájképi jellemzőket is érdemes figyelembe venni. Kutatásomban arra törekedtem, hogy a látványban kulcsfontosságú tájrészletek meghatározása ne csak a látható terület lehatárolásából álljon, hanem, hogy a látható területen belül a karaktert potenciálisan meghatározó tájelemek helye a térképi fedvényeken hangsúlyosan megjelenjen (106. a, b, c ábra (M87-M89)).

A látható terület távolsága a kilátóhelytől, a vertikális látószög szemmagasságtól eltérő mértéke olyan tényezők, melyek a látványban fontos felületeket részben meghatározzák. A lejtők meredeksége általában fontos tényező a tájkép-értékelésben. A tájkarakterelemzésekben kulcsfontosságú látvány lehet egy dominánsan megjelenő meredek domboldal és a domboldalon megjelenő tájelemek pedig potenciális karakterelemnek tekinthetők. Ezért meglátásom szerint a láthatóság-elemzést ajánlott „lejtősúlyokkal” kiegészíteni. Fontos azonban, hogy csak azok a lejtők kerüljenek be súlyként a rendszerbe, amelyek a kilátó felé lejtenek. Azokat a lejtőket, melyek a vizsgált kilátóhely irányába lejtenek - és emiatt a tájképi karakter szempontjából meghatározóak lehetnek - szembenéző lejtőknek nevezem.

Kutatásomban kidolgoztam egy olyan láthatóság-értékelést kiegészítő „szembenéző-lejtők” kimutatására alkalmas eljárást, mely lehetőséget biztosít a kilátóhely irányába tekintő lejtők térképezéséhez. A kilátóhellyel szembe néző lejtők látványbeli jelentősége alapvetően eltér azokétól, amelyek a kilátóhelytől „ellejtenek”, azaz a kilátóhelynek háttal állnak, azzal

\footnotetext{
${ }^{216}$ kilátó-építmények, kilátóhelyek, vagy jó kilátással bíró helyszínek, gyakran használt útvonalak, utcasarkok, erdőszegélyek, településszegélyek, parkok, megállók, pihenőhelyek

${ }^{217}$ Viewshed Analysis (ArcMap, ERDAS Imagine láthatóság-elemzésre használható funkciói)

${ }^{218}$ Kilátóhelyröl feltáruló látvány mérhető tulajdonságai: 1. mekkora a teljes látható terület, 2. milyen messze van a legtávolabbi látóhatár, 3. milyen égtáj irányába esik a legtávolabbi látóhatár, 4. mekkora terület esik a „közeltérbe” (0-5 km) „köztestérbe” (5-20 km) és a „távoltérbe” $(20-80 \mathrm{~km})$, 5. milyen a tájra nyíló rálátás domináns vertikális iránya (lefelé vagy felfelé tekintő a legnagyobb látható terület vertikális látószöge alapján), 6. mekkora területre nyílik rálátás különbözö vertikális látószögek esetén $\left(2^{\circ}\right.$ felett, $-2^{\circ}$ alatt, $-2^{\circ}$ és $2^{\circ}$ között a közel vízszintes tartományban)
} 
ellenkező irányba tekintenek. A kutatásom eredményeként elkészült digitális adatbázisban azok a területek, melyek teljes mértékben a kilátóhely irányába lejtenek, magasabb számjeggyel (döntően 0,5 felett) reprezentáltak, míg azok, melyek a kilátóval ellentétes irányba lejtenek, alacsonyabb értékkel szerepelnek (107. ábra).
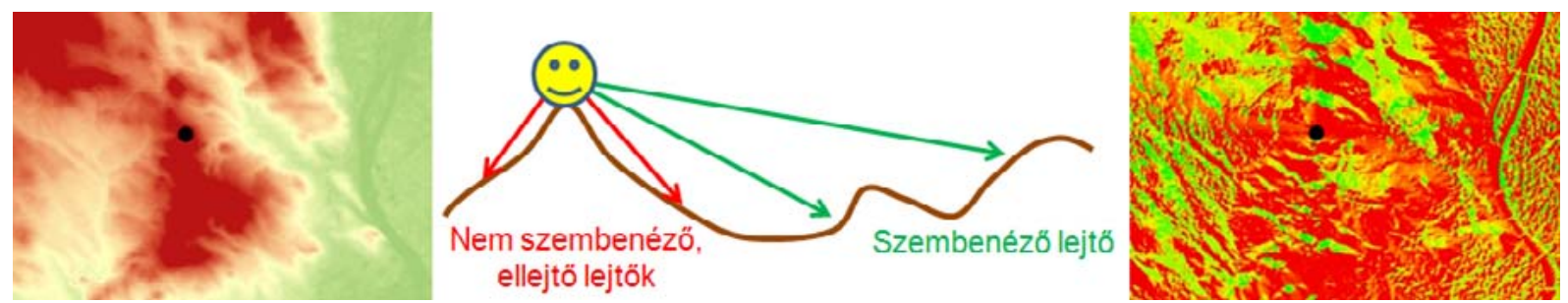

107. ábra. Szembenéző lejtők elve, felszínmodell és szembenéző-lejtő elemzés eredménye

A szembenéző-lejtő elve a Föld bármely pontján található kilátóhelyre alkalmazható. A technikai eljárás, melyet a mintaterületre kidolgoztam, Magyarország bármely területén használható, és egy kiválasztott kilátóhely koordinátáit megadva néhány perc alatt megadható a szembenéző lejtők elhelyezkedése. Feltétele, hogy rendelkezésre álljon digitális magassági modell és az általam kidolgozott „Elhelyezkedés-elemző” megfelelő felbontású adatállománya (108. ábra). Az eljárás kialakításához passzív távérzékeléssel készített, ingyenes ASTER GDEMv2 felszínmodell-adatokat használtam fel ERDAS és ArcGIS szoftverek együttes alkalmazásával. A szembenéző lejtők térképezésének fontosabb lépései:

1. Kitettség-elemzés - Égtájak szerinti kitettség-elemzés digitális felszínmodell felhasználásával (Eredményként: 0-361 ${ }^{\circ}$ számértékek szerepelnek a fájlban ${ }^{219}$ ).

2. Égtájirányba-lejtés elemzése - A vizsgált területrészek egyes égtájak irányába lejtő mértékének meghatározása. Minden égtáj esetében külön-külön fedvényen egy attribútum adattábla kapcsolásával történik. Az adatállomány négy rétegében mutatja, hogy a vizsgált tájegységben az egyes területrészek milyen mértékben lejtenek egy-egy égtáj felé. Amennyiben 100\%-ban, akkor „,1”-es érték, ha 0\%-ban, akkor „0” érték (és közötte tizedes-értékek) szerepelnek az adatállományban.

3. Elhelyezkedés-elemzés - A vizsgált terepfelszín kilátóponthoz viszonyított elhelyezkedésének jellemzése a kilátóhelyhez viszonyított irány függvényében, égtájanként eltérő rétegben, de végeredményben egyetlen elhelyezkedés-jellemző állományban összevontan (Eredményként: 0-1 tartományban értékek négy rétegben).

4. Szembenéző-lejtő elemzés - Az égtájirányba-lejtés adatállomány (2. pont) és az elhelyezkedés-jellemző (3. pont) adatállomány egymásnak megfeleltethető rétegei szorzatának kiszámítása, majd a szorzatok összeadása.

\section{A szembenéző lejtő kimutatására alkalmas képlet:}

$\mathrm{SZNL}=\mathrm{ÉIL}_{\text {észak }} * \mathrm{ELH}_{\text {észak }}+$ ÉIL $_{\text {kelet }} * \mathrm{ELH}_{\text {kelet }}+\mathrm{ÉIL}_{\text {dél }} * \mathrm{ELH}_{\text {dél }}+\mathrm{ÉIL}_{\text {nyugat }} * \mathrm{ELH}_{\text {nyugat }}$

Ahol: ÉIL $=$ Égtájirányba-lejtés

$\mathrm{ELH}=$ Elhelyezkedés-elemzés

$\mathrm{SZNL}=$ Szembenéző lejtő

${ }^{219}$ 0-361 fokig terjedő értékek az égájak irányát számokkal kódolják. $\left(90^{\circ}=\right.$ Kelet, $270^{\circ}=$ Nyugat, stb) 


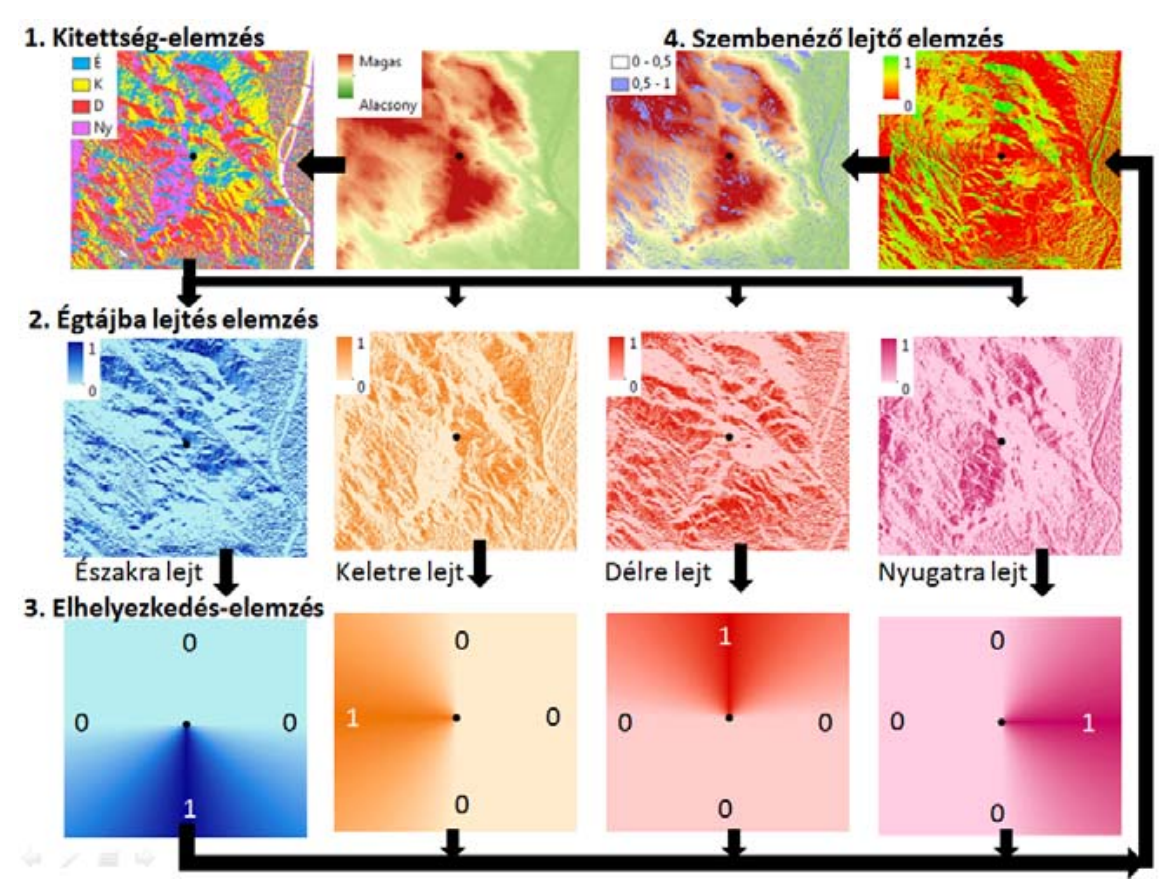

108. ábra (részlet (M90)) Szembenéző lejtők meghatározásához kidolgozott eljárás folyamata

Kutatásom eredményeként a Délnyugat-Budakörnyéki mintaterület kilenc kiemelt kilátóhelyéről látható területeken a látvány szempontjából fontos felsźneket egy-egy láthatóság-rétegben határoztam meg (106. ábra (M86-89)). A kutatás ennek érdekében a puszta láthatóságon túl súlyozottan figyelembe vette az alábbi tényezőket is:

- Távolság tényezö: a kilátóhelyhez közelebbi területeket többre értékeli, mint a távolabbiakat. Ezt 14 kategóriára bontva súlyoztam (34. táblázat (M86)).

- Vertikális látószög tényező: a kilátóhelyről a tájra nyíló rálátás vízszintestől mérhető eltérésének mértéke szerint súlyoztam. A súlyozás 12 kategória szerint történt abból a megfontolásból, hogy minél magasabban húzódó vagy mélyebben fekvő tájrészletre tekinthetünk egy kilátóhelyröl, annál izgalmasabb a tájkép (34. táblázat (M86)).

- Lejtőmeredekség tényező: a látható területek meredekségét veszi figyelembe 10 kategóriában. Minél meredekebb a látható terület lejtése, annál fontosabb a tájképben, eltekintve attól a kivételtől, amit a következő tényező küszöböl ki (34. táblázat).

- Szembenéző lejtő tényező: A lejtőmeredekség súlyt úgy engedi érvényesülni, hogy figyelembe veszi azt is, hogy a kilátóval szembe néz-e a lejtő. A tényező alkalmazása azért jelentős a tájkarakter szempontjából, mert minél inkább a kilátó felé néz egy lejtő, és nem azzal ellentétes irányban, annál fontosabb a tájképben betöltött szerepe.

A tényezők figyelembevételével a legismertebb János-hegyi Erzsébet Kilátó esetében több $\mathbf{k m}^{2}$-nyi területen lehetett pontosítani a látható területből kiemelni az igazán jelentős területeket. Érdekesség, hogy az Erzsébet kilátóról a János-hegy nyugati domboldala látható ugyan, de jó része ellejt a kilátótól, tehát a rálátás ezekre a tájrészletekre ugyan adott, de nagyon alacsony szögben valósul meg, ezért a látványban betöltött szerepe kevésbé jelentős, mint például a Csiki-hegyek északi lejtőinek, melyek ugyan távolabb vannak, de szembenéznek a János heggyel (109. ábra (M91)). 


\subsection{Megjelenítési (vizualizációs) megoldások a tájkarakter interpretálására}

A tájjelleg bemutatása, a karakteradó jellegzetességek beazonosítása, a vizuális sajátosságok kiemelése, a tájkarakter-változás megértetése és a karakterrel összefüggő adatok ismertetése komoly feladat elé állítja a tájépítészeket. Az alkalmazott eszköztár sokszor kimerül a terepi fényképek felvonultatásában. A következő fejezetek azokat a példákat mutatják be, melyeket az eszköztár bővítése érdekében mintaterületen teszteltem és hasznosnak találtam.

\subsubsection{A táj jellegének bemutatása}

A passzív képalkotó távérzékelés felvételeinek alkalmasságát a táj jellegének érthető láttatására mintaterületi kutatásaimban mértem fel. A kutatás előkészítéséhez felhasználtam a 3.1.2. alfejezetben már ismertetett alapadatokat. Alkalmaztam Landsat múholdfelvételeket, ortofotókat, madártávlati és terepi fényképeket, valamint domborzatmodellek és ortofotók vagy igen nagy felbontású ürfelvételek kombinálásával készített tájmodelleket. Ezeket Délnyugat-Budakörnyék és Nagyberek térségére különböző projektekben gyüjtöttem össze, vásároltam, készítettem, vagy készíttettem.

A mintaterületen kijelöltem 30 fókuszterületet, melyek jellegükben eltérőek voltak ${ }^{220}$. Ezeket a tájrészleteket legjellemzőbb tájelemeikkel egy meghatározó nézőpontból jelenítettem meg többféle típusú felvétellel (110. ábra (M92)) 40 fő interjúalany és további 215 kérdöívezett számára. A felvételek egy fókuszterület esetében mind terepen, mind madártávlatban, mind felülnézetben szinte azonos tájelemeket mutattak, csak a vertikális látószög volt eltérő (110. ábra (M92)). Célom annak megállapítása volt, hogy mely felvételek alkalmasak leginkább a táj jellegének megértetésére. Ennek érdekében többféle felmérést készítettem.

A kérdőívezés eredményeként meghatároztam, hogy míg a közepes felbontású ürfelvételeken a hétköznapi emberek 75\%-a számára legfeljebb néhány tájelem beazonosítása lehetséges (vízfelület, település, erdő), addig az interjúk alapján megállapítható, hogy a motoros siklóernyővel készíttetett ferdetengelyü madártávlati felvételeken a karakteradó tájelemeket (szőlősorok, gyümölcsösök, legelők, stb.) az interjúalanyok 80\%-a felismerte. Az utóbbi esetében a kérdőívezettek is többségében helyesen, tájtípusokhoz tudták kapcsolni az interpretált tájelemeket.

Megállapítottam, hogy a tájtípusok beazonosításában a légifelvételeknél kulcsfontosságú szerepet játszanak a színek. A vízfelszín mind az ortofotókon, mind a tájmodelleken sok esetben szürkés-barnás árnyalatban rajzolódik ki és így a válaszadóknak mindössze $\mathbf{3 5 \%}$-a tudta beazonosítani, míg a képszerkesztő programban „kékített” vízfelszínt szinte 100\%ban felismerik (111. ábra (M93)). Ugyanakkor látványmodellezésnél épp emiatt ügyelni kell arra, hogy kékeszöld felszínek ${ }^{221}$ ne legyenek megtévesztőek a terepen, mert azok gyakran

\footnotetext{
${ }^{220}$ pl.: lakótáj, erdőgazdasági táj, kertgazdasági táj stb.

${ }^{221} \mathrm{pl}$.: üde árnyékos rétek, májusvégi zöldellő gabonamezők, kékes árnyékot vető domboldalak
} 
tévesen vízfelszínként értelmezhetők (112. ábra (M93)). Megfigyeltem, hogy 15-20 kép után a válaszadók többsége tanul a korábban látott képekből és megérzi egy-egy területhasználat színét, érdességét, formáját, sőt a ferde látószögü 2,5D tájmodellekhez is kezd alkalmazkodni, még azok is, akik saját bevallásuk szerint hasonló felvételekkel nem foglalkoztak az interjút megelőzően.

\subsubsection{A tájkarakter sajátosságainak megjelenítése}

A tájépítészek, a tájkarakter egyedi sajátosságait - amennyiben azok a helybéliekkel folytatott kommunikáció fontos elemei - általában fényképeken mutatják be. A kérdőívezés és interjúkészítés során a képek vetítésével felmértem, milyen tájjelleg-interpretációs készséggel, és tájra vonatkozó megjelenítési elvárással állnak a nem szakmabeliek a tájépítész munkájához.

Az interjúkban és a kérdőívekben az egyedi karakteradó elemekre is rákérdeztem. A mutatott tájkép alapján meg kellett nevezni, vagy társítani egy települést, és tájegységekbe kellett besorolni a látottakat. A képeken szereplő tájrészletek beazonosítására és tájegységbe sorolására az interjúalanyok és a kérdőívezettek is a madártávlati felvételek segítségével voltak a legeredményesebbek (46\%), de a terepi és az ortofelvételek eredményei sem sokkal rosszabbak (113. ábra (M93)). Azok a tájrészletek kerültek nagy arányban helyes tájegységhez kapcsolásra, melyek erőteljes helyi identitást tükröztek ${ }^{222}$, a tájegység egyértelmü települési kötődéssel, településhez köthető névvel, nagyobb lakosságszámmal, ezáltal ismertséggel, központi földrajzi elhelyezkedéssel rendelkezett ${ }^{223}$ (114-115. ábra (M94)). Ellenben volt olyan helyszín is, melyet annak ellenére, hogy sikerült megnevezni, a tájegységhez kapcsolás már kevésbé volt sikeres (116-117. ábra (M95)).

Az interjúk és a kérdőívek is megmutatták, hogy milyen jellegbeli eltérés érzékelhető a párba állított madártávlati fotó és a közel azonos szögben készített $2,5 \mathrm{D}$ vagy $3 \mathrm{D}$ tájmodell ${ }^{224}$ között. Az eltérést az interjúalanyok különösen akkor tartották a táj szempontjából karakteradónak, amikor épített létesítmény, nagyobb markáns növényzet (fasor, erdőszél, vagy cserjés), esetleg változatos domborzat jelent meg a tájrészletben (118. ábra (M96)). A kérdőívezettek ötöde számára az építmények hiánya 2,5D tájmodellen még 250 hektáros kiterjedésü tájrészleten, a háttérben lévő 8 hektárnyi épület-együttes esetében is fontos jellegbeli eltérésnek bizonyult a tájmodell és a madártávlati tájkép között (Etyeki filmgyár a szőlőterület hátterében) (119. ábra).

A tájmodellt akkor tekintették karakterében a madártávlatihoz hasonlónak, amikor a karakteradó építmények 3D-s modelljei kiegészítették a 2,5D tájmodelleket. Ezt az igényt az alacsony vertikális és keskeny horizontális látószög, a kis kiterjedésü tájrészlet, vagy az

\footnotetext{
${ }^{222} \mathrm{Pl}$.: templomrom a Zsámbéki medencében, Erzsébet-kilátó a Budai hegyekben

${ }^{223}$ Pl.: Budai-hegység, az Etyeki-dombság vagy a Budaörsi-medence

${ }^{224}$ Tájmodell: domborzatmodellen nagyon nagy felbontású ürfelvétel vagy ortofotó
} 
épületek markáns, egyedi, karakteradó jellege tovább fokozta. Az 1 km-nél közelebbi épületek hiányát a válaszadók legalább kétharmada karakterbeli eltérésnek vélte a tájmodellek esetében (pl.: Budai Királyi Palota, János-hegyi kilátó), míg a foto-realisztikus modellekkel ez az arány 25-45\%-ra mérsékelődött. Az alacsony látószög, a vegetáció és a domborzat lapítottságával is fokozta a jellegbeli eltérés érzetét. Megállapítottam, hogy $\mathbf{1} \mathbf{k m}$-nél közelebbi fókuszterület és $30^{\circ}$ alatti látószög esetén az építmények és a növényzet 3Dmodellezése, valamint a domborzatmodell pontosítása indokolt (120. ábra (M97)) azért, hogy legalább az érintettek fele ne érzékeljen karakteres eltérést a valósághoz képest.

(a)

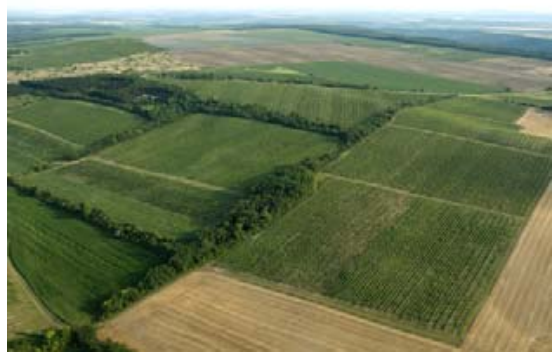

(b)

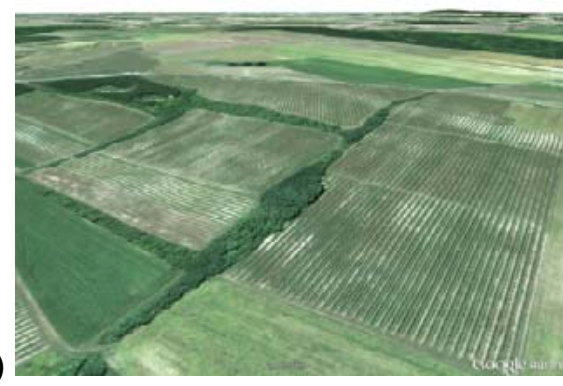

(c)

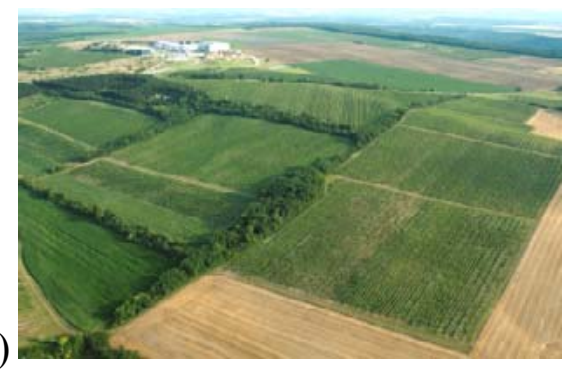

(d)

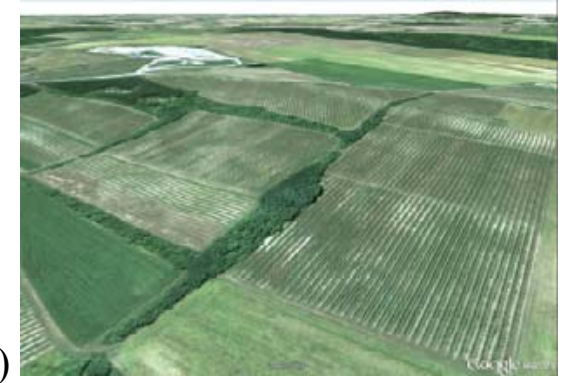

119. ábra Filmgyár nélküli tájrészlet és filmgyárral rendelkező tájrészlet az etyeki szőlődomb tetején, madártávlati képen és 2,5D tájmodellen ${ }^{225}$

Az interjúkból kiderült, hogy a felvételek értelmezése során az ember a konkrét helyszíneket, melyekről ismeretekkel rendelkezik, a kép nézőpontjától függően más és más objektumok alapján azonosítja be. Felülnézetből az elemek relatív elhelyezkedése, geometriai formája, színe ad támpontot, míg terepszinten egy-egy karakteres objektum részletgazdag képe, jól ismert nézőpontból felismerhető alakja, magassága és közvetlen környezete nyújt segítséget. A madártávlati felvételeknél és tájmodelleknél mindkettő lehetséges, és ez adja igazi előnyüket a táj jellegének megértése során. A nem terepi felvételek előnye, hogy a helybéliek többsége ilyenkor mozgásban képzeli feltárni a területet, útvonalakban, érkezési irányokban gondolkodik és ez segít összerakni a tájrészletet a fejében.

Kérdőívezés és interjúkészítés során kutattam, milyen mértékben használhatóak a különféle magassági modellek a táj modellek készítéséhez a tájjelleg bemutatása céljára. Három eltérő léptékü dombvidéki területen (121. ábra (M98)) vizsgáltam, hogy karakterében mennyire

\footnotetext{
${ }^{225}$ Az első épület nélküli (a-b) képpár esetében a megkérdezettek 3\%-a látott karakteres eltérést a madártávlati felvétel és a 2,5D tájmodell között. A második képpár (c-d) esetében már a megkérdezettek 23\%-a karakteres eltérésnek vélte az alsó képhez képest a felsőn látható tájrészlet eltérését, bár az csak a háttérben látható épületegyüttes részletességében és valószerüségében különbözött.
} 
hasonló megjelenítést lehet elérni DDM5 modellel készítettekhez képest négy ingyenesen elérhető magassági modellel (SRTM, ASTER GDEMv1 és v2, Google Earth). A megkérdezettek csak a kisebb kiterjedésü csak a tájrészlet szinten találtak karakteres eltérést a DDM5 és az ingyenes modellre építő tájmodell-változatok között. Itt is átlagosan csak a megkérdezettek fele vélte jellegbeli eltérésnek a különbséget. Települési szinten a válaszadók mindössze 12-16\% vélte fontos karakterbeli eltérésnek azt, amit a DDM5-höz képest az SRTM vagy az ASTER GDEMv2 mutatott, 40\%-uk egyáltalán nem is látott különbséget.

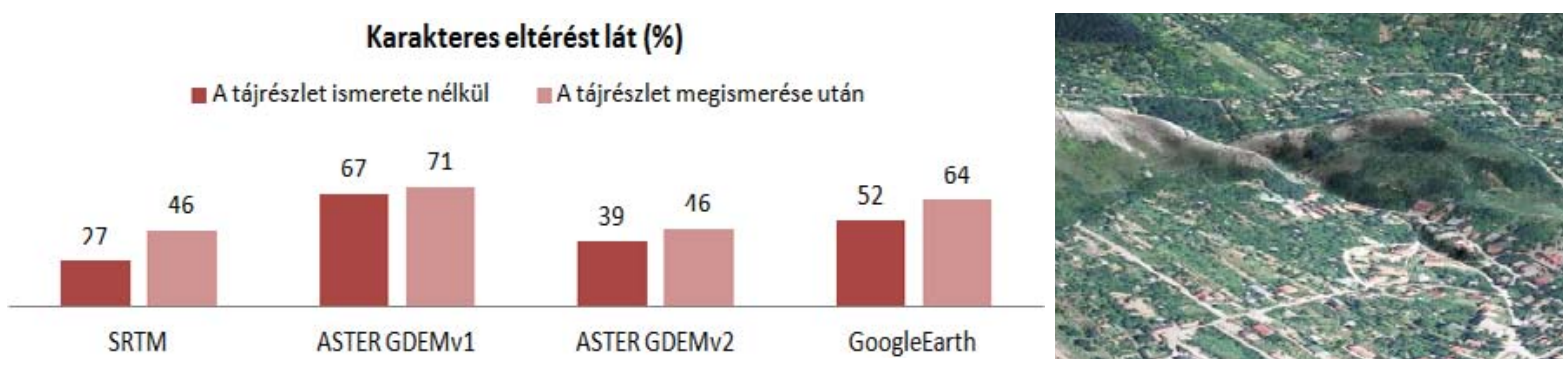

122. ábra (részlet (M99)) A tájjellegbeli eltérés megítélése különböző magassági modelleket használó 2,5D tájmodellek és a DDM5-re épülö tájmodell között (Alapadat: DDM5 (FÖMI))

Tájrészlet szinten az SRTM és az ASTER GDEMv2-es modell bizonyult a legjobbnak, mert a többi modell esetén a megkérdezettek 64-71\%-a jellegbeli eltérést állapított meg. Az ASTER GDEMv2 és az SRTM esetén ez az érték csak 46\% volt, még abban az esetben is, amikor a megkérdezettek már ismerték a modellezett tájrészletet (122. ábra (M99)). A legfontosabb jellegbeli eltérésként a dombok magasságát, elvétve a formáját, vagy a völgyek, árkok hiányát jegyezték meg a kérdöívezettek, különösen azok, akik ismerték a tájrészletet. A hullámzó vízfelszín a válaszadók 10-20\%-ának szúrt szemet, de nem tekintették fontos jellegbeli sajátosságnak. Megállapítottam, hogy az ASTER GDEMv2 felszínmodell térségi és települési szinten alkalmas a 2,5D látványmodellezésre. Tájrészlet, településrész szinten, mozgalmas felszínnel rendelkező dombvidékeken érdemes ügyelni a domborzat részletezettségére és indokolt lehet DDM5 vásárlás is a 2,5D-3D megjelenítés érdekében.

\subsubsection{A tájjelleg-változás érzékeltetése}

A tájjelleg változását mozgóképpel is lehet érzékeltetni. Hosszabb időtávból származó felvételek sorozatából készített mozgóképpel vagy animált gif készítésével a tájjellegben bekövetkezett változásokat néhány másodpercben foto-realisztikusan is bemutatható. A kihelyezett webkamerák esetében ennek rendkívül nagy költségvonzata lenne néhány év vagy akár hónap alatt is. Az általam kidolgozott eljárást követve a tájépítészek akár saját kézi kameráikkal, képfeldolgozó szoftvereikkel is képesek lehetnek arra, hogy a táj néhány év vagy évtized alatt lezajló karakterváltozásait érzékletesen, mozgóképszerüen mutassák be. Az általam kidolgozott és dokumentált módszerrel az egy-egy nézőpontból feltáruló tájjelleg monitorozása is megvalósítható. 


\section{A mozgóképanyag elkészítésének lépései:}

1. Fényképek készítése terepen, vagy légifelvételek gyüjtése archívumokból.

2. Felvételek idősorba állítása.

3. Felvételek korrekciója ${ }^{226}$ a bázis év felvételéhez. Az alábbi, betűkkel jelzett alpontok a 3. lépésen belül csak abban az esetben szükségesek, ha mérőképes légi- vagy ürfelvételt illesztünk ferde tengelyü madártávlati képhez:

a. A mérőképes felvételek domborzatmodellre helyezése egy 3D-s megjelenítésre alkalmas térinformatikai szoftverben.

b. A madártávlati fényképhez hasonló nézőpont megkeresése a tájmodellen és a látvány mentése képként.

c. A képként mentett látvány korrekciója a bázis-időpont madártávlati fényképéhez.

4. Felvételek korrigált eredményképeinek beillesztése egy prezentációs programba ( $\mathrm{pl}$.: PowerPoint) és a képek animálása, például félmásodperces áttűnésekkel.

5. Mozgókép készítése (pl.: ppt mentése mozgóképként)

A Délnyugat-Budakörnyéki mintaterületre gyüjtött terepi fényképekből és légifelvételekből sorozatokat állítottam össze és mintaprojekt jelleggel többféle mozgóképet készítettem. A tájat megjelenítő felvételek időrendben változnak és tanúsítják a tájjelleg átalakulását. Légifelvételekből és terepi fényképekből is lehetséges ilyen mozgóképet készíteni kellő számú felvétel feldolgozásával. A levegőből készített ferdetengelyü madártávlati felvételek esetében az azonos nézőpont beállítása szinte lehetetlen. Kutatási munkám során a rendelkezésre álló ferde tengelyü légifelvételhez igazító kétszeres korrekcióval megoldható volt a teljesen azonos nézőpont hatását keltő képsorozat előállítása (123. ábra (M100)).

A tájjelleg-változást mozgóképpel érzékeltetni kívánó munkafolyamat feltételei:

1. A kedvező eredmény elérése érdekében lehetőség szerint azonos felvevőrendszerrel / fényképezőgéppel / érzékelővel javasolt dolgozni éveken át.

2. A nagyobb vizuális élmény érdekében közel azonos felbontással és minőségben rögzített képekre van szükség. A kamera típusát, és beállításait (felbontás, zoom mértéke stb.) fel kell jegyezni a bázisév felvételének készítésekor és a későbbiek készítése során ugyanezekkel ajánlatos dolgozni!

3. A fényképeket / felvételeket mindig nagyobb területre, látképre kell készíteni, mint ami a munka témája, mert a feldolgozás során sok képszegély elvész, amikor több kép közös területét választjuk ki a mozgóképhez. Különösen igaz ez a bázisévre, melynek az elérhető legnagyobb látószöggel kell készülnie.

4. Terepi fényképek esetében egy 2-5 méteres pontossággal rendelkező terepi GPS-re sziikség van, hogy a helyszínt többször, évekkel később is megtaláljuk.

5. A bázisfénykép készítésének módját, helyzetünket, terepszint feletti magasságunkat, a készítés dátumát és időpontját, valamint a kép sorszámát pontosan rögzíteni kell, amit később nem szabad más látószögből készült felvételekkel összekeverni.

${ }^{226}$ A korrekció lehet geokorrekció egy térinformatikai képfeldolgozó szoftverben, vagy egy fénykép-szerkesztő szoftverben is (Gimp, Photoshop) 
6. A munkafolyamat fontos része, hogy a bázisév fényképét minden alkalommal a kamera kijelzőjének méretével egyező, nyomtatott formában is magunkkal vigyük, hogy fényképezőgépünkkel a megfelelő nézőpontot pontosan megtaláljuk, a fénykép tartalmát, irányát a bázisév tartalmához, irányához igazíthassuk.

7. Növekvő bokrok és fák közelében ne készítsünk képeket - hacsak nem épp a cserjésedés, és az erdősülés a karakterváltozás témája - mert ezek a tájelemek az évek folyamán a látkép nagy részét eltakarhatják.

8. A sorozat minden képének készítése, vagy kiválasztása során törekedni kell arra, hogy ugyanabban az évszakban, sőt hónapban, napszakban, hasonló időjárási és fény viszonyok között készült képpel dolgozhassunk minden évben.

9. Amennyiben gyors karakter-változás várható (pl.: beépítés hatására), és egy éven belül több felvétel is készül, akkor is ügyelni kell a közel azonos napállásra.

Változás-animáció egy-egy kockája (124. ábra (M101)) mutatja, hogy a jövőben várható változások megszerkesztett lépéseinek felvételeit is érdemes mozgóképpé alakítani a tájjellegváltozás tudatosítása érdekében. A mozgóképeket a melléklet végén található $C D$ tartalmazza.

\subsubsection{A tájkarakter online 3D-megjelenítése}

A tájkarakter-meghatározás egyik legfontosabb eredménye a tájegységek / tájtípusok térképe és leírása. Mindkettő megjelenítésében szerepet kaphat a passzív távérzékelési adatokra építő 3D-megjelenítés. A felszínmodellek felületén megjeleníthető légi-, vagy müholdfelvételek 2,5-dimenziós tájmodellként funkcionálnak, melyek egyes térinformatikai rendszerekben kiegészíthetők 3D-objektumokkal, tájelem-modellekkel, fényképekkel.

Az egyre terjedő „virtuális bolygó” alkalmazások közül a Google Earth megoldását találtam a legösszetettebbnek, mely fényképfelvételeket, sőt, az ezekből készített „,foto-realisztikus” modelleket és térinformatikai rendszerekből exportált térkép-fedvényeket is egy platformon képes kombinálni. Mindezek az adottságok és az a sajátosság, hogy a világhálón keresztül jelenleg ingyenesen nyújtja a táj szempontjából kulcsfontosságú alapadatait, alkalmassá teszik a tájkarakter-elemzés eredményeinek közérthető megjelenítésére is.

A Budapesti Corvinus Egyetem Tájtervezési és Területfejlesztési Tanszékének Vital Landscapes Projektje kutatócsoportjának tagjaként a Nagyberek térségére számos olyan mintaterületi alkalmazást teszteltem (JOMBACH és EGYED 2013), mellyel igazoltam, hogy a karakter-elemzés térképezo és leíró lépésének egyes részeredményei, információi közérthető módon megjeleníthetők háromdimenziós tájmodelleken is. A teszt-alkalmazás során a 3D-s Google Earth felületen jelenítettünk meg:

- Tájegység- és tájtípus-megnevezést és bizonyos jellemzőiket (125. ábra (M102)),

- Tájhatárokat, tájrészlet-határokat (125. ábra (M102)),

- Térinformatikai rendszerekből importált térképeket (125. ábra (M102)),

- Tájjelleg-leírást szöveges, táblázatos, ábrás, fényképes formában (125. ábra (M102)),

- Múltban történt tájváltozási folyamat térképeit (126. ábra (M103)), 
- A jövőben várhatóan átalakuló tájjelleg szcenárió-térképeit (125. ábra (M102)).

- Tájelemek modelljeinek százait (épített létesítmények, növények) (126. ábra (M103)).

A Google Earth-re építő mintaterületi alkalmazás további kihasználható előnyei, hogy

- honlapba ágyazható, ,online”, bárki számára elérhető, böngészhető,

- interaktív, egyéni navigációra van lehetőség a 3D-s felületen,

- tartalma a konzultációk során felmerülő igényeknek megfelelően módosítható,

- kapcsolódó tartalmakkal rendelkező weboldalak URL-lel direkt módon hivatkozhatók,

- a terület bemutatására fontosabb nézőpontokat felkereső körutazás (tour) készíthető,

- a Google Earth Pro verzió egyéb térinformatikai, tájkarakter-elemzési tartalmak minőségi importálására (attribútum-tábla szerinti színskála, méretezés) is lehetőséget ad (126. e-f ábra (M103)),

- a karakteradó tájelemek szerepe egyszerü, közérthető szimbólumokkal, ábrákkal feliratokkal magyarázható, illusztrálható (126. ábra (M103)).
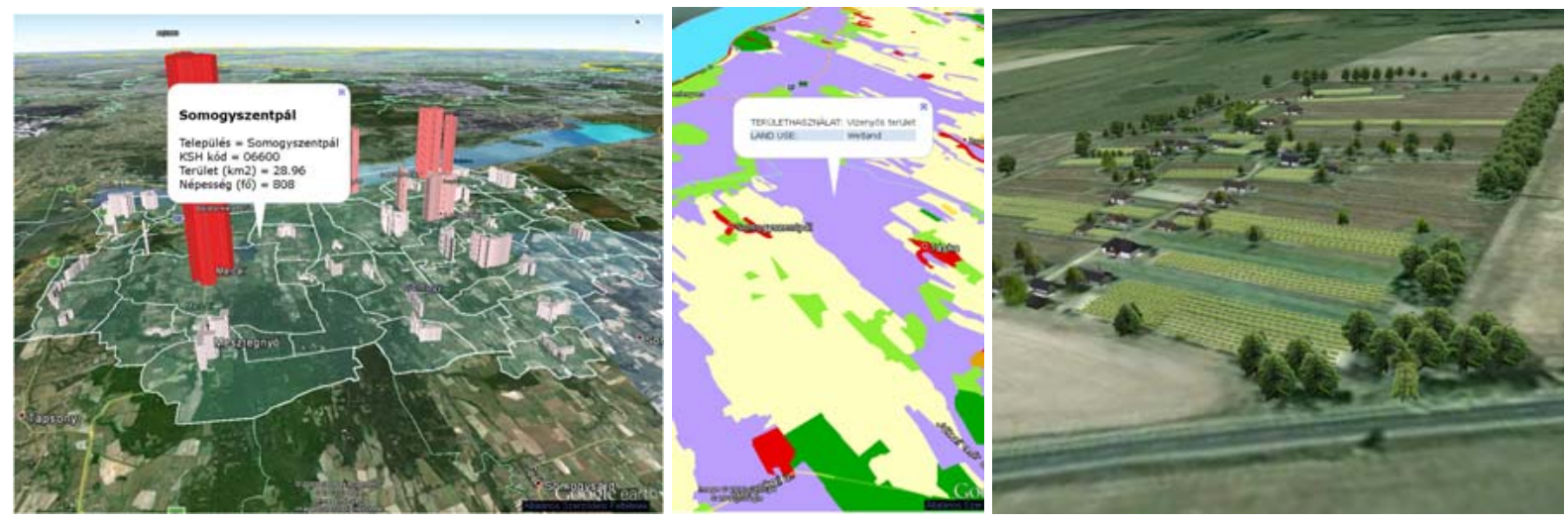

125-126. ábra (részletek (M102-M103)) Az Élő Berek weboldal (e-berek.hu) megjelenítő megoldásai Nagyberek térségére az Élő Tájak projektben, a honlapba integrált GoogleEarth felületen. 


\subsection{A tájkarakter jellemzése és lehatárolása}

Az irodalomkutatási eredmények alapján a tájhatárok meghúzásában azoknak az információknak van a legnagyobb szerepe, melyeket a tájegységek, vagy tájtípusok jellemzésére is felhasználunk. Ilyen típusos jellemző például a domborzat, vagy a felszínborítás, de ilyenek a társadalmi-kulturális sajátosságok is. Miután a passzív képalkotó távérzékelés felvételei és feldolgozási eljárásai nem képesek a tájkarakter teljes körü jellemzésére, célom mindössze a tájhatárok meghúzásakor figyelembe vehető tényezők feltárása és a lehatárolás eszköztárának bővítése volt.

Kutatásomban a Délnyugat-Budakörnyéki terület kistájainak lehatárolása során határoztam meg, melyek lehetnek azok a passzív képalkotó távérzékelésből származó adatok, amelyek potenciális határ-képző tájelemeket tartalmaznak. Olyan elemekre koncentráltam, melyek az irodalomkutatás alapján is a legtöbb esetben tájhatárként szerepeltek és passzív képalkotó távérzékeléssel előállíthatók (127. ábra (M104)). Így ezek körébe kerültek:

- vízválasztók, hegygerincek, hegycsúcsok, vízfolyások, mélyedések,

- erdőszegélyek, településszegélyek, vízfelületek szegélye,

- egyéb felszínborítás mintázatából származó szegélyek,

- nevezetes tengerszint feletti magasságok szintvonalai $(200 \mathrm{~m}, 500 \mathrm{~m})$,

- nagy lejtőmeredekséggel rendelkező területek (pl. 20\% feletti meredekség).

A tájkarakter típusok lehatárolásában az automatizáló megoldások az irodalom-kutatás során feldolgozott több tanulmány szerint is jó eredménnyel zártak. A tájkarakter területek lehatárolására azonban kevés automatizáló megoldás született. Lehatárolásukban az irodalom-kutatás szerint is jelentős a terepi ismerettel rendelkező szakértők szerepe. A tájkarakter-területeknél a helyi, egyedi sajátosságokat döntően társadalmi, esztétikai jellemzők alapján kell figyelembe venni. Mivel a tájegységek karakterében igen nagy az emberi tényező szerepe, ezért a fél-automatikus módszereket tartom a leginkább megfelelőnek lehatárolásuk során. Ebben az esetben a felhasznált passzív képalkotó távérzékelésből származó adatok vezetik ugyan a karakter-elemző kezét, de a határvonal helyéről nem egy szoftver, hanem az elemző maga dönt, figyelembe véve a táj várható változásait is. Utóbbi elengedhetetlen annak érdekében, hogy a tájkarakter-elemzés egy élő, a valós folyamatokra reflektáló értékelés legyen, ne egy „tájhalmazt” leíró esettanulmány.

A tájegységek lehatárolásához a „határvonal-választó” módszer alkalmazását javaslom, mely épp az elemző szakértő szerepét emeli ki a határvonalak meghúzása során. A módszer lényege, hogy az összes „potenciális tájhatárvonalat” felkínálja a szakértő számára, aki ezekből kiválasztja a meghatározóakat. Ehhez létre kell hozni a rendelkezésre álló adatokból a potenciális határvonalak sokaságát és érthetően meg kell jeleníteni ezeket egyetlen térinformatikai rendszerben. Az elemző/tervező pedig kiválasztja a felkínált választékból, 
hogy a vizsgált tájkarakter terület számára, a különféle szempontok figyelembevételével, milyen határvonal a leginkább megfelelő a tájegység lehatárolására (128. ábra (M104)).

Mintaterületi kutatásomban a kistáj-kataszterben megnevezett Budaörsi és Budakeszimedence tájegységgel foglalkoztam. Célom az országos lehatárolás pontosítása, módosítása volt, annak érdekében, hogy kezelhető tájegységet kapjak. Mivel a tájrendezés szempontjait tartottam elsődlegesnek, már a határvonal meghúzásakor is a tájkarakter-kezelés céljaként a beépítés és az intenzív tájhasználat koordinálását vettem figyelembe. Meghatározó, domináns tájváltozási folyamatnak tekintettem, hogy a térség agglomerálódó jellegű, és a beépítés mértéke folyamatosan növekszik.

A lehatárolást a határválasztó módszer alapján tettem meg. A határelemek képzését automatikus módszerekkel végeztem. Minden potenciális határvonalat megjelenítettem egy ortofotón - azt is feltüntetve, hogy melyik határvonal milyen alapadatból származik - majd kiválasztottam a tájegységhatárnak tekinthető vonalakat (129. ábra (M105)). Az elemzés eredményeként létrejött a Budaörsi és Budakeszi medence folthatáros térképe, melynek területe legalább 50\%-ban eltér az országos lehatárolástól. Az új határvonal gyakran több száz méterrel, nem ritkán több mint egy kilométerrel módosult (130-131. ábra (M105-M106)) az országos lehatároláshoz képest.

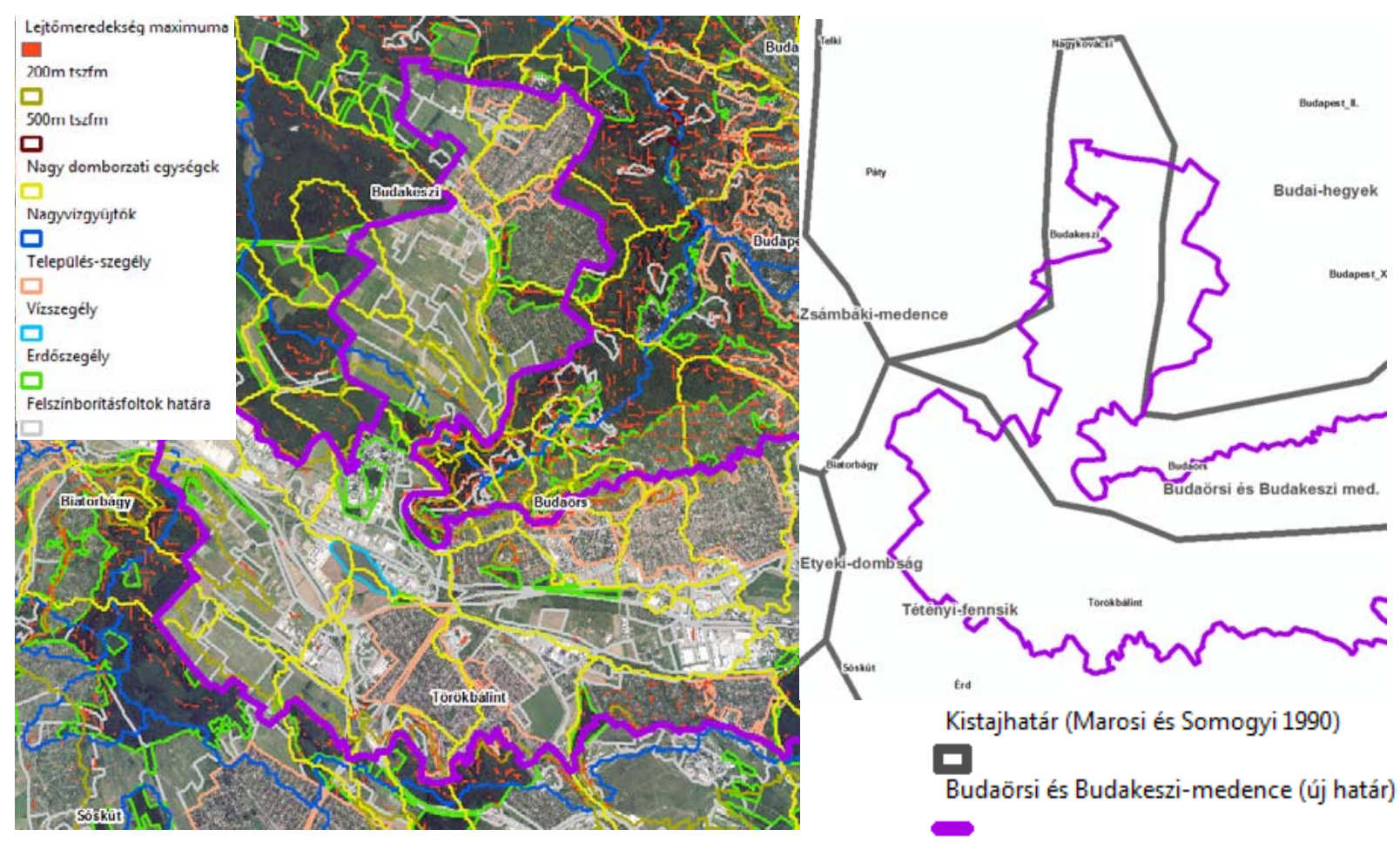

130-131. ábra (részletek) (M105-M106)) A „határvonal-választó” módszerrel történő tájhatárpontosítás és az eredményeként lehatárolt Budaörsi és Budakeszi-medence 
A lehatárolás érdekében definiáltam a „domborulat-határ" fogalmát, mely a domborzati kiemelkedések környezetében található mélyebb pontokat összekötve határozza meg azt a vonalat, mellyel az adott domborulat, domb, vagy hegy körülhatárolható (132. ábra és 133. ábra (M106)). Ez a vonal választja el a vizsgált domborzati formát a szomszédos domborulatoktól. Térképezéséhez kifejlesztettem egy eljárást, mely megmutatja hol húzódnak ezek a vonalak. Az eljárást ERDAS és ArcGIS szoftverrel, a magassági modell inverzének vízgyüjtő-elemzésével alakítottam ki és dokumentáltam.

Az elemzés két lépésből áll:

1. lépés: Magassági modell megemelt inverzének elkészítése.

Képlet $=$ Tengerszint feletti magasság $(\mathrm{m}) *(-1)+10000$

2. lépés: Vízgyüjtő-elemzés a magassági modell megemelt inverzén (1. lépés eredménye). Az így lehatárolt „inverz vízgyüjtők” határa valójában a nagyobb domborulatok között húzódó völgyfenék vonala.

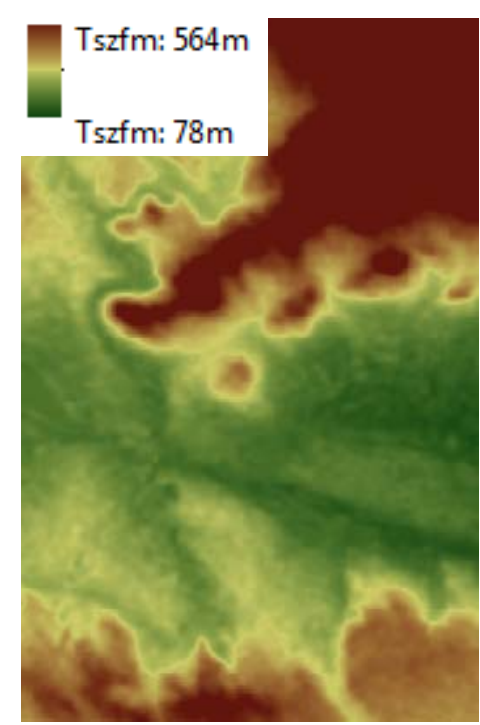

Alapadat: Magassági modell (ASTERGDEMv2)

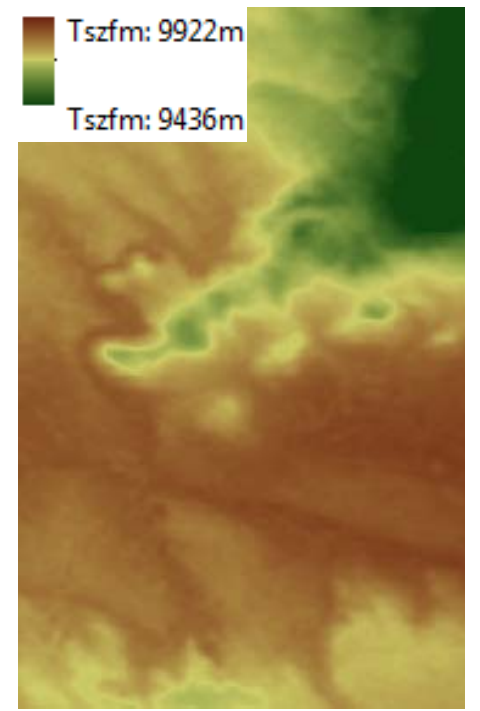

1. lépés: Magassági modell megemelt inverzének elkészítése

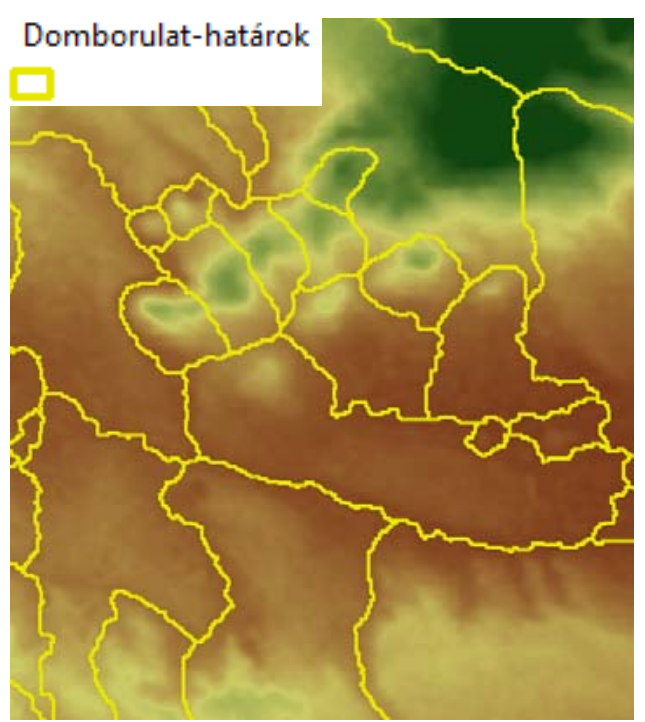

2. lépés: A megemelt inverzen végzett vízgyüj tő-elemzés $=$ domborulat-határolás

\section{2. ábra A domborulat-határok elemzésének folyamata}

A határvonalak meghúzásakor különösen fontosnak találtam meghatározni a medence és a hegy közötti határvonal meghúzásakor a meredek lejtőszakaszokon előforduló legnagyobb meredekség meghatározását, amit a „lejtőmeredekség maximuma” néven definiáltam. A lejtőmeredekség maximuma számításának eljárását és lépéseit meghatároztam (134. ábra (M107)). Lényege, hogy vízlefolyás-elemzést kell végezni a lejtőmeredekség réteg inverzén. A víz az inverzen ott gyülik össze, ahol az adott lejtőn a legnagyobb a meredekség, mert az inverz lejtőmeredekség adatokat a vízlefolyás-vizsgálat - mint minden normális esetben magassági adatnak tekinti. 


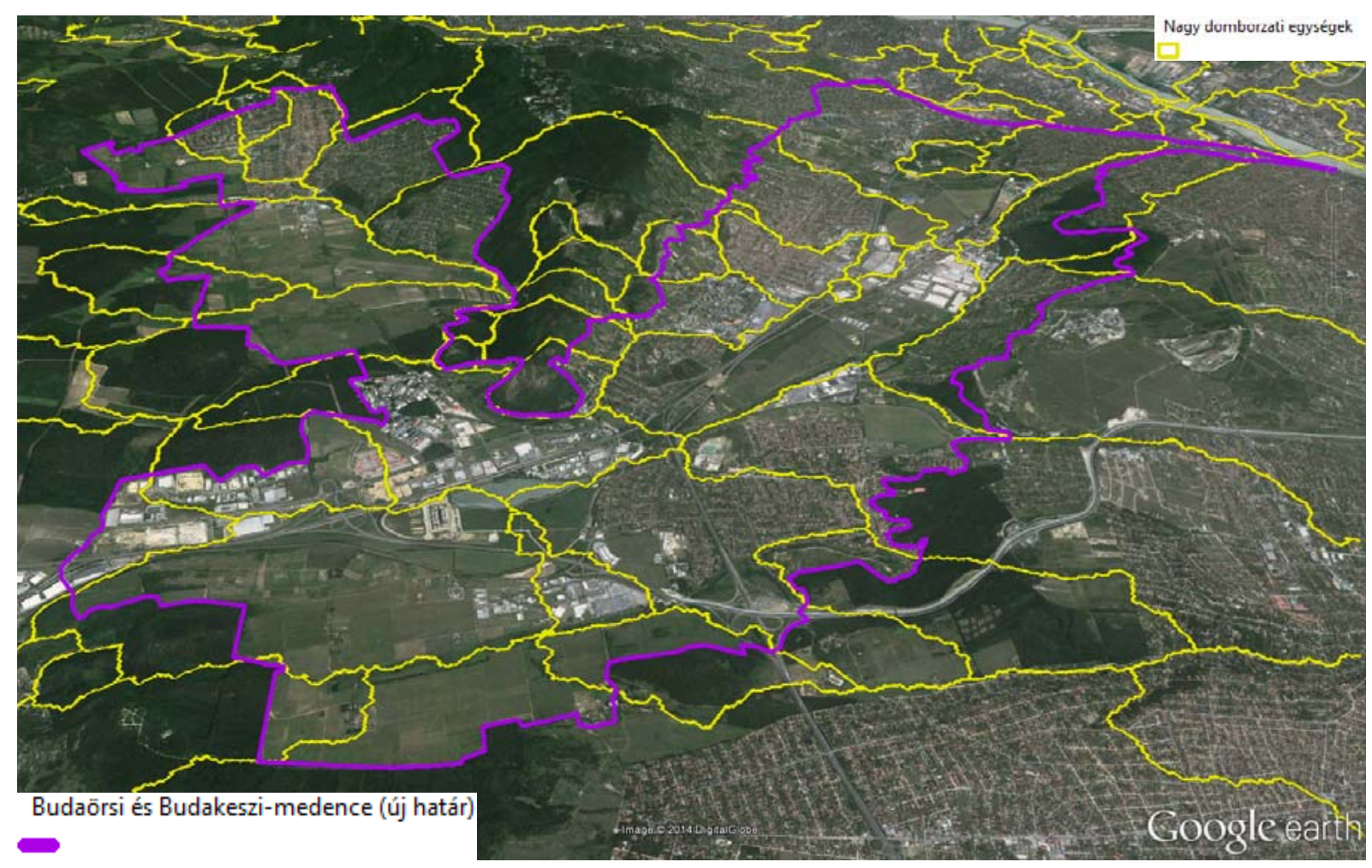

\section{6. ábra Tájegység-lehatárolás eredményei a Google Earth-ön}

A határvonal választó módszer nagy előnye, hogy a karakter-elemzés maga is a digitális 3D térbe költözhet, ahogy Schmid prognosztizálta a térrel kapcsolatos tervezés esetére (SCHMID 2001, 221), hiszen az adatok Google Earth-be importálásával lehetségessé válik a tájhatárok „3D-térben” történő meghúzása. A 3D-teret pedig a Google Earth maga bővíti a „4D-tér” felé azzal, hogy több időpontban rendelkezésre álló felvételeket biztosít a Föld egyre nagyobb területére (135. ábra (M107) és 136. ábra).

A határvonal-választó módszer előnye, hogy objektív és szubjektív tényezőket, valamint természeti, társadalmi és gazdasági szempontokat egyaránt figyelembe lehet venni a lehatárolásnál. A módszer szükségessé teszi a terepi bejárás tanulságainak felhasználását, kinyitja a személyes benyomások érvényesítésének lehetőségét, de ugyanakkor nyitva hagyja a felülről lefelé irányuló egységesítő célú, országos szintre is alkalmazható hierarchikus megközelítést. Ezáltal a bottom-up és a top-down megközelítést is ötvözi. 


\section{KÖVETKEZTETÉSEK ÉS JAVASLATOK}

A passzív képalkotó távérzékelést a tájkarakter-elemzés eszköztárához tartozónak tekintettem az értekezésben, ezért javaslataim is csak kiegészíteni, nem átalakítani igyekeznek a tájkarakter-elemzés módszerét. A kutatási eredményeimmel kiegészített eszköztár több eleme alapvető lehet az Európai Táj Egyezményben vállaltak megvalósítása során. A tájak számbavétele, a változások nyomon követése ma már szinte megvalósíthatatlan térinformatika és távérzékelés nélkül.

\subsection{Az eredmények gyakorlati hasznosíthatósága}

Kutatásommal igazoltam, hogy a passzív képalkotó távérzékelés felvételei és feldolgozási eljárásai igen változatosan hasznosíthatók a tájkarakter-elemzésben. Irodalomkutatásom eredményeként meghatároztam, hogy az elemezés egyes lépéseiben milyen feldolgozási eljárások, milyen felvételekkel, milyen kiterjedésü mintaterületre alkalmazhatók. Igazoltam, hogy a meglévő alkalmazások köre bővíthető a domborzat-elemzés, a térbeli mutatók alkalmazása, a változás-elemzés, a láthatóság-elemzés, a megjelenítés és a tájhatár-vonalak meghúzása területén.

A passzív képalkotó távérzékelés tájkarakter-elemzésben történő gyakorlati alkalmazását, és ezáltal kutatási eredményeim alkalmazását is indokolja és alátámasztja a táj jellegéröl tömegesen - esetenként térítésmentesen - beszerezhető, rendszeresen frissülő felvételek és adatbázisok sokasága, a képfeldolgozási és térinformatikai eljárások differenciálódása és terjedése, valamint az érintettek fokozódó igénye a vizuális információkra.

Az Európai Táj Egyezmény aláírásával vállalt kötelezettségek végrehajtása során a gyakorlatban is alkalmazhatók eredményeim. Az egyezmény szerinti „tájak számbavétele” feladat során a tájhatárvonal meghatározásának eljárásai hasznosíthatók. A tájak jellemzése, változásaik dokumentálása során a passzív képalkotó távérzékelésre építő térbeli mutatók és indikátorok használhatók fel, melyek közül a felszínborítási arányok, az erdőszegély, és a nyitottság változása indikátor alkalmazhatóságát több mintaterületen igazoltam.

Kutatásom eredményei hasznosíthatók a tervezés előkészítésére, alátámasztására a térségi vagy települési tervezésben. A domborzati sajátosságok vizsgálata és a láthatóság-elemzések karakteres látványelemeket hangsúlyozó fedvényei egyrészt a helyi építési szabályozás megalapozásában is szerepet kaphatnak, másrészt a megyei és az országos területrendezési tervekben is hasznosíthatók, a tájképvédelmi övezet pontosításához, harmadrészt láthatósági hatásvizsgálatok megalapozásához is hozzájárulhatnak. 
A zöldfelület-intenzitás elemzés eredményei nyomán - több évtizedes pilot-területeken bevezetett gyakorlati alkalmazási folyamat eredményeként - megvalósíthatónak tartom egy olyan monitorozási tevékenység rendszeresítését és szükség esetén kiegészítő jogi szabályozás megvalósítását, melynek célja a települések zöldfelületi arányainak megtartása. A zöldfelület-megőrzési célt a légi- és űrfelvételekkel történő monitorozással és a zöldfelületintenzitást megőrző tevékenységek támogatásával javaslom elérni.

\subsection{Eredményeim a „cél, módszer, eszköz” kérdéskör összefüggésében}

Kutatási eredményeim gyakorlati alkalmazásához meglátásom szerint a következő kérdések megválaszolása sorrendjében érdemes hozzákezdeni.

1. Mi a tájkarakter-elemzésünk célja?

2. Milyen módszert követünk az elemzés során?

3. Céljaink elérése érdekében milyen eszköztárral támogatható a módszer?

Az irodalomkutatás eredményei alapján véleményem szerint tájkarakter-elemzések alapvetően két célból születnek. Az egyik a tudományos kutatás, tájkutatás céljából, tájak jellemzése, leírását, összevetését jelenti annak érdekében, hogy referencia-felületként, alaptérképként hasznosítható kataszter jellegü karakter-elemzés szülessen. A másik, a tájrendezési célú karakter-elemzés, mely kifejezetten a tájkarakter kezelése céljából, egy aktuális tájrendezési szituációban, egy domináns változási folyamat koordinált rendezésének előkészítésére készül.

Az ELCAI projekt összegzése szerint a magyarországi tájkataszter a legrégebben készïltek egyike. Az észt, a német és a cseh példák után a magyar következett időrendben, a többi vizsgált ország mind frissebb karakter-elemzéssel, vagy tájkataszterrel rendelkezik (WASCHER 2005, 43). Ennek kapcsán indokolt lehet a tájkutatási célú karakter-elemzéssel egy újfajta kataszter összeállítása, a tájak számbavétele országos szinten. Ez az első célkitüzés megvalósítását jelentené egy általános keretben. Az Európai Táj Egyezmény szelleme azonban nem egy statikus rendszert, hanem egy dinamikus, változásokat, érdekeket, érintettek értékrendjét monitorozó rendszer müködtetését sugallja. Igaz, hogy a hazai tájépítészek évtizedek óta vallják és csinálják amit az Európai Táj Egyezményben az ország vállalt (CSIMA 2011, 43), de az egyezmény szerint ennek a tevékenységnek az intenzitását fenn is kell tartani és ki kell egészíteni a tájat monitorozó jellegü tevékenységgel. Az Európai Táj Egyezmény kapcsán Kabai egyenesen nemzeti tájkarakter-felmérést szorgalmaz (KABAI 2011). Egy ilyen dinamikus rendszerben a tájrendezési, tájkarakter-elemzési cél az elsődleges, a módszer másodlagos, és az eszközök fontosak ugyan, de csak harmadsorban.

Scott 2011-ben írt cikkében (SCOTT 2011, 2754-2762) az Európai Tájegyezmény gyakorlatba ültetése, kivitelezése kapcsán fogalmazta meg a legfontosabb teendőket, melyek között ott szerepel, hogy a tájak kezelésére célkitüzéseket kell megfogalmazni (137. ábra 
(M108)). Az eszköztár-alkalmazási javaslatom szerint is a legfontosabb, hogy eldöntsük tákarakter-elemzésünk célját.

Kabai külön hangsúlyozza a tájkarakter-elemzés tudományos jellegü feldolgozását és a gyakorlati hasznosíthatóságot. A stratégiai tervezésben, a terület- és településrendezésben, az engedélyezési eljárásokban történő alkalmazhatóságot alapvetőnek tartja a gyakorlatban. Területi szempontból illeszthető adatokat, technikai szempontból kompatibilis alkalmazást vár, ami a résztanulmányok összevethetőségét, országos összesítését teszi lehetővé. Fontosnak tartja a célkitüzés pontos tartalmának jelentőségét kiemelni, és szerinte a módszertant is ennek kell meghatároznia (KABAI 2010, 107-108).

A gyakorlati hasznosíthatóság jelentősége felveti a kérdést, hogy bízhatjuk-e a tájhatár-vonal meghúzását egy adathalmazt kezelő szoftverre. Kutatási eredményeim alapján ki lehet jelenteni, hogy a tájkarakter típusok lehatárolásában és jellemzésében talán igen, de ügyelni kell az eredmények érthetőségére és használhatóságára. A tájkarakter-területek esetében domináló egyedi jelleg esetében azonban a szakértői részvétel dominanciája indokoltabb. Az ELCAI projekt négyféle változatot emel ki a karakter-elemzés számára a karaktermeghatározás vonatkozásában:

- 1: egyszerü szakértői interpretáció

- 2: szakértői interpretáció automatikus elemzési támogatással

- 3: teljes mértékben automatikus elemzés

- 4: automatikus elemzés, interpretálás útján történő finomításokkal (WASCHER 2005, 39) Ezek alapján a passzív képalkotó eszköztár alkalmazására a tájkarakter típusok elemzése és határvonalainak térképezése során a 4., a tájkarakter területek elemzése és térképezése esetén pedig a 2. változatot javaslom. A kutatási eredményeimben ismertetett határvonal-választó módszer lényegében a második változatot támogatja.

Az országos szintü tájkarakter-elemzés vagy kataszterezés kulcsfontosságú kérdése, hogy hogyan juthatunk olyan eredményre, mely a gyakorlatban használhatóbb, mint a jelenlegi kistáj-kataszter. A passzív képalkotó távérzékelés eszköztárának jó része az ország teljes területére beszerezhető, alkalmazható. Javaslom, hogy egy egységes 3D alkalmazásokat is integráló honlapon biztosítsunk keretet arra, hogy a különféle léptékben és eltérő célból készült karakter-elemzések tartalmát a szakértők megoszthassák egymással. Erre alkalmas felületként szóba jöhet már meglévő oldal (pl.: TÉKA), melynek kibővítését jelentené ez az alkalmazás, jelenleg ugyanis nincs erre alkalmas felület.

Lehetséges megoldás egy teljesen új honlapon a Google Earth alkalmazás integrálásával egy látványos, közösségi megoldást keresni. Kutatásommal igazoltam, hogy a Google Earth a tájkarakter szempontjából releváns adatok, feliratok, leíró jellegű információk megjelenítésére 
- honlapba ágyazott formában is - alkalmas. Ezáltal bárki számára online, interaktív hozzáférhető, böngészhető, kezelhető, szerkeszthető formában elérhető felületet lehet biztosítani. Ebben a webes, többrétegü, többszintű formában az alulról felfelé építkező és a fentről lefelé indító tájkarakter-elemzés is egy rendszeren belül összeérhet. A rendszer egységesítése indokolt, hogy minden elemzéshez könnyen megtalálhatók és összevethetök legyenek a lehatárolt foltok jellemzői és a vonatkozó tájkezelési javaslatok.

Meglátásom szerint a passzív képalkotó távérzékelés nagyfelbontású elemeinek (ortofotó, nagyon nagy felbontású ürfelvétel) felhasználásával adódik lehetőség, hogy - a tájjelleg kezelése során - a felszínborítás-foltok szintjéről közelítsünk a telekhatár szinthez, és a tájjelleg kezelésére települési önkormányzatok felelősségi körében is sort kerítsünk. Az elemzéshez és tervezéshez ezen a szinten a passzív képalkotó távérzékelési eszköztár bizonyosan hozzá tud járulni. A legtöbb tájkarakter-kezelési feladatot véleményem szerint ezen a települési vagy település-csoport szinten lehet érdemben megoldani. A térségi, járási, vagy megyei szintü tájkarakter-kezelés már az a lépték, ahol a távérzékelési eszköztár a felszínborítás foltok szintjén járul hozzá a karakter-elemzéshez. A térképi illeszthetőség az igazgatási egységekhez természetesen mindkét esetben fontos, de ezt a georeferencia által egy térinformatikai rendszerben biztosítottnak lehet tekinteni.

\subsection{Társadalmi igények, technikai korlátok, szakértelem és pénzügyi realitás,}

Az elemzési, tervezési feladatok többségénél általános megbízói elvárás a kiváló minőség, a gyorsaság, a pontosság, a kedvező látvány, az érthetőség és a módosíthatóság. Mindezeknek a tájkarakter-elemzés esetében föként technikai, szakértelembeli és pénzügyi feltételei vannak. A különböző felvételek tájkarakter-elemzésben történő alkalmazásának technikai korlátait térinformatikai és tájértékelési szakértelemmel, a felvételek alkalmazásának pénzügyi realitásával, valamint a vizsgált területi egység táji sajátosságaival összefüggésben lehet meghatározni. Az olyan technikai sajátosságok, mint az adatmennyiség, a fájlméret, a szükséges tárhely, az adatminőség (spektrális és térbeli felbontás), a célul kitüzött elemzés paraméterei, az alkalmazott szoftver sajátosságai, a számítógép teljesítménye, stb. csak a tájelemző szakértő kvalitása és az elemzésre kijelölt terület ismeretében határozható meg. Alapvető, hogy a tájelemzői feladat megismerése után a szakértő mindezeket meg tudja határozni, és az elvárások tükrében felismerje a technikai és pénzügyi lehetőségeit.

A felvételek alkalmazásának mindig fontos tényezője a felvételek költség-igénye. Mára az alacsony vagy közepes felbontású felvételek némelyike (Landsat, Modis) és a származtatott adatbázisok egy része is (CLC50, Urban Atlas), ingyenesen és online hozzáférhetö, letölthetö, ami a térségi vagy települési szintü karakter-elemzést is erőteljesen támogathatja. Terepi fényképek saját terepi bejárásunk költségén készíthetők, vagy 
archívumokból változó költséggel beszerezhetők, gyüjthetők, fényképezhetők. Mindig is elengedhetetlen kellékei voltak az elemzésnek. Madártávlati fényképezést siklóernyővel, vagy pilóta nélküli repülőeszközökön végzett felmérés során képenként néhány ezer Ft-ért szervezhetünk.

A nagy pontosságú, igen nagy térbeli felbontású $1 \mathrm{~m}$ körüli vagy alatti felbontással rendelkező felvételek viszont meglehetősen költségesek. Utóbbiak egyértelmüen a települési szint alatti tájrészletekre koncentráló karakter-elemzés pontosításához, karakteradó tájelemek vagy azok változásának meghatározásához használatosak. Megemlítendő azonban, hogy a felvételek látható tartományban rögzített változatainak egy része sok weboldalról, online térinformatikai alkalmazásból, Google Earth-ről valamilyen módon letölthetőek. Ez különösen indokolttá teszi a nagyfelbontású tartalom integrálását az elemezésbe.

A felvételek ára alapján kijelenthető, hogy tájkarakter-elemzéshez minimum a közepes felbontású felvételek és származtatott térképi adatbázisok felhasználása elvárható, akár csak a látható színtartományban készített publikus nagyon nagy felbontású felvételek használata. Indokolt esetben a felvételsorozatot kiegészítheti az infravörös tartományban készített felvételek, vagy saját légifelvételezés.

\subsection{Tájkarakter jelentőségét tudatosító oktatás}

Kutatásaim során egyértelmüvé vált, hogy a tájkarakter-elemzéshez, a táj jellegbeli sajátosságait is szem előtt tartó fejlesztéshez, tervezéshez nyitott szakemberekre, tudatos, igényes, aktív civil társadalomra van szükség. A karakter-elemzés is csak akkor eredményes és több egy puszta tájmonográfiánál, ha a tájat dinamikájában értelmezzük és a folyamatosan zajló változásokat a táj jellegének megfelelően kívánjuk kezelni. Ennek érdekében egy-egy fejlesztés kapcsán a nagy nyilvánosság, a folyamatos párbeszéd, tudatos tájépítészeti szakterületi irányítás szükségeltetik, mely hatásokat tár fel, előnyöket és hátrányokat ismertet. $\mathrm{Az}$ angolszász eredetű tájkarakter-elemzés módszertana évtizedek / évszázadok óta öntudatos, gondolkodó, közremúködő helybéli polgárra épít, akinek hiányában az elemzés „féloldalas” lesz.

A passzív képalkotó távérzékelés felvételei és feldolgozási, megjelenítései technikái, a nyitottság fokozásának, a tárgyszerüség érvényesítésének és a látványos illusztrálásnak alkalmas eszközei, melyeket ki kell használni. A rendszeres, tudatos, igényes 3D megjelenítés tájmodelleken, vagy madártávlati képeken, elengedhetetlen előnyöket biztosít a karakter-elemzés eredményeinek megértetésében. Ennek érdekében a tájépítészeti 
szakterület képzésében ${ }^{227}$ az elmúlt években kollégáimmal együtt évről évre nagyobb hangsúlyt fektetek a 3D megjelenítésre az ingyenes távérzékelési adatok, képfeldolgozási eljárások és ingyenes szoftverek oktatására több tantárgy keretében ${ }^{228}$.

Önmagában a szakterületi képzés minőségi javítása nem elégséges. Növelni kell a tájkarakter téma iránt a fogadókészséget és folyamatosan fokozni kell a társadalom elvárásait az tájrendezői, tájkarakter-elemzési eredmények 3D-megjelenítésével kapcsolatban. A táj karakterét megértető illusztráló passzív képalkotó távérzékelési alkalmazásoknak rutinszerünek kell lenniük, akárcsak annak a társadalmi igénynek, mely igényli az effajta ismeretközlést. Ennek érdekében cél a felvételek beszerezhetőségének, elérhetőségének fokozatos javítása, a 3D tájmodell alkalmazások (pl. Google Earth) népszerüsítése és a megjelenítés ,jó gyakorlatának” bemutatása.

\footnotetext{
${ }^{227}$ Tájrendező és kertépítő mérnök BSc képzés, a tájépítész mérnöki és településmérnök MSc képzés

${ }^{228}$ GIS térinformatikai rendszerek, Térinformatika, Tájmodellezés, Táj- és településtervezés, Tájrendezés 1 ., Google Earth Landscapes
} 


\section{6. ÚJ TUDOMÁNYOS EREDMÉNYEK}

A tájkarakter-elemzés eszköztárának alkalmazási gyakorlatával kapcsolatos és az eszköztárat bővítő új tudományos eredményeimet kilenc tézisben foglaltam össze. A téziseket megalapozó kapcsolódó kutatást az eredmények fejezetben (4. fejezet) részletesen ismertettem. Téziseim a nagyobb eredménycsomagok témáihoz kapcsolódnak:

- Irodalomkutatás

- Domborzat-elemzés

- Térbeli mutatók

- Változás-elemzés

- Láthatóság-elemzés

- Megjelenítés

- Tájhatárok meghúzása
(4.1. fejezet)

(4.2. fejezet)

(4.3. fejezet)

(4.4. fejezet)

(4.5. fejezet)

(4.6. fejezet)

(4.7. fejezet)
(1. tézis)

(2. tézis)

(3. és 4. tézis)

(5. tézis)

(6. és 7. tézis)

(8. tézis)

(9. tézis)

\section{1. tézis Alapvető szerep megállapítása a felszínborítás és a nö vénytakaró jellemzésében}

Irodalomkutatásom alapján megállapítottam, hogy a passzív képalkotó távérzékelés felvételeinek és származtatott adatbázisainak alapvető szerepe van a tájkarakterelemzésen belül olyan potenciális karakterjegyek interpretálásában és elemzésében, mint a felszínborítás és növénytakaró.

Hazai és nemzetközi tájkarakter-elemzési tanulmányok, útmutatók, valamint tájkarakter témában készült egyéb források elemzésével megállapítottam, hogy melyek a tájkarakter meghatározása során figyelembe vett tájalkotó elemek, vagy tájelem-csoportok. Gyakorisági sorrendet állítottam fel, vizsgáltam a táj jellemzésére felhasznált adatokat. Megállapítottam, hogy több tájelem-csoport vizsgálata esetében jelentős a passzív képalkotó eszköztár szerepe, interpretálásuk és feldolgozásuk módszere változatos.

A kutatási eredmények alapján egyértelmü, hogy a prioritási sorrendben az elsők között szereplő felszínborítással és növénytakaróval a legtöbb karakter-elemzés foglalkozik valamilyen formában és néhány kivételtől eltekintve passzív képalkotó távérzékelési adatokat - légifelvételeket, ürfelvételeket vagy a belőlük származtatott adatbázisokat - vesz figyelembe. Igen gyakori a fényképek vagy felvételek alkalmazása a látványelemek, a tájszerkezet és a mintázat karakteradó jellegének megítélésében is. 
2. tézis Magassági modellek alkalmasságának megállapítása a domborzati tájkarakter meghatározásában

A tájkarakter domborzati jellemzésére használható magassági modelleket vizsgáló összehasonlító elemzésemmel igazoltam, hogy az ASTER GDEMv2 modell különösen hegyvidéki területen alkalmas a domborzati tájjelleg meghatározására.

A tájkarakter-elemzésekben a domborzatot sok esetben digitális magassági modellek jellemzik. Kutatásomban meghatároztam, hogy a hazánkban elérhető legrészletesebb digitális domborzatmodellhez (DDM5) viszonyítva, milyen pontosak a passzív képalkotó távérzékelési módszerekkel készített ASTER GDEM modellek és ezeket összevetettem az aktív távérzékelésből származó SRTM modellel is.

Az összevetés eredményeként megállapítottam, hogy az ASTER GDEMv2 modell a mintaterületi elemzések szerint hegyvidéken átlagosan 4,4 m-es eltérést mutat a DDM5höz képest, míg az SRTM esetében az eltérés 8,4 m. Az SRTM magassági modell alacsonyabb felbontása ellenére síkvidéken sem sokkal pontatlanabb az ASTER GDEMv2 modellnél. Dombvidéki területen a két modell pontossága között nincs jelentős eltérés.

3. tézis Zöldfelület-intenzitás mutató kidolgozása a növényborítottság jellemzésére

Kutatómunkám eredményeképpen megállapítottam és számításokkal igazoltam, hogy az NDVI index felhasználásával és átalakításával képzett ,zöldfelület-intenzitás” mutató egyetlen jelzőszámmal is képes kifejezni bármilyen lehatárolt területrész átlagos zöldfelület-intenzitását és ebből következően alkalmas a tájkarakter területek, vagy tájkarakter típusok zöldfelület-borítottságának jellemzésére is.

Több éves kutatómunkám során kidolgoztam a Zöldfelület-Intenzitás (ZFI) mutatót és folyamatosan pontosítottam számításának módszerét. A zöldfelület-intenzitás a Landsat müholdfelvételek vörös és közeli infravörös sávjait használó NDVI indexre épít, de annál érthetőbben jellemzi, teszi térképezhetővé, térben és időben átlagolhatóvá a tájkarakter területek vagy tájkarakter típusok zöldfelület-borítását. A zöldfelület intenzitás (ZFI) nullától százig terjedő értékekkel fejezi, hogy mekkora az adott területrészre (tájrészletre, településrészre) eső zöldfelület területi aránya és egészségi állapota. Lényegében ez a negatív értékektől mentes skála teszi térbeli és időbeli összesítésre alkalmasabbá a ZFI mutatót a spektrális NDVI indexnél. 
A ZFI mutatóval előállított 2010-es zöldfelület intenzitás adatbázist mintaterületi ellenőrzéseken összevetettem infravörös légifelvétellel és meghatároztam az adatbázis pontosságát Budapesten és agglomerációjában. Az adatbázis felhasználásával többféle mintaterületen igazoltam, hogy az adatok térinformatikai feldolgozásával lehetséges területegységek zöldfelületi jellemzése, mely térbeli összevetésre is alkalmas. A ZFI mutatóval előállított adatbázis felhasználásra került a Budapest Zöldfelületi-rendszerének Fejlesztési Koncepciója és Programja, valamint a Budapest 2030 hosszú távú városfejlesztési koncepció elkészítése során.

\section{4. tézis Rendszeresen változó felszínek zöldfelület-intenzitásának meghatározása}

Az 1986-2011 közötti, 25 éves időszak Landsat müholdfelvételeit elemző mintaterületi kutatásom során meghatároztam, hogy a mezőgazdasági területeken - melyeket rendszeresen változó zöldfelület, vagy időszakos zöldfelület-borítás jellemez - milyen zöldfelület-intenzitás átlagértékekkel indokolt számolni egy-egy tájkarakter típus vagy terület növényborítottságának jellemzése során.

Azokat a felszíneket, melyek zöldfelület-intenzitása folyamatosan változik (szántók, intenzíven kezelt gyepek stb.), a tájjelleg szempontjából nem célszerü egyetlen időpont értékével jellemezni. Megállapítottam, hogy a zöldfelület-intenzitás adatbázisban azokon a mezőgazdasági jellegü területeken, melyeken a rendszeres müvelés (szántás, vetés, aratás, kaszálás stb.), azt eredményezi, hogy a zöldfelület vitalitása egy éven belül, akár egyik hónapról a másikra is jelentősen változik, érdemes egy felszínborítás-kategóriánként átlagosan jellemző zöldfelület-intenzitás értéket használni.

Az átlagos zöldfelület-intenzitás (ZFI) értékeket kutatásom során egy kibővített, $15000 \mathrm{~km}^{2}$-es Délnyugat-Budakörnyék központú mintaterületen 25 év 31 db Landsat TM és ETM+ felvételeiből generált ZFI adatok hónaponként arányos átlagolásával határoztam meg. A gyakran változó intenzitású mezőgazdasági jellegű területeken a kutatás eredményei szerint a ZFI érték 6-7 hónapos vegetációs időszakra 45 és $66 \%$ között váltakozik. A táj állandósult karaktervonásainak jellemzésére ezek az értékek alkalmasabbak, mint egyetlen müholdfelvétellel rögzített pillanatnyi állapot alapján számított zöldfelületi értékek.

5. tézis

A „táj nyitottságának változása” indikátor megújítása

A „táj nyitottsága" térbeli mutató alapján definiáltam és leírtam a tájkarakter-változás jellemzésére tájegység szinten is alkalmazható ,táj nyitottságának változása” indikátort. Az indikátor tájegységekre összegezhető, mértékegységgel meghatározható számértékkel jellemzi a táj nyitottságának változását. Az indikátort európai és magyarországi régiók tájváltozásának jellemzése során teszteltem és igazoltam használhatóságát. 
A táj nyitottságát a szakirodalom a táj elemeinek magassága és sürüsége alapján határozza meg felszínborítás kategóriákra (pl.: az erdők zártak, a szőlők félig nyitottak, a gyepek nyitottak). A forrásokban szereplő nyitottság/zártság elemzések és változás-elemzések nyomán meghatároztam a „táj nyitottságának változása” indikátort, mely alkalmas bizonyos, a karakter szempontjából jelentős változások kimutatására (pl. erdősüléssel záródó tájrészletek aránya, gyümölcsösök kivágásával nyíló tájrészletek aránya). Kutatásom eredményeként megalkottam a változás-indikátor képletét, melynek alkalmazásával a vizsgált területen egyetlen számértékkel, egyértelműen meghatározható a nyitottságváltozással érintett terület aránya (\%), és a számérték előjele alapján a változás iránya is.

A mutatót 1990-2000 és 2000-2006 időszakokra CORINE felszínborítási változásadatokkal több mintaterületen teszteltem. Felhasználásával értékeltem Magyarország településeinek, kistájainak, valamint az EU28+3 állam területén található régiók nyitottság-változását. A táj nyitottságának változása országonként, régiónként és tájegységenként igen eltérő képet mutat. Hazánkban egyértelmüen a záródási tendencia érvényesült az 1990-2006 időszakban, mely részben a beépített területek és az erdőterületek növekedésének következménye.

6. tézis Látható tájrészletek meghatározása az „elméleti láthatósági mutató” szerint

Láthatóság-elemzéssel kapcsolatosan folytatott kutatásom eredményeként bevezettem az „elméleti láthatósági mutatót", mely felsźnmagassági alapadatok felhasználásával, számértékkel jellemzi a vizsgált tájrészletek láthatóságát. A mutató segítségével meghatároztam, hogy melyek Magyarország legtöbb helyről látható tájrészletei és kistájai.

Bevezettem az elméleti láthatósági mutatót, mely jelzi, hogy egy adott terület milyen százalékban látható a környező területek nézőpontjaiból. A mutató lényege, hogy a „látó” nézőpontokat az elemzés százalékos arányban fejezi ki az összes nézőponthoz képest, minden vizsgált tájrészlet esetében. A mutató alkalmazása lehetővé teszi a területi egységek szintjén történő összesítést is, melynek következtében a tájkarakter-területek és tájkarakter típusok is egy átlagos láthatóság értékkel jellemezhetők.

A passzív képalkotó távérzékelés eredményeként előállított ASTER GDEMv2 magassági modell felhasználásával országos szinten készítettem el az elméleti láthatóság-elemzést, amit látótávolság és vertikális látószög tényezőkkel is kiegészítettem. Az elméletileg legtöbb helyről látható tájrészletek közé a síkvidéki környezetből kiemelkedő tanúhegyek tartoznak (Ság, Somló, Badacsony), míg a tájegységek közül a síkvidéki környezetből kiemelkedő tagolatlan röghegységek, vulkáni kúpok a meghatározók, mint a Villányi-hegység és a Tokajhegy. 
Láthatóság-elemzéssel kapcsolatos kutatásom eredményeként definiáltam a „Szembenéző lejtő" fogalmát és meghatároztam jelentőségét a kilátópontról látható területek esetében. A „szembenéző lejtők” területi lehatárolásához kifejlesztettem egy fél-automatikus eljárást, mellyel az ország bármely pontjára meghatározható, hogy melyek a vizsgált kilátóhely felé tekintő lejtők.

A lejtők meredeksége fontos tényező a láthatóság-értékelésben, mert a kilátóhelyekről feltáruló tájelemek látványbeli jelentőségét fokozhatja. A kilátás-elemzés során a látható területeket érdemes lejtőmeredekséggel „súlyozni”, de csak azok a lejtők fontosak, melyek a kilátó felé lejtenek. Azt a lejtőt, mely a vizsgált kilátóhely irányába lejt és ezért tájképi szempontból meghatározó, szembenéző lejtőnek neveztem.

Kutatásom során ASTER GDEMv2 adatok felhasználásával kidolgoztam egy olyan láthatóság-értékelést kiegészítő, „szembenéző-lejtő” kimutatására alkalmas eljárást, mely lehetőséget biztosít a kilátóhely irányába tekintő lejtők térképezésére. Mintaterületi kutatással igazoltam a „szembenéző lejtő” térképezési módszerének alkalmasságát arra, hogy a tájjelleg szempontjából számottevő, az egyes kilátóhelyekről markánsan feltáruló domboldalakat meghatározzuk. Különösen jelentős lehet ez az alkalmazás a változások vizuális hatásának vizsgálata során, mely a tájkarakter-elemzésben is fontos szerepet kaphat.

8. tézis Megjelenítésre használt tájmodellek alkalmazási feltételeinek meghatározása

Megállapítottam, hogy a tájjelleg érzékeltetése érdekében készített megjelenítések (vizualizációk) céljára - a ferde tengelyű madártávlati légifényképek helyettesítésére az ASTER GDEMv2 magassági modell és ortofotó kombinációjával előállított 2,5D tájmodellek megfelelőek. A tájkarakter hiteles ábrázolásához azonban alacsony látószög és közeli földfelszín esetén szükséges a vertikális tájelemek (fasorok, építmények) 3D-modelljeinek megjelenítése is.

40 fövel folytatott interjúkészítés és 215 fö kérdőívezése alapján megállapítottam, hogy a kérdőívezettek 62\%-a 2,5D tájmodellek esetében megelégedne az ASTER GDEMv2 magassági modell részletességével, és megjelenítés során nem érzékel jellegbeli eltérést a DDM5 modell alapú tájmodellhez képest. A kutatásba bevont személyek $\mathbf{3 8 \%} \%$ a azonban elvárja, hogy a legnagyobb részletességű DDM5 modellt használjuk az $5 \mathrm{~km}^{2}$-nél kisebb dombvidéki tájrészlet megjelenítése esetén, még akkor is, ha ez az önkormányzat számára tízezer Forint többletköltséget jelent helyszínenként. 
A kérdőívezés és interjúkészítés eredményeként megállapítottam, hogy a tájmodelleken $1 \mathrm{~km}-$ nél közelebbi épületek hiányát a válaszadók legalább kétharmada karakterbeli eltérésnek vélte a madártávlati felvételekhez képest, míg a foto-realisztikus 3D modellekkel ezt az arányt 2545\%-ra lehetett mérsékelni. Az 1 km-nél közelebbi fókuszterület és 30 alatti látószög esetén az építmények és a növényzet 3D-modellezése indokolt, annak érdekében, hogy az egyedi vagy típusos jelleg érvényesüljön a megjelenítésben.

\section{9. tézis A domborulat-lehatárolás módszerének meghatározása}

Meghatároztam a tájak lehatárolásához szükséges passzív képalkotó távérzékelési adatok körét és felhasználásuk lehetőségeit a határvonal-választó módszerrel. A módszer új elemeként neveztem meg és mintaterületi alkalmazással teszteltem a „domborulat-lehatárolás" eljárást.

Az irodalomkutatás eredménye szerint a tájkarakter területek lehatárolása során jelentős a terepi ismerettel rendelkező szakértők szerepe. A „határvonal-választó módszer” lényege, hogy a passzív képalkotó távérzékelés eszköztárával előállított adatok sokaságából egy térinformatikai rendszerben feltárjuk, és megjelenítjük az összes „,potenciális tájhatárvonalat”, melyekből a tájhatárt meghatározókat az elemző szakértő választja ki. Ez a fél-automatikus módszer lehetőséget ad az objektív és szubjektív elemek ötvözésére.

A potenciális tájhatárvonalak egyikeként definiáltam a domborulat-határt. A „domborulathatár" a domborzati kiemelkedés (pl.: hegy, domb) környezetében található legmélyebb pontokat összekötő, önmagába záródó vonal, mely elválasztja a vizsgált domborzati formát a szomszédos domborulatoktól. Domborulat-határok meghatározásának eljárását a térinformatikai programokban meglévő funkciók kombinált használatával - a magassági modell megemelt inverzének vízgyüjtő-elemzésével - dolgoztam ki és dokumentáltam. Az eljárás alkalmazhatóságát a délnyugat-budakörnyéki dombvidéki területen eredményesen teszteltem. 


\section{ÖSSZEFOGLALÁS}

Kutatásomban elemeztem, hogy a tájkarakter-elemzésben milyen szerepet töltenek be a passzív képalkotó távérzékelés felvételei, származtatott adatbázisai és feldolgozási eljárásai. Irodalomkutatásomban vizsgáltam a tájkarakter jelentőségét, a tájkarakter-elemzés lényegét, módszerét, eszköztárát. Elemeztem a passzív képalkotó távérzékelés alapvető sajátosságait, melyek alapján hasznosíthatóságára következtetni lehet. Meghatároztam, hogy mely tájelemcsoportokat vesz figyelembe a tájkarakter témában született irodalom és elemzési gyakorlat.

Négy mintaterületen végzett kutatásom módszereit meghatározták a felhasznált alapadatok. A legfontosabb módszereknek az irodalomkutatás mellett a terepi felmérést, a kérdőív- és interjúkészítést, a távérzékelési képfeldolgozási eljárásokat és a térinformatikai elemzési alkalmazásokat tekintettem. Az értekezésben kitüzött kutatási célom az volt, hogy a tájkarakter-elemzés egyes lépéseit kiegészítsem a passzív képalkotó távérzékelési alkalmazásokkal és ezt követően igazoljam használhatóságukat.

Eredményeim megmutatták, hogy a passzív képalkotó távérzékelés felvételeinek és származtatott adatbázisainak alkalmazásai több területen bővíthetők. A domborzat karakteradó szerepe vizsgálható, a tájkarakter területek és tájkarakter típusok domborzati jellemzése változatosan megoldható. A térbeli mutatók újszerű feldolgozásával a táj növényborítottságának egyes jellemzői meghatározhatók bármilyen lehatárolt területi egységre. Olyan mutatókkal, mint a „zöldfelület-intenzitás” és a „táj nyitottsága” a karakter jellemzéséhez járulhatunk hozzá. Igazoltam és többféle mintaterületen bemutattam, hogy a „táj nyitottságának változása” indikátor alkalmas a tájegységek változásának jellemzésére.

A láthatóság-elemzés területén bevezettem az elméleti láthatósági mutatót, és megalkottam a szembenéző lejtők fogalmát, kifejlesztettem egy fél-automatikus módszert a szembenéző lejtők meghatározására, majd mintaterületen alkalmaztam a módszert a kilátóhelyekről feltáruló látvány értékelésére. A tájak lehatárolásához javasoltam a passzív képalkotó távérzékelésből származó adatokra építő határválasztó eljárást, valamint meghatároztam a domborulat-határolás módszerét.

Összegeztem a disszertációban dokumentált új tudományos eredményeket. Kutatási eredményeim gyakorlati hasznosítására javaslatokat fogalmaztam meg, az Európai Táj Egyezmény végrehajtása során kiemelt „tájak számbavétele” és „változások dokumentálása” feladatok passzív képalkotó eszköztárral történő alátámasztására. 


\section{SUMMARY}

In my $\mathrm{PhD}$ research $\mathrm{I}$ analysed the role of passive remote sensing in landscape character assessment. Literature on the importance, the essence, the method and the toolbar of landscape character analysis were examined. I have analysed the basic characteristics of remote sensing images like photos, aerial photographs, satellite images, derived database and data processing methods in order to conclude their usability. I have determined the groups of landscape elements taken into account by the literature on landscape character or landscape character assessment.

My research methods in four study areas were determined by the data used during the process. Besides literature overview, I used field surveys, questionnaires, interviews and applied image processing techniques and GIS analysis. The goals of the dissertation were to integrate passive remote sensing applications in the steps of landscape character assessment and to justify their usability.

The results have proved that the use of passive remote sensing images and their processing can be extended in several fields in order to support landscape character assessment. The role of relief in landscape character can be analysed, and topographical characterization of the landscape character areas and landscape character types can be various. By a novel application of spatial indices, specific characteristics of vegetation cover can be determined for any designated area. Indices like green space intensity and openness of landscape can contribute to landscape characterisation. I have demonstrated at several study areas that the change in the landscape openness can characterise distinct visual landscape changes.

In the area of visibility analysis I introduced the theoretical visibility pointer and created the concept of facing slopes. I developed a semi-automated method for the mapping of facing slopes. I used this method to assess the view from observation points. The boundary selection method based on passive remote sensing is defined as an optional method for delineating landscape character areas and landscape character types. An important input to this method is the hill-boundary method, defined and tested in the pilot area.

I have summarised the new scientific results of the dissertation. I concluded the usability of my results and gave proposals for their application, especially for the implementation of European Landscape Convention. Key applications according to the convention are significant for landscape identification and in the analysis of landscapes changes. 


\section{FORRÁSJEGYZÉK}

\section{Nyomtatott irodalom jegyzéke}

1 ADAMS és GILLESPIE 2006

2

AHERN 2004

3

ALMÁSY 1903

4

ANTONSON 2009

5

ANTROP 2004

6

ANTROP 2005

7

APAN, RAINE és

PATERSON 2002

APPLETON és LOVETT 2003

ARENDT 2004

ARONOFF 2005

BAILEY, LEE és THOMPSON 2006

BAKOS 1994

BAKOS és HEREDEA 1987

14 BAKTAY 1930

15 BALÁZS 1993

16 BÁRCZINÉ KAPOVICS, SALLAY és CSEMEZ 2010
Adams, John. B., Gillespie, Alan. R. (2006): Remote Sensing of Landscapes with Spectral Images - A Physical Modelling Approach. Cambridge University Press, Cambridge

Ahern, Jack. (2004): People and Places on the Outer Cape: A Landscape Character Study. University of Massachusetts Amherst, National Park Service, Cape Cod National Seashore

Almásy György (1903): Vándor-utam Ázsia szivébe. Természettudományi Könyvkiadó-vállalat, Budapest

Antonson, Hans (2009): The treatment of landscape in a Swedish EIA process. Environmental Impact Assessment Review 31. pp. 195-205

Antrop, Marc. (2004): Landscape change and the urbanization process in Europe. Landscape and Urban Planning. 67. pp. 9-26

Antrop, Marc. (2005): Why landscapes of the past are important for the future. Landscape and Urban Planning 70 pp. 21-34

Apan, Armando. A., Raine, Steven. R., Paterson, Mark. S. (2002): Mapping and analysis of changes in the riparian landscape structure of the Lockyer Valley catchment, Queensland, Australia. Landscape and Urban Planning 59. 43-57

Appleton, Katy., Lovett, Andrew. (2003): GIS-based visualisation of rural landscapes: defining 'sufficient' realism for environmental decision-making. Landscape and Urban Planning 65. pp. 117-131

Arendt, Randall. (2004): Linked landscapes Creating greenway corridors through conservation subdivision design strategies in the northeastern and central United States. Landscape and Urban Planning 68 pp. 241-269

Aronoff, Stan. (2005): Remote Sensing for GIS Managers. ESRI PRESS, Redlands, California

Bailey, Neil., Lee, John. T., Thompson, Stewart. (2006): Maximising the natural capital benefits of habitat creation: Spatially targeting native woodland using GIS. Landscape and Urban Planning 75 pp. 227-243

Bakos Ferenc (Szerk.) (1994): Idegen szavak és kifejezések szótára. Akadémiai Kiadó, Budapest

Bakos Béla, Heredea László (1987): Geodézia és Távérzékelés. Agrártudományi Egyetem Debrecen, Mezőgadasági Főiskolai Kar, Meliorációs Szak, Szarvas

Baktay Ervin (1930) A világ tetején. Franklin társulat, Budapest

Balázs Dénes (szerk.) (1993): Magyar Utazók lexikona. Panoráma, Budapest

Bárcziné Kapovits Judit, Sallay Ágnes, Csemez Attila (2010): Opportunities for the development of greenways in Hungary, based on the example of the BudaVidék Greenway. In: FÁBOS, JULIUS GY., RYAN, ROBERT L., LINDHULT, MARK. S., KUMBLE, PETER., KOLLÁNYI LÁSZLÓ, AHERN, JACK., JOMBACH SÁNDOR (Szerk.) (2010): Proceedings of Fábos Conference on Landscape and Greenway Planning 2010, Corvinus University of Budapest, Department of Landscape Planning and Regional Development, University of Massachusetts Amherst, Department of Landscape Architecture and Regional Planning

Belényesi Márta (Szerk.) Belényesi Márta, Kristóf Dániel, Neidert Dóra (2008): Távérzékelés a természetvédelemben. Szent István Egyetem, Mezőgazdasági- és Környezettudományi Kar, Környezet- és Tájgazdálkodási Intézet, Gödöllő 
BLASCHKE 2006

BLASCHKE, LANG és HAY 2008

BOHNET és SMITH 2007 2011

BULLA 1962

BULLA és MENDÖL 1947

CALETRÍO 2010

CHEN et al. 2006
Bell, Simon. (1999): Landscape: Pattern, Perception and Process. E \& fn Spon, London

Benkő Melinda (2010): Tervezési elvek a kortárs európai városépítészetben. 231-241 p. In: SALLAY ÁGNES (Szerk.) Ormos Imre Tudományos Ülésszak LOV 2009 Tájépitészeti tanulmányok. Budapesti Corvinus Egyetem, Tájépítészeti Kar, Budapest

Beriatos, Elias., Gospodini, Aspa (2004): "Glocalising” urban landscapes: Athens and the 2004 olympics. Cities, 21, 3, pp. 187-202

Ian Bishop, Eckart Lange (Szerk.) (2005): Visualisation in Landscape and Environmental Planning - Technology and Applications. Taylor and Francis, London and New York

Blaschke, Thomas (2006): The role of the spatial dimension within the framework of sustainable landscapes and natural capital. Landscape and Urban Planning 75 pp. 198-226

Blaschke, Thomas., Lang, Stefan., Hay, Geoffrey. J. (Szerk.) (2008): Object-Based Image Analysis, Spatial Concepts for Knowledge-Driven Remote Sensing Applications. Springer-Verlag Berlin Heidelberg

Bohnet, Iris., Smith, Douglas. Mark. (2007): Planning future landscapes in the Wet Tropics of Australia: A social-ecological framework. Landscape and Urban Planning 80 pp. 137-152

Boromisza Zsombor (2012): Tópartok tájépitészeti szempontú vizsgálati elvei és módszerei a velencei-tó példáján. Doktori értekezés, Budapesti Corvinus Egyetem, Budapest

Botequilha Leitão, André., Miller, Joseph., Ahern, Jack., McGarigal, Kevin (2006): Measuring Lnadscapes - A Planner's Handbook. Island Press, Washington, Covelo, London

Brabyn, Lars. (2005): Solutions for characterising natural landscapes in New Zealand using geographical information systems. Journal of Environmental Management 76. pp. 23-34

Brabyn, L., Mark, D.M. (2011): Using viewsheds, GIS, and a landscape classification to tag landscape photographs. Applied Geography 31 1115-1122

Bulla Béla (1962): Magyarország természetföldrajza. Tankönyvkiadó, Budapest

Bulla Béla, Mendöl Tibor (1947): Kárpát-medence földrajza. Lucidus Kiadó, Budapest

Busics György, Engler Péter, Guszlev Antal, Jancsó Tamás (2009): Digitális adatgyüjtési technológiák. FVM Vidékfejlesztési Képzési és Szaktanácsadási Intézet, Budapest

Caletrío, Javier., (2010): Tourism, Landscape Change and Critical Thresholds. Annals of Tourism Research. Vol. 38, No. 1, pp. 313-316

Chen, Xiao-Ling., Zhao, Hong-Mei., Li, Ping-Xiang., Yin, Zhi-Yong., (2006): Remote sensing image-based analysis of the relationship between urban heat island and land use/cover changes. Remote Sensing of Environment 104. pp. 133-146

Cholnoky Jenő 1943: A sivatag. Franklin társulat, Budapest

Chou, Yue-Hong. (1997): Exploring Spatial Analysis in Geographic Information Systems. OnWorld Press, Albany, New York USA

Tomáš Chuman, Dušan Romportl (2010): Multivariate classification analysis of cultural landscapes: An example from the Czech Republic. Landscape and Urban Planning 98 pp. 200-209

Chuvieco, Emilio., Huete, Alfredo., (2010): Fundamentals of satellite Remote Sensing. CRC Press Taylor \& Francis Group, Boca Raton, London, New York 
39 CLOQUELL-

BALLESTER et al. 2011

40

COLE 2002

COLLINS és KEARNS 2010

COROZA, EVANS és BISHOP 1997 BARBERA 2011

CSERHALMI 2009

CSIMA 2008

CSIMA 2011

CSIMA és GÖNCZ 2002

CSIMA és MÓDOSNÉ BUGYI 2010

52 CSIMA et al. 2008

53 CSORBA 2006

54 CSORBA 2008
Clark, Jo., Darlington, John., Fairclough, Graham., (2004): Using Historic Landscape Characterisation English Heritage's review of HLC Applications 2002 - 03. English Heritage \& Lancashire County Council

Cloquell-Ballester, Vicente-Agustín., Torres-Sibille, Ana del Carmen., Cloquell-Ballester, Víctor-Andrés., Santamarina-Siurana, María Cristina (2011): Human alteration of the rural landscape: Variations in visual perception. Environmental Impact Assessment Review 32, 1, pp. 50-60

Cole, Lyndis. (2002): Landscape Character Assessment Guidance for England and Scotland, Topic Paper 2 Landscape Character Assessment - Links to other sustainability tools. The Countryside Agency and Scottish Natural Heritage

Collins, Damian., Kearns, Robin. (2010): “It's a gestalt experience”: Landscape values and development pressure in Hawke's Bay, New Zealand. Geoforum 41. pp. 435-446

Coroza, Oliver., Evans, David., Bishop, Ian., (1997): Enhancing runoff modeling with GIS. Landscape and Urban Planning 38 pp. 13-23

Cullotta, Sebastiano., Barbera, Giuseppe. (2011): Mapping traditional cultural landscapes in the Mediterranean area using a combined multidisciplinary approach: Method and application to Mount Etna (Sicily; Italy) Landscape and Urban Planning 100 pp. 98108

Czárán Gyula (1903): Kalauz a Biharfüredi kirándulásopkhoz. Sussmann Lázár nyomdája, Belényes

Csemez Attila (1996): Tájtervezés - Tájrendezés. Mezőgazda Kiadó 1996, Budapest

Csemez Attila, Kollányi László (2010): Az egyedi tájértékektől a táji értékek kataszterezéséig. Falu Város Régió Folyóirat, 2010/2-3. pp.116-125

Cserhalmi Dániel (2009): Pánkromatikus felvételekre és képszegmentációra alapozott vegetációrekonstrukciós vizsgálatok az Észak-alföldi lápok példáján. Doktori $(\mathrm{PhD})$ értekezés, Szent István Egyetem, Környezettudományi Doktori Iskola, Gödöllő

Csima Péter (2008): Tájvédelmi szabályozás a településrendezési tervekben. 401-407 p. In: CSORBA PÉTER, FAZEKAS ISTVÁN (Szerk.) Tájkutatás-tájökológia. Meridián Alapítvány. Debrecen.

Csima Péter (2011): Gondolatok a tájvédelemről, az egyedi tájértékekről és a tájkarakterről. 43-49 p. In: SALLAY ÁGNES (Szerk.) Tájakadémia -1. konferenciakötet, Budapest

Csima Péter, Göncz Annamária (2002): A területrendezési tervek tájterhelési és táj-terhelhetöségi vizsgálatának módszere, Tervezési Útmutató. Szent István Egyetem Tájvédelmi és Tájrehabilitációs Tanszék, Budapest

Csima Péter, Módosné Bugyi Ildikó (2010): Települési tájkarakter elemzés az Ipoly vidékén. 201-210 p. In: SALLAY ÁGNES (Szerk.) Ormos Imre Tudományos Ülésszak LOV 2009 Tájépitészeti tanulmányok. Budapesti Corvinus Egyetem, Tájépítészeti Kar, Budapest

Csima Péter, Boromisza Zsombor, Jombach Sándor, Módosné Bugyi Ildikó, Pádárné Török Éva (2008): Nyergesújfalui Cementgyár Környezeti hatástanulmány - tájvédelmi munkarész. BCE Tájvédelmi és Tájrehabilitációs Tanszék

Csorba Péter (2006): Tájökológia. Kossuth Egyetemi Kiadó, Debrecen Csorba Péter (2008): Tájhatárok és foltgrádiensek. Tájökológiai Kutatások 83-89 p. In: CSIMA PÉTER és BODA BRIGITTA (Szerk.) Budapesti Corvinus Egyetem, Tájvédelmi és Tájrehabilitációs Tanszék, Budapest 

2007

DE LA FUENTE DE VAL, ATAURI és DE LUCIO 2006

DEANWOOD et al. 2002

DETREKÖI és SZABÓ 2002

DIBARI 2003

DIBARI 2007

DOCKERTY et al. 2006

DONALDSON-SELBY 2007

\section{DÖVÉNYI 2010}

DRĂGUT és BLASCHKE 2006

DRAMSTAD et al. 2001

DREXLER 2010

DUERKSEN és GOEBEL 1999

EGYED 2012

ELEK 2006

ELEK 2007

ENGLER 2000
Csorba Péter, Bodnár Réka Kata (2007): The European Landscape Convention and tourism. Acta Geographica Debrecina Landscape and Environment 1, 1 pp. 75-84

Davis, Chris., Schaub, Tim. (2005): A transboundary study of urban sprawl in the Pacific Coast region of North America: The benefits of multiple measurement methods. International Journal of Applied Earth Observation and Geoinformation 7 pp. 268-283

de la Fuente de Val, Gonzalo., Atauri, José. A., de Lucio, José. V., (2006) Relationship between landscape visual attributes and spatial pattern indices: A test study in Mediterranean-climate landscapes. Landscape and Urban Planning 77 pp. 393-407

Deanwood, Robert., Adams, Kay., Kersey, Jim. (2002): Landscape Character Assessment Guidance for England and Scotland, Topic Paper 9: Climate change and natural forces - the consequences for landscape character. The Countryside Agency and Scottish Natural Heritage

Detrekői Ákos, Szabó György (2002): Térinformatika. Nemzeti Tankönyvkiadó, Budapest

DiBari, John. N. (2003): Scaling exponents and rank-size distributions as indicators of landscape character and change. Ecological Indicators 3. pp. $275-284$

John N. DiBari (2007): Evaluation of five landscape-level metrics for measuring the effects of urbanization on landscape structure: the case of Tucson, Arizona, USA. Landscape and Urban Planning 79 pp. 308313

Dockerty, Trudie., Lovett, Andrew., Appleton, Katy., Bone, Alex., Sünnenberg, Gilla. (2006): Developing scenarios and visualisations to illustrate potential policy and climatic influences on future agricultural landscapes. Agriculture, Ecosystems and Environment. 114 pp. 103120

Donaldson-Selby, G., Hill, T., Korrubel, J. (2007): Photorealistic visualisation of urban greening in a low-cost high-density housing settlement, Durban, South Afrika, Urban Forestry \& Urban Greening. 6 pp. 3-14.

Dövényi Zoltán (Szerk) (2010): Magyarország kistájainak katasztere. MTA Földrajztudományi Kutatóintézet, Budapest (az 1. kiadás szerkesztői: Marosi Sándor, Somogyi Sándor, 1990)

Drăguț, Lucian., Blaschke, Thomas (2006): Automated classification of landform elements using object-based image analysis. Geomorphology, 81, 3-4, pp. 330-344

Dramstad, W. E., Fry, G., Fjellstad, W. J., Skar, B., Helliksen, W., Sollund, M. -L. B., Tveit, M. S., Geelmuyden, A. K., Framstad, E. (2001): Integrating landscape-based values - Norvegian monitoring of agricultural landscapes. Landscape and Urban Planning 57. pp. 257268

Drexler Dóra (2010): Táj és tájértelmezés. Akadémiai Kiadó, Budapest Duerksen, Christopher. J., Goebel, R. Matthew. (1999): Aesthetics, Community Character, and the Law. Scenic Amerika, American Planning Association, Planning Advisory Service Report

Egyed Adrienn (2012): Tájalakulás vidéki térségekben. Kistelepülések funkció- és karakterváltozásainak összefüggései három kistérség példáján. Doktori értekezés, Budapesti Corvinus Egyetem, Budapest

Elek István (2006): Bevezetés a geoinformatikába. ELTE Eötvös Kiadó, Budapest

Elek István (Szerk.) (2007): Térinformatikai gyakorlatok. ELTE Eötvös Kiadó, Budapest

Engler Péter (2000): Távérzékelés. Agrárszakoktatási Intézet, Budapest 
FABOS és CASWELL 1977

76 FAIRCLOUGH és MACINNES 2002

77 FAIRWEATHER és SWAFFIELD 2001

FALCÃO, DOS SNATOS és BORGES, 2006

FERANEC et al. 2010

FIRNIGL 2012

FISCHER et al. 2010

FJELLSTAD et al. 2009

FRANCO et al 2003
FRY et al. 2009

GAÁL 1944

FRANTÁL és KUNC 2010

GÁBOR és JOMBACH 2008

GÁL 2009
Engler Péter (2007): Fotogrammetria I. FVM Vidékfejlesztési, Képzési és Szaktanácsadási Intézet, Budapest

Eplényi Anna (2012): Kalotaszeg tájkarakter-elemzése. Doktori értekezés, Budapesti Corvinus Egyetem, Budapest

Fabos, Julius. Gy., Caswell, Stephanie. J. (1977): Composite Landscape Assessment. Massachusetts Agricultural Experiment Station, University of Massachusetts at Amherst

Fairclough, Graham., Macinnes, Lesley. (2002): Landscape Character Assessment Guidance for England and Scotland, Topic Paper 5: Understanding Historic Landscape Character, The Countryside Agency and Scottish Natural Heritage

Fairweather, John. R., Swaffield, Simon. R. (2001): Visitor Experiences of Kaikoura, New Zealand: an interpretative study using photographs of landscapes and Q method. Tourism Management 22 pp. $219-228$

Falcão, A. O., dos Snatos, M. P., Borges, J. G. (2006): A real-time visualization tool for forest ecosystem management decision support. Computers and Electronics in Agriculture 53 pp. 3-12.

Feranec, Jan., Jaffrain, Gabriel., Soukup, Tomas., Hazeu, Gerard. (2010): Determining changes and flows in European landscapes 1990 2000 using CORINE land cover data. Applied Geography 30. pp. 1935

Filepné Kovács Krisztina (2013): Tájhasználati szempontok a vidéki térségek versenyképességének értelmezéséhez. Doktori értekezés, Budapesti Corvinus Egyetem, Budapest

Firnigl Anett (2012): Római kori villák történeti környezetének vizsgálata a Balaton-felvidéken. Doktori értekezés, Budapesti Corvinus Egyetem, Budapest

Fischer, Günther., Prieler, Sylvia., van Velthuizen, Harrij., Berndes, Göran., Faaij, André., Londo, Marc., de Wit, Marc., (2010): Biofuel production potentials in Europe: Sustainable use of cultivated land and pastures, Part II: Land use scenarios. Biomass and bioenergy 34. pp. 173-187

Fjellstad, Wendy., Mittenzwei, Klaus., Dramstad, Wenche., Øvren, Eva. (2009): Landscape protection as a tool for managing agricultural landscapes in Norway. Environmental Science \& Policy. 12. pp. 1144 1152

Franco, Daniel., Franco, Davide., Manninoa, Ilda., Zanetto, Gabriele. (2003): The impact of agroforestry networks on scenic beauty estimation The role of a landscape ecological network on a sociocultural process. Landscape and Urban Planning 62 pp. 119-138

Frantál, Bohumil., Kunc, Josef. (2010): Wind turbines in tourism landscapes - Czech Experience. Annals of Tourism Research, Vol. 38, No. 2, pp. 499-519

Fry, G., Tveit, M.S., Ode, Å., Velarde, M.D. (2009): The ecology of visual landscapes: Exploring the conceptual common ground of visual and ecological landscape indicators. Ecological Indicators. 9. pp. 933947

Gaál István (1944): Szép magyar tájak. Királyi Magyar Természettudományi Társulat.

Gábor Péter, Jombach Sándor (2008): A zöldfelület intenzitás és a városi hősziget jelenségének összefüggései Budapesten. Falu Város Régió 1. Városi zöldfelületek, pp. 31-36.

Gál Tamás Mátyás (2009): Összetett városi felszín geometriáját leíró paraméterek számítása és városklimatológiai alkalmazása, Szegedi Tudományegyetem Földtudományok Doktori Iskola, Éghajlattani és Tájföldrajzi Tanszék, Szeged 

GULINCK 2009

GATE és ÖKOPLAN 1984

GOSPODINI 2006

GROOT, JELLEMA és ROSSINGA 2009

GRÓSZ 2010

GYENIZSE és NAGYVÁRADI 2008

GYULAI 2009

101 GYULAI és BULLA 2002

102 HAGGETT 2006

ILLÉS 1981

JANCSÓ 2006

108 JASMINKA., VASILJEVIC és TUTUNDŽIĆ 2007
Garré, Sarah., Meeus, Steven., Gulinck, Hubert. (2009): The dual role of roads in the visual landscape: A case-study in the area around Mechelen (Belgium). Landscape and Urban Planning 92 pp. 125-135

GATE, ÖKOPLAN Kft. (1984): Pest megyei agroökológiai potenciál értékelés. Zárójelentés 1984. A PAP elvi- és operatív bizottsága együttes ülése számára készített kivonatos anyag. VÁTI Kht. (DKT Tervező szervezet) ; MTA - Magyar Tudományos Akadémia, Budapest (DKT Megbízó szervezet) ;

Ghimessy László (1984): A tájpotenciál - Táj, víz, ember, energia. Mezőgazdasági Kiadó, Budapest

Gibson, Paul. J., (2000): Indroductory Remote Sensing - Principles and Concepts. Paul J. Gibson Routledge, London, New York 2001

Gibson, Paul. J., Power, Clare. H., (2000): Indroductory Remote Sensing - Digital Image Processing and Applications. Routledge, London, 2000

Gospodini, Aspa. (2006): Portraying, classifying and understanding the emerging landscapes in the post-industrial city. Cities, 23, 5, pp. 311330

Griffiths, Geoffrey. H., Vogiatzakis, Ioannis. N., Porter, Jonathan. R. Burrows, Clare. (2011): A landscape scale spatial model for seminatural broadleaf woodland expansion in Wales, UK. Journal for Nature Conservation 19. pp. 43-53

Groot, Jeroen. C.J., Jellema, André., Rossinga, Walter. A.H. (2010): Designing a hedgerow network in a multifunctional agricultural landscape: Balancing trade-offs among ecological quality, landscape character and implementation costs. European Journal of Agronomy 32. pp. 112-119. 32 (2010) 112-119

Grósz (2010): Digitális képfeldolgozás alkalmazása üvegházi és szabadföldi kisérletek kiértékelésénél. PhD doktori értekezés, Pannon Egyetem, Állat- és Agrárkörnyezet-tudományi Doktori Iskola, Keszthely

Gyenizse Péter, Nagyváradi László (Szerk.) (2008): Térinformatika és alkalmazása II. Pécsi Tudományegyetem Természettudományi Kar, Földrajzi Intézet egyetemi jegyzet, Pécs

Gyulai István (2009): A preciziós mezigazdaság segitése távérzékelt adatokkal. Nyugat-magyarországi Egyetem, Mezigazdaság- és élelmiszertudományi Kar, Mosonmagyaróvár

Gyulai István, Bulla Miklós (2002): Távérzékelés. Széchenyi István Egyetem, Környezetmérnöki Tanszék, Győr

Haggett, Peter. (2006) Geográfia - Globális szintézis. Typotex Kiadó, Budapest

Horányi Gábor (2004): Magyar világjárók újabb kalandjai.Palatinus Kiadó, Budapest

Hulse, David., Gregory, Stan., Baker, Joan. (Szerk.) (2002): Willamette River Basin Planning Atlas. Oregon state University Press, Corvallis

Marcel Hunziker (1995): The spontaneous reafforestation in abandoned agricultural lands: perception and aesthetic assessment by locals and tourists. Landscape and Urban Planning. 31. pp. 399-410

Illés István (Szerk.) (1981): Tavunk a Balaton. Natura, Budapest

Jancsó Tamás (2006): Nemlineáris modellek fotogrammetriai alkalmazása a geokörnyezettudományban. Nyugat-magyarországi Egyetem, Erdőmérnöki kar, Kitaibel Pál Környzezettudományi Doktori Iskola. Sopron

Cvejic, Jasminka., Vasiljevic, Nevena., Tutundžić, Andreja (Цвејић, Јасминка., Васиљевић, Невена., Тутунџић, Андреја.) (2007): Tipologija predjela Beograda za potrebe primjene Europske konvencije o predjelima. Штампа Планета Принт, Београд 
109 JAT, GARG és KHARE 2008

110 JELLEMA et al. 2009

111 JENSEN 2007

112 JESSEL 2006

113 JI et al. 2006

114 JODIDO 2012

115 JOMBACH 2012

116 JOMBACH 2012

117 JOMBACH és EGYED 2013

118 JOMBACH et al. 2013

119 JUDE 2003

120 JUHÁSZ 2008

121 JULIE MARTIN ASSOCIATES 2006

122 KABAI 2010

123 KABAI 2011

124 KARDOS 2009
Jat, Mahesh. Kumar., Garg, P.K., Khare, Deepak. (2008): Monitoring and modelling of urban sprawl using remote sensing and GIS techniques. International Journal of Applied Earth Observation and Geoinformation 10. pp. 26-43

Jellema, André., Stobbelaar, Derk-Jan., Groot Jeroen. C.J., Rossing Walter. A.H. (2009): Landscape character assessment using region growing techniques in geographical information systems. Journal of Environmental Management 90, pp. S161-S174

Jensen, John R., (2007): Remote Sensing of the Environment - An Earth Resource Perspective. Pearson Education, Inc, Upper Saddle River $(\mathrm{Nj})$

Jessel, Beate. (2006): Elements, characteristics and character information functions of landscapes in terms of indicators. Ecological Indicators 6. pp. 153-167

Ji, Wei ., Ma, Jia., Twibell, Rima. Wahab., Underhill, Karen. (2006): Characterizing urban sprawl using multi-stage remote sensing images and landscape metrics. Computers, Environment and Urban Systems 30 pp. $861-879$

Jodido, Philip. (2012): Landscape Architecure Now. Taschen, Cologne Jombach Sándor (2012): Térségi vagy települési szintű zöldfelületintenzitás távérzékelési elemzésének módszere. 4D: Tájépitészeti és Kertmüvészeti Folyóirat Különszám, 219-232.

Jombach Sándor (2012): Távérzékelés és a térinformatikai feldolgozás szerepe a tájkarakter-elemzésben. 29-41 p. In: SALLAY ÁGNES (Szerk.) Tájmetria/Tájértékelés. Budapesti Corvinus Egyetem Tájtervezési és Területfejlesztési Tanszék, Budapest

Jombach Sándor, Egyed Adrienn (2013): Tájkezelési módszerek és megoldások az "Élö Tájak" projektben. Budapesti Corvinus Egyetem, Tájtervezési és Területfejlesztési Tanszék, Budapest

Jombach Sándor, Kollányi László, Szabó Áron, Filepné Kovács Krisztina, Nagy Gergő Gábor,Molnár József László, Tóth Tádé Dániel, Magyar Veronika, Szilvácsku Zsolt, Duray Balázs, Sallay Ágnes, Valánszki István, Csemez Attila (2013) Visualisation and landscape modelling to understand landscapes in transition Applications in landscape management of "Nagyberek" (in press)

Jude, S., Jones, A., Bateman, I., Andrews, J. (2003): Developing Techniques to Visualise Future Coastal Landscapes. In: BUHMANN és ERVIN (Szerk.): Trends in Landscape Modeling, Proceedings at Anhalt University of Applied Sciences 2003, Herbert Wichmann Verlag, Heidelberg, pp. 228-238.

Juhász Attila (2008): Hadtörténeti folyamatok rekonstrukciója távérzékelés és térinformatika segitségével. Budapesti Müszaki és Gazdaságtudományi Egyetem, Építőmérnöki Kar, Fotogrammetria és Térinformatika Tanszék, Budapest

Julie Martin Associates (2006): Landscape Character Assessment (LCA) in Ireland: Baseline Audit and Evaluation

Kabai Róbert (2010): Skócia Tájkarakter felmérése és az eredmények gyakorlati hasznositása. Tájökológiai lapok 8 (1) pp. 97-109.

Kabai Róbert (2011): The importance of National Landscape Character Survey in Landscape Protection. Acta Universitatis Sapientiae. Agriculture and Environment Supplement, pp. 62-67

Kardos Ibolya (2009): Digitális képfeldolgozás és szines metallográfia alkalmazása gömbgrafitos öntöttvasak szövetszerkezetének jellemzésére. Doktori értekezés, Miskolci Egyetem, M/szaki Anyagtudományi Kar, Anyagtudományi Intézet. Miskolc 
KOLLÁNYI 2006

KOLLÁNYI és CSEMEZ 2006

137 KOLLÁNYI és CSEMEZ 2011

KOLLÁNYI et al. 2012

KONKOLY GYURÓ 2006

141 KONKOLY GYURÓ 2007

142 KONKOLY GYURÓ, JOMBACH és TATAI 2008
Kearney, Anne. R., Bradley, Gordon. A., Petrich, Carl. H., Kaplan, Rachel. Kaplan, Stephen., Simpson-Colebank,. (2008): Public perception as support for scenic quality regulation in a nationally treasured landscape Landscape and Urban Planning 87 pp. 117-128

Kent, Richard. L., Elliott, Cynthia L. (1995): Scenic routes linking and protecting natural and cultural landscape features: a greenway skeleton. Landscape and Urban Planning 33 pp. 341-355

Kerényi Attila (2007): Tájvédelem. Pedellus Tankönyvkiadó, Debrecen Kertész Ádám (2003): Tájökológia. Holnap Kiadó, Budapest

Kéz Andor (Szerk.) (1397): Felfedezők lexikona. Franklin - Társulat, Budapest

Kim, Keun-Ho., Pauleit, Stephan. (2007): Landscape character, biodiversity and land use planning: The case of Kwangju City Region, South Korea. Land Use Policy 24 pp. 264-274

Kiss Gábor (2009): Az Európa Tanács táj díja és a nemzeti szintü tájdíj pályázat szakmai tapasztalatai. Lippay János - Ormos Imre - Vas Károly Tudományos Ülésszak összefoglalói, Budapest, 96

Kiss Gábor (2011): A TÉKA program keretében zajló egyedi tájértékkataszterezés módszertani alapjai. 93-101 p. In: SALLAY ÁGNES (Szerk.) Tájakadémia -1. konferenciakötet, Budapest

Kollányi László (2004): Táji indikátorok alkalmazási lehetőségei a környezetállapot értékeléséhez. BKAE Tájtervezési és Területfejlesztési Tanszék. Budapest, Környezetállapot értékelés program

Kollányi László (2006): Tájindikátorok és alkalmazási lehetőségeik a tájértékelésben. 4D: Tájépítészeti és Kertmüvészeti Folyóirat 1., pp. $39-43$

(2010): Tájértékek kataszterezésének metodikája. 159-166 p. In: SALLAY ÁGNES (Szerk.) Ormos Imre Tudományos Ülésszak LOV 2009 Tájépitészeti tanulmányok. Budapesti Corvinus Egyetem, Tájépítészeti Kar, Budapest

Kollányi László, Csemez Attila (2006): Módositási javaslat az Országos Területrendezési Tervröl szóló 2003. évi XXVI. tv. Módositásához - Tájképvédelmi terület övezetének szabályozása. Megbízó: VÁTI Kht. Budapest

Kollányi László, Csemez Attila (2011): Táji értékek, egyedi tájértékek egy egységes rendszerben. 103-115 p. In: SALLAY ÁGNES (Szerk.) Tájakadémia -1. konferenciakötet, Budapest

Kollányi László, Jombach Sándor, Filepné Kovács Krisztina, Nagy Gergő Gábor (2012): Tájindikátorok alkalmazása a tájképvédelmi területek lehatárolására és a tájkarakter meghatározására In: Szenteleki Károly és Szilágyi Kinga (Szerk): Fenntartható fejlődés. Élhető régió. Élhető táj. Budapesti Corvinus Egyetem, Budapest. pp. 175-188

Konecny, Gottfried. (2003): Geoinformation Remote sensing, Photogrammetry and Geographic Information Systems. Taylor and Francis, London and New York

Konkoly Gyuró Éva (2006): Tájökológiai és -tervezési Glosszárium. Szakmai egyeztetési anyag, Budapest

Konkoly Gyuró Éva (2007): The Pannonian Gerat Plain - A flourishing garden? 295-308 p. In : PEDROLI, BAS., VAN DOORN, ANNE., DE BLUST, GEERT., PARACCHINI, MARIA. LUISA., WASCHER, DIRK., BUNCE, FREDA. (Szerk.): Europe's Living Landscapes. Essays exploring our identity in the countryside. Landscape Europe, Wageningen / KNNV Publishing, Zeist.

Konkoly Gyuró Éva, Jombach Sándor, Tatai Zsombor (2008): A tájidentitás indikátorai európai fenntarthatósági hatásvizsgálatban. $4 D$ : Tájépitészeti és Kertmüvészeti Folyóirat 9, 52-58. 
143 KONKOLY-GYURÓ 2010

144 KONKOLYNÉ GYURÓ 2003

145 KONKOLYNÉ GYURÓ 2006a

146 KONKOLYNÉ GYURÓ 2006b

147 KONKOLYNÉ GYURÓ 2007

148 KÖRMENDY 2010

149 KRETZLER, 2002

150 KRISTÓF 2005

151 KUBASSEK 2008

152 KUGLER 2008

153 KUN és MOLNÁR 1999

154 LANG és BLASCHKE 2007

155 LANG és TEIDE 2003

156 LANGE és HEHLLANGE 2010

157 LASANTA et al. 2007

158 LE CALLOC'H 2000

159 LEGATES 2005

160 LEWIS és SHEPPARD 2006
Dr. Konkoly-Gyuró Éva (Szerk.) (2010): Határon átívelő tájak karaktere - A Fertö-Hanság medence és Sopron térsége. NyugatMagyarországi Egyetem Kiadó, Sopron

Konkolyné Gyuró Éva (2003): Környezettervezés. Mezőgazda Kiadó, Budapest

Konkolyné Gyuró Éva (2006): A tájkarakter Tartalom és forma egysége a térben. Falu Város Régió Folyóirat, 2006,/3 pp. 26-32

Konkolyné Gyuró Éva (2006): Tájvédelmi modellterv a Zemplénihegység és térsége mintaterületre. Konkoly Mérnöki Iroda (Készült: A Környezetvédelmi és Vízügyi Minisztérium Természetvédelmi Hivatalának

Konkolyné Gyuró Éva (2007): Tájvédelmi Modellterv a Fertö-Hanság medence térségére. Tájmühely Kft. (Készült a Fertö-Hanság Nemzeti Park Igazgatóság megbízásából)

Körmendi Imre (2010): A nagyberuházások városrendezési dilemmái. 283-297 p. In: SALLAY ÁGNES (Szerk.) Ormos Imre Tudományos Ülésszak LOV 2009 Tájépitészeti tanulmányok. Budapesti Corvinus Egyetem, Tájépítészeti Kar, Budapest

Kretzler, E. (2002): Computer Visualisation of Environmental Impacts, Trends in GIS and Virtualization in Environmental Planning and Design In: BUHMANN, ERICH., NOTHELFER, U., PIETSCH. M., (Szerk), Trends in GIS and Virtualization in Environmental Planning and Design Proceedings at Anhalt University of Applied Sciences 2002 Herbert Wichmann Verlag, Heidelberg, pp. 58-67.

Kristóf Dániel (2005): Távérzékelési módszerek a környezetgazdálkodásban. Doktori $(\mathrm{PhD})$ értekezés, Szent István Egyetem, Környezettudományi Doktori Iskola, Gödöllő

Kubassek János (2008): Útkeresők, Magyar utazók és földrajzi felfedezők. Kossuth Kiadó, Budapest

Kugler Zsófia (2008): Geographic Information Systems and Remote Sensing for steady state flow calculations and flood detection. $\mathrm{PhD}$ thesis. Budapest University of Technology and Economics Faculty of Civil Engineering, Department of Photogrammetry and Geoinformatics, Budapest

Kun András és Molnár Zsolt (1999): Élöhely-térképezés. Scientia Kiadó, Budapest

Lang, Stefan., Blaschke, Thomas., (2007): Landschaftsanalyse mit GIS. UTB-Reihe. - Ulmer Verlag, Stuttgart

Stefan Lang, Dirk Teide (2003): ${ }^{v}$ LATE Extension für ArcGIS vektorbasiertes Tool zur quantitativen Landschaftsstrukturanalyse. Institut für Geographie und angewandte Geoinformatik, Universität Salzburg, Salzburg

Lange, E., Hehl-Lange, S. (2010): Making visions visible for long-term landscape management. Futures 42 pp. 693-699

Lasanta, Teodoro., Laguna, María., Vicente-Serrano, Sergio. M., (2007): Do tourism-based ski resorts contribute to the homogeneous development of the Mediterranean mountains? A case study in the Central Spanish Pyrenees. Tourism Management. 28. pp. 1326-1339

Le Calloc'h, Bernard (2000): Körösi Csoma Sándor útinaplója. Püski kiadó, Budapest

Richard LeGates (2005): Think Globally, Act Regionally. ESRI Press, Redlands, California, USA

Lewis, John. L., Sheppard, Stephen. R.J., (2006): Culture and communication: Can landscape visualization improve forest management consultation with indigenous communities? Landscape and Urban Planning 77. pp. 291-313 
161 LILLESAND, KIEFER és CHIPMAN 2004

LÓCZY 2002

163

164
MATSUSHITA 2007

METI/ERSDAC NASA/LPDAAC USGS/EROS 2009

MEYER 2011

MAROSI és SÁRFALVI 1970

MAROSI és SOMOGY 1990

\section{MATHER 2004}

MEYER 2006

MILICS 2008

Lillesand, Thomas. M., Kiefer, Ralph. W.., Chipman, Jonathan. W., (2004): Remote Sensing and Image Interpretation. John Wiley and Sons, Hoboken, New Jersey, USA

Lóczy Dénes (2002): Tájértékelés, földértékelés. Dialóg Campus Kiadó, Budapest-Pécs, 2002

Lóki József (2002): Távérzékelés. Debreceni Egyetem , Természettudományi Kar, Debrecen

Lokocz, Elizabeth., Ryan, Robert. L., Sadler, Anna. Jarita. (2011): Motivations for land protection and stewardship: Exploring place attachment and rural landscape character in Massachusetts. Landscape and Urban Planning 99. pp. 65-76

Longley, Paul. A.., Goodchild, Michael. F., Maguire, David. J., Rhind, David. W., (2011): Geographic Information Systems and Science. John Wiley and Sons, Hoboken, New Jersey, USA

Konrad Lorenz (2002, (az eredeti 1973)): A civilizált emberiség nyolc halálos büne. Cartaphilus Kiadó, Budapest

Lyon, John. G. (2001): Wetland Landscape Characterisation GIS, Remote Sensing and Image Analysis. Sleeping Bear Press, Chelsea, (MI) USA

Makhzoumi, J.M. (1997): The changing role of rural landscapes: olive and carob multi-use tree plantations in the semiarid Mediterranean. Landscaape and Urban Planning 37 pp. 115-122

Marosi Sándor, Sárfalvi Béla (1970): Európa I.-II. Gondolat, Budapest

Marosi Sándor, Somogyi Sándor (Szerk.) (1990): Magyarország kistájainak katasztere I. II. MTA Földrajztudományi Kutató Intézet, Budapest

Mather, Paul. M., (2004): Computer Processing of Remotely-Sensed Images - An introduction. John Wiley and Sons, Hoboken, New Jersey

Mather, Paul. M., Koch, Magaly. (2011): Computer Processing of Remotely-Sensed Images - An introduction. John Wiley and Sons, Hoboken, New Jersey

Matsushita, Bunkei., Yang, Wei., Chen, Jin. Onda, Yuyichi. Qiu, Guoyu (2007): Sensitivity of the Enhanced Vegetation Index (EVI) and Normalized Difference Vegetation Index (NDVI) to topographic Effects: A Case Study in High-Density Cypress Forest. Sensors 7, pp. 2636-2651.

METI/ERSDAC - NASA/LPDAAC - USGS/EROS (2009): ASTER Global DEM Validation Summary Report. ASTER GDEM Validation Team: METI/ERSDAC, NASA/LPDAAC, USGS/EROS

Burghard Christian Meyer (Szerk.) (2006): Sustainable Land Use in Intensively Used Agricultural Regions. Landscape Europe. Alterra Report No. 1338, Wageningen

Meyer, Dave., (Szerk.) (2011): ASTER Global Digital Elevation Model Version 2 - Summary of Validation Results. NASA Land Processes Distributed Active Archive Center and the Joint Japan-US ASTER Science Team

Mezősi Gábor (2011): Magyarország természetföldrajza. Akadémiai Kiadó, Budapest

Milics Gábor (2008): A térinformatika és a távérzékelés alkalmazása a preciziós (helyspecifikus) növénytermesztésben. Pécsi Tudományegyetem, Természettudományi Kar, Földtudományok Doktori Iskola, Pécs 
180 MOLNÁR 2013

181 MOTTET et al. 2006

182 MÖLLER 2010

183 MTA

NYELVTUDOMÁNYI

INTÉZET 1986

184 MUCSI 2004

185 MÜCHER és WASCHER 2007

MÜCHER et al. 2010

187 NAGY 1998

188

NAGY és CSIMA 2010

189

NOHL 2001

190

ODE et al 2009

191 ODE, TVEIT és FRY 2010

192

OHTA 2001

193 OLÁH 2012

194 ÖKOPLAN 1994
Molnár László (2010): Az infrastruktúra mint a történeti, települési tájszervezés része - gondolatok egy előadáshoz. 243-251 p. In: SALLAY ÁGNES (Szerk.) Ormos Imre Tudományos Ülésszak LOV 2009 Tájépitészeti tanulmányok. Budapesti Corvinus Egyetem, Tájépítészeti Kar, Budapest

Molnár Zsófia (2013): Az Alsó-Tisza-völgyi holtágak tájvizsgálata és tájrehabilitációs elvei. Doktori értekezés, Budapesti Corvinus Egyetem, Budapest

Mottet, Anne., Ladet, Sylvie., Coqué, Nathalie., Gibon, Annick., (2006): Agricultural land-use change and its drivers in mountain landscapes: A case study in the Pyrenees. Agriculture, Ecosystems and Environment 114 pp. 296-310

Möller, Bernd (2010): Spatial analyses of emerging and fading wind energy landscapes in Denmark. Land Use Policy. 27. pp. 233-241

A Magyar Tudományos Akadémia Nyelvtudományi Intézete (1986): A Magyar Nyelv Értelmezö Kéziszótára III. kötet. Akadémiai Kiadó, Budapest

Mucsi László (2004): Müholdas távérzékelés. Libellus Kiadó, Szeged

Wascher, Dirk., Mücher, Sander., (2007): European landscape characterisation. 11-18. p. In : PEDROLI, BAS., VAN DOORN, ANNE., DE BLUST, GEERT., PARACCHINI, MARIA. LUISA., WASCHER, DIRK., BUNCE, FREDA. (Szerk.): Europe's Living Landscapes. Essays exploring our identity in the countryside. Landscape Europe, Wageningen / KNNV Publishing, Zeist.

Mücher, Caspar. A., Klijn Jan. A., Wascher, Dirk. M., Schaminée, Joop. H. J., (2010): A new European Landscape Classification (LANMAP): A transparent, flexible and user-oriented methodology to distinguish landscapes. Ecological Indicators. 10. pp. 87-103

Nagy Jenő (1998): Fotogrammetria I. Agrárszakoktatási Intézet, Budapest

Nagy Enikö, Csima Péter (2010): A tájkarakter változása Kőszeg környékén a 19-20. században. 237-240 p. In: FÜLEKY GYÖRGY (Szerk.) A táj változásai a Kárpát-medencében - Tájhasználat és tájátalakulás a 18-20. században. Környezetkímélő Agrokémiáért Alapítvány, Tájvédelmi Oktatásért és Kutatásért Alapítvány

Nohl, Werner (2001): Sustainable landscape use and aesthetic perception - preliminary reflections on future landscape aesthetics. Landscape and Urbaan Planning 54 pp. 223-237

Ode, Åsa., Fry, Gary., Tveit, Mari. S., Messager, Pernette., Miller, David. (2009): Indicators of perceived naturalness as drivers of landscape preference. Journal of Environmental Management 90. 375383

Ode, Åsa., Tveit, Mari. Sundli., Fry, Gary. (2010): Advantages of using different data sources in assessment of landscape change and its effect on visual scale. Ecological Indicators 10 pp. 24-31

Ohta, Hirohiko., (2001) A phenomenological approach to natural landscape cognition. Journal of Environmental Psychology 21, pp. 387-403

Oláh András Béla (2012): A városi beépitettség és a felszintipusok hatása a kisugárzási hömérsékletre. Doktori értekezés, Budapesti Corvinus Egyetem, Budapest

ÖKOPLAN Kft. (1994) Budapesti digitális zöldfelületi kataszter. Budapest Főváros Főpolgármesteri Hivatala Környezetvédelmi Ügyosztály, Budapest 
PÉCSI és SÁRFALVI 1960

PEDROLI, ELSEN és MANSVELT 2007

PEONEER VALLEY

PLANNING COMMISION 1997

PETRIK 2007

208 POLO 1984

209 PORTER és AHERN 2002

210 ROGGE, NEVENS és GULINCK 2007
Pádárné Török Éva (2010): Tájrehabilitáció és természetvédelem a településrendezés tervek tükrében, a Tétényi-fennsík egy részének arculatváltozása. 221-228 p. In: SALLAY ÁGNES (Szerk.) Ormos Imre Tudományos Ülésszak LOV 2009 Tájépitészeti tanulmányok. Budapesti Corvinus Egyetem, Tájépítészeti Kar, Budapest

Paládi-Kovács Attila (2007): Ipari táj. Akadémiai Kiadó, Budapest

James F. Palmer, Robin E. Hoffman (2001): Rating reliability and representation validity in scenic landscape assessments. Landscape and Urban Planning 54 pp. 149-161

Palmer, James. F., Lankhorst, Janneke. Roos-Klein. (1998): Evaluating visible spatial diversity in the landscape. Landscape and Urban Planning 43. pp.) 65-78

Paracchini, Maria. Luisa., Terres, Jean-Michel., Petersen, Jan-Erik., Hoogeveen, Ybele. (2007): High nature value farmland and traditional agricultural landscapes. 21-34. p. In : PEDROLI, BAS., VAN DOORN, ANNE., DE BLUST, GEERT., PARACCHINI, MARIA. LUISA., WASCHER, DIRK., BUNCE, FREDA. (Szerk.): Europe's Living Landscapes. Essays exploring our identity in the countryside. Landscape Europe, Wageningen / KNNV Publishing, Zeist.

Patay István (2003): A szélenergia hasznositása. Szaktudás Kiadó Ház, Budapest

Peccol, Elisabetta., Bird, A. Chris., Brewer, Tim. R. (1996): GIS As A Tool For Assessing The Influence Of Countryside Designations and Planning Policies On Landscape Change. Journal of Environmental Management 47, pp. 355-367

Pécsi Márton (Szerk.) (1989): Magyarország Nemzeti Atlasza. Magyar Tudományos Akadémia és a Mezőgazdasági és Élelmezésügyi Minisztérium megbízásából a Kartográfiai Vállalat

Pécsi Márton, Sárfalvi Béla (1960): Magyarország földrajza. Akadémiai Kiadó, Budapest

Pedroli, Bas., Wascher, Dirk., de Blust, Geert., Paracchini, Maria. Luisa., van Doorn, Anne., (2007): High nature value farmland and traditional agricultural landscapes. 11-18. p. In : PEDROLI, BAS., VAN DOORN, ANNE., DE BLUST, GEERT., PARACCHINI, MARIA. LUISA., WASCHER, DIRK., BUNCE, FREDA. (Szerk.): Europe's Living Landscapes. Essays exploring our identity in the countryside. Landscape Europe, Wageningen / KNNV Publishing, Zeist.

G.B.M. Pedrolil.(*), Th. Van Elsen (2) and J.D. Van Mansvelt (3) (2007): Values of rural landscapes in Europe: inspiration or by-product? NJAS - Wageningen Journal of Life Sciences, 54, 4. pp. 431-447

Peoneer Valley Planning Commision (1997): Conserving Rural Lands New Tools for Small Communities in Protecting Natural Resources, Managing Growth and Enhancing Community Character. Scenic Amerika, American Planning Association, Planning Advisory Service Report

Petrik Ottó (2007): Mikrohullámú távérzékelt adatok integrálása a felszínvizsgálatokba. PhD doktori értekezés, Földtudományi Doktori Iskola, ELTE. Budapest

Polo, Marco (1984): Marco Polo utazásai. Gondolat Kiadó, Budapest

Porter, Jonathan., Ahern, Kate., (2002): Landscape Character Assessment Guidance for England and Scotland, Topic paper 4 Use of Geographical Information Systems and other computer methods. The Countryside Agency and Scottish Natural Heritage

Rogge, Elke., Nevens, Frank., Gulinck, Hubert. (2007): Perception of rural landscapes in Flanders: Looking beyond aesthetics. Landscape and Urban Planning 82 pp. 159-174 
211 ROGGE, NEVENS és GULINCK 2008

212 ROTTLE 2006

213 SALEH 2001

214 SALLAY 2011

215 SALLAY és BÁRCZINÉKAPOVITS 2010

216 SALLAY, JOMBACH és FILEPNÉ KOVÁCS 2012

217 SANDERSON 2009

218 SAYADI et al. 2009

219 SCHMID 2001

220 SCHNEEBERGER et al. 2007

221 SCHNELLER 2010

222 SCOTT 2011

223 SERRA, PONS és SAURÍ 2008

224 SEVENANT és ANTROP 2009

225 SHANNON, SMARDON és KNUDSON 1995

226 SHEPPARD és CIZEK 2009
Rogge, Elke., Nevens, Frank., Gulinck, Hubert. (2008): Reducing the visual impact of 'greenhouse parks' in rural landscapes. Landscape and Urban Planning 87 pp. 76-83

Rottle, Nancy D. (2006): Factors in the landscape-based greenway: a Mountains to Sound case study. Landscape and Urban Planning 76 134-171. Landscape and Urban Planning 76 pp. 134-171

Saleh, Mohammed. A. Eben. (2001): Environmental cognition in the vernacular landscape: assessing the aesthetic quality of Al-Alkhalaf village, Southwestern Saudi Arabia. Building and Environment 36 pp. 965-979

Sallay Ágnes (2011): Tájértékek a zsámbéki medencében. 97-104 p. In: MÁTÉ ZSUZSANNA, KOLLÁNYI LÁSZLÓ (Szerk.) Rejtőzködő kincsek. Budapesti Corvinus Egyetem. Tájtervezési és Területfejlesztési Tanszék, Budapest

(2010): Zöldút tervezés. 179-189 p. In: SALLAY ÁGNES (Szerk.) Ormos Imre Tudományos Ülésszak LOV 2009 Tájépitészeti tanulmányok. Budapesti Corvinus Egyetem, Tájépítészeti Kar, Budapest

Sallay Ágnes, Jombach Sándor, Filepné Kovács Krisztina (2012): Landscape changes and function lost landscape values. Applied Ecology and Environmental Research 2., pp. 157-172.

Sanderson, Eric. W. (2009): Mannahatta, A natural history of New York City. Abrams, New York, USA

Sayadi, Samir., González-Roa, M. Carmen., Calatrava-Requena, Javier. (2009): Public preferences for landscape features: The case of agricultural landscape in mountainous Mediterranean areas. Land Use Policy 26 .pp. 334-344

Schmid, Willy. A. (2001): The emerging role of visual resource assessment and visualisation in landscape planning in Switzerland. Landscape and Urban Planning 54 pp. 213-221

Schneeberger, Nina., Bürgi, Matthias., Hersperger, Anna. M., Ewald, K.C. (2007): Driving forces and rates of landscape change as a promising combination for landscape change research - An application on the northern fringe of the Swiss Alps. Land Use Policy 24 pp. 349 361

Schneller István (2010): Lakóparkok Budapesten. 253-270 p. In: SALLAY ÁGNES (Szerk.) Ormos Imre Tudományos Ülésszak LOV 2009 Tájépítészeti tanulmányok. Budapesti Corvinus Egyetem, Tájépítészeti Kar, Budapest

Scott, Alister (2011): Beyond the conventional: Meeting the challenges of landscape governance within the European Landscape Convention? Journal of Environmental Management 92, pp. 2754-2762

Serra, P., Pons, X., Saurí, D. (2008): Land-cover and land-use change in a Mediterranean landscape: A spatial analysis of driving forces integrating biophysical and human factors. Applied Geography 28, pp. 189-209

Sevenant, Marjanne., Antrop, Marc. (2009): Cognitive attributes and aesthetic preferences in assessment and differentiation of landscapes. Journal of Environmental Management 90 pp. 2889-2899

Shannon, Scott., Smardon, Richard., Knudson, Melinda. (1995): Using visual assessment as a foundation for greenway planning in the St. Lawrence River Valley. Landscape and Urban Planning 33 pp. 357-371

Sheppard, Stephen. R.J., Cizek, Petr (2009): The ethics of Google Earth: Crossing thresholds from spatial data to landscape visualisation. Journal of Environmental Management 90. pp. 2102-2117 
227 SKÅNES és BUNCE 1997

228 SKÄRBÄCK és BECHT 2005

229 SOLIVA és HUNZIKER 2009

230 SOTO és PINTÓ 2010

231 SOUTHERN et al. 2011

232 STEINITZ et al. 2003

233 STRAND 2011

234 SWANWICK 2002

SWANWICK 2002 TP1

SWANWICK 2002 TP6

237 SWANWICK et al. 2002 TP3

238 SWENSEN és JERPÅSEN 2008

SZABÓ 1954

240

SZABÓ 2011

SZTEJN, ŁABĘDŹ és OZIMEK 2012
Skånes, H.M., Bunce, R.G.H. (1997): Directions of landscape change (1741- 1993) in Virestad, Sweden - characterised by multivariate analysis. Landscape and Urban Planning 38 pp. 61-75

Erik Skärbäck , Peter Becht (2005): Landscape perspective on energy forests. Biomass and Bioenergy 28 pp. 151-159

Soliva, R., Hunziker, M. (2009): Beyond the visual dimension: Using ideal type narratives to analyse people's assessments of landscape scenarios. Land Use Policy. 26. pp. 284-294.

Soto, Sandra., Pintó, Josep. (2010): Delineation of natural landscape units for Puerto Rico. Applied Geography 30 pp. 720-730

Southern, Adrian., Lovett, Andrew., O'Riordan, Tim., Watkinson, Andrew., (2011): Sustainable landscape governance: Lessons from a catchment based study in whole landscape design. Landscape and Urban Planning 101. pp. 179-189

Steinitz, Carl., Arias, Hector., Bassett, Scott., Flaxman, Michael., Goode, Tomas., Maddock III, Thomas., Mouat, Davis., Peiser, Richard., Shearer, Allan. (Szerk.) (2003): Alternative Futures for Changing Landscapes. - The Upper San Pedro riverbasin in Arizona and Sonora. Island Press, Washington, Covelo, London

Strand, Geir-Harald. (2011): Uncertainty in classification and delineation of landscapes: A probabilistic approach to landscape modeling. Environmental Modelling \& Software 26. pp. 1150-1157

Swanwick, Carys (2002): Landscape Character Assessment Guidance for England and Scotland. The Countryside Agency and Scottish Natural Heritage

Swanwick, Carys., (2002): Landscape Character Assessment Guidance for England and Scotland Topic Paper 1: Recent practice and the evolution of Landscape Character Assessment. The Countryside Agency and Scottish Natural Heritage

Swanwick, Carys (2002 TP6): Landscape Character Assessment Guidance for England and Scotland Topic Paper 6: Techniques and Criteria for Judging Capacity and Sensitivity, The Countryside Agency and Scottish Natural Heritage

Swanwick, Carys., Bingham, Liz., Parfitt, Alison. (2002): Landscape Character Assessment Guidance for England and Scotland Topic Paper 3: Landscape Character Assessment - How stakeholders can help. The Countryside Agency and Scottish Natural Heritage

Swensen, Grete., Jerpåsen, Gro. B. (2008): Cultural heritage in suburban landscape planning - A case study in Southern Norway. Landscape and Urban Planning 87 pp. 289-300

Szabó László (1954): Magyarország földrajza. Müvelt Nép Könyvkiadó, Budapest

Szabó Gergely (2011): Az ASTER GDEM adatbázis pontosságának vizsgálata egy hazai mintaterületen. 421-429. p. In: LÓKI JÁNOS (Szerk.) Az elmélet és a gyakorlat találkozása a térinformatikában: II. Térinformatikai Konferencia és Szakkiállítás Debrecen. Debreceni Egyetem, Debrecen, pp. 421-429.

Szabó Gergely, Szabó Szilárd (2010): A Shuttle Radar Topography Mission (SRTM) során nyert adatbázis pontosságának vizsgálata hazai mintaterületeken. Geodézia és Kartográfia 62/(3) pp. 31-35.

Sztejn, Jan., Łabędź, Piotr., Ozimek, Paweł (2012): Visual Landscape Character in the Approach of GeoDesign. 227-234 p. In: BUHMANN, ERVIN, PIETSCH (Szerk.) Peer Reviewed Proceedings of Digital Landscape Architecture 2012. Anhalt University of Applied Sciences, Herbert Wichmann Verlag, Berlin 
243 TAILLEFUMIER és PIÉGAY 2003

244 TAMÁS 2000

245 TELEKI 1996

246 THE LANDSCAPE INSTITUTE 2002

247 TIRÁSZI 2008

248 TIRÁSZI 2011

249 TIRÁSZI, TERPÓ és KONKOLY-GYURÓ 2013

250 TORREGGIANI és TASSINARI 2012

251 TRESS és TRESS 2003

252 TRIMBLE 2010

253 TSO és MATHER 2001

254 TVEIT 2009

255 US FOREST SERVICE 1989

256 VÁMBÉRY 1966

257 VAN EETVELDE és ANTROP 2004

258 VAN EETVELDE és ANTROP 2009a

259 VAN EETVELDE és ANTROP 2009b

260 VEJRE, PRIMDAHL és BRANDT 2007
Fabrice Taillefumier, Hervé Piégay (2003): Contemporary land use changes in prealpine Mediterranean mountains: a multivariate GISbased approach applied to two municipalities in the Southern French Prealps. Catena 51 pp. 267-296

Tamás János (2000): Térinformatika I. Debreceni Egyetem Mezőgazdaságtudományi Kar, Debrecen

Teleki Pál (1996, (eredeti 1917)): A földrajzi gondolat története. Kossuth Könvkiadó, Budapest

The Landscape Institute with the Institute of Environmental Management and Assessment (2002): Guidelines for Landscape and Visual Impact Assessment. Spoon Press Taylor and Francis Group, London and New York

Tirászi Ágnes (2008): Tájindikátorok alkalmazásának története Európában. 99-106 p. In: CSIMA PÉTER és BODA BRIGITTA (Szerk.) Budapesti Corvinus Egyetem, Tájvédelmi és Tájrehabilitációs Tanszék, Budapest

Tirászi Ágnes (2011): A tájakat formáló országos és Európai Uniós politikák hatásvizsgálata. Doktori értekezés, Nyugat-magyarországi Egyetem, Sopron

Tirászi Ágnes, Terpó Veronika, Konkoly-Gyuró Éva (2013): Tájváltozás vizsgálata múltbéli és jelenkori fényképfelvételek alapján a Fertő tájon. Tájökológiai Lapok. 11/2. pp. 325-333

Torreggiani, Daniele., Tassinari, Patrizia (2012): Landscape quality of farm buildings: The evolution of the design approach in Italy. Journal of Cultural Heritage 13 pp. 59-68

Tress, B., Tress, G., (2003): Scenario visualisation for participatory landscape planning - a study from Denmark, Landscape and Urban Planning. 64 pp. 161-178.

Trimble (2010): eCognition Developer - User Guide. Trimble Documentation, München Germany

Tso, Brandt., Mather, Paul. M., (2001): Classification Methods for Remotely Sensed Data. Taylor \& Francis, London,

Mari Sundli Tveit (2009): Indicators of visual scale as predictors of landscape preference; a comparison between groups. Journal of Environmental Management 90. 2882-2888

US Forest Service (1989): Landscape Character Types of the National Forests in Arizona and New Mexico, The Visual Management System. United States Department of Agriculture, Forsest Service, Southwestern Region

Vámbéry Ármin (1966): Dervisruhában Közép-Ázsián át. Gondolat kiadó, Budapest

Van Eetvelde, Veerle. Antrop, Marc. (2004): Analyzing structural and functional changes of traditional landscapes - two examples from Southern France. Landscape and Urban Planning 67 pp. 79-95

Van Eetvelde, Veerle. Antrop, Marc. (2009): A stepwise multi-scaled landscape typology and characterisation for trans-regional integration, applied on the federal state of Belgium. Landscape and Urban Planning, Volume 67, Issues 1-4, pp. 79-95

Van Eetvelde, Veerle. Antrop, Marc. (2009): Indicators for assessing changing landscape character of cultural landscapes in Flanders (Belgium). Land Use Policy 26. pp. 901-910

Vejre, Henrik., Primdahl, Jørgen., Breandt, Jesper. (2007): The Copenhagen Finger Plan, Keeping an green space structure by a simple planning metaphor. 311-328 p. In : PEDROLI, BAS., VAN DOORN, ANNE., DE BLUST, GEERT., PARACCHINI, MARIA. LUISA., WASCHER, DIRK., BUNCE, FREDA. (Szerk.): Europe's Living Landscapes. Essays exploring our identity in the countryside. Landscape Europe, Wageningen / KNNV Publishing, Zeist. 
Verburg, Peter., H. Schulp, C.J.E., Witte, N., Veldkamp, A. (2006): Downscaling of land use change scenarios to assess the dynamics of European landscapes. Agriculture, Ecosystems and Environment. 114. pp. 39-56

262 WALKER és RYAN 2008

Walker, Amanda J., Ryan, Robert L. (2008): Place attachment and landscape preservation in rural New England: A Maine case study. Landscape and Urban Planning 86 pp. 141-152

263 WASCHER 2005

Wascher, Dirk. M. (Szerk.) (2005): European Landscape Character Areas - Typologies, Cartography and Indicators for the Assessment of Sustainable Landscapes. LANDSCAPE EUROPE in collaboration with ELCAI project partners

264 WU et al 2006

Wu, Qiong., Li, Hong-qing., Wang, Ru-song ., Paulussen, Juergen., He, Yong., Wang, Min., Wang, Bi-hui., Wang, Zhen., (2006): Monitoring and predicting land use change in Beijing using remote sensing and GIS. Landscape and Urban Planning 78 pp. 322-333

265 XU 2006

$\mathrm{Xu}$, Hanqiu (2006): Modification of normalised difference water index (NDWI) to enhance open water features in remotely sensed imagery. International Journal of Remote Sensing. Vol. 27, No. 14. pp. 30253033

$266 \quad \mathrm{XU} 2007$

$267 \quad$ YANG 2011

268 YEH és HUANG 2009

269 ZHANG, WANG és LI 2006

270 ZOMENI, TZANOPOULOS és PANTIS 2008

Xu, Hanqiu (2007): Extraction of Urban Built-up Land Features from Landsat Imagery Using a Thematicoriented Index Combination Technique. Photogrammetric Engineering \& Remote Sensing Vol. 73, No. 12, December 2007, pp. 1381-1391.

Yang, Xiaojun. (2011): Urban remote sensing. Wiley-Blackwell, John Wiley and Sons, Hoboken, NJ, USA

Chia-Tsung Yeh, Shu-Li Huang (2009): Investigating spatiotemporal patterns of landscape diversity in response to urbanization. Landscape and Urban Planning 93 pp. 151-162

Zhang, Jinqu., Wang, Yunpeng., Li, Yan (2006): A C++ program for retrieving land surface temperature from the data of Landsat TM/ETM+ band6. Computers \& Geosciences 32 pp. 1796-1805

Maria Zomeni, Joseph Tzanopoulos, John D. Pantis (2008): Historical analysis of landscape change using remote sensing techniques: An explanatory tool for agricultural transformation in Greek rural areas. Landscape and Urban Planning 86 pp. 38-46

\section{Világhálójegyzék}

INT-001 N.R.T.M. BMW 20123-as Limousine gépjármüvet http://nrtm.lapunk.hu/?modul=oldal\&tartalom=1174279 bemutató oldala (2012-07-12)

INT-002 Az ÖKOPLAN Kft Alsó-Duna-völgyi Tájérték www.aduvizig.hu Leltára az 1997-es Duna felmérés eredményeivel (2004. 11.05.)

INT-003 A Tájérték-kataszter Projekt honlapja (2014. 01. http://tajertektar.hu/hu/ 17.)

INT-004 A NASA SRTM felmérését bemutató oldala http://www2.jpl.nasa.gov/srtm/ (2014. 01. 18.)

INT-005 SRTM adatok letöltésére szolgáló oldal (2014. 01. http://srtm.csi.cgiar.org/SELECTION/inputCoord.asp 18.)

INT-006 ASTER GDEM adatokat ismertető oldal (2014. http://gdem.ersdac.jspacesystems.or.jp/ 01. 18.)

INT-007 A fényképezésről szóló wikipédia oldal (2014. 01. http://hu.wikipedia.org/wiki/F\%C3\%A9nyk\%C3\%A9pez\% 18.) C3\%A9s

INT-008 A bruel.hu hőkamerákat bemutató oldala (2014. http://www.bruel.hu/hokamera.htm\#ismerteto 01. 18.)

INT-009 A PIXINFO.com infravörös fényképezést http://pixinfo.com/cikkek/fujifilm_finepix_is-1_r/ bemutató oldala (2014. 01. 18.)

INT-010 Magyar Múzeumi Képeslap Katalógus oldala http://muzeum.arcanum.hu/kepeslapok/opt/a120529.htm?v (2014. 01. 18.) $=$ pdf\&a $=$ start 
INT-011 HM Zrínyi Térképészeti és Kommunikációs http://www.topomap.hu/ Szolgáltató Közhasznú Nonprofit Kft oldala (2014. 01. 18.)

INT-012 A FÖMI honlapjának légifelvételeket bemutató http://www.fomi.hu/portal/index.php/termekeink/legifelvet oldala (2014. 01. 18.) elek

INT-013 Az Interspect Kft. Ferde tengelyü légifotókat http://www.interspect.hu/index.php/legifotok-ferdebemutató oldala (2014. 01. 19.) tengely-legifelvetelek.html

INT-014 Az Európai Ürügynökség (ESA) NOAA AVHRR- http://earth.esa.int/object/index.cfm?fobjectid=3754 $\mathrm{t}$ ismertető honlapja (2014. 01. 19.)

INT-015 Az Amerikai Nemzeti Repülési és Ürhajózási http://landsat.gsfc.nasa.gov/ Hivatal (NASA) Landsat Programot ismertető oldala (2014. 01. 19.)

INT-016 A Satellite Imaging Corporation SPOT http:/www.satimagingcorp.com/gallery-spot5-images.html müholdakat bemutató oldala (2014. 01. 19.)

INT-017 A Satellite Imaging Corporation müholdakat http://www.satimagingcorp.com/satellite-sensors.html bemutató oldala (2014. 01. 19.)

INT-018 A JRC IMAGE 2000 projektet bemutató honlapja http://image2000.jrc.ec.europa.eu/ (2014. 01. 19.)

INT-019 A JRC CLC 2000 projektet bemutató honlapja http://image2000.jrc.ec.europa.eu/index.cfm/page/clc_2000 (2014. 01. 19.)

INT-020 Az Európai Környezetvédelmi Ügynökség CLC-t http://www.eea.europa.eu/publications/COR0-landcover bemutató oldala (2014. 01. 19.)

INT-021 A FÖMI CORINE Felszínborítási Adatokat http://fomi.hu/portal/index.php/termekeink/corine bemutató oldala (2014. 01. 19.)

INT-022 Az Európai Környezetvédelmi Ügynökség http://www.eea.europa.eu/data-and-maps/data/corine-landCLC2000 letöltését biztosító oldala (2014. 01. cover-2000-clc2000-seamless-vector-database-4 19.)

INT-023 Az Európai Környezetvédelmi Ügynökség CLC http://www.eea.europa.eu/data-andváltozásadatok letöltését biztosító oldala $(2014$. maps/data\#c11=landuse \&c17=\&c5=all\&c0=5\&b_start=5 01. 19.)

INT-024 A FÖMI CLC50 adatbázist ismertető oldala (2014. http://www.fomi.hu/corine/clc50_index.html 01. 19.)

INT-025 Az Európai Környezetvédelmi Ügynökség http://www.eea.europa.eu/data-and-maps/data/urbanEuropean Urban Atlas-t ismertetö oldala (2014. atlas/mapping-guide 01. 19.)

INT-026 A NASA MODIS termékeket bemutató oldala http://modis-land.gsfc.nasa.gov/\# (2014. 01. 19.)

INT-027 A japán J-spacesystems honlap ASTERGDEM http://www.jspacesystems.or.jp/ersdac/GDEM/E/1.html adatbázist bemutató oldala (2014. 01. 19.)

INT-028 A NASA NDVI-t ismertető honlapja (2014. 01. http://earthobservatory.nasa.gov/Features/MeasuringVegeta 20.) tion/measuring_vegetation_2.php

INT-029 Az EEA Európai Tájtípus térképét bemutató oldala http://www.eea.europa.eu/data-and-maps/figures/the(2014. 01.25.)

INT-030 A DEM Explorer honlapja (2014. 02. 05.)

INT-031 A SENSOR projekt honlapja (2014. 01. 28.) dominant-landscape-types-of-europe http://ws.csiss.gmu.edu/DEMExplorer/

INT-032 Budapesti Corvinus Egyetem Entz Ferenc http://efkl.uni-corvinus.hu/ Könyvtár és Levéltár honlapja (2013. 06. 16.)

INT-033 BOKU könyvtárának honlapja (2013. 06. 16.) http://www.boku.ac.at/

INT-034 Belgrádi Egyetem könyvtárának honlapja (2013. http://prijemni.infostud.com/Sumarski-fakultet/Beograd/98 06. 16.)

INT-035 UMASS Amherst könyvtárának honlapja (2013. http://www.umass.edu/ 06. 16.)

INT-036 Elektronikus Információszolgáltatás honlapja http://www.eisz.hu (2014. 02. 11.)

INT-037 Az ELTE földkutatás oldalán összegzett SRTM http://sas2.elte.hu/mg/foldkutatas_v3/11radar3srtm.htm kutatás összefoglalója (2014. 02. 12.)

INT-038 Google Books Bölöni Farkas Sándor Útazás Észak http://books.google.hu/books?id=6_82GP iCvcC\&printsec Amerikában könyvének szkennelt változatáról =frontcover\&dq=inauthor:\%22S\% $\% 3 \% \mathrm{C}$ ndor $+\mathrm{B} \% \mathrm{C} 3 \% \mathrm{~B}$ (2014. 02. 09.) $61 \% \mathrm{C} 3 \%$ B6ni + Farkas $\% 22 \& \mathrm{hl}=$ en\&sa $=\mathrm{X} \&$ ei $=$ YrnFUuz4Fs GTywOqr4D4DQ\&ved=0CDAQ6AEwAA\#v= onepage \&q $\& \mathrm{f}=$ false

INT-039 Terebess Ázsia E-Tár (2014. 02. 09.) http://terebess.hu/keletkultinfo/orban2.html 
INT-040 Magyar Elektronikus Könyvtár, Orbán Balázs: http://mek.niif.hu/04800/04804/html Székelyföld leírása (2014. 02. 09.)

INT-041 Magyar Elektronikus Könyvtár összefoglalója http://mek.oszk.hu/04900/04915/html/teleki samuel0000.ht Teleki Sámuel gróf felfedező útjáról (2014. 02. ml 09.)

INT-042 Magyar Elektronikus Könyvtár Czárán Gyula http://mek.oszk.hu/05400/05473/index.phtml Pdf kalauzáról rendelkezésre álló információk (2014. 02. 09.)

INT-043 Magyar Elektronikus Könyvtár, Cholnoky Jenő: A http://mek.oszk.hu/07500/07532/pdf/sivatag1.pdf sivatag (2014. 02. 09.) http://mek.oszk.hu/07500/07532/pdf/sivatag2.pdf

INT-044 FÖMI DDM Domborzati adatatokat ismertető http://www.fomi.hu/portal/index.php/termekeink/domborza oldala (2014. 02. 11.)

INT-045 NOAA National Geophysical Data Center http://www.ngdc.noaa.gov/mgg/global/etopo5.HTML ETOPO5 modellt ismertető oldala (2014. 02. 11.)

INT-046 GLSDEM adatokat ismertető oldal (2014. 02. 11.) http://www.landcover.org/data/glsdem/

INT-047 A NASA SRTM-et ismertető oldala (2014. 02. http://www2.jpl.nasa.gov/srtm/ 11.)

INT-048 A NASA ASTER GDEMv2 modellt ismertető http://asterweb.jpl.nasa.gov/gdem.asp oldala (2014. 02. 11.)

INT-049 Az EEA World DEM letöltését biztosító oldala http://www.eea.europa.eu/data-and-maps/data/world(2014. 02. 11.) digital-elevation-model-etopo5

INT-050 Az SRTM adatok letöltését biztosító oldal (2014. http://www.cgiar-csi.org/data/srtm-90m-digital-elevation02. 11.) database-v4-1

INT-051 A METI ASTER GDEMv2 modell letöltését http://gdem.ersdac.jspacesystems.or.jp/search.jsp biztosító oldala (2014. 02. 11.)

INT-052 A NASA ASTER GDEMv2 modell letöltését http://reverb.echo.nasa.gov/reverb/\#utf8=\%E2\%9C\%93\&s biztosító oldala (2014. 02. 11.) patial_map $=$ satellite\&spatial_type $=$ rectangle

INT-053 A USGS ASTER GDEMv2 modell letöltését http://gdex.cr.usgs.gov/gdex/ biztosító oldala (2014. 02. 11.)

INT-054 Eurostat adatok honlapja (2014. 01. 28.)

INT-055 A KSH lakónépességről szóló oldala (2014. 01. 29.) http://epp.eurostat.ec.europa.eu/portal/page/portal/statistics/ themes

http://www.ksh.hu/docs/hun/xstadat/xstadat_eves/i_wdsd00 3b.html

\section{Jogszabályok jegyzéke}

1996. évi LIII. Törvény

1996. évi LXXVI. Törvény

2003. évi XXVI. Törvény

2007. évi CXI. törvény

2012. évi XLVI. Törvény

21/1997. (III. 12.) FM-HM együttes rendelet

34/2003./X.21./ XI.ÖK sz. rendelete

34/2003./X.21./ XI.ÖK sz. rendelete (egységes szerkezetben 2009. június 10-i hatállyal)

399/2012. (XII. 20.) Korm. Rendelet

COUNCIL OF EUROPE 2000 a természet védelméről

a földmérési és térképészeti tevékenységről

az Országos Területrendezési Tervröl

a Firenzében, 2000. október 20-án kelt, az Európai Táj Egyezmény kihirdetéséről

a földmérési és térképészeti tevékenységről

a földmérési és térképészeti tevékenységről szóló 1996. évi LXXVI. törvény egyes rendelkezéseinek végrehajtásáról

Budapest Főváros XI. Kerületi Önkormányzat, 34/2003./X.21./ XI.ÖK sz. rendelete, Budapest XI. kerület Kerületi Városrendezési és Építési Szabályzatáról

Budapest Főváros XI. Kerületi Önkormányzat, 34/2003./X.21./ XI.ÖK sz. rendelete, Budapest XI. kerület Kerületi Városrendezési és Építési Szabályzatáról (egységes szerkezetben 2009. június 10-i hatállyal)

a légi távérzékelés engedélyezésének és a távérzékelési adatok használatának rendjéről

Council of Europe (2000): European Landscape Convention. ETS No. 176, Florence 


\section{TÁBLÁZATJEGYZÉK}

1. táblázat Tájfogalmak

2. táblázat Tájkarakter fogalmak

3. táblázat Tájelem-példák, tájelem-típusok elméleti és gyakorlati megközelítésben

4. táblázat A tájkarakter-elemzés lehetséges céljai (SWANWICK 2002, 53 alapján)

5. táblázat Jelentősebb, tájkarakterre is kiható tájváltozási folyamatok

6. táblázat Néhány utazó és tájmonográfia szerző munkájában fellelhető karakter-elemzési jellegủ módszertani elem és eszköz

7. táblázat Tájkarakter-elemzés technikai eszköztárának elemei

8. táblázat Távérzékelés fogalmak

9. táblázat Passzív és aktív távérzékelés összevetése néhány szempont alapján (feldolgozott források: LILLESAND, KIEFER és CHIPMAN 2004, MUCSI 2004)

10. táblázat A legfontosabb távérzékeléssel kapcsolatos fogalmak

11. táblázat A 2012. évi XLVI. a földmérési és térképészeti tevékenységről szóló törvény szövegének részlete az állami távérzékelési adatbázisról

12. táblázat Kontraszt és élesség kezelésének fontosabb eljárásai

13. táblázat A távérzékelés interpretációs elemei. (BUITEN 1993 in KRISTÓF 2005, 44; LILLESAND ET AL. 2004, 306-310; ARONOFF 2005, 262-266; 39-40; JENSEN 2007, 133 munkáinak feldolgozásával)

14. táblázat A passzív képalkotó távérzékelés szerepét indokoló témák a tájkarakter-elemzési útmutatóban és kapcsolódó függelékekben.

15. táblázat Digitális magassági adatok alapvető sajátosságainak összevetése

16. táblázat A felhasznált felvételek listája

17. táblázat A felhasznált térképek listája

18. táblázat A felhasznált térképi adatbázisok listája

19. táblázat A mintaterületek főbb sajátosságai

20. táblázat Az irodalomkutatás és terepbejárás során feltárt domináns tájváltozási tendenciák a négy mintaterületen, vagy azok egy részén

21. táblázat Tájelemek interpretálhatósága, elemezhetősége passzív képalkotó távérzékelés eszközeivel.

22. táblázat Passzív képalkotó távérzékeléssel nyert adatok felhasználásának gyakorlata léptéktől függően

23. táblázat Tájkarakter-elemzés folyamatához illeszkedő képfelhasználási javaslatok és képfeldolgozási eljárások

24. táblázat A tájkarakter-elemzés „osztályozás és leírás” lépéséhez illeszkedő felhasználási javaslatok és feldolgozási eljárások

25. táblázat Passzív távérzékelési adatok feldolgozásához használható indexek és térbeli mutatók

26. táblázat A ZFI mezőgazdasági területekre felhasznált landsat4-5 TM és Landsat ETM+ müholdfelvételek készítésének időpontja és USGS azonosítója

27. táblázat Zöldfelület-intenzitás átlagértékek 1986 és 2011 közötti időszak 25 Landsat TM és ETM+ felvétele alapján.

28. táblázat A CLC 100 adatbázisban előforduló felszínboritás kategóriák jellemzése tájképi nyitottság szerint (felszínborítás-kódokkal)

29. táblázat Az erdők szerepe az európai felszínborítások változásában a CLC 2000-2006 adatbázis szerint (Görögország esetében 1990-2000 időszakra)

30. táblázat A „táj nyitottságának változása” indikátor számításának módszere

31. táblázat Eltűnő és megjelenő tájelemek

32. táblázat Budapest Főváros XI. Kerületi Önkormányzat 49/2005./X.28./ XI.ÖK számú rendeletéből

33. táblázat Délnyugat-Budakörnyéki mintaterület 9 kilátóhelyének jellemzése

34. táblázat Délnyugat-Budakörnyéki mintaterület 9 kilátópontjáról feltáruló táj elemzéséhez felhasznált tényezők 


\section{ÁBRAJEGYZÉK}

1. ábra A táj összetettségét érzékeltető ábra Swanwick Tájakrakter-elemzési útmutatójából „Mi a táj?” címmel (SWANWICK 2002, 2) és magyar és német (KONKOLY-GYURÓ 2010, 9) valamint szerb fordítása (JASMINKA., VASILJEVIC és TUTUNDŽIĆ 2007, 4)

2. ábra Anglia és Skócia tájkarakter-térképei (SWANWICK 2002, 48-49)

3. ábra A tájkarakter-elemzés fontosabb lépései (SWANWICK 2002, 13)

4. ábra Az integrált tájmegfigyelés adatforrásai és felhasználhatóságuk Glauser nyomán Konkolyné Gyuró szerint (KONKOLYNÉ GYURÓ 2003, 161)

5. ábra A LANMAP2 Európai tájtipológia térképhez felhasznált alapadatok (MÜCHER et al. 2010, 89, 91)

6. ábra A LANMAP2 Európai tájtipológia térkép alapadatai, egyszerüsítésük módja a kategóriák összevonásával (MÜCHER et al. 2010, 101)

7. ábra A LANMAP2 módszertan folyamatábrája (MÜCHER et al. 2010, 90)

8. ábra A LANMAP2 olaszországi és spanyolországi részlete (MÜCHER et al. 2010, 93, 97)

9. ábra Alapadatok a Csehország tájtípusait lehatároló elemzésben és a térképezett tájkarakter típusok (CHUMAN és ROMPORTL 2010, 202, 207)

10. ábra Módszertani javaslat a térinformatikai adatok felhasználására és a karakter-elemzés lépéseinek elvégzésére (VAN EETVELDE és ANTROP 2009a 164)

11. ábra Puerto Rico tájkarakter típus (a) és tájkarakter terület (c) térképezése és az elemzés folyamata (b) (SOTO és PINTÓ 2010, 723, 725, 728)

12. ábra Ábrák Antonson tanulmányából, melyek az infrastruktura-tevezéshez javasolt tájkarakter-térképet és látványrajzot mutatnak be (ANTONSON 2009, 169-177)

13. ábra Az Etna „,tradicionális kultúrtáj” térképezésének adatfeldolgozási lépéseinek és szintjeinek modellje (CULLOTTA és BARBERA 2011, 103-104)

14. ábra Domborzati formák osztályozásának elve és gyakorlata Dikau alapján (DRĂGUȚ és BLASCHKE 2006, 330-344)

15. ábra A domborzati forma osztályozás részletei (DRĂGUŢ és BLASCHKE 2006, 330-344)

16. ábra A tájkarakter-elemzés a tájökölógiai elemzés módszerével kiegészítve (KIM és PAULEIT 2007, 267)

17. ábra Brabyn által leírt „,aggregáló osztályozás” módszerével készített elemzés egyes alapfedvényei, „lépései” és végeredménye egy új-zélandi tanulmányban (Coromandel-félsziget) (BRABYN 2005, 27-30)

18. ábra A 3Q Program tájváltozás-indikátorai Norvégiában az agrártájak változásának elemzéséhez (DRAMSTAD et al. 2001, 260)

19. ábra Történeti tájváltozás-térképezés elemei (SKÅNES és BUNCE 1997, 65)

20. ábra A VisuLands keretrendszer által vázolt indikátorok koncepcionális alapját megjelenítő, és a nyitottság változását szemléltető ábrák (ODE, TVEIT és FRY 2010, 26)

21. ábra Taipei térségének légifelvételekből digitalizált felszínborítás adatok alapján készített tájdiverzitás-változás elemzésének eredménye (YEH és HUANG 2009, 153, 155, 157)

22. ábra Az utak kettős szerepét elemző kutatás lényege (GARRÉ, MEEUS és GULINCK 2009, 130)

23. ábra Ortofotó és digitális domborzatmodell alapú tájmodellre épített 3D megjelenítés (LANGE és HEHLLANGE 2010, 696-697)

24. ábra Manhattan-sziget jellegének fotorealisztikus vizualizációja az ember tömeges megjelenése előtti időszakban és ma (SANDERSON 2009, 28-29, 208 )

25. ábra Strand valószínüség térképe (STRAND 2011, 1150-1157)

26. ábra A kutatás célja a passzív képalkotó távérzékelés alkalmazási lehetőségeinek bővítése a tájkarakterelemzésben

27. ábra EU $28+3$ állam (Izland, Norvégia, Svájc) mintaterület

28. ábra Magyarország mintaterület

29. ábra Nagyberek térsége mintaterület

30. ábra Délnyugat-Budakörnyék mintaterület

31. ábra A kérdőívekben felhasznált felvételek és kérdőívek mintája a tájmodellek megjelenítéséhez használt magassági modellekről

32. ábra A kérdőívekben és interjúkban felhasznált felvételek mintái és a feltett kérdések a tájrészletek beazonosíthatóságáról

33. ábra A kérdőívekben és interjúkban feltett kérdések a valóság és a 3D tájmodell közötti tájkarakter-megjelenítés különbségeiröl

34. ábra Magassági modellek eltérése a DDM100-hoz képest Magyarország területére

35. ábra Magassági modellek eltérése a DDM5-höz képest mintaterületeken

36. ábra GLS magassági modell eltérése az SRTM-hez képest

37. ábra Magassági modellek eltérései a valóságos tengerszintfeletti magasságot leginkább tükröző DDM100-hoz képest.

38. ábra Tényleges tengerszint-feletti magasság változás hatása a magassági modellek eltéréseire bányagödör feltöltés esetén 
39. ábra Magassági modellek a DDM100 adatbázishoz viszonyított eltéréseinek átlaga (m) Magyarországon különböző domborzati típusok esetén

40. ábra Magassági modellek DDM100-hoz viszonyított eltéréseinek gyakorisága (\%) különbözö kategóriák és domborzati tájtípusok esetén

41. ábra Magassági modellek a DDM5 adatbázishoz viszonyított eltéréseinek átlaga (m) magyarországi mintaterületeken különböző domborzati típusok esetén

42. ábra Magassági modellek DDM5-hoz viszonyított eltéréseinek gyakorisága (\%) különböző kategóriák és domborzati tájtípusok esetén

43. ábra Felvételek, domborzatmodellek és metszetek a Budaörsi Kálváriadomb és Kö-hegy környékére

44. ábra Magassági modellek DDM5-höz viszonyított eltéréseinek átlaga és szórása eredeti felbontású (20-30m) és $5 \mathrm{~m}$-es felbontásra transzformált változat esetén

45. ábra Magassági modellek DDM5-hoz viszonyított eltéréseinek gyakorisága (\%-ban) eredeti felbontású adatok (20-30m) és $5 \mathrm{~m}$-es felbontásúra transzformált adatok esetén (\%)

46. ábra Magassági modelleken mért tengerszint feletti magasság értékek terjedelme európai nagytavak esetén

47. ábra A DDM10-hoz viszonyított domborzatmagasság-különbségek ASTER GDEM változatoknál Balaton nyugati részén és a Marcali víztározó területén

48. ábra Az ASTER GDEMv2 modell felszínborítás típusonkénti eltérései DDM5 modellhez képest

49. ábra Az ASTER GDEMv2 magassági modell eltérései a DDM5-höz képest lejtőkitettség kategóriánként gerecsei mintaterületen

50. ábra Tengerszint feletti magasság maximuma (m) kistájanként

51. ábra Felszínmozgalmasság a kistájak területén belül (m/kistáj)

52. ábra Terep-változatosság

53. ábra A terep átlagos változatossága a kistájak területén

54. ábra Lejtömeredekség

55. ábra Lejtőmeredekség átlaga a kistájak területén

56. ábra Kitettség karakteradó szerepe

57. ábra NDVI vegetációs index elemzés eredményei IMAGE2000 adatok feldolgozásával

58. ábra MNDWI (a Landsat 2,5csatornákra építő) vízfelületi index elemzésének eredményei IMAGE2000 adatok feldolgozásával

59. ábra Erdők aránya Magyarország kistájainak területén

60. ábra Beépített jellegú terület aránya Magyarország kistájainak területén

61. ábra Szántók aránya Magyarország kistájainak területén

62. ábra Rét/legelö és természet-közeli gyep aránya Magyarország kistájainak területén

63. ábra Gyümölcsösök aránya Magyarország kistájainak területén

64. ábra Szölök aránya Magyarország kistájainak területén

65. ábra Vizenyős területek aránya Magyarország kistájainak területén

66. ábra Vízfelszín aránya Magyarország kistájainak területén

67. ábra A Zöldfelület Intenzitás (ZFI) mutató számítási módszere

68. ábra A zöldfelület intenzitás térkép jelkulcsa és magyarázata

69. ábra Zöldfelület-intenzitás adatok felhasználhatósága a lehatárolt területek jellemzésére

70. ábra A zöldfelület-intenzitás minteterületi ellenörzése

71. ábra A ZFI adatbázis mintaterületi ellenőrzése során tapasztalt eltérések (\%) abszolútértéke, különböző típusú mintanégyzetekben

72. ábra A ,nem elfogadható eltérés”

73. ábra Zöldfelület-intenzitás jellemzés Délnyugat-Budakörnyék térségére

74. ábra Mesterséges jellegü felszínborítások (CLC 1all+2all) aránya (\%) a természetszerủ felszínborítás típusokhoz (CLC 3all+4all+5all) viszonyítva kistájanként

75. ábra Természetszerủ felszínborítások arányának (CLC 3all+4all+5all) és a mesterséges jellegủ felszínborítás típusok arányának (CLC 1all+2all) különbségét mutatják kistájanként

76. ábra Kistájak felszínborítás-adatokból számítható nyitottság a jellemző tájelemek magasságától függően

77. ábra Közép-Európai nagyvárosok jellemzése természetszerủ felszínek egyes térbeli sajátosságai alapján

78. ábra Zöldfelület-intenzitás területi átlagolása az Urban Atlas adatbázis foltjaira

79. ábra Településszerkezetre jellemzö zöldfelület-intenzitás

80. ábra Gyakran változó felszínủ területek

81. ábra Tájjelleg-változást eredményező vízfelszín-növekedés

82. ábra Az erdők szerepe az európai felszínborítások változásában a CLC 2000-2006 adatbázis szerint

83. ábra Az erdőszegély változása a korábbi értékhez képest (\%) 2000-2006 közötti időszakban (a) EU28+3 állam területén, (b) NUTS2/NUTS3 régiókban, (c) Biogeográfiai régiókban

84. ábra Az erdőszegély és erdőterület változása a korábbi értékhez képest (\%) 2000-2006 közötti időszakban NUTS2/NUTS3 régiókban az EU28+3 állam területén

85. ábra Az erdőszegély változása a korábbi értékhez képest (\%) Magyarország kistájain 2000-2006 között

86. ábra Az erdőterület változása a korábbi értékhez képest (\%) Magyarország kistájain 2000-2006 között

87. ábra Az településszerkezet változása 
88. ábra A mesterséges felszínek változása

89. ábra A mezőgazdasági jellegü felszínek változása

90. ábra A szántók változása

91. ábra A Táj nyitottságának változása 2000 és 2006 időpontok között Európa egyes államaiban

92. ábra A Táj nyitottságának változása 1990 és 2006 időpontok között Magyarországon

93. ábra Tájjelleg változást tanúsító légifelvételek történeti idősora a Budaörsi-medence központi területére 1940-es évektől 2010-ig

94. ábra A kérdőívezéshez felhasznált képpár az 1920-as évekből és 2008-ból

95. ábra Tájrészletek láthatósága a Nagyberek térségében az elméleti láthatósági mutató alapján (\%).

96. ábra Magyarország területén található tájrészletek és kistájainak elméleti láthatósága

97. ábra Magyarország tájrészleteinek kistájankénti átlagos láthatósága (\%) a közeltérben, köztestérben és távoltérben

98. ábra Magyarország tájrészleteinek és kistájainak lefelé tekintő elméleti láthatósága

99. ábra Magyarország tájrészleteinek és kistájainak felfelé tekintő elméleti láthatósága

100. ábra A tervezett nyergesújfalui cementgyár szállítószalagjának láthatósága Bajóton

101. ábra A Perenyére tervezett szélerőmüvek láthatóságának-elemzése

102. ábra Budapest XI. Kerület, KVSZ, RM-1 számú melléklet, Övezeti térkép, 2003

103. ábra A 2003-as Szabályozási terv 2005 augusztusi módosítása szinkronban a kerület 49/2005./X.28./ XI.ÖK számú rendeletével (6. Melléklet)

104. ábra A Gellért-hegy és a Szabadság-hegy láthatóságának elemzése a Lágymányosi Öböl Közpark közelébe tervezett épületek eltérö építménymagassága esetén

105. ábra A Délnyugat-Budakörnyéki térségben vizsgált kilátóhelyek elhelyezkedése

106. ábra Egyszerű kilátás-fedvények és a fontos látványelemek figyelembevételével készült kilátás-fedvények

107. ábra. Szembenéző lejtők elve, felszínmodell és szembenéző-lejtő elemzés eredménye

108. ábra Szembenéző lejtők meghatározásához kidolgozott eljárás folyamata

109. ábra A János-hegy kilátóhellyel szembenéző lejtők megjelenítése a GoogleEarth-ön

110. ábra Három tájtípus felvételének mintája a 30 fókuszterületből a Délnyugat-Budakörnyéki térségből

111. ábra A vízfelszínek színének tájjelleg-meghatározó szerepe a felvételeken

112. ábra Tévesen vízfelszínnek értelmezett kékeszöld kaszálófolt

113. ábra A különböző felvételeken megjelenő tájrészletek helyes besorolásának aránya (\%) településekbe, a kérdőivek és interjúk eredménye alapján

114. ábra A nagy arányban helyes településhez és kistájhoz kapcsolt tájrészletek felvételei

115. ábra A tájrészletek helyes településbe sorolásának aránya (\%), a különböző felvételeket bemutató kérdőívek és interjúk eredménye alapján

116. ábra A nagy arányban helyesen településhez, de nem megfelelö kistájhoz sorolt helyszínek felvételei

117. ábra A tájrészletek helyes tájegységbe sorolásának aránya (\%), a madártávlati felvételeket bemutató interjúk eredménye alapján

118. ábra A tájjelegbeli eltérés megítéséle madártávlati fényképek és 2,5D tájmodellek között

119. ábra Filmgyár nélküli tájrészlet és filmgyárral rendelkező tájrészlet az etyeki szőlődomb tetején, madártávlati képen és 2,5D tájmodellen

120. ábra A tájjelegbeli eltérés megítéséle madártávlati fényképek és 2,5D és 3D tájmodellek között

121. ábra A tájjelegbeli eltérés megítéséle különböző magassági modelleket használó 2,5D tájmodellek és a DDM5re épülő tájmodell között, eltérő szinteken (térségi, települési, tájrészlet)

122. ábra A tájjelegbeli eltérés megítéséle különböző magassági modelleket használó 2,5D tájmodellek és a DDM5re épülő tájmodell között, tájrészlet szinten a tájrészlet ismerete nélkül és a tájrészlet megismerése után

123. ábra Felvételek készítésének, feldolgozásának, igazításának módszere tájjelleg-változás megjelenítésének minőségi animálása érdekében

124. ábra Jövőben várható tájjellegváltozás megjelenítése képszerkesztéssel és mozgóképkészítéssel

125. ábra Az Élő Berek weboldal (e-berek.hu) vizualizációs megoldásai

126. ábra Megjelenítési megoldások az Élő Tájak projektben Nagyberek térségére a honlapba integrált GoogleEarth felületen

127. ábra A passzív képalkotó távérzékelési adatokkal előállítható potenciális tájhatárvonalak a Budaörsi és Budakeszi-medence térségében

128. ábra Potenciális tájhatárvonalak a domborzati modell előterében és a meglévő tájhatárok

129. ábra A „határvonal-választó” módszer

130. ábra A ,határvonal-választó” módszer eredményeként lehatárolt Budaörsi és Budakeszi-medence

131. ábra Tájhatár pontosítása

132. ábra A domborulat-határok elemzésének folyamata

133. ábra A domborulat-határok megjelenítése GoogleEarth-ön

134. ábra A lejtőmeredekség maximumának meghatározása

135. ábra Tájegység-lehatárolás eredményei és a felhasznált adatok egy része a GoogleEarth-ön

136. ábra Tájegység-lehatárolás eredményei a Google Earth-ön

137. ábra Az Európai Táj Egyezmény megvalósításának lépései (SCOTT 2011, 2758) 


\section{MELLÉKLETEK}




\begin{tabular}{|c|c|c|}
\hline A fogalom szerzője & Tájfogalmak & Forrás \\
\hline $\begin{array}{l}\text { A Magyar Nyelv } \\
\text { Értelmezö Szótára (1966) }\end{array}$ & $\begin{array}{l}\text { föld felületének valamely szempontból jellegzetes része, vidéke, kisebb területti egysége. Akácos, dombos, erdös, fenyves, hegyes, lankkás, mocsaras, szikes, sziklás táj; elhagyott, idegen, ismeretlen, kihalt, kietlen, kopár, sivár, } \\
\text { vigaszzalan táj; kedves, kies, otthonos táj; öszi, téli tajj. }\end{array}$ & CSEMEZ 1996, 13 \\
\hline Balogh Ákos (1993) & Dinamikus egyensúlyú társadalmasított természet, az emberi közösségek élettere. Tartalmában és formájában múltját ôrzi, tükrözi a természeti adottságokat, a társadalmi-gazdasági-politikai viszonyokat. & CSEMEZ 1996, 15 \\
\hline Bulla Béla (1947) & $\begin{array}{l}\text { Tájalkotó tényezök (szerkezet, domborzat, éghajlat, hidrológiai hálózat, termézzetes növvénytakaró) és az ember tájalkotó, kultúrateremtő̉ tevékenysé́gének természzetes együttese, szintézise. Földrajzi területe gység, amelyhez } \\
\text { hasonlo van a Földön, de teljesen azonos soha. Tehát minden táj önálló individuum, egyéniség. }\end{array}$ & KERTÉSZ 2003, 17 \\
\hline Bulla Béla (1962) & A tájalkotó (egyben tájalakitó) tényezöknek fejlö́désében ellentmondásos, diszharmonikus egysége & BULLA 1962 \\
\hline Bulla Béla (1962) & Az övezetes tagolódást mutató földrajzi buroknak a taxonómiai egysége & KERTÉSZ 2003, 17 \\
\hline Csemez Attila (1996) & A természet és a társadalom kölcsönhatásaiban fejlolodő komplex területi egység. Tükrözi a természeti adottságokat, a társadalmi és gazdasági viszonyokat, ugyanakkor magas szintú vizuális-esztétikai értékek hordozója. & CSEMEZ 1996, 278 \\
\hline Csorba Péter (2006) & $\begin{array}{l}\text { Funkcionális földfelszíni egység, egy meghatározott terület, amely megjelenése és müködése alapján a szomszédos egységekektöl (tájjaktól) elválaszztható. Olyan, a térben ellhatárolható funkcionális egység, aminek természetes } \\
\text { múködésébe az ember egyre erösebben beavatkozik, miközben létével maga is annak részét képezi. }\end{array}$ & CSORBA 2006, 5 \\
\hline $\begin{array}{l}\text { Európai Táj Egyezmény } \\
\text { I. Fejejezt- } \\
\text { 1. Cikk (2000) }\end{array}$ & $\begin{array}{l}\text { It meeans an area, as perceived by people, whose character is the result of the action and interaction of natural and/or human factors. } \\
\text { (A disszertáció szerzzöjének forditásában: Az ember ấltal érzékelt terület, melynek jellege természeti tényezzök és/vagy emberi tevékenységek hatása és kölesönhatása eredményeként alakult ki.) }\end{array}$ & $\begin{array}{c}\text { COUNCIL OF EUROPE } \\
2000 \\
\text { 2007. évi CXI. törvény }\end{array}$ \\
\hline $\begin{array}{c}\text { Fabos, Julius. Gy., } \\
\text { Caswell, Stephanie. J. } \\
(1977)\end{array}$ & Landscape represents a section of the environment. It consists of natural entities such as soil, trees, landform, water, and various cultural entities & FABOS 1977, 6 \\
\hline $\begin{array}{c}\text { Ghimessy László és } \\
\text { Báthory Katalin (1978) }\end{array}$ & 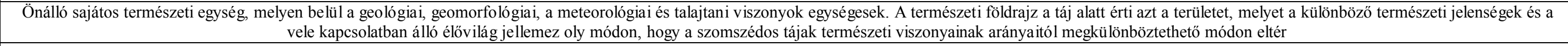 & GHIMESSY 1984, 11 \\
\hline Hettner, Alfred (1923) & A térbeli hierarchia egyik sajátos, megjelenésében egységes szintje & LÓCZY 2002, 13 \\
\hline Hommeyer, H. G. (1805) & Igen magas helyről áttekintett területetk körzete vagy vidékek sokasága, amely a szomszédos téregységektőll föképpen hegyekkel és erdőségekkel el-, illetve körülhatárolt. & CSEMEZ 1996, 13 \\
\hline Hortobágyi Tibor (1975) & $\begin{array}{l}\text { A természet által kialakított és a társadalmi igényeknek megfe lelöen átalakított földfelszín, a atalaj, a víz, a növényzet, az állatvilág, az ember és az ember által létrehozott, létesítmények együ̈ttes megjelenése, amely az állandó } \\
\text { egymásra hatás következtében állandóan fejlö́dik és változik }\end{array}$ & GHIMESSY 1984, 10 \\
\hline Kerényi Attila (2007) & $\begin{array}{l}\text { A földfelszin (geoszféra) sajátos arculatú része, önálló individuum, olyan térbeli egység, amelynek alapvetö tulajdonságai és határai természzeti folyamatok eredményeként alakultak ki, egyszersmind az emberi tevékenységek } \\
\text { hatására többé-kevésbé módosultak. }\end{array}$ & KERÉNYI 2007, 5 \\
\hline Kertész Ádám (2003) & 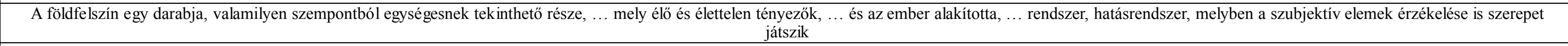 & KERTÉSZ 2003, 17 \\
\hline Kislexikon (1968) & A földfe lszínnek több szempontból egységesen jellemezhetô része (lehet természeti, gazdasági, illetve műttajj). & CSEMEZ 1996, 13 \\
\hline Kollányi László (2004) & $\begin{array}{l}\text { Olyan zónát vagy területet jelent a helyi lakosok vagy a látogatók felfogása szerint, } \\
\text { amelynek látható jegyeit és egyéb jellemzö́t természeti és/vagy kulturális (vagyis emberi) tényezök tevéke }\end{array}$ & KOLLÁNYI 2004, 27 \\
\hline $\begin{array}{l}\text { Konkoly Gyuró Éva } \\
\text { (2006) }\end{array}$ & $\begin{array}{l}\text { A földfe lszín egyedi karakterú, (individuális sajátosságokkal bíró), sokrétúu funkciókkal bíró területégységé, a terméézzeti tájalkotóó elemek révén meghatározott életfeltétel, az emberi tevékenység által átalakított élettér és } \\
\text { élményter, amelyben a természet és a társadalom kölssônhatásának lenyomata jelenik meg. }\end{array}$ & $\begin{array}{l}\text { KONKOLY GYURÓ } \\
2006,16\end{array}$ \\
\hline $\begin{array}{c}\text { Konkolyné Gyuró Éva } \\
\text { (2003) }\end{array}$ & Ember-természet kapcsolat lényegi, teljes hordozója és megjelenítóje & $\begin{array}{c}\text { KONKOLYNÉ GYURÓ } \\
2003,369\end{array}$ \\
\hline Leser, H. (1976) & A geoszféra (földrajzi burok) tetszőleges területi kiterjedésủ részletének (kivágatának) a konkrét, azaz a valóságban létező ökoszisztémája & KERTÉSZ 2003, 16 \\
\hline $\begin{array}{l}\text { Magyar Értelmezö } \\
\text { Kéziszótár (1972) }\end{array}$ & Földrajza, növényzete stb. alapján egységes v. összefüggő (kisebb) terület. Dombos táj; a Duna tája. & CSEMEZ 1996, 13 \\
\hline Möcsényi Mihály (1968) & A természet és a társadalom kölcsönhatásainak ellentmondásos, ezért dialektikus egysége. & CSEMEZ 1996, 15 \\
\hline Mö́csényi Mihály (1968) & A társadalmi igényeknek megfelelö́n a bioszférából nooszférává alakított, emberiesített természet, emberi környezet. & CSEMEZ 1996, 15 \\
\hline Neef, E. (1967) & A földfelszín egy olyan konkrét részlete, amelyet egységes szerkezet és a & KERTÉSZ 2003, 16 \\
\hline $\begin{array}{l}\text { Országos Erdészeti } \\
\text { Egyesület (1981) }\end{array}$ & $\begin{array}{c}\text { A természeti erők által formált és az emberi tevékenység révén módositott földfelszín állandóan változó, sajátos ökológiai rendszerből álló egysége, mely megközelitőlleg hasonló formájú és funkciójú, de különbözö } \\
\text { nagyságrendú lehet. }\end{array}$ & CSEMEZ 1996, 14 \\
\hline Pécsi Márton (1964) & 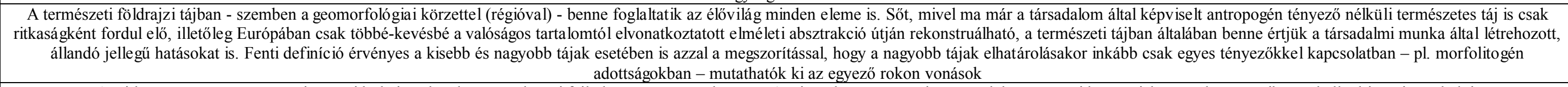 & CSEMEZ 1996, 14 \\
\hline Pécsi Márton (1972) & A táj hosszú természettörténeti és rövid, de igen hatékony gazdasági fejlödés együ̈ttes eredménye. A tájat tehát term & KERTÉSZ 2003, 17 \\
\hline Schmithüsen, J. (1963) & $\begin{aligned} \text { A táj a geoszféra totálkaraktere alapján egységként felfogható résznek földrajzilag releváns nagyságrendú alakulata (Csemez forditísában), a táj a geoszz } \\
\text { minősül, jellemvonásainak összessége szerint pedig egységként értelmezhetö. (Kertész ford }\end{aligned}$ & $\begin{array}{l}\text { CSEMEZ 1996, 14; } \\
\text { KERTÉSZ 2003, } 16\end{array}$ \\
\hline Somogyi Sándor (1964) & A Föld felszínének olyan része, melyben a külső és belső erök által keltett anyagmozgás-folyamatok törvény-szerứségei, valamint az általuk létrehozott formák típusai időben és térben azonosak & CSEMEZ 1996, 14 \\
\hline Steiner, F. (1991) & $\begin{array}{l}\text { Landscape is all the natural features such as fields, hills, forests, and water that distinguish one part of the surface of the earth form another part. Usually, a landscape is that portion of land or territory which the eye can } \\
\text { comprehend in a single view, including all its natural characteristics. }\end{array}$ & WASCHER 2005, 2 \\
\hline Teleki Pál (1937) & $\begin{array}{l}\text { A Föld egy olyan területe, amelyen a földfelszíni élet természettől való szintézise összes jelenségeivel megtalálhatóc. A tájépító tényezők funkcióík szerint olyan egységet alakítanak ki a tájban, amellyel még egy megegyező a } \\
\text { Földôn nincsen, tehát minden táj individuum. }\end{array}$ & CSEMEZ 1996, 14 \\
\hline $\begin{array}{l}\text { Természetvédelmi } \\
\text { törvény (1996) }\end{array}$ & $\begin{array}{l}\text { A földfelszín térben lehatáro lható, jellegzetes felépitésủ és sajátosságú rézze, a rá jellemző természeti értékekkel és természeti rendszerekkel, valamint az emberi kultúra jellegzetességeivel együtt, ahol kölcsönhatásban találhatók } \\
\text { a természeti erök és a mesterséges (ember által létrehozott) környezeti elemek }\end{array}$ & 1996. évi LIII. törvény \\
\hline $\begin{array}{l}\text { The Landscape Institute } \\
\text { (2002) }\end{array}$ & Human perception of the land conditioned by knowledge and identity with a place & $\begin{array}{l}\text { THE LANDSCAPE } \\
\text { INSTITUTE 2002, } 120\end{array}$ \\
\hline Troll (1950) & $\begin{array}{l}\text { A földfelszín egy olyan részét értiük, amely külső megjelenése, jelenségeinek együtt-hatása, valamint belső és külső fekvésvonzatai alapján meghatározott jellegú téregységet képez, és amely a földrajzi határokon más jellegü } \\
\text { tájakba megy át. }\end{array}$ & CSEMEZ 1996, 14 \\
\hline $\begin{array}{l}\text { Új Magyar Lexikon } \\
\text { (1962) }\end{array}$ & 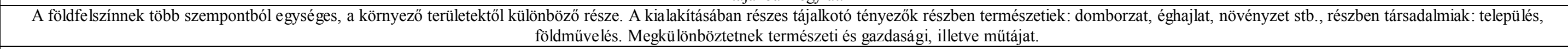 & CSEMEZ 1996, 13 \\
\hline $\begin{array}{c}\text { von Humboldt, } \\
\text { Alexander (1807) }\end{array}$ & $\begin{array}{l}\text { Total character of an Earth district } \\
\text { Egy földdarab totáklkaraktere, egy földfelszíni egység össztulajdonságainak megielenése }\end{array}$ & $\begin{array}{l}\text { WASCHER 2005, } 1 \\
\text { CSORBA 2006, } 4\end{array}$ \\
\hline
\end{tabular}




\begin{tabular}{|c|c|c|}
\hline Szerző & Tájkarakter / tájjelleg fogalmak & Források \\
\hline $\begin{array}{l}\text { André Jellema, } \\
\text { Derk-Jan } \\
\text { Stobbelaar, } \\
\text { Jeroen C.J. } \\
\text { Groot, Walter } \\
\text { A.H. Rossing }\end{array}$ & $\begin{array}{l}\text { The presence, variety and arrangement of landscape } \\
\text { features, which give a landscape a specific identity and } \\
\text { make it stand out from surrounding landscapes. } \\
\text { A tájelemek jelenléte, sokfélesége és elrendezése, mely } \\
\text { a táj sajátos identitását adja, és mely a környezö } \\
\text { tájegységektől elkülöníti (fordítás: Jombach Sándor) }\end{array}$ & $\begin{array}{l}\text { JELLEMA et al. } \\
\text { 2009, S161 }\end{array}$ \\
\hline Beate Jessel & $\begin{array}{l}\text { The overall area perception of a landscape, as the result } \\
\text { of a characterisation process, that classifies, illustrates } \\
\text { and describes areas that are similar in appearance. }\end{array}$ & $\begin{array}{c}\text { JESSEL 2006, } \\
153\end{array}$ \\
\hline $\begin{array}{c}\text { Carys } \\
\text { Swanwick }\end{array}$ & $\begin{array}{l}\text { A distinct, recogniseable and consistent pattern of } \\
\text { elements in the landscape that makes one landscape } \\
\text { different form another, rather than better or worse }\end{array}$ & $\begin{array}{l}\text { SWANWICK } \\
2002,8\end{array}$ \\
\hline Csemez Attila & $\begin{array}{l}\text { A sajátos természeti elemekbőll a gazdálkodás és a népi } \\
\text { kultúra együttesébőll kialakult karakter (jelleg) }\end{array}$ & $\begin{array}{l}\text { CSEMEZ 1996, } \\
279\end{array}$ \\
\hline Csima Péter & $\begin{array}{l}\text { A tájkarakter a tájkép mellett a történelmileg kialakult } \\
\text { tájszerkezet, valamint az adott tájhoz kötődő érzelmek } \\
\text { és hagyományok együttesen határozzák meg }\end{array}$ & $\begin{array}{l}\text { CSIMA 2008 } \\
405\end{array}$ \\
\hline Jack Ahern & $\begin{array}{l}\text { Landscape "character" includes physiographic structure } \\
\text { of the land, patterns of vegetation, spatial experiences } \\
\text { and sequences, and the means of moving through the } \\
\text { landscape. Landscape character derives from cultural } \\
\text { features and particular ways of life, as well as geology } \\
\text { and topography; it combines patterns of human activity } \\
\text { and the physical patterns of the places that are shaped by } \\
\text { those activities, or conversely that have shaped them. }\end{array}$ & AHERN 2004, 8 \\
\hline $\begin{array}{l}\text { Konkoly Gyuró } \\
\text { Éva (Swanwick } \\
\text { nyomán) }\end{array}$ & $\begin{array}{l}\text { A természeti és antropogén tájalkotó elemek } \\
\text { elkülöníthető, felismerhető, konzisztens rendszerébőll, } \\
\text { sajátos együtteséből kialakult jellemzök összessége, } \\
\text { mely a tájat egyedivé, megkülönböztethetővé teszi. }\end{array}$ & $\begin{array}{l}\text { KONKOLY } \\
\text { GYURÓ 2006, } \\
18\end{array}$ \\
\hline $\begin{array}{l}\text { The Landscape } \\
\text { Institute }\end{array}$ & $\begin{array}{l}\text { The distinct and recognisable pattern of elements that } \\
\text { occurs consistently in a particular type of landscape, and } \\
\text { how this is perceived by people. It reflects particular } \\
\text { combinations of geology, landform, soils, vegetation, } \\
\text { land use and human settlement. It creates the particular } \\
\text { sense of place of different areas of the landscape }\end{array}$ & $\begin{array}{l}\text { THE } \\
\text { LANDSCAPE } \\
\text { INSTITUTE } \\
2002,12\end{array}$ \\
\hline $\begin{array}{l}\text { Jombach } \\
\text { Sándor } \\
\text { (Swanwick és } \\
\text { Konkoly Gyuró } \\
\text { nyomán) }\end{array}$ & $\begin{array}{l}\text { A tájelemek elkülöníthető, felismerhető egyedinek vagy } \\
\text { tipikusnak tekinthető rendszere és / vagy mintázata, } \\
\text { mely a táj kezelése céljából az egyik tájat } \\
\text { megkülönbözteti a másiktól, nem pedig jóként vagy } \\
\text { rosszként minösíti azokat }\end{array}$ & $\begin{array}{l}\text { a disszertáció } \\
\text { szerzỏjének } \\
\text { adaptációja, annnak } \\
\text { érdekében, hogy a } \\
\text { passziv távérzékelési } \\
\text { adatok térinformatikai } \\
\text { alkalmazási } \\
\text { lehetőséé́t érthetöbbé } \\
\text { tegye }\end{array}$ \\
\hline
\end{tabular}
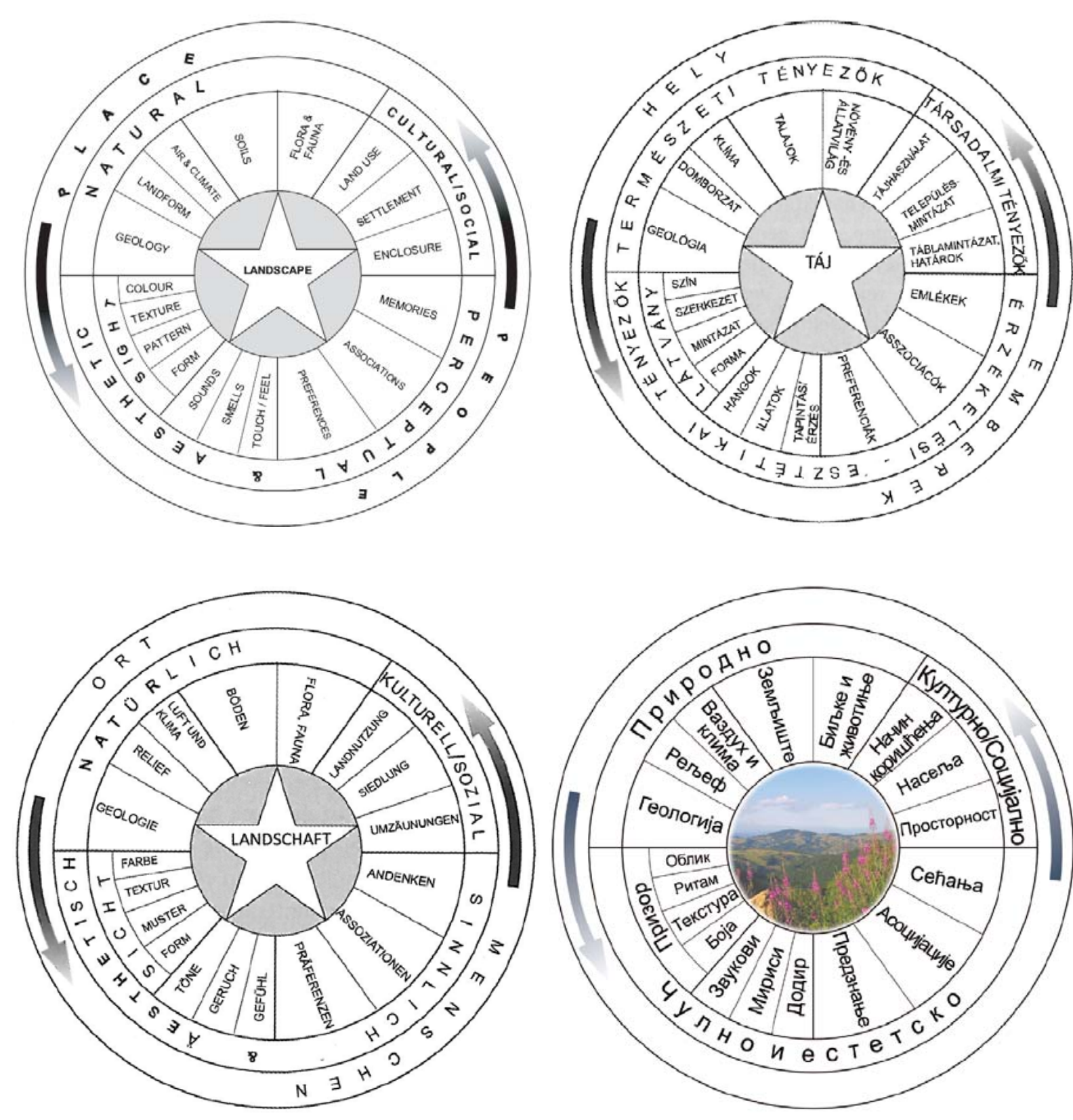

1. ábra A táj összetettségét érzékeltető ábra Swanwick Tájakrakter-elemzési útmutatójából „Mi a táj?" címmel (SWANWICK 2002, 2) és magyar és német (KONKOLY-GYURÓ 2010, 9) valamin szerb fordítása (JASMINKA., VASILJEVIC és TUTUNDŽIĆ 2007, 4) 
3. táblázat Tájelem-példák, tájelem-típusok elméleti és gyakorlati megközelítésben

\begin{tabular}{|c|c|c|c|c|}
\hline \multirow{2}{*}{$\begin{array}{c}\text { Kapesolódó pillérek } \\
\text { Tájelemek tipusa }\end{array}$} & \multirow[b]{2}{*}{ Elemesoportok } & \multicolumn{3}{|c|}{ Példák tájelemekre } \\
\hline & & $\begin{array}{c}\text { elméleti } \\
\text { megközelitésben }\end{array}$ & jelenség, folyamat & $\begin{array}{c}\text { gyakorlati } \\
\text { megközelitésben }\end{array}$ \\
\hline \multirow{7}{*}{$\begin{array}{c}\text { Természet- } \\
\text { tudományi } \\
\text { Természeti, vagy } \\
\text { természeti eredetü } \\
\text { tájelemek }\end{array}$} & Földtan és talajtan & talajtípusok & szikesedés & barlang \\
\hline & Éghaj lat (Klíma) & éghajlati zónák & $\begin{array}{l}\text { csapadékmennyiség } \\
\text { változása }\end{array}$ & szélirány \\
\hline & Domborzat & felszínmozgal masság & hegységek gyürődése & \begin{tabular}{|l|} 
sziklaképzödmény \\
\end{tabular} \\
\hline & Vízrajz & vízgyúijtőkk kiterjedése & áradások gyakorisága & vízhozam \\
\hline & Növénytakaró (Flóra) & flórajárások & $\begin{array}{c}\text { jellemzö társulások } \\
\text { csökkenése }\end{array}$ & egy idegenhonos faj \\
\hline & Állatvilág (Fauna) & élöhelyek & $\begin{array}{c}\text { jellemzó populációk } \\
\text { változása }\end{array}$ & egy öshonos faj \\
\hline & stb & $\mathrm{stb}$ & stb & stb \\
\hline \multirow{7}{*}{$\begin{array}{l}\text { Gazdaság- } \\
\text { tudományi } \\
\text { Antropogén, vagy } \\
\text { antropocentrikus } \\
\text { tájelemek }\end{array}$} & Területhasználat & erdőterület & beépítés növekedése & tűlevelű erdőfolt \\
\hline & Mezőgazdaság & $\begin{array}{l}\text { gabonafélék aránya a } \\
\text { termelésben }\end{array}$ & legeltetés megszünése & magtár \\
\hline & Ipar & $\begin{array}{l}\text { ipari tevékenység } \\
\text { domináns típusa }\end{array}$ & $\begin{array}{l}\text { bányamúvelés } \\
\text { felhagyása }\end{array}$ & gyárépület \\
\hline & $\begin{array}{c}\text { Szolgáltatás és } \\
\text { kutatás-fejlesztés }\end{array}$ & infrastruktúra-elemek & innováció & könyvtár \\
\hline & Energiagazdálkodás & megújuló energia aránya & $\begin{array}{l}\text { kőolaj mezők } \\
\text { kimerülése }\end{array}$ & szélerőmü \\
\hline & Turizmus & föszezon hossza & $\begin{array}{c}\text { növekvö } \\
\text { vendégéjszakák száma }\end{array}$ & $\begin{array}{l}\text { szállodai férőhelyek } \\
\text { száma }\end{array}$ \\
\hline & stb & stb & stb & stb \\
\hline \multirow{6}{*}{$\begin{array}{l}\text { Társadalom- } \\
\text { tudományi } \\
\text { Antropogén, vagy } \\
\text { antropocentrikus } \\
\text { tájelemek }\end{array}$} & Felszínborítá & zöldfelületi arány & felszínboritás változás & gyümölcsös \\
\hline & Látványeleme & a táj láthatósága & szép kilátás & kilátó \\
\hline & $\begin{array}{c}\text { Egyéb érzékelhetö } \\
\text { elemek }\end{array}$ & ételek ízvilága & zajhatás & szag \\
\hline & Népesség & $\begin{array}{l}\text { egy kisebbség } \\
\text { részaránya }\end{array}$ & mi gráció & lakosok száma \\
\hline & Ide & politikai hovatartozás & értékrend átalakulása & tájház \\
\hline & $\begin{array}{l}\text { Emlékek, } \\
\text { Asszociációk, } \\
\text { Elöképek }\end{array}$ & a hely szelleme & $\begin{array}{l}\text { figyelemfelkeltés, } \\
\text { népszerúsités }\end{array}$ & történeti emlékhely \\
\hline
\end{tabular}

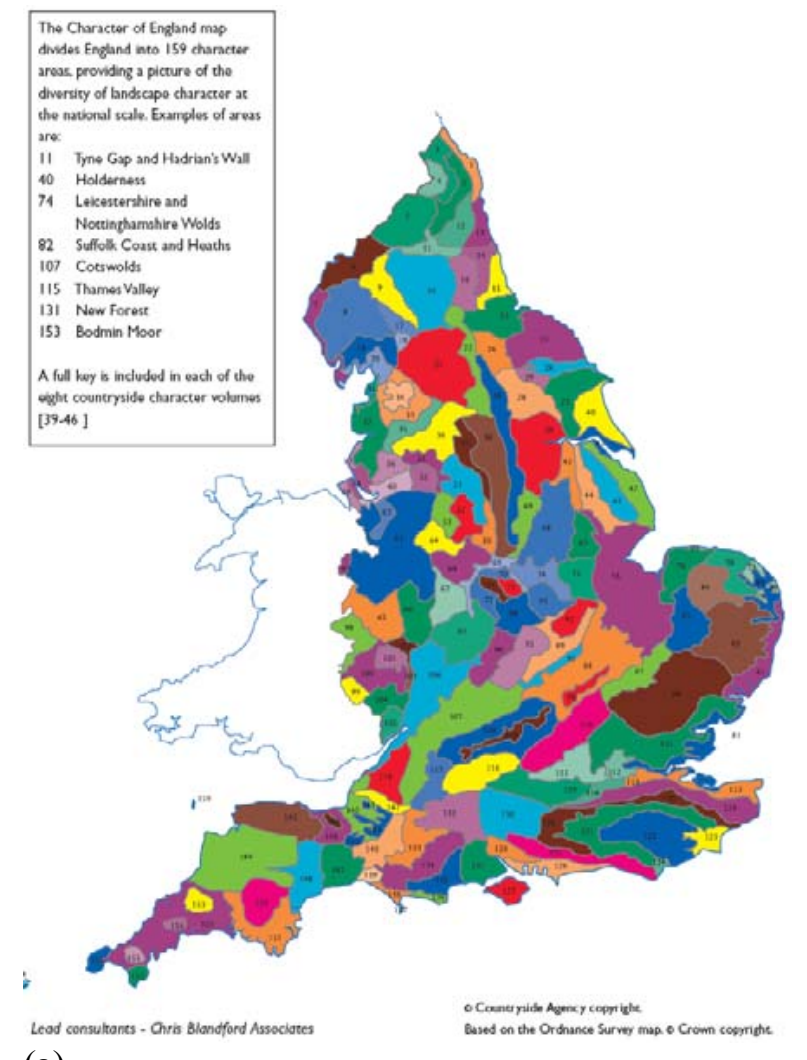

(a)

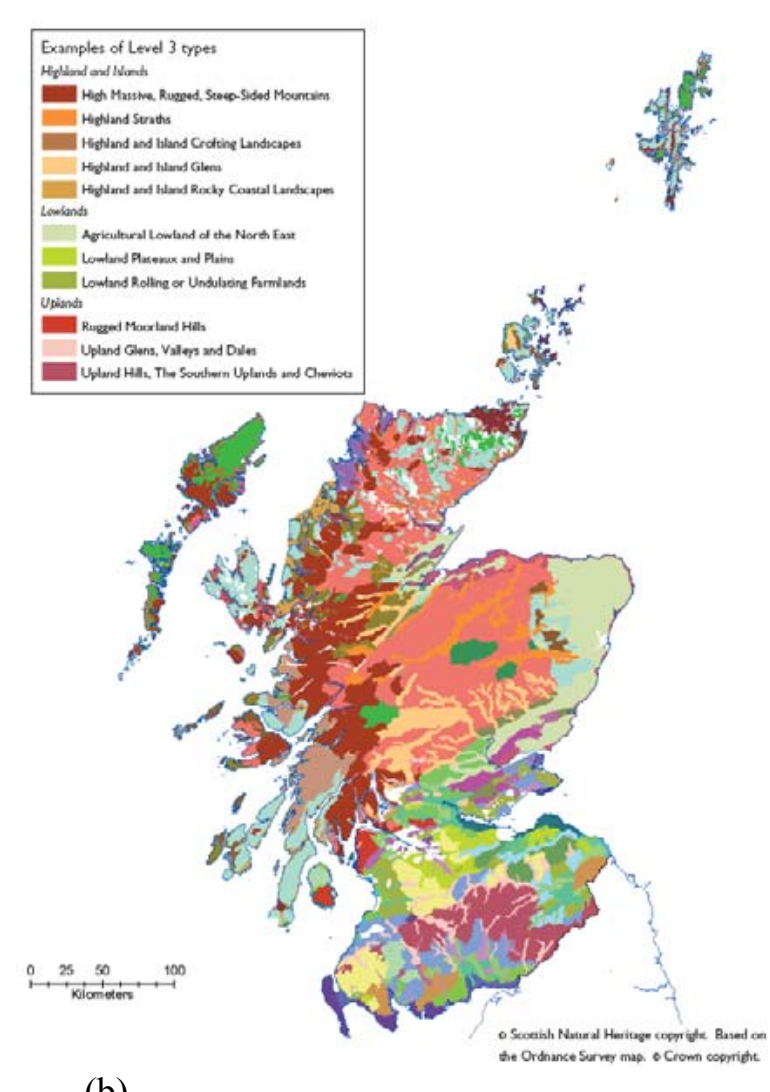

(b)
2. ábra Anglia és Skócia tájkarakter-térképei (SWANWICK 2002, 48-49) Anglia tájkarakter területeit (a) és Skócia tájkarakter típusait (b) megjelenítő ábrák a jelmagyarázatra vonatkozóan a teljesség igénye nélkül. (SWANWICK 2002, 48-49)

\section{4. táblázat A tájkarakter-elemzés lehetséges céljai (SWANWICK 2002, 53 alapján)}

\begin{tabular}{|c|c|c|}
\hline Objectives & Célok & Példák \\
\hline $\begin{array}{l}\text { Conservation and } \\
\text { maintenance }\end{array}$ & $\begin{array}{c}\text { Fenntartás, megörzés, } \\
\text { védelem }\end{array}$ & $\begin{array}{l}\text { A meglévő tájkarakter megtartására kell koncentrálni az } \\
\text { útmutatások során, a meglévő optimális karakter- } \\
\text { jellemzők megörzése érdekében. }\end{array}$ \\
\hline Enhancement & Erösítés & $\begin{array}{l}\text { Egyes esetekben (pl.: fokozott turisztikai hasznosítás) a } \\
\text { fejlesztés célja maga a meglévő karakter erősitése is lehet, } \\
\text { a karakteradó elemek hangsúlyozásával, kiemelésével }\end{array}$ \\
\hline Restoration & Létrehozás & $\begin{array}{l}\text { Bizonyos esetekben (pl.: egy nagy területen megvalósuló } \\
\text { repülötér, raktár-logisztikai központ létesítésével) egyes } \\
\text { fejlesztésekkel óhatatlanul új tájkarakter is létrejöhet. A } \\
\text { kezelés lényege ilyen esetben a fejlesztések során a táj } \\
\text { karakterváltozásának koordinálása, kedvező tájjelleg } \\
\text { kialakítása. }\end{array}$ \\
\hline Creation & Helyreállítás & $\begin{array}{l}\text { Némelykor egy korábban még érvényesülő mára azonban } \\
\text { karakterjegyeit elvesztett táj karakterének visszaadása } \\
\text { tipikus példa lehet történeti tájak kezelése esetén. }\end{array}$ \\
\hline $\begin{array}{l}\text { Some combination of } \\
\text { these options }\end{array}$ & A fentiek kombinációi & A fenti példák bármilyen kombinációja esetén \\
\hline
\end{tabular}


5. táblázat Jelentősebb, tájkarakterre is kiható tájváltozási folyamatok

\begin{tabular}{|c|c|c|}
\hline Változási folyamatok & Példák & Források \\
\hline $\begin{array}{l}\text { Beénített területek } \\
\text { növekedése }\end{array}$ & $\begin{array}{l}\text { terjeszkedő lakóterületek, ipari, } \\
\text { logisztikai és kereskedelmi célú } \\
\text { területek }\end{array}$ & 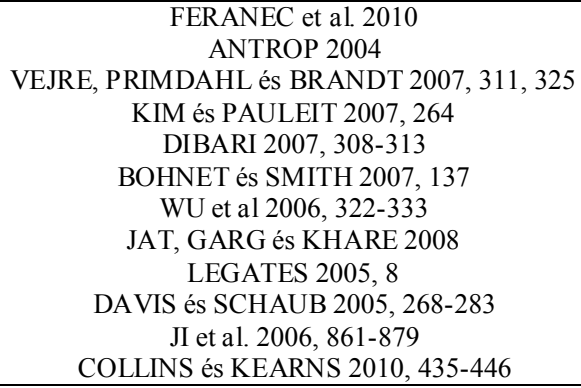 \\
\hline $\begin{array}{c}\text { Épített vonalas } \\
\text { infrastruktúra területi } \\
\text { fejlódése }\end{array}$ & $\begin{array}{l}\text { autópálya, vasúthálózat, energia és } \\
\text { információs hálózatok }\end{array}$ & $\begin{array}{l}\text { GARRÉ, MEEUS és GULINCK 2009, } 125 \\
\text { ANTONSON 2009, } 169\end{array}$ \\
\hline $\begin{array}{l}\text { Erổmüvek építése, } \\
\text { bővítése, terjedése }\end{array}$ & $\begin{array}{l}\text { szél-, víz-, atom-, illetve bioenergia } \\
\text { erömüvek }\end{array}$ & $\begin{array}{c}\text { MÖLLER 2010 } \\
\text { FRANTÁL és KUNC 2010 } \\
\text { DUERKEN és GOEBEL 1999, } 143 \\
\text { STEINITZ et al. 2003, XII } \\
\end{array}$ \\
\hline $\begin{array}{c}\text { "Elhasznált tájak" } \\
\text { növekedése, rekultivációja }\end{array}$ & \begin{tabular}{|c|} 
felhagyott bányák és mezógazdasági \\
területek, hulladéklerakók, egykori \\
katonai hasznositás alatt álló területek \\
\end{tabular} & $\begin{array}{l}\text { PALÁDI-KOVÁCS 2007, } 247 \\
\text { PÁDÁRNÉ TÖ RÖK 2010, 221-228 }\end{array}$ \\
\hline $\begin{array}{l}\text { Energiaültetvények } \\
\text { telepítése }\end{array}$ & erdők, gabonák, füvek, repce & $\begin{array}{c}\text { FISCHER et al. 2010 } \\
\text { SKÄRBÄCK és BECCTT 2005, 151-159 }\end{array}$ \\
\hline Gyepterület csökkenése & $\begin{array}{c}\text { legelök és kaszálók csökkenése, legelö } \\
\text { állatok eltünése }\end{array}$ & $\begin{array}{c}\text { FERANEC et al. 2010 } \\
\text { HUNIKER 1995, } \\
\text { SKANAS és BUNCE 1997, } 61 \\
\end{array}$ \\
\hline $\begin{array}{c}\text { Vidéki mezőgazdasági } \\
\text { tájhasználat } \\
\text { területhasználatainak } \\
\text { válttozása }\end{array}$ & $\begin{array}{c}\text { szölök, gyümölcssösök, kertek, } \\
\text { szántóterületek felhagyása, erdősülése, } \\
\text { extenzifikáció, beépülés, helyenként } \\
\text { intenzitás növekedése }\end{array}$ & 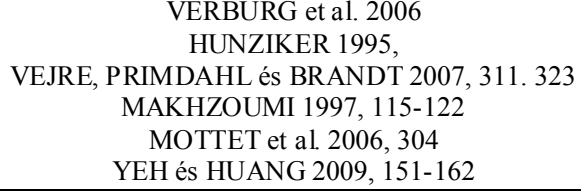 \\
\hline $\begin{array}{l}\text { Klímaváltozás sokféle } \\
\text { hatásai }\end{array}$ & $\begin{array}{l}\text { gleccserek, jég és hófelszín eltünése, } \\
\text { szárazodási folyamat eredményei, } \\
\text { szélsőséges idójárásí jelenségek } \\
\text { szaporodása }\end{array}$ & DIBARI 2003, 275-284 \\
\hline $\begin{array}{c}\text { Csökkenőó élóhelyek és } \\
\text { biodiverzitás, helyenként } \\
\text { élőhhely-rehabilitáció }\end{array}$ & $\begin{array}{l}\text { féltermészetes és vizenyös területek } \\
\text { növekedése }\end{array}$ & $\begin{array}{l}\text { KIM és PAULEIT 2007, 264, } 271 \\
\text { BAILEY, LEE és THOMPSON 2006, 227-243 } \\
\text { APAN, RAINE és PATERSON } 2002,55 \\
\text { BAILEY, LEE és THOMPSON 2006, 227-243 }\end{array}$ \\
\hline $\begin{array}{l}\text { Turisztikai központok } \\
\text { átalakulása és } \\
\text { terjeszke dése, }\end{array}$ & $\begin{array}{l}\text { kalandparkok, élményparkok } \\
\text { létesítése, wellness turizmus, városi } \\
\text { tömegturizmus és falusi turizmus } \\
\text { erösödése és elkülönülése }\end{array}$ & $\begin{array}{c}\text { LASANTA et al. 2007 } \\
\text { CALETRIOI 2010 } \\
\text { COLLINS és KEARNS 2010, 435-446 } \\
\text { VEJRE, PRIMDAHL és BRANDT 2007,320 }\end{array}$ \\
\hline $\begin{array}{c}\text { Városi és elő́városi } \\
\text { zöldfelületek szerepének } \\
\text { változása, } \\
\text { multifunkcionalitásának } \\
\text { erösödése }\end{array}$ & $\begin{array}{l}\text { véderdök, zöld övek, parkerdők, } \\
\text { zöldutak létesítése / megörzése }\end{array}$ & $\begin{array}{l}\text { VEJRE, PRIMDAHL és BRANDT } 2007 \\
\text { FÁBOS et al. } 2010 \\
\text { ARENDT 2004, 241-269 } \\
\text { SHANNON SMMARDON és KNUDSON } 1995\end{array}$ \\
\hline $\begin{array}{l}\text { Városok, városi terek és } \\
\text { parkok megújulása }\end{array}$ & \begin{tabular}{|c|} 
rozsdaövezetek megújulása, \\
épületállomány "glokalizációja" városi \\
parkok, szabad terek, egyéb \\
zöldfelületek társadalmi, ökológiai \\
szerepének növekedése és \\
fenntartásuk gazdaságossági \\
kérdéseinek kiemelkedése. \\
\end{tabular} & $\begin{array}{l}\text { GOSPODINI 2006, 311-330 } \\
\text { BERIATOS és GOSPODINI 2004, 187-202 } \\
\text { JODIDO 2012 }\end{array}$ \\
\hline Tájidenditás változása & $\begin{array}{l}\text { nemzeti vagy regionális identitás } \\
\text { elvesztése, uniformizálódás }\end{array}$ & $\begin{array}{c}\text { NOHL 2001,225 } \\
\text { SALEH 2001, } 965 \\
\text { ANRROP 205, } 21 \\
\text { PEDROLI tet a 2 2007, 11-12 } \\
\end{array}$ \\
\hline
\end{tabular}

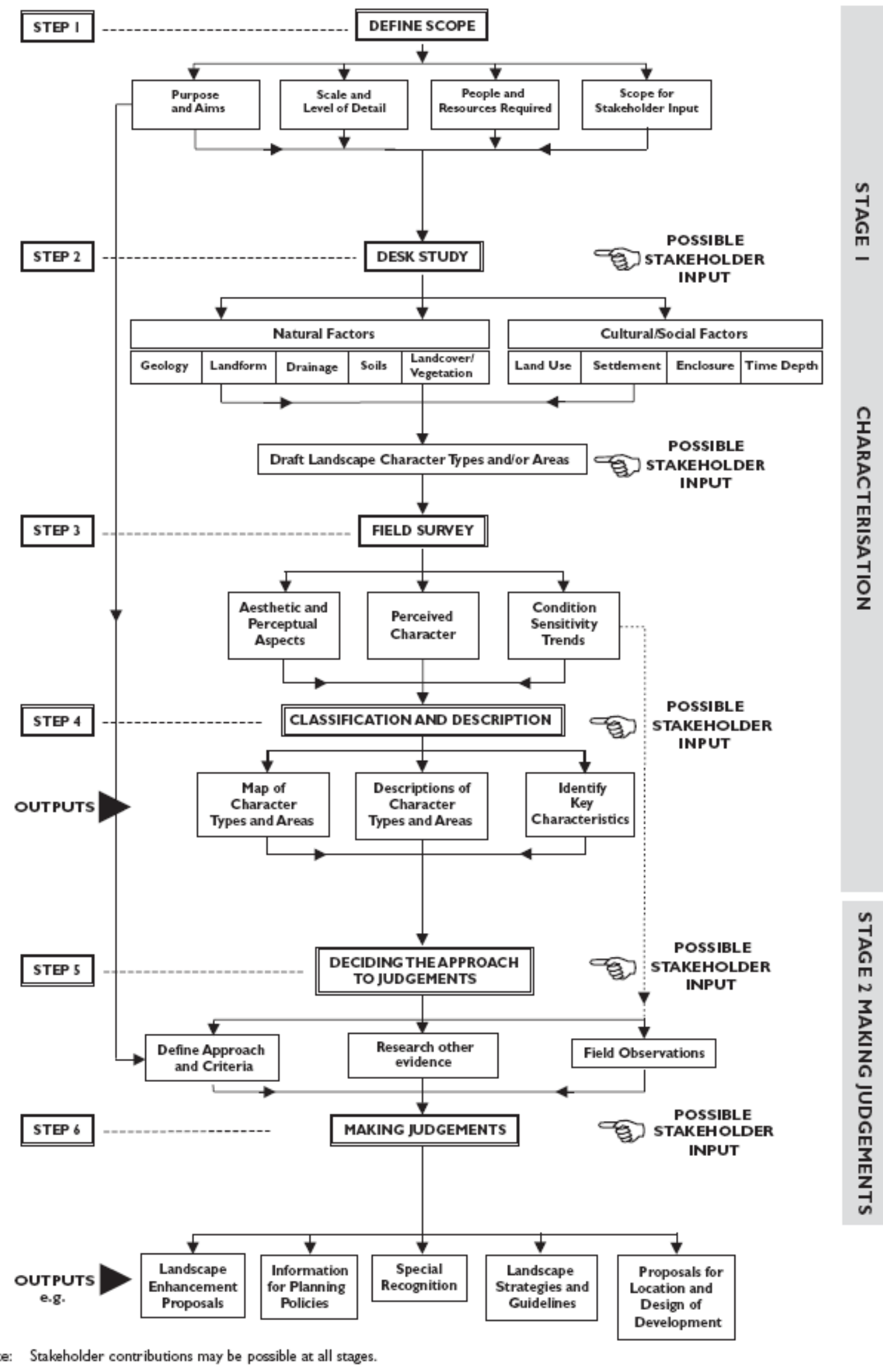

The whole process may be itentive.

3. ábra A tájkarakter-elemzés fontosabb lépései (SWANWICK 2002, 13) 
6. táblázat Néhány utazó és tájmonográfia szerző munkájában fellelhető karakter-elemzési jellegủ módszertani elem és eszköz

\begin{tabular}{|c|c|c|c|c|c|c|c|c|c|c|c|c|c|c|c|}
\hline Név & Élt & 票 & 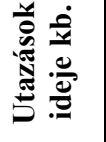 & $\begin{array}{l}\text { Utazás } \\
\text { célja }\end{array}$ & Útvonal & 愛 & 童 & 部 & 离 & Saját könyv & Összevetés & $\begin{array}{l}\text { Elérhető̋ tájléŕás } \\
\text { (könyvcím, oldalszám) }\end{array}$ & Karakter szempontjából érdekesség & Különlegesség & Forrás \\
\hline $\begin{array}{c}\text { Marco } \\
\text { Polo }\end{array}$ & 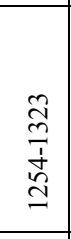 & 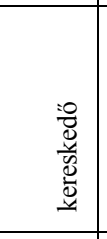 & 产 & 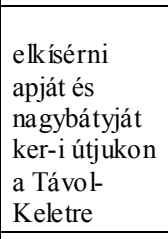 & $\begin{array}{l}\text { Velence, Moszul, Bagdad, } \\
\text { Perzsia, Pamir, Khotan, } \\
\text { Lop-nor, Sang-tu Kambalu } \\
\text { (Peking - Tibet - Perzsia, } \\
\text { Örményo., Trapezunt. } \\
\text { Velence. }\end{array}$ & 嫣 & 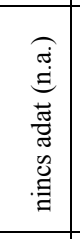 & 鄫 & 苛 & $\begin{array}{l}\text { "Marco Polo utazásai"- } \\
\text { tollba mondta genovai } \\
\text { fogsága idején } \\
\text { fogolytársának. } 40 \\
\text { másolt példảny ma is } \\
\text { létezik. }\end{array}$ & $\begin{array}{l}\text { "Marco Polo utazásai" Kis-és Nagy- } \\
\text { Örményország ôsszevetése }\end{array}$ & 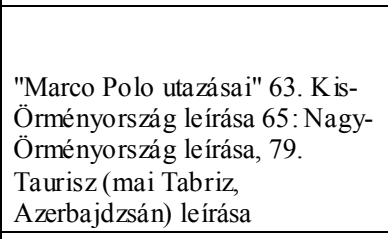 & 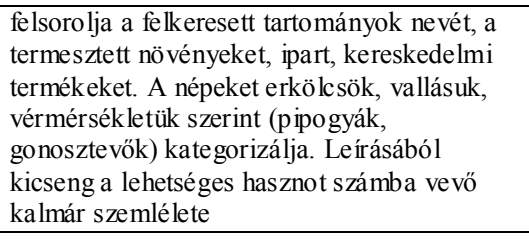 & & $\begin{array}{l}\text { (KÉZ 1937, 109- } \\
111) \\
\text { (POLO 1984) }\end{array}$ \\
\hline $\begin{array}{l}\text { Körösi } \\
\text { Csoma } \\
\text { Sándor }\end{array}$ & 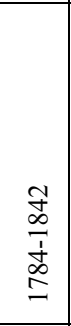 & 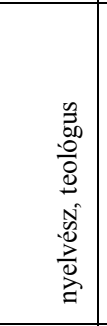 & 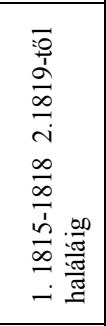 & $\begin{array}{l}\text { l. } \\
\text { tanulmányok } \\
\text { 2. } \\
\text { oshazazaututáá } \\
\text { s, nyelvesszet }\end{array}$ & $\begin{array}{l}\text { 1.Göttingeni egyetem } \\
\text { 2. Torök birodalom, } \\
\text { Alexandria, Sziria, Bagdad, } \\
\text { Perzzia, Bokkhar, Kabul, } \\
\text { India (Kasmir, Zanszkar, } \\
\text { Zangla, Calcutta, Darjiling) }\end{array}$ & 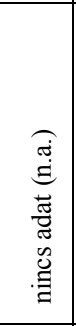 & 要 & 要 & 苞 & 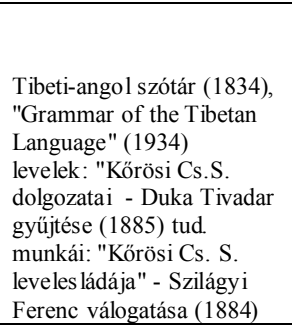 & $\begin{array}{l}\text { Le Calloc'h } \\
\text { 49. o.: Himalája - Kárpátok, Nagyenyed } \\
\text { és Leh (Ladak fóv.) lakosainak száma, } \\
65 \text {. o: Ladak - Zanszkár összzevetése }\end{array}$ & 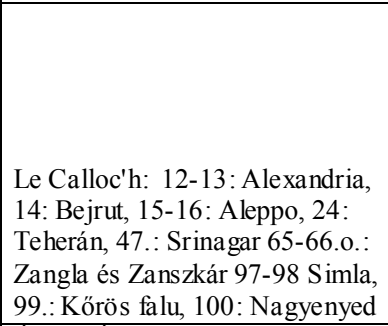 & 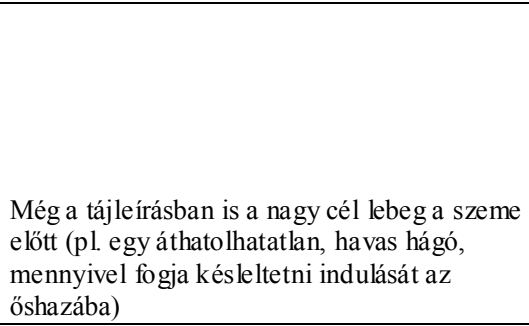 & 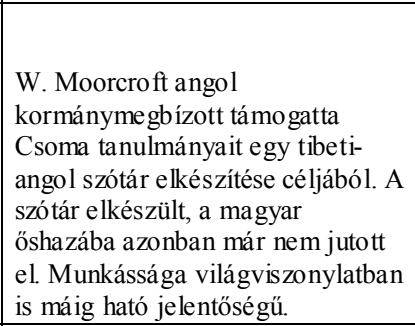 & $\begin{array}{l}\text { (KUBASSEK 2008, } \\
\text { 36-43) } \\
\text { (KEZ 1937, 71-73) } \\
\text { (LE CALLOC'H, } \\
\text { 2000) } \\
\text { (BATAY 1930) } \\
\text { (BALAZS 1993, 220- } \\
\text { 225) } \\
\text { Magyar Földrajzi } \\
\text { Mizzeum - Erd }\end{array}$ \\
\hline $\begin{array}{l}\text { Bölöni } \\
\text { Farkas } \\
\text { Sándor }\end{array}$ & 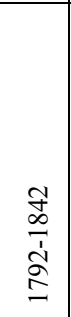 & $\because$ & 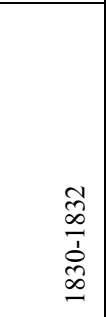 & $\begin{array}{l}\text { tapastzalat } \\
\text { gyüutís }\end{array}$ & $\begin{array}{l}\text { Nyugat-E } \\
\text { Amerika }\end{array}$ & זٓ & 常 & 苛 & $\stackrel{\overbrace{}}{\sharp}$ & $\begin{array}{l}\text { "Útazás Észak- } \\
\text { Amerikaban" } 1834) \\
\text { "Nyugateurópai utazás" } \\
\text { (1943) }\end{array}$ & 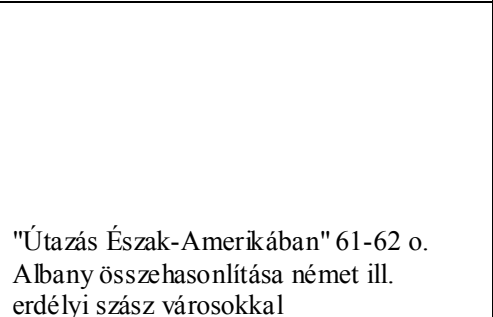 & 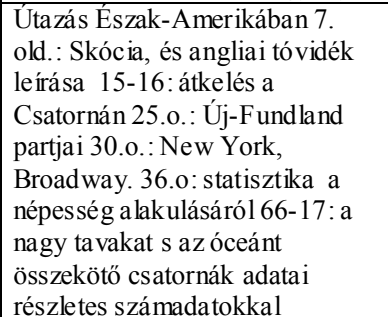 & 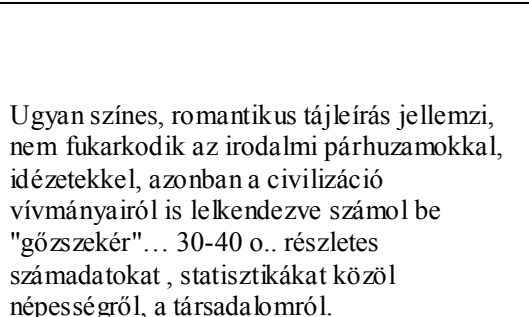 & $\begin{array}{l}\text { A fejlett amerikai demokráciáról } \\
\text { szóló beszámolója a magyar } \\
\text { reform- mozgaalom egyik eszmei } \\
\text { piillére lett. A negativumokat is } \\
\text { meglátita (indiánok, feketék } \\
\text { helyzete) }\end{array}$ & $\begin{array}{l}\text { Magyar Földrajzi } \\
\text { Mizzeum- Err } \\
\text { (BALȦZS 1993, 66- } \\
\text { 67) } \\
\text { (INT-038) }\end{array}$ \\
\hline $\begin{array}{l}\text { Orbán } \\
\text { Balázs }\end{array}$ & $\begin{array}{l}\infty \\
\infty \\
\infty \\
\infty \\
\infty \\
\infty\end{array}$ & | & 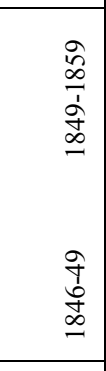 & $\begin{array}{l}\text { tanulmányút } \\
\text { emigráció, } \\
\text { nérrajzic } \\
\text { kutatas }\end{array}$ & $\begin{array}{l}\text { Közzel-Kelet London, } \\
\text { Konstantinápoly, } \\
\text { Szźkelyfóld } \\
\end{array}$ & 㢇 & 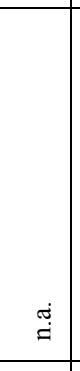 & 吾 & 胥 & $\begin{array}{l}\text { "Utazás Keleten I-VI" } \\
\text { (1861) "A székelyföld } \\
\text { leirása I-VI" (1867), } \\
\text { "Kolozsvár" (1868- } \\
\text { 1873), "Brassó szabad } \\
\text { királyi város léŕása } \\
\text { történelmi, régészei, } \\
\text { természetrajzi és } \\
\text { népismei szempontból" } \\
\text { (1872)," Torda város és } \\
\text { környéke (1889) stb. } \\
\end{array}$ & kertjei - Andalúz & 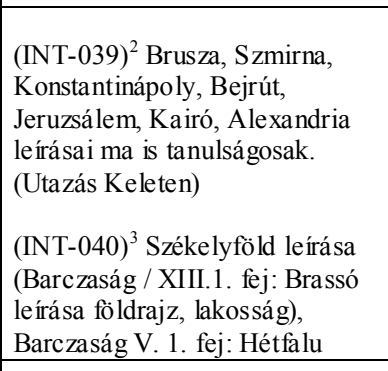 & 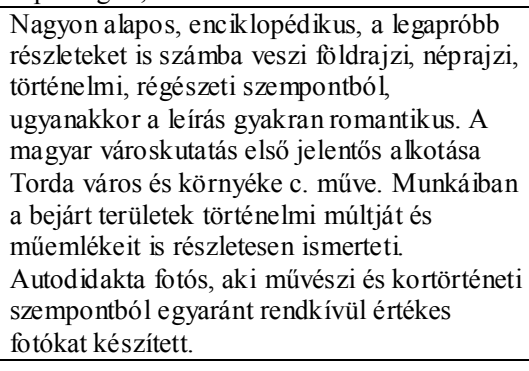 & 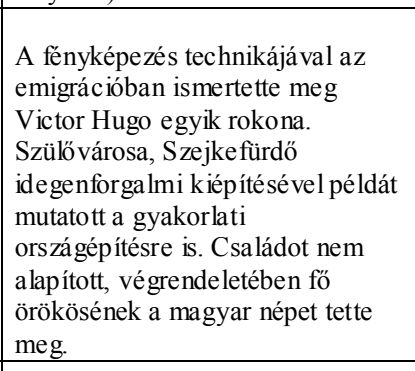 & $\begin{array}{l}\text { HORÁNYI 2004, } \\
\text { 108-11I) } \\
\text { (BALAZS 1993, 286- } \\
\text { 287) } \\
\text { Magyar Földrajzi } \\
\text { Muizeum - Erd }\end{array}$ \\
\hline $\begin{array}{l}\text { Vámbéry } \\
\text { Ármin }\end{array}$ & $\begin{array}{l}\stackrel{m}{\vec{T}} \\
\stackrel{\vec{\lambda}}{\infty} \\
\stackrel{\infty}{-} \\
\end{array}$ & 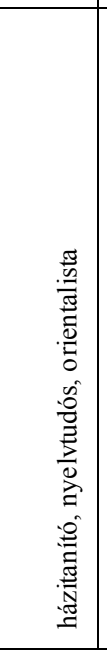 & 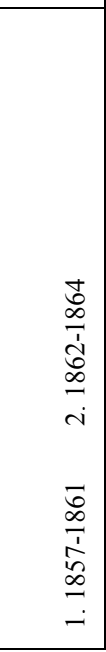 & $\begin{array}{l}1 . \\
\text { nyelvtanulás } \\
2 . \\
\text { nyelvrokons } \\
\text { ag- öhhaza- } \\
\text { ess } \\
\text { tánsadalom } \\
\text { kutatás }\end{array}$ & $\begin{array}{l}\text { 1. Konstantinánpoly } \\
\text { 2. Perzzia, Közép-Azsia } \\
\text { (Kaspi tó, Khiva, Oxus f. } \\
\text { Samarkand, Bokhara, } \\
\text { Teherán, Pest) }\end{array}$ & 吾 & 离 & 总 & $\bar{\Sigma}$ & 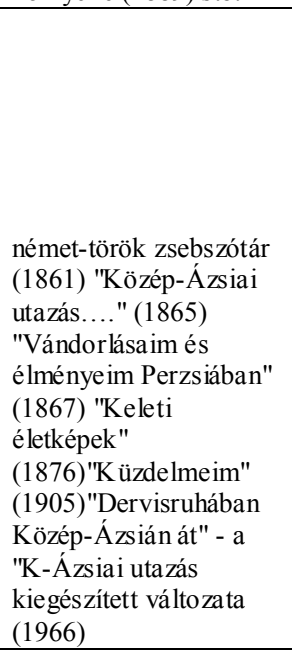 & 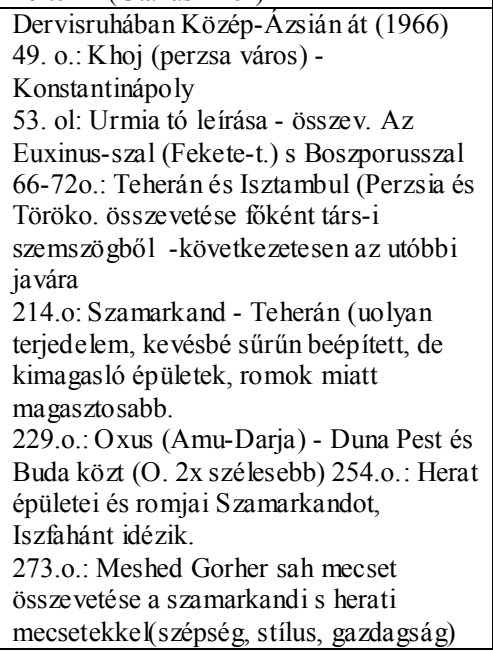 & 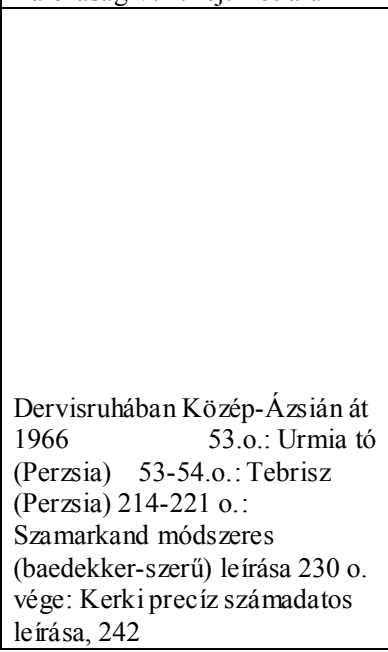 & 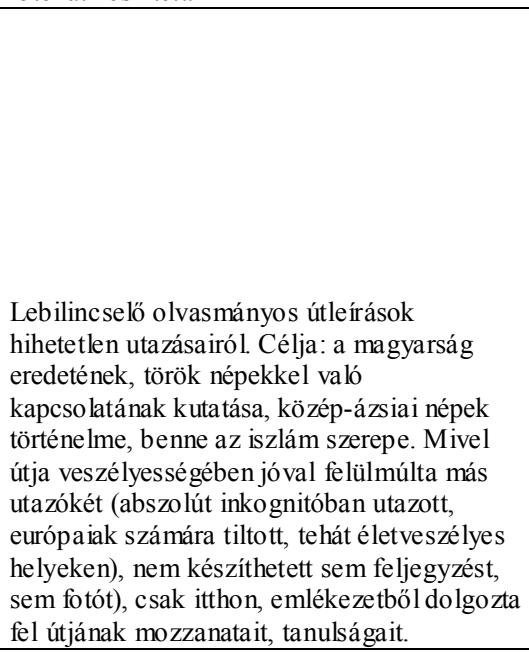 & 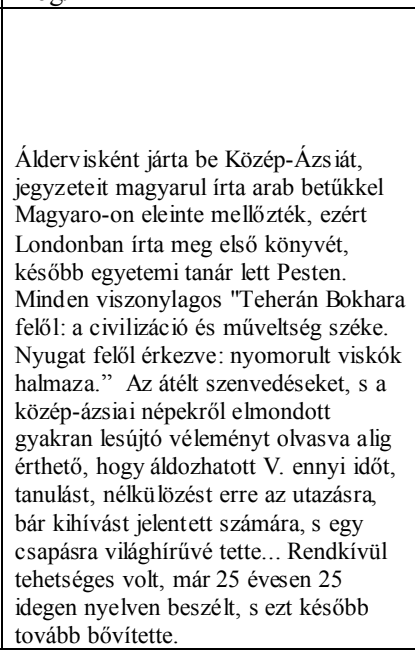 & $\begin{array}{l}\text { (KUBASSEK 2008, } \\
\text { 50-55) } \\
\text { (BALAZS 1993, 401- } \\
\text { 404) } \\
\text { (VABBÉRY 1966) } \\
\text { (KEZ 1937, 149- } \\
153)\end{array}$ \\
\hline
\end{tabular}

${ }^{1}$ INT-038: Google Books Bölöni Farkas Sándor Útazás Észak Amerikában könyvének szkennelt változatáról (2014. 02. 09.)

INT-039: Terebess Ázsia E-Tár (2014. 02. 09.) (2014. 02.09)

${ }^{3}$ INT-040: Magyar Elektronikus Könyvtár, Orbán Balázs: Székelyföld leírása (2014. 02. 09.) 


\begin{tabular}{|c|c|c|c|c|c|c|c|c|c|c|c|c|c|c|c|}
\hline Név & Élt & 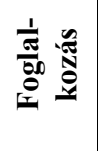 & 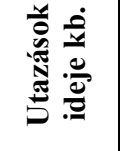 & $\begin{array}{l}\text { Utazás } \\
\text { célja }\end{array}$ & Útvonal & 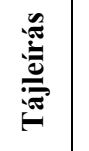 & 产 & 常 & 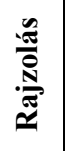 & Saját könyv & Összevetés & $\begin{array}{l}\text { Elérhetö tájleírás } \\
\text { (könyvcím, oldalszám) }\end{array}$ & Karakter szempontjából érdekesség & Különlegesség & Forrás \\
\hline $\begin{array}{l}\text { Teleki } \\
\text { Sámuel }\end{array}$ & 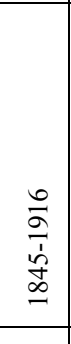 & 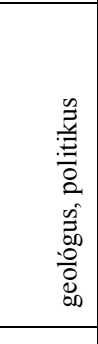 & 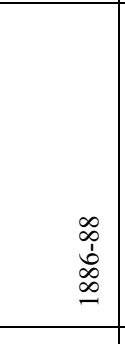 & $\begin{array}{l}\text { vadászat, } \\
\text { ffildrajzi } \\
\text { felfedezés } \\
\text { (Rudolf } \\
\text { trónörökös } \\
\text { biztááára), } \\
\text { zoológiai, } \\
\text { botanikai } \\
\text { gyüités }\end{array}$ & $\begin{array}{l}\text { Zanzibár, Tanganyika, } \\
\text { Kenya (késobbb Javaa, } \\
\text { Borneo, Eló-India) }\end{array}$ & & 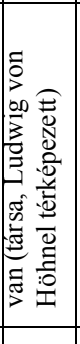 & 唇 & 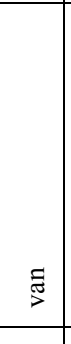 & 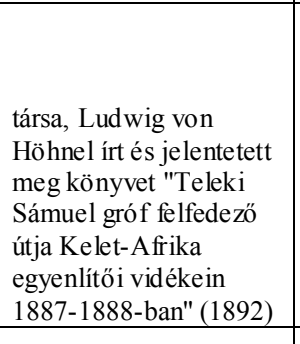 & 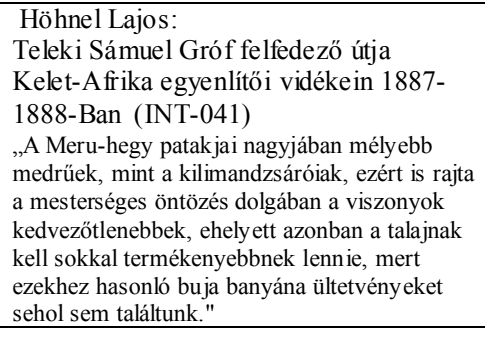 & (INT-041) & 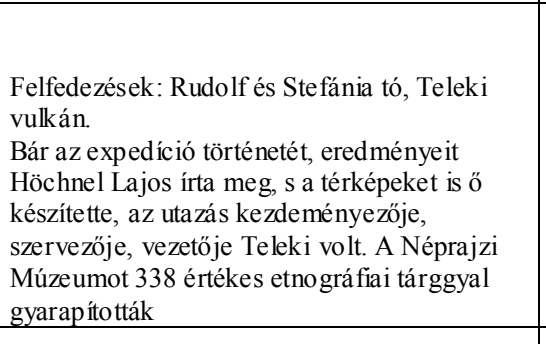 & 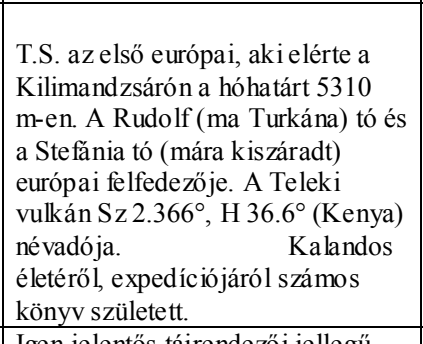 & 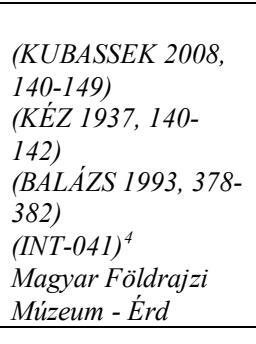 \\
\hline $\begin{array}{l}\text { Czárán } \\
\text { Gyula }\end{array}$ & 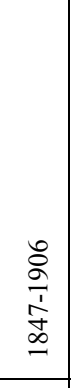 & 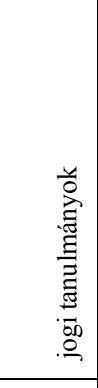 & 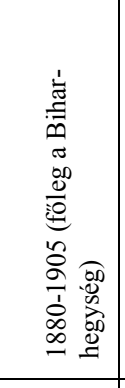 & $\begin{array}{l}\text { geologgia, } \\
\text { természettud } \\
\text { omány }\end{array}$ & $\begin{array}{l}\text { Európa, Törökország, } \\
\text { Erdély, Al-Duna }\end{array}$ & 焉 & 㼛 & $\stackrel{g}{ت}$ & 苞 & $\begin{array}{l}\text { Kalauz a biharfurredi } \\
\text { kirándulásokra (1903) }\end{array}$ & $\begin{array}{l}\text { CZárán 1903, } \\
\text { 122.2.. A mezídi barlang összzevetése az } \\
\text { Aggeteleki cseppköbarlanggal }\end{array}$ & $\begin{array}{l}\text { Czárán 1903, 122-136: A } \\
\text { mezizícicsepkobobarlang } \\
\text { részletes leirasas }\end{array}$ & 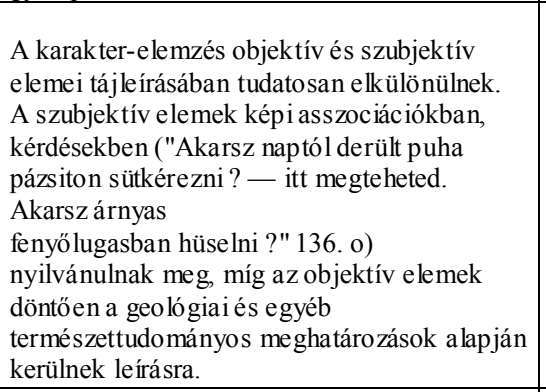 & 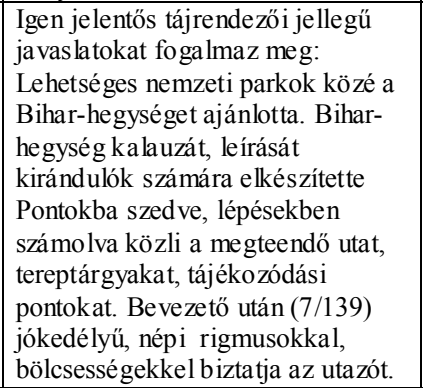 & $\begin{array}{l}(\text { HORÁNYI 2004, } \\
28-31) \\
(\text { CZARAAN, 1903) } \\
(I N T-042)^{5}\end{array}$ \\
\hline $\begin{array}{l}\text { Stein } \\
\text { Aurél }\end{array}$ & 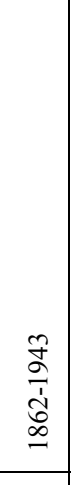 & 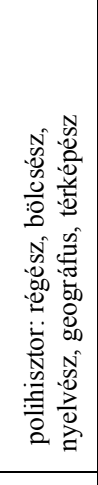 & 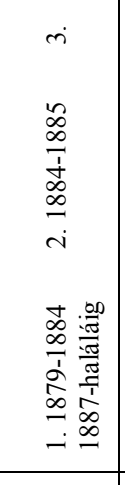 & $\begin{array}{l}1 . \\
\text { tanulmányok } \\
\text { 2-- } \\
\text { 3.történelmi, } \\
\text { foldrajzi, } \\
\text { nyelvészeti, } \\
\text { régészeti } \\
\text { stb... } \\
\text { kutatások } \\
\end{array}$ & 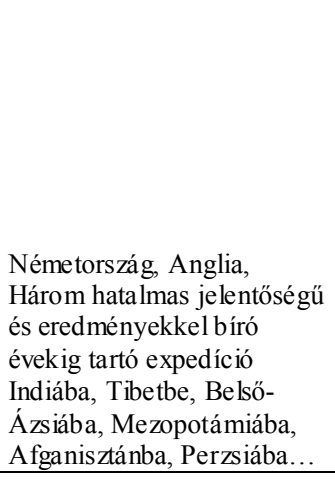 & 吾 & זٓ & 咂 & 咂 & $\begin{array}{l}\text { "Homokba temetett } \\
\text { városok" (1908) "Nagy } \\
\text { Sándor nyomában } \\
\text { Indiába" (1929) "Ösi } \\
\text { ösvényeken Ázsíban" } \\
\text { (1934) }\end{array}$ & 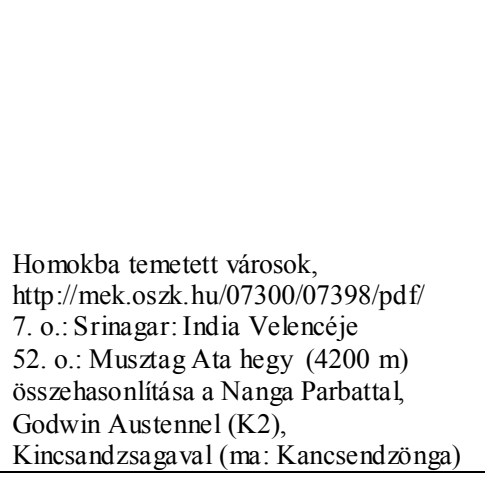 & 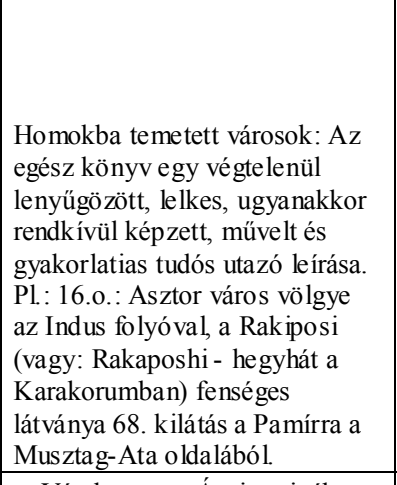 & 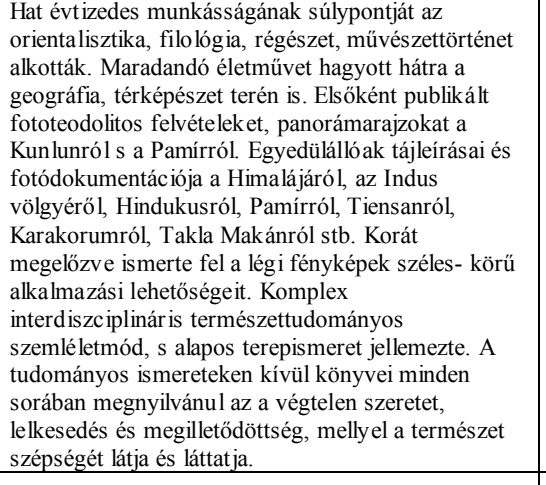 & 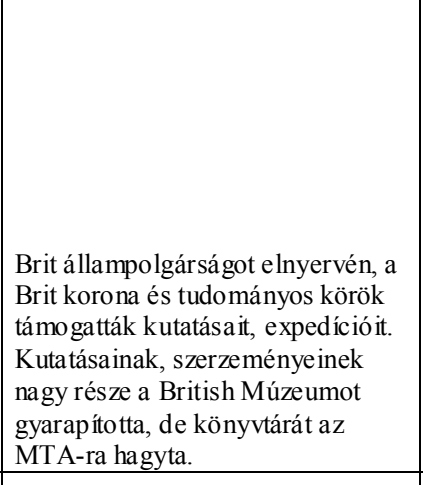 & $\begin{array}{l}\text { (KUBASSEK 2008, } \\
\text { 88-93) (BALAZS } \\
\text { 1993,3 346-350) } \\
\text { (KEE 1937, 132- } \\
\text { 135) } \\
\text { Magyar Földrajzi } \\
\text { Mizeum - Erd }\end{array}$ \\
\hline $\begin{array}{l}\text { Almásy } \\
\text { György }\end{array}$ & $\begin{array}{l}\stackrel{M}{0} \\
\frac{0}{1} \\
\stackrel{0}{0} \\
\stackrel{\infty}{\infty} \\
\end{array}$ & 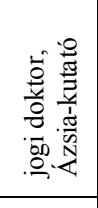 & 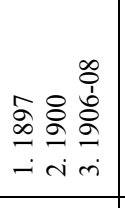 & $\begin{array}{l}\text { földrajzi, } \\
\text { zoológiai, } \\
\text { filóógiai, } \\
\text { néprajizi } \\
\text { kutatás, } \\
\text { gyüjtés }\end{array}$ & $\begin{array}{l}\text { 1. Dobrudzza, Duna-delta } \\
\text { 2. Turkestan, Belsó-Ázsia, } \\
\text { Tien-san } \\
\text { 3. Belsó-Azzsia, É-Kína }\end{array}$ & 吉 & $\stackrel{\overbrace{}}{\sharp}$ & 吾 & 莒 & $\begin{array}{l}\text { "Madártani betekintés a } \\
\text { román Dobrudzasába" } \\
\text { (1898), "Utazásom } \\
\text { orosz Turkesztána" } \\
\text { (1901), "Vándor-utam } \\
\text { Ázsia szivébe" (1903) } \\
\end{array}$ & & 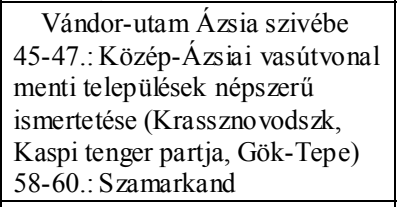 & $\begin{array}{l}\text { Könyvében közvetlen, szinn } \\
\text { számolt be a látottakról. }\end{array}$ & 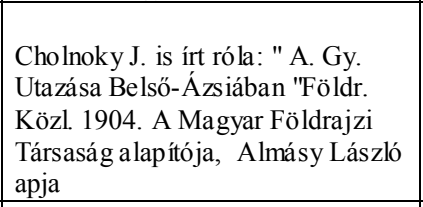 & $\begin{array}{l}\text { (KÉZ 1937, 7-8) } \\
\text { (ALMÁSY 1903) } \\
\text { Magyar Foldragizi } \\
\text { Mizzeum - Erd } \\
\text { (BALAZZS 1993, 18) } \\
\end{array}$ \\
\hline $\begin{array}{l}\text { Cholnoky } \\
\text { Jenö }\end{array}$ & $\begin{array}{ll}0 \\
\frac{0}{2} \\
\frac{1}{3}\end{array}$ & 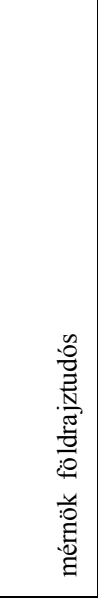 & 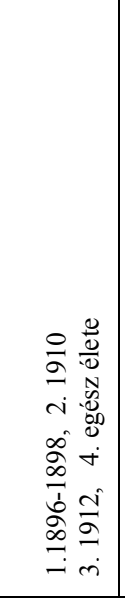 & $\begin{array}{l}\text { geomorfológ } \\
\text { iai, } \\
\text { hidrológiai } \\
\text { tanulmányút }\end{array}$ & $\begin{array}{l}\text { 1. Kína-Mandzáríria } \\
\text { 2. Spitzbergak } \\
\text { 3. Amerikai Egyesült } \\
\text { Államok } \\
\text { 4. Magyarország - Balaton }\end{array}$ & 层 & 辰 & 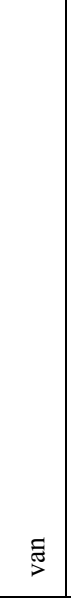 & 吾 & 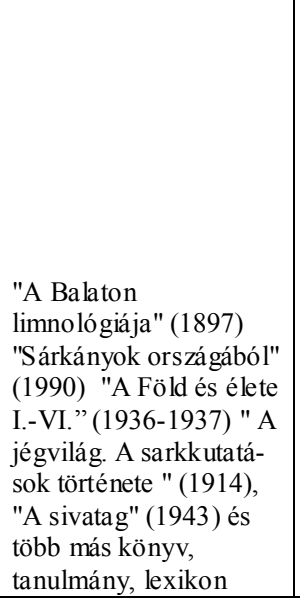 & 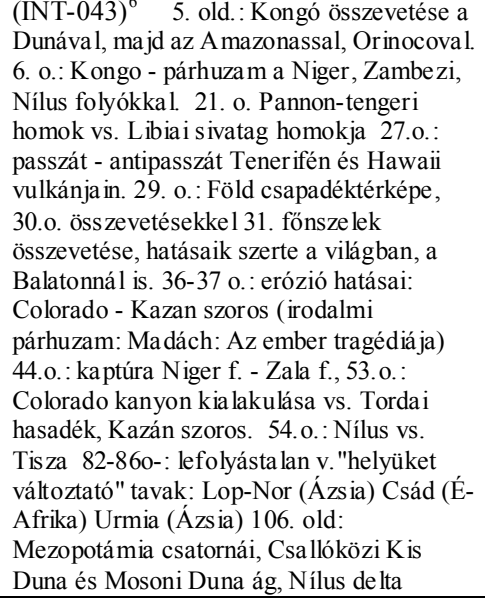 & 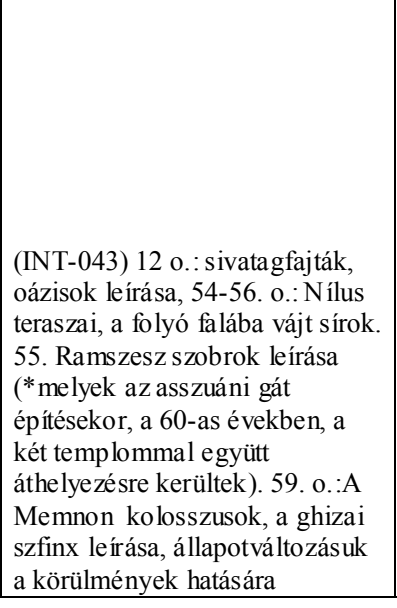 & 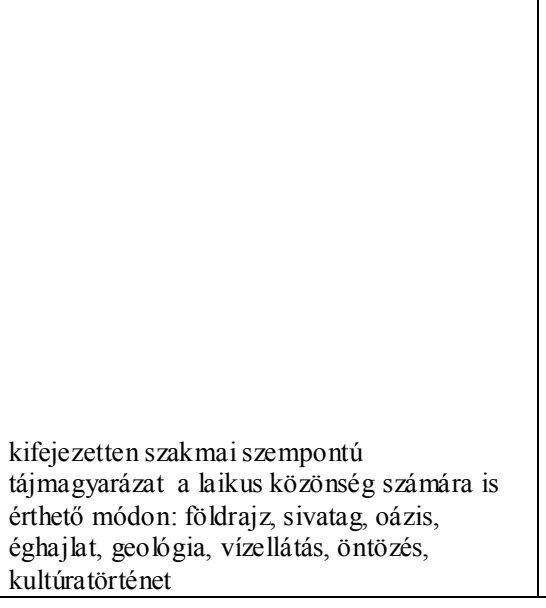 & 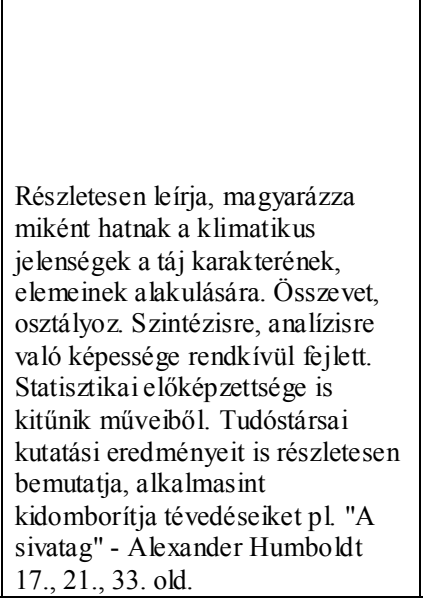 & 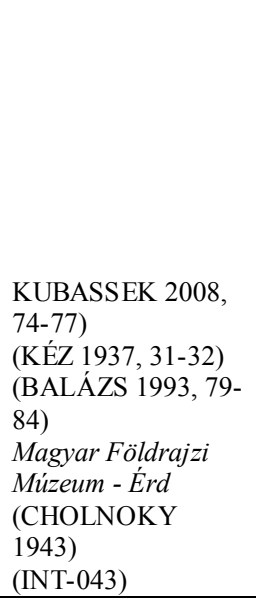 \\
\hline
\end{tabular}

${ }^{4}$ INT-041: Magyar Elektronikus Könyvtár összefoglalója Teleki Sámuel gróf felfedező útjáról (2014. 02. 09.)

${ }^{5}$ INT-042: Magyar Elektronikus Könyvtár, Czárán Gyula kalauzáról rendelkezésre álló információk (2014. 02. 09.)

${ }^{6}$ INT-043: Magyar Elektronikus Könyvtár, Cholnoky Jenő: A sivatag (2014. 02. 09.) 
7. táblázat Tájkarakter-elemzés technikai eszköztárának elemei

\begin{tabular}{|c|c|}
\hline Eszköztár elemei & $\begin{array}{c}\text { Passzív képalkotó } \\
\text { távérzékelés } \\
\text { alkalmazása } \\
\end{array}$ \\
\hline $\begin{array}{l}\text { irodalmazás eszközei } \\
\text { (a dokumentumtáraktól, a fénymásolón át a jegyzetfüzetig) }\end{array}$ & nem jellemző \\
\hline szabadkézi rajzolás, mindmap készítés és kellékeik & lehetséges \\
\hline kitölthető terepi tájkarakter-felmérési ívek & lehetséges \\
\hline terepi kérdőívek, interjúk kérdései & lehetséges \\
\hline $\begin{array}{l}\text { terepbejáráshoz használható térképek, terepre vihető digitális } \\
\text { adatok és ezek megjelenítő eszközei }\end{array}$ & van \\
\hline $\begin{array}{l}\text { térbeli mérőeszközök } \\
\text { (a mérőszalagtól a geodéziai műszereken át a GPS-ig) }\end{array}$ & van \\
\hline kataszterezés, leltárkészítés, listaírás, táblázatkészítés & van \\
\hline térképek, látványrajzok, látványtervek, 3D tájmodellezés & van \\
\hline $\begin{array}{l}\text { történeti térképek, történeti fényképek, légifelvételek, ürfelvételek } \\
\text { és belőlük származtatott digitális adatbázisok }\end{array}$ & van \\
\hline $\begin{array}{l}\text { aktuális jelenkori fényképek, légifényképek, ortofotók, } \\
\text { ürfelvételek radarfelvételek, }\end{array}$ & van \\
\hline térképi adatok és ezek digitalizálása & van \\
\hline tájfejlődési forgatókönyvek, szcenáriók készítése és megjelenítése & van \\
\hline $\begin{array}{l}\text { digitális adatbázisok, statisztikai adattárak, ábrák, képek, } \\
\text { diagramok }\end{array}$ & van \\
\hline $\begin{array}{l}\text { digitális képfeldogozó-, elemző-, térképező-szoftverek és } \\
\text { kapcsolódó technikák, eljárások, módszerek }\end{array}$ & van \\
\hline térinformatikai feldolgozó és elemző szoftverek és funkcióik & van \\
\hline látványkészítő (vizualizációs) szoftverek & van \\
\hline indikátorképzés és monitorozás eszközei & van \\
\hline
\end{tabular}




\section{8. táblázat Távérzékelés fogalmak}

\begin{tabular}{|c|c|}
\hline Fogalom & Forrás \\
\hline $\begin{array}{c}\text { Olyan adatnyerési eljárások, amelyek az adatokat a vizsgált objektummal } \\
\text { létrehozott közvetlen, fizikai kapcsolat nélkül állítják elő }\end{array}$ & $\begin{array}{l}\text { 2012. évi XLVI. Törvény, } 1 . \\
\S 1 .\end{array}$ \\
\hline $\begin{array}{c}\text { It is not just an interesting technical phenomenon, it has become an essential part of an } \\
\text { urgent quest to understand our changing environment }\end{array}$ & ADAMS és GILLESPIE 2006 \\
\hline $\begin{array}{c}\text { It is the science, technology, and art of obtaining information about objects from a } \\
\text { distance }\end{array}$ & ARONOFF 2005, 2 \\
\hline $\begin{array}{l}\text { Információgyűjtést és feldolgozást jelent olyan rendszerekkel, amelyek a vizsgált vagy } \\
\text { jelenséggel közvetlen kapcsolatban nincsenek }\end{array}$ & $\begin{array}{l}\text { BAKOS és HEREDEA 1987, } \\
158\end{array}$ \\
\hline $\begin{array}{c}\text { Azon technikák összessége, amelyek segítségével információt szerezhetünk a megfigyelés } \\
\text { tárgyáról, anélkül, hogy azzal közvetlen fizikai értintkezésbe kerülnénk }\end{array}$ & BELÉNYESI 2008, 8 \\
\hline $\begin{array}{l}\text { Aquisition of information about the state and condition of an object through sensors that } \\
\text { are not in physical contact with it }\end{array}$ & $\begin{array}{l}\text { CHUVIECO és HUETE 2010, } \\
1\end{array}$ \\
\hline $\begin{array}{c}\text { The measurement or acquisition of information of some property of an object or } \\
\text { phenomenon, by a recording device that is not in physical or intimate contact with the } \\
\text { object or phenomenon under study }\end{array}$ & $\begin{array}{l}\text { COLWELL 1983, in JENSEN } \\
2007,3\end{array}$ \\
\hline $\begin{array}{r}\text { A tárgyakról, területekről (felületekről) jelenségekről, folya } \\
\text { nyerhető adat- és információszerzés, illetve feldolg }\end{array}$ & ENGLER 2000, 4 \\
\hline $\begin{array}{c}\text { The acquisition and recording of information about an object without being in direct } \\
\text { contact with that object (egy tárgyról történö információrögzítés és -szerzés oly módon, } \\
\text { hogy nem kerülünk közvetlen kapcsolatba az tájggyal) }\end{array}$ & GIBSON 2000, 1 \\
\hline $\begin{array}{c}\text { Az a tudományág, amely a tárgyakra vagy jelenségekre jellemző információk beszerzésével } \\
\text { és megérésével foglalkozik olyan rögzítő berendezések segítségével, amelyek nincsenek } \\
\text { közvetlen (fizikai) kapcsolatban a vizsgált tárggyal vagy jelenséggel }\end{array}$ & $\begin{array}{l}\text { GYENIZSE és NAGYVÁRADI } \\
2008,25\end{array}$ \\
\hline $\begin{array}{c}\text { Tárgyakról, területekről, folyamatokról nyerhető adat- és információszerzés } \\
\text { elektromágneses hullámok segítségével }\end{array}$ & GYULAI és BULLA 2002, 1 \\
\hline $\begin{array}{l}\text { A földfelszín megyfigyelése és felvételezése repülőgépen vagy műholdon elhelyezett } \\
\text { eszközökkel }\end{array}$ & HAGGETT 2006, 803 \\
\hline $\begin{array}{l}\text { It is the art and science of obtaining information about an object without beeing in direct } \\
\text { physical contact with the object (egy tárgyról történö információszerzés tudománya és } \\
\text { müvészete oly módon, hogy nem kerülünk közvetlen fizikai kapcsolatba a tárggyal) }\end{array}$ & JENSEN 2007, XIII \\
\hline $\begin{array}{r}\text { Identification or survey of objects by indirect me } \\
\text { created force }\end{array}$ & KONECNY 2003, 7 \\
\hline $\begin{array}{l}\text { It is the science and art of obtaining information about an object, area, or phenomenon } \\
\text { through the analysis of data acquired by a device, that is not in contact with the object, } \\
\text { area, or phenomenon under investigation }\end{array}$ & $\begin{array}{l}\text { LILLESAND, KIEFER és } \\
\text { CHIPMAN 2004, } 1\end{array}$ \\
\hline $\begin{array}{c}\text { Speciális műszeres adatgyűjtés ... mellyel többletínformációkhoz juthatunk, amelyeket az } \\
\text { érzékszerveink segítségével közvetlenül nem ismerhetünk meg ... a természet tárgyairól, } \\
\text { jelenségeiről, folyamatairól. }\end{array}$ & LÓKI 2002, 11 \\
\hline $\begin{array}{l}\text { It is a technique used to derive information about the physical, chemical, and biological } \\
\text { properties of objects without direct contact }\end{array}$ & LONGLEY et al. 2011, 232 \\
\hline $\begin{array}{l}\text { It comprises the analysis and interpretation measurements of electromagnetic radiation } \\
\text { that is reflected from or emitted by a target and observed or recorded from a vantage } \\
\text { point by an observer or instrument that is not in contact with the target }\end{array}$ & MATHER 2004, 1 \\
\hline $\begin{array}{c}\text { A távérzékelés több értelemben is egy olvasási folyamat. Különféle szenzorokat alkalmazva } \\
\text { távérzékelés útján gyűjtjük össze az adatokat, melyeket elemezve információt kapunk a } \\
\text { vizsgált tárgyakról, területekről, jelenségekről }\end{array}$ & MUCSI 2004, 11 \\
\hline $\begin{array}{l}\text { Egy olyan adatgyűjtési eljárás, mely adatokat szolgáltat a vizsgálati tárgyról vagy } \\
\text { jelenségről úgy hogy a műszer nincs közvetlen fizikai kapcsolatban a vizsgálat tárgyával }\end{array}$ & TAMÁS 2000, 33 \\
\hline $\begin{array}{l}\text { It is the use of sensors installed on aircraft or satellites to detect electromagnetic energy } \\
\text { scattered from or emitted by the Earth's surface }\end{array}$ & TSO és MATHER 2001, 5 \\
\hline $\begin{array}{l}\text { It is the art, science and technology of acquiring information about physical objects and } \\
\text { the environment though recording, measuring and interpreting imagery and digital } \\
\text { representations of energy patterns derived from noncontact sensors }\end{array}$ & YANG 2011, 5 \\
\hline
\end{tabular}




\section{9. táblázat Passzív és aktív távérzékelés összevetése néhány szempont alapján (feldolgozott források: LILLESAND, KIEFER és CHIPMAN 2004, MUCSI 2004)}

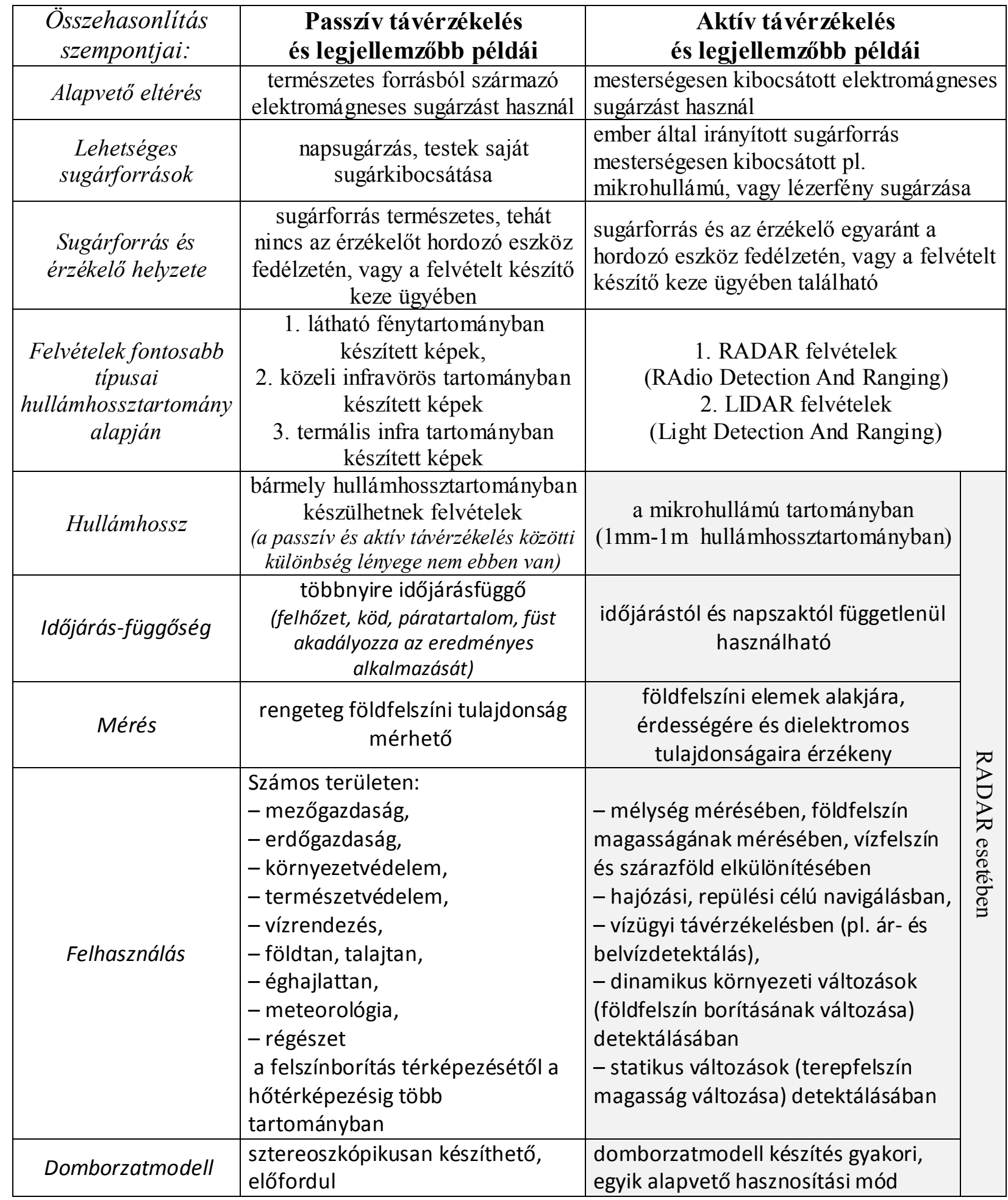




\section{0. táblázat A legfontosabb távérzékeléssel kapcsolatos fogalmak}

\begin{tabular}{|l|l|c|}
\hline Fogalom & Magyarázat & Forrás \\
\hline Geometriai felbontás & $\begin{array}{l}\text { Megadja, hogy egy-egy képpont, (pixel), amelyböl a digitális } \\
\text { kép felépül, mekkora területnek felel meg a valóságban. }\end{array}$ & $\begin{array}{c}\text { a szerző } \\
\text { megfogalmazásában }\end{array}$ \\
\hline Időbeli felbontás & $\begin{array}{l}\text { Megmutatja, hogy az egymást követő azonos területre } \\
\text { koncentráló felvételezések között mekkora idő telik el. (Például } \\
\text { megadja azt az időtartamot, ami alatt a mühold a földfelszín } \\
\text { egy bizonyos pontja fölé újra visszatér) }\end{array}$ & $\begin{array}{c}\text { megfogalmazásában } \\
\text { a szerző }\end{array}$ \\
\hline Pixel & A legkisebb elem, melyet a képalkotó eszköz létre tud hozni & (ELEK 2006, 107) \\
\hline Spektrális felbontás & $\begin{array}{l}\text { Megmutatja, hogy az érzékelő rendszer, hány sávban } \\
\text { (csatornán), és milyen szük spektrális tartományban érzékeli az } \\
\text { elektromágneses sugárzást. }\end{array}$ & $\begin{array}{c}\text { a szerző } \\
\text { megfogalmazásában }\end{array}$ \\
\hline Térbeli kiterjedés & $\begin{array}{l}\text { Információt ad arról, hogy mekkora a valós területi kiterjedése } \\
\text { a területnek, amit a kép/felvétel ábrázol. }\end{array}$ & $\begin{array}{c}\text { a szerzó } \\
\text { megfogalmazásában }\end{array}$ \\
\hline
\end{tabular}

\section{1. táblázat A 2012. évi XLVI. a földmérési és térképészeti tevékenységről szóló törvény szövegének részlete az állami távérzékelési adatbázisról}

\begin{tabular}{|c|c|}
\hline & állami távérzékelési adatbázisok \\
\hline & $\begin{array}{l}\text { 19. \$ (1) A földmérési és térinformatikai államigazgatási szervnek és a honvédelem } \\
\text { térképészeti támogatásáért felelős szervnek állami digitális távérzékelési adatbázist kell } \\
\text { létrehoznia és üzemeltetnie az általuk előállított, illetve kezelt távérzékelési anyagokból } \\
\text { és adatokból, amelynek részei: } \\
\text { a) analóg és digitális légifényképtár, } \\
\text { b) légi távérzékelési adatbázis, } \\
\text { c) ürtávérzékelési adatbázis, } \\
\text { d) földi távérzékelési adatbázis. }\end{array}$ \\
\hline & $\begin{array}{l}\text { (2) Digitális légifényképtárban kell megőrizni a Magyarország területéről készült } \\
\text { légifelvételeket. Az analóg (film) technológiával készült felvételeket digitálissá kell } \\
\text { alakítani és adatbázisba kell szervezni. }\end{array}$ \\
\hline & $\begin{array}{l}\text { (3) A digitális ortofotó-adatbázis része a légi távérzékelési adatbázisnak, amely az } \\
\text { ország bármely területét ábrázoló, az állami alapfeladatokhoz és alapmunkákhoz } \\
\text { felhasználható digitális ortofotókból áll. }\end{array}$ \\
\hline & $\begin{array}{l}\text { (4) Az ürtávérzékelési adatbázis müholdak által készített, az adott mühold érzékelöinek } \\
\text { megfelelő felbontású űrfelvételeiből áll. }\end{array}$ \\
\hline & $\begin{array}{l}\text { (5) Földi távérzékelési adatbázisnak kell tekinteni azon földi távérzé } \\
\text { készült felvételek összességét, amelyekkel állami alapadatok állíthat }\end{array}$ \\
\hline
\end{tabular}




\section{2. táblázat Kontraszt és élesség kezelésének fontosabb eljárásai}

A „szürke küszöb” alapján készített bináris maszk (Grey-level thresholding) készitése során egy a kép valamely csatornáján rögzített adatokat két „osztályra” bontjuk egy bizonyos, a felhasználó által megválasztott határérték mentén. Ez a módszer egyike azoknak melyek segítségével bináris maszkot ${ }^{7}$ állíthatunk elő. Ezek a maszkok elősegítik, hogy a további feldolgozást, például képpont-osztályozást csak a felvétel számunkra érdekes területén tegyük meg (LILLESAND, KIEFER és CHIPMAN 2004, 509).

A szintező szeletelés (Level slicing) alkalmazás a kép hisztogramjának $\mathrm{x}$ tengelye mentén a digitális értékeket $\left(\mathrm{DN}^{8}\right)$ szintszerüen intervallumokra bontja, azaz szeleteli az adatokat Eredménye általában egy szintvonalas térképhez hasonlít mivel az azonos intervallumba esö értékeket azonos színnel (árnyalattal), egy adott DN köré csoportosítva jeleníti meg (LILLESAND, KIEFER és CHIPMAN 2004, 512).

Kontrasztfokozás / Kontrasztnövelés (Contrast stretching) a legismertebb eljárás, melynek során a képpontok digitális értékét módosítják (szorozzák meg) egy olyan számmal, mely

biztosítja, hogy a digitális értékek keskeny tartománya a kijelzö teljes dinamikai tartományára kiterjedjen. Ennek következtében a hisztogram azt mutatja, hogy az értékek nagyobb tartományra kiterjednek. Több fajtája van, többféle függvénnyel. A kontrasztnövelés egyik legegyszerübb módja a lineáris kontraszt (linear stretch), mely lineárisan torzítja az értékeket (LILLESAND, KIEFER és CHIPMAN 2004, 513). Az egyik leggyakoribb nem lineáris módja pedig a Hisztogram-kiegyenlítés, (Histogram-equalised stretch) (ELEK 2006, 149) (GIBSON és POWER 2000, 38-39), mely azt is figyeli, hogy milyen értékekből van több a hisztogramban és azokat még jobban széthúzza az $\mathrm{X}$ tengely mentén.

A térbeli szürỏk, (Spatial Filtering) alkalmazásával lehetséges a képek élesítése, vagy lágyítása egy úgynevezett „mozgó ablak” (kernel) felhasználásával. A térbeli szürők kiemelik (hangsúlyozzák) vagy elsimítják (elrejtik, elmossák) a változatos térbeli frekvenciával rendelkező képrészleteket. Az alulvágó szürők (MATHER 2005, 181 alapján „low pass filters” vagy „smoothing filters”) azok, melyek a nagy kiterjedésủ foltok tehát az alacsony térbel frekvenciával rendelkező képrészletek közötti eltéréseket emelik ki (LILLESAND-KIEFERCHIPMAN 2004, 519). Ezzel szemben a felülvágó szürők („,high pass filters” vagy „, sharpening ஜ filters") (MATHER 2005, 188 alapján) kiemelik a nagy térbeli frekvenciával rendelkező képrészleteket, azaz élesítik a képet.

Az éldetektálásnak (Edge detection) fontos szerepe lehet a különböző formák, alakzatok felismerésében (ELEK 2006, 134) vagy a raszteres képek vektoros digitalizálásában. Ez a módszer a térbeli mintázat felismerését segíti elő (ARONOFF 2005, 294). Elnek a kép azon részét tekintjük, ahol az intenzitás változása (pl. két szomszédos pixel között) a legnagyobb, tehát ahol a pixelek digitális értékei között hirtelen nagy különbség van. Sokféle éldetektálási módszer közül érdemes kiemelni azokat, melyek lehetőséget adnak arra, hogy egyfajta irányt (pl. vertikális vagy horizontális) kiemelten figyelembe vegyen az élek meghatározásakor (ELEK 2006, 137), de említésre méltó az élfokozás (Edge enhancement), és a Fourier-elemzés is (LILLESAND-KIEFER-CHIPMAN 2004, 521-529).
13. táblázat A távérzékelés interpretációs elemei. (BUITEN 1993 in KRISTÓF 2005, 44; LILLESAND et al. 2004, 306-310; ARONOFF 2005, 262-266; 39-40; JENSEN 2007, 133 munkáinak feldolgozásával)

\begin{tabular}{|c|c|c|c|}
\hline & $\begin{array}{l}\text { Interpretációs } \\
\text { elem (angol } \\
\text { megfelelő́je) }\end{array}$ & $\begin{array}{c}\text { Az elem leírása, magyarázata: } \\
\text { Mi alapján történik a felismerés / beazonosítás / } \\
\text { besorolás / mérés? }\end{array}$ & $\begin{array}{c}\text { Az elemet } \\
\text { megnevezök }\end{array}$ \\
\hline 1 & Alak (shape) & $\begin{array}{l}\text { A vizsgált földfelszíni tájelem jellegzetes körvonala, } \\
\text { formája, alakja, elemei alapján }\end{array}$ & $\begin{array}{l}\text { BUITEN in KRISTÓF, } \\
\text { ARONOFF, JENSEN }\end{array}$ \\
\hline 2 & Méret (size) & $\begin{array}{l}\text { A tárgy méretei (hosszúság, szélesség, magasság, } \\
\text { terület, kerület, térfogat) alapján }\end{array}$ & $\begin{array}{l}\text { BUITEN in KRISTÓF, } \\
\text { ARONOFF, JENSEN }\end{array}$ \\
\hline 3 & Tónus (tone) & $\begin{array}{l}\text { A felszínt ábrázoló kép átlagos világossága, vagy } \\
\text { tájelemek világossága, világossági átmenetei alapján }\end{array}$ & $\begin{array}{l}\text { LILLESAND ET AL. } \\
\text { ARONOFF, JENSEN }\end{array}$ \\
\hline 4 & Szín (color) & $\begin{array}{l}\text { A tárgyról visszaverōdő, vagy kibocsájtott sugárzás } \\
\text { rögzítése után megjelenített "szín" alapján }\end{array}$ & $\begin{array}{l}\text { BUITEN in KRISTÓF, } \\
\text { ARONOFF, JENSEN }\end{array}$ \\
\hline 5 & $\begin{array}{l}\text { Árnyék és } \\
\text { árnyasság } \\
\text { (shadow, shade) }\end{array}$ & $\begin{array}{l}\text { Egyes tájelemek földfelszínre, környezetére, vagy } \\
\text { magára a tájelemre vetülő árnyéka, esetenként } \\
\text { pusztán árnyas oldala alapján }\end{array}$ & $\begin{array}{l}\text { BUITEN in KRISTÓF, } \\
\text { ARONOFF, JENSEN }\end{array}$ \\
\hline 6 & $\begin{array}{l}\text { Mintázat } \\
\text { (pattern) }\end{array}$ & $\begin{array}{l}\text { A földfelszín és domborzatának elemei vagy a rajta } \\
\text { elhelyezkedő tájelemek elhelyezkedéséből, } \\
\text { elrendezésébő́l látható vagy kiolvasható formák, } \\
\text { alakzatok alapján }\end{array}$ & $\begin{array}{l}\text { BUITEN in KRISTÓF, } \\
\text { LILLESAND et al. } \\
\text { ARONOFF, JENSEN }\end{array}$ \\
\hline 7 & $\begin{array}{l}\text { Szerkezet / } \\
\text { textúra (texture) }\end{array}$ & $\begin{array}{l}\text { A földfelszín vagy egyes elemei felületeinek } \\
\text { szerkezete, texturája, anyagának jellege alapján }\end{array}$ & $\begin{array}{l}\text { BUITEN in KRISTÓF, } \\
\text { LILLESAND et al. } \\
\text { ARONOFF, JENSEN }\end{array}$ \\
\hline 8 & Helyszín (site) & $\begin{array}{l}\text { A felismerhető felszínhez, vagy tájelemekhez képest } \\
\text { egy-egy beazonosíthatatlan tájelem ismeretlen } \\
\text { funkciója esetén elhelyezkedésének } \\
\text { szükségszerüsége alapján }\end{array}$ & $\begin{array}{l}\text { BUITEN in KRISTÓF, } \\
\text { ARONOFF, JENSEN }\end{array}$ \\
\hline 9 & $\begin{array}{l}\text { Földraj } \\
\text { (locatio }\end{array}$ & $\begin{array}{l}\text { Földrajzi koordinátaértékek terepi megkeresése } \\
\text { alapján }\end{array}$ & JENSEN \\
\hline 10 & $\begin{array}{l}\text { Asszo } \\
\text { (assoc }\end{array}$ & $\begin{array}{l}\text { Tájelemek egymás közötti kapcsolatainak } \\
\text { értelmezése, elemzése alapján }\end{array}$ & $\begin{array}{l}\text { BUITEN in KRISTÓF, } \\
\text { ARONOFF, JENSEN }\end{array}$ \\
\hline 11 & $\begin{array}{l}\text { Szitu } \\
\text { (situa }\end{array}$ & yított helyzete & JENSEN \\
\hline 12 & $\begin{array}{l}\text { Térbeli felbontás } \\
\text { (spatial } \\
\text { resolution) }\end{array}$ & $\begin{array}{l}\text { Az érzékelö felbontásától függő̋en eltérő méretü és } \\
\text { jellegú beazonosítható tájelemek alapján }\end{array}$ & BUITEN in KRISTÓF \\
\hline 13 & Sztereo (stereo) & $\begin{array}{l}\text { Egy azonos földfelszínről eltérő szögben készült } \\
\text { több felvétel felhasználásával sztereo- } \\
\text { fotogrammetira elve alapján }\end{array}$ & JENSEN \\
\hline 14 & $\begin{array}{l}\text { Időbeliség } \\
\text { (time scale) }\end{array}$ & $\begin{array}{l}\text { Több időpontból származó felvételen látható } \\
\text { tájelemek fejlődéstörténetének összeállitása alapján }\end{array}$ & KRISTÓF \\
\hline 15 & $\begin{array}{l}\text { Térbeli eltérés } \\
\text { (spatial } \\
\text { difference) }\end{array}$ & $\begin{array}{l}\text { Több tájkarakter területből vagy tájkarakter típusból } \\
\text { származó felvételen látható jellegzetes különbségek } \\
\text { összevetése alapján }\end{array}$ & $\begin{array}{l}\text { A disszertáció } \\
\text { szerzöjének } \\
\text { megállapítása, a tájak } \\
\text { összevetése során } \\
\text { alkalmazott } \\
\text { interpretációs elemröl }\end{array}$ \\
\hline
\end{tabular}

bináris maszk: egy határérték mentén két részre osztott értéktartomány egy felvétel esetén

${ }^{8} \mathrm{DN}$ : digital number $=$ digitális számérték, amit az érzékelők a felvételekbe rögzítettek 
14. táblázat A passziv képalkotó távérzékelés szerepét indokoló témák a tájkarakterelemzési útmutatóban és kapcsolódó függelékekben.

\begin{tabular}{|c|c|c|}
\hline Téma, Témakör & Indoklás / Megjegyzés & Előfordulás útmutatásokban \\
\hline $\begin{array}{l}\text { Változást kiváltó erők } \\
\text { (,forces for change”) }\end{array}$ & $\begin{array}{l}\text { A tájváltozást eredményezó erök, több } \\
\text { légi-, vagy ürfelvétel áttekintésével } \\
\text { térbeli összefüggések feltárásával, } \\
\text { nagyobb eséllyel beazonosithatók. }\end{array}$ & $\begin{array}{l}\text { (SWANWICK 2002, 9, 14,46,51,54) } \\
\text { (DEANWOOD tal. 2002, 2, 14) } \\
\text { (FAIRCOUGH és MACINNES 2002, 10) }\end{array}$ \\
\hline $\begin{array}{l}\text { Térbeli hierarchia vagy } \\
\text { különbözzö szintek, } \\
\text { (,,spatial h hierarchy”, } \\
\text {,different levels”) }\end{array}$ & $\begin{array}{l}\text { A karakter-elemzés több szinten } \\
\text { folytatható, ami indokolhatja, hogy eltéró } \\
\text { szinteken eltérö felbontású és spektrumú } \\
\text { felvételeket szükséges alkal mazni. }\end{array}$ & $\begin{array}{c}\text { (SWANWICK 2002, 11-12, 38, 43, 54, 78) } \\
\text { (FAIRCLUGGH és MACNNES 2002, 6) } \\
\text { (SWANWICK 2002 TP6, 14) (SW ANWICK, } \\
2002 \text { TP1, 6) } \\
\text { (PORTER Ré AHERN 2002, 5-6) } \\
\text { (DEANWOOD et al. 2002, 3-4) } \\
\end{array}$ \\
\hline $\begin{array}{l}\text { Lépték és részletezettség } \\
\text { (,scale and level of detail”) }\end{array}$ & 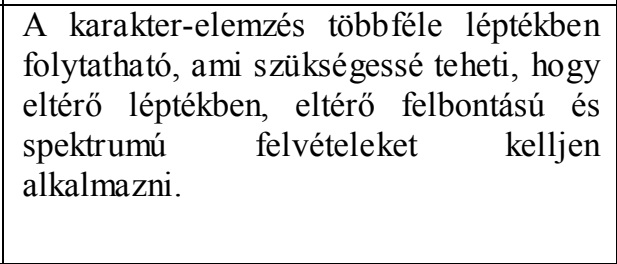 & $\begin{array}{c}\text { (SWANWICK 2002, 6, 13, 17-20, 23, 31, 36, } \\
40,46,76) \\
\text { (SWANWICK, 2002 TP1, 6) } \\
\text { (PORTER és AHERN 2002, 2, 12) } \\
\text { (DEANWOOD et al. 2002, 4) } \\
\text { (SWANWICK 2002 TP6, 15-16) } \\
\text { (FAIRCLOUGH és MACINNES 2002, 9) } \\
\text { (COLE 2002, 3) }\end{array}$ \\
\hline $\begin{array}{l}\text { Érintettek részvétele vagy } \\
\text { érintettek bevonása } \\
\text { (,participation of } \\
\text { stakeholders" or stakeholder } \\
\text { involvement") }\end{array}$ & $\begin{array}{l}\text { Látványos, érthetö megjelenitístst követel, } \\
\text { amit a hétköznapi ember számára jól } \\
\text { interpretálható nagyfelbontású felvételek } \\
\text { kiválóan támogatnak, teljesitenek, 2,5D } \\
\text { és 3D vizualizációra is alkalmasak. }\end{array}$ & $\begin{array}{c}\text { (SWANWICK 2002, 15, 18, 35, 38, 51, 53, 55, } \\
\text { 57, 71, 77, 80) (SWANWWICK, 2002 TP1, 2) } \\
\text { (SWANWIC et al. 2002 TP3) } \\
\text { (PORTER és AHERN 2002, 10-11, 14) } \\
\text { (DEANWOOD et al. 2002, 8) } \\
\text { (COLE 2002, 2, 4) } \\
\text { (SWANWICK 2002 TP6, 13-14) } \\
\text { (KABAI 2011, 65) }\end{array}$ \\
\hline $\begin{array}{l}\text { Térinformatikai } \\
\text { felkészültség } \\
\text { (,GIS skills”) }\end{array}$ & 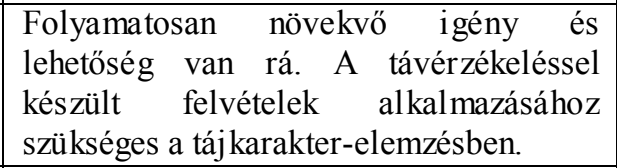 & $\begin{array}{r}\text { SWANWWICK } \\
\text { (PORTER és AHERN } \\
\text { (FAIRCDUGH és M } \\
\text { (SWANWICK 2002 T } \\
\end{array}$ \\
\hline $\begin{array}{l}\text { Térképi fedvények } \\
\text { téradat-szerkesztés, } \\
\text { térkép-szerkesztés } \\
\text { („,map overlays” } \\
\text {,GIS data } \\
\text { manipulation") }\end{array}$ & $\begin{array}{l}\text { A térképi fedvényekkel, fedvények } \\
\text { közöttii műveletekkel, elemzésekkel, és } \\
\text { az elemzések kombinálásával } \\
\text { ürfelvételek, légifelvételek, felszin- } \\
\text { modellek és származtatott felszínborítási } \\
\text { adatok is felhasznál hatók a karakter } \\
\text { jellemzésére. }\end{array}$ & $\begin{array}{c}\text { (SWANWICK 2002, 21-22, 21, 26, 28, 37-38) } \\
\text { (SWANWICK, 2002 TP1, 5) }\end{array}$ \\
\hline $\begin{array}{l}\text { Idóttávlat, } \\
\text { történeti dime nzió } \\
\text { (,time depth”, } \\
\text { „historic dimension”) }\end{array}$ & $\begin{array}{l}\text { Az időbeli távlatok kitágítására lehet } \\
\text { szükség, amit a történeti légifelvételek } \\
\text { idösorai igen jól támogatnak egy } \\
\text { történeti tájkarakter-elemzés esetén. }\end{array}$ & $\begin{array}{l}\text { (SWANWICK 2002, 21, 23, 28-29) } \\
\text { (FAIRCLOUGH és MACINNES 2002, 2-3, 4, } \\
\text { 7, 9, } 10 \text { ) } \\
\text { (SWANWICK, 2002 TP1, 2) } \\
\text { (SWANWICK 2002 TP6, 4, 8) }\end{array}$ \\
\hline $\begin{array}{l}\text { Mintázat } \\
\text { (,pattern") }\end{array}$ & $\begin{array}{l}\text { A területhasználat foltokat és a települési } \\
\text { mintázatokat, melyek elemzésére } \\
\text { elengedhetetlenül szükség van a } \\
\text { karakter-elemzésben, szinte csak légi- } \\
\text { vagy ưrfelvételekkel lehet feltárni. }\end{array}$ & 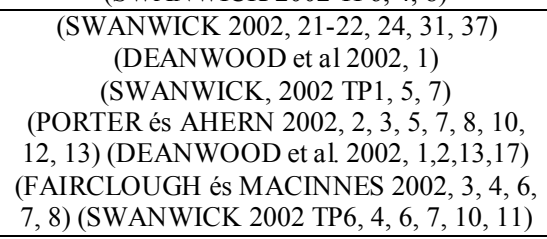 \\
\hline $\begin{array}{lcc}\text { Egyensúly } & \text { és } & \text { arányok } \\
\text { (,,balance } & \text { and } & \text { proportion”) } \\
\text { lépték } & \text { (,scale”), } \\
\text { körülzártság } & \text { (,enclosure) } \\
\text { szerkezet } & \text { („texture”) } \\
\text { szín } & \text { (,colour”) } \\
\text { változatosság } & \text { (,diveristy”) } \\
\text { egységesség } & \text { (,,unity”) } \\
\text { alakzatok } & \text { (,form”) } \\
\end{array}$ & $\begin{array}{l}\text { A terepi bejáráshoz és a tájjelleg } \\
\text { meghatározásához számos olyan elemet } \\
\text { köt Swanwick, melyek a passzív } \\
\text { képalkotót távérzékelés felvételeivel, és } \\
\text { képfeldolgozón móndszereivel } \\
\text { dokumentálhatók, bemutathatók }\end{array}$ & (SWANWICK 2002, 34-35) \\
\hline $\begin{array}{l}\text { Számítógépes osztályozási } \\
\text { technikák } \\
\text { (,,computer classification”) }\end{array}$ & $\begin{array}{l}\text { Az osztályozást geokorrigált formáb } \\
\text { távérzékelési adatokra épító rasz } \\
\text { térinformatika kiválóan támogatja. }\end{array}$ & $\begin{array}{l}\text { (SWANWICK } 2002 \text { TP1, 3,5) } \\
\text { (PORTER és AHERN 2002, 10) }\end{array}$ \\
\hline
\end{tabular}

\begin{tabular}{|c|c|c|c|c|c|}
\hline \multirow[b]{2}{*}{$\begin{array}{l}\text { Tájelemzési } \\
\text { témakör }\end{array}$} & \multirow[b]{2}{*}{$\begin{array}{l}\text { Rendszer- } \\
\text { paraméter }\end{array}$} & \multicolumn{4}{|c|}{ Információhordozó } \\
\hline & & légifénykép & $\begin{array}{c}\text { földi } \\
\text { fénykép }\end{array}$ & $\begin{array}{l}\text { helyszini } \\
\text { bejárás }\end{array}$ & interview-k \\
\hline \multirow{2}{*}{ Tájökológia } & élöhelyek & & & & \\
\hline & használat & & & 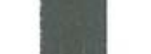 & \\
\hline Tájkép & szerkezet & & & & \\
\hline \multirow{2}{*}{$\begin{array}{l}\text { Tájjelleg- } \\
\text { azonositás }\end{array}$} & kép & & & & \\
\hline & $\begin{array}{l}\text { területi } \\
\text { identitás }\end{array}$ & & & & \\
\hline
\end{tabular}

4. ábra Az integrált tájmegfigyelés adatforrásai és felhasználhatóságuk Glauser nyomán Konkolyné Gyuró szerint (KONKOLYNÉ GYURÓ 2003, 161) 

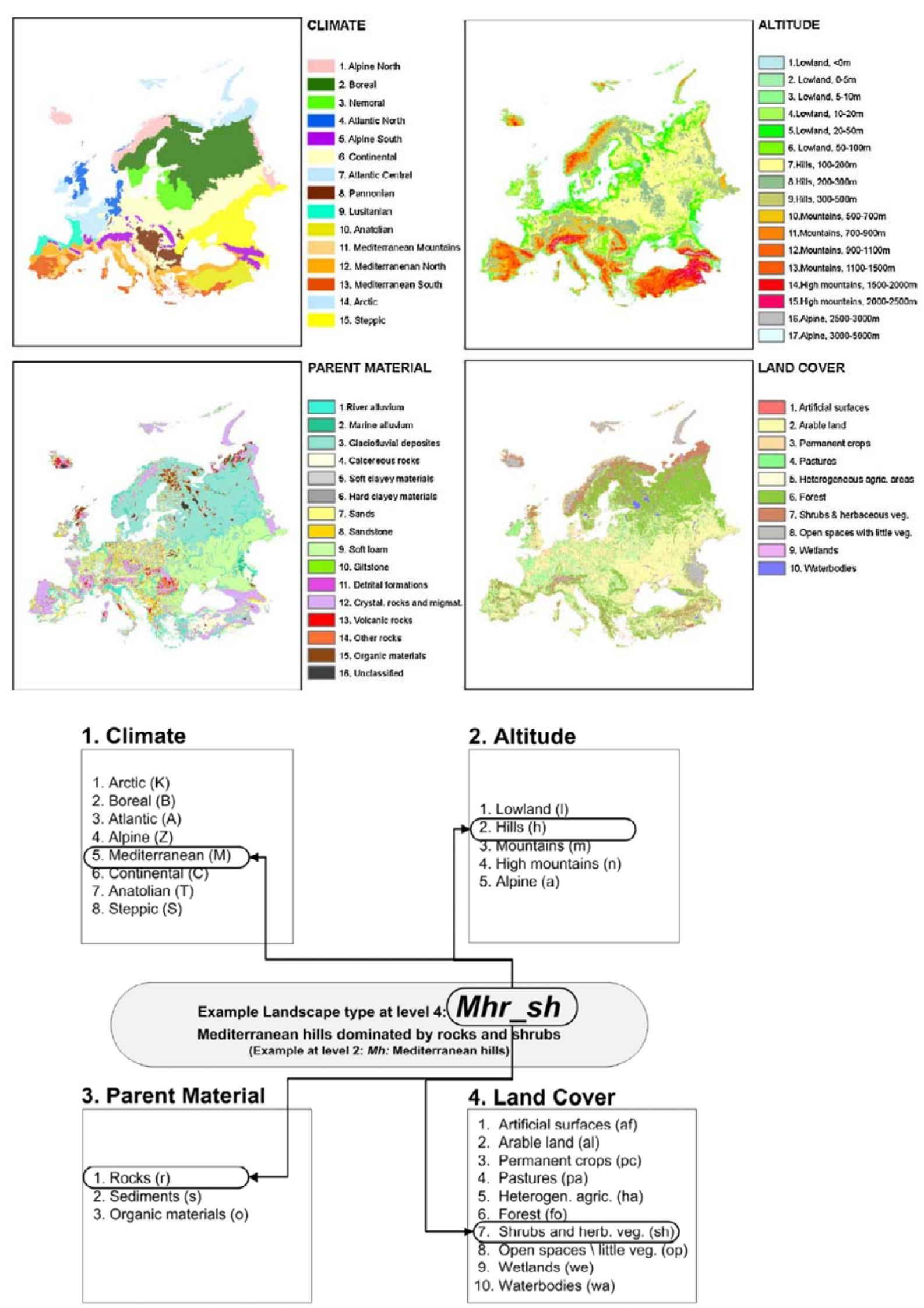

5. ábra A LANMAP2 Európai tájtipológia térképhez felhasznált alapadatok (MÜCHER et al. 2010, 89, 91) Éghajlat, Tengerszint feletti magasság, Alapkőzet, Felszínborítás és ezek felhasználásával kialakított jellemzés betűkódja, mely rétegenként egy tulajdonságot kódol

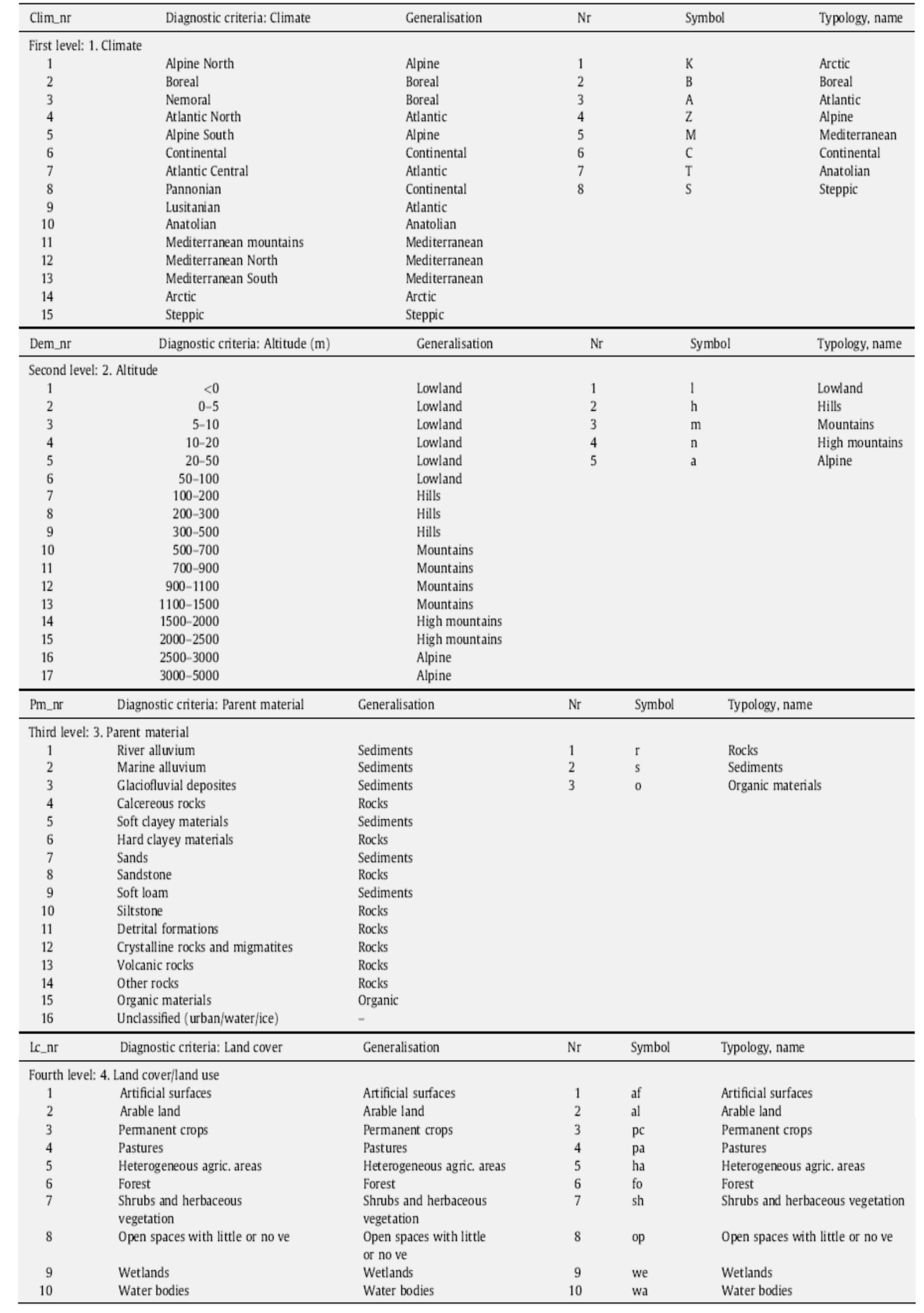

6. ábra A LANMAP2 Európai tájtipológia térkép alapadatai, egyszerüsítésük módja a kategóriák összevonásával (MÜCHER et al. 2010, 101) 


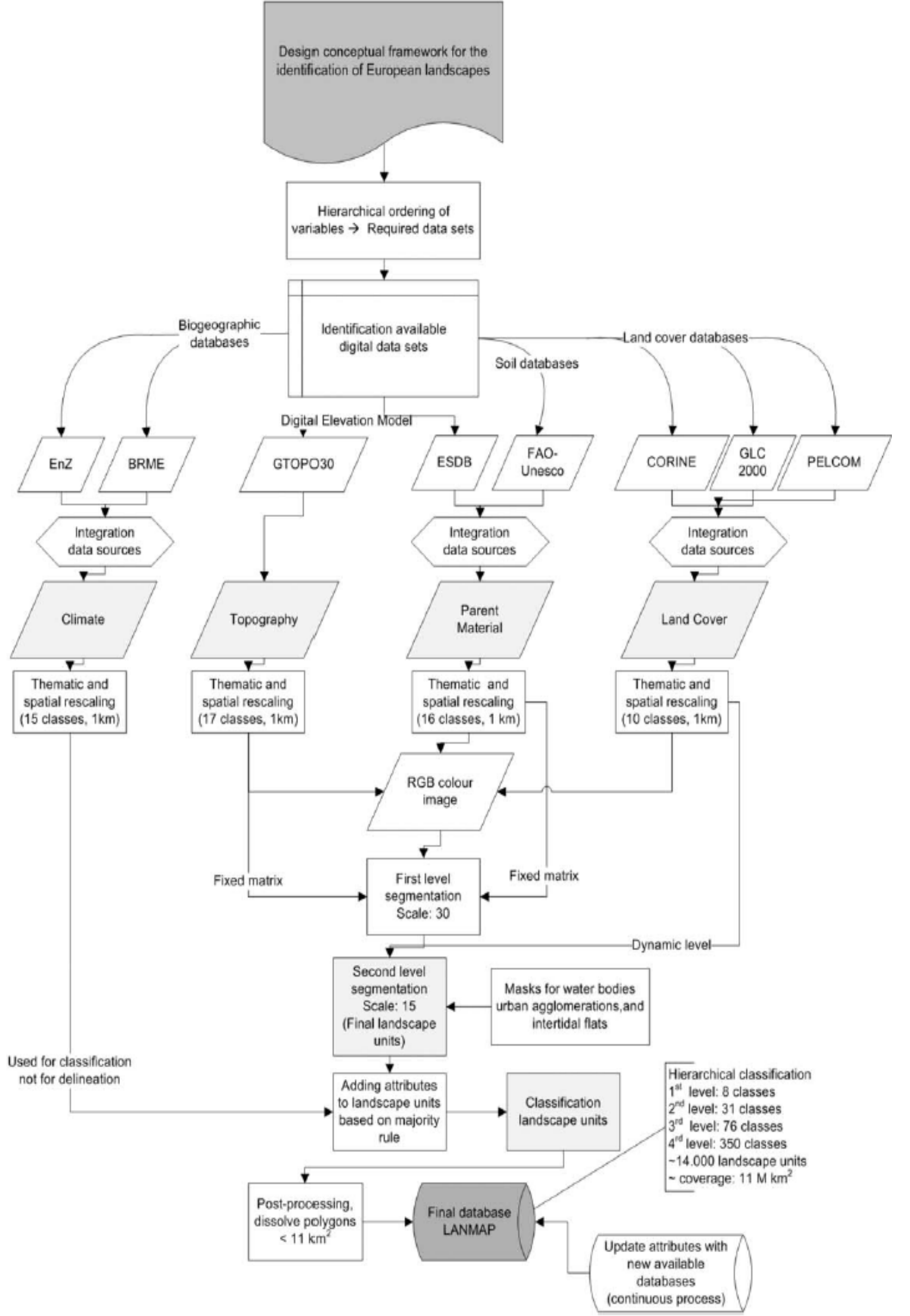

7. ábra A LANMAP2 módszertan folyamatábrája (MÜCHER et al. 2010, 90)

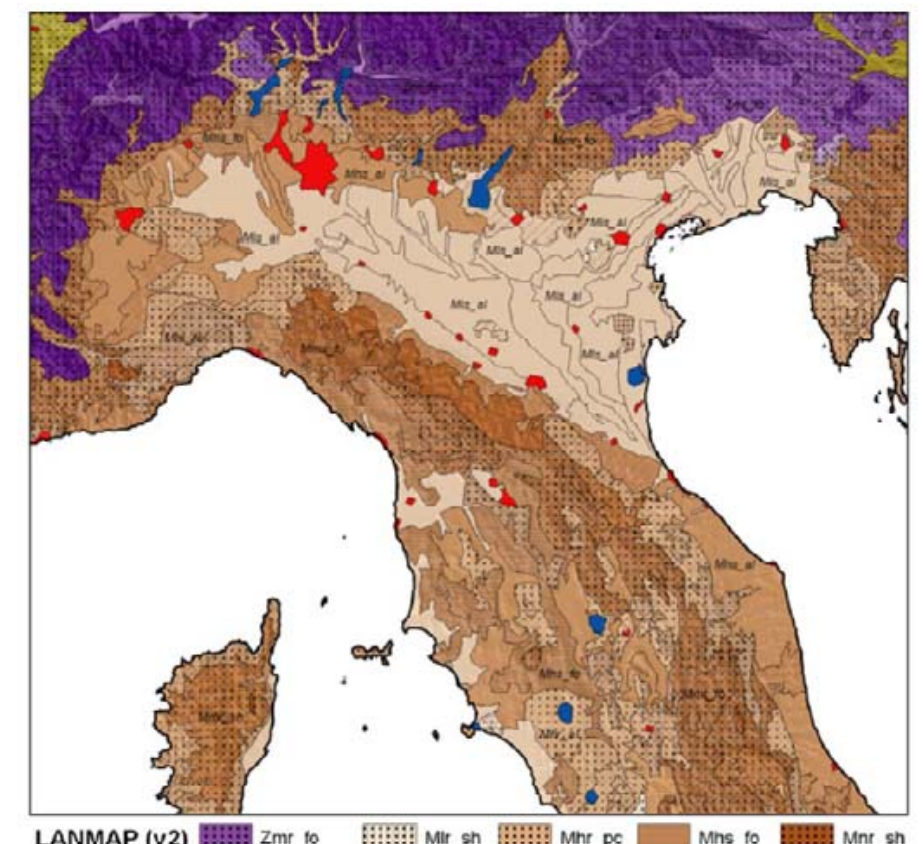

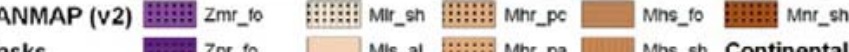

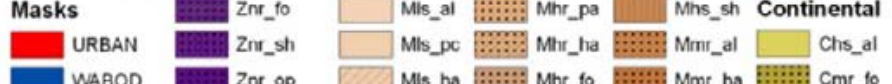

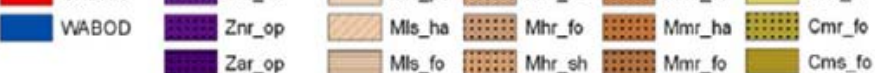

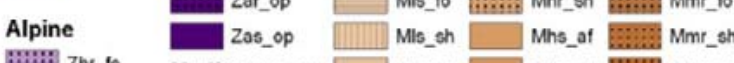

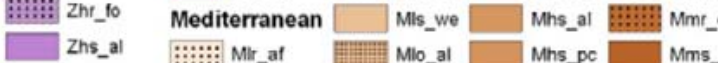

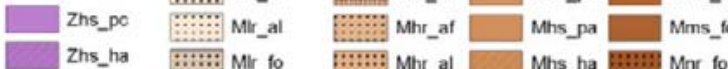

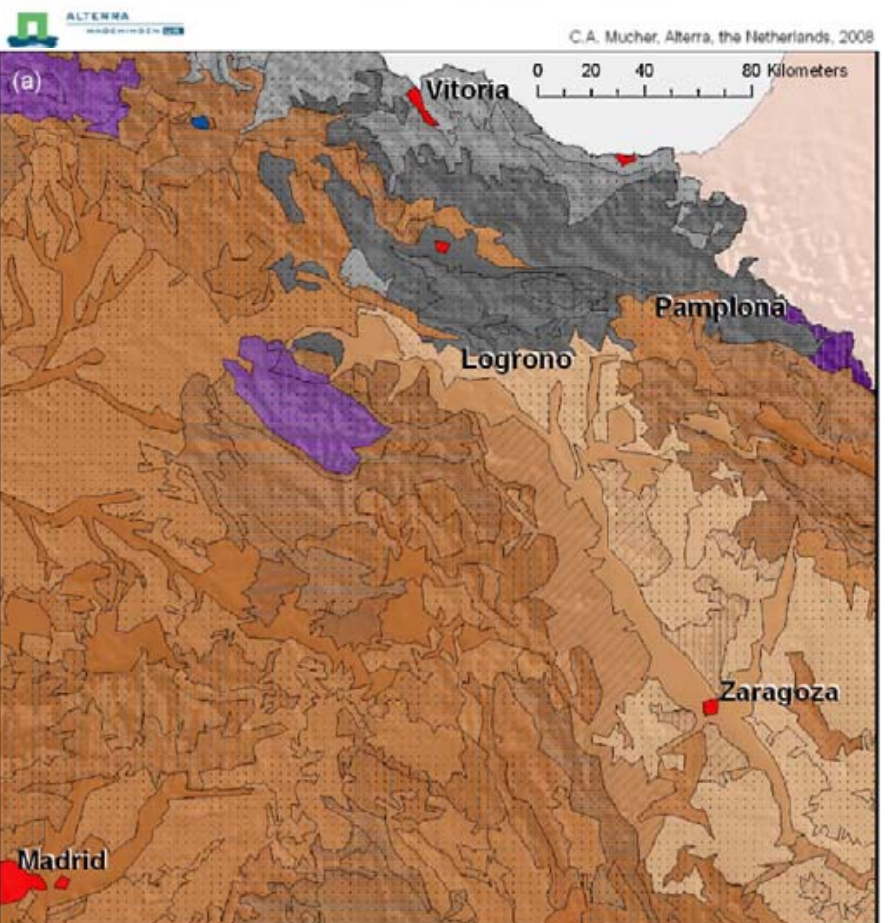

LANMAP 3. Atlantic Mhs_al [Mmr_sh Mhs_al [in Mmr_sh URBAN N Ahr_pa 4.Alpine 周Mhr_al

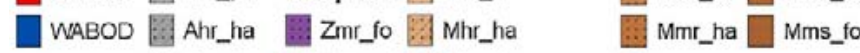

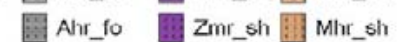

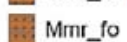

Explanation Legend 1. Climate

B. Boreal

A. Atlantic

Z. Alpine

- M. Mediteranean

C. Continental

- T. Anatolian

2. Altitude

h. Hills

m. Mountains

n. High Mountains

a. Alpine

3. Parent material

...:-i. r. Rocks

.. o. Organic material

4. Land use

af. Artificial surfaces

al. Arable land

pc. Permanent crops

pa. Pastures

27. ha. Heterogeneous

agriciculturl areas

$\Longrightarrow$ fo. Forests

IIII) sh. Shrubs and herbaceous (semi-) natural vegetation op. Open spaces with little

or no vegetation

we. Wetlands

Masks

wa. Waterbodies

- URBAN, built-up area

FLATS, intertidal flats WABOD, waterbodies

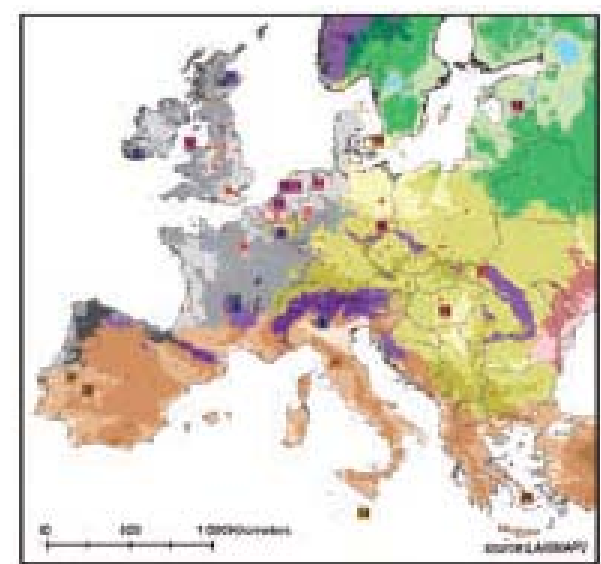

8. ábra A LANMAP2 olaszországi és spanyolországi részlete (MÜCHER et al. 2010, 93, 97) 


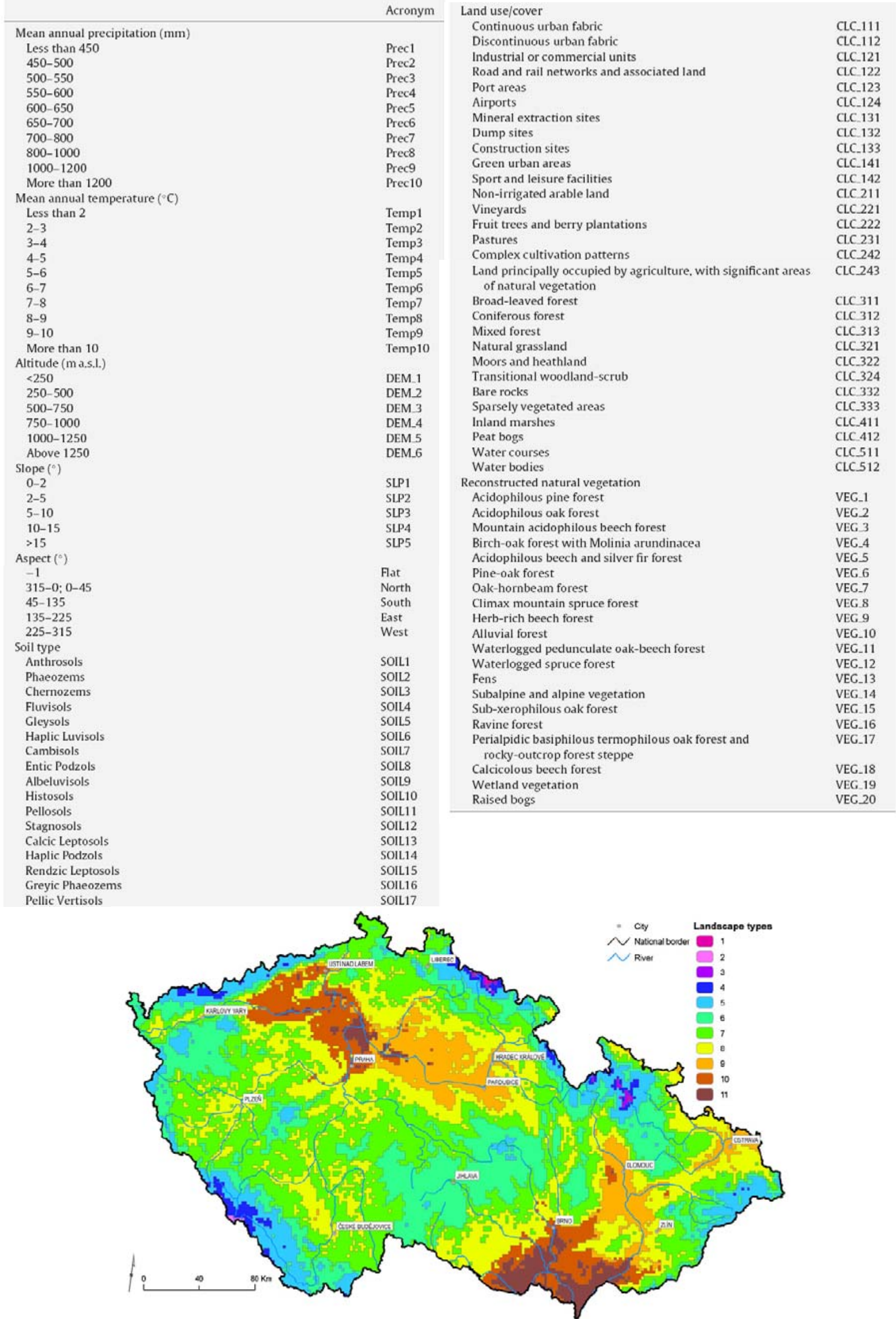

9. ábra Alapadatok a Csehország tájtípusait lehatároló elemzésben és a térképezett tájkarakter típusok (CHUMAN és ROMPORTL 2010, 202, 207) 


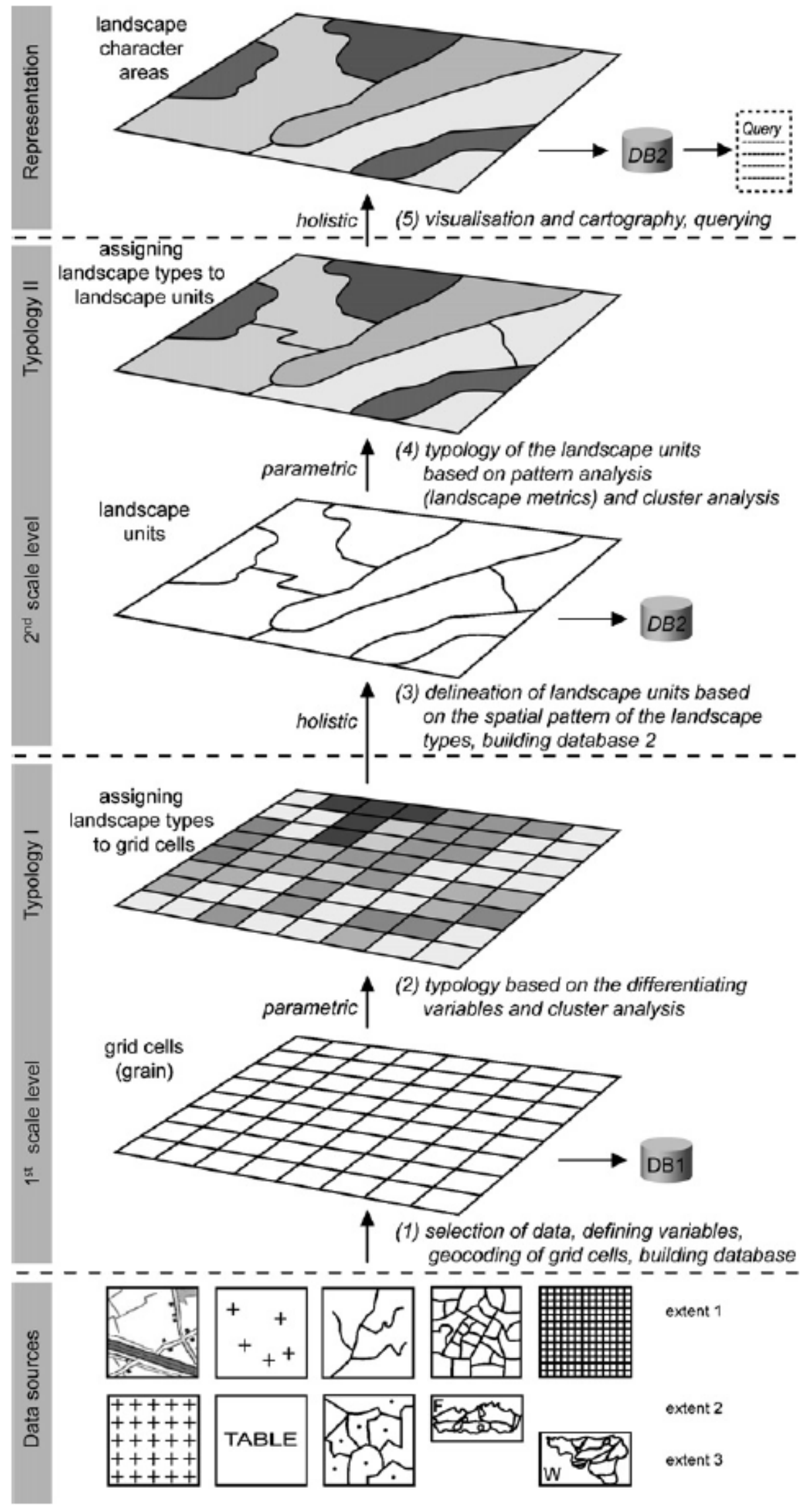

10. ábra Módszertani javaslat a térinfor matikai adatok felhasználására és a karakterelemzés lépéseinek elvégzésére (VAN EETVELDE és ANTROP 2009a 164) 
(a)
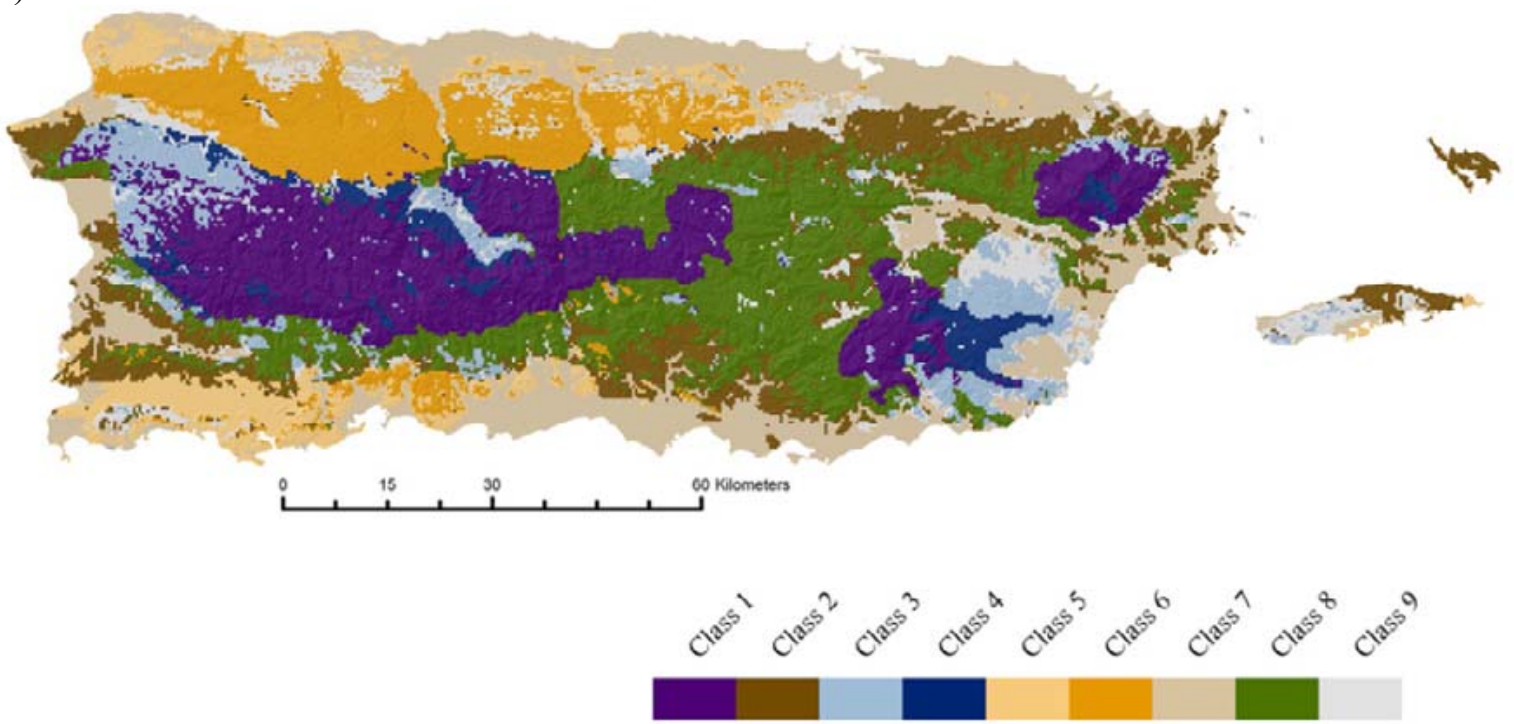

(b)

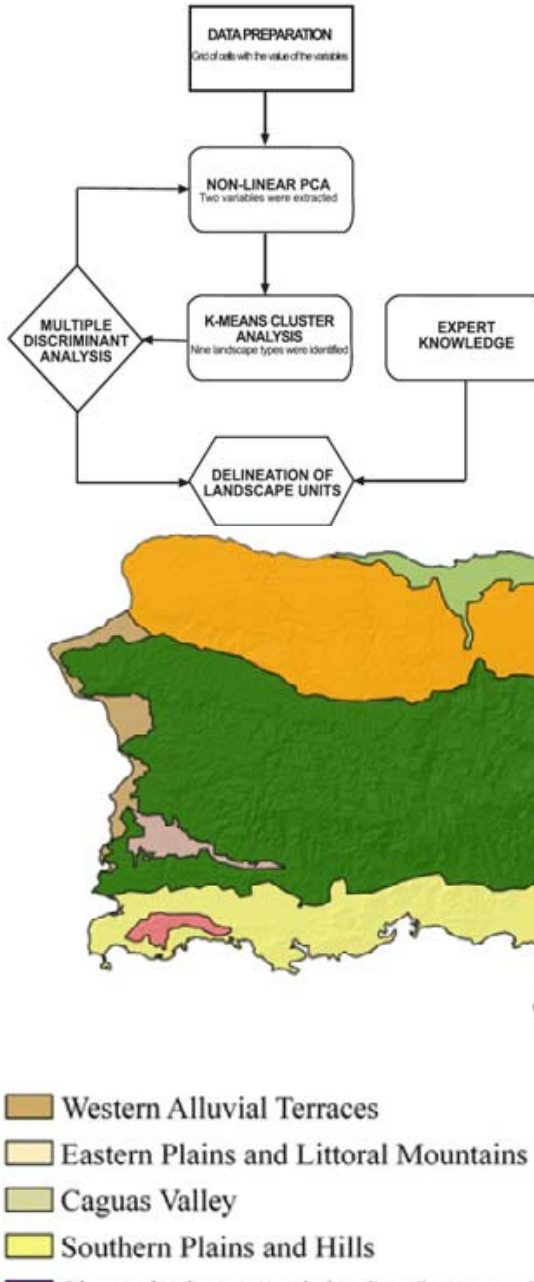

(c) 


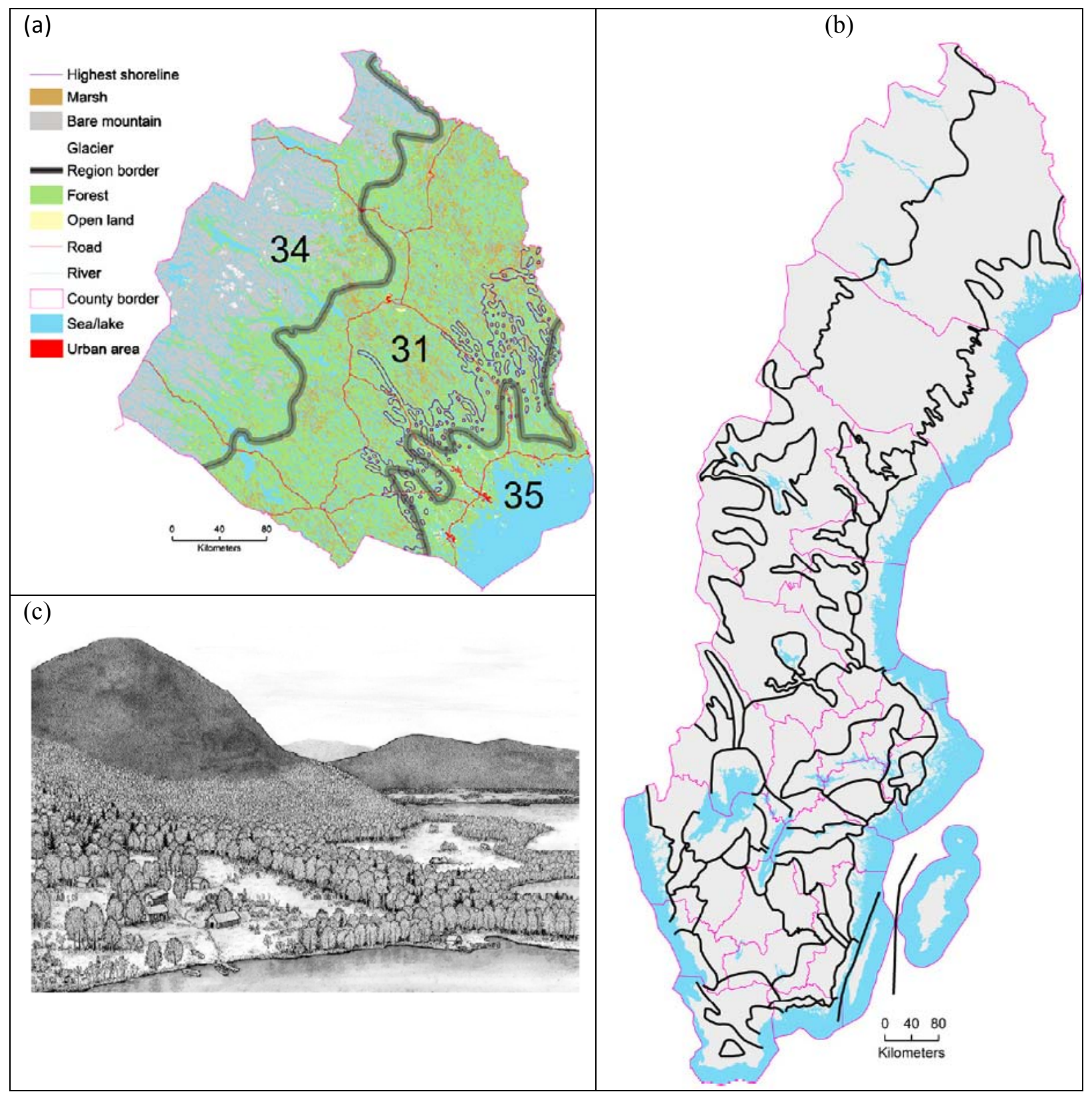

12. ábra Ábrák Antonson tanulmányából, melyek az infrastruktura-tevezéshez javasolt tájkarakter-térképet és látványrajzot mutatnak be. (ANTONSON 2009, 169-177) (a) Norrbotten megye és három jellemző tájkarakter-típusa kopár sziklás hegyvidék (34), erdőscserjés vizenyős térség (31), és a tengerpart (35); (b) tájkarakter-típusokat ábrázoló térkép, (c) szabadkézi rajz az egyik típusról 


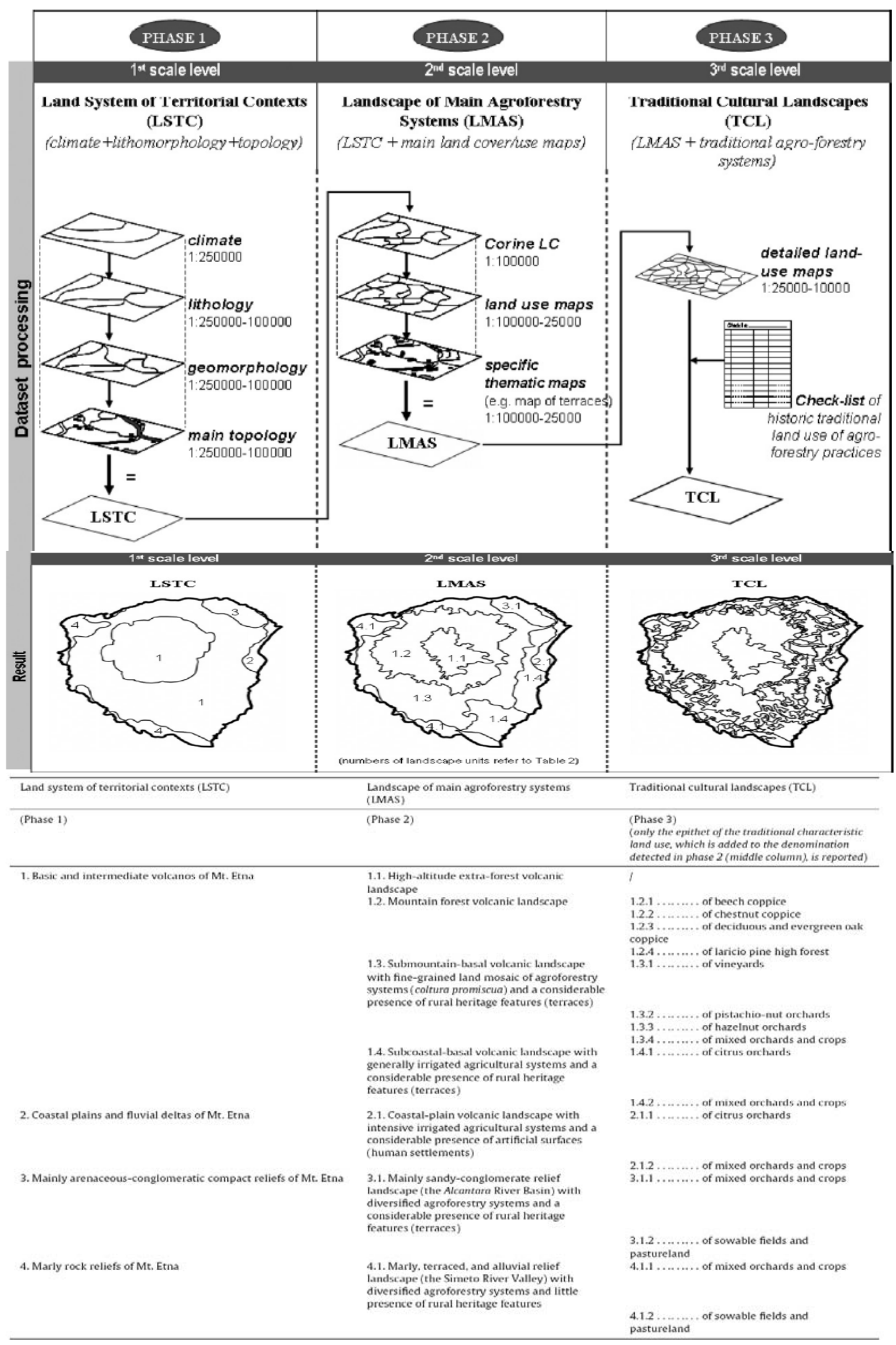

13. ábra Az Etna „tradicionális kultúrtáj” térképezésének adatfeldolgozási lépéseinek és szintjeinek modellje. (CULLOTTA és BARBERA 2011, 103-104) A domborzati adatok az alapszinten, a felszínborítási adatok a második szinten jelennek meg, és az alsó részben olvasható, hogy a hierarchikus osztályozási rendszer egyes lépéseiben milyen tájtípusok voltak beazonosíthatók, meghatározhatók. 


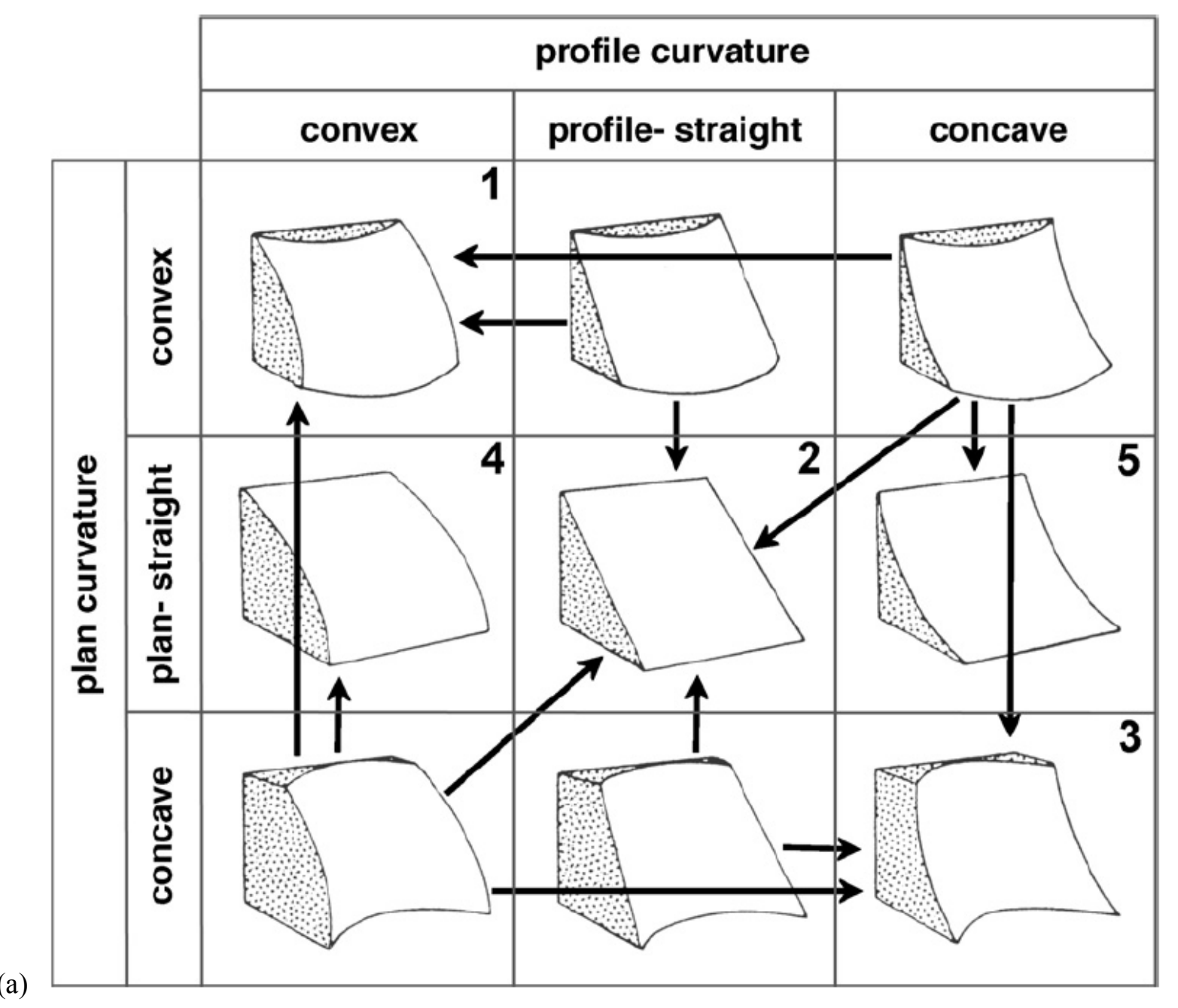

(a)

\begin{tabular}{|c|c|c|c|c|c|}
\hline \multicolumn{2}{|c|}{$\begin{array}{l}\text { Parameters directly } \\
\text { Landform element }\end{array}$} & \multicolumn{4}{|c|}{ Morphometric feature (directly defined) } \\
\hline \multirow[t]{2}{*}{ No. Name } & \multirow[t]{2}{*}{ Description } & \multicolumn{2}{|c|}{ Curvature $(1 / \mathrm{m})$} & \multirow{2}{*}{$\begin{array}{l}\text { Slope } \\
\left({ }^{\circ}\right)\end{array}$} & \multirow[t]{2}{*}{ Altitude } \\
\hline & & Profile & Plan & & \\
\hline 1 Peak & $\begin{array}{l}\text { Dominant } \\
\text { surfaces }\end{array}$ & ND & ND & ND & $\begin{array}{l}\text { Higher than } \\
\text { neighbors }\end{array}$ \\
\hline 2 Shoulder & $\begin{array}{l}\text { Convex } \\
\text { element }\end{array}$ & + & - or \pm 0 & ND & ND \\
\hline $\begin{array}{l}3 \text { Steep } \\
\text { slope }\end{array}$ & & ND & ND & $>45$ & ND \\
\hline $\begin{array}{l}4 \text { Flat or } \\
\text { gentle } \\
\text { slope }\end{array}$ & & ND & ND & $<2$ & ND \\
\hline $\begin{array}{l}5 \text { Side } \\
\text { slope }\end{array}$ & $\begin{array}{l}\text { Rectilinear } \\
\text { slope }\end{array}$ & \pm 0 & \pm 0 & ND & ND \\
\hline $\begin{array}{l}6 \text { Nose } \\
\text { slope }\end{array}$ & $\begin{array}{l}\text { Convex } \\
\text { slope }\end{array}$ & + & + & ND & ND \\
\hline $\begin{array}{r}7 \text { Head } \\
\text { slope }\end{array}$ & $\begin{array}{l}\text { Concave } \\
\text { slope }\end{array}$ & - & - & ND & ND \\
\hline $\begin{array}{l}8 \text { Negative } \\
\text { contact }\end{array}$ & & - & + or \pm 0 & ND & ND \\
\hline 9 Toeslope & $\begin{array}{l}\text { Flat, bottom } \\
\text { position }\end{array}$ & ND & ND & $<2$ & ND \\
\hline
\end{tabular}

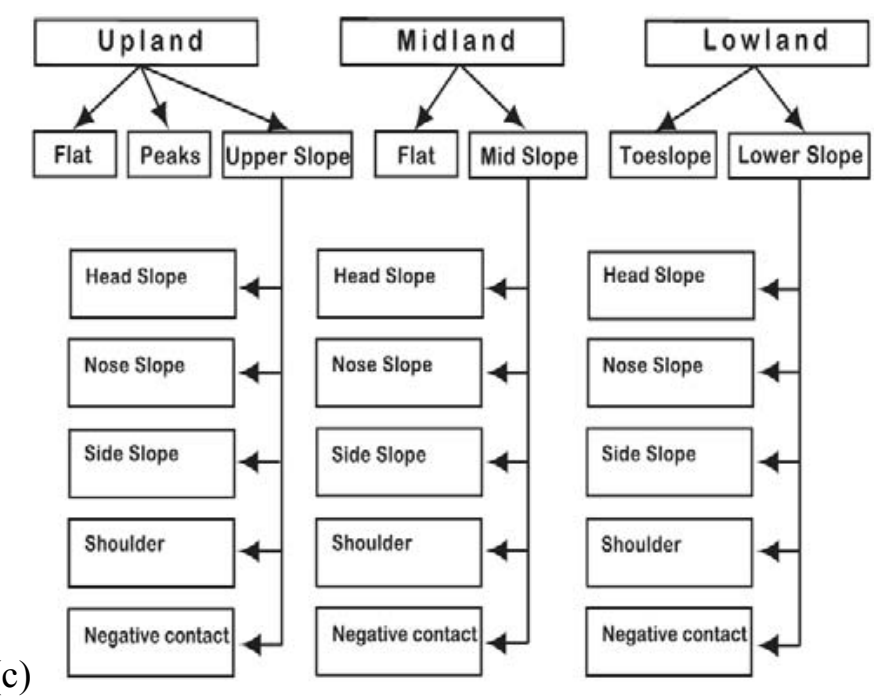

14. ábra Domborzati formák osztályozásának elve és gyakorlata Dikau alapján. (DRĂGUŢ és BLASCHKE 2006, 330-344) Az (a) részben az elvi megközelítés szerepel, a (b) részben a felszínforma osztályozás paraméterei szerepelnek, míg a (c) részben az osztályozási hierarchiát ismertetik. 


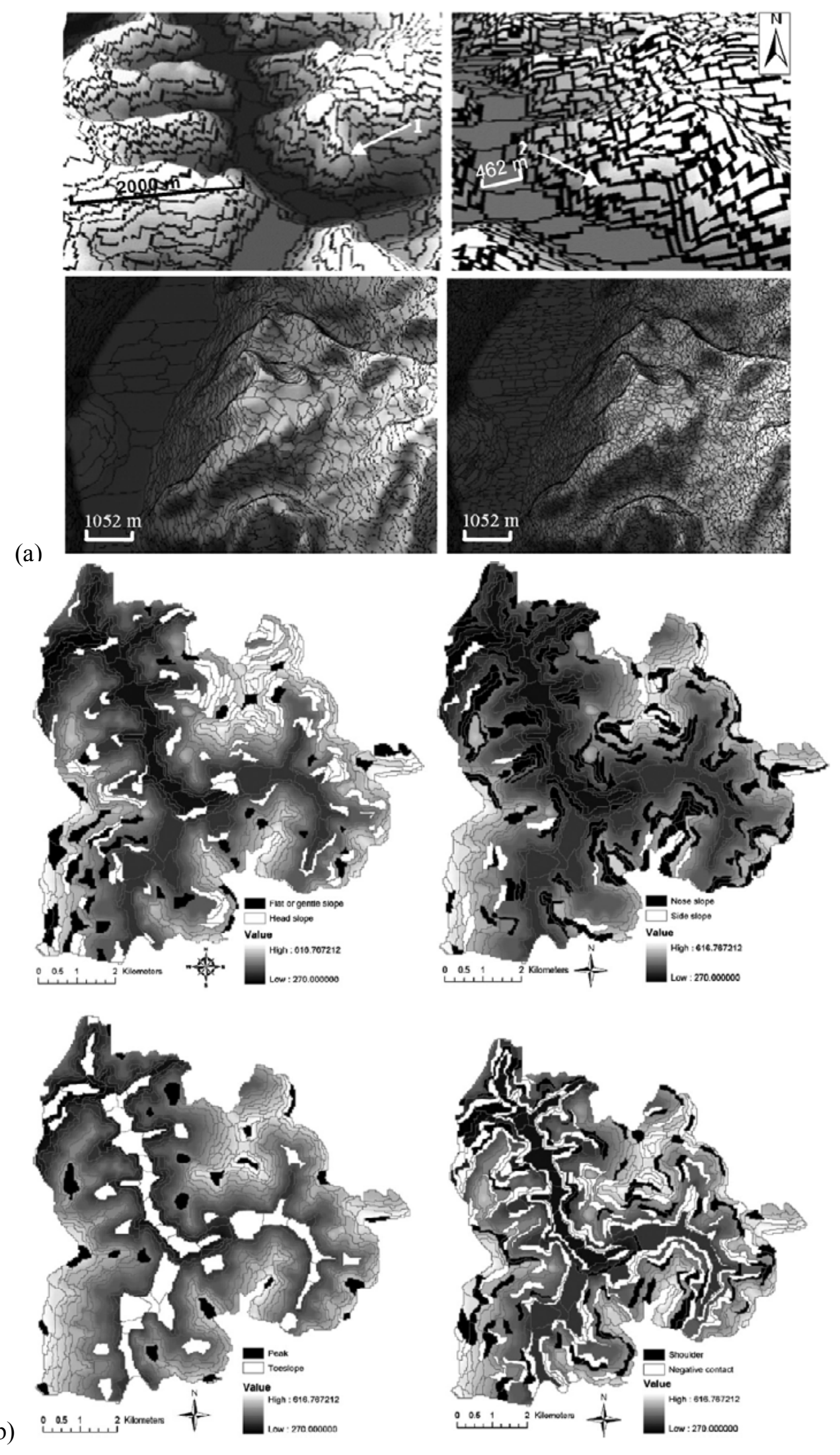

15. ábra A domborzati forma osztályozás részletei (DRĂGUȚ és BLASCHKE 2006, 330344) (a) Képobjektumok megjelenítése digitális terepmodellen, és (b) az objektum-alapú képelemzés módszerének felhasználásával lehatárolt domborzati formák egy romániai mintaterületen (Unguras). 


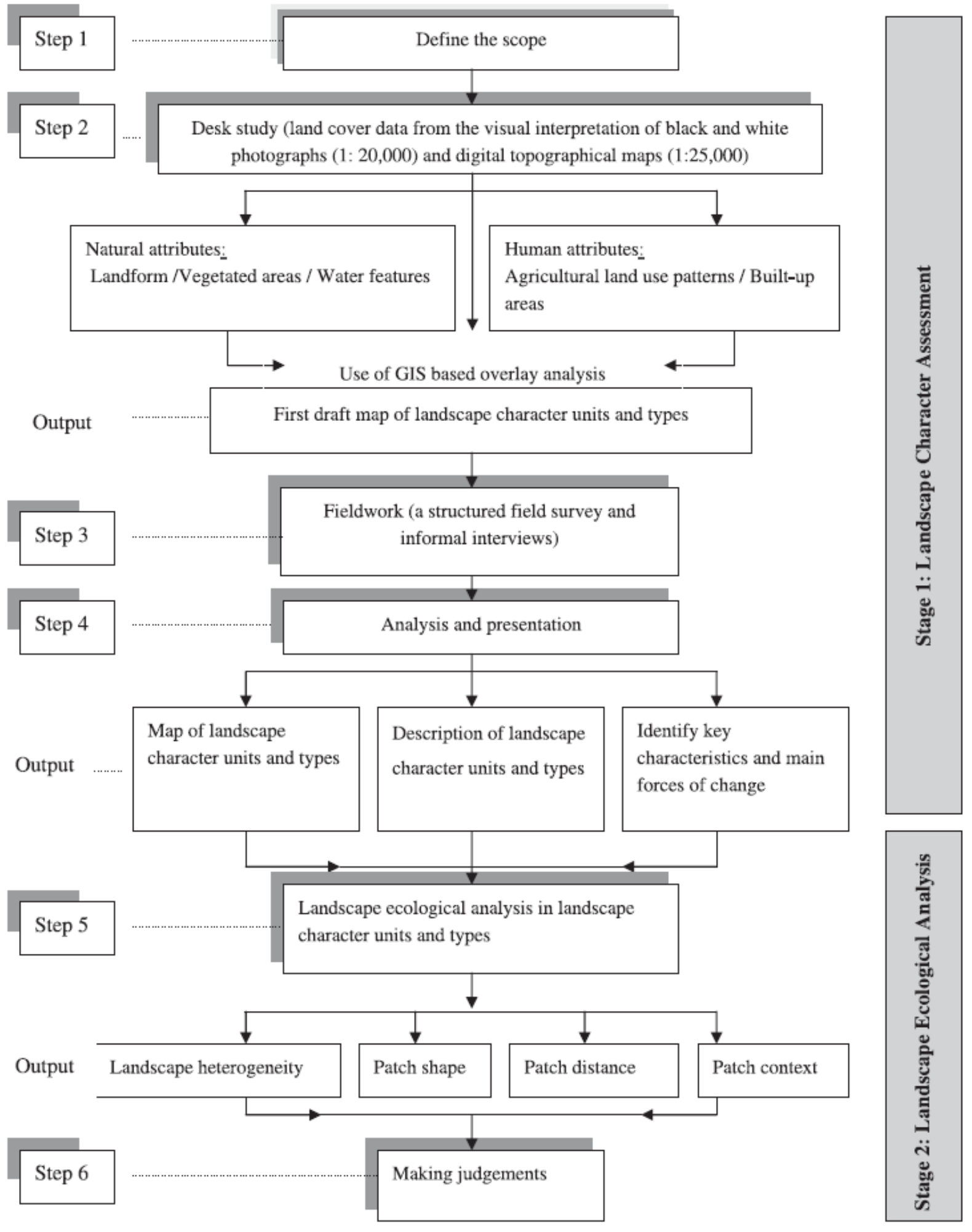

16. ábra A tájkarakter-elemzés a tájökológiai elemzés módszerével kiegészítve. (KIM és PAULEIT 2007, 267) Kim és Pauleit a modellt Dél-Korában alkalmazta 

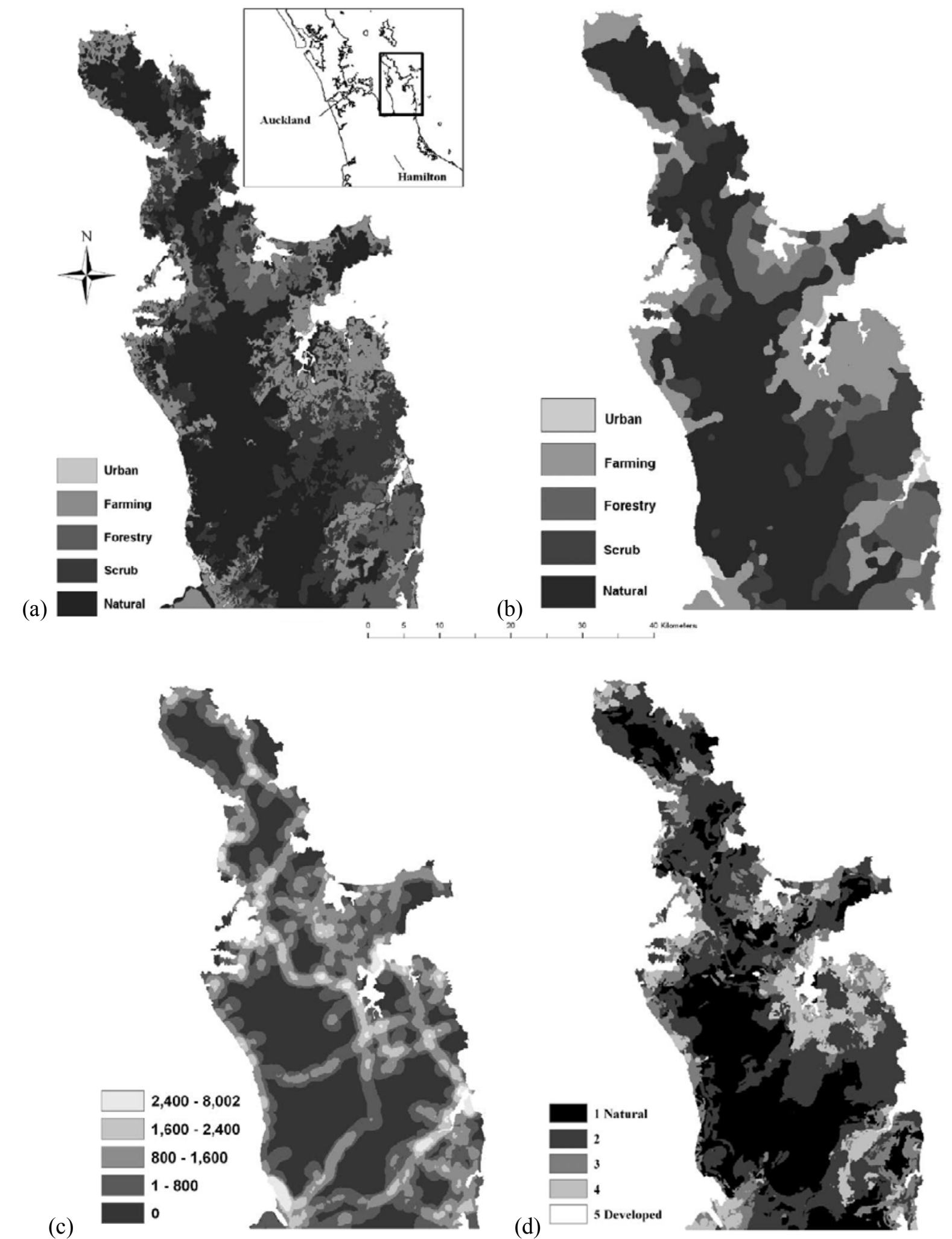

(d)

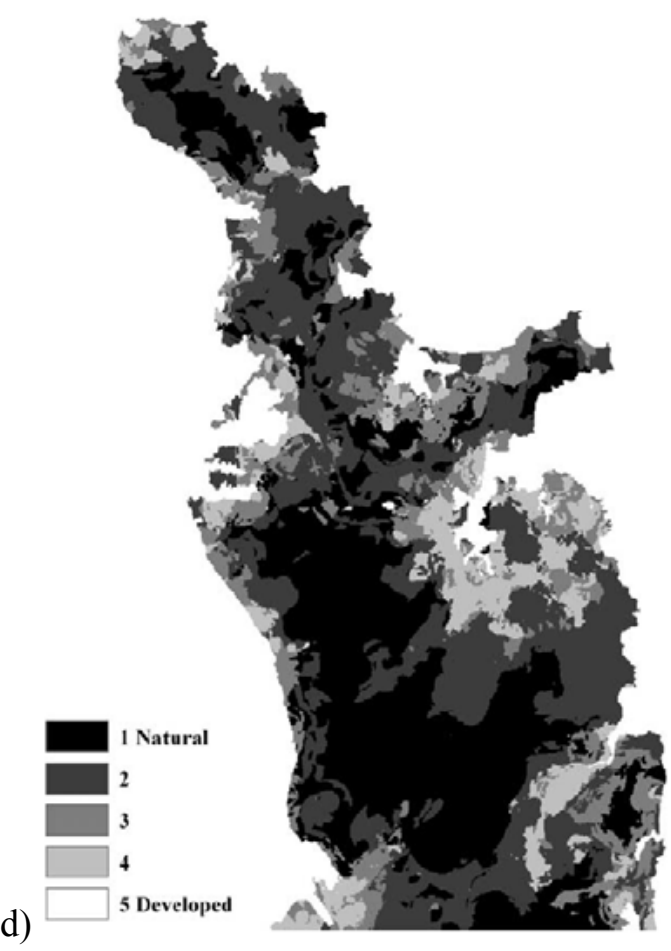

17. ábra Brabyn által leírt „aggregáló osztályozás” módszerével készített elemzés egyes alapfedvényei, „lépései” és végeredménye egy új-zélandi tanulmányban (Coromandelfélsziget) (BRABYN 2005, 27-30). (a) Felszínborítás térkép egyszerüsített osztályaival dolgozó raszteres adatbázis, (b) ennek feldolgozott változata „majority” (többség) filter alkalmazásával, (c) úthálózat sürüsége $\left(\mathrm{m} / \mathrm{km}^{2}\right)$,density” (sürüség filter alkalmazásával. (d) Az eredménytérkép, mely a táj természetes karakterét jellemzi „,wilderness” (vadon) jelzővel. Itt a két szélső értéket a természetes (natural) és a fejlesztett (developed) adja 
Indicators used in the Norwegian monitoring programme for agricultural landscapes (the " $3 Q$ " programme)

\begin{tabular}{|c|c|c|c|c|}
\hline & $\begin{array}{l}\text { Landscape } \\
\text { spatial structure }\end{array}$ & $\begin{array}{l}\text { Biological } \\
\text { diversity }\end{array}$ & $\begin{array}{l}\text { Cultural } \\
\text { heritage }\end{array}$ & Accessibility \\
\hline Area of agricultural and non-agricultural land types & $\mathrm{x}$ & $\mathrm{x}$ & $\mathrm{x}$ & $\mathrm{x}$ \\
\hline $\begin{array}{l}\text { Patches of habitat distribution (average size of patches, number of } \\
\text { patches per square kilometre) }\end{array}$ & $\mathrm{x}$ & $\mathrm{x}$ & & \\
\hline Length of different types of edge between adjacent land types & $\mathrm{x}$ & $\mathrm{x}$ & & \\
\hline Diversity (Shannon's diversity index) & $\mathrm{x}$ & $\mathrm{x}$ & & \\
\hline Heterogeneity & $\mathrm{x}$ & $\mathrm{x}$ & $\mathrm{x}$ & \\
\hline $\begin{array}{l}\text { Number and spatial distribution of point features, e.g. ponds, rocky } \\
\text { outcrops, solitary trees, semi-natural habitat islands }\end{array}$ & $x$ & $\mathrm{x}$ & & \\
\hline Number and length of linear elements, e.g. streams, ditches, hedges & $\mathrm{x}$ & $\mathrm{x}$ & & \\
\hline Length of edge between water and different land cover categories & $\mathrm{x}$ & $\mathrm{x}$ & & \\
\hline $\begin{array}{l}\text { Area of different land cover categories within a } 10 \text { wide buffer zone } \\
\text { beside water }\end{array}$ & $\mathrm{x}$ & $\mathrm{x}$ & & \\
\hline Number of historical agricultural buildings (from before 1900) & & & $\mathrm{x}$ & \\
\hline Number of grave-mounds, ruins, cairns and signs of earlier cultivation & & & $\mathrm{x}$ & \\
\hline Number and length of fences and stone walls & & & $\mathrm{x}$ & \\
\hline Number and length of historical roads and paths & & & $\mathrm{x}$ & \\
\hline Length of roads and paths & & & & $\mathrm{x}$ \\
\hline Connectivity in the road/path network & 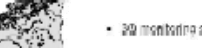 & & & $\mathrm{x}$ \\
\hline Area within $100 \mathrm{~m}$ distance intervals from roads and built-up areas & & $\mathrm{x}$ & & $\mathrm{x}$ \\
\hline $\begin{array}{l}\text { Proportion of the agricultural landscape that is legally and } \\
\text { physically accessible to the general public }\end{array}$ & i & & & $\mathrm{x}$ \\
\hline
\end{tabular}

a Indicators are assumed to be relevant for the themes indicated by a cross in the table.

18. ábra A 3Q Program tájváltozás-indikátorai Norvégiában az agrártájak változásának elemzéséhez (DRAMSTAD et al. 2001, 260) Az elemzés módszerét 1998-tól ötévente frissülő légifelmérések felvételeinek feldolgozásához fejlesztették ki. Az ábra megmutatja, hogy az egyes indikátorok a vizsgált négy téma közül (tájszerkezet, biológiai sokféleség, kulturális örökség, elérhetőség) mely témákban lehetnek érintettek. 


\section{Landscape organisation}

\section{Colour infrared} derial photographs

13 / 1993

The most recent registration available

\section{Black and white} aerial photographs

$12 / 1946$

In the study area this is before the modern rural landscape

\section{Old cadastral maps 11/1741-1811 In the study area the maps reflect the main organisation prior to the enclosures}

The present-day landscape

The modern landscape AD 1940 .

1900-1940 (transition period)

The enclosure landscape

1750 - AD 1900

The historical landscape 1100 - AD 1750

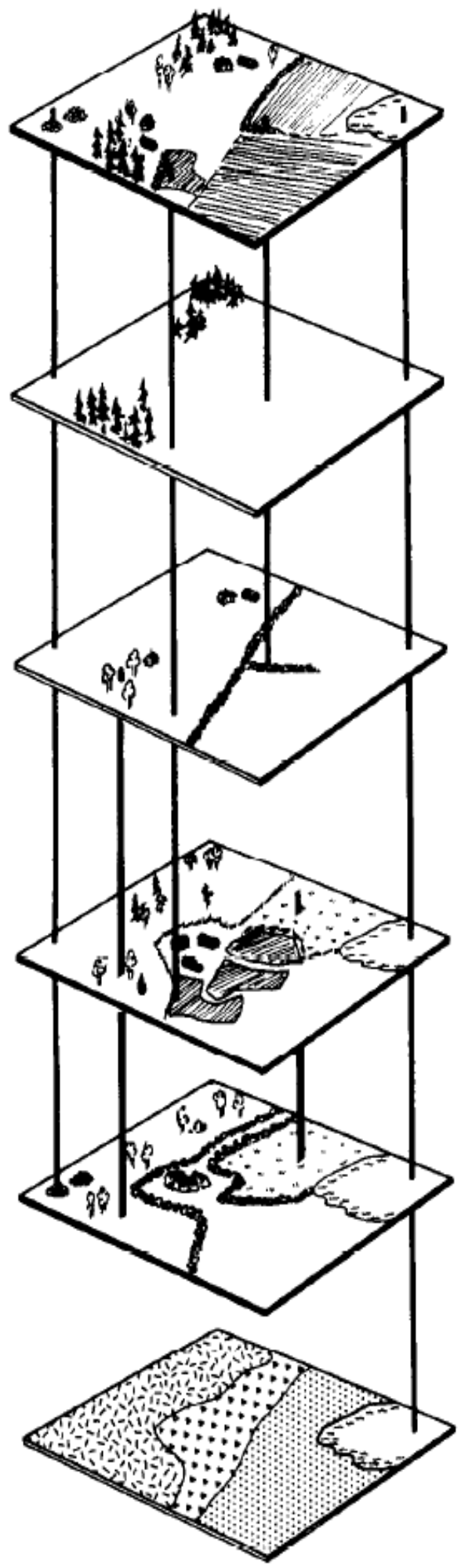

A composite of physical and intangible structures and elements from recent and earlier time periods.

Erasing layer with disappearing structures. Abandonment, fragmentation and isolation of agricultural land

Re-organisation of holdings, new fencing systems. Large scale reciamation, mainly for arable land.

Spatial organisation of settlements. Permanent inägo - utmark system including vast areas of fodderproducing ecosystems

The prehistoric landscape 1500 BC - AD 1100

Prehistoric stone walls, clearance cairns.

\section{The physical landscape}

A prerequisite for human utilisation.

19. ábra Történeti tájváltozás-térképezés elemei (SKÅNES és BUNCE 1997, 65). Skånes és Bunce légifelvételekre és térképekre alapozó történeti tájelemzésének legfontosabb rétegei a régebbi és mai tájelemek között meglévő és lehetséges kapcsolatok feltárása érdekében Svédországban. 


\begin{tabular}{|c|c|c|c|c|}
\hline & Landscape photos & Orthophotos & Land cover & Field studies \\
\hline \multicolumn{5}{|l|}{ 1. Open area indicators } \\
\hline $\begin{array}{l}\text { Example of basic data } \\
\text { processing }\end{array}$ & sing & & & \\
\hline Proporion of open land & $\%$ of open land & $\%$ of open land & $\%$ of open land & Proportion of open land \\
\hline Viewshed size & & Size of viewshed & Size of viewshed & \\
\hline Viewshed shape & $\begin{array}{l}\text { Classification of shape (1- } \\
\text { 3) }\end{array}$ & Shepe index & Shepe Index & $\begin{array}{l}\text { Classification of shape (1- } \\
\text { 3) }\end{array}$ \\
\hline Depth/breadith of views & $\begin{array}{l}\text { Estimation of depth of } \\
\text { view } \\
(1-3)^{b}\end{array}$ & $\begin{array}{l}\text { Length of radius of } \\
\text { view }\end{array}$ & $\begin{array}{l}\text { Length of radius of } \\
\text { view }\end{array}$ & $\begin{array}{l}\text { Estimation of depth of } \\
\text { view } \\
(1-3)^{b}\end{array}$ \\
\hline \multicolumn{5}{|l|}{$\begin{array}{l}\text { 2. Obstruction of the view } \\
\text { indicators }\end{array}$} \\
\hline $\begin{array}{l}\text { Density of obstructing } \\
\text { objects }\end{array}$ & $\begin{array}{l}\text { Density of obstructing } \\
\text { objects }\end{array}$ & $\begin{array}{l}\text { Density of obstructing } \\
\text { objects }\end{array}$ & & $\begin{array}{l}\text { Density of obstructing } \\
\text { objects }\end{array}$ \\
\hline $\begin{array}{l}\text { Degree of visual penetration } \\
\text { of vegetation }\end{array}$ & $\begin{array}{l}\text { Proportion of vegetation } \\
\text { with different levels of } \\
\text { visual penetration }(1-4)^{c}\end{array}$ & & & $\begin{array}{l}\text { Proportion of vegetation } \\
\text { with different levels of } \\
\text { visual penetration }(1-4)^{\mathrm{c}}\end{array}$ \\
\hline
\end{tabular}
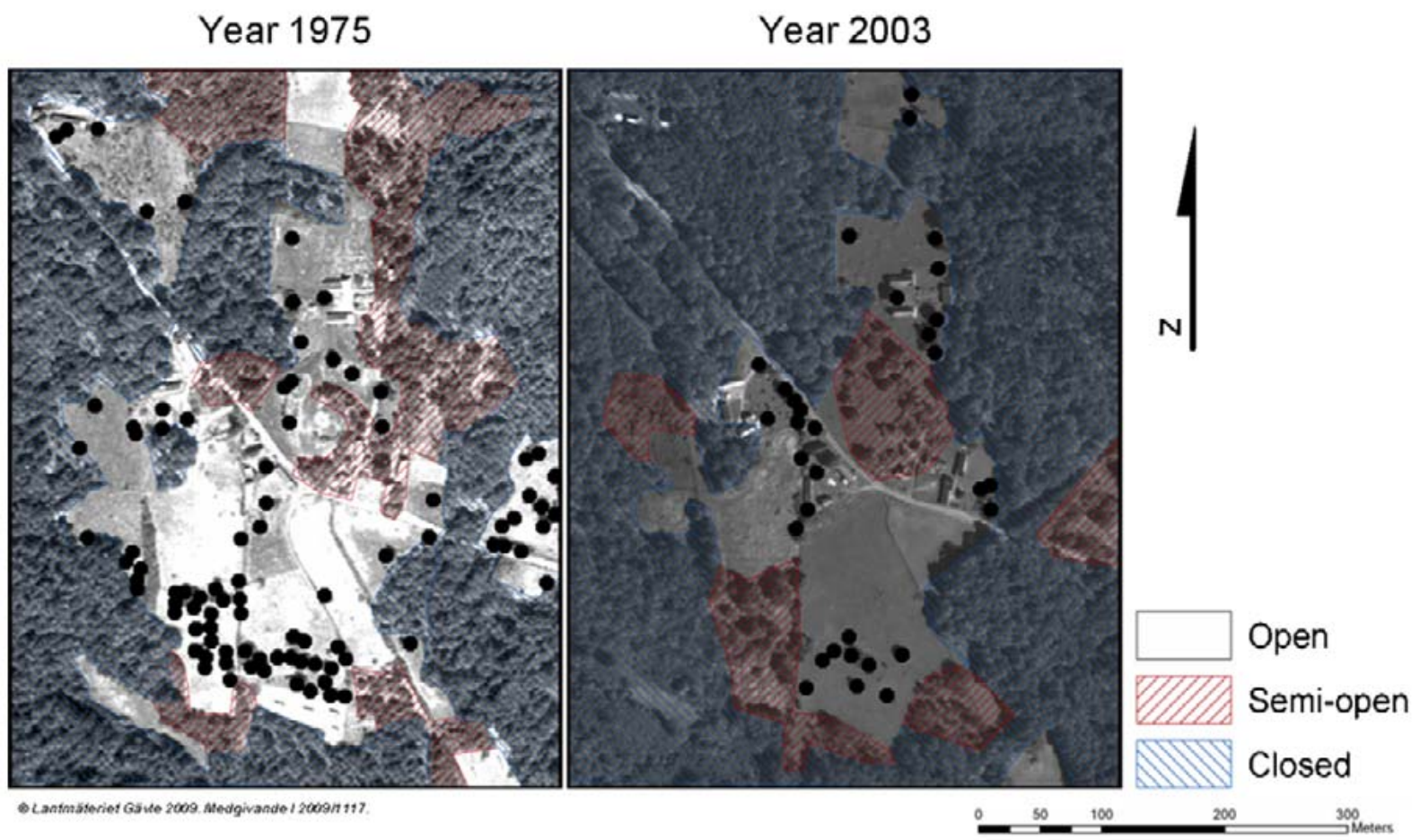

20. ábra A VisuLands keretrendszer által vázolt indikátorok koncepcionális alapját megjelenítő, és a nyitottság változását szemléltető ábrák (ODE, TVEIT és FRY 2010, 26) A javasolt - terepi fényképekre, légifelvételekre, felszínborítás adatokra építő - indikátorok közül az egyik a zárt, nyitott és félig nyitott kategóriákba sorolja például vizuális interpretáció útján az egyes tájelemek dominálta tájrészleteket 
1971

(a)

(b)

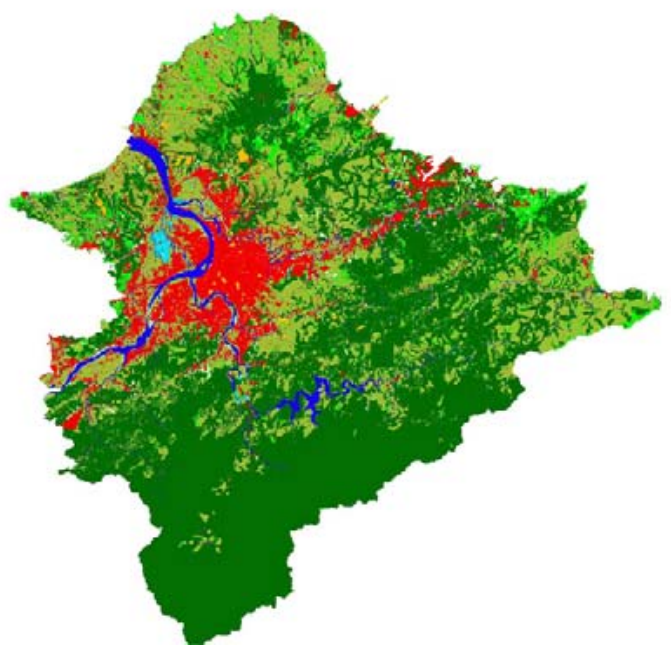

(a)

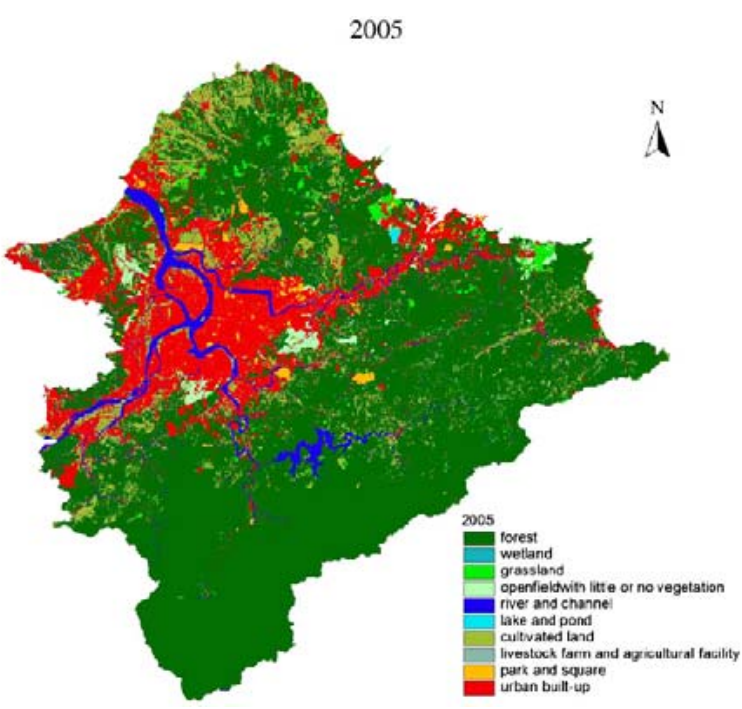

(b)
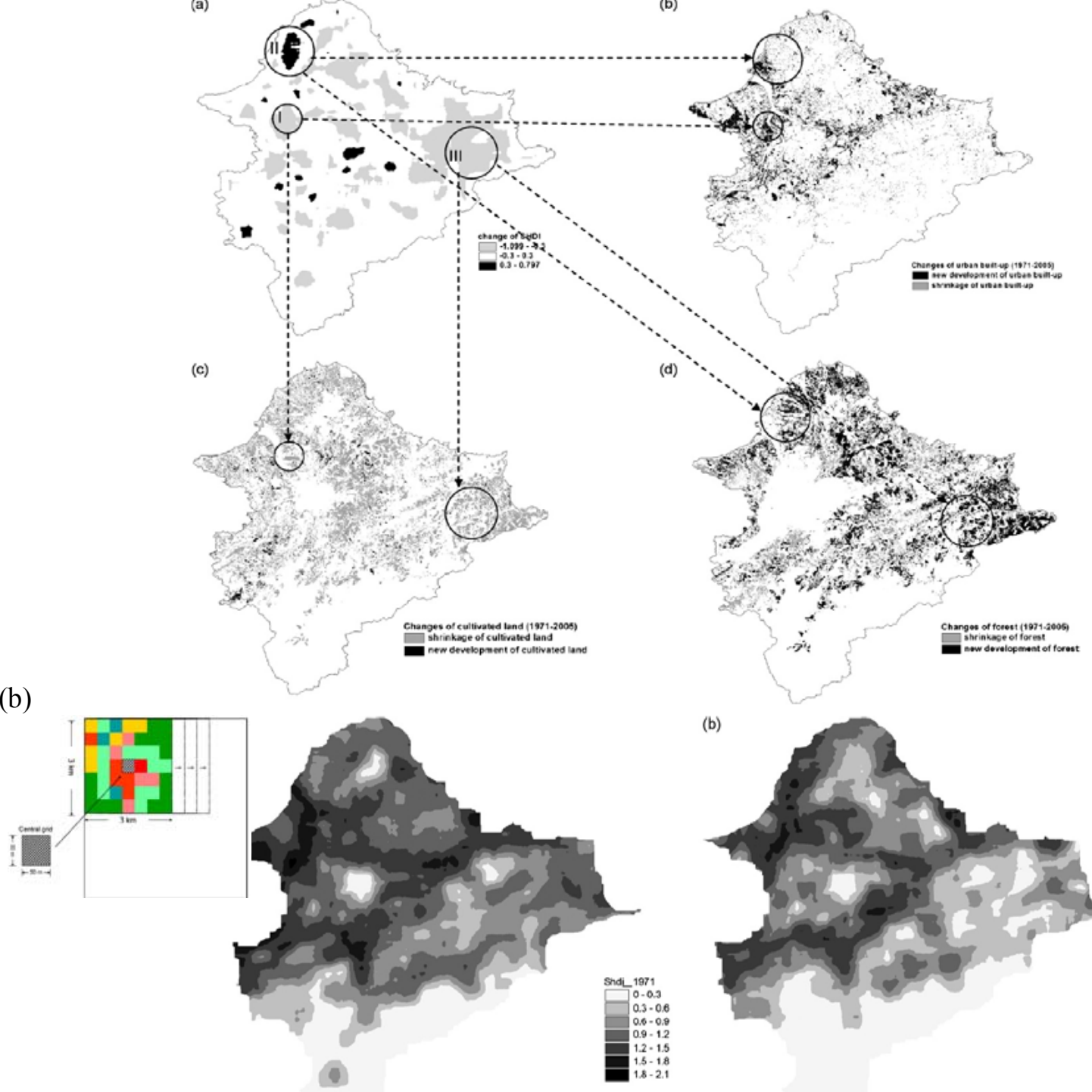

(b)

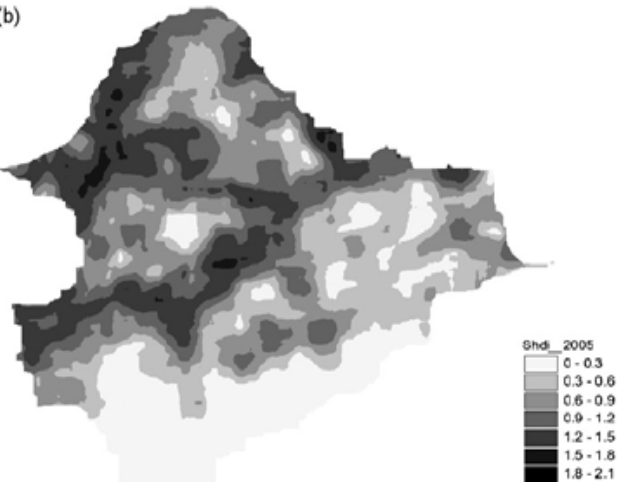

(c)

21. ábra Taipei térségének légifelvételekből digitalizált felszínborítás adatok alapján készített tájdiver zitás-változás elemzésének eredménye (YEH és HUANG 2009, 153, 155, 157) (a) Területhasználat-térképek, (b) a fontosabb különbségek valamint (c) a Shannon féle tájdiverzitás mutató értékei 1971 és 2005 időpontra 


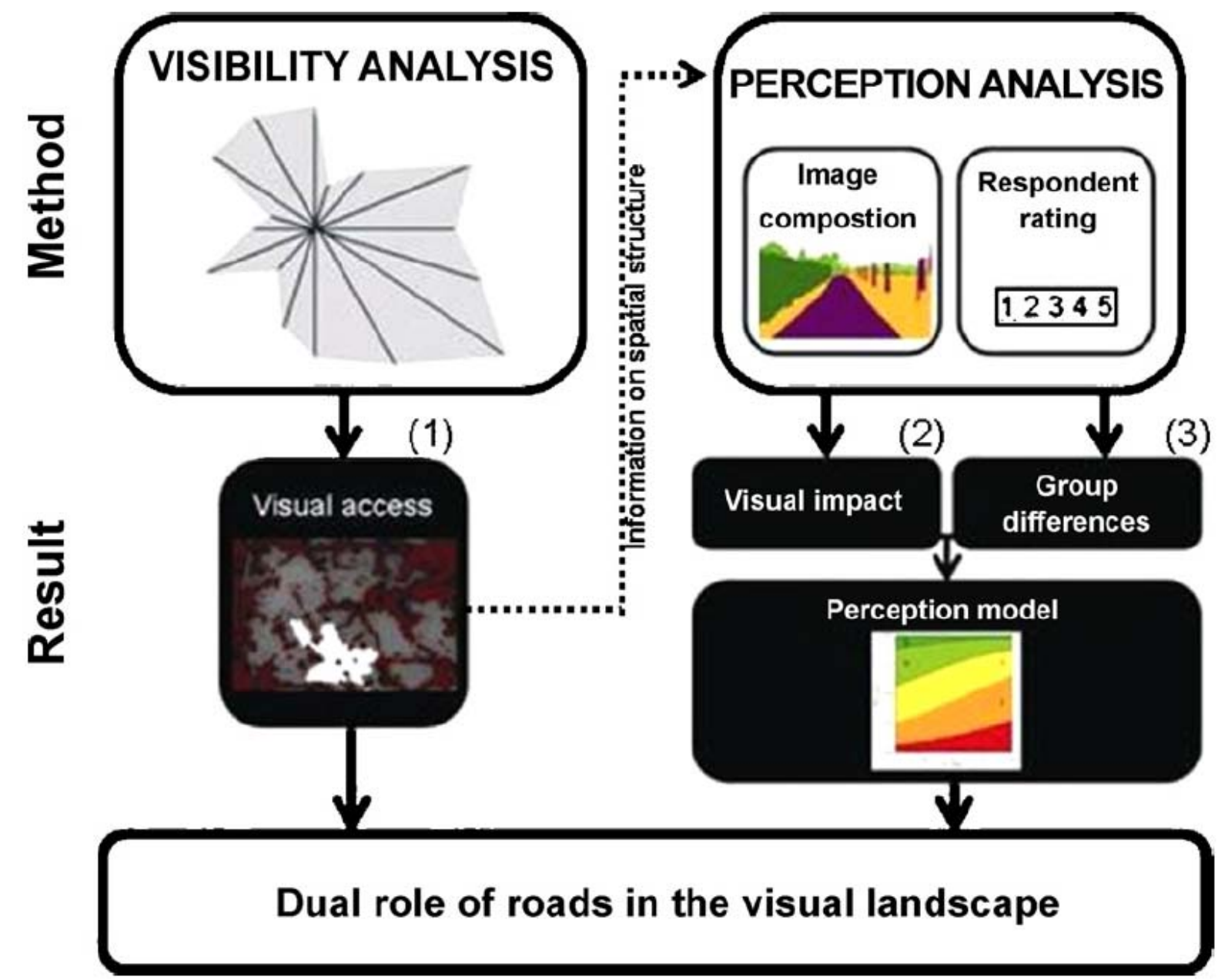

(a)

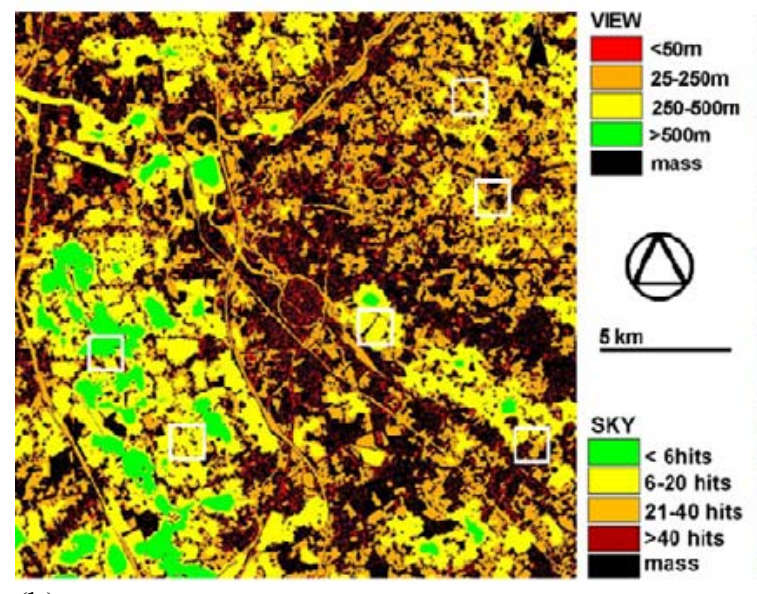

(b)
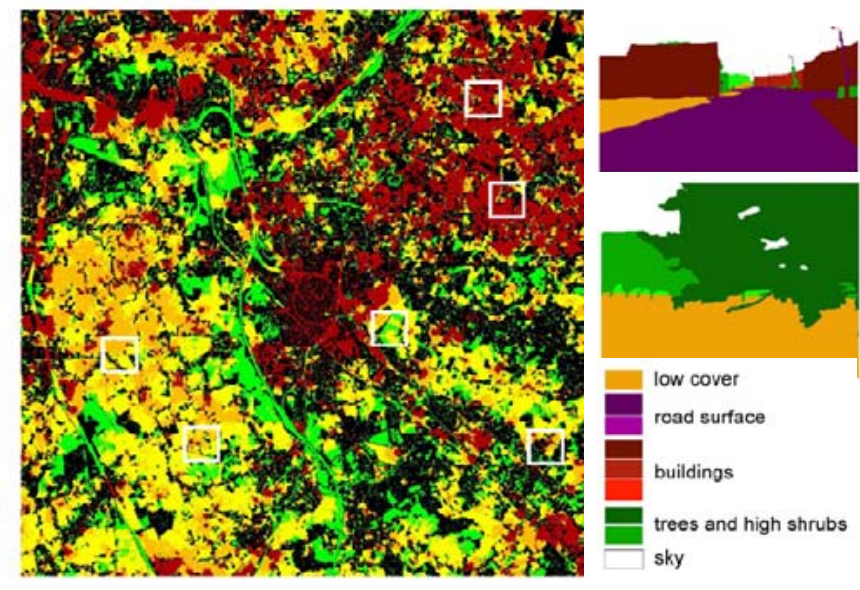

(c)

22. ábra Az utak kettős szerepét elemző kutatás lényege (GARRÉ, MEEUS és GULINCK 2009, 130) (a) A módszert illusztráló ábra. A módszer végrehajtása során számos passzív képalkotó távérzékeléssel készített fénykép, felvétel, és felszínboritási adatbázist használtak fel ebben a belga tanulmányban. Elemezték a táj láthatóságát az utakról, és az elemzés eredményét vizuális kérdőívezéssel ellenőrizték. (b) Átlagos látótávolság (VIEW) és házfalnak ütköző látósugarak száma (SKY), (c) Osztályozott terepi fényképek 
(a)

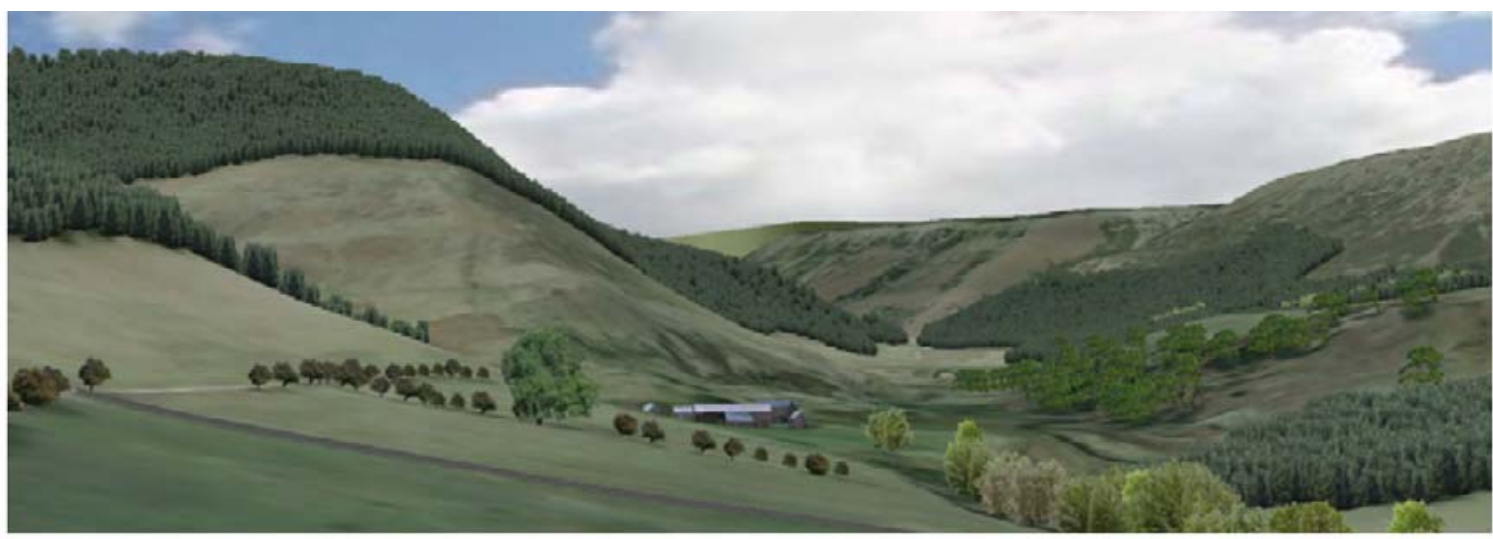

(b)

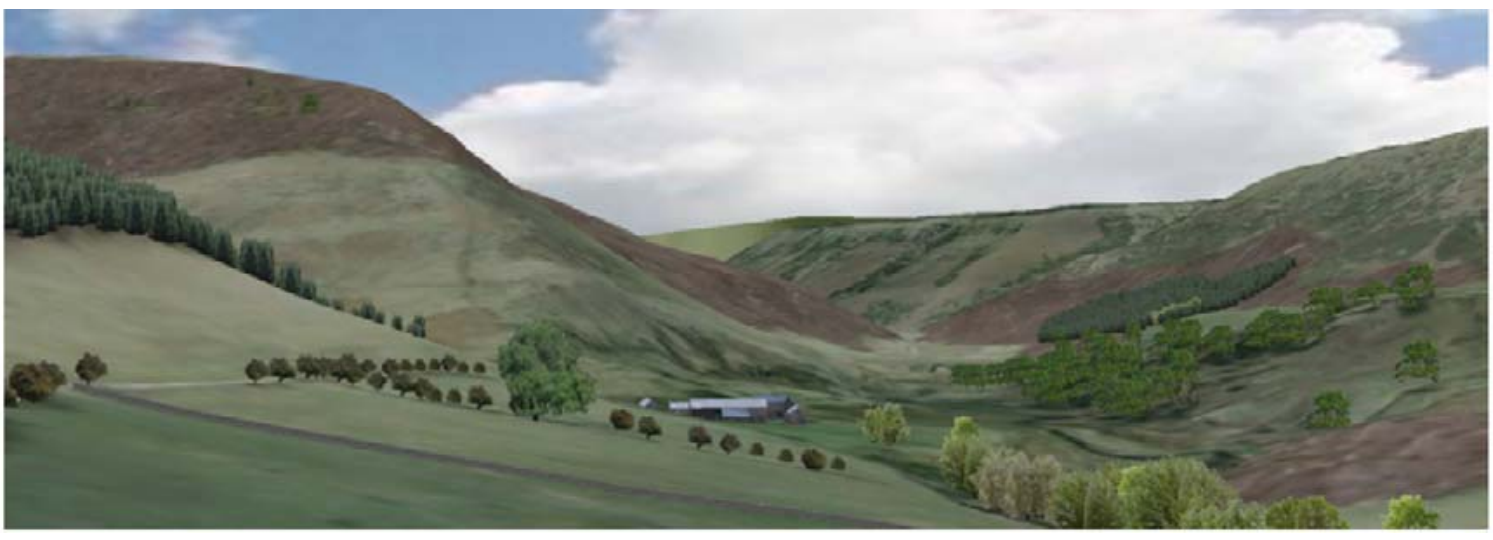

(c)

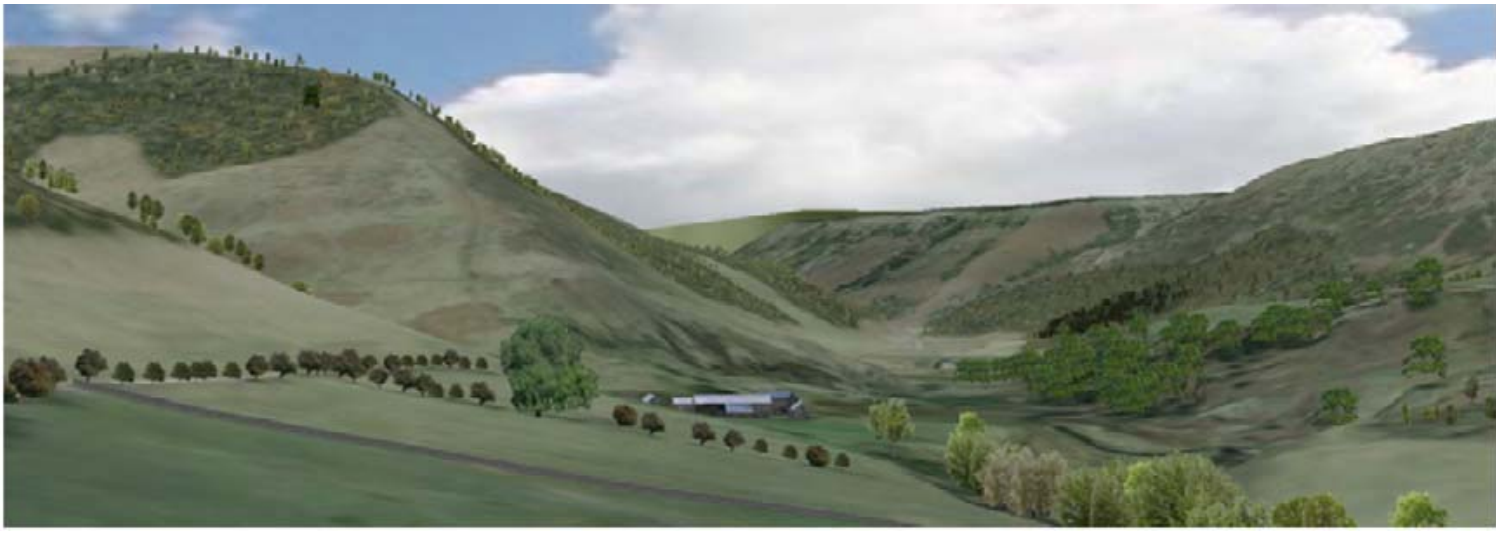

(d)

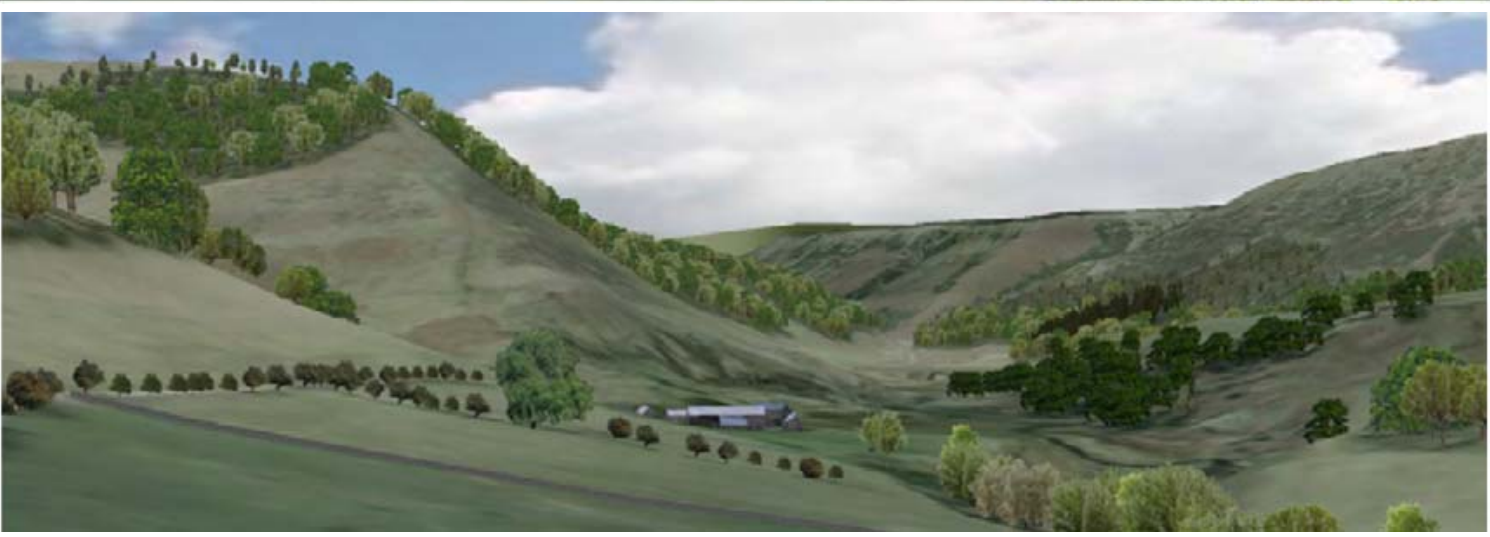

23. ábra Ortofotó és digitális domborzatmodell alapú tájmodellre épített 3D megjelenítés (LANGE és HEHL-LANGE 2010, 696-697) Egy angliai völgyben (Alport Valley) az erdőmüvelés változásával tölgyes-nyíres erdők növekednek karakteradó szerepben. 

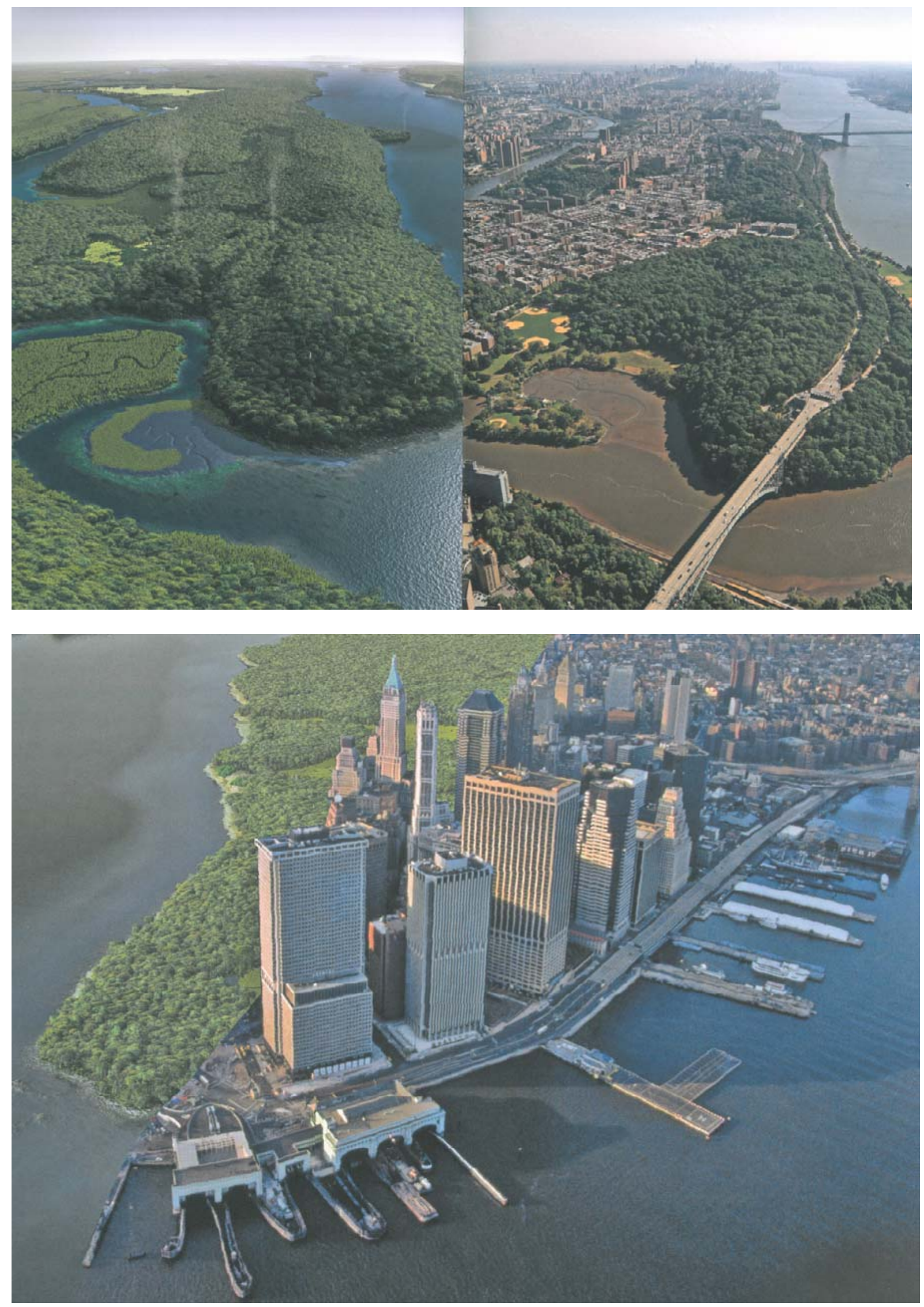

24. ábra Manhattan-sziget jellegének fotorealisztikus vizualizációja az ember tömeges megjelenése előtti időszakban és ma. (SANDERSON 2009, 28-29, 208 ) 


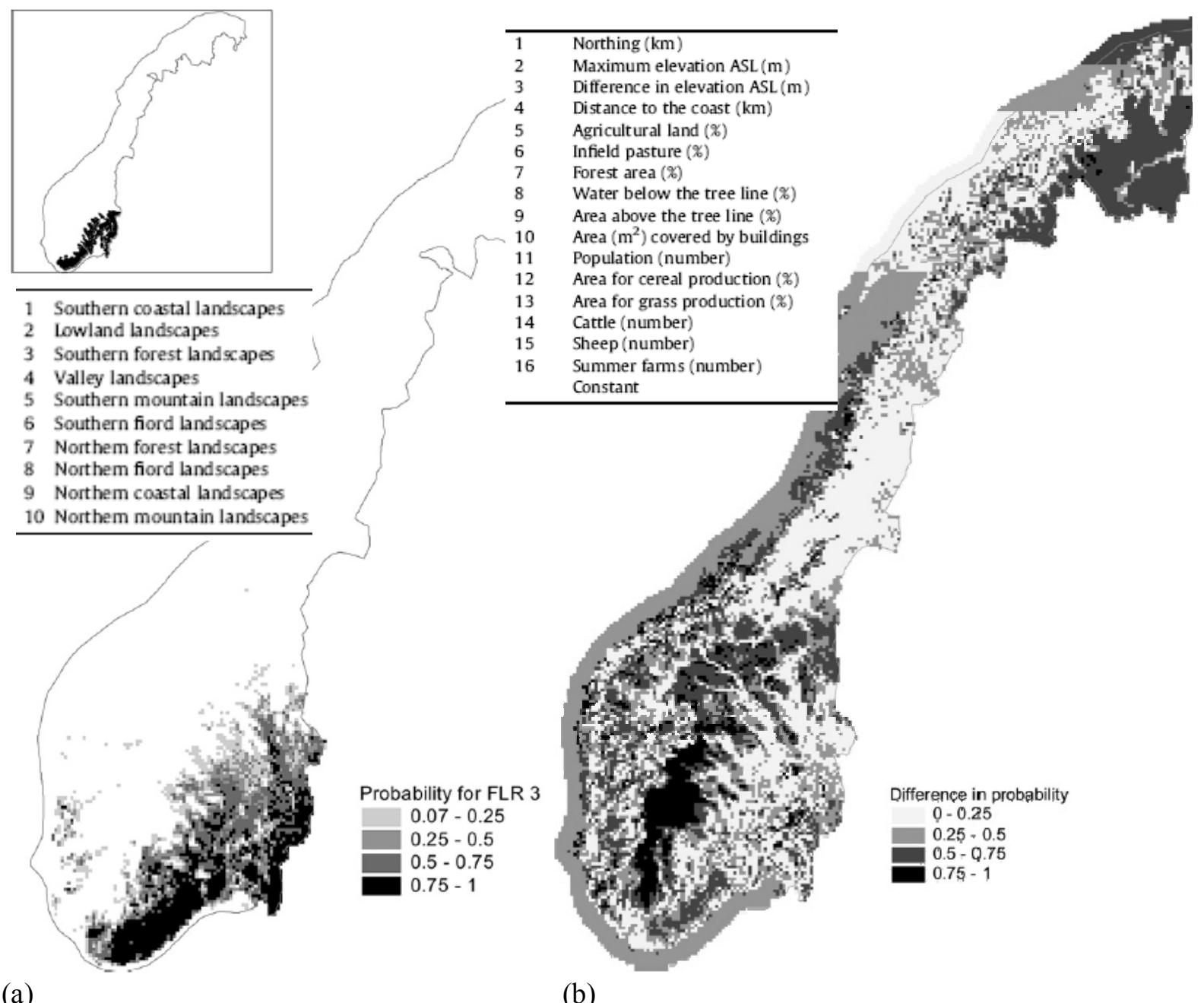

(a)

(b)

25. ábra Strand valósźnüség térképe (STRAND 2011, 1150-1157). A térkép Strand modellje szerint megmutatja, hogy Norvégia teljes területén vizsgált és képpontokkal jellemzett tájrészletei milyen valószínüséggel esnek bele egy kiválasztott tájegységbe. Az (a) térkép esetében ez a „Déli erdős tájak” (Southern forest landscapes) kategóriába sorolás valószínűségét láthatjuk. Minél inkább délen található erdős terület és ennek jellemzői voltak mértékadók a területen, annál inkább beletartozónak osztályozta a modell és annál magasabb értéket kapott 0 és 1 között. A (b) térkép sötétebb színnel szerepelnek azokat tájrészletek, melyeknél leginkább egyértelmü volt, hogy melyik tájtípusba is tartoznak. A legnagyobb és második legnagyobb beletartozási valószínüség közötti különbség magas értéke ( 0 és 1 között) azt jelenti, hogy egyértelmü a terület besorolhatósága. Ott volt igazán nagy a bizonyosság a beletartozást illetően, ahol a kétféle szempont (tengerpart és hegységek, vagy észak és dél esetében) a szélsőértékeket vették fel. Strand szerint a skálák közepén mindig nagy a bizonytalanság. Ez Norvégiában az erdős völgyes területeket jelenti. (STRAND 2011, 1157). A felsorolás a 10 tájtípust és a 16 figyelembe vett tényezőt mutatja (STRAND 2011, 1150-1157). 

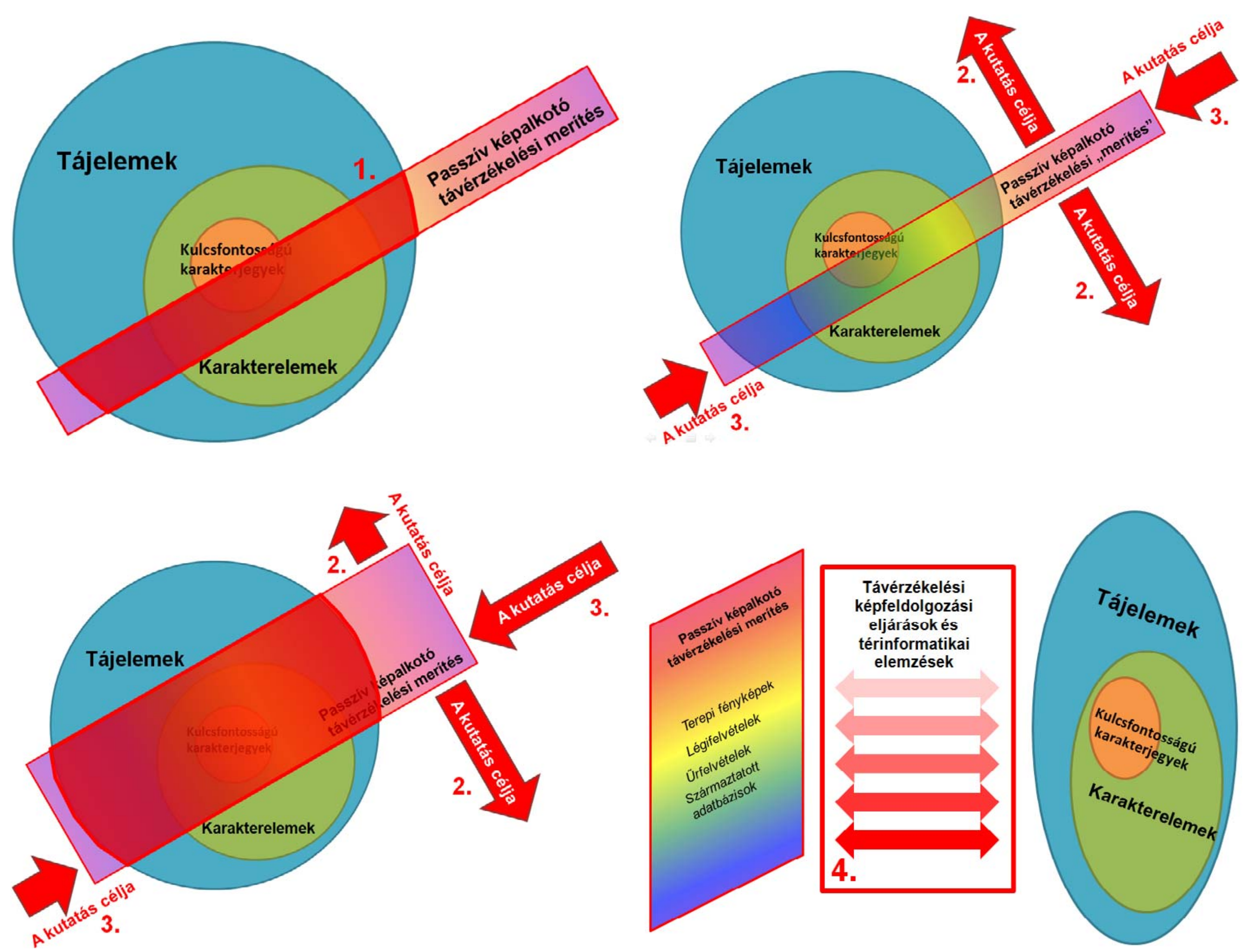

26. ábra A kutatás célja a passzív képalkotó távérzékelés alkalmazási lehetőségeinek bővítése a tájkarakter-elemzésben

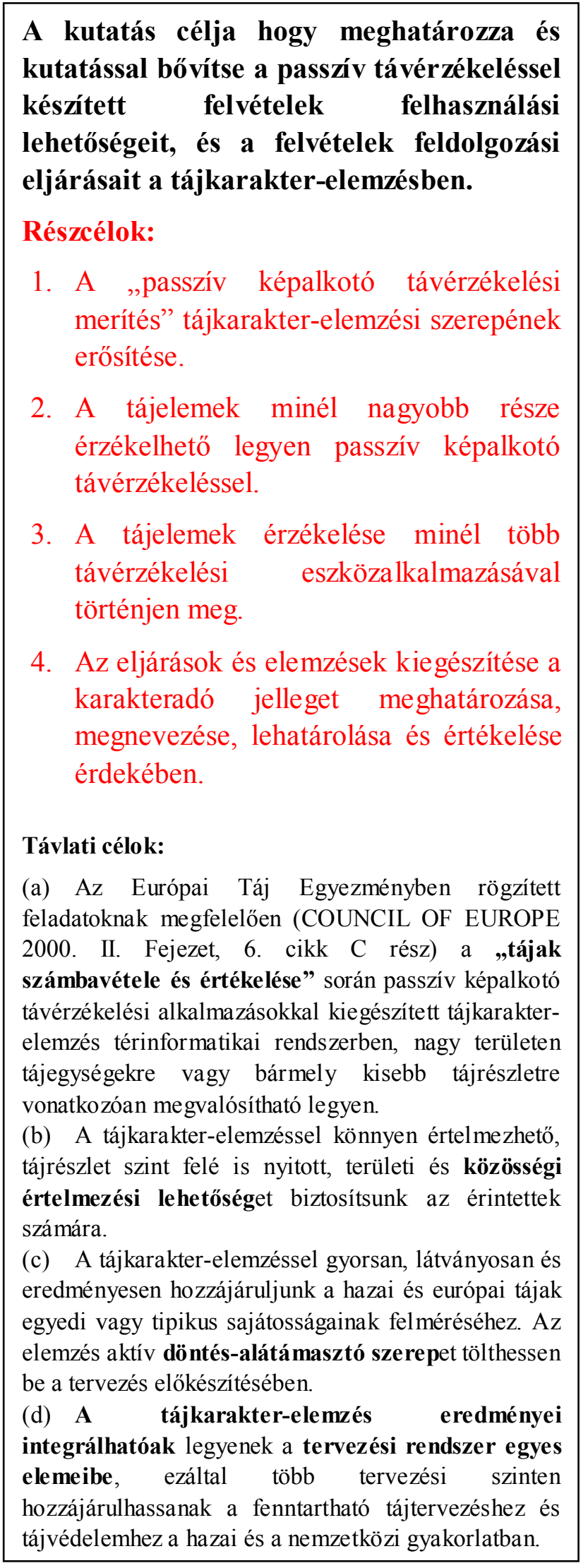


15. táblázat Digitális magassági adatok alapvető sajátosságainak összevetése

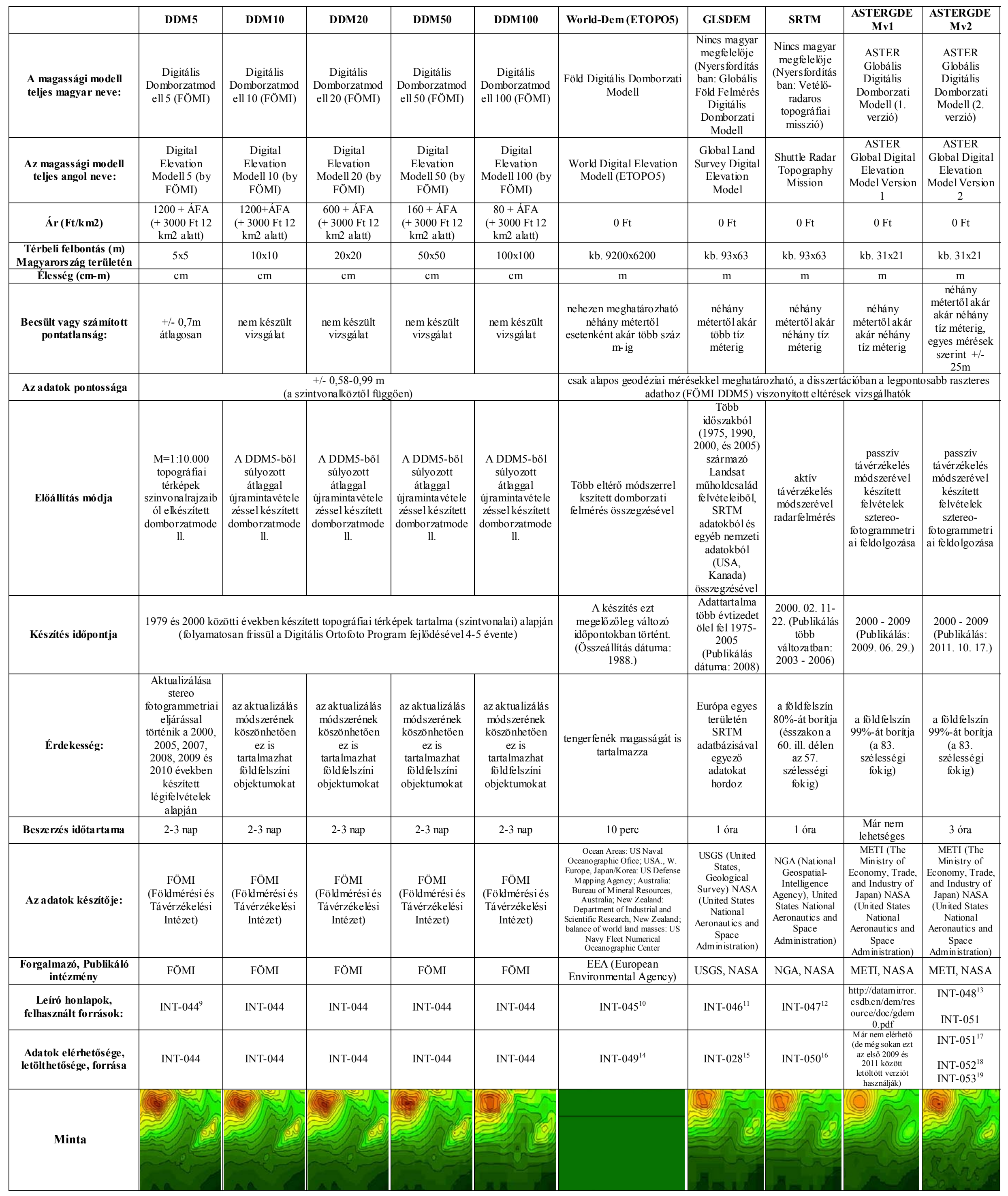

${ }^{9}$ INT-044: FÖMI DDM Domborzati adatokat ismertető oldala (2014. 02. 11.)

${ }^{10}$ INT-045: NOAA National Geophysical Data Center ETOPO5 modellt ismertető oldala (2014. 02. 11.)

${ }^{11}$ INT-046: GLSDEM adatokat ismertető oldal (2014. 02. 11.)

${ }^{12}$ INT-047: A NASA SRTM-et ismertető oldala (2014. 02. 11.)

${ }^{13}$ INT-048: A NASA ASTER GDEMv2 modellt ismertető oldala (2014. 02. 11.)

${ }^{14}$ INT-049: Az EEA World DEM ETOPO5 letöltését biztosító oldala (2014. 02. 11.)

${ }^{15}$ INT-030: A DEM Explorer honlapja (2014. 02. 05.)

${ }^{16}$ INT-050: Az SRTM ada tok letöltését biztosító oldal (2014. 02. 11.)

${ }^{17}$ INT-051: A METI ASTER GDEMv2 modell letöltését biztosító oldala (2014. 02. 11.)

${ }^{18}$ INT-052: A NASA ASTER GDEMv2 modell letöltését biztosító oldala (2014. 02. 11.)

${ }^{19}$ INT-053: A USGS ASTER GDEMv2 modell letöltését biztosító oldala (2014. 02.11.) 


\section{6. táblázat A felhasznált felvételek listája}

\begin{tabular}{|c|c|c|}
\hline $\begin{array}{l}\text { A felvételek típusa } \\
\text { (Forrása) }\end{array}$ & $\begin{array}{c}\text { felvételek sorszáma és készítésének } \\
\text { dátuma }\end{array}$ & Területi kiterjedés \\
\hline \multirow{31}{*}{$\begin{array}{l}\text { Müholdfelvételek } \\
\text { (Landsat TM5, } \\
\text { ETM+) (USGS) }\end{array}$} & 1986_05_25_1t51880271986145xxx03 & Délnyugat-Budakörnyék térségére \\
\hline & 1986_09_14_1t51880271986257xxx03 & Délnyugat-Budakörnyék térségére \\
\hline & 1986_10_16_1t51880271986289xxx03 & Délnyugat-Budakörnyék térségére \\
\hline & 1990_10_11_etp188r27_5t19901011 & Délnyugat-Budakörnyék térségére \\
\hline & 1992_07_04_1t41880271992186xxx02 & Délnyugat-Budakörnyék térségére \\
\hline & 1992_09_22_lt41880271992266xxx02 & Délnyugat-Budakörnyék térségére \\
\hline & 1994_07_02_1t51880271994183xxx02 & Délnyugat-Budakörnyék térségére \\
\hline & 1994_07_18_1t51880271994199xxx02 & Délnyugat-Budakörnyék térségére \\
\hline & 1999_10_28_le71880271999301ags01 & Délnyugat-Budakörnyék térségére \\
\hline & 2000_04_21_le71880272000112edc00 & Délnyugat-Budakörnyék térségére \\
\hline & 2000_06_08_le71880272000160edc00 & Délnyugat-Budakörnyék térségére \\
\hline & 2000_10_14_le71880272000288edc00 & Délnyugat-Budakörnyék térségére \\
\hline & 2001_01_18_le71880272001018sgs00 & Délnyugat-Budakörnyék térségére \\
\hline & 2001_03_07_le71880272001066edc00 & Délnyugat-Budakörnyék térségére \\
\hline & 2001_06_27_le71880272001178edc00 & Délnyugat-Budakörnyék térségére \\
\hline & 2002_02_22_le71880272002053sgs00 & Délnyugat-Budakörnyék térségére \\
\hline & 2002_06_22_lt51880272002173mti00 & Délnyugat-Budakörnyék térségére \\
\hline & 2003_04_30_le71880272003120asn00 & Délnyugat-Budakörnyék térségére \\
\hline & 2003_07_27_lt51880272003208mti01 & Délnyugat-Budakörnyék térségére \\
\hline & $2003 \_10 \_15 \_1 \mathrm{t} 51880272003288 \mathrm{mti0}$ & Délnyugat-Budakörnyék térségére \\
\hline & 2005_06_14_lt51880272005165kis00 & Délnyugat-Budakörnyék térségére \\
\hline & 2005_09_02_lt51880272005245kis00 & Délnyugat-Budakörnyék térségére \\
\hline & 2006_07_19_lt51880272006200kis01 & Délnyugat-Budakörnyék térségére \\
\hline & 2006_08_20_lt51880272006232kis01 & Délnyugat-Budakörnyék térségére \\
\hline & 2006_10_07_lt51880272006280mor00 & Délnyugat-Budakörnyék térségére \\
\hline & 2007_07_22_1t51880272007203mor00 & Délnyugat-Budakörnyék térségére \\
\hline & 200708 23_1t51880272007235mor00 & Délnyugat-Budakörnyék térségére \\
\hline & 2010_06_12_1t51880272010163mor00 & Délnyugat-Budakörnyék térségére \\
\hline & 2010_07_14_lt51880272010195mor00 & Délnyugat-Budakörnyék térségére \\
\hline & 2011_07_17_lt51880272011198mor00 & Délnyugat-Budakörnyék térségére \\
\hline & 2011_09_03_1t51880272011246mor00 & Délnyugat-Budakörnyék térségére \\
\hline $\begin{array}{l}\text { Nagyon nagy } \\
\text { felbontású } \\
\text { ürfelvételek látható } \\
\text { tartományban } \\
\text { rögzített tömörített } \\
\text { változata (Google } \\
\text { Earth) } \\
\end{array}$ & (2006-2012 időszak felvételei) & $\begin{array}{l}\text { Délnyugat-Budakörnyékre } \\
\text { és a Nagyberek térségére }\end{array}$ \\
\hline Ortofotók (FÖMI) & $2000,2005,2008,2010$ & $\begin{array}{l}\text { Délnyugat-Budakörnyékre } \\
\text { és a Nagyberek térségére }\end{array}$ \\
\hline $\begin{array}{c}\text { Történeti } \\
\text { légifelvételek 1927- } \\
\text { től 1992-ig } \\
\text { (Hadtörténeti } \\
\text { Múzeum, FÖMI) }\end{array}$ & $\begin{array}{c}\text { 1927, 1940-es évek, 1951-55, 1958, } \\
1962,1978-79,1986,1992\end{array}$ & Délnyugat-Budakörnyékre \\
\hline $\begin{array}{c}\text { Saját terepi } \\
\text { fényképfelvételek } \\
(3000 \mathrm{db})\end{array}$ & 2006-2012 & $\begin{array}{l}\text { Délnyugat-Budakörnyékre } \\
\text { és a Nagyberek térségére }\end{array}$ \\
\hline $\begin{array}{c}\text { Ferde tengelyü } \\
\text { madártávlati } \\
\text { felvételek }(800 \mathrm{db})\end{array}$ & 2012 & $\begin{array}{l}\text { Délnyugat-Budakörnyékre } \\
\text { és a Nagyberek térségére }\end{array}$ \\
\hline
\end{tabular}


17. táblázat A felhasznált térképek listája

\begin{tabular}{|l|l|l|}
\hline \multicolumn{1}{|c|}{ A térképek típusa (neve) } & \multicolumn{1}{c|}{ Területi kiterjedés } & \multicolumn{1}{c|}{ Forrás } \\
\hline Katonai felmérések térképlapjai & $\begin{array}{l}\text { Nagyberek térségére, és } \\
\text { Délnyugat-Budakörnyékre }\end{array}$ & (ARCANUM Kiadó) \\
\hline Topográfiai térképek (10 000-es méretarány) & $\begin{array}{l}\text { Nagyberek térségére, és } \\
\text { Délnyugat-Budakörnyékre }\end{array}$ & (FÖMI) \\
\hline Topográfiai térképek (25 000-es máretarány) & $\begin{array}{l}\text { Nagyberek térségére, és } \\
\text { Délnyugat-Budakörnyékre }\end{array}$ & (FÖMI és HM TÉHI) \\
\hline
\end{tabular}

\section{8. táblázat A felhasznált térképi adatbázisok listája}

\begin{tabular}{|c|c|c|}
\hline Térképi adatbázisok & $\begin{array}{l}\text { Felhasznált adatok } \\
\text { kiterjedése }\end{array}$ & Adat forrása, és letöltésének forrása \\
\hline CLC100 $(1990,2000,2006)$ & EU28 + 3 állam területére & (EEA és FÖMI) (INT-022) \\
\hline CLC50 (2000) & $\begin{array}{l}\text { A Délnyugat-Budakörnyéki } \\
\text { térségre }\end{array}$ & (FÖMI) (INT-024) \\
\hline European Urban Atlas & $\begin{array}{l}\text { Közép-Európai nagyvárosok } \\
\text { területére (Bécs, Budapest, } \\
\text { Krakkó, München, Prága, } \\
\text { Varsó) }\end{array}$ & (EEA) (INT-025) \\
\hline ASTERGDEMv1 és v2 & Európa teljes területére & (NASA és METI) (INT-081) \\
\hline SRTM domboratmodell & Európa teljes területére & (NASA) (INT-079) \\
\hline DDM5 és DDM100 & $\begin{array}{l}\text { Magyarország területére, } \\
\text { Gerecse, Nagyberek, és } \\
\text { Budaörsi kopárok térségére }\end{array}$ & (FÖMI) \\
\hline GLSDEM & $\begin{array}{l}\text { Skandináv államok és } \\
\text { Magyarország területére }\end{array}$ & (USGS) (INT-075) \\
\hline World-Dem(ETOPO5) & Európa teljes területére & (INT-076) \\
\hline TM World Borders & EU28 +3 állam területére & Bjorn Sandvik, (thematicmapping.org) \\
\hline NUTS0 és NUTSX & EU28 + 3 állam területére & $\begin{array}{l}\text { (EUROSTAT) (INT-068) (SENSOR } \\
\text { Projekt) }\end{array}$ \\
\hline $\begin{array}{l}\text { Település } \quad \text { közigazgatási } \quad \text { határa } \\
\text { (NUTS5) }\end{array}$ & Magyarország területére & (FÖMI) \\
\hline Kistájhatáros térkép & Magyarország területére & $\begin{array}{l}\text { MTA TAKI GIS Labor, MAROSI S. } \\
\text { és SOMOGYI S. (szerk., 1990): } \\
\text { Magyarország kistájainak katasztere I- } \\
\text { II. alapján MTA Földrajztudományi } \\
\text { Kutató Intézet, Budapest, } 1023 \text { old. } \\
\text { (www.novenyzetiterkep.hu) } 2009\end{array}$ \\
\hline DTA 50 & $\begin{array}{l}\text { Nagyberek térségére, és } \\
\text { Délnyugat-Budakörnyék } \\
\text { térségére }\end{array}$ & (HM TÉHI) (INT-011) \\
\hline
\end{tabular}


19. táblázat A mintaterületek fóbb sajátosságai

\begin{tabular}{|c|c|c|c|c|}
\hline & $\begin{array}{c}\text { Európai Unió } 28 \\
+3 \text { állam }\end{array}$ & Magyarország & Nagyberek térsége & $\begin{array}{l}\text { Délnyugat- } \\
\text { Budakörnyék }\end{array}$ \\
\hline Terület $\left(\mathrm{km}^{2}\right)$ & 4353451 & 93030 & 1194 & 721 \\
\hline $\begin{array}{l}\text { Adatok forrása és } \\
\text { felmérés éve: }\end{array}$ & EUROSTAT 2012 & KSH 2011 & $\begin{array}{r}\text { Térinformatikai tudásbázis } \\
\text { segítésével KSH adatok összesitése } \\
\text { alapján }\end{array}$ & $\begin{array}{r}\text { Térinformatikai tudásbázis } \\
\text { segítésével KSH adatok } \\
\text { összesitése alapján (2011) }\end{array}$ \\
\hline $\begin{array}{l}\text { Lakosság (fö) } \\
\text { (lakónépesség) }\end{array}$ & 520037400 & 9938000 & 61928 & 574988 \\
\hline $\begin{array}{l}\text { Adatok forrása és } \\
\text { felmérés éve: }\end{array}$ & $\begin{array}{r}\text { EUROSTAT 2012, } \\
122\end{array}$ & KSH 2011 & $\begin{array}{r}\text { Térinformatikai tudásbázis } \\
\text { segítésével KSH adatok összesitése } \\
\text { alapján (2010) }\end{array}$ & $\begin{array}{r}\text { Térinformatikai tudásbázis } \\
\text { segitésével KSH adatok } \\
\text { összesitése alapján (2011) }\end{array}$ \\
\hline Népsürüség (fö//km²) & 119 & 107 & 52 & 797 \\
\hline $\begin{array}{l}\text { Adatok forrása és } \\
\text { felmérés éve: }\end{array}$ & $\begin{array}{r}\text { Eurostat } 2011 \\
\left(\text { INT-054 }{ }^{20}\right)\end{array}$ & $\begin{array}{r}\text { KSH } 2011 \\
(\text { INT-055 } \\
\end{array}$ & $\begin{array}{r}\text { Térinformatikai tudásbázis } \\
\text { segitésével KSH adatok összesitése } \\
\text { alapján (2010) }\end{array}$ & $\begin{array}{r}\text { Térinformatikai tudásbázis } \\
\text { segitésével KSH adatok } \\
\text { összesitése alapján (KSH) } \\
\end{array}$ \\
\hline $\begin{array}{l}\text { Kataszter / } \\
\text { Kataszterek szerinti } \\
\text { tájegységek }\end{array}$ & 350 & $\begin{array}{l}6 \text { nagytáj } \\
35 \text { középtáj, } \\
230 \text { kistáj }\end{array}$ & $\begin{array}{l}\text { Nagyberek kistáj } \\
\text { (100\%-ban a lehatárolt } \\
\text { terület része) }\end{array}$ & $\begin{array}{c}6 \text { kistáj } \\
\text { (Budai-hegyek, Budaörs- } \\
\text { Budakeszi-medence, } \\
\text { Tétényi-fennsík, Etyeki- } \\
\text { dombság, Zsámbéki- } \\
\text { medence, Érd-Ercsi- } \\
\text { hátság kistájak Legalább } \\
\text { 30\%-ával a lehatárolt } \\
\text { területbe esik) }\end{array}$ \\
\hline Forrás: & $\begin{array}{r}\text { MÜCHER et al. } \\
2010\end{array}$ & $\begin{array}{r}\text { Marosi-Somogyi } \\
1990\end{array}$ & gyi 1990 & $\begin{array}{r}\text { Marosi-Somogyi } \\
1990\end{array}$ \\
\hline $\begin{array}{l}\text { Beletartozó } \\
\text { statisztikai régiók } \\
\text { száma }\end{array}$ & $\begin{array}{l}28 \text { tagállam }+3 \\
\text { állam } \\
\text { (NUTS } 0 \text { szinten) }\end{array}$ & $\begin{array}{c}19 \text { megye és a } \\
\text { főváros } \\
\text { (NUTS } 3 \text { szinten) }\end{array}$ & $\begin{array}{c}42 \text { település } \\
\text { (NUTS } 5 \text { szinten) }\end{array}$ & $\begin{array}{l}22 \text { település, és } 5 \\
\text { budapesti kerület } \\
\text { (NUTS } 5 \text { szinten) }\end{array}$ \\
\hline $\begin{array}{l}\text { Beletartozó } \\
\text { statisztikai régiók: } \\
\text { (határvonaluk } \\
\text { egyben a } \\
\text { mintaterületek } \\
\text { lehatárolásának } \\
\text { alapja) }\end{array}$ & $\begin{array}{l}\text { Ausztria, Belgium, } \\
\text { Bulgária, Ciprus, } \\
\text { Csehország, Dánia, } \\
\text { Egyesült Királyság, } \\
\text { Észtország, Finnország, } \\
\text { Görögország, Hollandia, } \\
\text { Horvátország, Írország, } \\
\text { Lengyelország, } \\
\text { Lettország, Litvánia, } \\
\text { Luxembourg, } \\
\text { Magyarország, Málta, } \\
\text { Németország, } \\
\text { Olaszország, Portugália, } \\
\text { Románia, } \\
\text { Spanyolország, } \\
\text { Svédország, Szlovákia, } \\
\text { Szlovénia + Izland, } \\
\text { Norvégia, Svájc }\end{array}$ & $\begin{array}{l}\text { Baranya, Bács- } \\
\text { Kiskun, Békés, } \\
\text { Borsod-Abaúj } \\
\text { Zemplén, } \\
\text { Budapest, } \\
\text { Csongrád, Fejér, } \\
\text { Győr-Moson- } \\
\text { Sopron, Hajdú- } \\
\text { Bihar, Heves, Jász- } \\
\text { Nagykun-Szolnok, } \\
\text { Komárom- } \\
\text { Esztergom, } \\
\text { Nógrád, Pest, } \\
\text { Somogy, Szabolcs- } \\
\text { Szatmár-Bereg, } \\
\text { Tolna, Vas, } \\
\text { Veszprém, Zala }\end{array}$ & $\begin{array}{c}\text { Balatonberény, Balatonboglár, } \\
\text { Balatonfenyves, } \\
\text { Balatonkeresztúr, } \\
\text { Balatonlelle, } \\
\text { Balatonmáriafürdő, } \\
\text { Balatonszentgyörgy, } \\
\text { Balatonújlak, Bodrog, Buzsák, } \\
\text { Csömend, Fonyód, Gadány, } \\
\text { Gamás, Gyugy, Hács, Hollád, } \\
\text { Hosszúviz, Kelevíz, Kéthely, } \\
\text { Kisberény, Látrány, } \\
\text { Lengyeltóti, Libickozma, } \\
\text { Marcali, Mesztegnyő, Nikla, } \\
\text { Ordacsehi, Osztopán, Öreglak, } \\
\text { Pamuk, Polány, Pusztakovácsi, } \\
\text { Somogyfajsz, Somogysámson, } \\
\text { Somogyszentpál, Somogytúr, } \\
\text { Somogyvámos, Somogyvár, } \\
\text { Somogyzsitfa, Szőlősgyörök, } \\
\text { Táska, }\end{array}$ & $\begin{array}{l}\text { Budapest I. II. XI. XII. } \\
\text { XXII. kerületei, } \\
\text { Biatorbágy, Budajenő, } \\
\text { Budakeszi, Budaörs, } \\
\text { Diósd, Etyek, Érd, } \\
\text { Herceghalom, Mány, } \\
\text { Nagykovácsi, Perbál, } \\
\text { Pusztazámor, Páty, } \\
\text { Remeteszőlős, } \\
\text { Százhalombatta, } \\
\text { Sóskút, Telki, Tinnye, } \\
\text { Tárnok, Tök, } \\
\text { Törökbálint, Zsámbék }\end{array}$ \\
\hline Környező területek: & $\begin{array}{c}\text { Atlanti-óceán, Norvég- } \\
\text { tenger, Jeges-tenger, } \\
\text { Oroszország, } \\
\text { Fehéroroszország, } \\
\text { Ukrajna, Moldova, } \\
\text { Fekete-tenger, } \\
\text { Törökország, Égei- } \\
\text { tenger, Földközi-tenger, } \\
\text { Jón-tenger, Macedónia, } \\
\text { Szerbia, Albánia, } \\
\text { Montenegro, Bosznia } \\
\text { és Hercegovina, Adriai- } \\
\text { tenger, Tirrén-tenger, } \\
\text { Ligur-tenger }\end{array}$ & $\begin{array}{c}\text { Környező országok: } \\
\text { Ausztria, } \\
\text { Horvátország, } \\
\text { Románia, Szerbia, } \\
\text { Szlovákia, } \\
\text { Szlovénia, Ukrajna }\end{array}$ & $\begin{array}{c}\text { Környező / határoló } \\
\text { tájegységek: } \\
\text { Balaton, Marcali-hát, } \\
\text { Nyugat-Külső Somogy, } \\
\text { Kelet-Belső-Somogy, } \\
\text { Somogyi parti-sík, } \\
\text { Kis-Balatoni-medence, } \\
\text { Nyugat-Belső-Somogy } \\
\text { (Kevesebb mint 80\%-a esik } \\
\text { a lehatárolt területbe) }\end{array}$ & $\begin{array}{l}\text { Környező / határoló } \\
\text { tájegységek: } \\
\text { Csepeli-sík, } \\
\text { Vác-Pesti Duna-völgy, } \\
\text { Pilisi-hegyek, } \\
\text { Pilisi-medencék, } \\
\text { Keleti-Gerecse, } \\
\text { (Kevesebb mint 40\%-a } \\
\text { esik a lehatárolt } \\
\text { területbe) }\end{array}$ \\
\hline
\end{tabular}

${ }^{20}$ INT-054: Eurostat adatok honlapja (2014. 01. 28.)

${ }^{21}$ INT-055: A KSH lakónépességről szóló oldala (2014. 01. 29.) 
20. táblázat Az irodalomkutatás és terepbejárás során feltárt domináns táj változási tendenciák a négy mintaterületen, vagy azok egy részén

\begin{tabular}{|c|c|}
\hline EU $28+3$ állam & Forrás \\
\hline Beépített területek növekedése & $\begin{array}{l}\text { (VEJRE, PRIMDAHL és BRANDT 2007, 311), (FERANEC et al. 2010) } \\
\text { (ANTROP 2004) }\end{array}$ \\
\hline Energiaültetvények telepítése & (FISCHER et al. 2010) (SKÄRBÄCK és BECHT 2005, 151-159) \\
\hline $\begin{array}{l}\text { „Rurbán” tájak létesülése ("rurban landscapes") ahol kis területen lakhatás, termesztés, rekreáció és } \\
\text { üzleti élet is egyszerre előfordul }\end{array}$ & $\begin{array}{l}\text { (VEJRE, PRIMDAHL és BRANDT 2007, 324) (SWENSEN és JERPÅSEN } \\
2008,290,293 \text { ) }\end{array}$ \\
\hline $\begin{array}{l}\text { Agrárterületek feldarabolódása, zárvánnyá alakulása az épített infrastruktúra és beépített területek } \\
\text { hálójában }\end{array}$ & VEJRE, PRIMDAHL és BRANDT 2007, 323 \\
\hline Előhelyek létrehozása, természetközeli élőhelyek létesítése vagy rehabilitálása & $\begin{array}{l}\text { (BAILEY, LEE és THOMPSON 2006, 227-243) (VEJRE, PRIMDAHL és } \\
\text { BRANDT 2007, 320) }\end{array}$ \\
\hline Unirformizálódás, sokféleség elvesztése, tájidentitás, vagy regionális identitás elvesztése & (NOHL 2001, 225) (ANTROP 2005, 21) (PEDROLI et al 2007, 11-12) \\
\hline Mezögazdasági területek felhagyása, a müvelés extenzifikációja & $\begin{array}{l}\text { (PARACCHINI et al. 2007, 24, 32) (TAILLEFUMIER és PIÉGAY 2003, 267- } \\
\text { 268) (ZOMENI, TZANOPOULOS és PANTIS 2008, 38) (SAYADI et al. } \\
2009,2)\end{array}$ \\
\hline $\begin{array}{l}\text { Helyenként a mezőgazdasági területek müvelésének intenzi fikációja, táblák homogenizálódása } \\
\text { természeti értékének csökkenése }\end{array}$ & $\begin{array}{l}\text { (PARACCHINI et al. 2007, 21, 23) (PEDROLI et al 2007, 13) (TVEIT 2009, } \\
\text { 2882) (ZOMENI, TZANOPOULOS és PANTIS 2008, 38) (MAKHZOUMI } \\
\text { 1997, 115-122) (ROGGE, NEVENS és GULINCK 2008, 76-83) }\end{array}$ \\
\hline $\begin{array}{l}\text { Hagyományos gazdálkodás turizmust vonzó hatása egyre fokozottabban érvényesül, élénkül az } \\
\text { agro-turizmus }\end{array}$ & PARACCHINI et al. 2007, 31-32 \\
\hline $\begin{array}{l}\text { Periférián lévő tájak elnéptelenednek, a fiatal lakosság a központokba áramlik, a vidéki tájélmény } \\
\text { csökken }\end{array}$ & a szerzö megállapitása és részben PARACCHINI et al. 2007, 32 \\
\hline $\begin{array}{l}\text { Kalandparkok, élményparkok egyéb rekreációs szabadidöparkok létesítése, wellness turizmus, } \\
\text { városi tömegturizmus helyenkénti erösödése és elkülönülése }\end{array}$ & $\begin{array}{l}\text { a szerző megállapítása és részben (PEDROLI et al 2007, 12) (LASANTA et al. } \\
\text { 2007), (CALETRÍO 2010) }\end{array}$ \\
\hline Erdösülés & $\begin{array}{l}\text { (SERRA, PONS és SAURÍ 2008, 189-209) (SKÅNES és BUNCE 1997, 61) } \\
\text { (MOTTET et al. 2006, 304) }\end{array}$ \\
\hline Városok identitásának erősödése, városi parkok és terek folyamatos megújulása & (BERIATOS és GOSPODINI 2004, 187-202) (JODIDO 2012) \\
\hline
\end{tabular}

\begin{tabular}{|c|c|}
\hline Magyarország & Forrás \\
\hline Vonalas közlekedési infrastruktura-elemek (autópályák, autóutak) létesítése, bővítése & MOLNÁR 2010, 243-251 \\
\hline Erdöterületek növekedése & (KONKOLY GYURÓ 2007, 303) (CSEMEZ 1996) \\
\hline Széttelepülés & CSEMEZ 1996, 114-116 \\
\hline Települések beépítésre szánt területének növekedése, települések összenövése & a szerző megállapítása \\
\hline $\begin{array}{l}\text { Extrém vízjárási szélsőségek (áradás és szárazság) szerepének növekedése. Árvízi vésztározók } \\
\text { létesítése várható és a hozzákapcsolódó extenziv mezö- és erdőgazdál kodás terjedése }\end{array}$ & KONKOLY GYURÓ 2007, 301, 303 \\
\hline Ipari táj felhagyása, átalakulása, elrozsdásodása, elgyomosodása esetleges megújulása & PALÁDI-KOVÁCS 2007, 247 \\
\hline Erőmüvek (szél-, víz-, atom- illetve bioenergia) létesítése & a szerző megállapítása \\
\hline Kavicsbánya-tavak terjedése, felhagyott bányatavak utóhasznosításának szerepe megnő & a szerző megállapítása \\
\hline Cserjésedés, gyümölcsösök, szölőterületek felhagyása egyes területeken & (TIRÁSZI 2011) (NAGY és CSIMA 2010, 237-240) \\
\hline $\begin{array}{l}\text { Fiatal népesség elhagyja a vidéki tájat, nem érdekeltek a tájban élö hagyományok, gazdálkodás } \\
\text { fenntartásában }\end{array}$ & (KONKOLY GYURÓ 2007, 303) \\
\hline Dinamikusan fejlődő és hanyatló térségek folyamatosa és egyre markánsabb elkülönülése & (CSEMEZ 1996, 108-109) \\
\hline Kerékpáros, falusi, öko- és egészség-turizmus helyenként erösödése & (KONKOLY GYURÓ 2007, 305) \\
\hline $\begin{array}{l}\text { Nagyberuházások terjedése, Zöldmezős beruházások terjedése lakóterületek, raktár és } \\
\text { kereskedelmi célú létesítmények létesítése esetén }\end{array}$ & a szerző megállapítása és részben: (KÖRMENDY 2010,283) \\
\hline Gyep területek, föként dombvidéki gyepek csökkenése, szántók gyepes & a szerzö me gállapítása és részben: (TIRÁSZI 2011) \\
\hline
\end{tabular}

\section{Nagyberek térsége}

Az M7 autópálya mentén fokozódó beépítés

Üdülőterületi hasznosítás intenzitásának növekedése

A tóparttól kilométerekre távol eső déli területrészek, falusias települések többségének

elnéptelenedése, népességének elöregedése

A mezőgazdasági művelés extenzifikációja. Szántóművelést helyenként felváltja a legeltetés

A felhagyott mezőgazdasági területek erdősülése

A felhagyott vonalas infrastruktúra-elemek és kapcsolódó épített létesítmények állapotromlása

A falusi turizmus egy-egy "kulturális-tradicionális" közpotban történő megerősödése (Buzsák

Mesztegnyő, Somogyvámos)

Természetközeli területek emberi hasznosítástól függö ökológiai értékváltozása

Földhasználattal kapcsolatos viták a terület hosszú távú tudatos kezelését megnehezítik

Vadászat, és vadászturizmus dominanciájának növekedése

Tóparti tömegturizmus és kapcsolódó épített létesítményeinek fokozódása

Halastavak létesítése

Vízpart feltöltése, vízfelszín csökkenése strand, lakóterület, park létesítése céljából

\section{Délnyugat-Budakörnyék}

A autópályák és autóutak mentén fokozódó beépítés (raktár, logisztika, kereskedelem megjelenése)

Városközpontokban és közelében elhelyezkedő terek, parkok megújítása

Népességnövekedés főként a térség középső városperemi, elővárosi részén.

A mezőgazdasági területek zöldmezős fejlesztési potenciállal történő tartalékolása, helyenként a

müvelés felhagyása

Autóút, elkerülő utak létesítése

Bányaterületek felhagyása, feltöltése és utóhasznosítása

Nemzetközi turizmus intenzitásának stabilizálódása, esetleg növekedése a fövárosi területeken

Zöldterületek felértékelődése, parkerdők szerepének (mint potenciális kirándulóhelyek) növekedése

Rekreációs jellegű zöldfelületi elemek szerepének erősödése

Egyes kis méretű tavak feltöltődése (pl.: Garancsi-tó)

Tủlevelű erdők kiszáradása, kidőlése, eltünése, és lomblevelű cserjésedő-erdősödő területek terjedése

Intenzív lakóterületi beépítés, föként a lakópark-építés jelenségének terjedése

Mezőgazdasághoz köthető hagyományos tájértékek csökkenése

\section{Forrás}

a szerző megállapítása a szerző megállapítása

a szerző megállapítása a szerző megállapítása a szerző megállapítása

a szerzố megállapítása

a szerző megállapítása

a szerző megállapítása

a szerző megállapítása

a szerző megállapítása

a szerző megállapítása

a szerző megállapítása

(ILLÉS 1981)

\section{Forrás}

a szerző megállapítása

a szerző megállapítása

a szerző megállapítása (SALLAY 2011, 100)

a szerző megállapítása

a szerző megállapítása

a szerző megállapítása, (PÁDÁRNÉ TÖRÖK 2010, 221-228)

a szerző megállapítása

a szerző megállapítása

a szerző megállapítása (PÁDÁRNÉ TÖRÖK 2010, 221-228)

(SALLAY és BÁRCZINÉ-KAPOVITS 2010)

a szerző megállapítása

a szerző megállapítása

(SCHNELLER 2010, 266)

(SALLAY 2011, 100) 


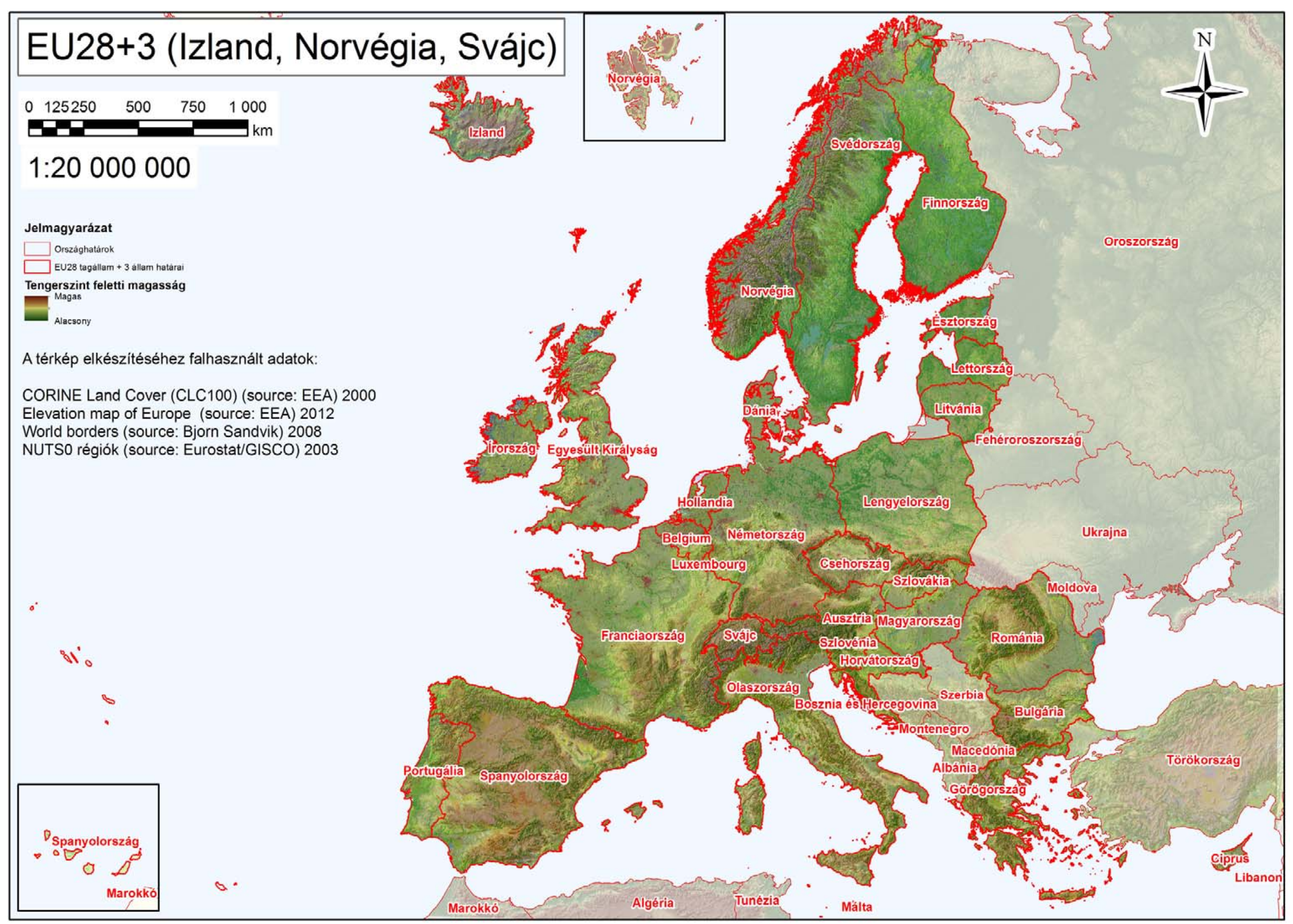

27. ábra EU $28+3$ állam (Izland, Norvégia, Svájc) mintaterület

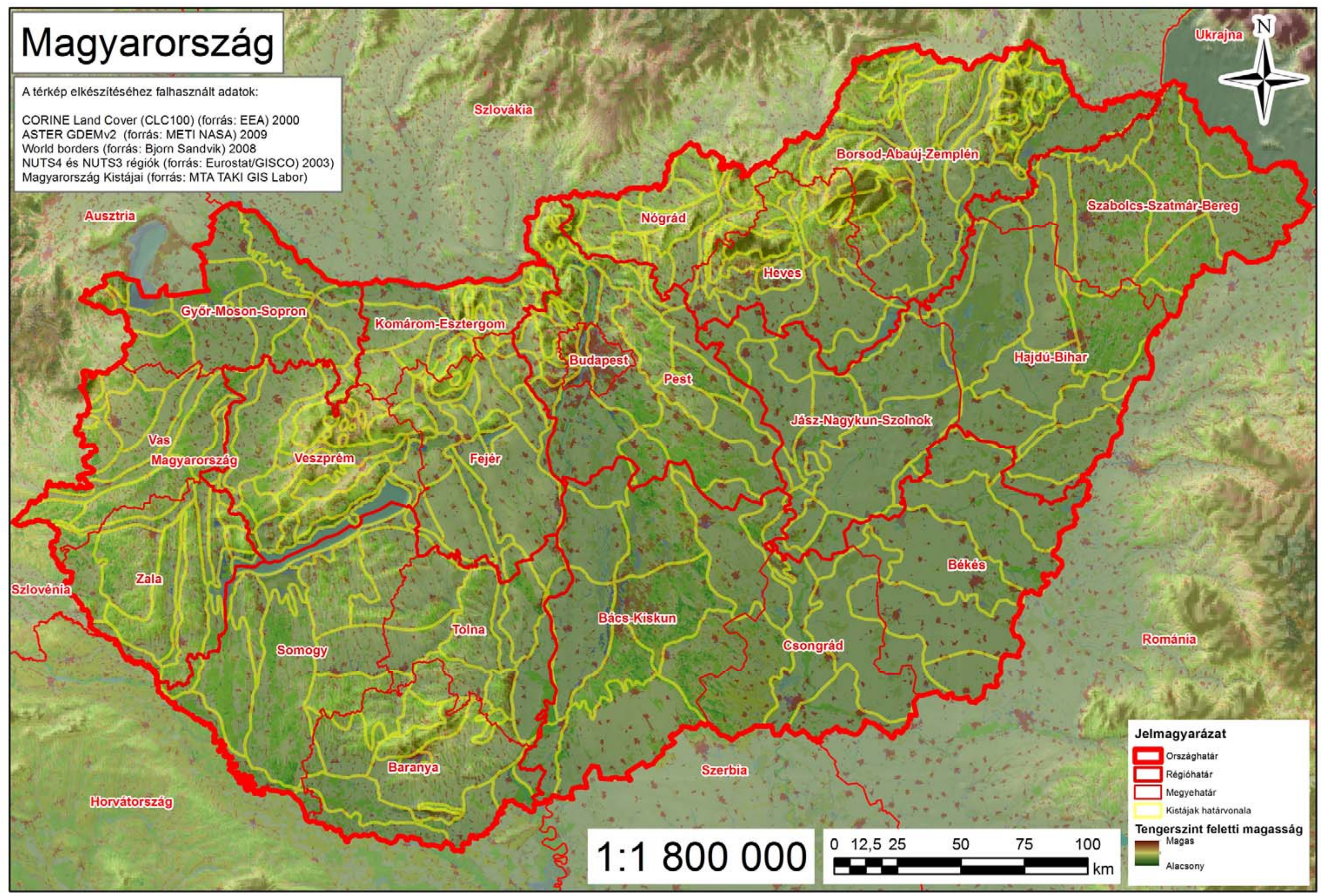




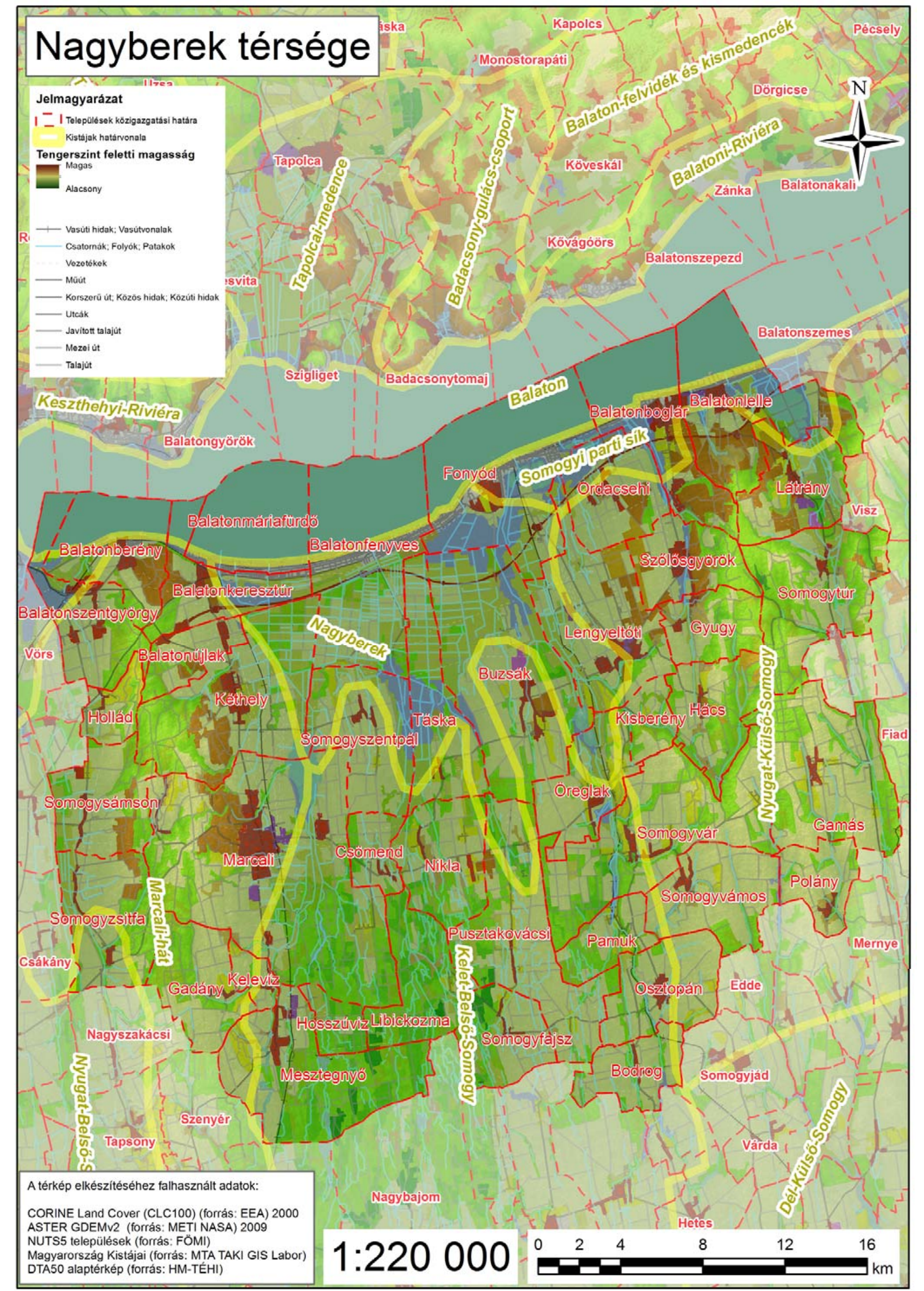

29. ábra Nagyberek térsége mintaterület

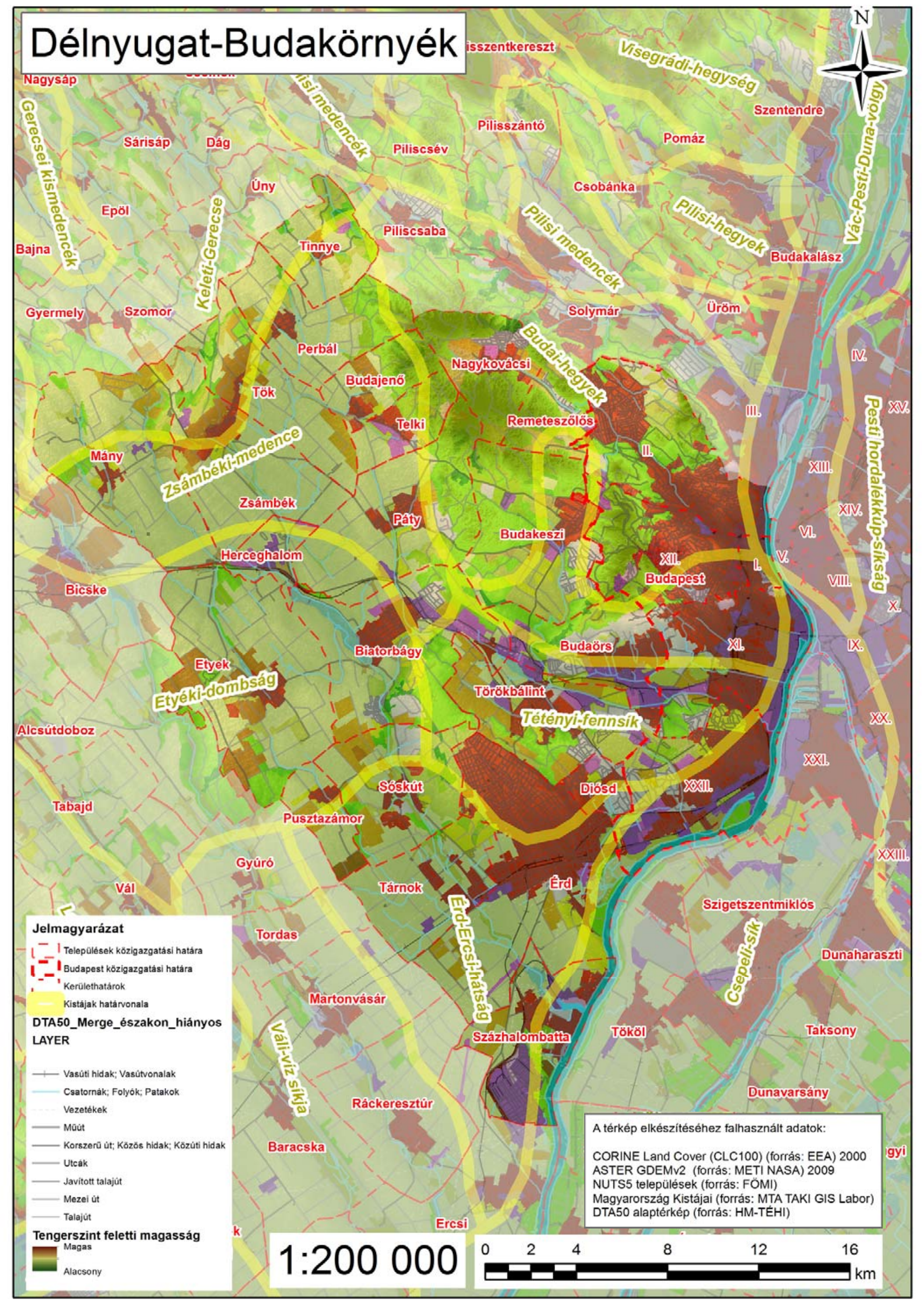

30. ábra Délnyugat-Budakörnyék mintaterület 
31. ábra A kérdőívekben felhasznált felvételek és kérdőívek mintája a tájmodellek megjelenítéséhez használt magassági modellekről

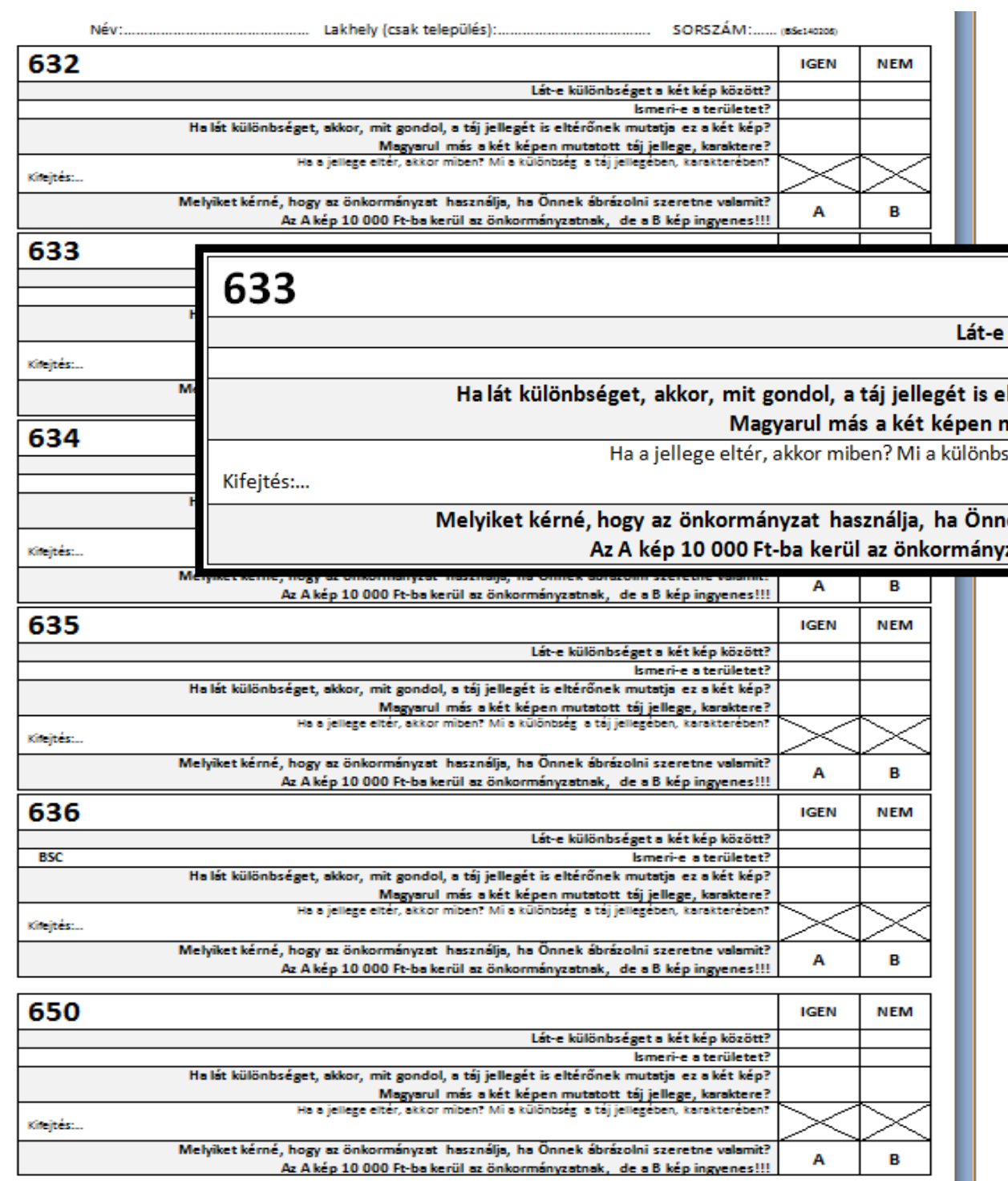

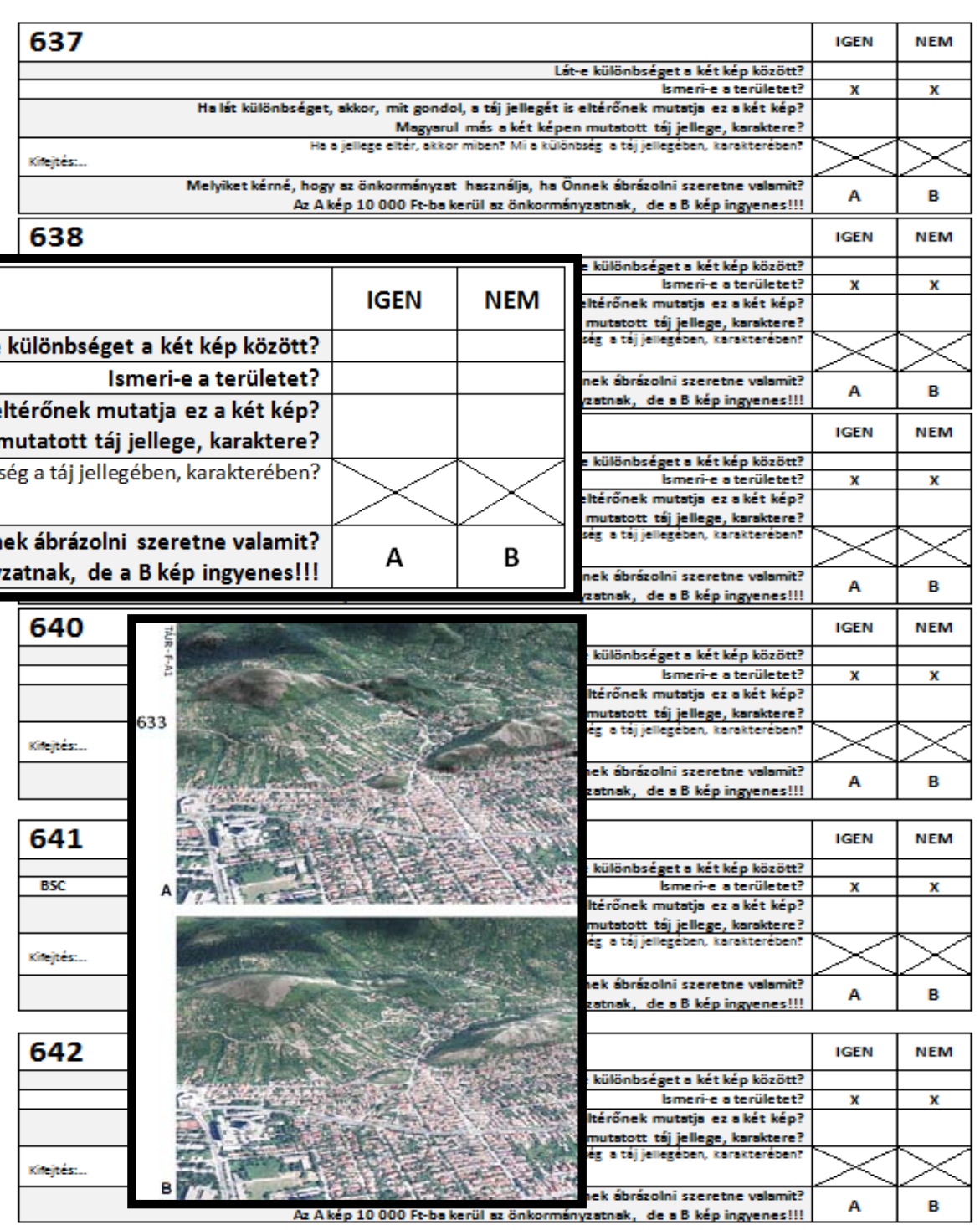


32. ábra A kérdőívekben és interjúkban felhasznált felvételek mintái és a feltett kérdések a tájrészletek beazonosíthatóságáról

Névi: SORSZám:-...

Lakhely (hosszúi idốszak, csaktelepülés):

Válassza ki, hogya vetített tájkép Ön szerint melyiktelepülést mutatja!

Karikázza be az Ön szerint helyes település betüjelét a vetített kép sorszáma mellett!

\begin{tabular}{|c|c|}
\hline $\begin{array}{c}\text { Kép } \\
\text { sorszáma }\end{array}$ & $\begin{array}{c}\text { Helyszin / Település betújele } \\
\text { Bekarikázandó: }\end{array}$ \\
\hline 5 & A, B, C, D, E, F, G, H, I, J \\
\hline 12 & A, B, C, D, E, F, G, H, I, J \\
\hline 21 & A, B, C, D, E, F, G, H, I, J \\
\hline 28 & A, B, C, D, E, F, G, H, I, J \\
\hline 35 & A, B, C, D, E, F, G, H, I, J \\
\hline 41 & A, B, C, D, E, F, G, H, I, J \\
\hline 52 & A, B, C, D, E, F, G, H, I, J \\
\hline 53 & A, B, C, D, E, F, G, H, I, J \\
\hline 65 & A, B, C, D, E, F, G, H, I, J \\
\hline
\end{tabular}

\begin{tabular}{|l|}
\hline Lehetséges válaszok \\
\hline (A) Budapest \\
\hline (B) Gyôrr \\
\hline (C) Érd \\
\hline (D) Budaörs \\
\hline (E) Dunakeszi \\
\hline (F) Biatorbágy \\
\hline (G) Balatonboglár \\
\hline (H) Fonyód \\
\hline (I) Zsámbék \\
\hline (J) Nem tudom \\
\hline
\end{tabular}

\begin{tabular}{|l|l|}
\hline 205 & A, B, C, D, E, F, G, H, I, J \\
\hline 223 & A, B, C, D, E, F, G, H, I, J \\
\hline 228 & A, B, C, D, E, F, G, H, I, J \\
\hline 240 & A, B, C, D, E, F, G, H, I, J \\
\hline 243 & A, B, C, D, E, F, G, H, I, J \\
\hline 247 & A, B, C, D, E, F, G, H, I, J \\
\hline 262 & A, B, C, D, E, F, G, H, I, J \\
\hline 263 & A, B, C, D, E, F, G, H, I, J \\
\hline 273 & A, B, C, D, E, F, G, H, I, J \\
\hline
\end{tabular}

\begin{tabular}{|l|l|}
\hline 311 & A, B, C, D, E, F, G, H, I, J \\
\hline 317 & A, B, C, D, E, F, G, H, I, J \\
\hline 340 & A, B, C, D, E, F, G, H, I, J \\
\hline 361 & A, B, C, D, E, F, G, H, I, J \\
\hline 366 & A, B, C, D, E, F, G, H, I, J \\
\hline 367 & A, B, C, D, E, F, G, H, I, J \\
\hline 380 & A, B, C, D, E, F, G, H, I, J \\
\hline 386 & A, B, C, D, E, F, G, H, I, J \\
\hline 390 & A, B, C, D, E, F, G, H, I, J \\
\hline
\end{tabular}
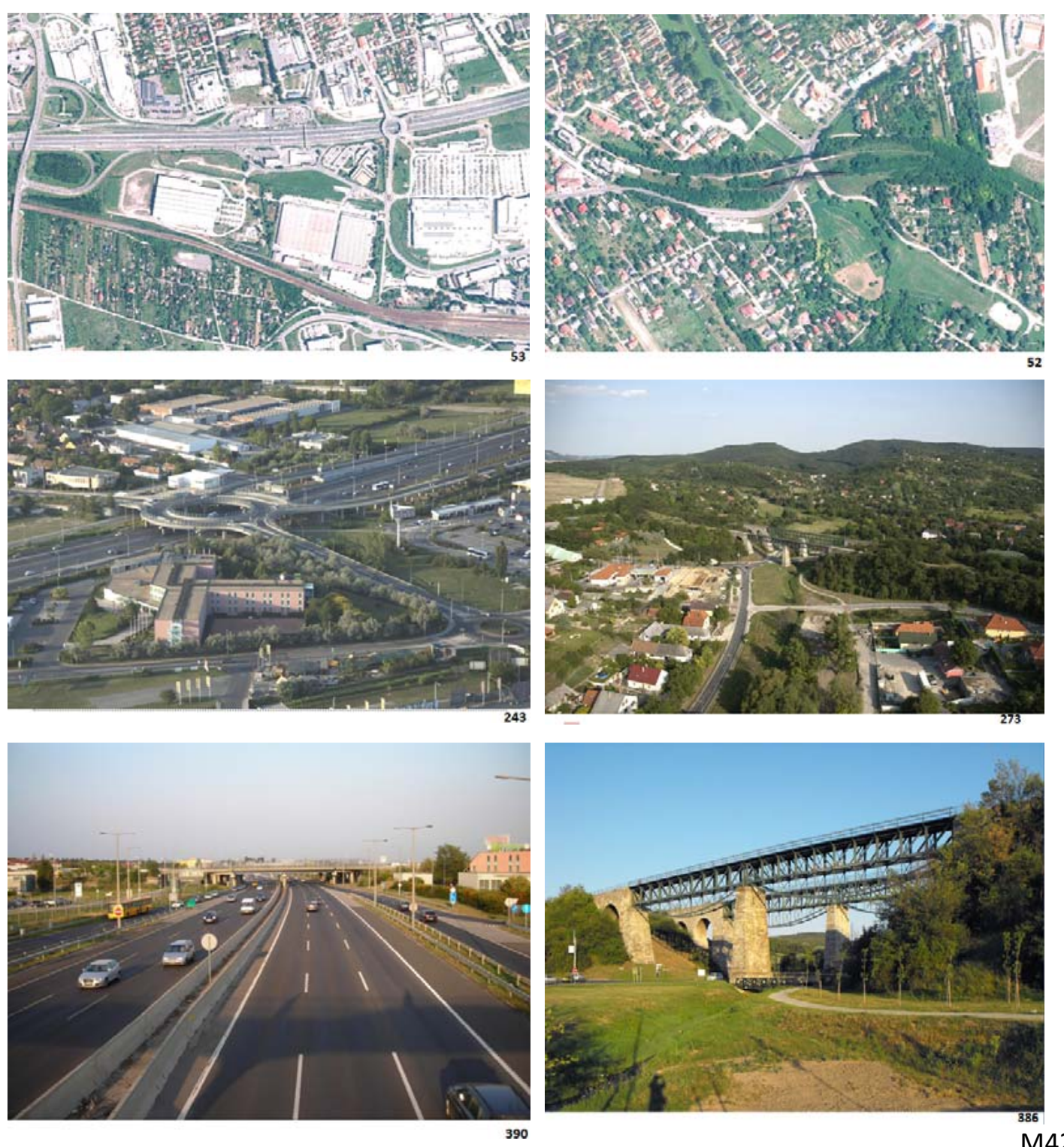
33. ábra A kérdőívekben és interjúkban feltett kérdések a valóság és a 3D tájmodell közötti tájkarakter-megjelenítés különbségeiről

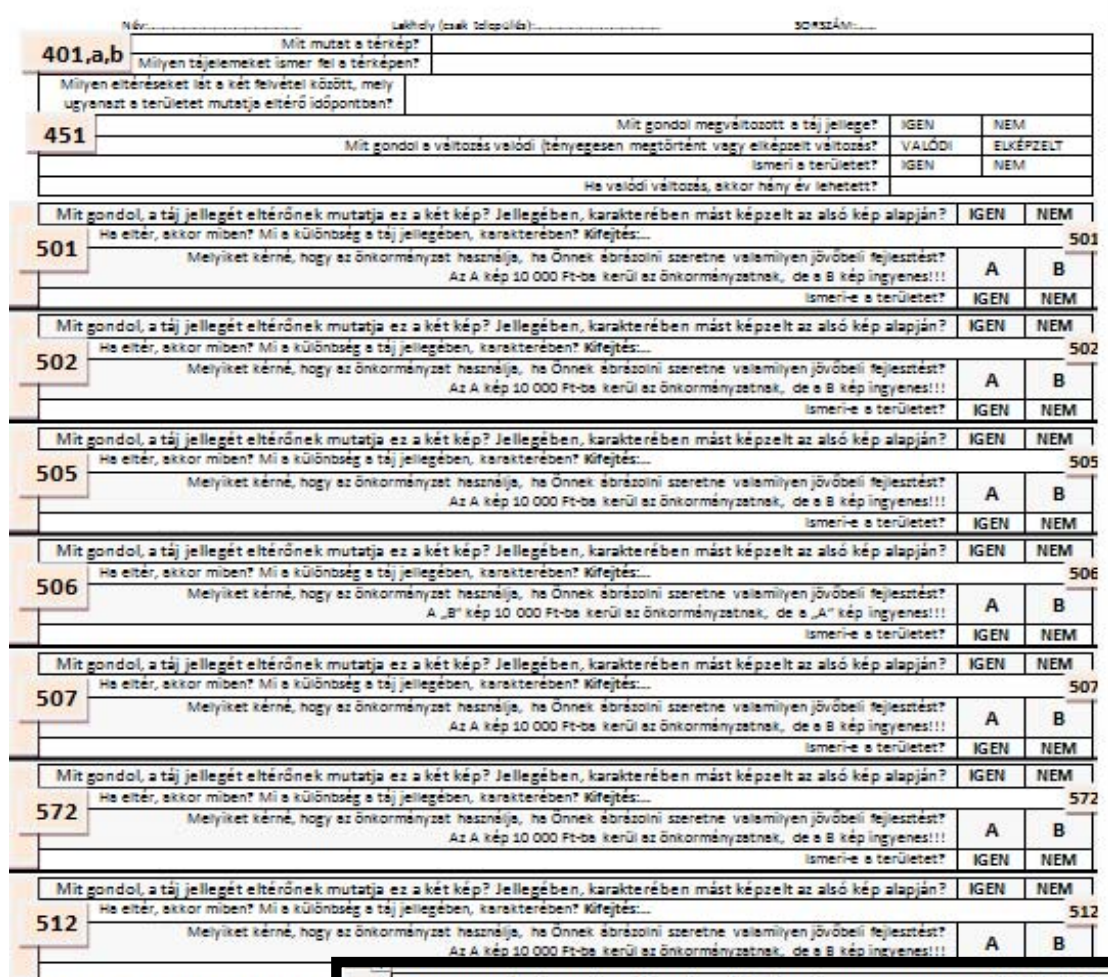

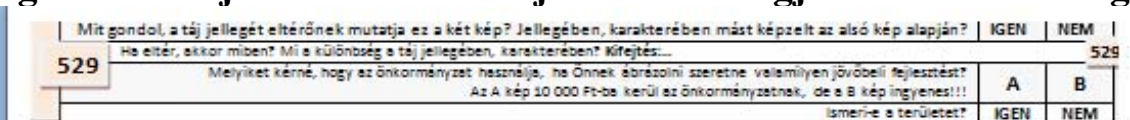

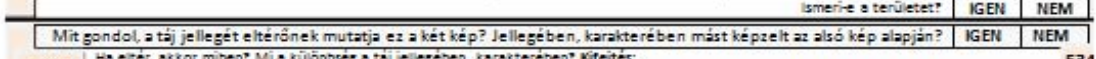

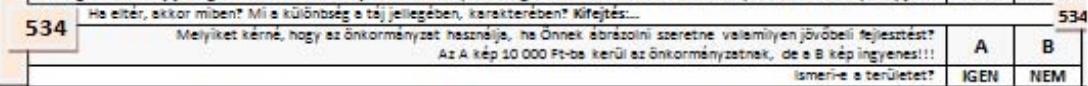

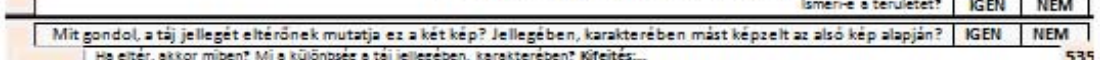

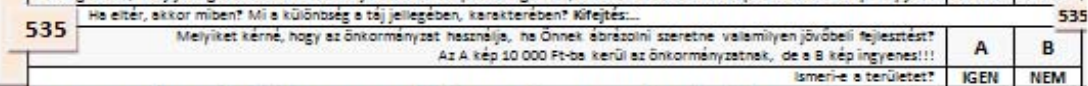

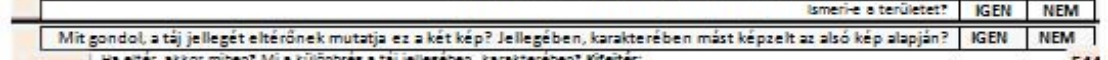

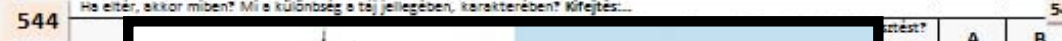

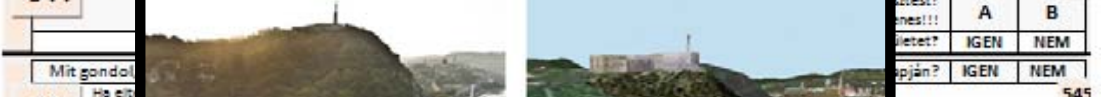
545  Mit gon 548 Mits 553 r

Mit gondol 549 Mit gondol

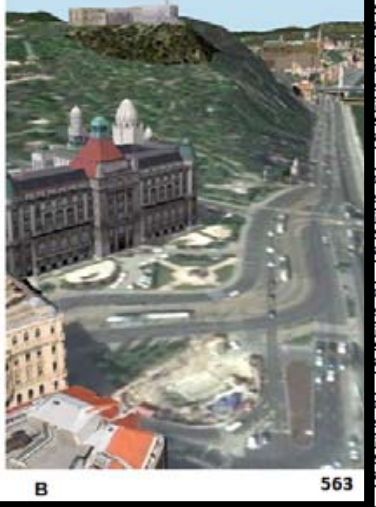
: \begin{tabular}{|l|l|l}
\hline met? & IGEN & NEM \\
\hline Iin? & IGEN & NEM \\
\hline
\end{tabular} tast: A \begin{tabular}{|l|l|l|}
\hline IGEN & NEM \\
\hline
\end{tabular}

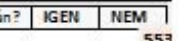
\begin{tabular}{|l|l|}
\hline$: !$ & A \\
\hline
\end{tabular} \begin{tabular}{|c|c|c|c|}
\hline Get: & IGEN & NEM \\
\hline
\end{tabular} \begin{tabular}{|l|l|l|}
\hline pján? & IGEN & NEM \\
\hline 549
\end{tabular} \begin{tabular}{|c|c|c|}
\hline & B \\
\hline
\end{tabular}

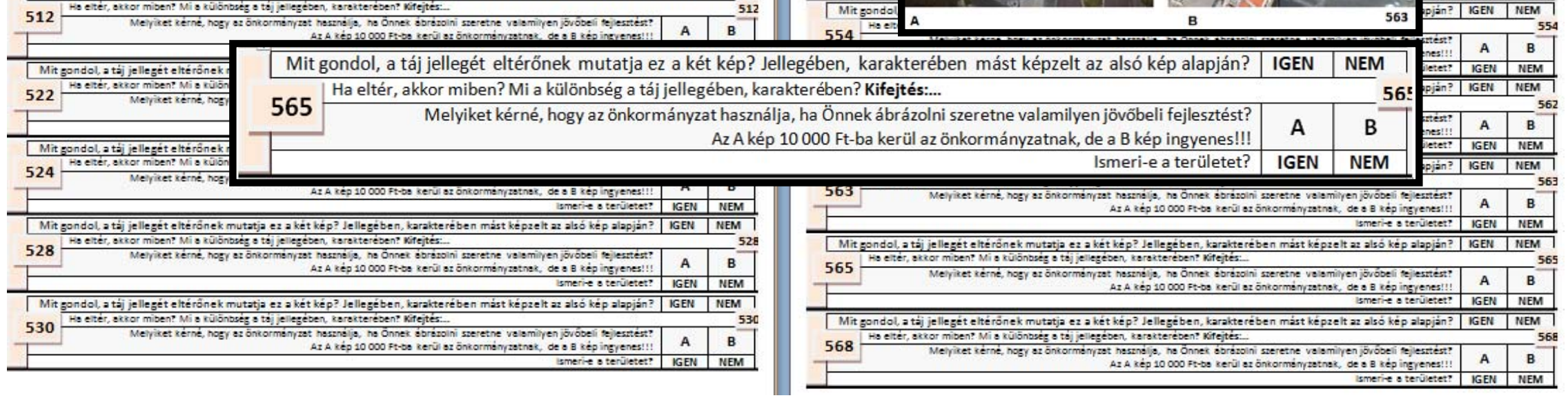




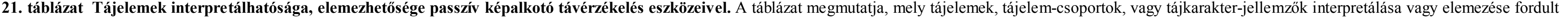

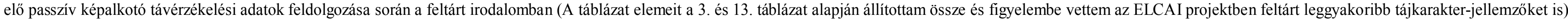

\begin{tabular}{|c|c|c|c|c|c|c|c|c|c|c|c|c|c|c|c|c|c|c|c|}
\hline & $\begin{array}{l}\begin{array}{r}\text { Tájelem- } \\
\text { csoportok }\end{array} \\
\text { iterpretációs } \\
\text { emek }\end{array}$ & $\begin{array}{c}\text { Földtan } \\
\text { és } \\
\text { talajtan }\end{array}$ & $\begin{array}{l}\text { Éghajlat } \\
\text { (Klíma) }\end{array}$ & Domborzat & Vízrajz & $\begin{array}{l}\text { Növény- } \\
\text { takarón } \\
\text { (Flóra) }\end{array}$ & $\begin{array}{l}\text { Állatvilág } \\
\text { (Fauna) }\end{array}$ & $\begin{array}{l}\text { Terület- } \\
\text { használat }\end{array}$ & $\begin{array}{l}\text { Természeti } \\
\text { terület }\end{array}$ & $\begin{array}{c}\text { Mezó- } \\
\text { gazdaság }\end{array}$ & $\begin{array}{l}\text { Szolgáltatás } \\
\text { eś kutatats-s- } \\
\text { fejleszztés }\end{array}$ & $\begin{array}{c}\text { Ipar } \\
\text { Energia- } \\
\text { gazdálkodás } \\
\text { Turizmus } \\
\end{array}$ & $\begin{array}{l}\text { Felszín- } \\
\text { boritás }\end{array}$ & $\begin{array}{c}\text { Látvány- } \\
\text { elemek, } \\
\text { (percepció) }\end{array}$ & $\begin{array}{c}\text { Táj- } \\
\text { szerkezet }\end{array}$ & Mintázat & $\begin{array}{l}\text { Egyéb } \\
\text { érzékelhetó } \\
\text { elemek }\end{array}$ & Népesség & $\begin{array}{l}\text { Identitás, } \\
\text { Emlékek, } \\
\text { Asszociációk, } \\
\text { Elöképek }\end{array}$ \\
\hline 1 & Alak (shape) & & & volt & volt & volt & & & & & & & volt & volt & volt & volt & & & \\
\hline 2 & Méret (size) & & & lehetne & volt & volt & & & & & & & volt & volt & volt & volt & & & \\
\hline 3 & Tónus (tone) & & & & & volt & & & & & & & volt & volt & volt & volt & & & \\
\hline 4 & Szín (color) & & & & volt & volt & & & & & & & volt & volt & volt & volt & & & \\
\hline 5 & $\begin{array}{l}\text { Árnyék és } \\
\text { árnyasság } \\
\text { (shadow, shade) }\end{array}$ & & & volt & & volt & & & & & & & volt & volt & volt & volt & & & \\
\hline 6 & $\begin{array}{l}\text { Mintázat } \\
\text { (pattern) }\end{array}$ & & & volt & volt & volt & & & & & & & volt & volt & & volt & & & \\
\hline 7 & $\begin{array}{l}\text { Szerkezet / } \\
\text { textúra (texture) }\end{array}$ & & & volt & volt & volt & & & & & & & volt & volt & volt & & & & \\
\hline 8 & Helyszín (site) & & & lehetne & lehetne & volt & & & & & & & volt & volt & volt & volt & & & \\
\hline 9 & \begin{tabular}{|l} 
Földrajzi hely \\
(location)
\end{tabular} & & & lehetne & lehetne & volt & & & & & & & volt & volt & & & & & \\
\hline 10 & $\begin{array}{l}\text { Asszociáció } \\
\text { (association) }\end{array}$ & & & volt & lehetne & volt & & & & & & & volt & & volt & volt & & & \\
\hline 11 & $\begin{array}{l}\text { Szituáció } \\
\text { (situation) }\end{array}$ & & & lehetne & lehetne & volt & & & & & & & volt & & volt & volt & & & \\
\hline 12 & $\begin{array}{l}\text { Térbeli felbontás } \\
\text { (spatial } \\
\text { resolution) }\end{array}$ & & & lehetne & & volt & & & & & & & volt & volt & volt & volt & & & \\
\hline 13 & Sztereo (stereo) & & & & & lehetne & & & & & & & lehetne & & & & & & \\
\hline 14 & \begin{tabular}{|l} 
Időbeliség \\
(time scale)
\end{tabular} & & & lehetne & lehetne & volt & & & & & & & volt & volt & volt & volt & & & \\
\hline 15 & $\begin{array}{l}\text { Térbeli eltérés } \\
\text { (spatial } \\
\text { difference) }\end{array}$ & & & lehetne & lehetne & volt & & & & & & & volt & volt & volt & volt & & & \\
\hline
\end{tabular}


23. táblázat Tájkarakter-elemzés folyamatához illeszkedó képfelhasználási javaslatok és képfeldolgozási eljárások

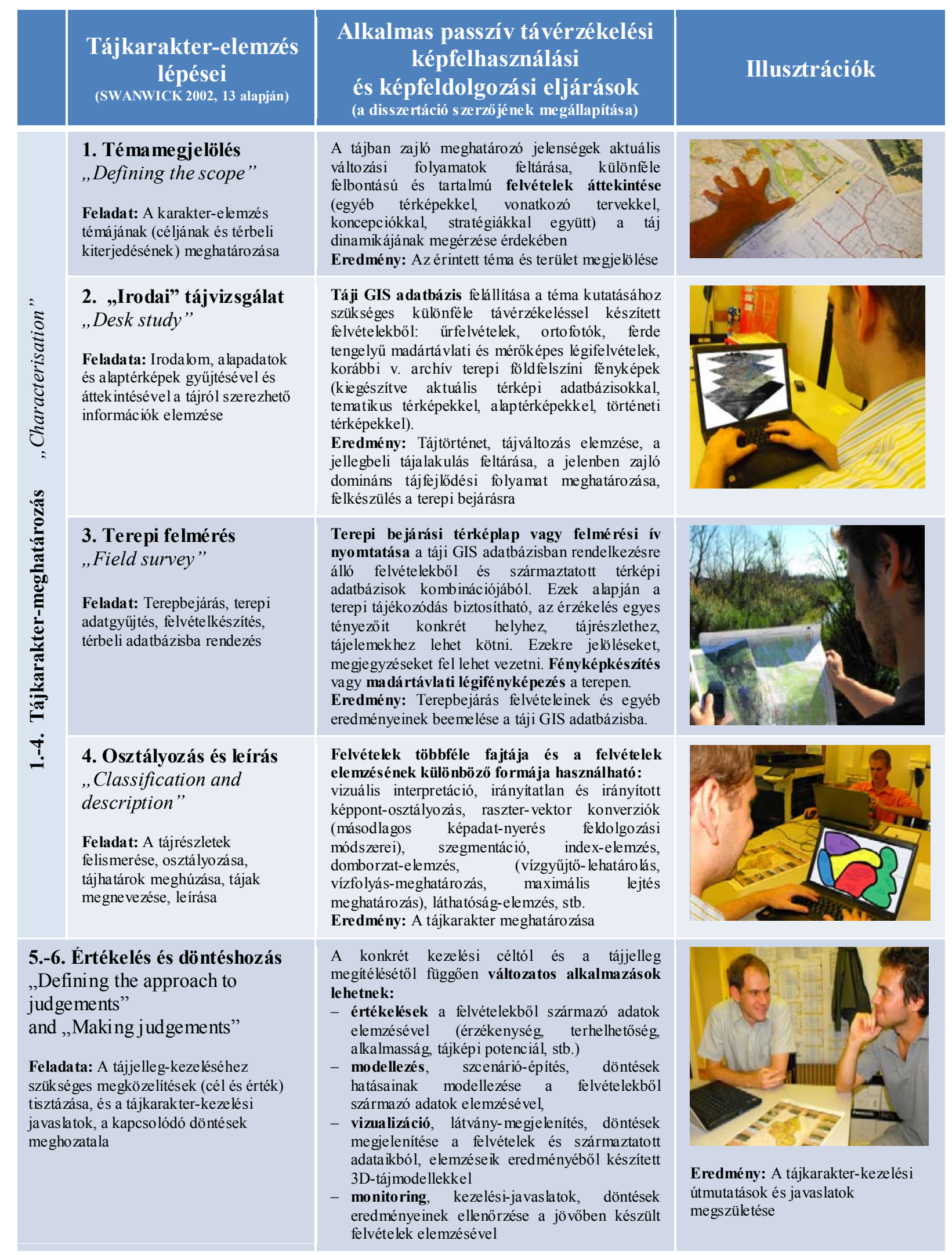

24. táblázat A tájkarakter-elemzés „osztályozás és leírás” lépéséhez illeszkedő felhasználási javaslatok és feldolgozási eljárások

\begin{tabular}{|c|c|c|}
\hline $\begin{array}{l}\text { Osztályozás } \\
\text { és leírás } \\
\text { (SWANwICK 2002, 37-51 } \\
\text { alapjản) }\end{array}$ & $\begin{array}{l}\text { Alkalmas passzív távérzékelési } \\
\text { képfelhasználási } \\
\text { és képfeldolgozási eljárások } \\
\text { (a disszertáció szerzơjének megállapitása) }\end{array}$ & ációk \\
\hline $\begin{array}{l}\text { 4.a) tájak felosztása } \\
\text {,dividing } \\
\text { landscapes" } \\
\text { Feladat: A táj } \\
\text { alcotoelemeinek szintére } \\
\text { (tajelemekre, } \\
\text { tajireszletekre) bontása }\end{array}$ & 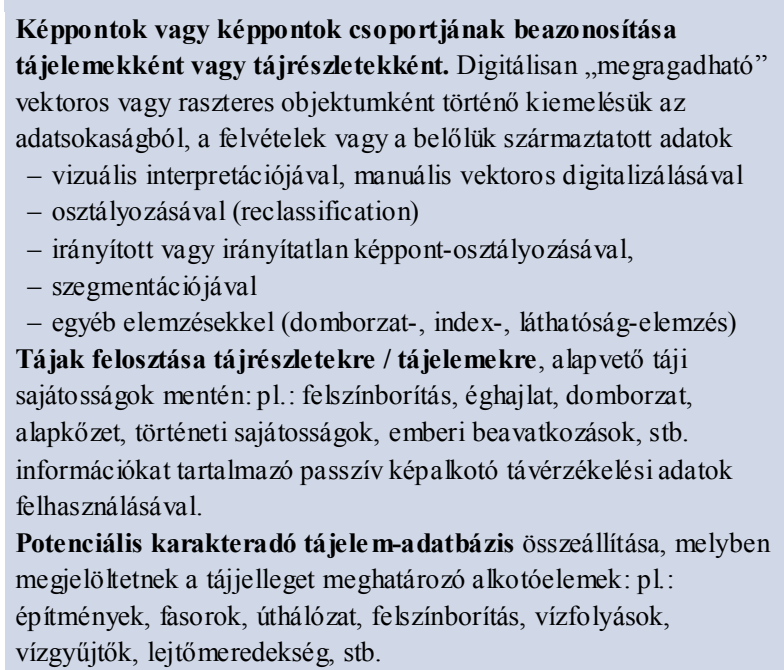 & \\
\hline $\begin{array}{l}\text { 4.b) tájelemek, } \\
\text { tájrészletek } \\
\text { csoportosítása } \\
\text {,grouping" } \\
\text { Feladat: Az egyjellegü } \\
\text { tájelemek és tajrészletek } \\
\text { osszevonása csoportositása }\end{array}$ & 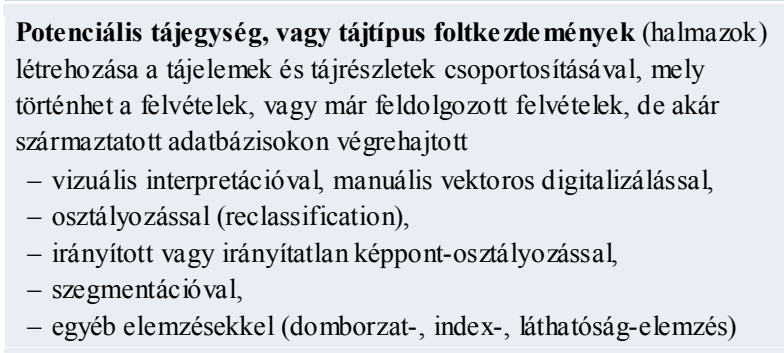 & \\
\hline $\begin{array}{l}\text { 4.c) megnevezés } \\
\text {,identification" } \\
\text { Feladat: } \text { A rendelkezésre } \\
\text { álló információkból a } \\
\text { legiellemzzöbb megnevezés } \\
\text { megalkotása }\end{array}$ & 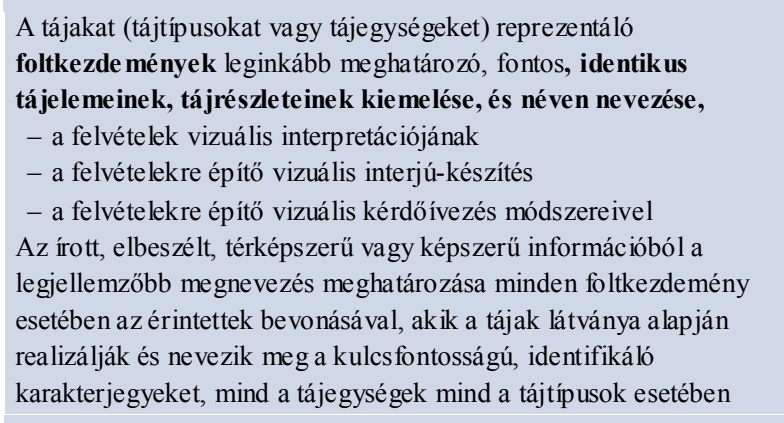 & $A$ \\
\hline $\begin{array}{l}\text { 4.d) térképezés } \\
\text {,mapping } \\
\text { boundaries" } \\
\text { Feladat: A tajjak } \\
\text { határvonalainak meghizása } \\
\text { térképen }\end{array}$ & 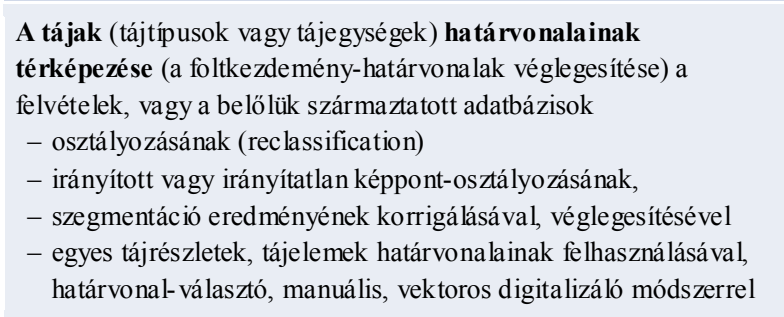 & \\
\hline $\begin{array}{l}\text { 4.e) jellemzés } \\
\text {,description" } \\
\text { Feladat: A Áajak } \\
\text { jellemzóinek, } \\
\text { sajátossagainak, } \\
\text { karakterelemeinek leirása }\end{array}$ & 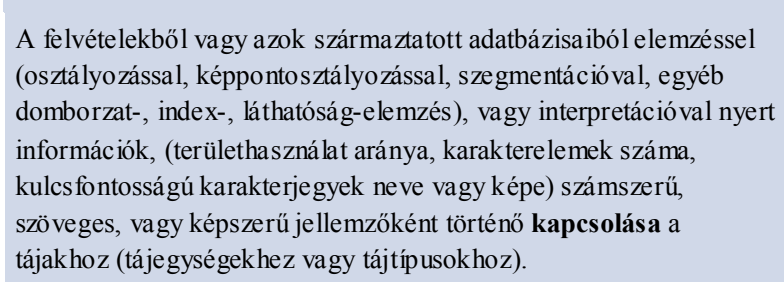 & 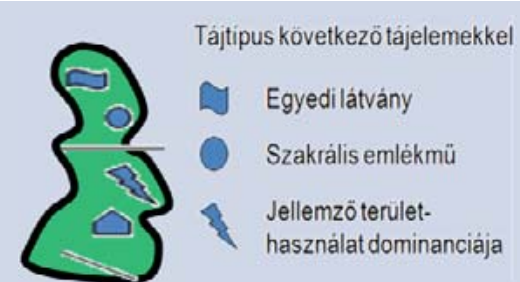 \\
\hline
\end{tabular}



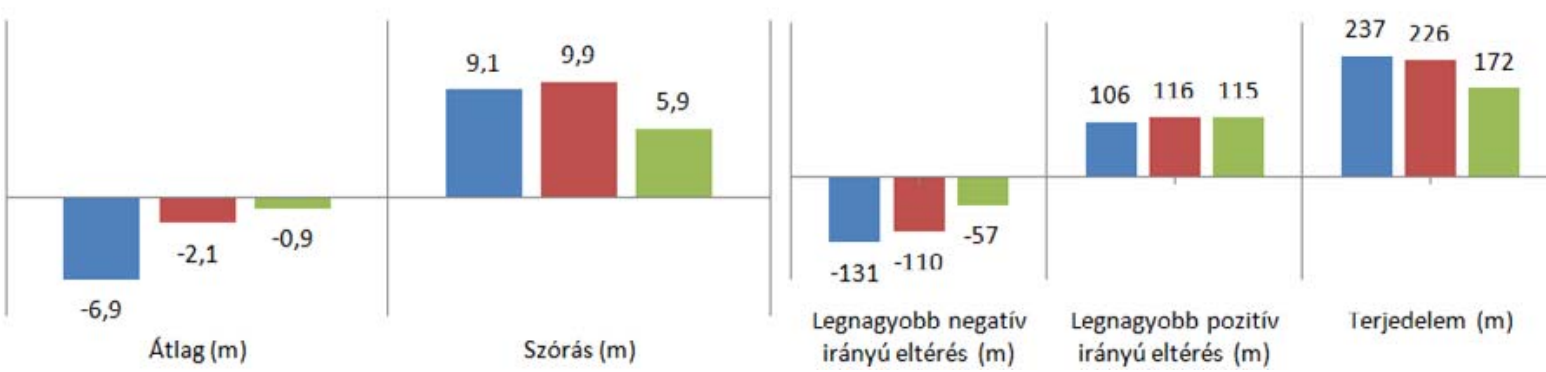

34. ábra Magassági modellek eltérése a DDM100-hoz képest Magyarország területére. Ingyenesen hozzáférhető digitális magassági modellek DDM100 (FÖMI) adatbázishoz viszonyított eltéréseinek jellemzői. (Adatok forrása: Magvarország területére szabályos rácsháló

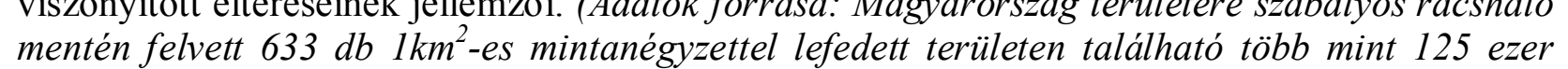
(SRTM) és 1 millió pont (Aster GDEM) összevetése alapján)

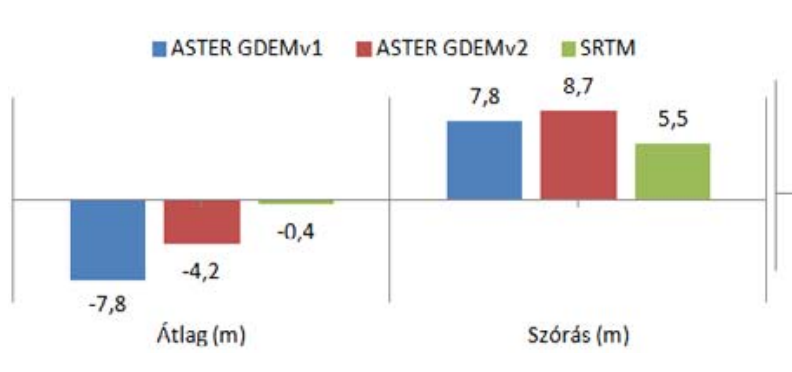

$\because$ ASTER GDEMV1 $\because A S T E R$ GDEMv2 $\amalg S R T M$

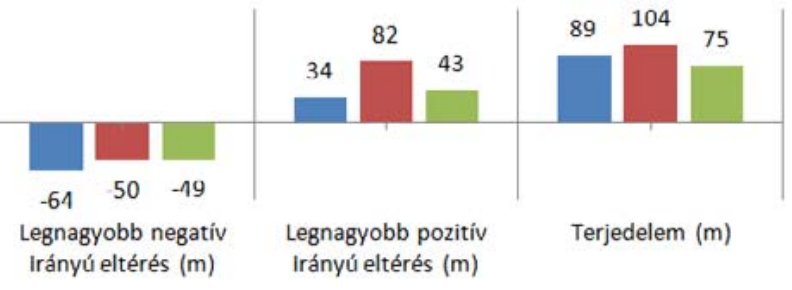

35. ábra Magassági modellek eltérése a DDM5-höz képest mintaterületeken. Ingyenesen hozzáférhető digitális magassági modellek DDM5 (FÖMI) adatbázishoz viszonyított eltéréseinek jellemzői. (Adatok forrása: Magyarország területén kijelölt három mintaterületen felvett 34db $1 \mathrm{~km}^{2}$-es mintanégyzet területén található közel 125 ezer pontban (SRTM) és 1 millió pontban (Aster GDEM) történt összevetés alapján)
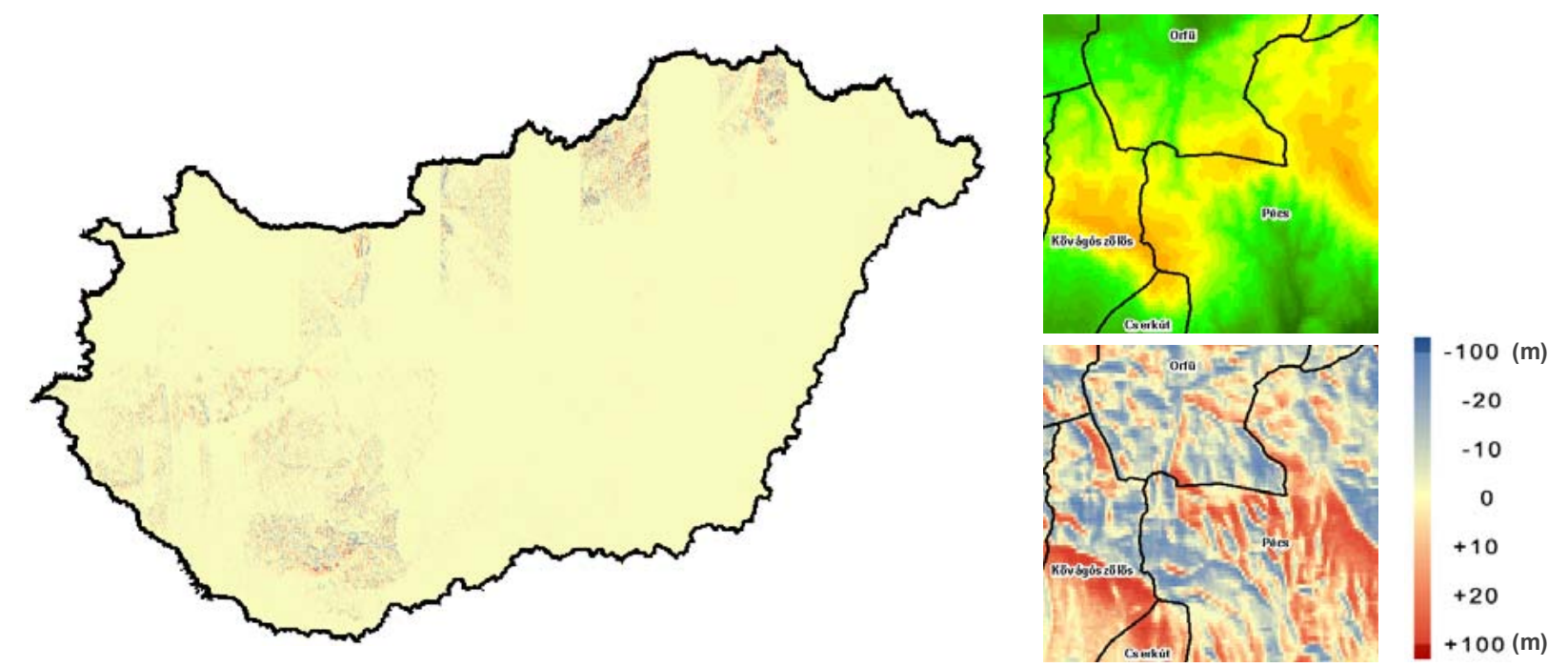

36. ábra GLS magassági modell eltérése az SRTM-hez képest. A GLS modell helyenként akár 30-40m-rel is magasabb vagy alacsonyabb az SRTM adataihoz képest. Látható, hogy az eltérés csak egy-egy sávban érvényesül de az ország több mint felén nem tapasztalható. Ebböl arra lehet következtetni, hogy a GLSDEM magyarország területén helyettesítésre került SRTM adatokkal. Az eltérések helyenként a horizontális pontatlanságból is eredeztethetők, mert az eltérést ábrázoló térképen a meredek helyeken szerepelnek magas értékek, de látható, hogy a gerincen, és a völgyfenéken nincsenek jelentős eltérések.

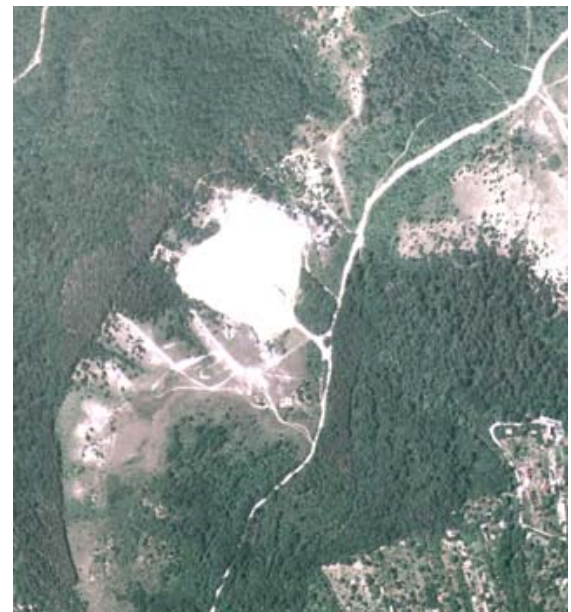

Ortofotó 2005

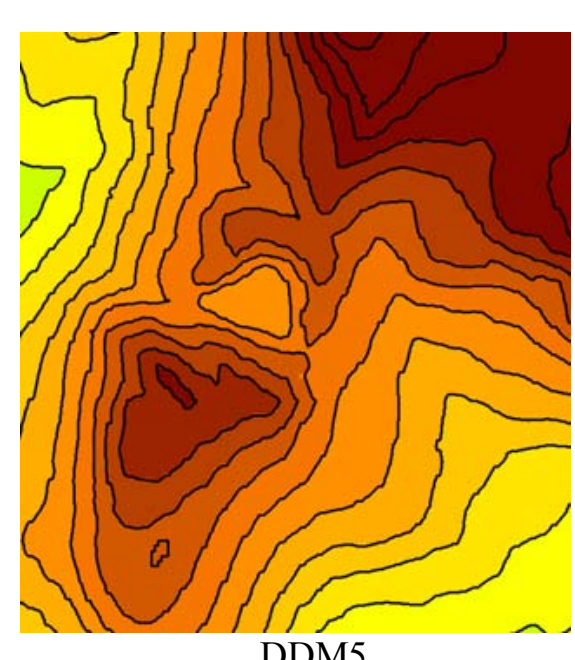

DDM5

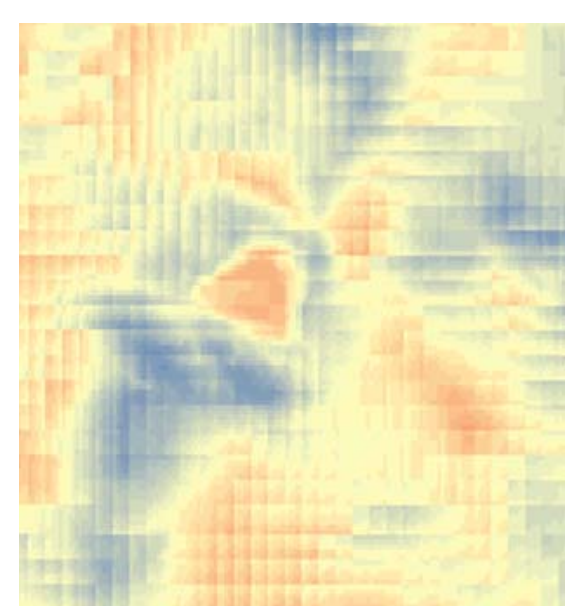

ASTER GDEMv2 (felb·20-30m)-DDM5

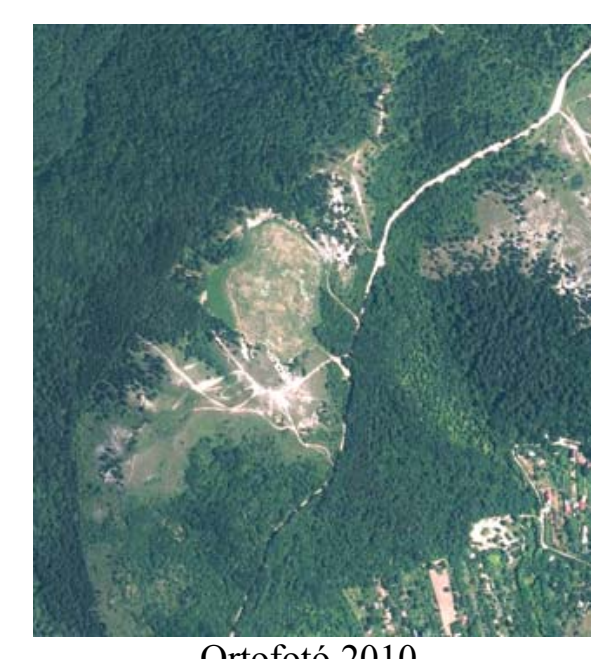

Ortofotó 2010

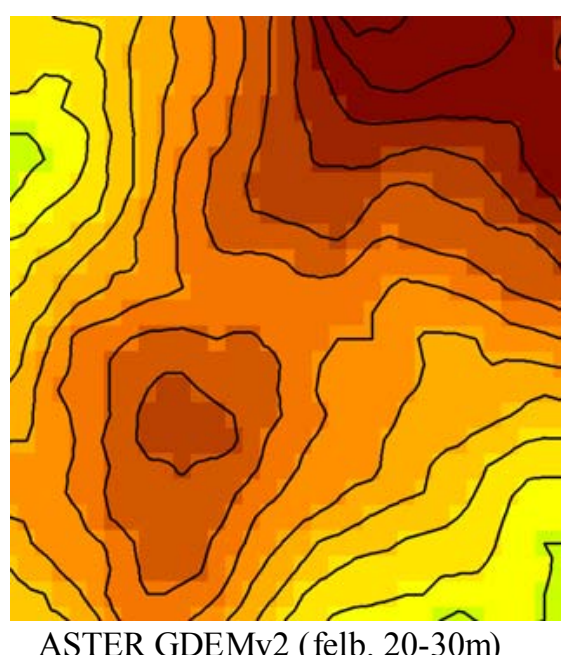

ASTER GDEMv2 (felb. 20-30m)

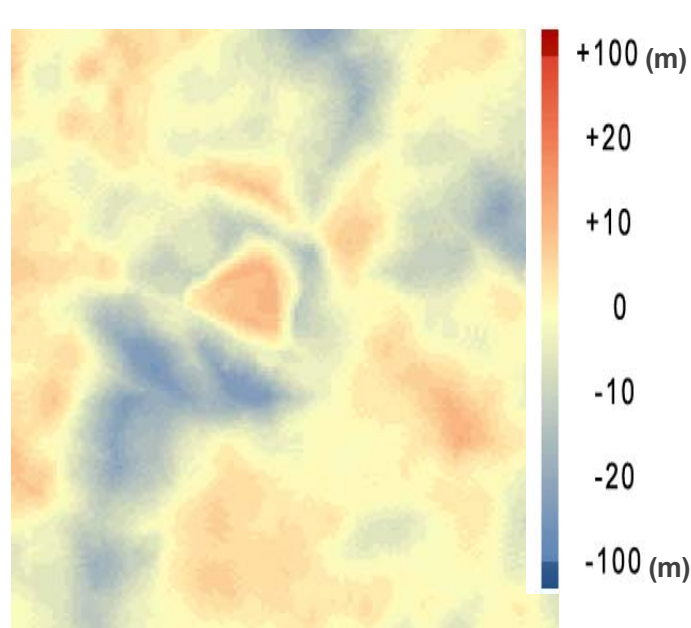

ASTER GDEMv2 (felb:5m)-DDM5
38. ábra Tényleges tengerszint-feletti magasság változás hatása a magassági modellek eltéréseire bányagödör feltöltés esetén. A 2005-ös ortofotón még látható a budaörsi murvabánya fehérlő felszíne, de 2010-ben már a feltöltött, rekultivált állapot látható ami az ASTERGDEMv2 domborzatmodell esetében már magasabb terepfelszínként jelentkezik. ASTERGDEMv2 domborzatmodell esetében már magasabb terepfelszinkent jelentkezik.
Érzékelhetö, hogy erdősebb területeken átlagosan magasabb, erdömentes területen viszont inkább alacsonyabb az ASTER GDEMv2 magassági modell mint a DDM5 domborzatmodell. 


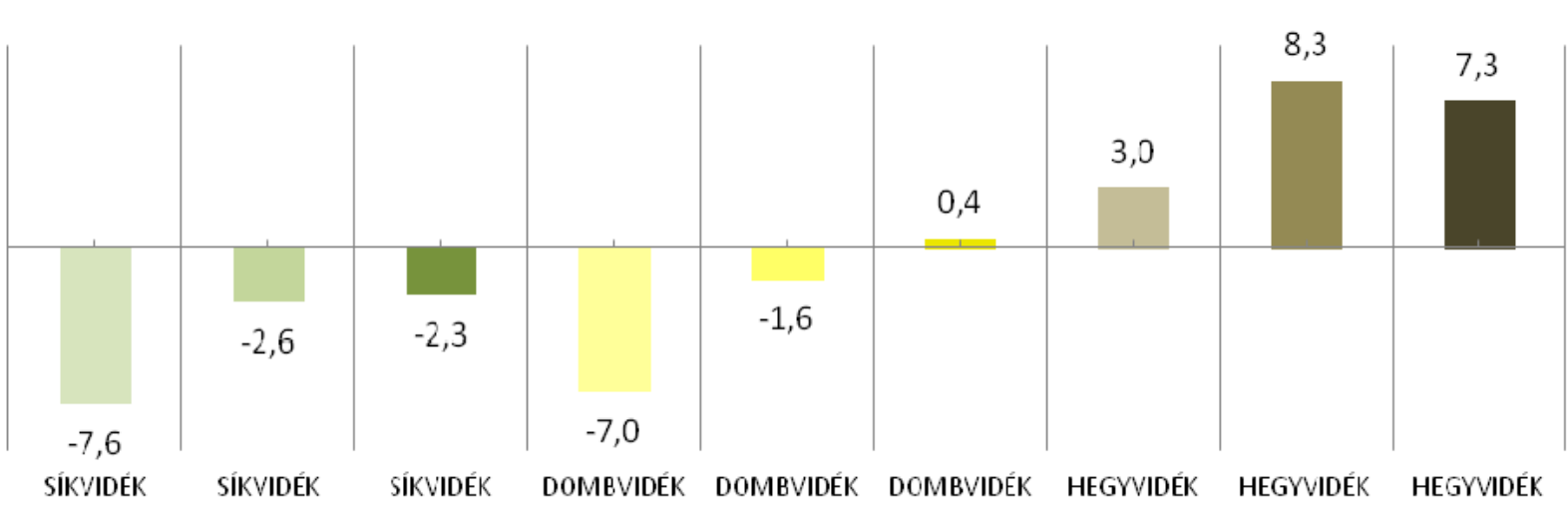

ASTERGDEMV1ASTERGDEMV2

SRTM ASTERGDEMVIASTERGDEMV2

SRTM ASTERGDEMV1ASTERGDEMv2

SRTM

39. ábra Magassági modellek a DDM100 adatbázishoz viszonyított eltéréseinek átlaga (m) Magyarországon különbözó domborzati típusok esetén. A domborzati adatok síkvidéken inkább negatív, míg hegyvidéken inkább pozitív irányban térnek el a valóságos domborzati adottságoktól

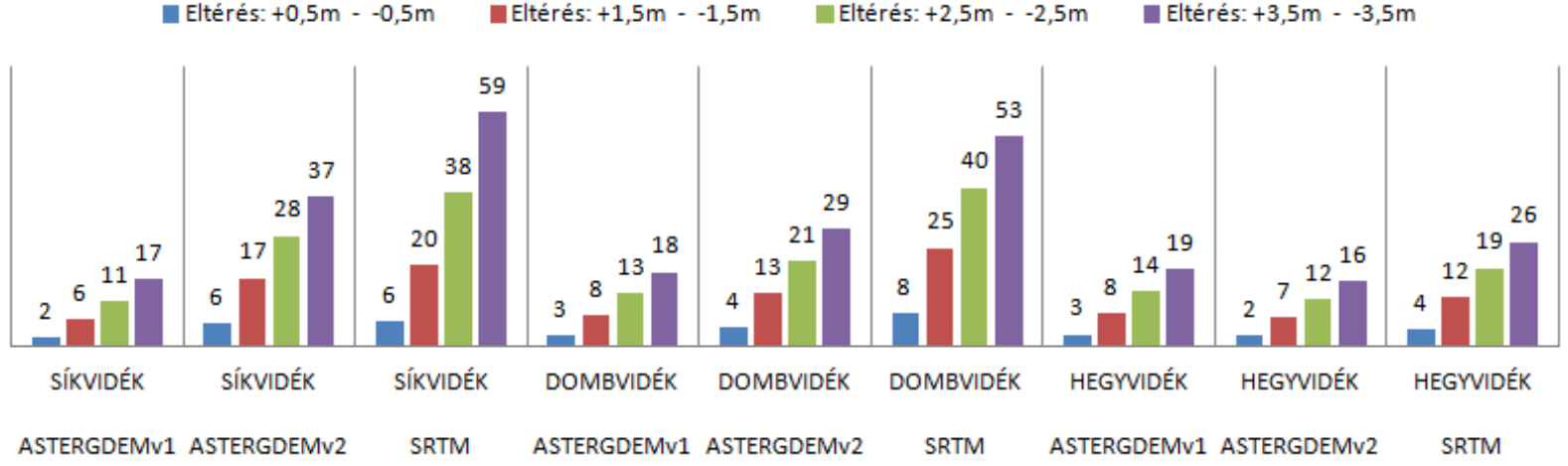

40. ábra Magassági modellek DDM100-hoz viszonyított eltéréseinek gyakorisága (\%) 40. äbra Magassági modellek DDM100-hoz viszonyitott eltéréseinek gyakorisága (\%)
különbözö kategóriák és domborzati tájtípusok esetén. (39. és 40 ábra esetében különbözö kategóriák és domborzati tájtípusok esetén. (39. és 40 ábra esetében
Magyarország területén kijelölt három domborzati meghatározottságú tájtípus területén felvett típusonként $600 \mathrm{db} 1 \mathrm{~km}^{2}$-es mintanégyzet területén található közel 100 ezer pontban (SRTM) és 800 ezer pontban (Aster GDEM) történt összevetés alapján)

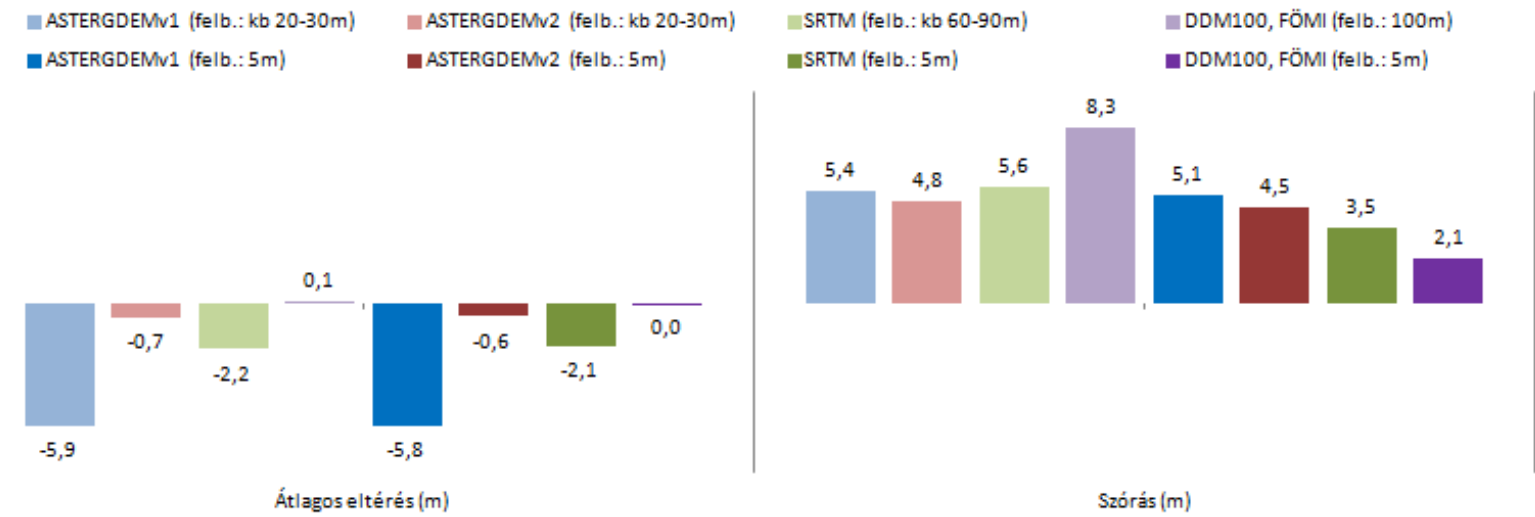

44. ábra Magassági modellek DDM5-höz viszonyított eltéréseinek átlaga és szórása eredeti felbontású $(\mathbf{2 0 - 3 0 m})$ és $5 \mathrm{~m}$-es felbontásra transzfor mált változat esetén. Budaörsikopárok mintaterületen összesen $16 \mathrm{~km}^{2}$ vizsgálatának eredményeként. Az újramintavételezés 5m-es felbontásra ,, bilinear spline” módszerrel történt ERDAS Imagine szoftverrel.

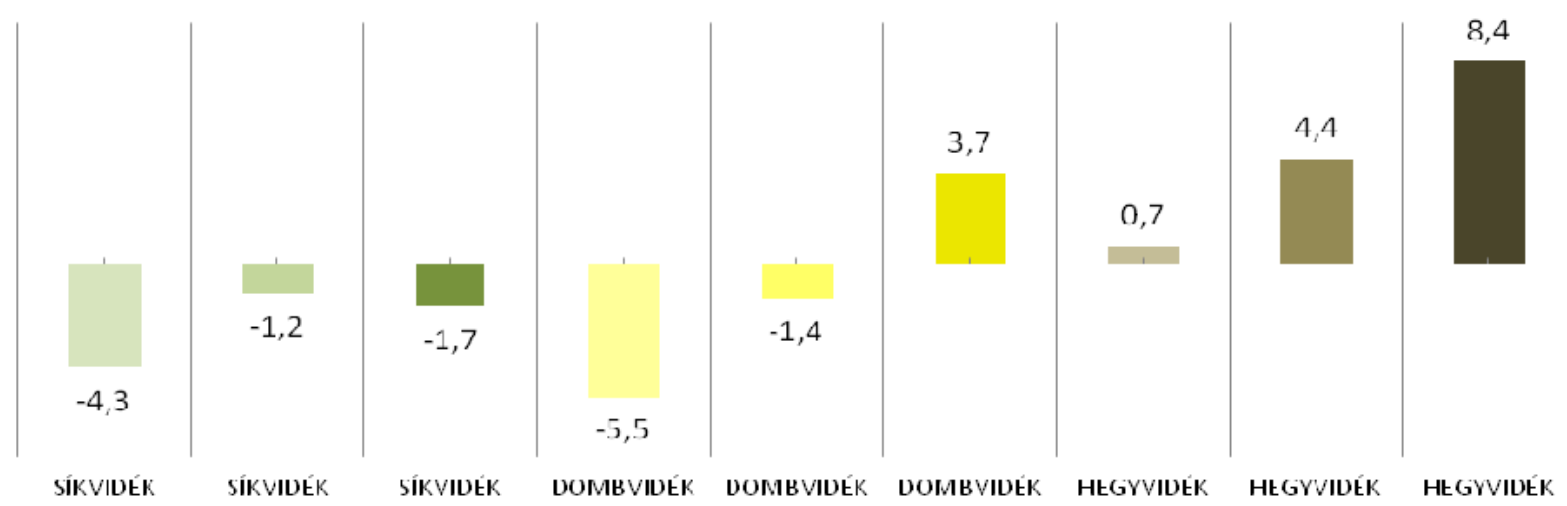

ASIERGDEMVIASIERGDEMV2 SHIM ASIERGDEMVIASIERGDEMV2 SRIM ASILRGDEMVINSIERGDEMV2 SRIM

41. ábra Magassági modellek a DDM5 adatbázishoz viszonyított eltéréseinek átlaga (m) magyarországi mintaterületeken különböző domborzati típusok esetén.

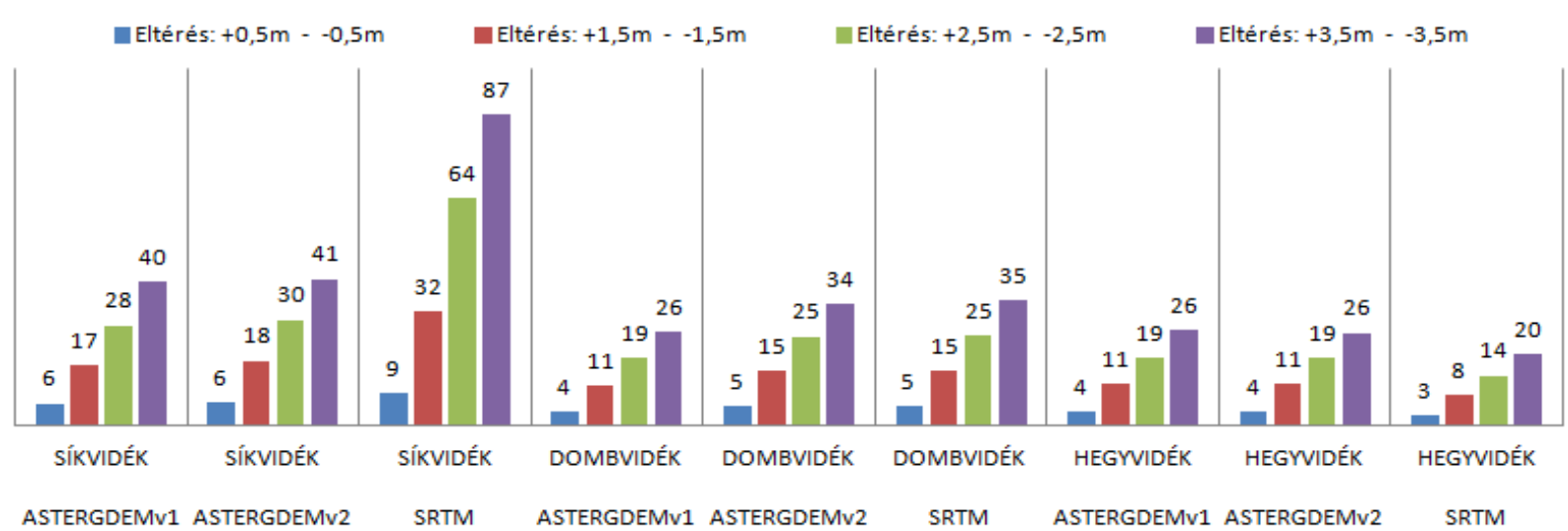

42. ábra Magassági modellek DDM5-hoz viszonyított eltéréseinek gyakorisága (\%) különböző kategóriák és domborzati tájtípusok esetén. (41 és 42 ábra esetében Magyarország területén kijelölt három domborzati meghatározottságú tájtípuson mintaterületeken tipusonként felvett $25 \mathrm{db} 1 \mathrm{~km}^{2}$-es mintanégyzet területén található közel 125 ezer pontban (SRTM) 1 millió pontban (Aster GDEM) történt összevetés alapján)

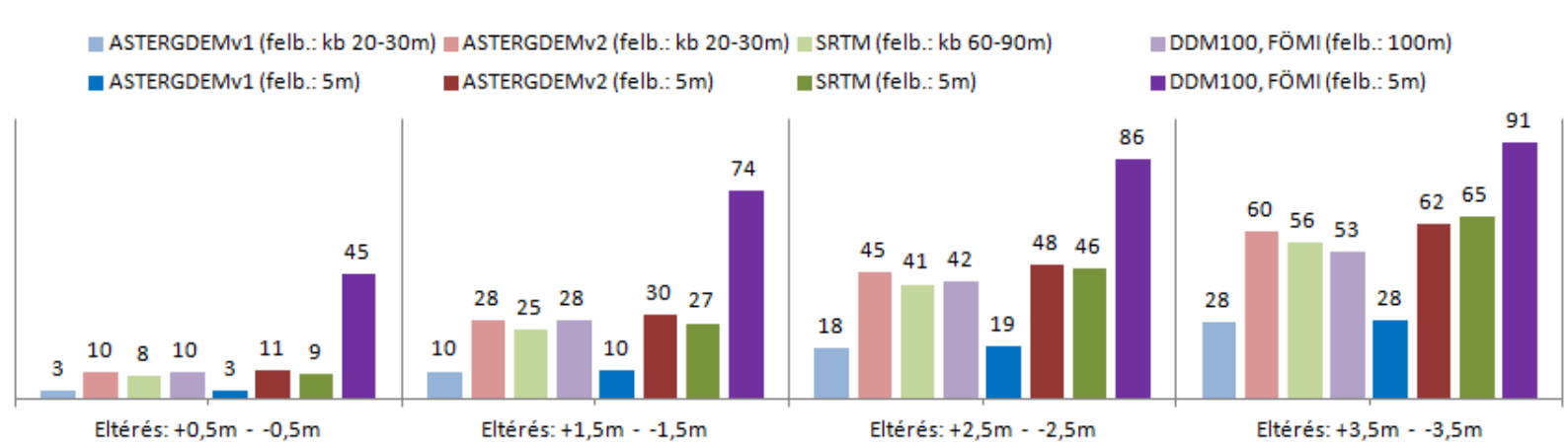

45. ábra Magassági modellek DDM5-hoz viszonyított eltéréseinek gyakorisága (\%-ban) eredeti felbontású adatok $(20-30 \mathrm{~m})$ és $5 \mathrm{~m}$-es felbontásúra transzformált adatok esetén (\%) Az 5m-es felbontásra alakítás jelentősen egyik képalkotó távérzékeléssel készített domborzatmodell esetében sem segít érdemben. Budaörsi-kopárok mintaterületen összesen 16 $\mathrm{km}^{2}$ vizsgálatának eredményeként. Az újramintavételezés $5 \mathrm{~m}$-es felbontásra „, bilinear spline” módszerrel történt ERDAS Imagine szoftverrel. 
\#STERGDEMv2, Legmagassabb és a legalacsonyabb magassági adat közötti eltérés (m)

— SRTM, Legmagassabb és a legalacsonyabb magassági adat közötti eltérés (m)

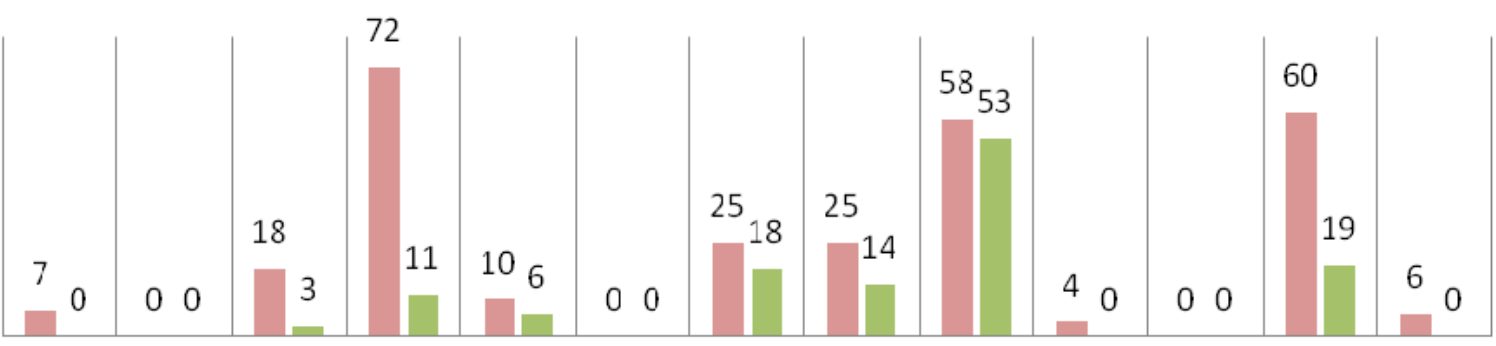

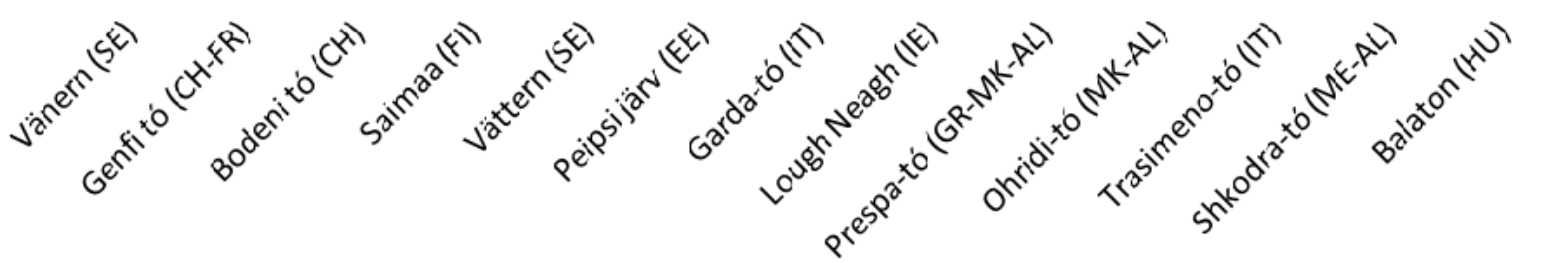

46. ábra Magassági modelleken mért tengerszint feletti magasság értékek terjedelme európai nagytavak esetén. A domborzati adatok a partoktól 1 km-nél távolabbi vízfelszínekre az esetek többségében meglehetősen nagy szélsőérték-különbségekkel rendelkeznek, ami alátámasztja, hogy tájkarakter-elemzésben történő hasznosításhoz a passzív és az aktív távérzékelésből származó domborzati adatok korrekciójára feltétlenül szükség van. (Az adatok Európa 13 nagy taván legalább 1 km-re a parttól CLC100 2006-os adatbázis alapján kiválasztott összesen $4255 \mathrm{~km}^{2}$ nyílt vízelszín vizsgálata eredményeként kerültek felhasználásra)

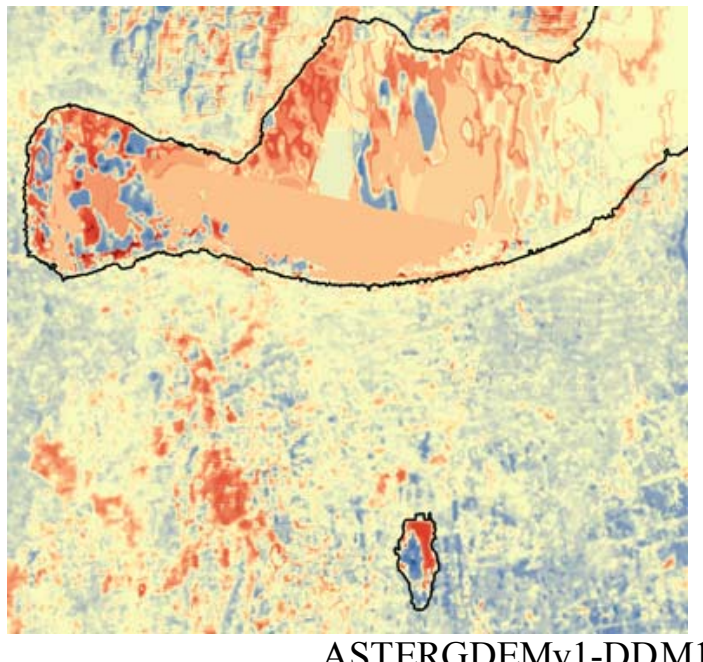

ASTERGDEMv1-DDM100

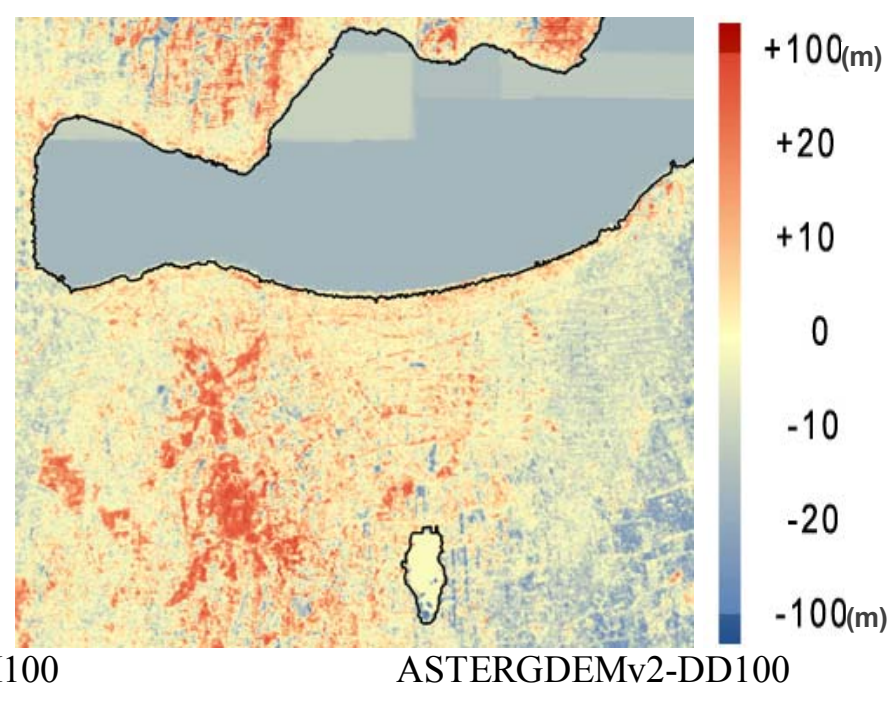

ASTERGDEMv2-DD100

47. ábra A DDM10-hoz viszonyított domborzatmagasság-különbségek ASTER GDEM változatoknál Balaton nyugati részén és a Marcali víztározó területén. (Felhasznált alapadatok: FÖMI, METI és NASA) 


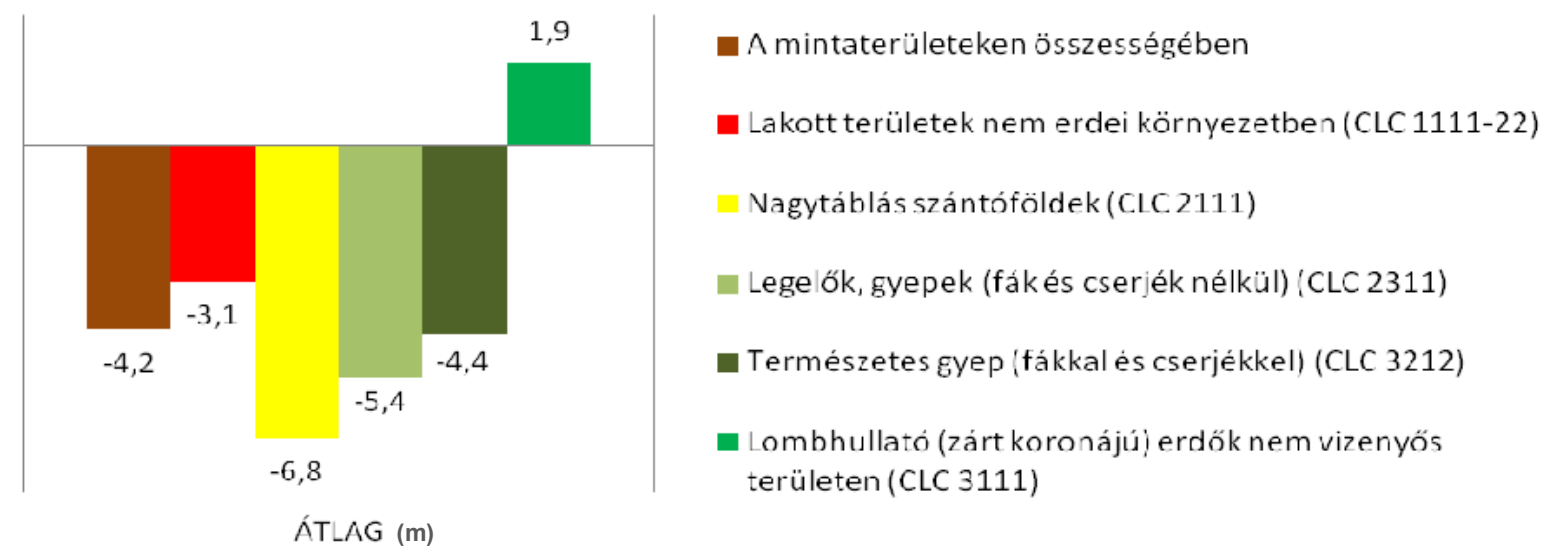

48. ábra Az ASTER GDEMv2 modell felszínborítás típusonkénti eltérései DDM5 modellhez képest. (Három magyarországi mintaterületen CLC50-es adatbázis alapján lehatárolt összesen $34 \mathrm{~km}^{2}$ vizsgálatának eredményeként.)

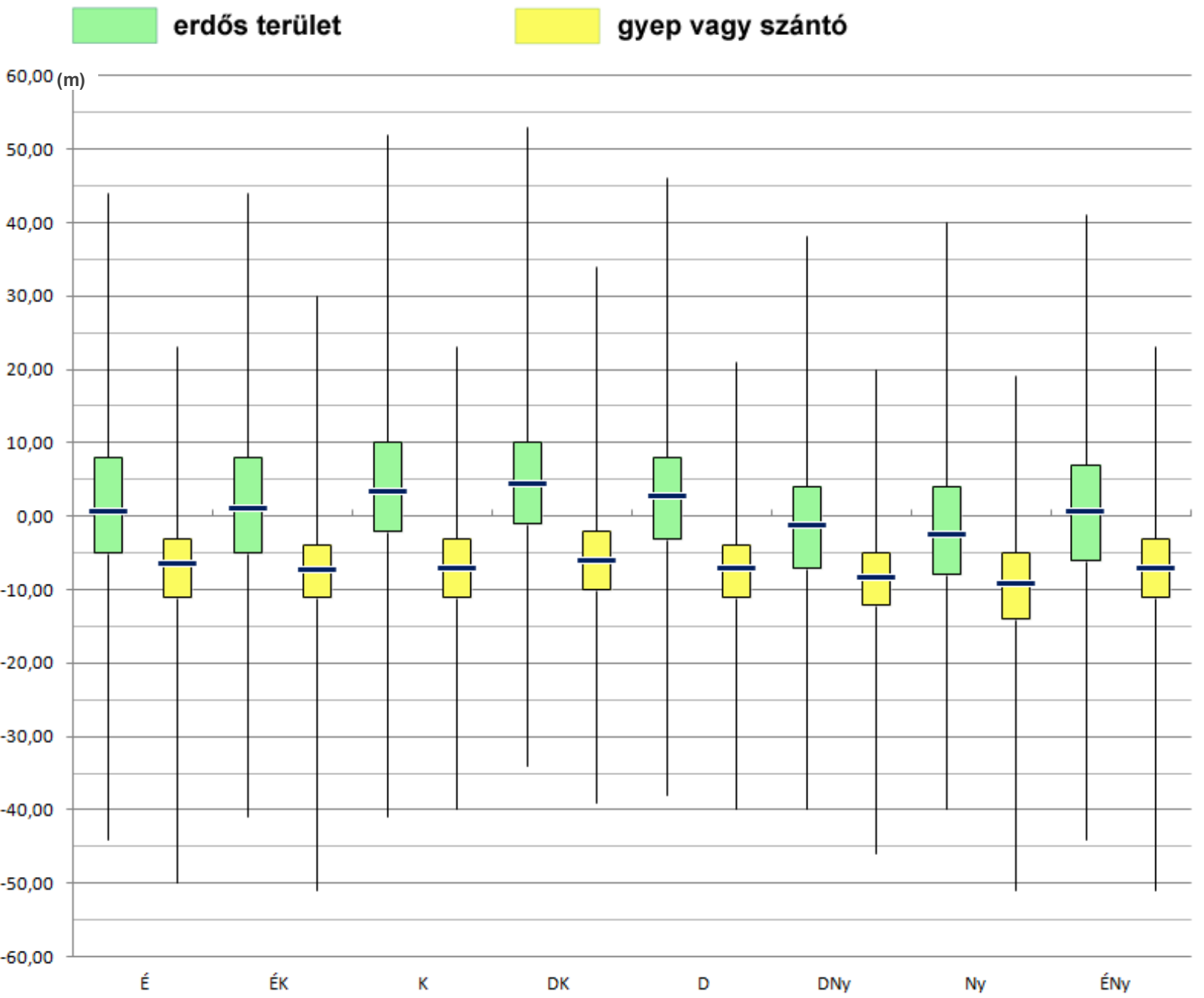

49. ábra Az ASTER GDEMv2 magassági modell eltérései a DDM5-höz képest lejtőkitettség kategóriánként gerecsei mintaterületen. Az ábrán kitettség kategóriánkénti átlag értékek mellett feltüntettem az eltérés terjedelmét és az interkvartilis értékeket is. 


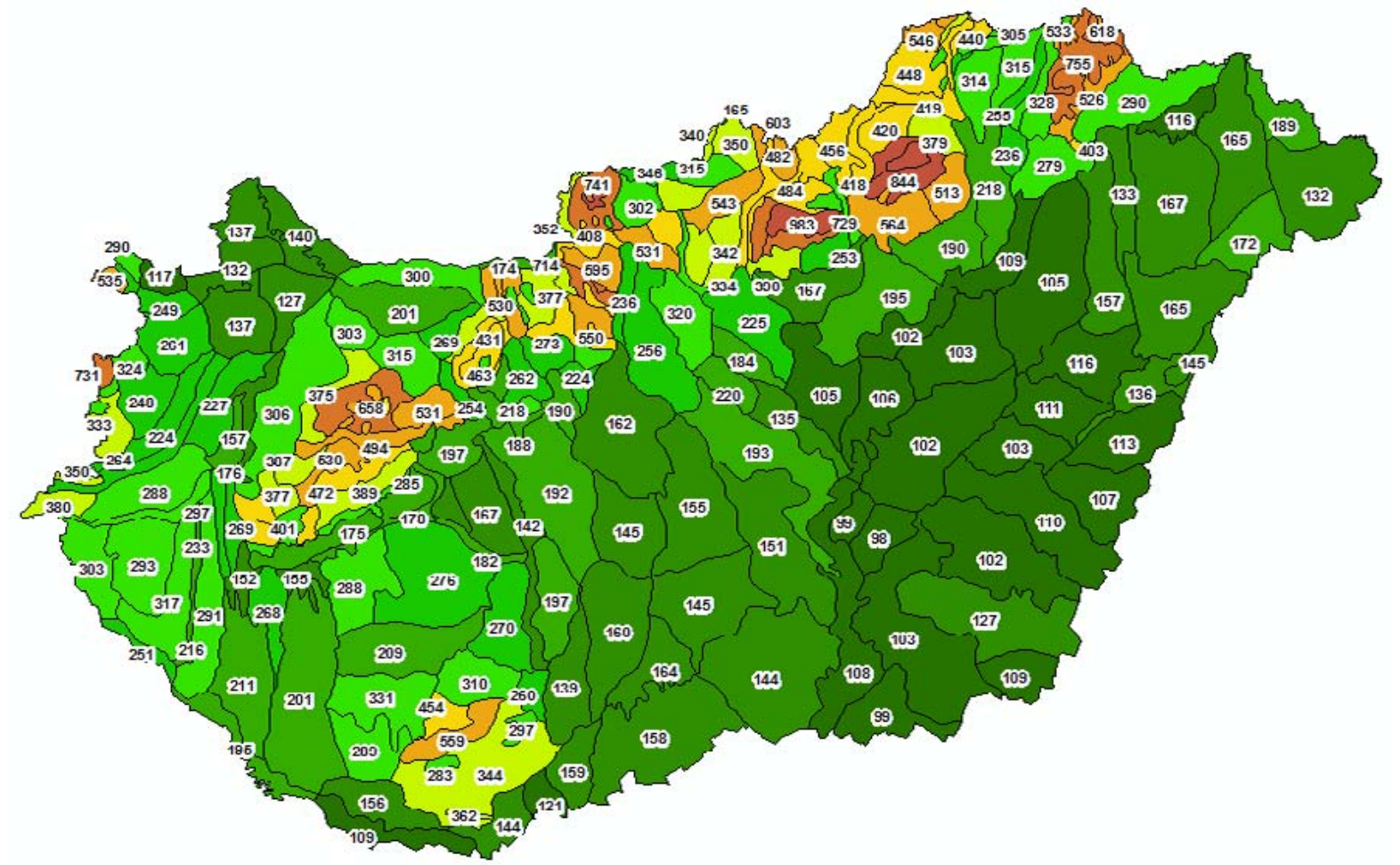

50. ábra Tengerszint feletti magasság maximuma (m) kistájanként (ASTER GDEMv2 modell $1000 \mathrm{~m}$-es felbontású változatával)

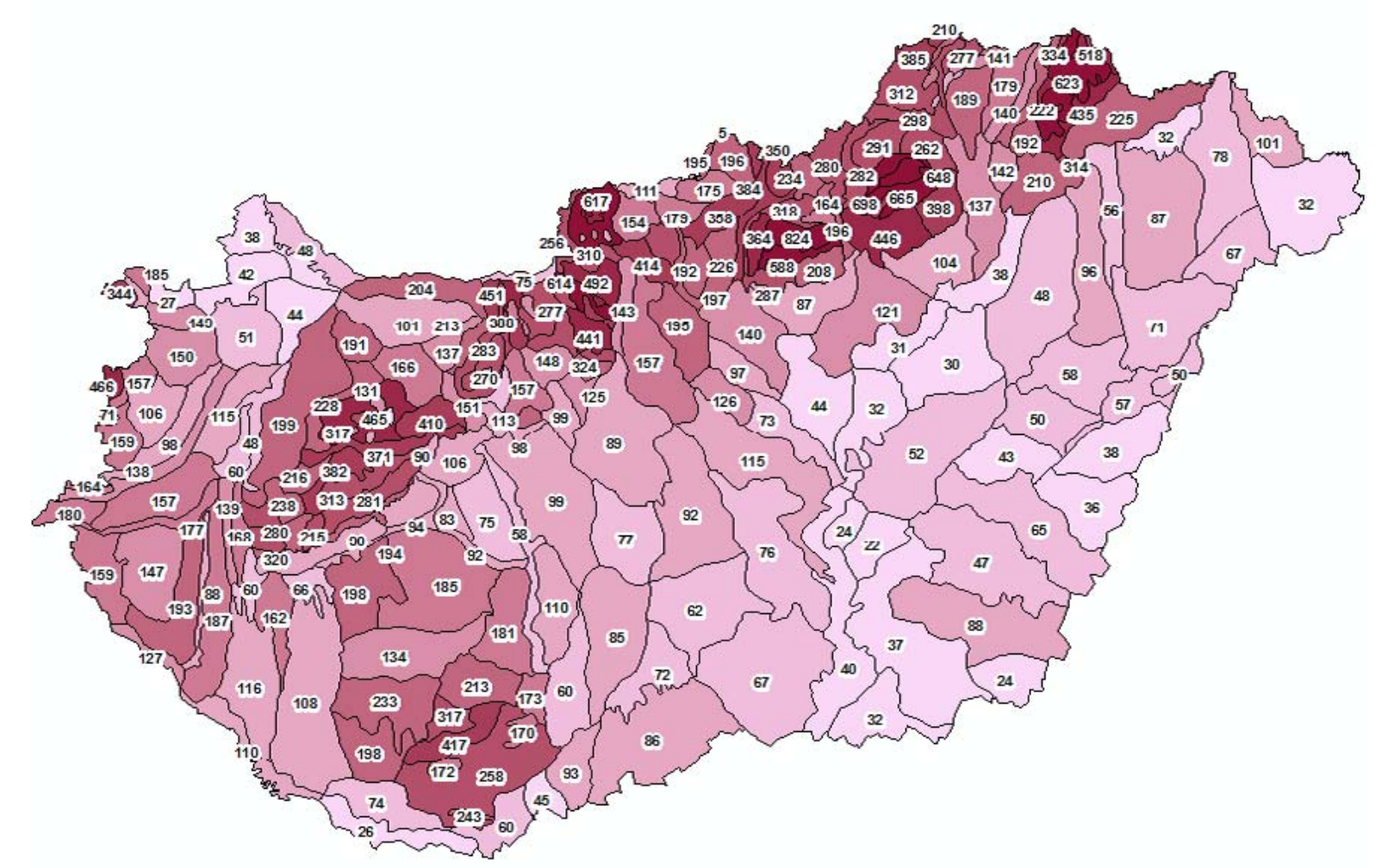

51. ábra Felsźnmozgalmasság a kistájak területén belül (m/kistáj) (ASTER GDEMv2 model 1000m-es felbontású változatával)

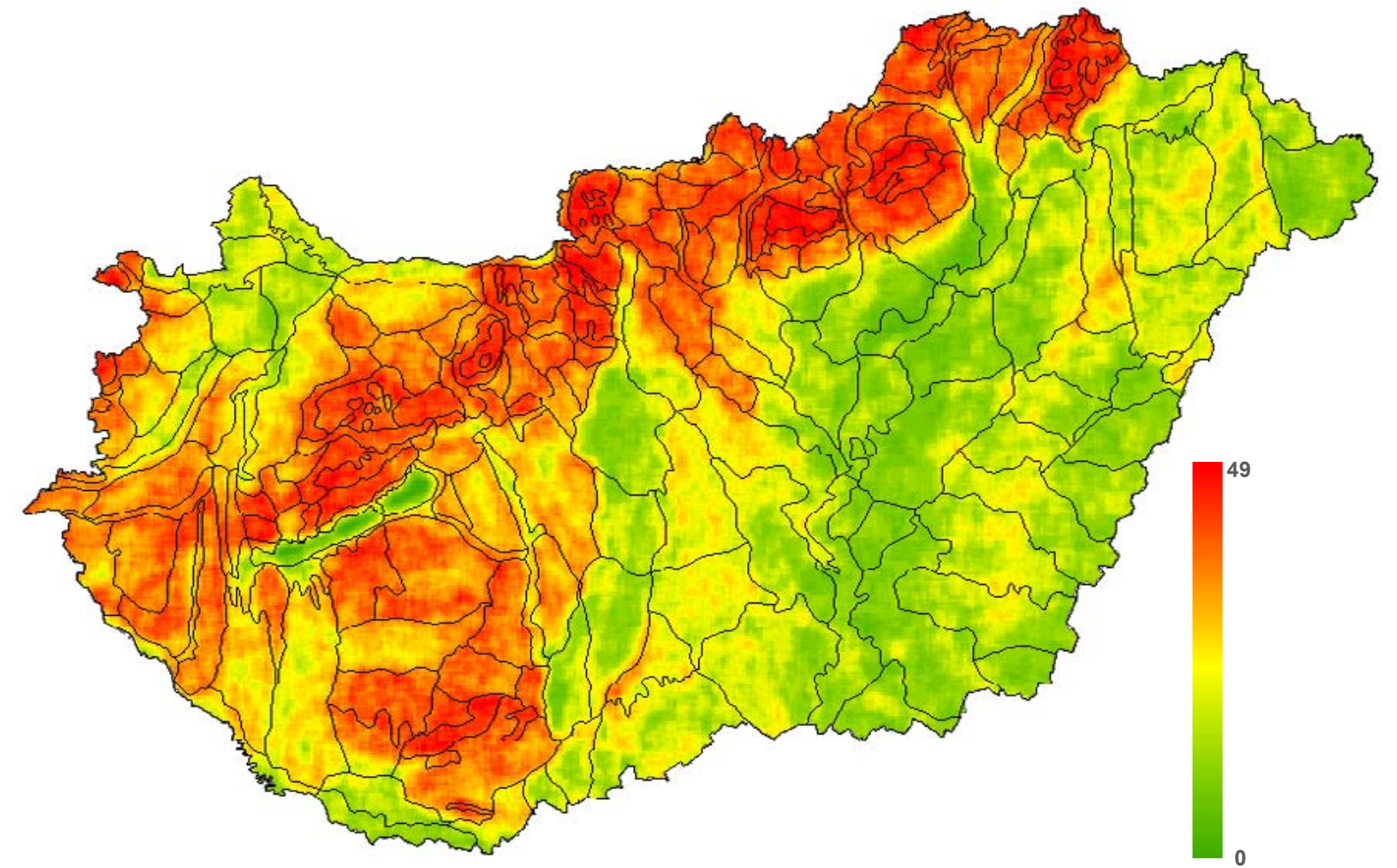

52. ábra Terep-változatosság (eltérő magasságú szomszédok száma alapján 1-től 49-ig tartó skálán) (ASTER GDEMv2 modell 1000m-es felbontású változatával)

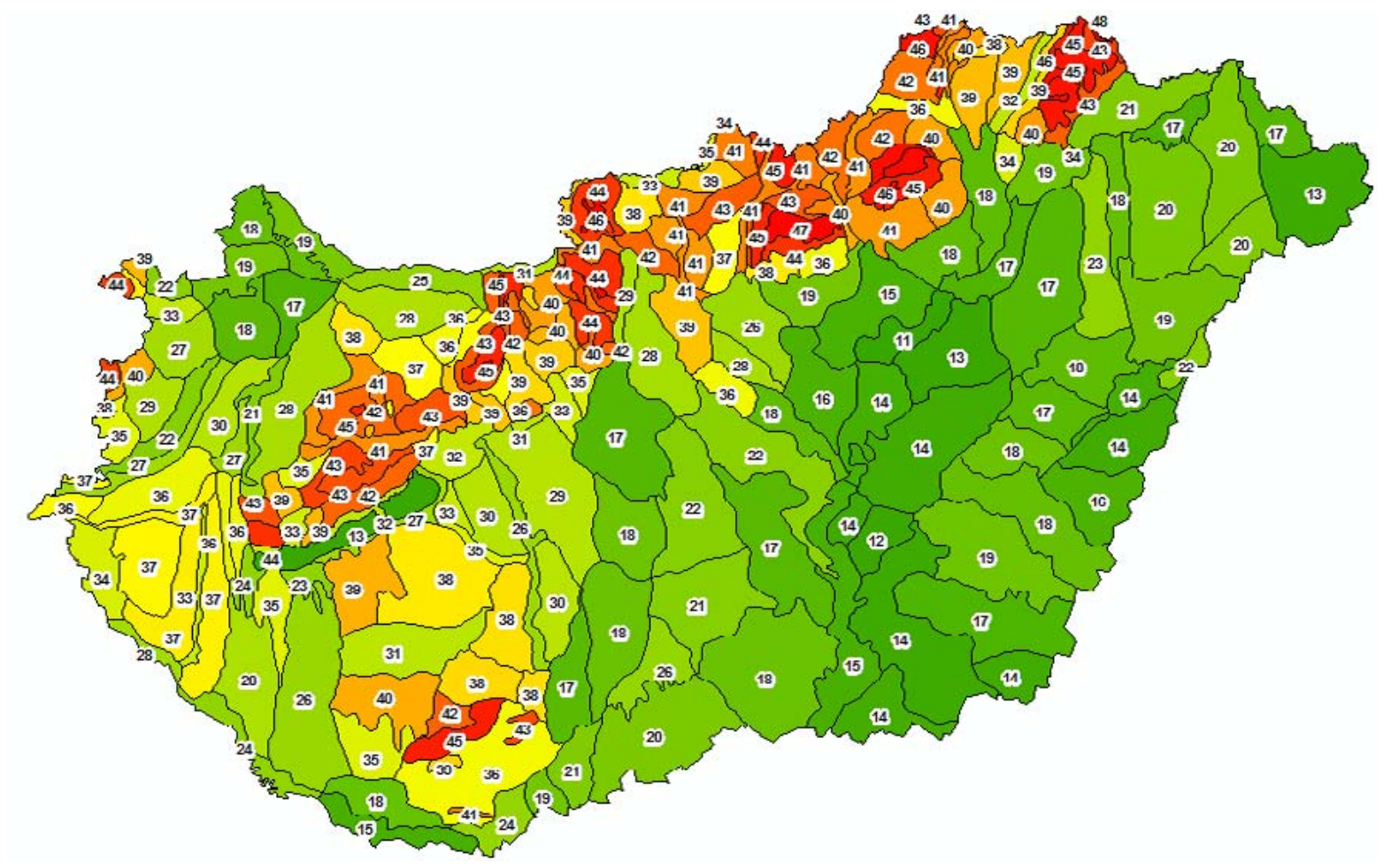

53. ábra A terep átlagos változatossága a kistájak területén (1-től 49-ig tartó skálán) (ASTER GDEMv2 modell 1000m-es felbontású változatával) 


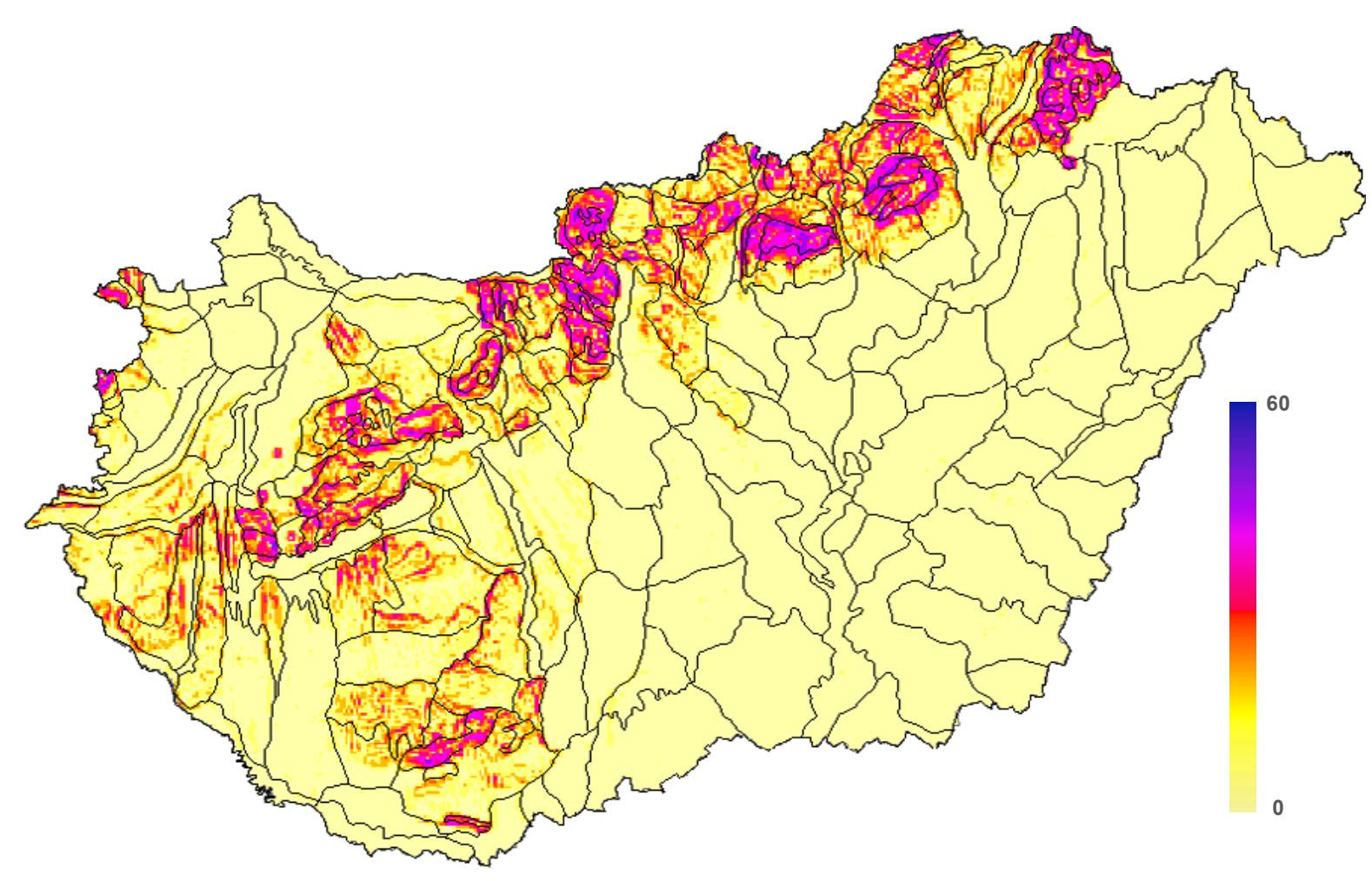

54. ábra Lejtőmeredekség (\%) (ASTER GDEMv2 modell 1000m-es felbontású változatával)

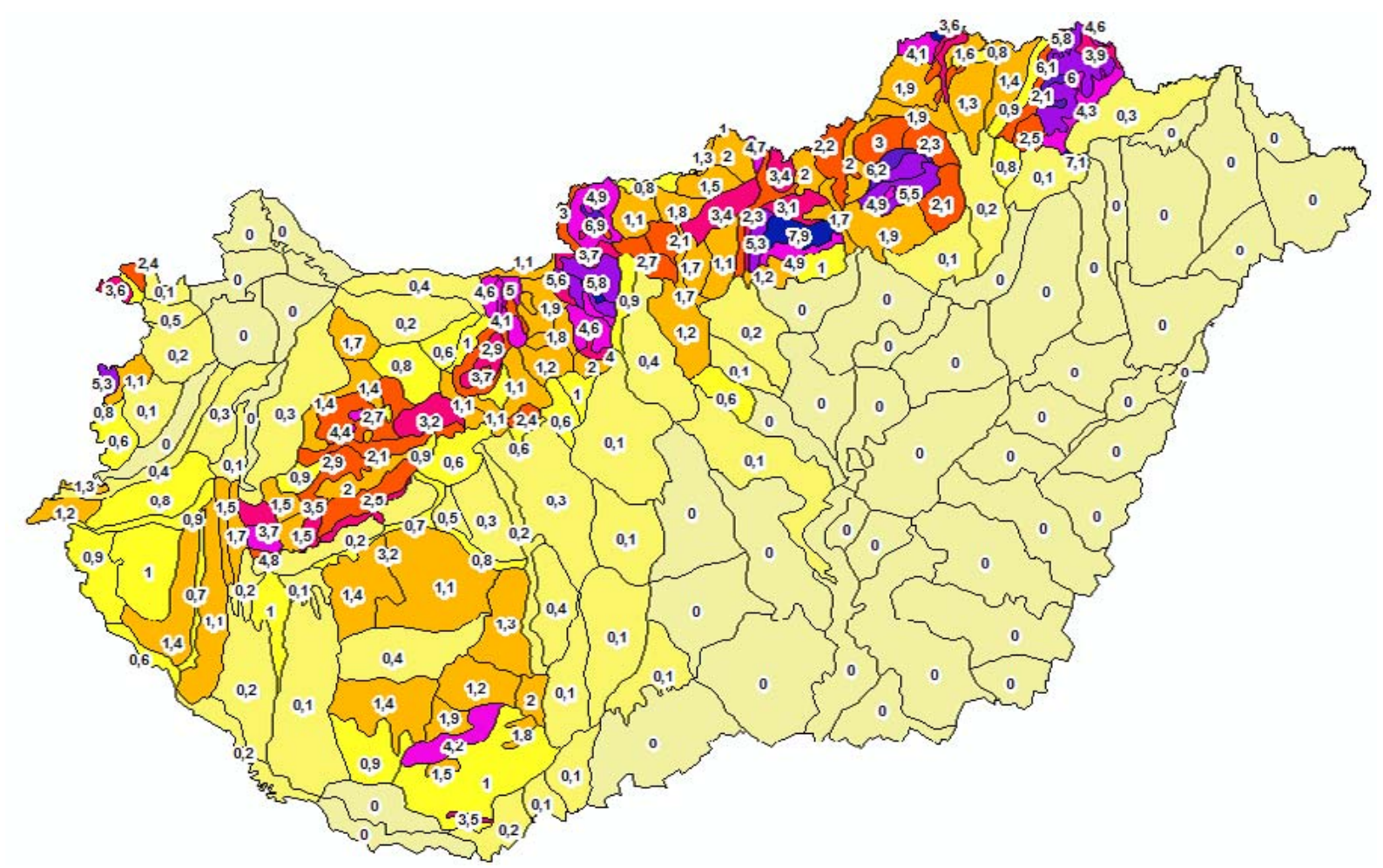

55. ábra Lejtőmeredekség átlaga a kistájak területén (\%) (ASTER GDEMv2 modell 1000m-es felbontású változatával)
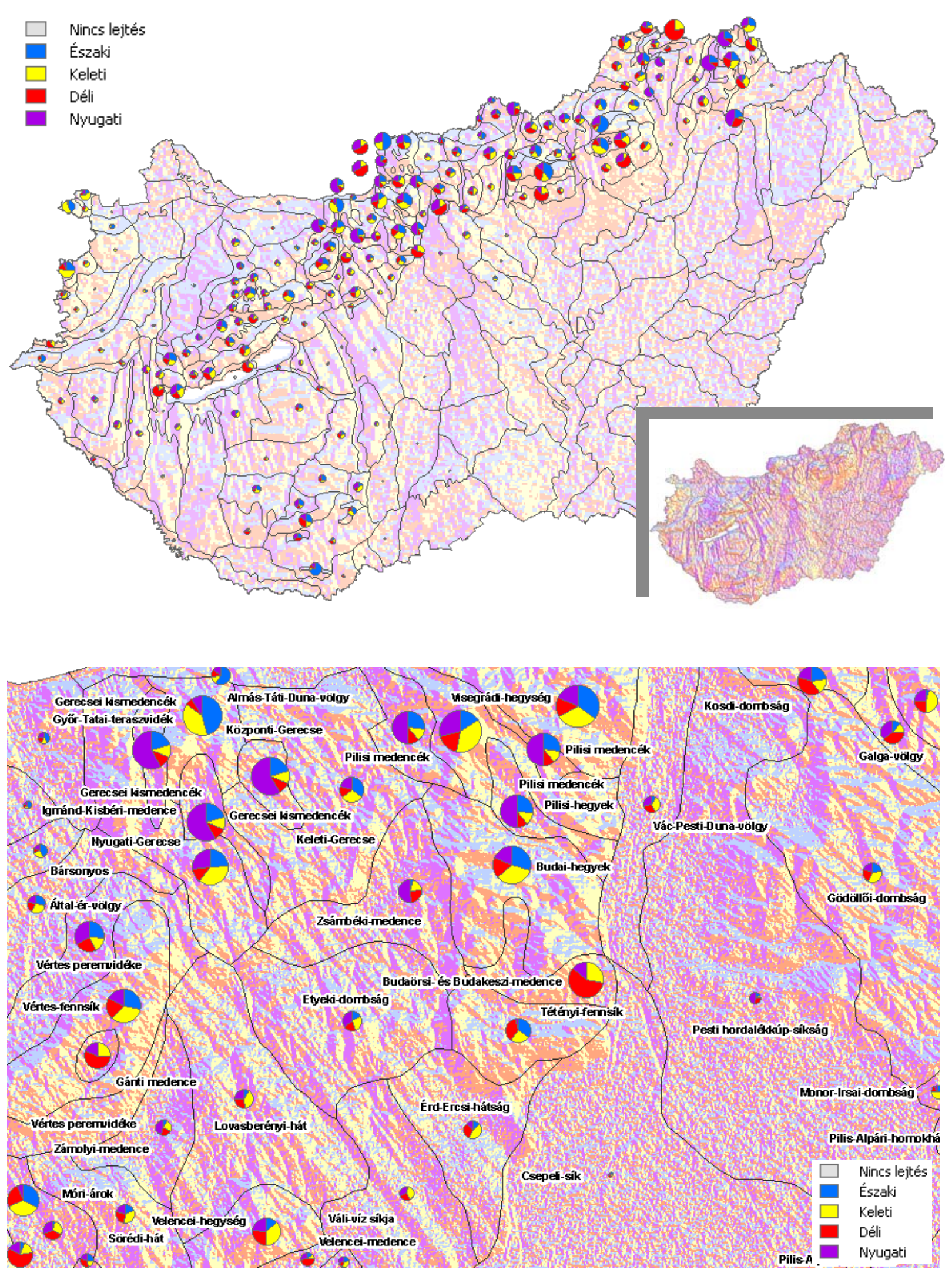

56. ábra Kitettség karakteradó szerepe (ASTER GDEMv2 modell 1000m-es felbontású változatával) A lejtőkitettség Magyarországon (középen) a karakter-meghatározó szerepük kistájak területén és a Délnyugat-Budakörnyék kistájain. A kördiagram mérete a kitettség tájkarakterben betöltött szerepétől függ, nagyobb átlagos lejtőmeredekség esetén nagyobb a diagram is. 
25.a. táblázat Passźv távérzékelési adatok feldolgozásához használható indexek és térbeli mutatók

\begin{tabular}{|c|c|c|c|c|c|}
\hline \multicolumn{6}{|c|}{ Felvételek spektrális sajátosságaira építő automatikus indexek } \\
\hline Index rövid neve & Index teljes neve (angol v. magyar) & Az index jelzi: & Képlet (pl.: műhold, szenzor) & Intervallum & $\begin{array}{c}\text { Az indexet felhaszzáló } \\
\text { vagy hivatkozó irodalmak }\end{array}$ \\
\hline NDVI & Normalized Difference Vegetation Index & vegetáció jelenlétét és egészségi állapotát & $(4-3) /(4+3)($ LandsatTM, ETM +$)$ & $(-1)-(+1)$ & $\begin{array}{l}\text { LILLESAND et al. 2004, } \\
545\end{array}$ \\
\hline NDWI $(2,4)$ (McFeeters 1996) & Normalized Difference Water Index & Vízfelszín jelenlétét & $(2-4) /(2+4)($ LandsatTM, ETM +$)$ & $(-1)-(+1)$ & XU 2006, 3026 \\
\hline NDWI $(4,5)$ (Gao 1996) & Normalized Difference Water Index & Növényzet víztartalmát & $(4-5) /(4+5)($ LandsatTM, ETM+) & $(-1)-(+1)$ & CHEN et al. 2006, 136 \\
\hline MNDWI $(2,5)$ & Modified Normalized Difference Water Index & Vízfelszín jelenlétét & $(2-5) /(2+5)($ LandsatTM, ETM +$)$ & $(-1)-(+1)$ & XU 2007, 1384 \\
\hline NDBI & Normalized Difference Built-up Index & „Beépített terület” jelenlétét, a beépítettség mértékét & $(5-4) /(5+5)($ LandsatTM, ETM+) & $(-127)-(+0,5)$ & CHEN et al. 2006, 134 \\
\hline NDBaI & Normalized Difference Bareness Index & Kopár terület jelenlétét, a kopárságának mértékét & $(5-6) /(5+6)($ LandsatTM, ETM+) & $(-1)-(+1)$ & CHEN et al. 2006, 137 \\
\hline EVI & Enhanced Vegetation index & $\begin{array}{l}\text { vegetáció jelenlétét és egészzségi állapotát nagy hangsúllyal a } \\
\text { biomasszára és a légköri hatások minimalizálására }\end{array}$ & $\begin{array}{c}2,5 *(\mathrm{NIR}-\mathrm{RED}) /\left(\mathrm{NIR}+\mathrm{C}_{1} * \mathrm{RED}-\right. \\
\left.\mathrm{C}_{2} * \mathrm{BLUE}+\mathrm{L}\right)(\text { MODIS esetén: } \mathrm{L}=1, \\
\left.\mathrm{C}_{1}=6 \text {, and } \mathrm{C}_{2}=7.5 .\right)\end{array}$ & $0-1$ & MATSUSHITA 2007 \\
\hline LST & Land Surface Temperature indexek & Földfelszín hőmérsékletét & $\begin{array}{l}\text { LST software tool és LANDSAT TM, } \\
\text { ETM+ }+ \text {. sáv felhasználásával }\end{array}$ & $\begin{array}{c}\text { hömérséklet } \\
\text { értékek }\end{array}$ & $\begin{array}{l}\text { ZHANG, WANG és LI } \\
2006\end{array}$ \\
\hline Az indexek sora folytatható & & & & & \\
\hline
\end{tabular}

A fenti indexekre építő tájkarakter-elemzés érdekében bevezetésre javasolt mutatók:

\begin{tabular}{|c|c|c|c|c|c|}
\hline Mutató rövid neve & Mutató teljes neve (angol v. magyar) & A mutató jelzi & Képlet & Intervallum & $\begin{array}{c}\text { Az indexet felhasználó } \\
\text { vagy hivatkozó irodalmak } \\
\text { (szerzö, évszám) }\end{array}$ \\
\hline GSI (ZFI) & Green Space Intensity & Zöldfelület-intenzitását & $\begin{array}{c}\mathrm{ZFI}= \\
0, \text { ha } 200 * \mathrm{NDVI}<0 \\
200 * \mathrm{NDVI} \text { egyébként } \\
100, \text { ha } 200 * \mathrm{NDVI}>100\end{array}$ & $0-100$ & $\begin{array}{l}\text { JOMBACH 2012, 219-232. } \\
\text { Képzésének módját } \\
\text { meghatárotam, teszzteltem és } \\
\text { publikáltam }\end{array}$ \\
\hline WSI (VFI) & Water Surface Intensity & Vízfelszin-intenzitását & $\begin{array}{c}\text { Javasolt képlet: VFI }= \\
0, \text { ha MNDWI*100<0 } \\
50 \text {, ha } 0<\text { MNDWI }^{*} 100<=10 \\
100 \text {, ha MNDWI* } 100>10\end{array}$ & $0-100$ & $\begin{array}{l}\text { Bevezetését további sikeres } \\
\text { tesztek után lehetségesnek } \\
\text { tartom }\end{array}$ \\
\hline BSI (BEPI) & Built-up Intensity & Beépített terület-intenzitását & Nincs kidolgozott képlet & $0-100$ & Kidolgozását javaslom \\
\hline BaSI (CSUFI) & Bareland Intensity & Csupasz felszín intenzitását & Nincs kidolgozott képlet & $0-100$ & Kidolgozását javaslom \\
\hline MAX NDVI & Maximal Normalized Difference Vegetation Index & Az elért legmagasabb zöldfelület intenzitását & Idősoron elért legnagyobb NDVI érték & $((-1)-(+1))$ & Kidolgozását javaslom \\
\hline MAX NDWI & Maximal Normalized Difference Water Index & A legnagyobb vízzel borított területet & Idősoron elért legnagyobb NDWI érték & $((-1)-(+1))$ & Kidolgozását javaslom \\
\hline GSI-ED (ZFI-SzS) & Edge Density based on Green Space Intensity & Zöldfelület-intenzitásra épülő szegélysürüségét & Green edge length / Area & $0-\ldots$ & Kidolgozását javaslom \\
\hline
\end{tabular}


Felszínborítások arányát jelző mutatók

\begin{tabular}{l}
\begin{tabular}{|l|c|}
\multicolumn{1}{|c|}{ Rövid neve } & Teljes neve (angol v. magyar) \\
\hline CLCRI-WAT & Corine Land Cover Ratio Index Water \\
\hline CLCRI-FOR & Corine Land Cover Ration Index Forest \\
\hline CLCRI-BLF & Corine Land Cover Ratio Index Broadleaf forest \\
\hline CLCRI-CNF & Corine Land Cover Ratio Index Coniferous forest \\
\hline CLCRI-MXF & Corine Land Cover Ratio Index Mixed forest \\
\hline CLCRI-AGR & Corine Land Cover Ratio Index Agriculture \\
\hline CLCRI-ARL & Corine Land Cover Ratio Index Arable land \\
\hline CLCRI-PNG & Corine Land Cover Ratio Index Pasture and Natural Grassland \\
\hline CLCRI-VIN & Corine Land Cover Ratio Index Vineyard \\
\hline CLCRI-ORC & Corine Land Cover Ratio Index Orchard \\
\hline CLCRI-CPX & Corine Land Cover Ratio Index Complex cultivation \\
\hline CLCRI-WET & Corine Land Cover Ratio Index Wetland \\
\hline CLCRI-SLE & Corine Land Cover Ratio Index Sport and Liesure \\
\hline CLCRI-URB & Corine Land Cover Ratio Index Urban \\
\hline CLCRI-TWS & Corine Land Cover Ratio Index Transitional woodland-shrubland \\
\hline CLCRI-GLA & Corine Land Cover Ratio Index Glacier \\
\hline CLCRI-BUR & Corine Land Cover Ratio Index Burned \\
\hline A mutatók sora további kombinációkkal folytatható...
\end{tabular} \\
\hline
\end{tabular}

A mutatók sora további kombinációkkal folytatható...

\begin{tabular}{|c|}
\hline Megmutatja \\
\hline Vízfelület-arányát \\
\hline Erdőarányt \\
\hline Lomboserdő-arányt \\
\hline Fenyveserdő-arányt \\
\hline Vegyeserdö-arányt \\
\hline Mezőgazdasági-arányt \\
\hline Szántó-arányt \\
\hline Gyep arányt \\
\hline Szölö-arányt \\
\hline Gyümölcsös-arányt \\
\hline Komplex müvelés arányát \\
\hline Vízenyős arányt \\
\hline Üdülő-arányt \\
\hline Lakott terület arány \\
\hline Átmeneti erdős-cserjés arány \\
\hline Gleccser-arány \\
\hline
\end{tabular}

Képlet

(AreaCLC511+AreaCLC512) / AreaCLCall*100

Intervallum

Megjegyzés $0-100 \%$ Egyszerúen képezhető mutató (AreaCL311+AreaCLC312+AreaCLC313)

AreaCLCall*100

$0-100 \%$ Egyszerủen képezhetö mutatò AreaCLC312 / AreaCLCall*100 $\quad 0-100 \%$ Egyszerúen képezhetô mutató AreaCLC313) / AreaCLCall*100 $\quad 0-100 \%$ Egyszerüen képezhető mutató

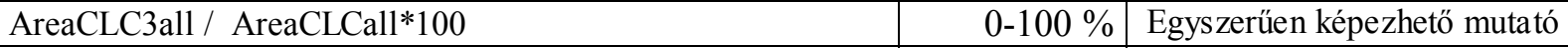
\begin{tabular}{|lll|}
\hline AreaCLC211 / AreaCLCall*100 & $0-100 \%$ & Egyszerúen képezhető mutató \\
\hline
\end{tabular} (AreaCLC231+AreaCLC321)/AreaCLCall*100 $\quad 0-100 \%$ Egyszerüen képezhető mutá AreaCLC21 / AreaCLCal1*100 0-100\% Egyszerüen képezhető mutá tó A $0-100 \%$ Egyszer"en képezhetö AreaCLC22 / AreaCLCal*100

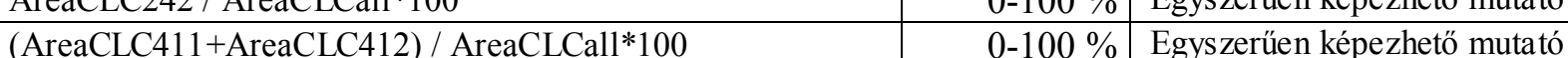
\begin{tabular}{|c|c|c|}
\hline AreaCLC411+AreaCLC412)/ AreaCLCall*100 & $0-100 \%$ & Egyszeruen képezhetó mutató \\
\hline
\end{tabular} AreaCLC142/ AreaCLCall*100 $\quad 0-100 \%$ Egyszerúen képezhetó mutató \begin{tabular}{ll|l} 
(AreaCLC111+AreaCLC112) / AreaCLCall*100 & $0-100 \%$ & Egyszerüen képezhető mutató \\
\hline
\end{tabular} AreaCLC324 / AreaCLCall*100 $\quad 0-100 \%$ Egyszerúen képezhető mutato AreaCLC335 / AreaCLCall*100 $\quad 0-100 \%$ Egyszerúen képezhető mutató AreaCLC334/AreaCLCal1*100

\section{Felszínborítások egymáshoz viszonyított arányát jelző mutatók}

\begin{tabular}{|c|c|c|c|c|c|}
\hline Rövid neve & Teljes neve (angol v. magyar) & Megmutatja & Képlet & Intervallum & Megjegyzés \\
\hline CLC-RR-URB-NUB & $\begin{array}{l}\text { Corine Land Cover Relative Ratio Index Urban to Non-urban } \\
\text { Built-up }\end{array}$ & $\begin{array}{l}\text { Településszövet arányát a nem települési mesterséges } \\
\text { felszín arányához képest }\end{array}$ & $\begin{array}{l}\text { (AreaCLC111+AreaCLC112)/(AreaCLC121 } \\
\text { +AreaCLC122+AreaCLC123+AreaCLC124) }\end{array}$ & $0-100 \%$ & Egyszerüen képezhetö mutató \\
\hline CLC-RR-TWS-FOR & $\begin{array}{l}\text { Corine Land Cover Relative Ratio Index Transitional woodland- } \\
\text { shrubland to Forest }\end{array}$ & $\begin{array}{l}\text { Átmeneti erdős-cserjés arányát valamennyi erdőhöz } \\
\text { képest }\end{array}$ & $\begin{array}{l}\text { AreaCLC324/(AreaCLC311 } \\
\text { +AreaCLC312+AreaCLC313) }\end{array}$ & $0-100 \%$ & Egyszerüen képezhetö mutató \\
\hline CLC-RR-CNF-BLF & $\begin{array}{l}\text { Corine Land Cover Relative Ratio Index Coniferous forest to } \\
\text { Broadleaf forest }\end{array}$ & Tülevelü és lombos erdő egymáshoz viszonyított arányát & AreaCLC312/AreaCLC311 & $0-100 \%$ & Egyszerüen képezhetö mutató \\
\hline CLC-RR-BLF-FOR & Corine Land Cover Relative Ratio Index Broadleaf forest to Forest & Lombos erdő arányát valamennyi erdőhöz képest & $\begin{array}{l}\text { AreaCLC311/(AreaCL } \\
\text { +AreaCLC312+AreaCl }\end{array}$ & $0-100 \%$ & Egyszerủen képezhetỏ mutató \\
\hline CLC-RR-CNF-FOR & $\begin{array}{c}\text { Corine Land Cover Relative Ratio Index Coniferous forest to } \\
\text { Forest }\end{array}$ & Tủlevelủ erdő arányát valamennyi erdőhöz képest & $\begin{array}{l}\text { AreaCLC312/(AreaCLC } \\
\text { +AreaCLC312+AreaCl }\end{array}$ & $\%$ & Egysze \\
\hline CLC-RR-MXF-FOR & Corine Land Cover Relative Ratio Index Mixed forest to Forest & Vegyes erdő arányát valamennyi erdőhöz képest & $\begin{array}{l}\text { AreaCLC313/(AreaCLC311 } \\
\text { +AreaCLC312+AreaCLC313) }\end{array}$ & $\%$ & Egyszerủen képezhetỏ mutató \\
\hline CLC-RR-ARL-AGR & $\begin{array}{c}\text { Corine Land Cover Relative Ratio Index Arable land to } \\
\text { Agricultural }\end{array}$ & Szántó arányát a teljes mezőgazdasági arányához képest & AreaCLC211/AreaCLC3all & $0-100 \%$ & Egyszerüen képezhetö mutató \\
\hline CLC-RR-PNG-AGR & $\begin{array}{c}\text { Corine Land Cover Relative Ratio Index Pasture and Natural } \\
\text { Grassland to Agricultural }\end{array}$ & $\begin{array}{c}\text { Gyep/legelő arányát a teljes mezőgazdasági arányához } \\
\text { képest }\end{array}$ & rea & $0-100 \%$ & Egyszerüen képezhető mutató \\
\hline CLC-RR-VIN-AGR & Corine Land Cover Relative Ratio Index Vineyard to Agricultural & Szölő arányát a teljes mezőgazdasági arányához képest & (AreaCLC221)/AreaCLC3all & $0-100 \%$ & Egyszerüen képezhetổ mutató \\
\hline CLC-RR-ORC-AGR & Corine Land Cover Relative Ratio Index Orchard to Agricultural & $\begin{array}{c}\text { Gyümölcsös arányát a teljes mezőgazdasági arányához } \\
\text { képest }\end{array}$ & (AreaCLC222)/AreaCLC3all & $0-100 \%$ & Egyszerūen képezhetö mutató \\
\hline CLC-RR-CPX-AGR & $\begin{array}{l}\text { Corine Land Cover Relative Ratio Index Complex cultivation to } \\
\text { Agricultural }\end{array}$ & $\begin{array}{l}\text { Komplex mủvelés arányát a teljes mezőgazdasági } \\
\text { arányához képest }\end{array}$ & (AreaCLC242)/AreaCLC3all & $0-100 \%$ & Egyszerüen képezhetỏ mutató \\
\hline CLC-RR-URB-ART & Corine Land Cover Relative Ratio Index Urban to Artificial & $\begin{array}{c}\text { Településszövet arányát a teljes mesterséges felszín } \\
\text { arányához képest }\end{array}$ & (AreaCLC111+AreaCLC112)/( & $0-100 \%$ & Egyszerüen képezhető mutató \\
\hline
\end{tabular}

CLC-RR-URB-ART Corine Land Cover Relative Ratio Index Urban to Artificia arányához képest 
25.c. táblázat Felvételekből származtatott adatbázisokra épülő mutatók

Felszínborítások természetességi foka alapján felállított viszony szerint

\begin{tabular}{|c|c|c|c|c|c|}
\hline Index rövid neve & Index teljes neve (angol v. magyar) & Az index jelzi / megmutatja & Képlet & Intervallum & Megjegyzés \\
\hline CLC-RNR-ART-AGR & $\begin{array}{l}\text { Corine Land Cover Relative Naturalness Ratio } \\
\text { Index Artificial to Agricultural }\end{array}$ & $\begin{array}{l}\text { Mesterséges felszín arány mezőgazdasági } \\
\text { felszínhez képest }\end{array}$ & CLC lall / CLC 2all & $0-100 \%$ & Egyszerūen képezhetö mutató \\
\hline CLC-RNR-ART-NAL & $\begin{array}{l}\text { Corine Land Cover Relative Naturalness Ratio } \\
\text { Index Artificial to Nature like }\end{array}$ & $\begin{array}{l}\text { Mesterséges felszín arány természetközeli } \\
\text { felszín arányhoz képest }\end{array}$ & CLC 1all / (CLC 3all +4all +5all) & $0-100 \%$ & Egyszerüen képezhető mutató \\
\hline CLC-RNR-AGR-NAL & $\begin{array}{l}\text { Corine Land Cover Relative Naturalness Ratio } \\
\text { Index Agricultural to Nature like }\end{array}$ & $\begin{array}{l}\text { Mezőgazdasági felszín arány természetközeli } \\
\text { felszín arányhoz képest }\end{array}$ & CLC 2all / (CLC 3all +4all+5all) & $0-100 \%$ & Egyszerüen képezhető mutató \\
\hline CLC-RNR-ARAG-NAL & $\begin{array}{l}\text { Corine Land Cover Relative Naturalness Ratio } \\
\text { Index Artificial and Agricultural to Nature like }\end{array}$ & $\begin{array}{l}\text { Mesterséges és mezögazdasági felszín arány } \\
\text { természetközeli felszín arányhoz képest }\end{array}$ & (CLC 1all + CLC2all $) /($ CLC 3all+4all + 5all $)$ & $0-100 \%$ & Egyszerüen képezhető mutató \\
\hline
\end{tabular}

A mutatók sora további kombinációkkal folytatható!

Felszínborításból származtatható tájszerkezeti indexek

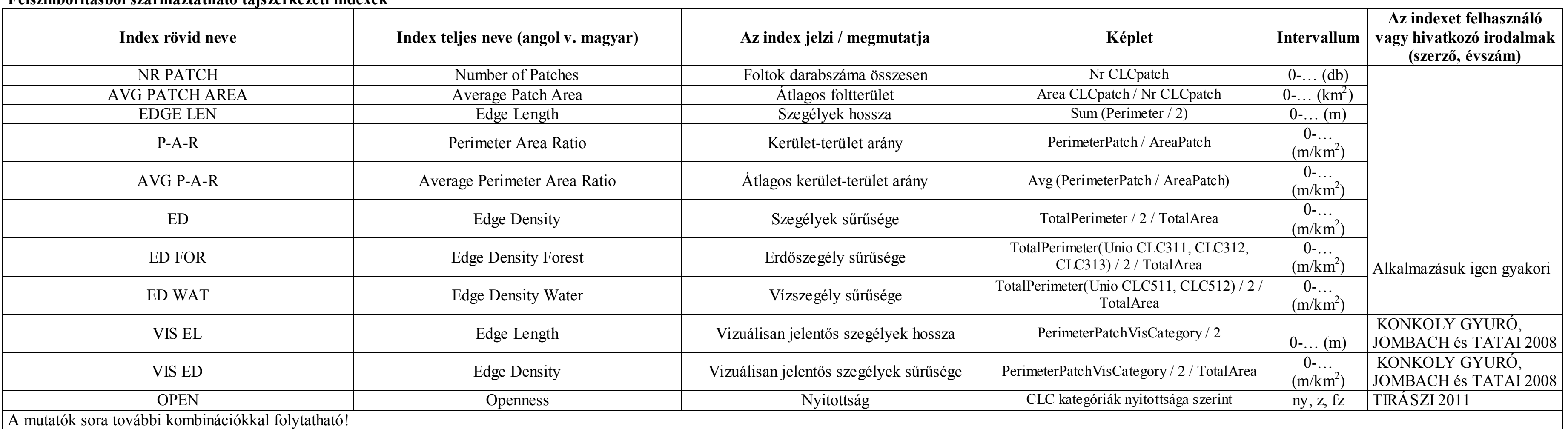

Kombinált indexek: Tájegységben vagy tájtípusban kiemelt jelentőségủ tájrészleten belüli arányok

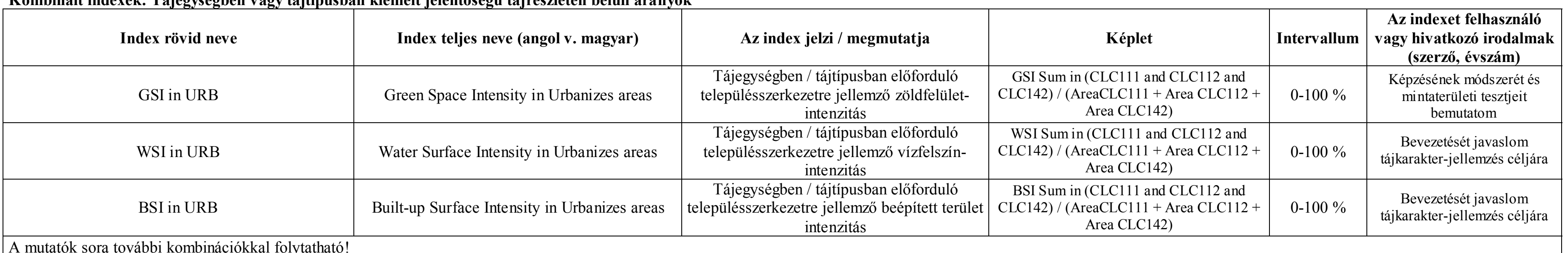



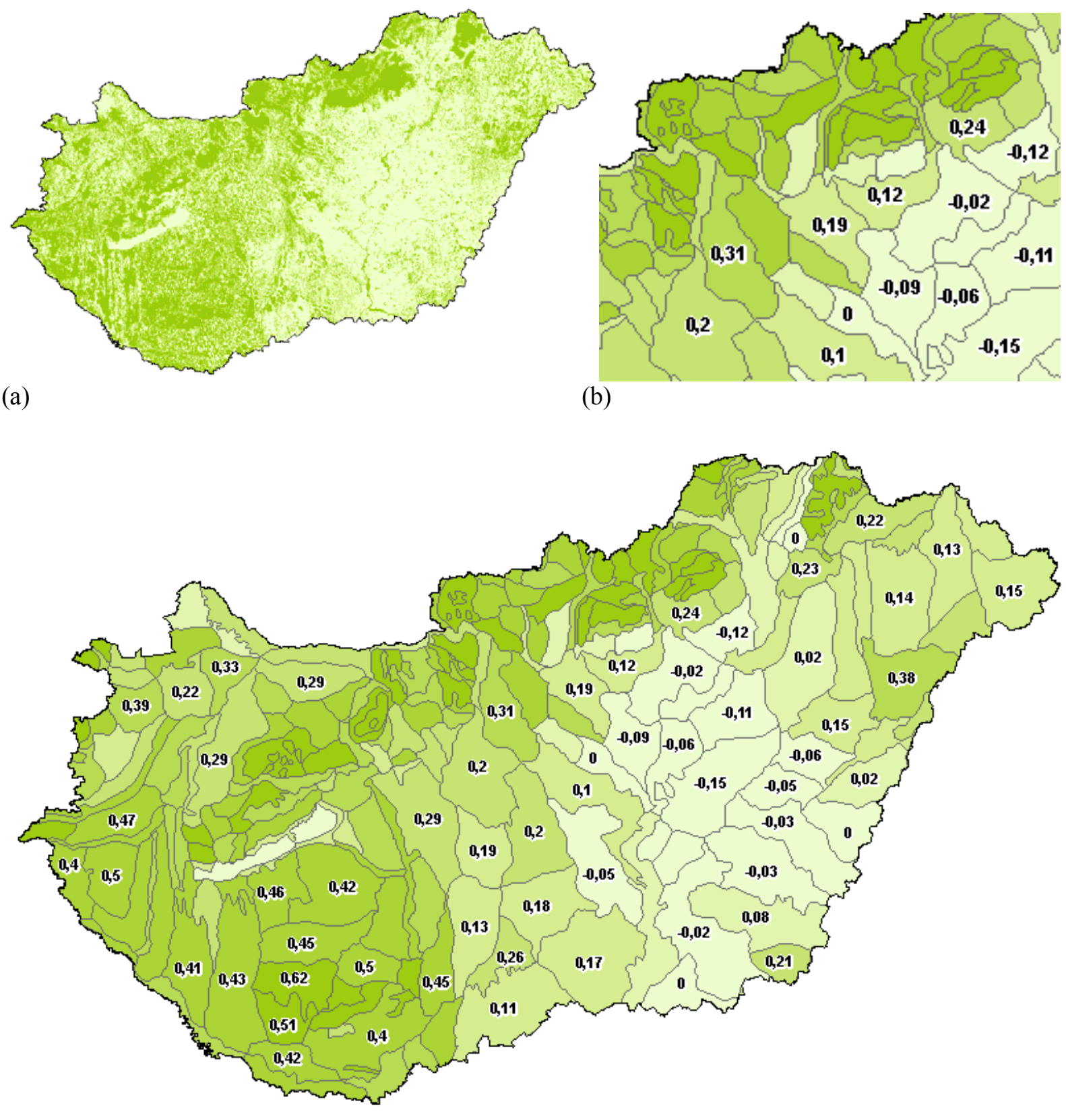

(c)

57. ábra NDVI vegetációs index elemzés eredményei IMAGE2000 adatok feldolgozásával Magyarország teljes területére (a), kistájak területére aggregált NDVI értékek (b és c) melyek ebben a formában nehezen értelmezhetőek, a tájak jellemzésére számértékükkel nem alkalmasak.
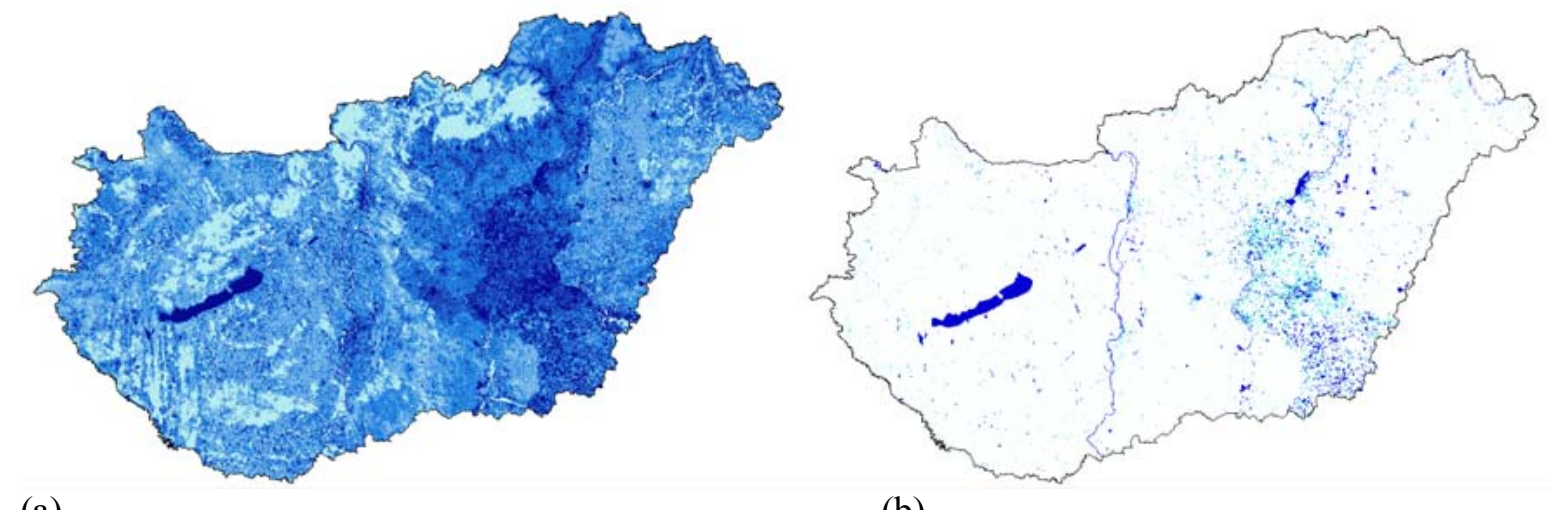

(b)
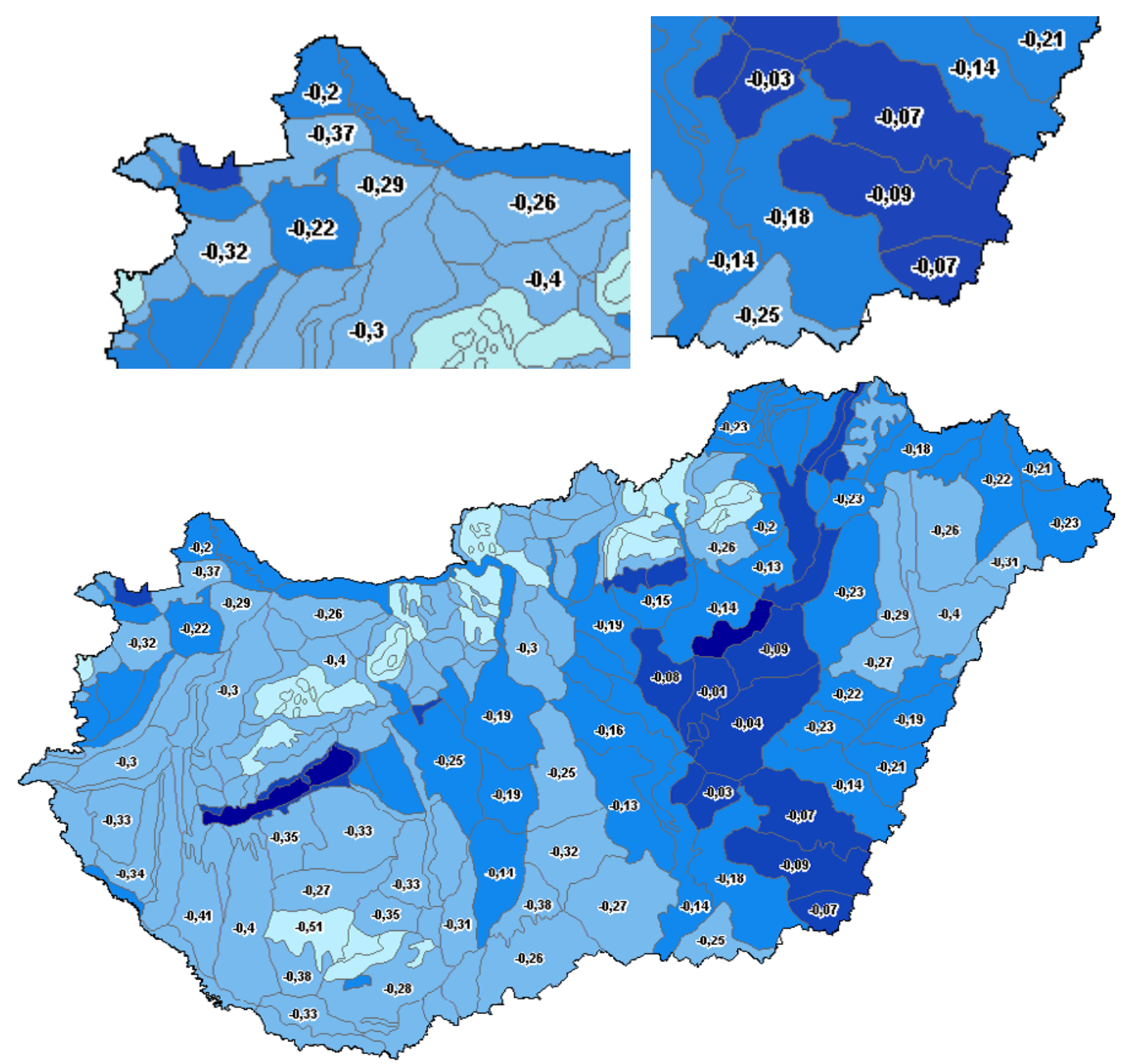

(c)

58. ábra MNDWI (a Landsat 2,5csatornákra építő) vízfelületi index elemzésének eredménye IMAGE2000 adatok feldolgozásával Magyarország teljes területére (a), a 0-nál magasabb MNDWI értékek kékkel (b), kistájak területére agoregalt MNDWI értékek (c) melyek ebben a formában nehezen értelmezhetőek, a tájak jellemzésére számszerúen nem alkalmasak. 


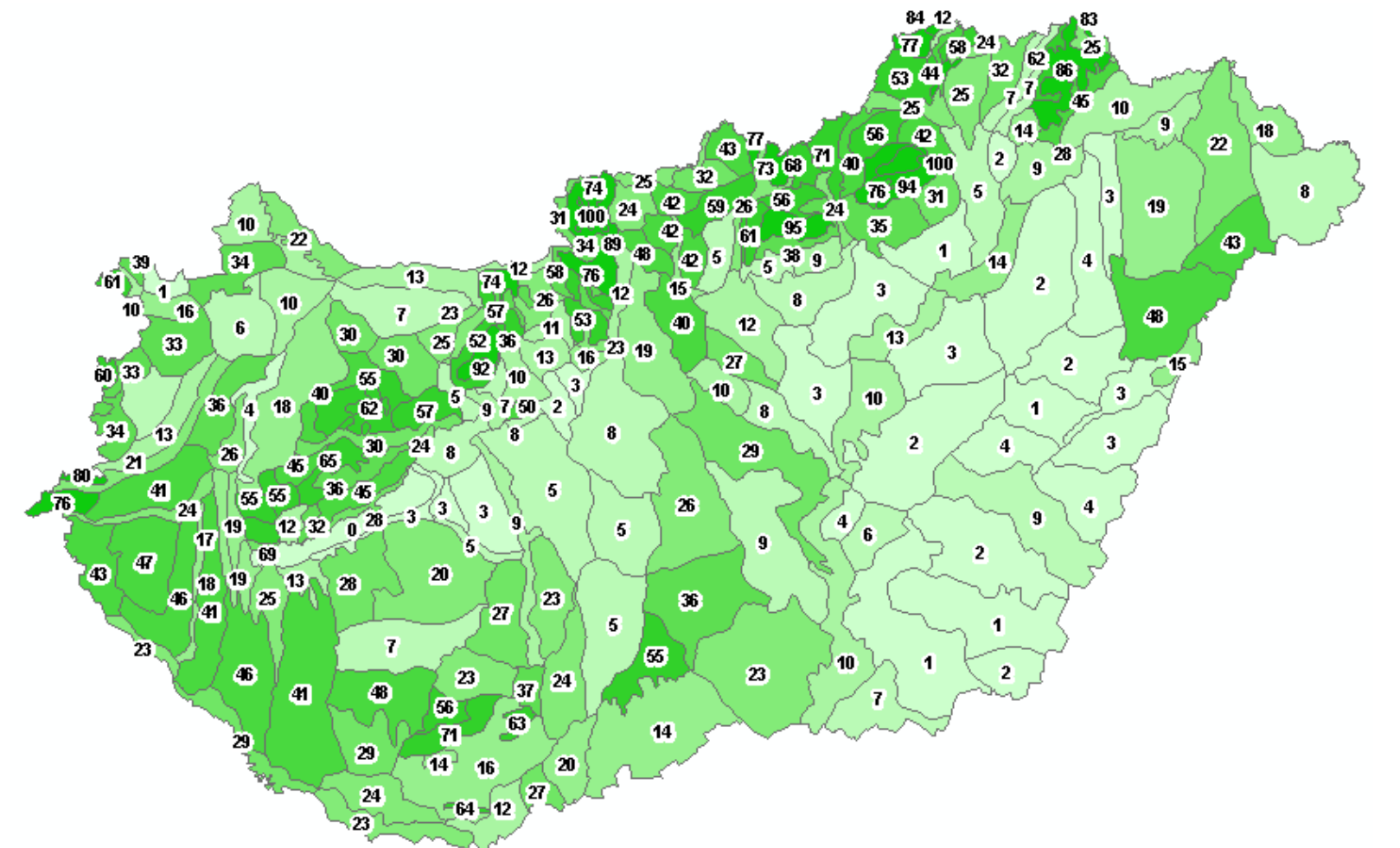

59. ábra Erdők aránya Magyarország kistájainak területén (CLC 2006 adatbázis alapján, kód: $311,312,313)$

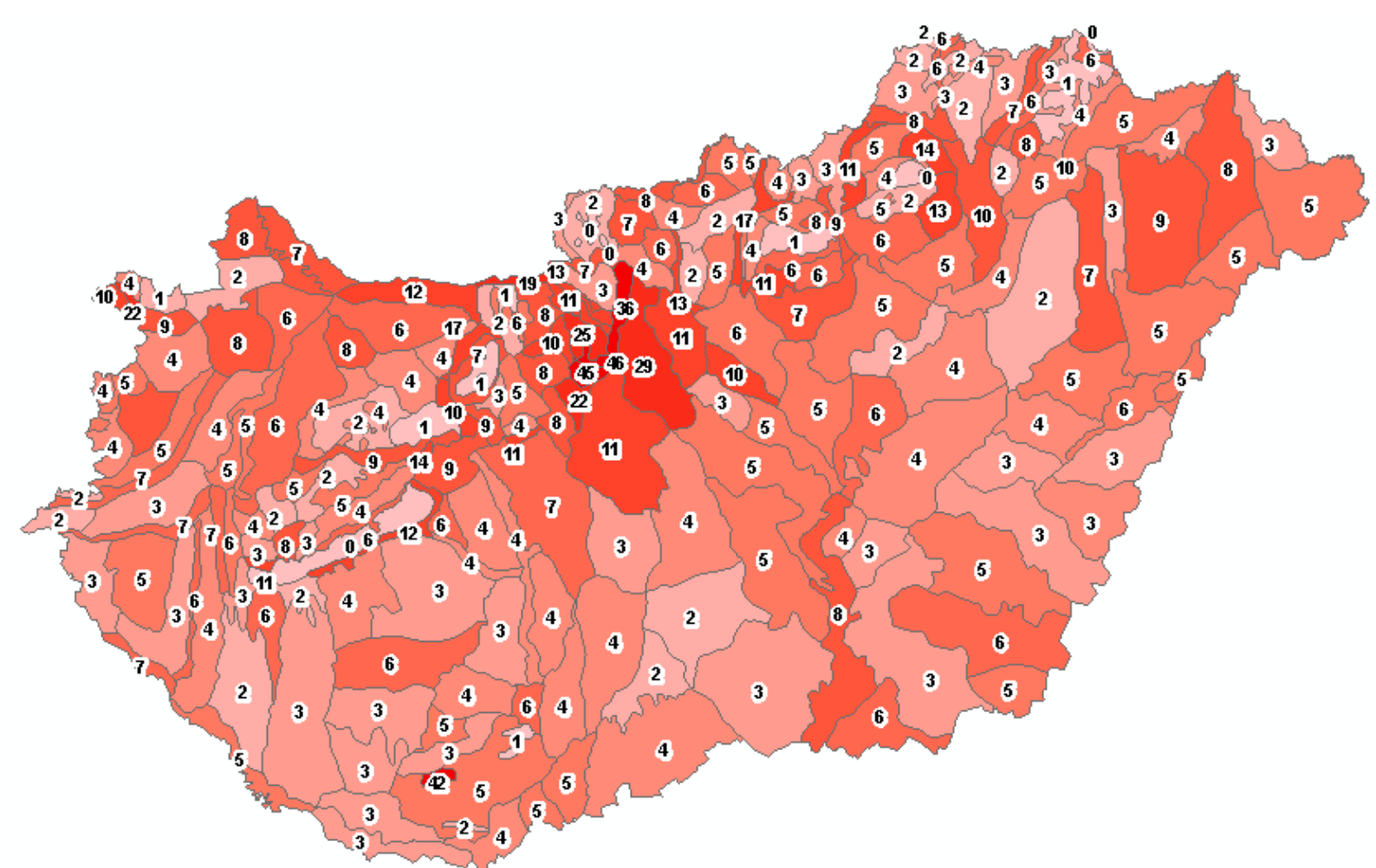

60. ábra Beépített jellegü terület aránya Magyarország kistájainak területén (CLC 2006 adatbázis alapján, kód: 111, 112, 121, 122, 123,133)

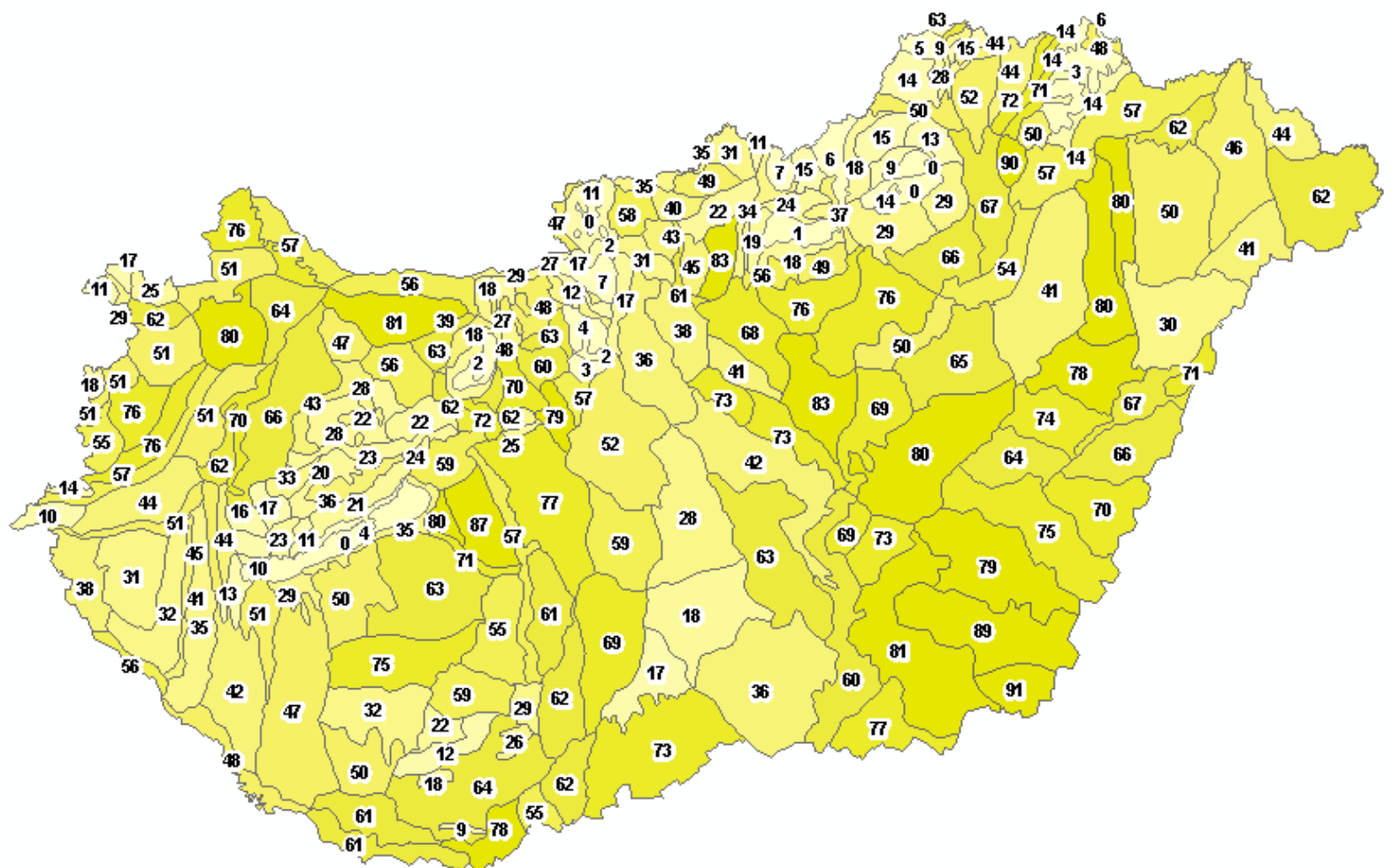

61. ábra Szántók aránya Magyarország kistájainak területén (CLC 2006 adatbázis alapján, kód 211)

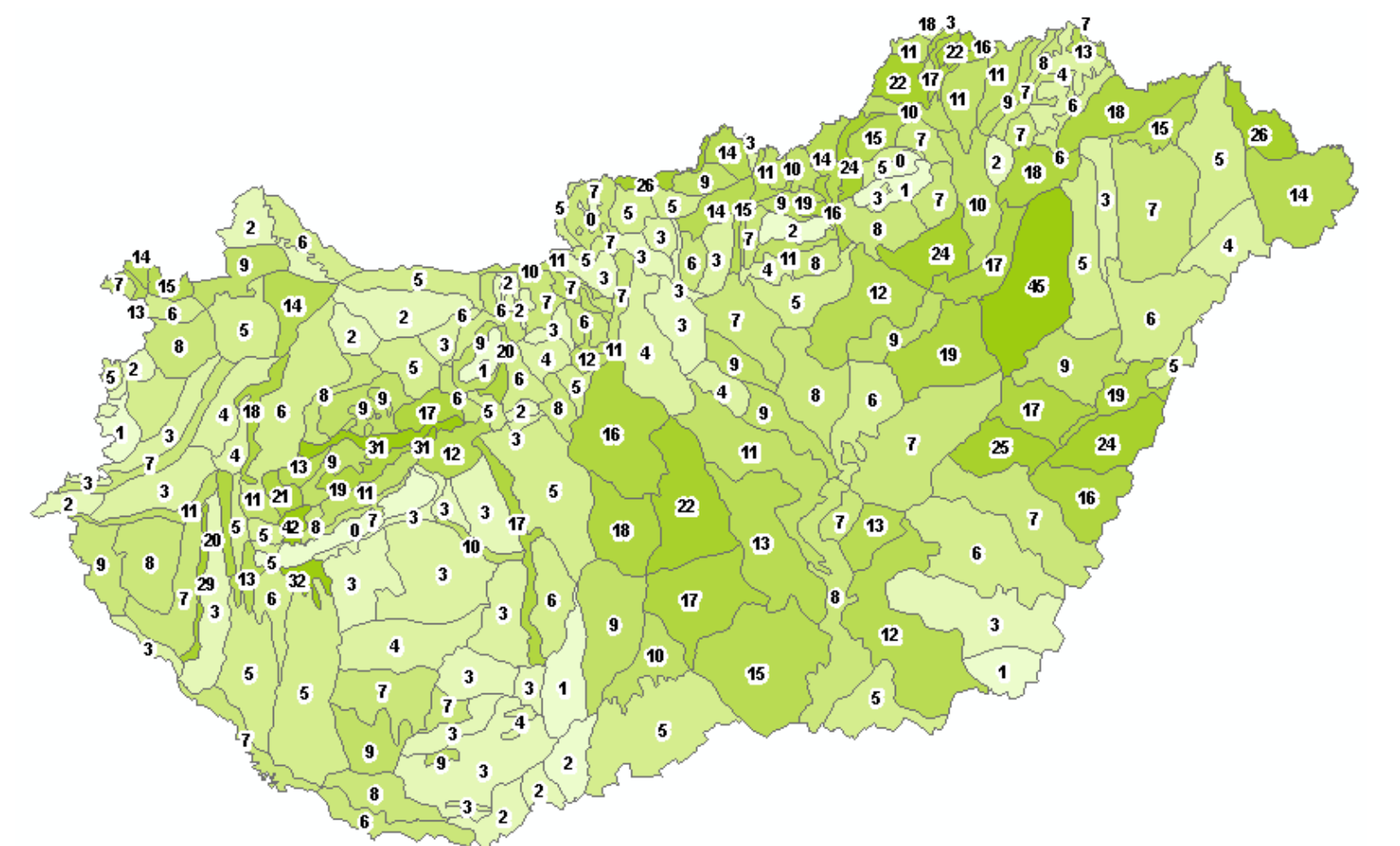

62. ábra Rét/legelő és természet-közeli gyep aránya Magyarország kistájainak területén (CLC 2006 adatbázis alapjan, kod: 231,321 ) 


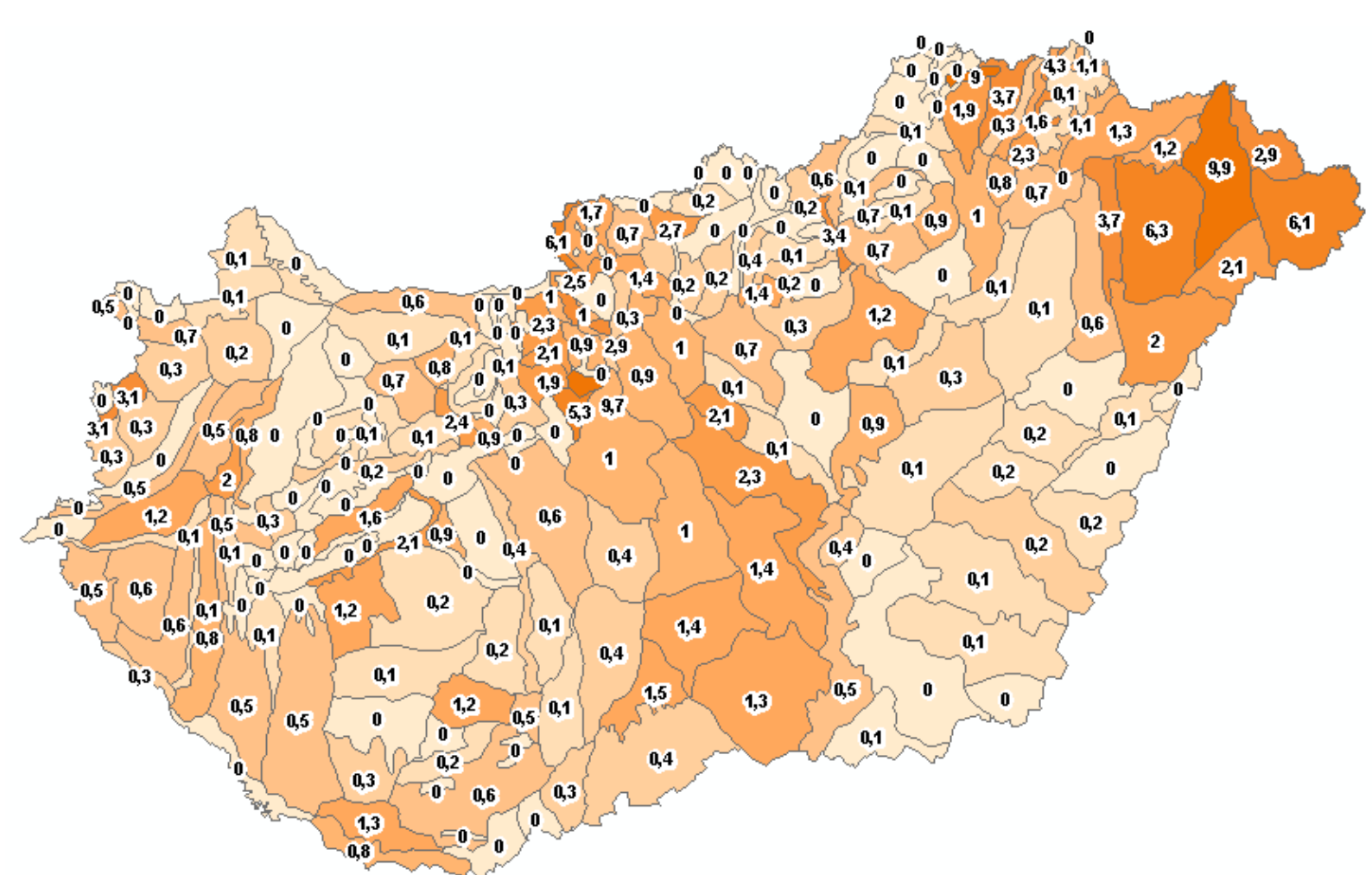

63. ábra Gyümölcsösök aránya Magyarország kistájainak területén (CLC 2006 adatbázis alapján, kód: 222)

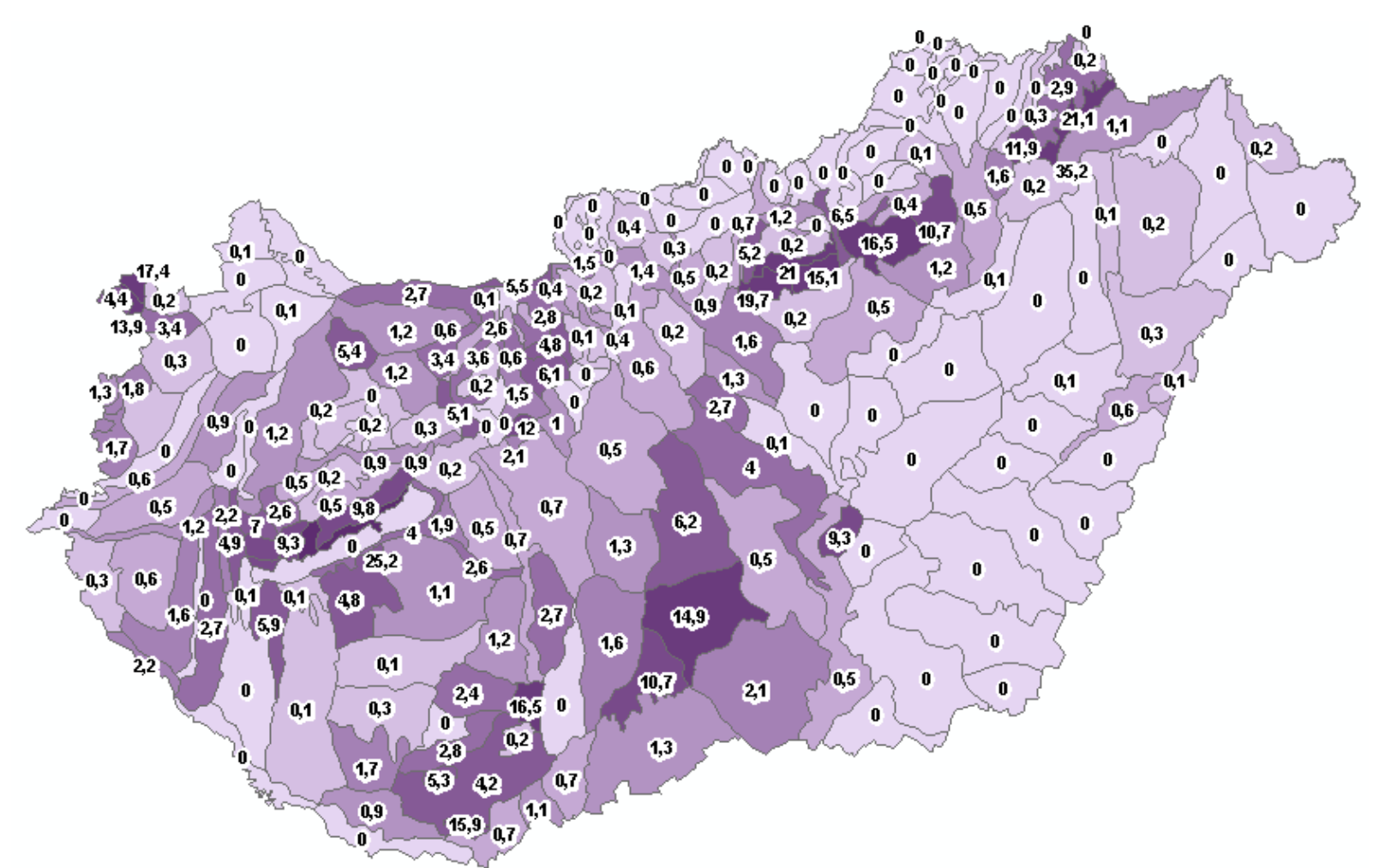

64. ábra Szőlőkk aránya Magyarország kistájainak területén (CLC 2006 adatbázis alapján, kód: 221)

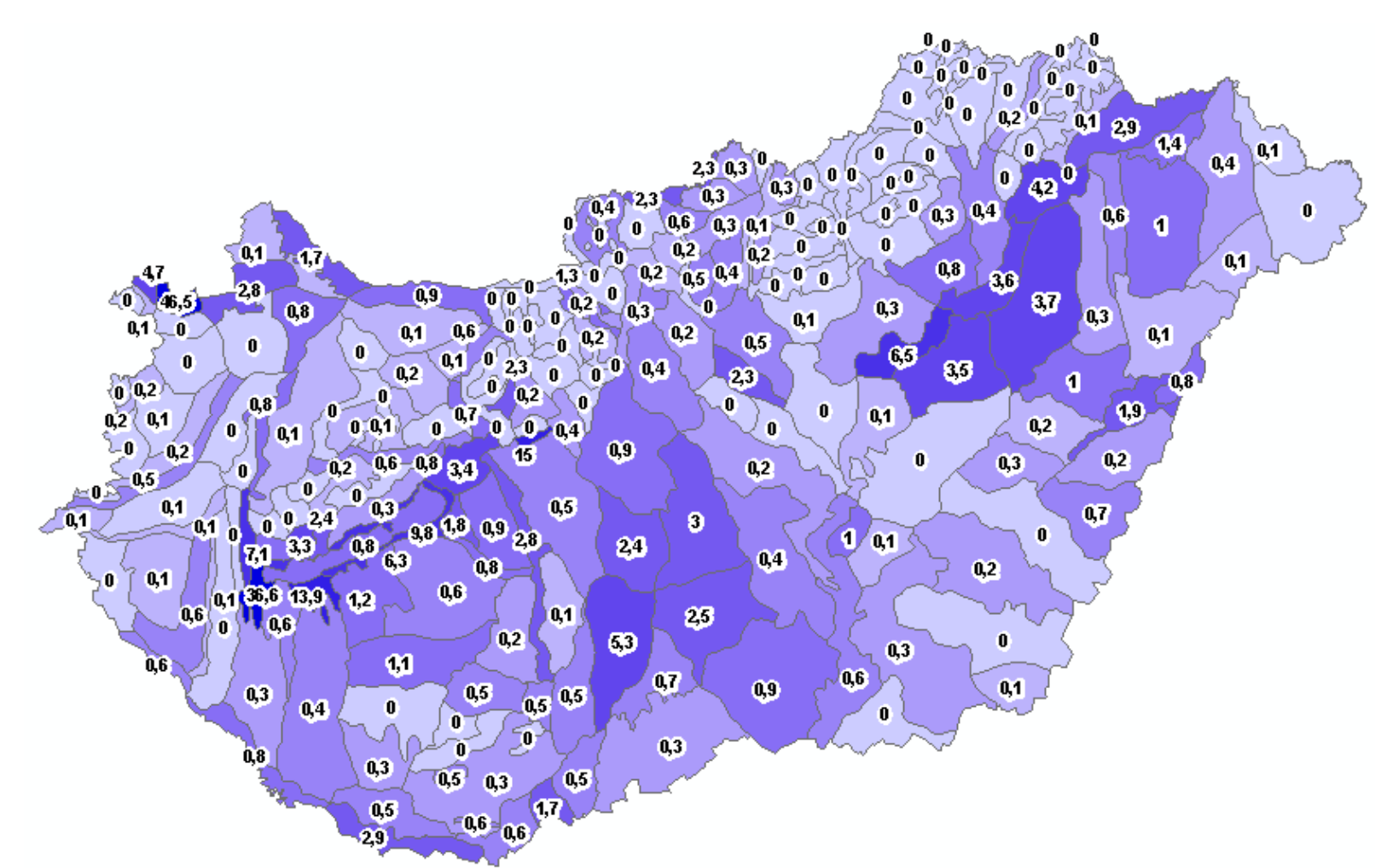

65. ábra Vizenyős területek aránya Magyarország kistájainak területén (CLC 2006 adatbázis alapján, kód: 411, 412)

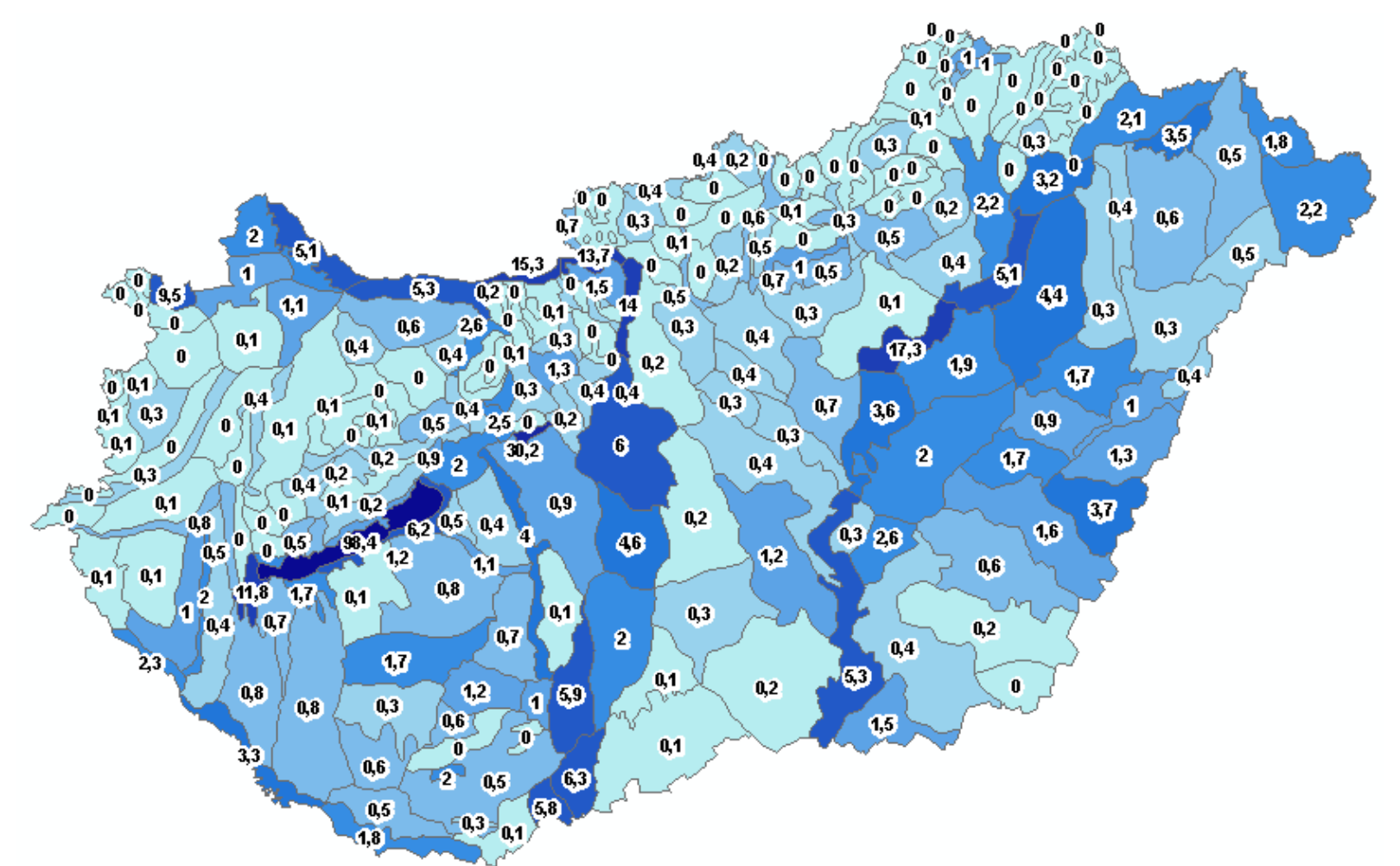

66. ábra Vízfelszín aránya Magyarország kistájainak területén (CLC 2006 adatbázis alapján, kód: 511,512) 


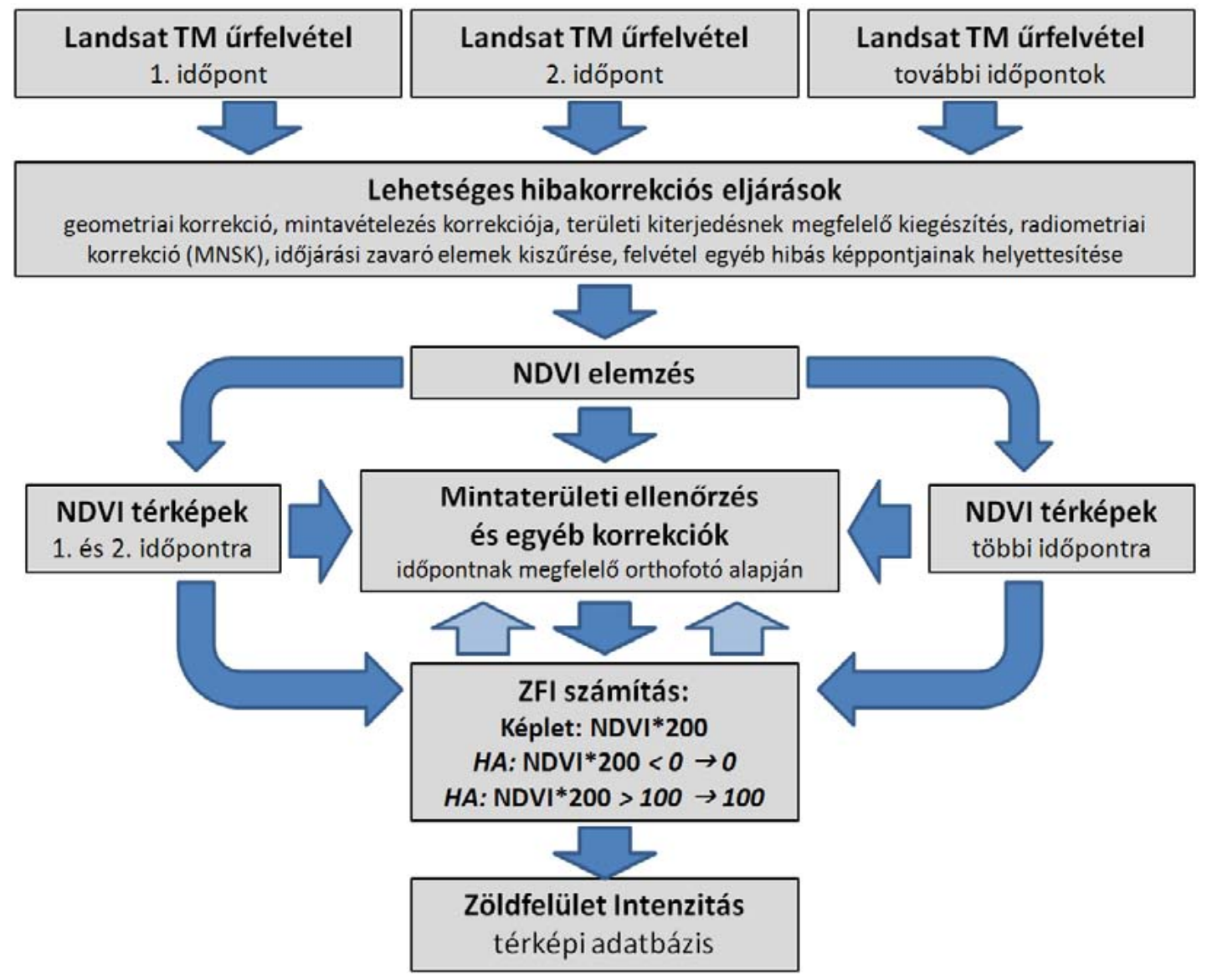

67. ábra A Zöldfelület Intenzitás (ZFI) mutató számítási módszere

\begin{tabular}{|c|c|c|c|c|}
\hline Szinkód & $\mathrm{ZFI} \%$ & NDVI & Terület jellege & Minta \\
\hline & $0 \%$ & $(-1)-0$ & $\begin{array}{c}\text { Beépített terület, burkolt felszín, bányaterület, csupasz } \\
\text { talajfelszin, vizfelszín és minden olyan terület ahol nincs } \\
\text { biológiailag aktív zöldfelület }\end{array}$ & \\
\hline & $0,01-19,99 \%$ & $0-0,1$ & $\begin{array}{c}\text { PI.: erôteljesen beépitett területek, igen alacsony } \\
\text { zöldfelületi aránnyal }\end{array}$ & \\
\hline & 20 - 39,99 \% & $0,1-0,2$ & $\begin{array}{l}\text { Pl.: beépített terület, alacsony zöldfelületi aránnyal } \\
\text { (sürün beépitett kertvárosi terület, lakóparkszerü } \\
\text { beépítés) }\end{array}$ & \\
\hline & 40 - 59,99 \% & $0,2-0,3$ & $\begin{array}{l}\text { PI.: közepes beépitettség mellett közepes zöldfelületi } \\
\text { arány (kertvárosi területek) }\end{array}$ & \\
\hline & $60-79,99 \%$ & $0,3-0,4$ & $\begin{array}{l}\text { PI.: relative alacsony beépítettség mellett relative magas } \\
\text { zöldfelületi arány (lakótelepi beépítés nagy kiterjedésü } \\
\text { parkokkal) }\end{array}$ & \\
\hline & 80 - 99,99 \% & $0,4-0,5$ & $\begin{array}{l}\text { Pl.: alacsony beépitettséggel jellemezhetö terület, igen } \\
\text { nagy arányú erốteljes növénytakaróval (kertek, parkok, } \\
\text { útmenti jelentösebb zöldfelületek) }\end{array}$ & \\
\hline & $100 \%$ & $0,5-1$ & $\begin{array}{l}\text { Egészséges erdöállomány, park összefüggő fásszárú } \\
\text { növényzettel és gyeppel, eröteljes üde gyepterület }\end{array}$ & \\
\hline & változó & változó & $\begin{array}{l}\text { Időben állandóan változó zöldfelület-intenzitással } \\
\text { rendelkezö felszínek, pl.: szántók, intenziven kezelt } \\
\text { gyepek, gyepes repülőterek stb. }\end{array}$ & \\
\hline
\end{tabular}

68. ábra A zöldfelület intenzitás térkép jelkulcsa és magyarázata 

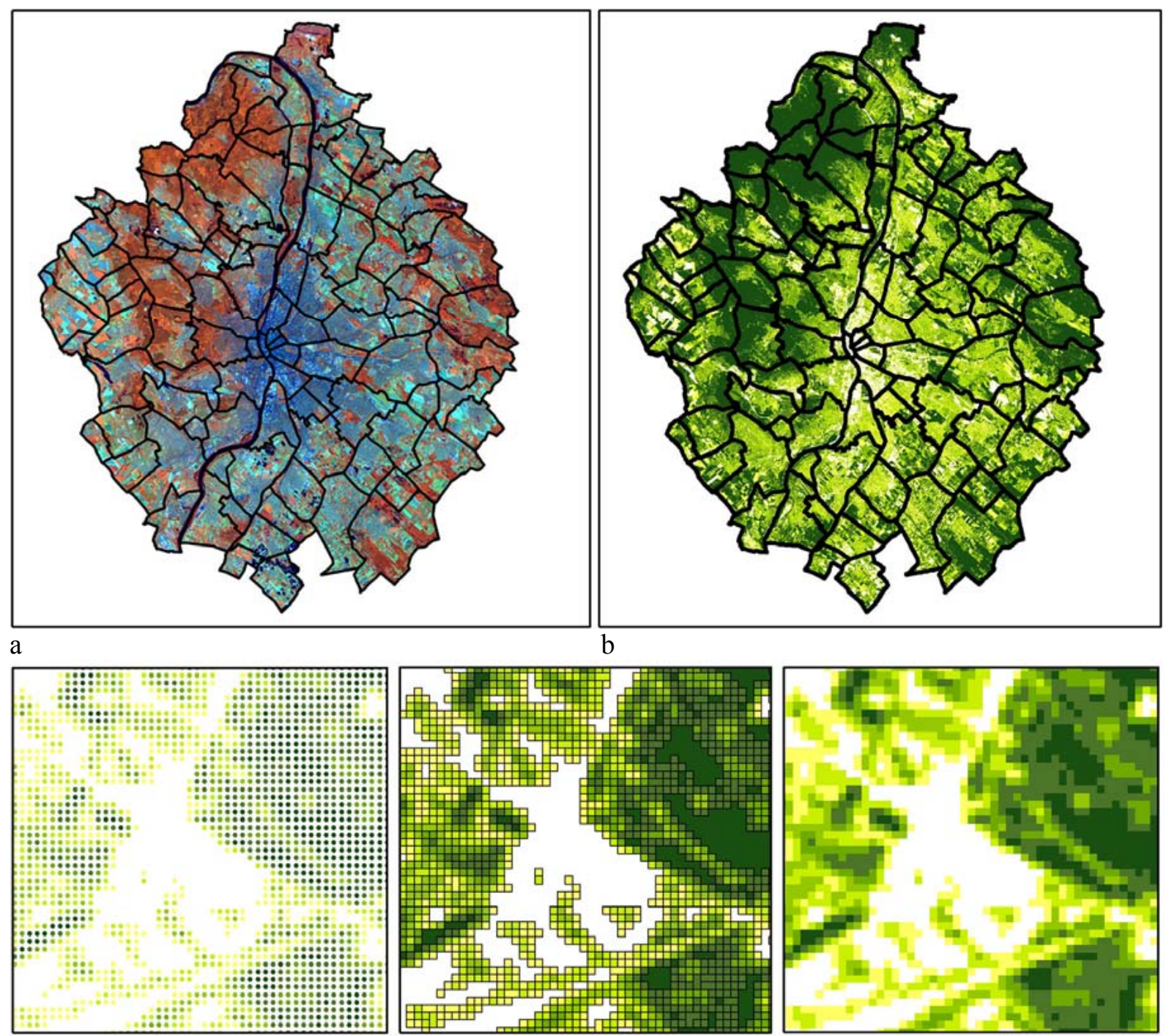

c

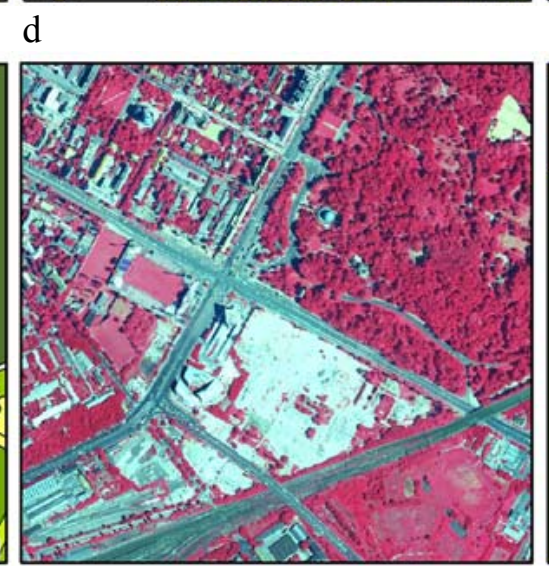

e

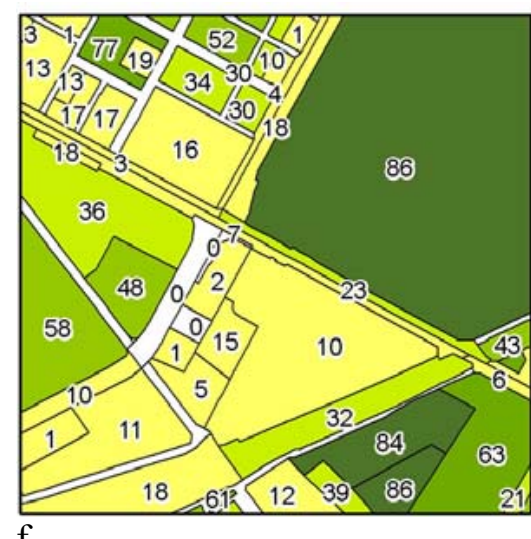

$\mathrm{g}$

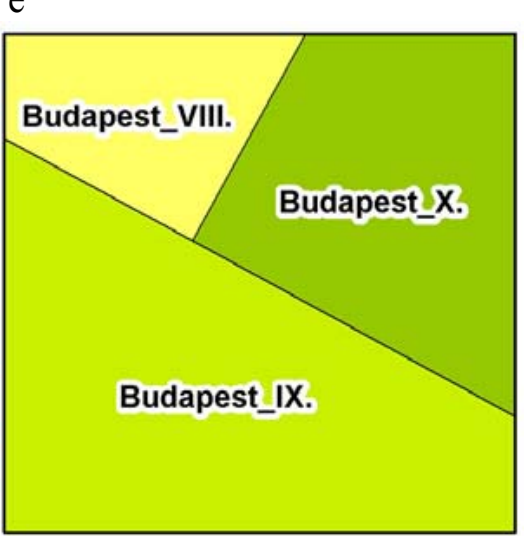

h

69. ábra Zöldfelület-intenzitás adatok felhasználhatósága a lehatárolt területek jellemzésére. a) az eredeti Landsat felvétel (2010) b) a ZFI elemzés eredménye a Budapesti Agglomerációra, c) pontszerü adatok, d) sokszög-alapú adatbázis egy részlete, e) raszteres adatbázis egy részlete a Népliget környékén, f) jellemzés ZFI értékekkel tömbökre, g) infra ortofotó 2010 (FÖMI), h) ZFI aggregálása Budapest egyes kerületeire. 


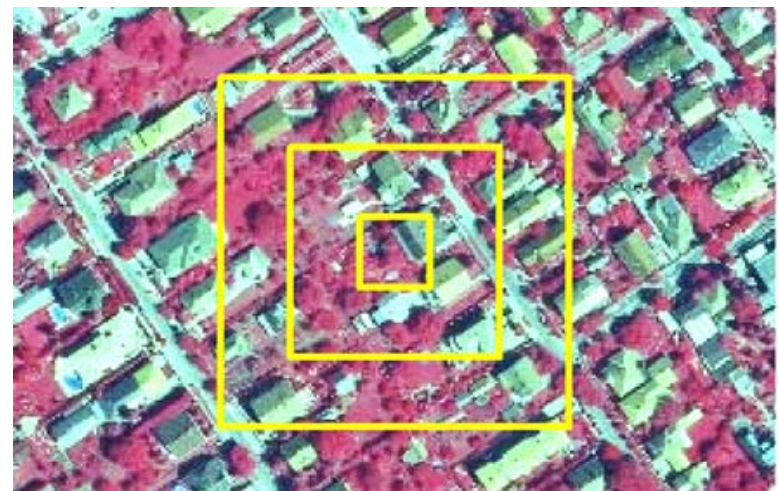

\begin{tabular}{|l|l|l|l|l|l|l|l|l|l|l}
\hline 23 & 51 & 46 & 25 & 12 & 21 & 44 & 55 & 46 & 29 & 34 \\
\hline 38 & 65 & 77 & 64 & 43 & 27 & 33 & 42 & 38 & 30 & 32 \\
\hline 27 & 21 & 57 & 80 & 63 & 39 & 40 & 42 & 37 & 35 & 19 \\
\hline 21 & 14 & 32 & 62 & 64 & 41 & 19 & 23 & 28 & 27 & 11 \\
\hline 34 & 13 & 21 & 43 & 73 & 56 & 19 & 13 & 23 & 25 & 8 \\
\hline 45 & 8 & 5 & 19 & 72 & 78 & 38 & 15 & 25 & 37 & 42 \\
\hline 49 & 25 & 18 & 20 & 64 & 89 & 65 & 38 & 38 & 48 & 49 \\
\hline
\end{tabular}

VI: $55 \quad 45 \quad 42$

$\begin{array}{lllll}\text { Kertváros (XVI. ker.) } & \text { SZ: } & 40,8 & 46 & 44,4\end{array}$
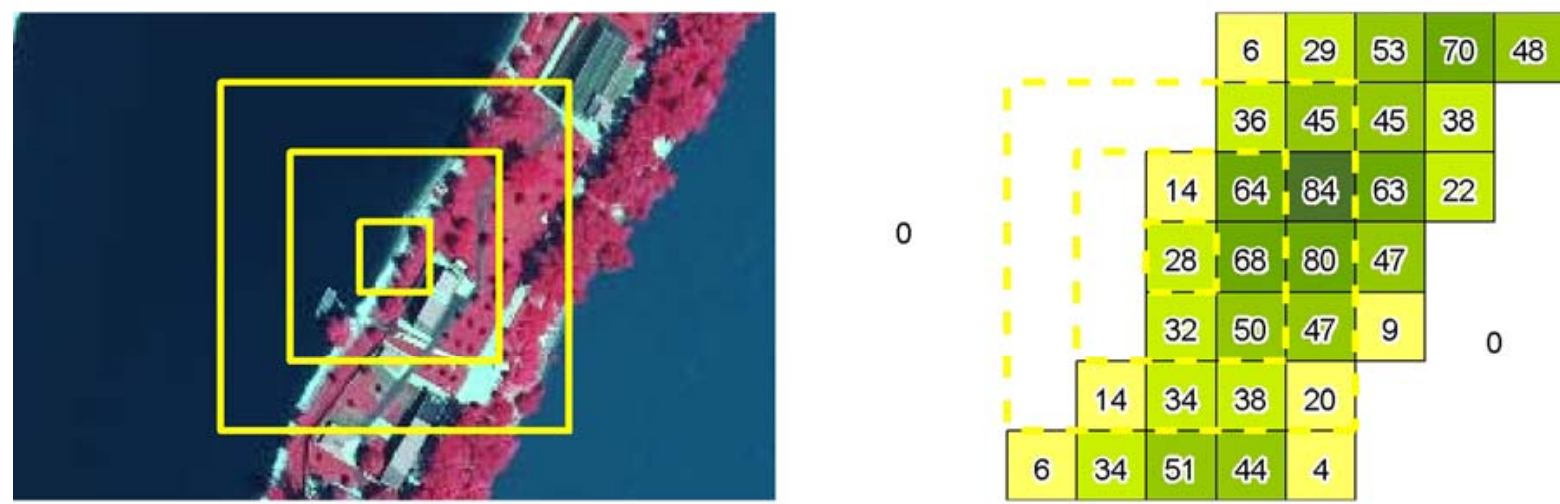

\section{VI: $35 \quad 30 \quad 25$}

Kopaszi gát (XI. ker.)

SZ: $27,9 \quad 28,5 \quad 26,2$
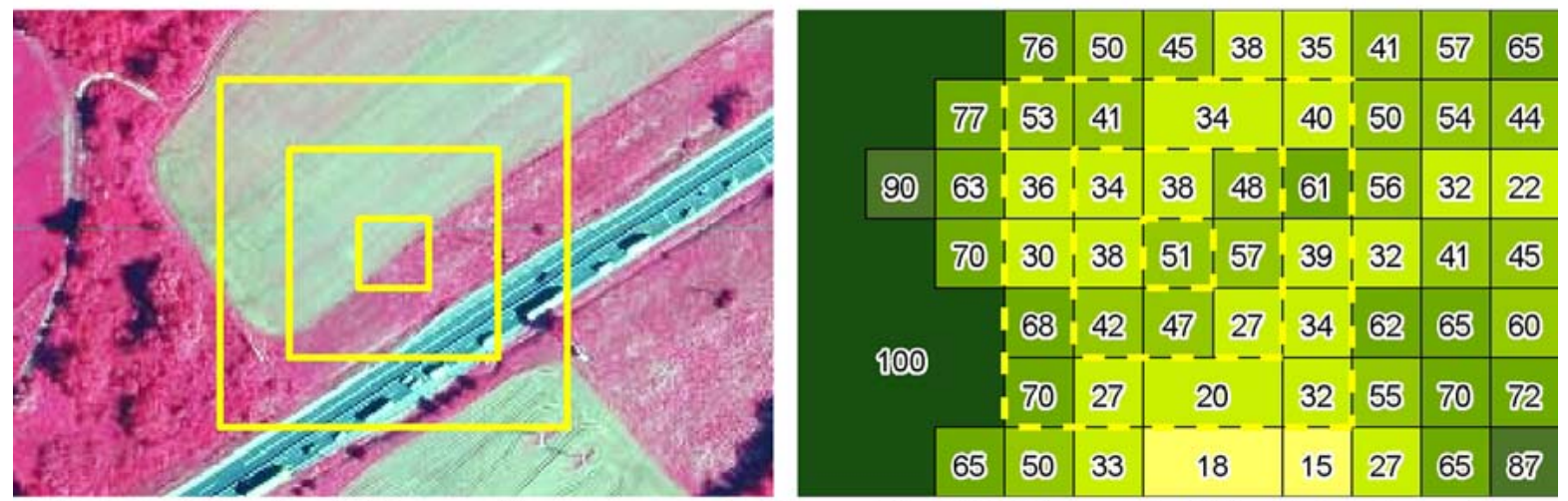

VI: 503020 M0-menti gyep, szántó, erdő (XXIII. ker.) SZ: $5143 \quad 41$
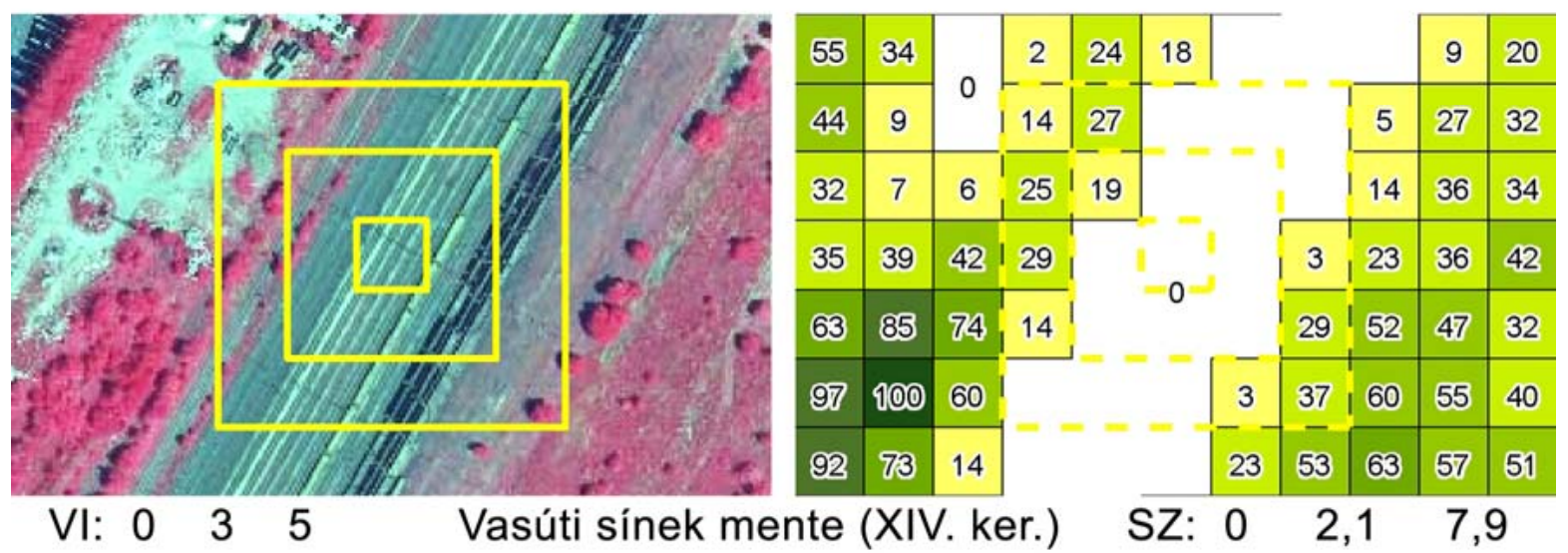

70. ábra A zöldfelület-intenzitás minteterületi ellenőrzése. Vizuális interpretáció (VI) és számítás (SZ) a ZFI helyességének ellenőrzésére. (Infra ortofoto 2010, FÖMI) 


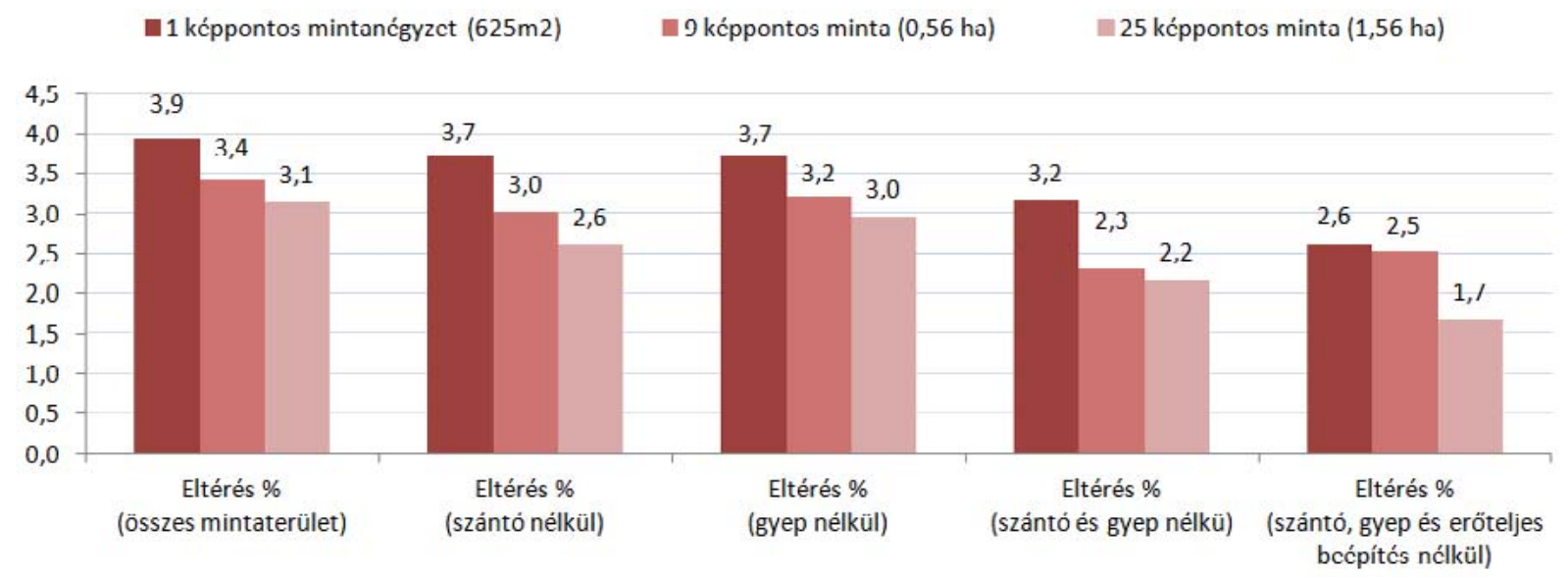

72. ábra A „nem elfogadható eltérés”. A ZFI adatbázis mintaterületi ellenőrzése során tapasztalt eltérés a vizuális interpretációval infra ortofotóról becsült és a Landsat felvételekből ZFI képlettel számított zöldfelület intenzitás (\%) között, különböző mintanégyzetekben. Az értékek a nem elfogadható eltérések abszolutértékének átlagát mutatják. A „nem elfogadható eltérés" az ami biztosan hibának tekinthető és nem a vizuális interpretáció becslő jellegéből fakad.

26. táblázat A ZFI mezőgazdasági területekre felhasznált landsat4-5 TM és Landsat ETM+ müholdfelvételek készítésének időpontja és USGS azonosítója

\begin{tabular}{|l|l|}
\hline 1986_05_25_It51880271986145xxx03 & 2002_06_22_It51880272002173mti00 \\
\hline 1986_09_14_It51880271986257xxx03 & 2003_04_30_le71880272003120asn00 \\
\hline 1986_10_16_It518880271986289xxx03 & 2003_07_27_It51880272003208mti01 \\
\hline 1990_10_11_etp188r27_5t19901011 & 2003_10_15_It51880272003288mti01 \\
\hline 1992_07_04_It41880271992186xxx02 & 2005_06_14_It51880272005165kis00 \\
\hline 1992_09_22_It41880271992266xxx02 & 2005_09_02_It51880272005245kis00 \\
\hline 1994_07_02_It51880271994183xxx02 & 2006_07_19_It51880272006200kis01 \\
\hline 1994_07_18_It51880271994199xxx02 & 2006_08_20_It51880272006232kis01 \\
\hline 1999_10_28_le71880271999301ags01 & 2006_10_07_It51880272006280mor00 \\
\hline 2000_04_21_le71880272000112edc00 & 2007_07_22_It51880272007203mor00 \\
\hline 2000_06_08_le71880272000160edc00 & 2007_08_23_It51880272007235mor00 \\
\hline 2000_10_14_le71880272000288edc00 & 2010_06_12_It51880272010163mor00 \\
\hline 2001_01_18_le71880272001018sgs00 & 2010_07_14_It51880272010195mor00 \\
\hline 2001_03_07_le71880272001066edc00 & 2011_07_17_It51880272011198mor00 \\
\hline 2001_06_27_le71880272001178edc00 & 2011_09_03_It51880272011246mor00 \\
\hline 2002_02_22_le71880272002053sgs00 & \\
\hline
\end{tabular}



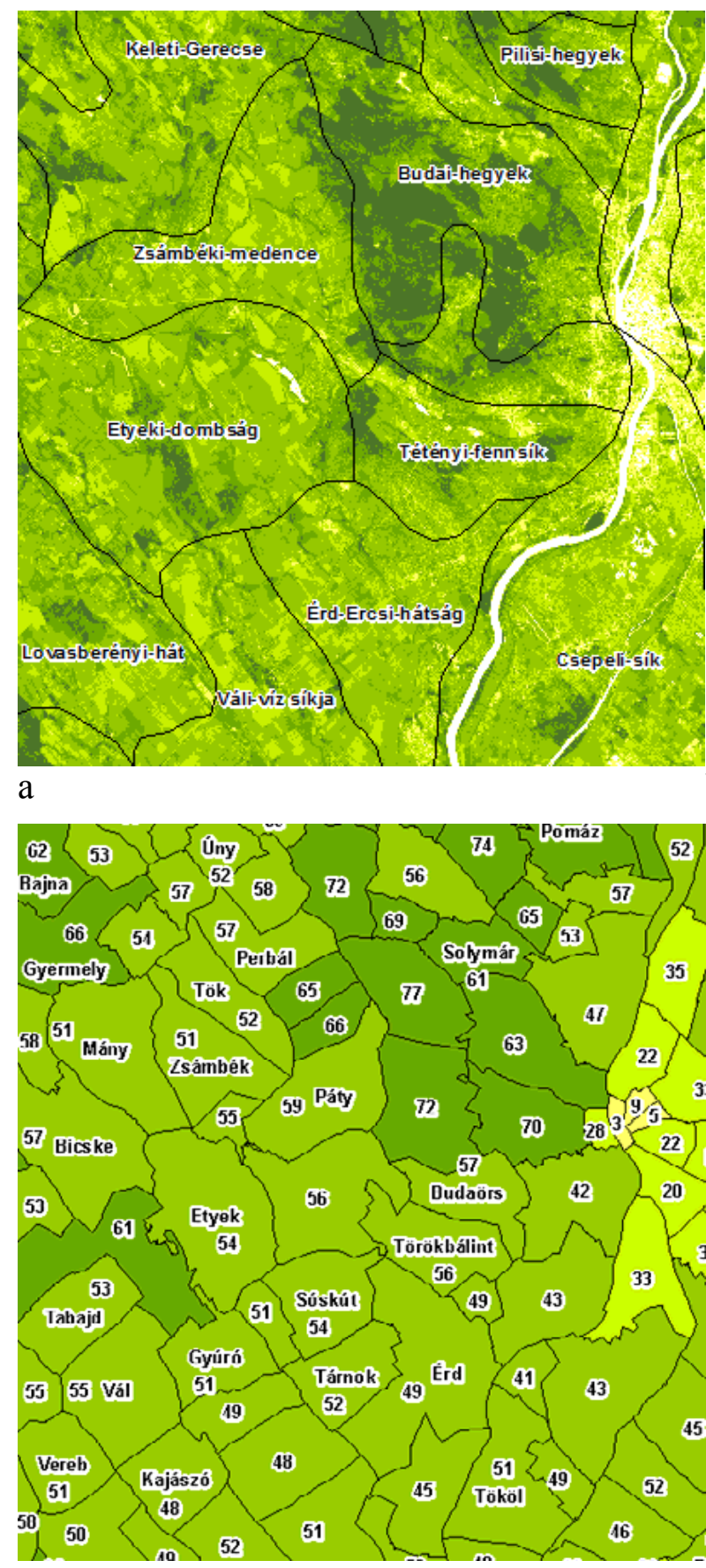

c

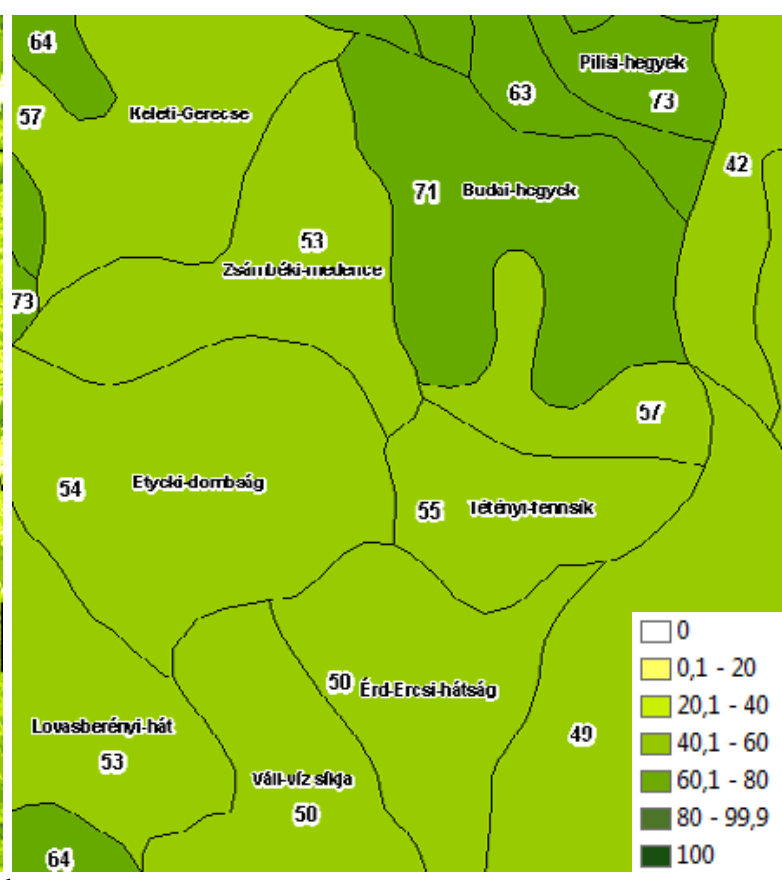

b

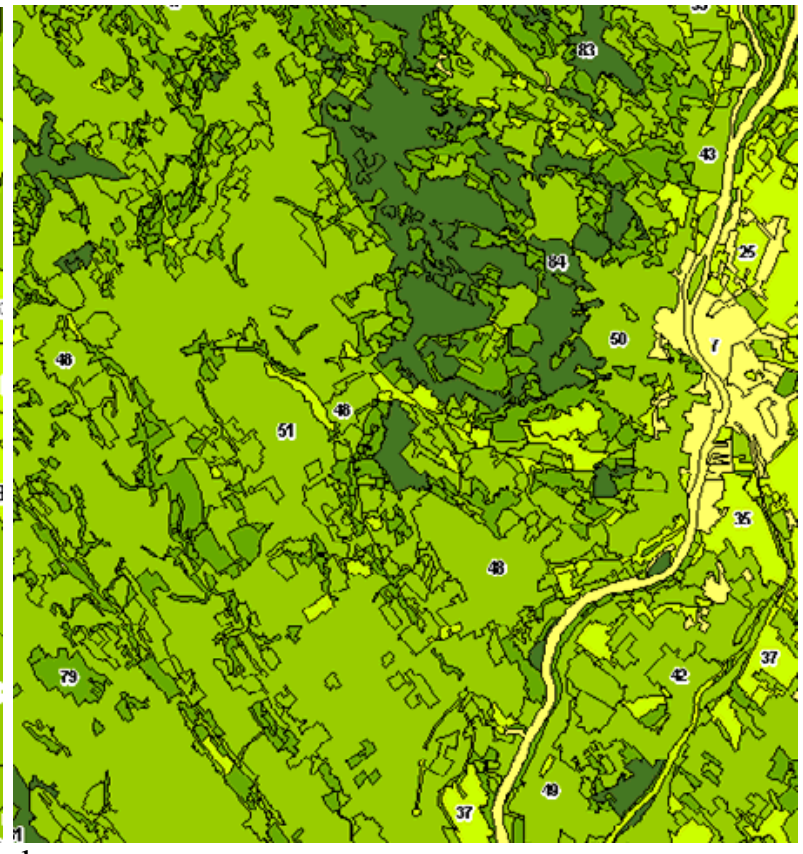

73. ábra Zöldfelület-intenzitás jellemzés Délnyugat-Budakörnyék térségére. A térképek 1986 és 2011 között 6 hónapos vegetációs időszakban (ápr-szept) készült 22 Landsat felvétel NDVI index feldolgozásával készültek a táj ez időszakban állandósultnak tekinthető zöldfelületi karaktervonását (zöldfelület intenzitás \%) jellemzik (a), kistájakra (b), településekre (c) és felszínborítás-foltokra (d). 


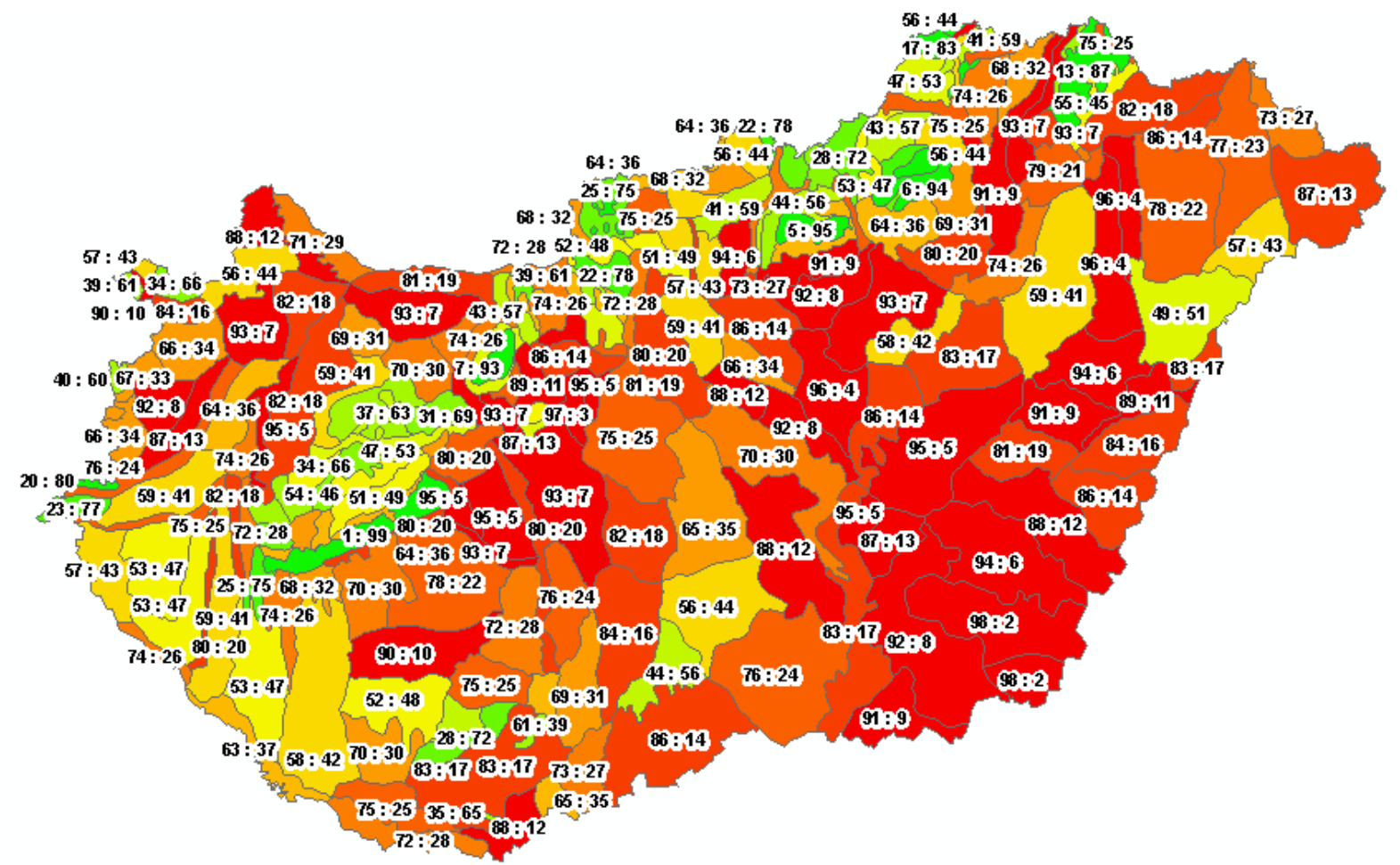

74. ábra Mesterséges jellegü felszínborítások (CLC 1all+2all) aránya (\%) a természetszerü felsźnborítás típusokhoz (CLC 3all+4all+5all) viszonyítva kistájanként. (Felhasznált alapadat: CLC2006)

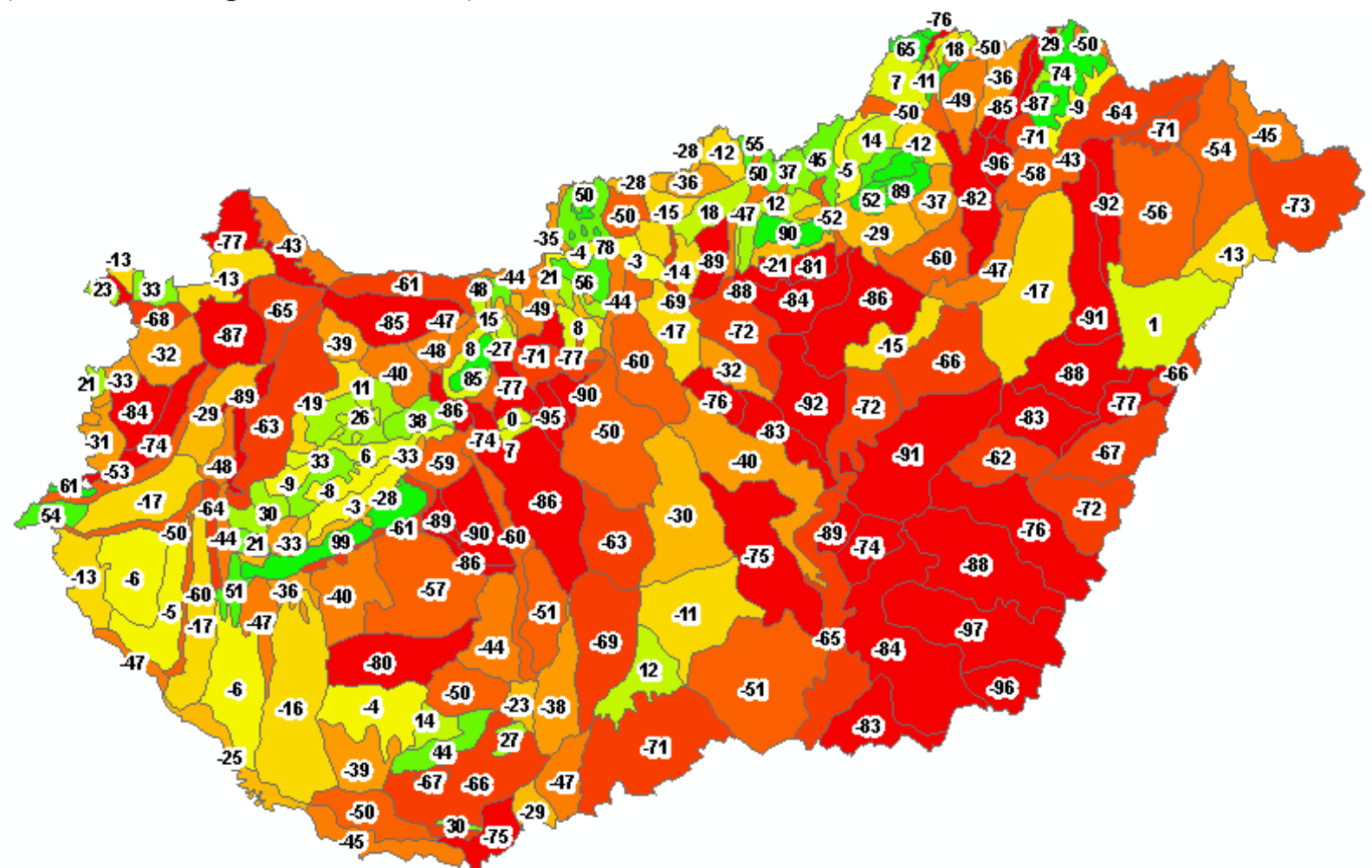

75. ábra Természetszerü felszínborítások arányának (CLC 3all+4all+5all) és a mesterséges jellegü felszínborítás típusok arányának (CLC 1all+2all) különbségét mutatják kistájanként. A számértékek a (CLC 3all+4all+5all területarány)-(CLC 1all+2all területarány) képlet eredményei (\%). A negatív számok azt jeletik, hogy a mesterséges felszínborítások dominálnak, míg a pozitív számok a természetesebb felszínborítások dominanciáját mutatják -100-tól +100-ig tartó skálán (Felhasznált alapadat: CLC2006) 
28. táblázat A CLC 100 adatbázisban előforduló felszínborítás kategóriák jellemzése tájképi nyitottság szerint (felszínborítás-kódokkal)

\begin{tabular}{|c|c|c|}
\hline Zárt (1 pont) & Átmeneti (2 pont) & Nyitott (3 pont) \\
\hline $\begin{array}{llll}111 & 112 & 121 & 133 \\
311 & 312 & 313 & 323\end{array}$ & $\begin{array}{lllll}141 & 142 \\
221 & 222 & 223 & 242 & 244 \\
324 & & & & \end{array}$ & $\begin{array}{llllllll}122 & 123 & 124 & 131 & 132 & & \\
211 & 212 & 213 & 231 & 241 & 243 & \\
321 & 322 & 331 & 332 & 333 & 334 & 335 \\
411 & 412 & 421 & 422 & 423 & & \\
511 & 512 & 521 & 522 & 523 & & \end{array}$ \\
\hline
\end{tabular}

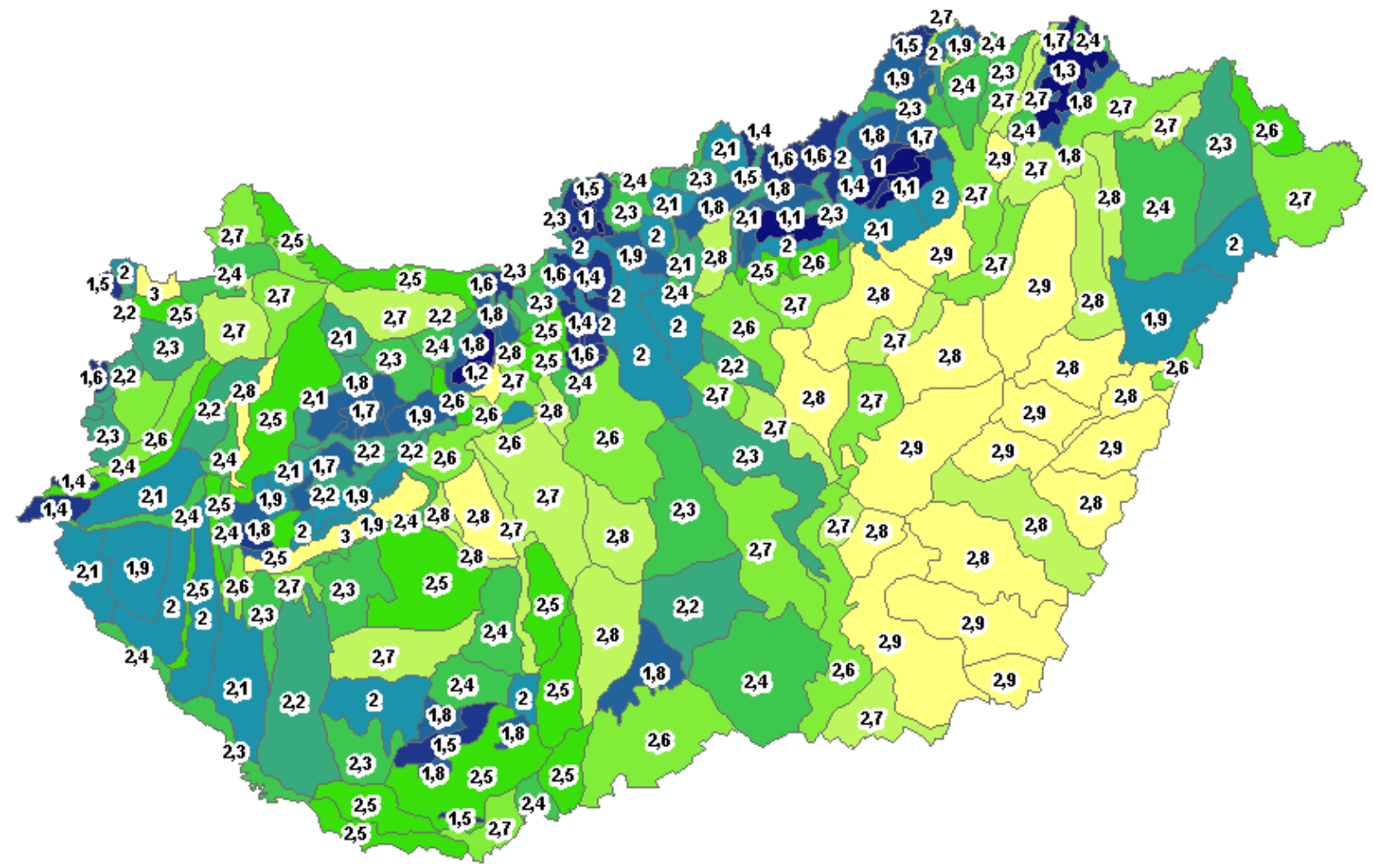

76. ábra Kistájak felsźnborítás-adatokból számítható nyitottság a jellemző tájelemek magasságától függően $\mathrm{A}$ nyitottabb tájegységek magasabb a zártabbak alacsonyabb pontszámmal szerepelnek (1-től 3-ig tartó skálán). 


\section{Természetszerú foltok területaránya (\%) Közép-Európai nagyvárosokban}

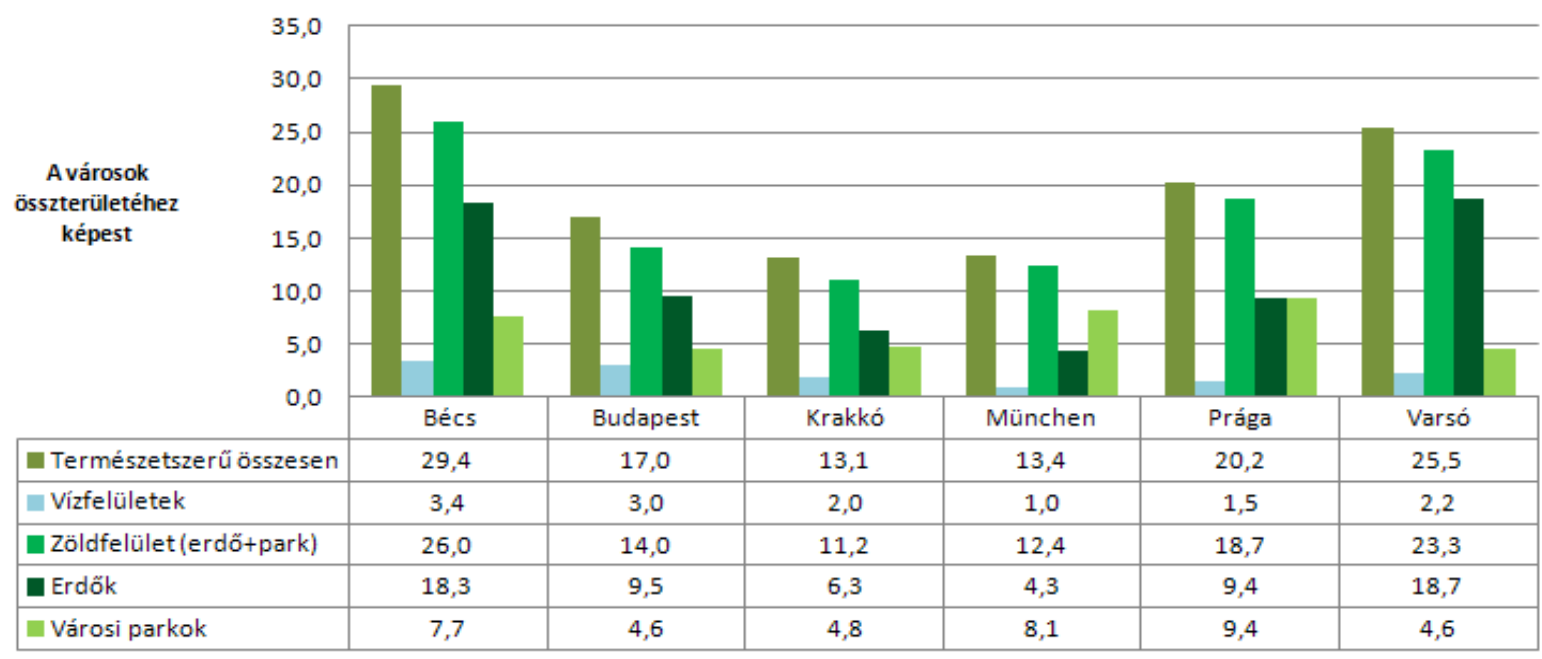

Természetszerú foltok "kerület/terület arány" mutatója Közép-Európai nagyvárosokban
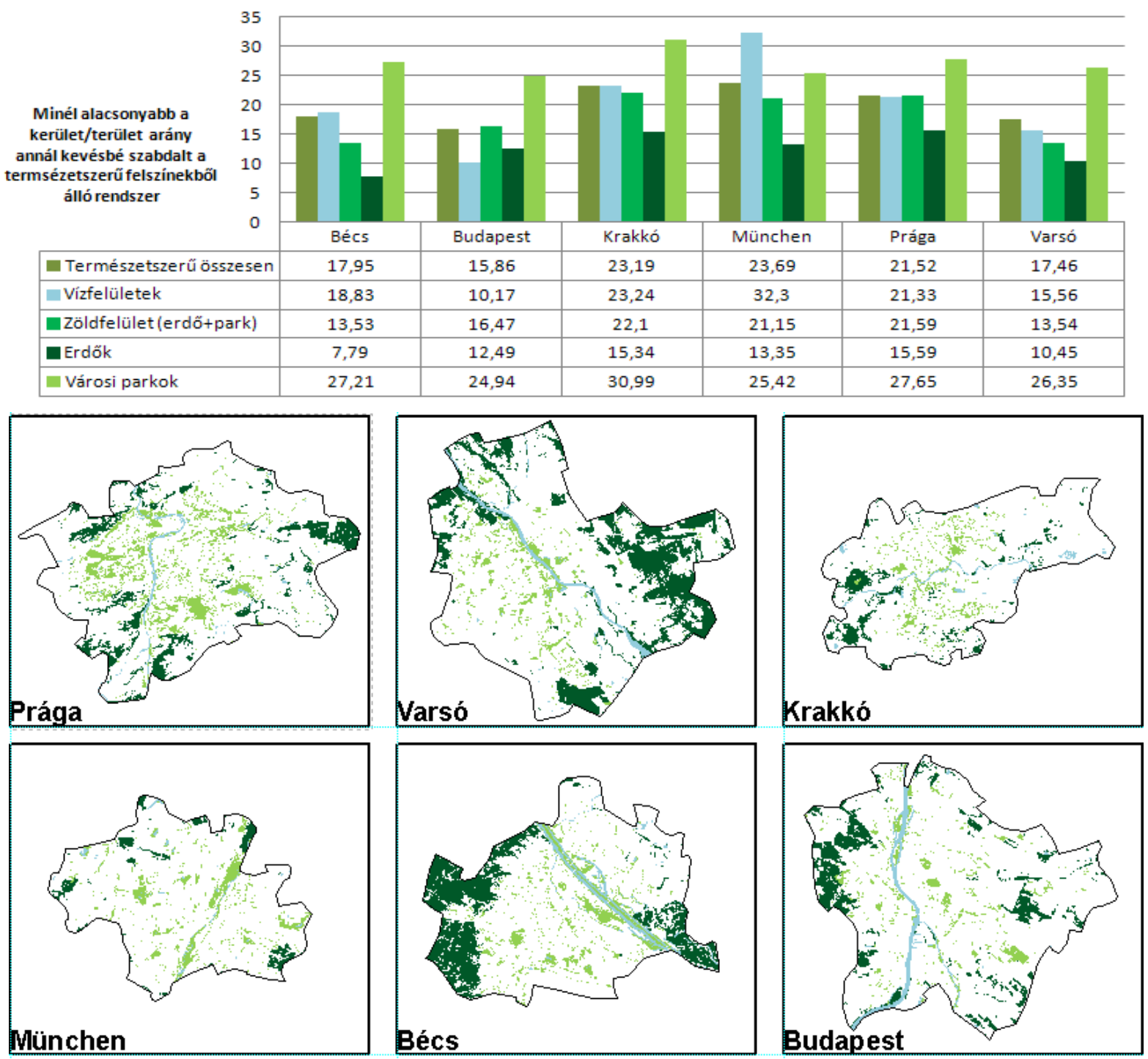

77. ábra Közép-Európai nagyvárosok jellemzése természetszerü felszínek egyes térbeli sajátosságai alapján. (felhasznált adatok forrása: European Urban Atlas, EEA) 

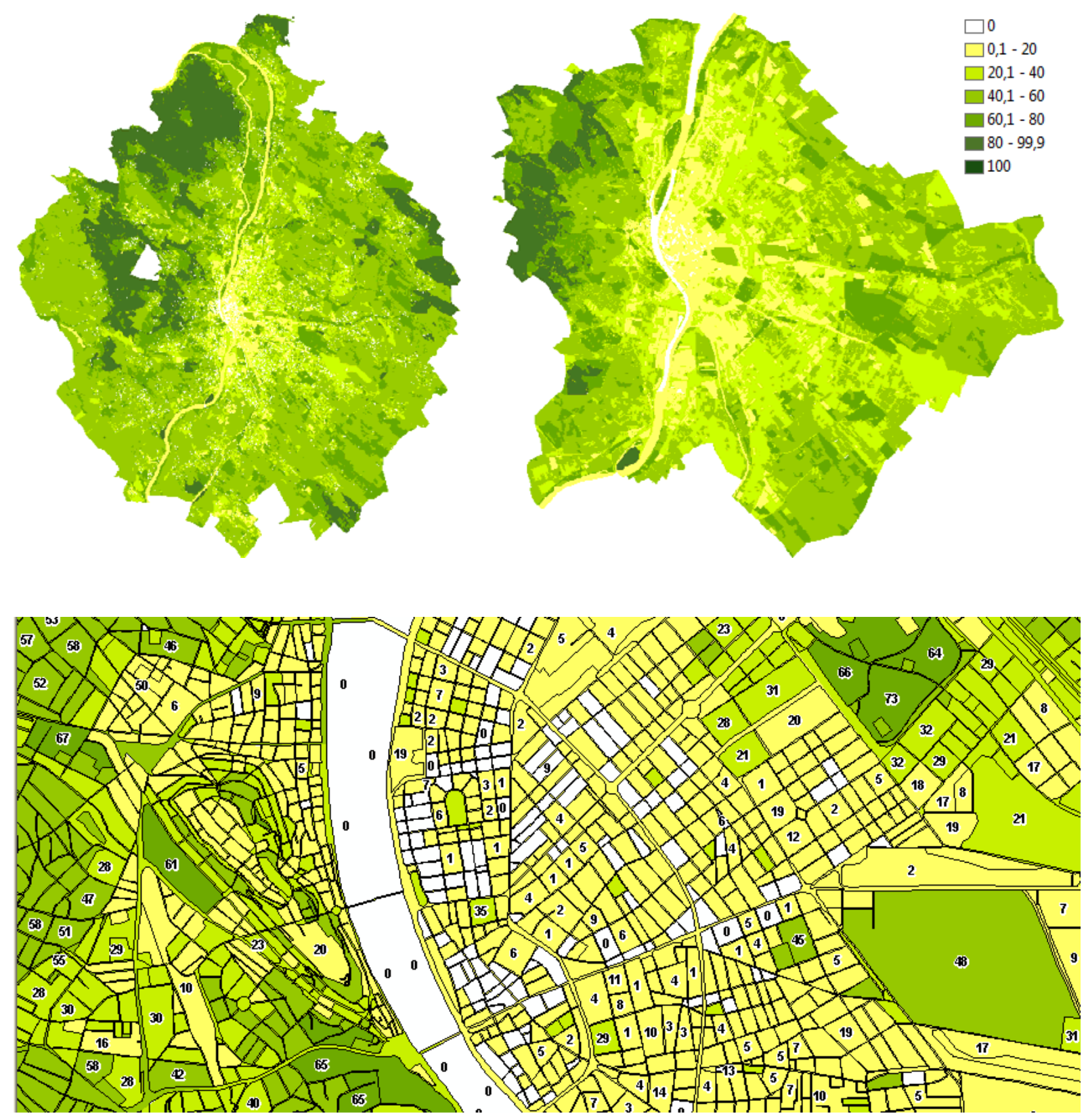

78. ábra Zöldfelület-intenzitás területi átlagolása az Urban Atlas adatbázis foltjaira (\%). Felhasznált alapadatok: Landsat felvételek ZFI elemzése 1986-2011 időszakra, Urban Atlas adatok. 

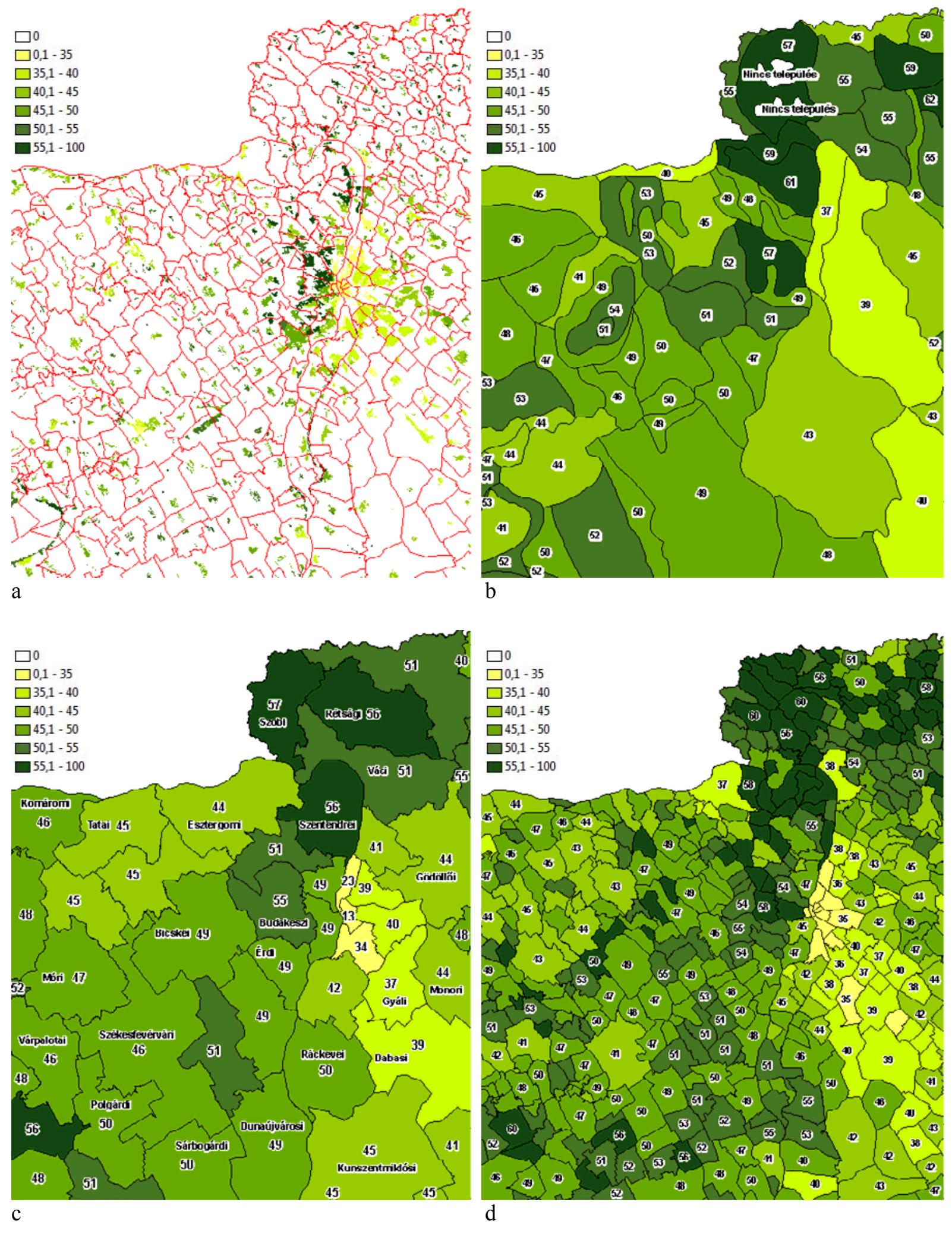

79. ábra Településszerkezetre jellemző zöldfelület-intenzitás (\%). Délnyugat-Budakörnyék térsége (a), kistájain (b) járásain (c) és településein (d). Felhasznált alapadatok: Landsat felvételek ZFI elemzése 1986-2011 időszakra, CLC50 2000-es adatok. 

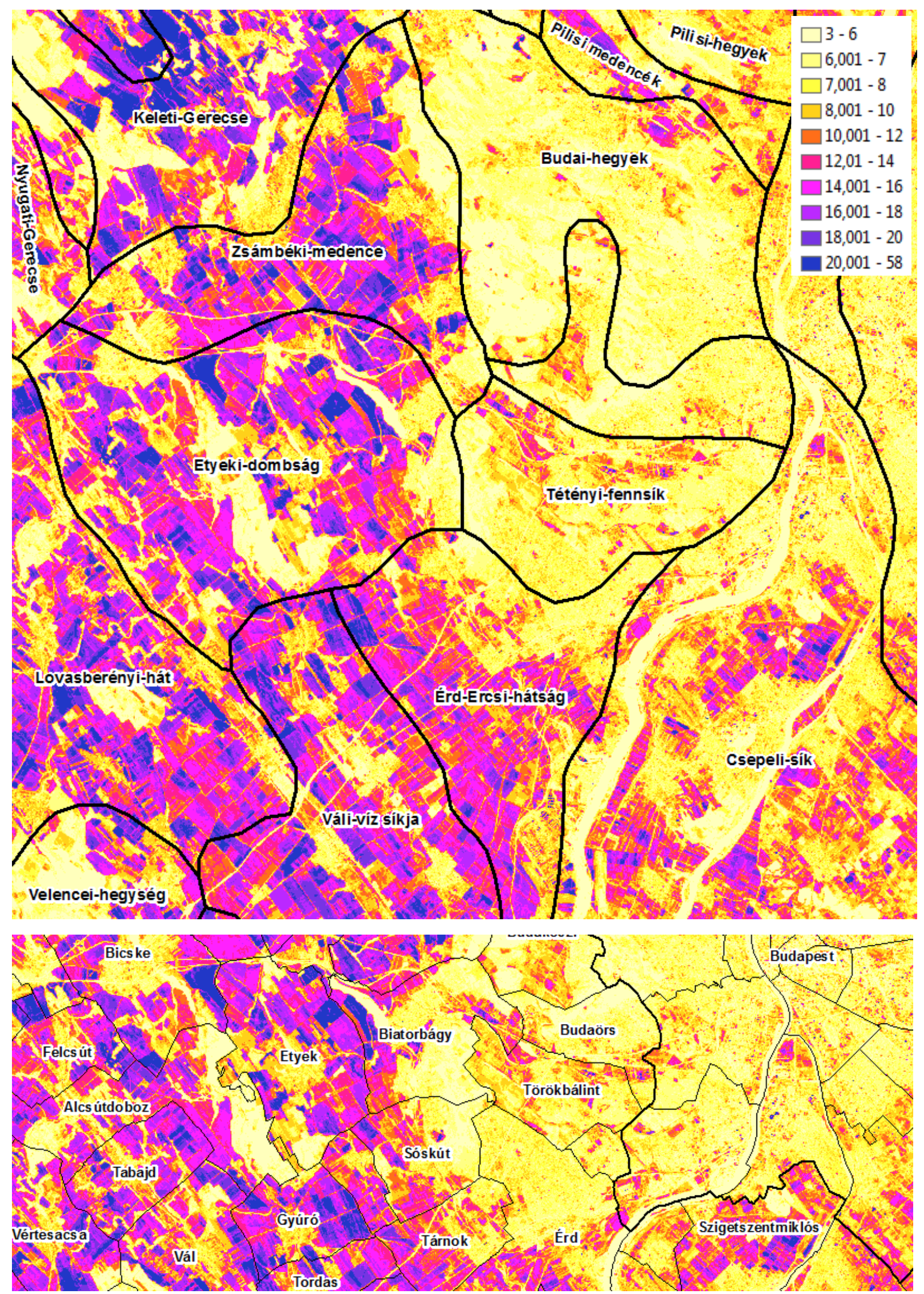

80. ábra Gyakran változó felszínü területek. A gyakran változó felszín kékkel, lilával jelenik meg (Az ábra Landsat TM5 felvételek felhasználásával 1986-2011 korszakban digitális számérték-különbségek (dn) abszolút értékei alapján készült) 


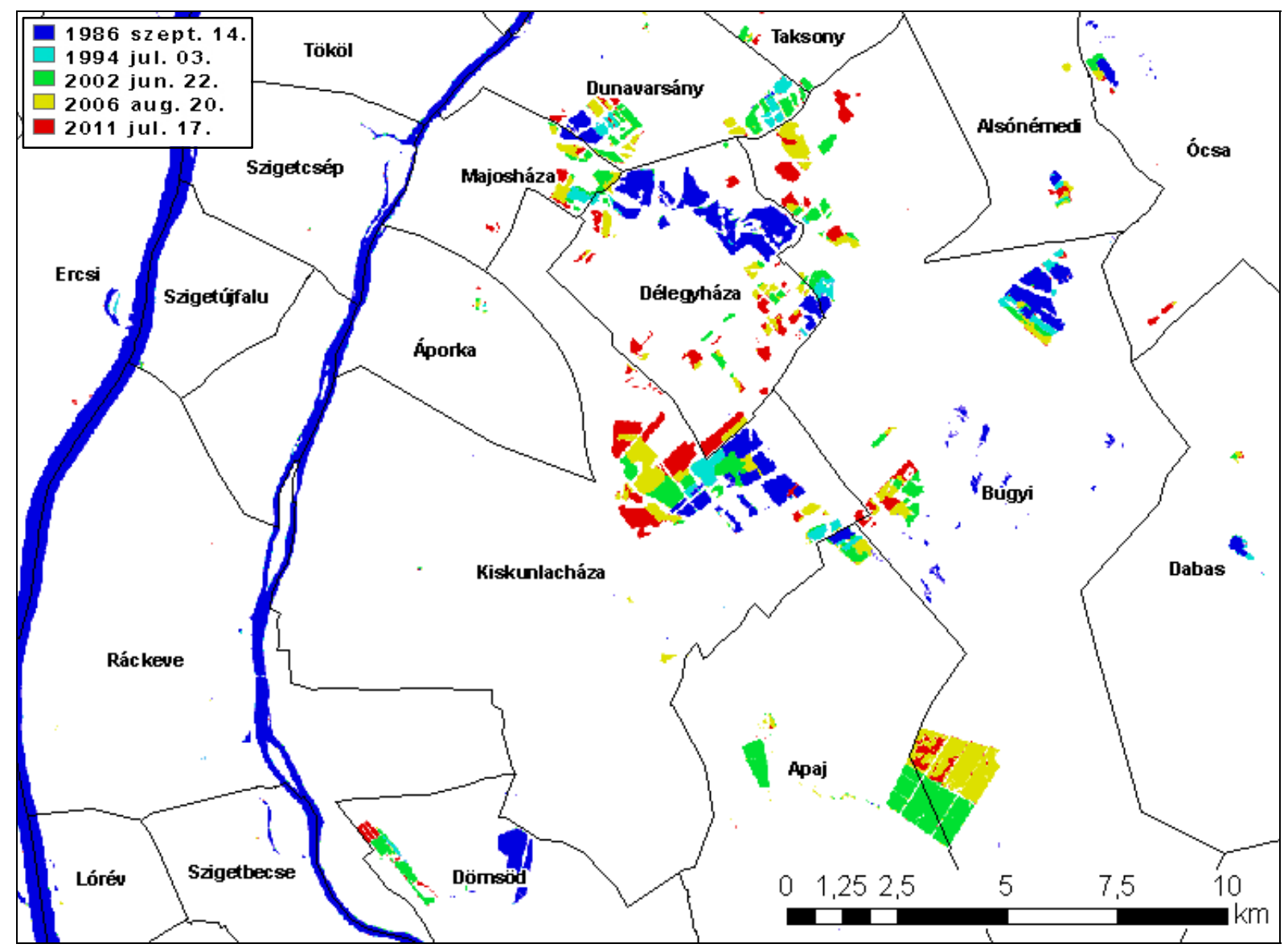

Vízfelszín növekedés, több időpontban készült Landsat TM5 és ETM+ felvételek MNDWI elemzésével
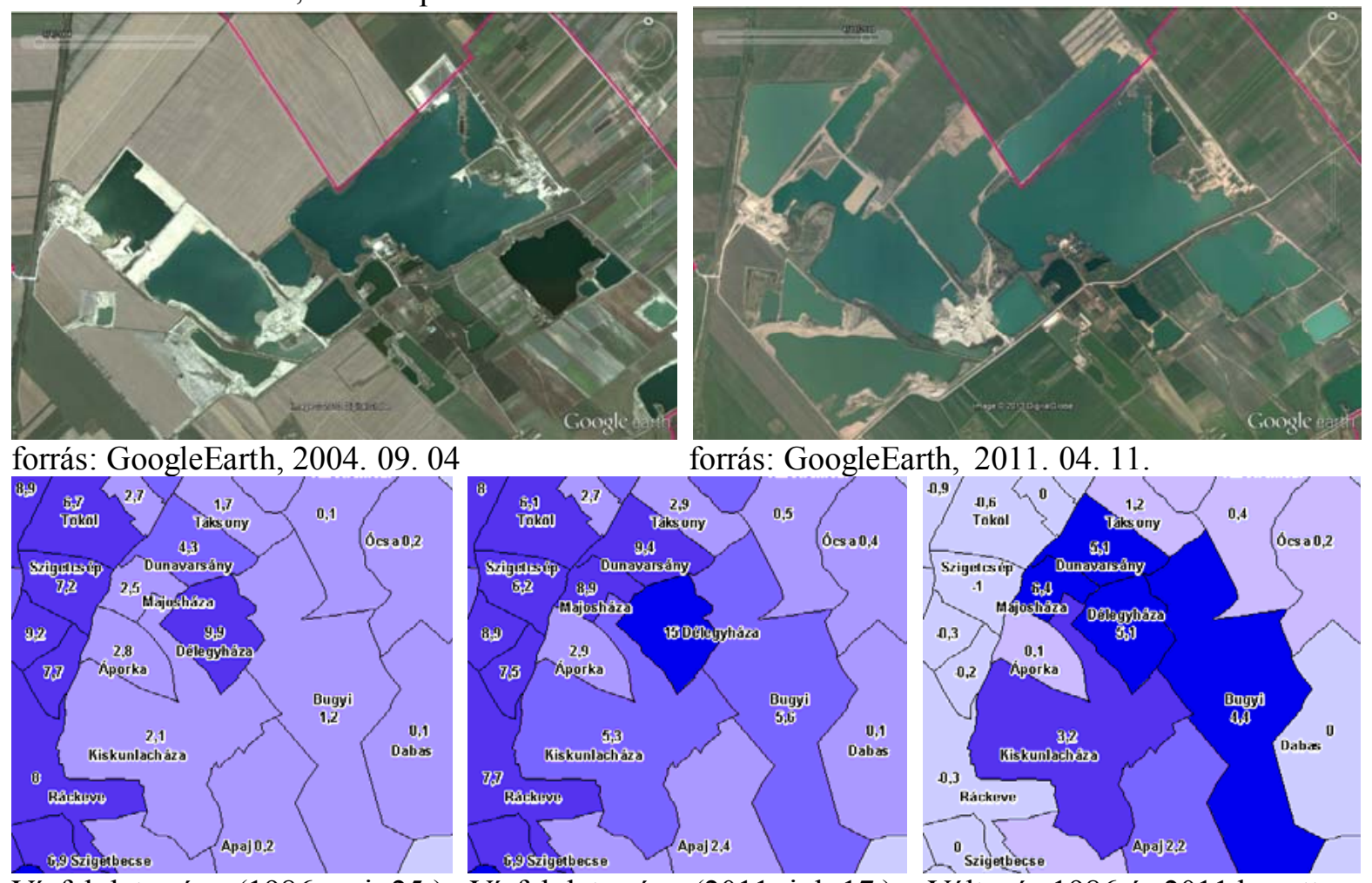

forrás: GoogleEarth, 2011. 04. 11.
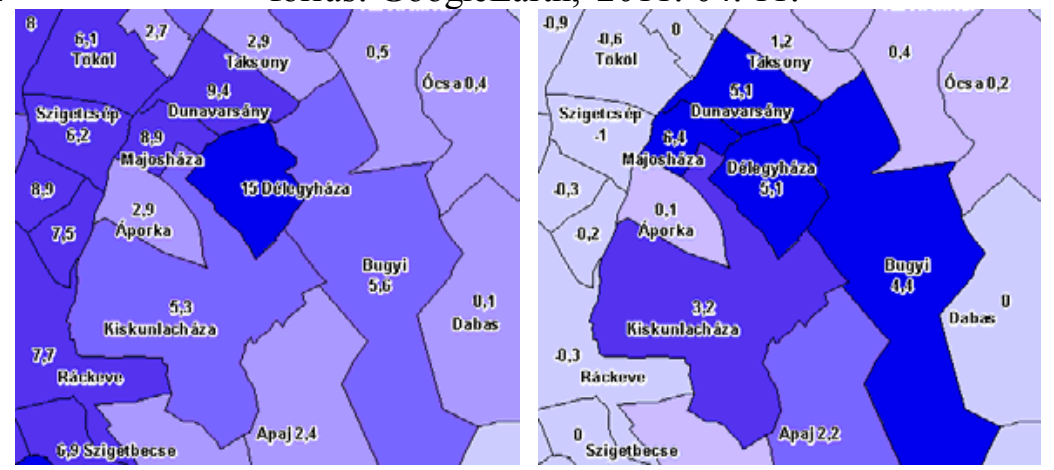

81. ábra Tájjelleg-változást eredményező vízfelszín-növekedés. Vízfelszín-növekedés (\%) Dél-pest környékén Landsat felvételek alapján. Kiskunlacháza és Délegyháza határában található tavakat ábrázoló nagyon nagy felbontású ürfelvételek forrása: GoogleEarth 
29. táblázat Az erdők szerepe az európai felszínborítások változásában a CLC 2000-2006 adatbázis szerint (Görögország esetében 1990-2000 időszakra)

\begin{tabular}{|l|r|c|}
\hline Jellemző & Érték & Mérőszám \\
\hline Változások összes száma (nem csak erdők) & 362849 & $\mathrm{db}$ \\
\hline Változások összterülete (nem csak erdő́k) & 73260 & $\mathrm{~km} 2$ \\
\hline Változások összes szegélye (nem csak erdők) & 786182 & $\mathrm{~km}$ \\
\hline & & \\
\hline A pusztán erdómúvelésból adódó változások száma & 260399 & $\mathrm{db}$ \\
\hline A puszzán erdómúvelésból adódó változások számaránya & 72 & $\%$ \\
\hline & 272092 & \\
\hline Az erdóterületet érintő változások száma & 75 & $\%$ \\
\hline Az erdőterületet érintő változások számaránya & & \\
\hline & 49186 & $\mathrm{~km} 2$ \\
\hline Erdóterülettel kapcsolatos változások kiterjedése & 67 & $\%$ \\
\hline Erdőterülettel kapcsolatos változások területi aránya & 565580 & $\mathrm{~km}$ \\
\hline A potenciálisan érintett erdőszegély maximális hossza & 72 & $\%$ \\
\hline Erdőterülettel kapcsolatos változások max. szegélyének aránya & & \\
\hline
\end{tabular}

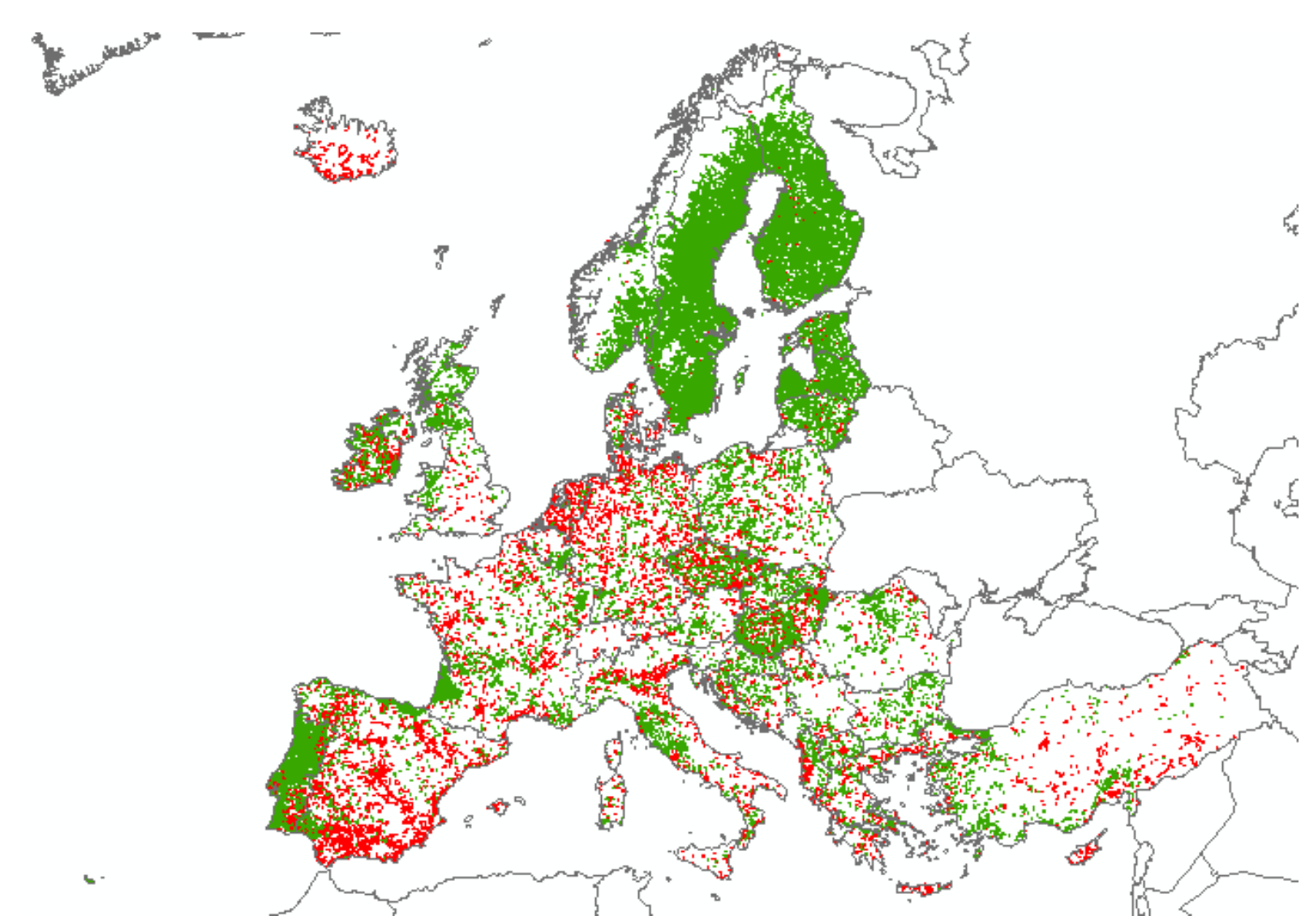

82. ábra Az erdők szerepe az európai felsźnborítások változásában a CLC 2000-2006 adatbázis szerint (Görögország esetében 1990-2000 időszakra). Az ábrán valamennyi változásfolt szerepel. Zölddel jelennek meg azok, amelyek erdőkkel érintettek.

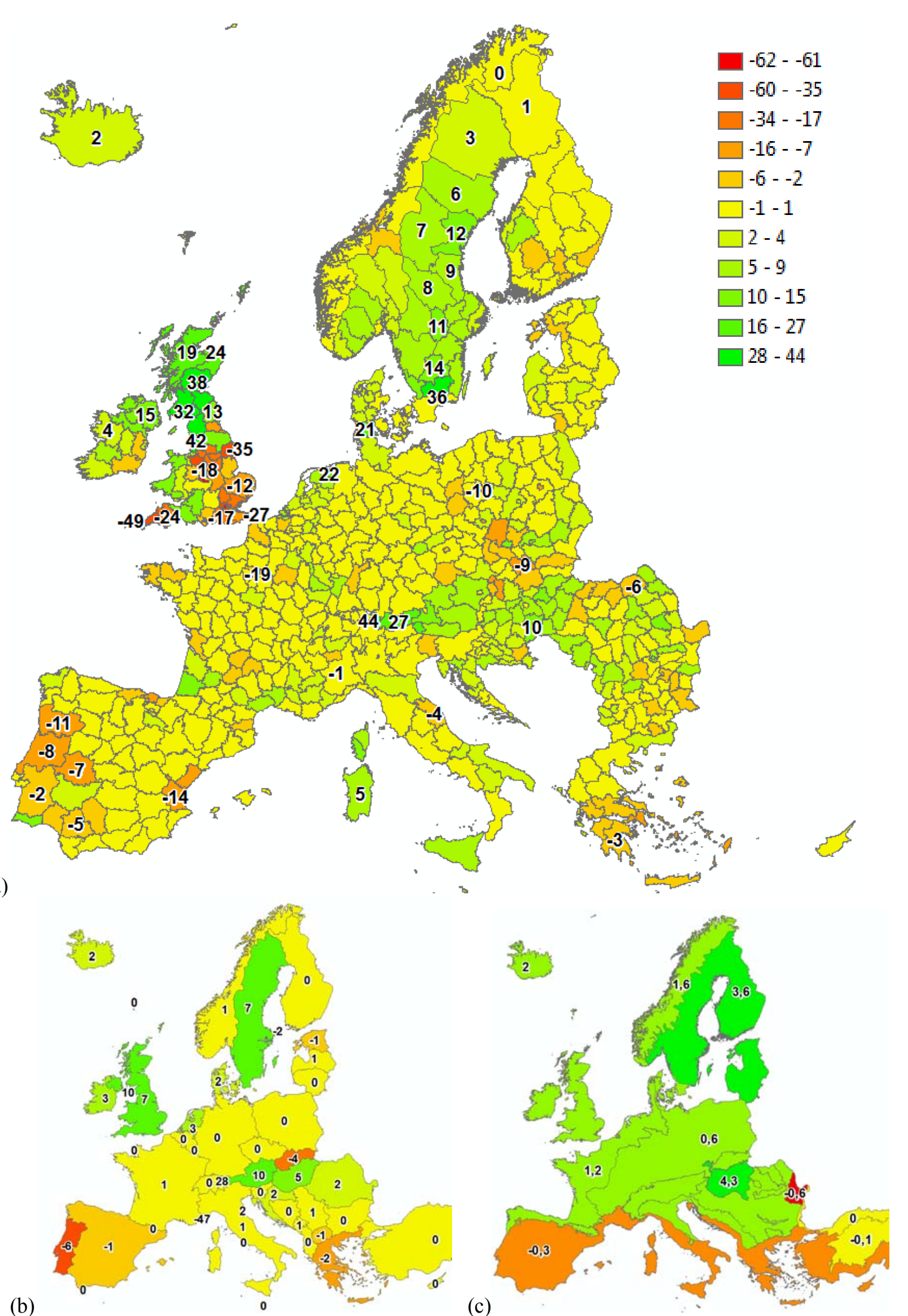

83. ábra Az erdőszegély változása a korábbi értékhez képest (\%) 2000-2006 közötti idószakban (a) EU28+3 állam területén, (b) NUTS2/NUTS3 régiókban, (c) Biogeográfiai régiókban (CLC100 2000 és 2006 Adatbázis alapján, Görögország területén 1990-2000 időszakra) 


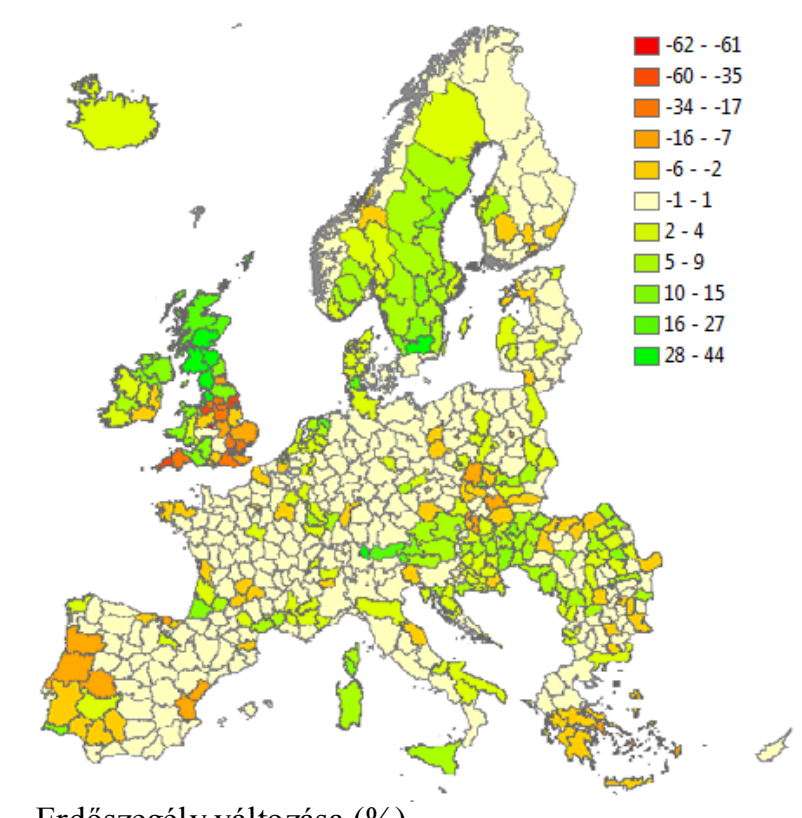

Erdőszegély változása (\%)

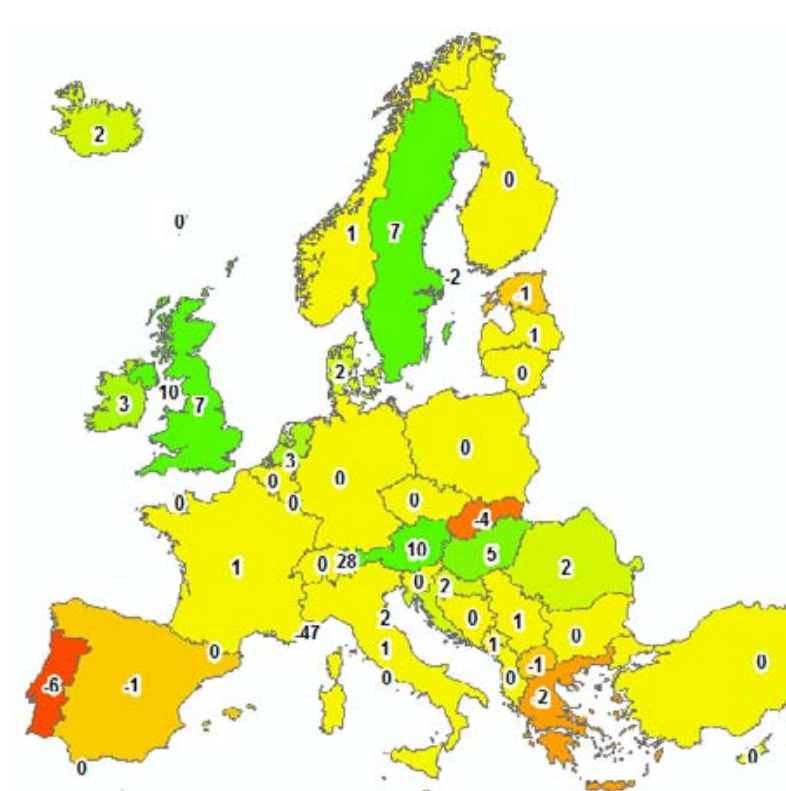

Erdőszegély változása (\%)

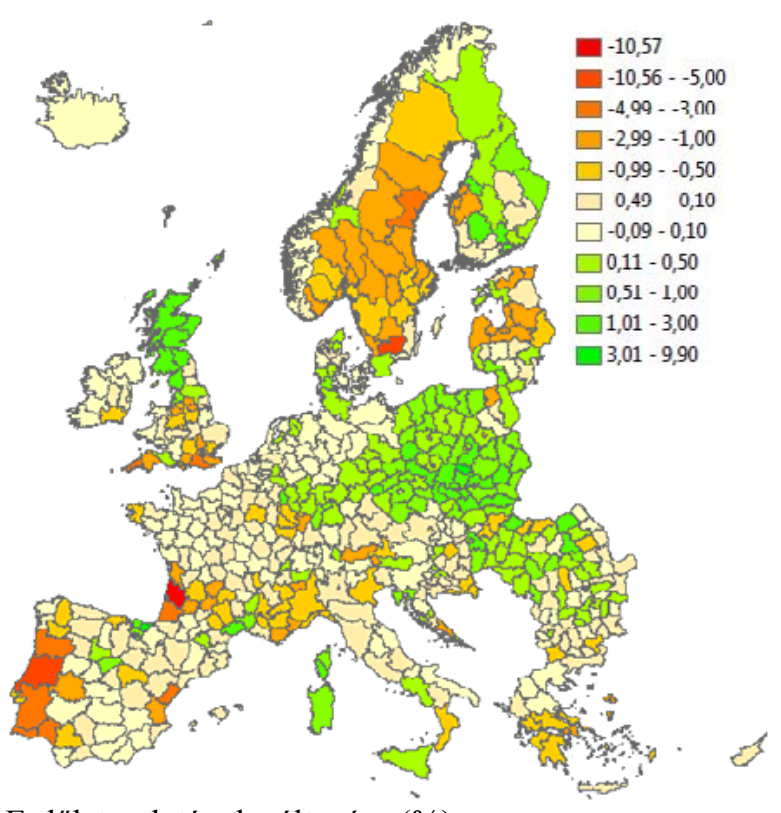

Erdök területének változása (\%)

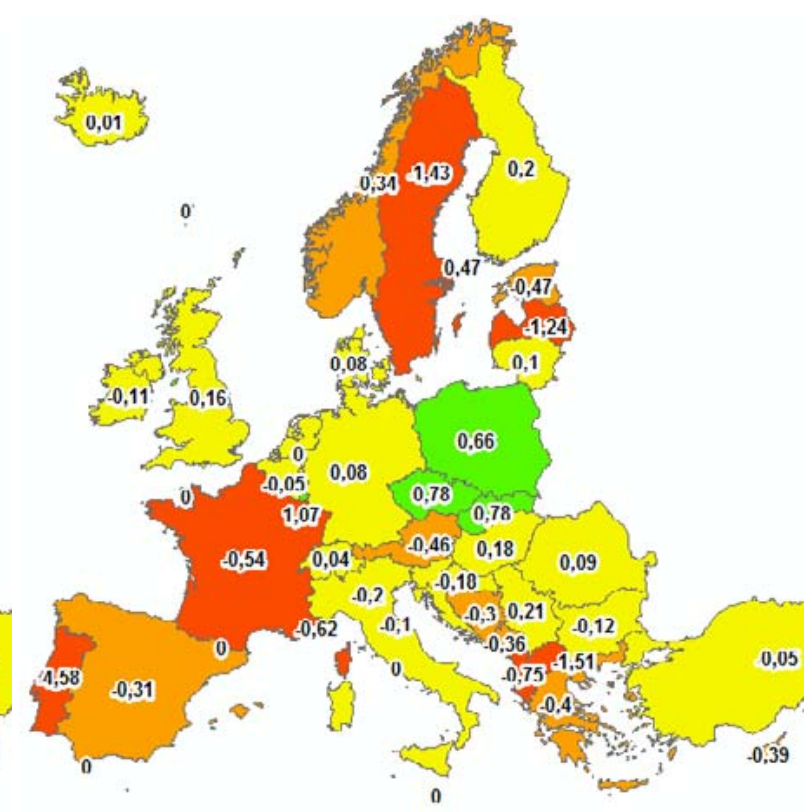

Erdők területének változása (\%)

84. ábra Az erdőszegély és erdőterület változása a korábbi értékhez képest (\%) 20002006 közötti időszakban NUTS2/NUTS3 régiókban az EU28+3 állam területén (CLC100 2000 és 2006 Adatbázis alapján, Görögország területén 1990-2000 időszakra)

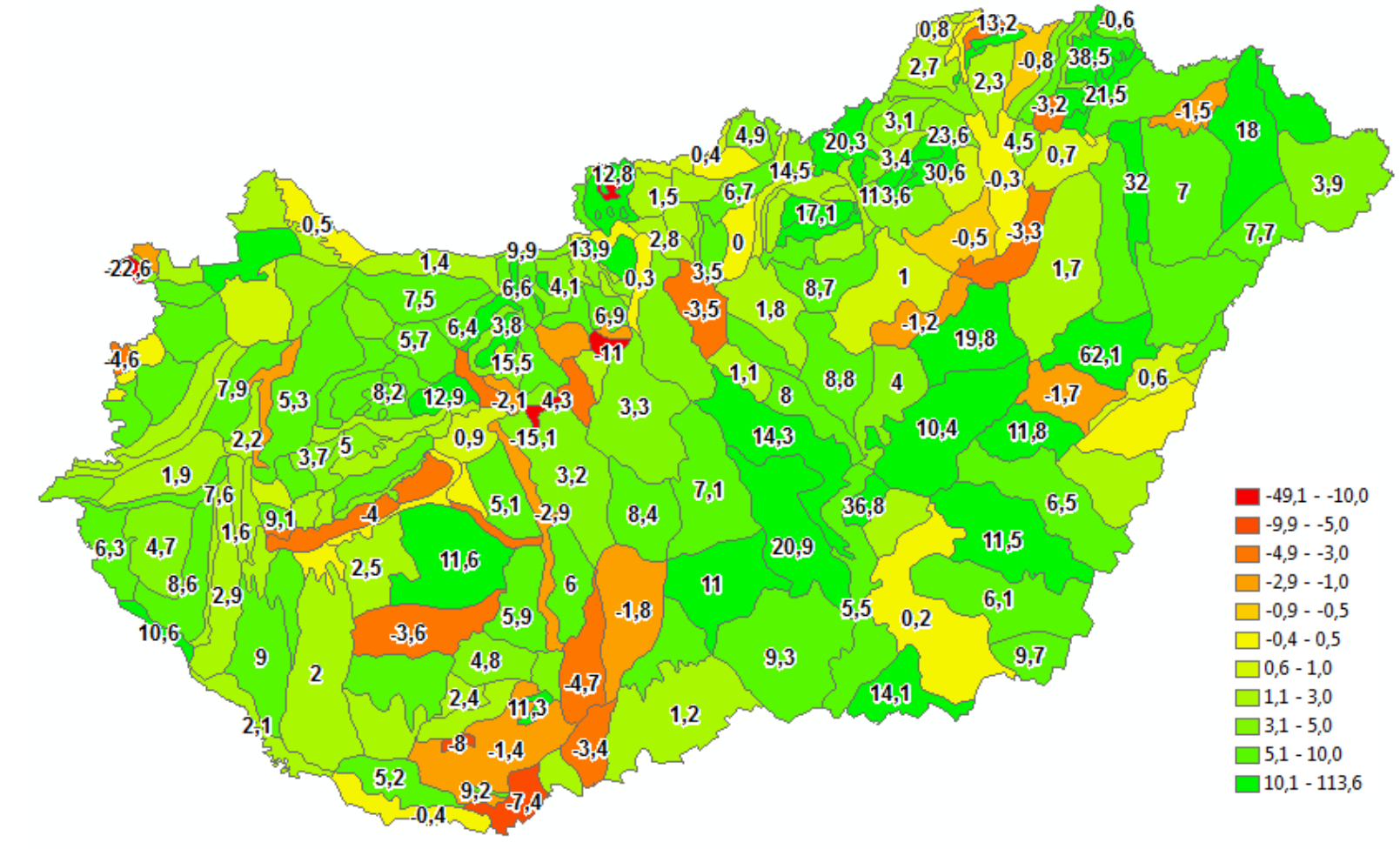

85. ábra Az erdőszegély változása a korábbi értékhez képest (\%) Magyarország kistájain 2000-2006 között (CLC2000 és CLC2006 adatbázis felhasználásával)

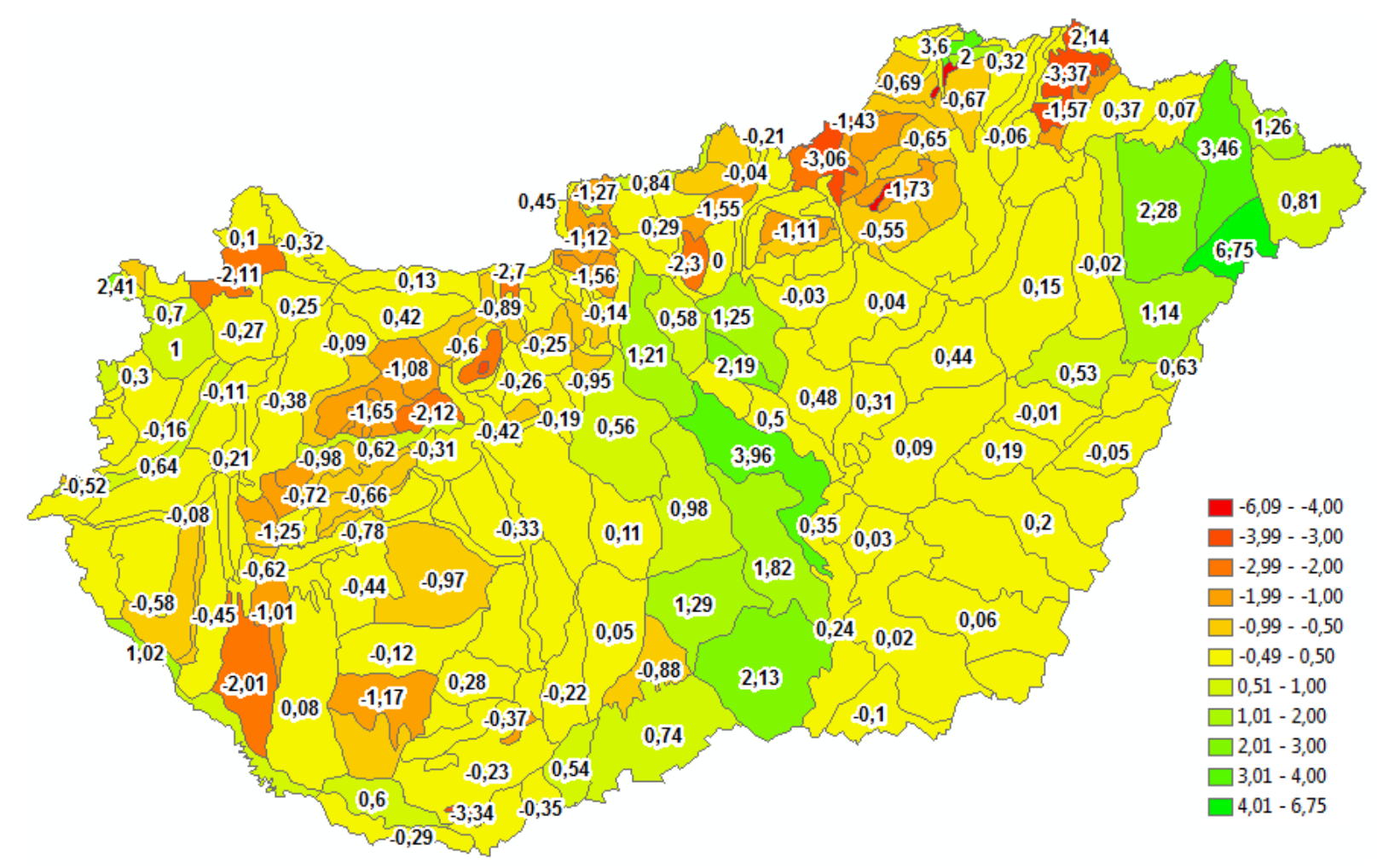

86. ábra Az erdőterület változása a korábbi értékhez képest (\%) Magyarország kistájain 2000-2006 között (CLC2000 és CLC2006 adatbázis felhasználásával) 


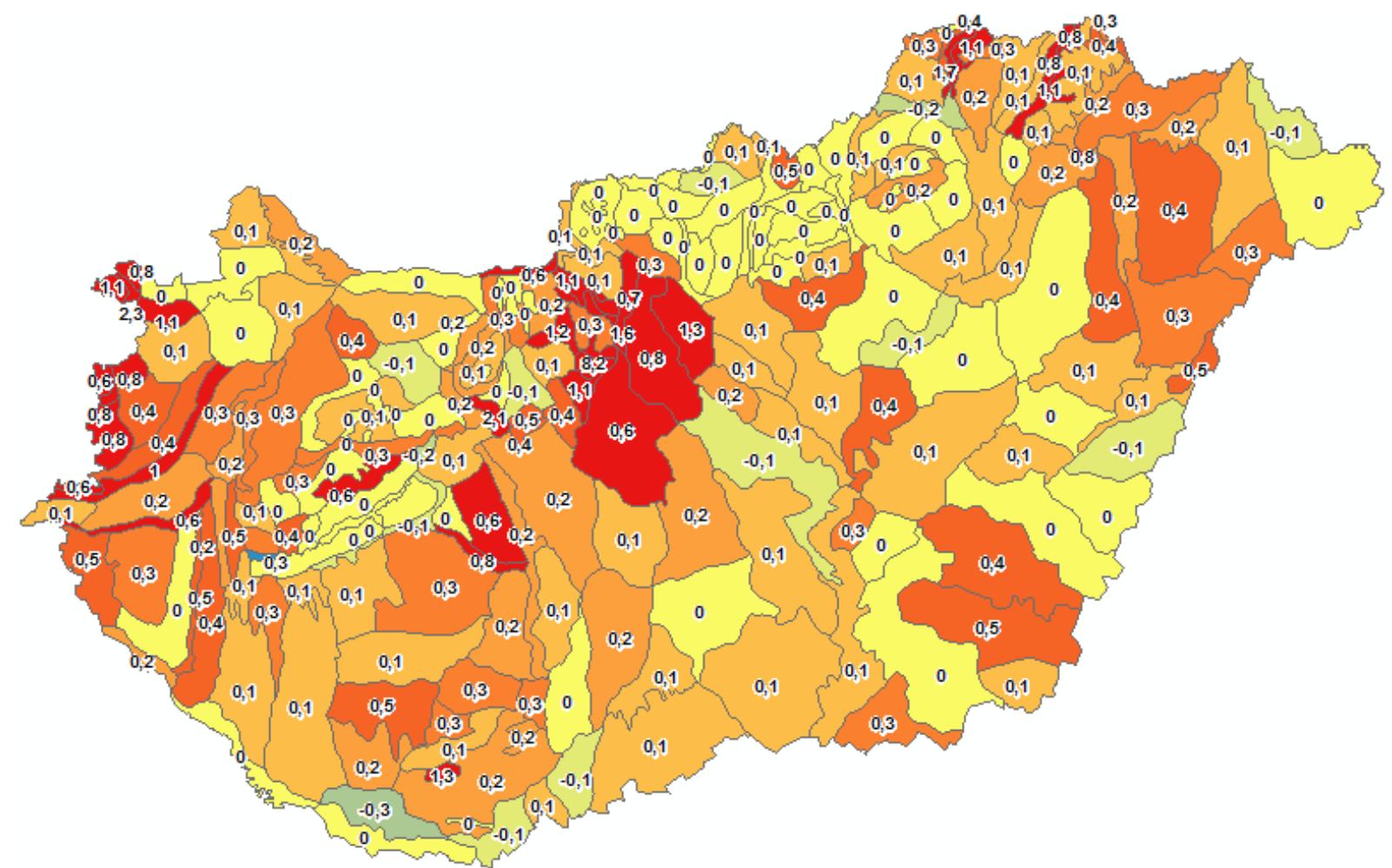

87. ábra Az településszerkezet változása a korábbi értékhez képest (\%) (CLC111, CLC112) Magyarország kistájain 1990-2006 között (CLC2000 és CLC2006 adatbázis felhasználásával)

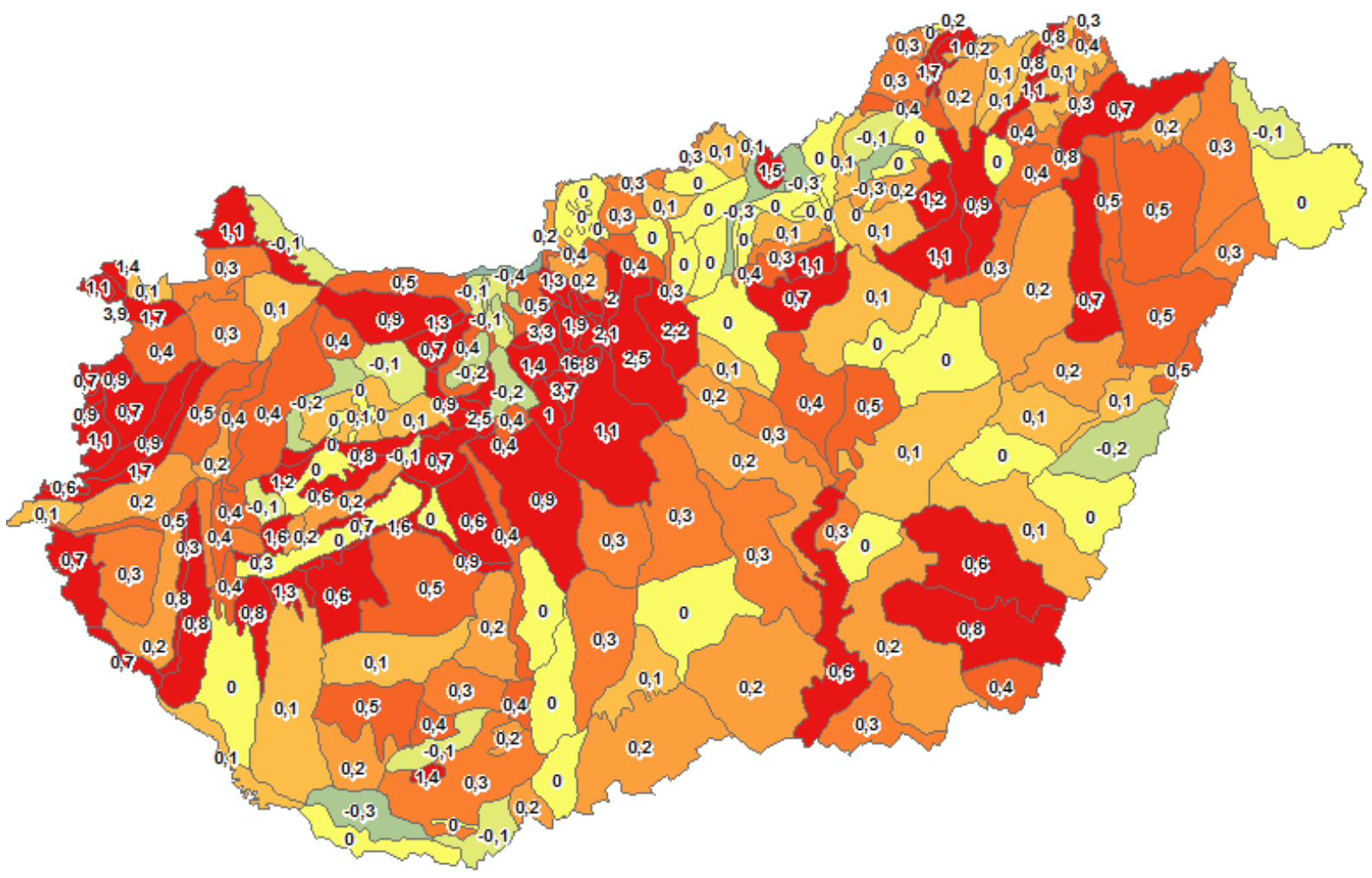

88. ábra A mesterséges felszínek változása a korábbi értékhez képest (\%) (CLC 1xx) Magyarország kistájain 1990-2006 között (CLC2000 és CLC2006 adatbázis felhasználásával) 


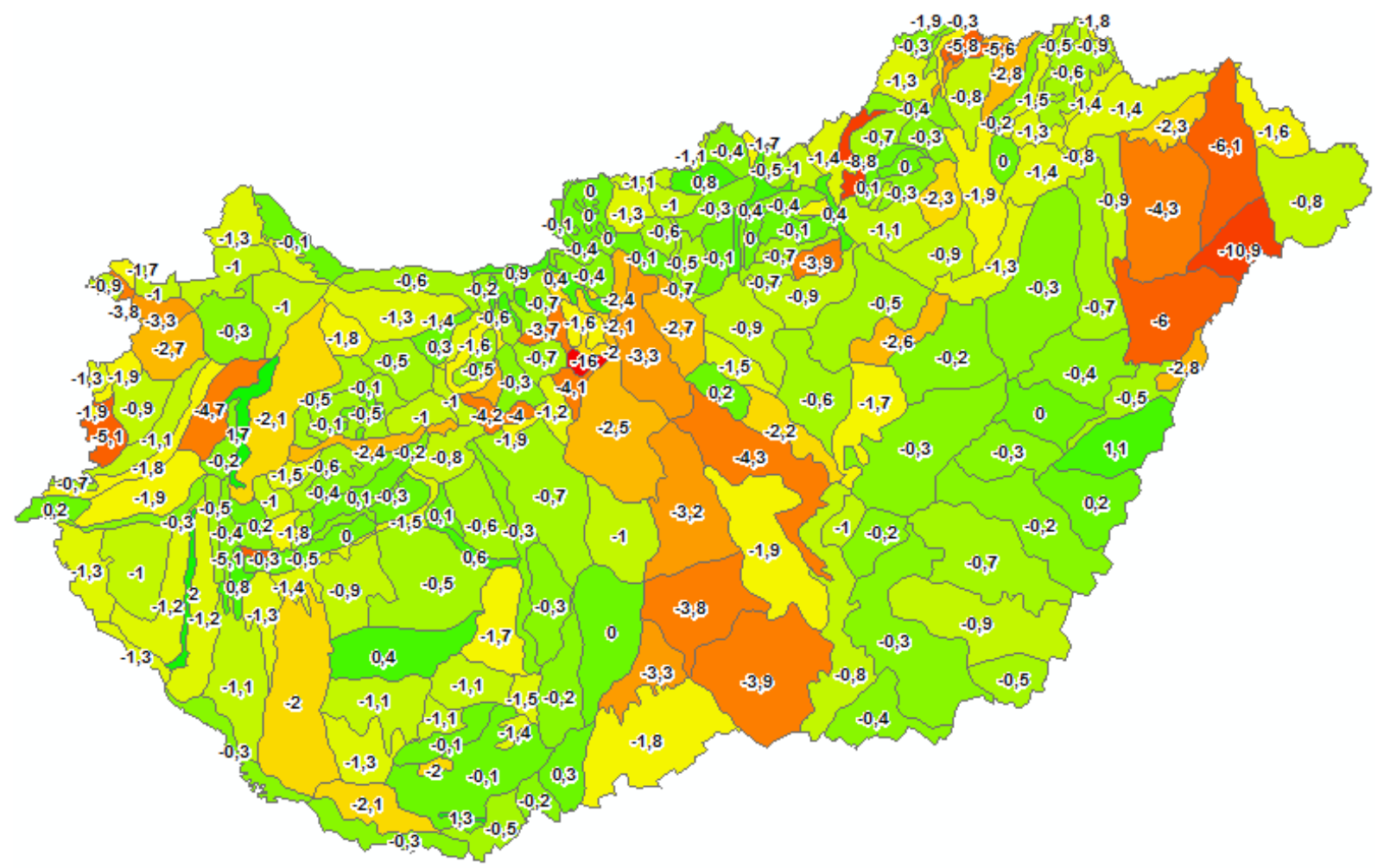

89. ábra A mezőgazdasági jellegü felszínek változása a korábbi értékhez képest (\%) (CLC 2xx) Magyarország kistájain 1990-2006 között (CLC2000 és CLC2006 adatbázis felhasználásával)

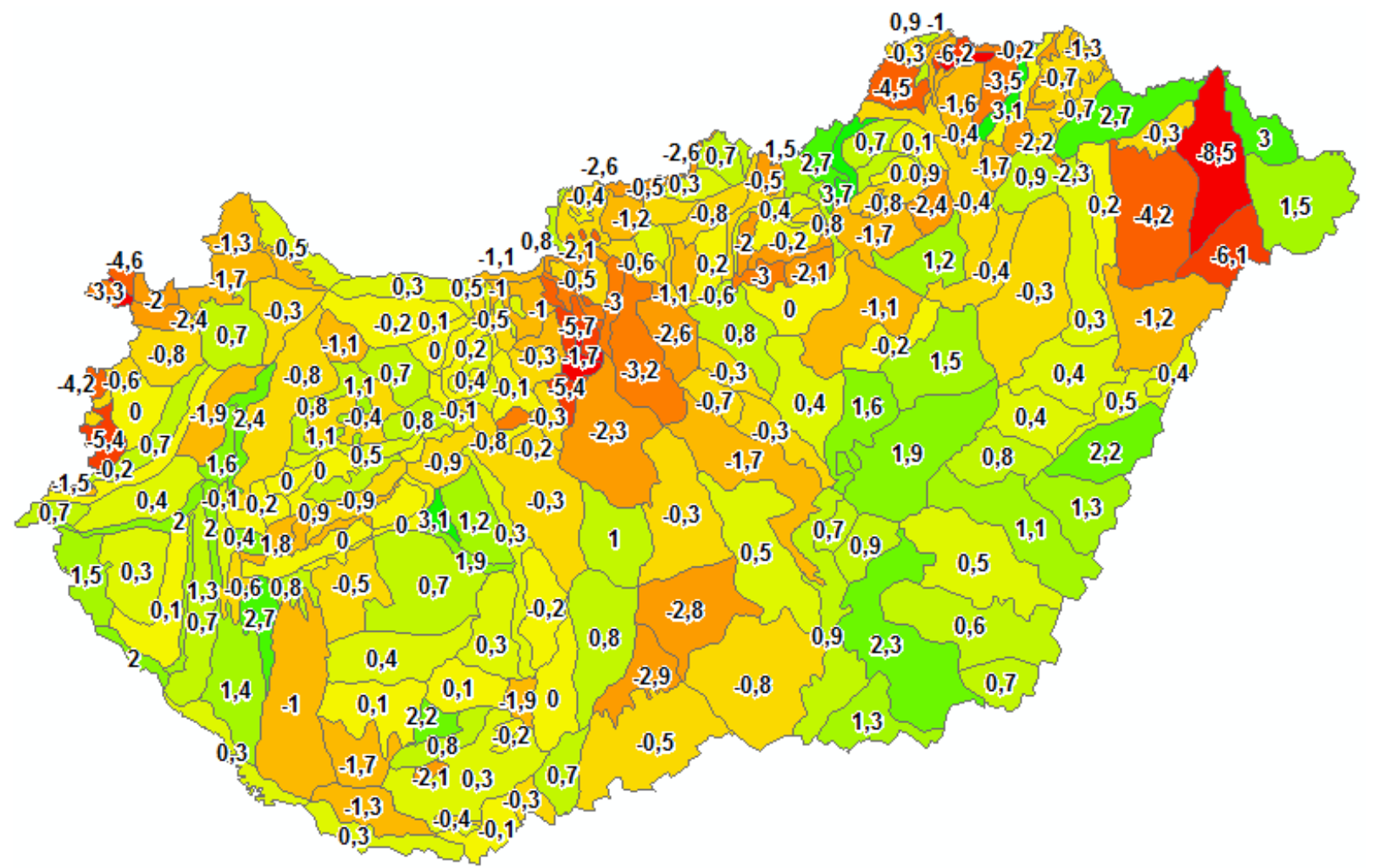

90. ábra A szántók változása a korábbi értékhez képest (\%) (CLC211) Magyarország kistájain 1990-2006 között (CLC2000 és CLC2006 adatbázis felhasználásával) 


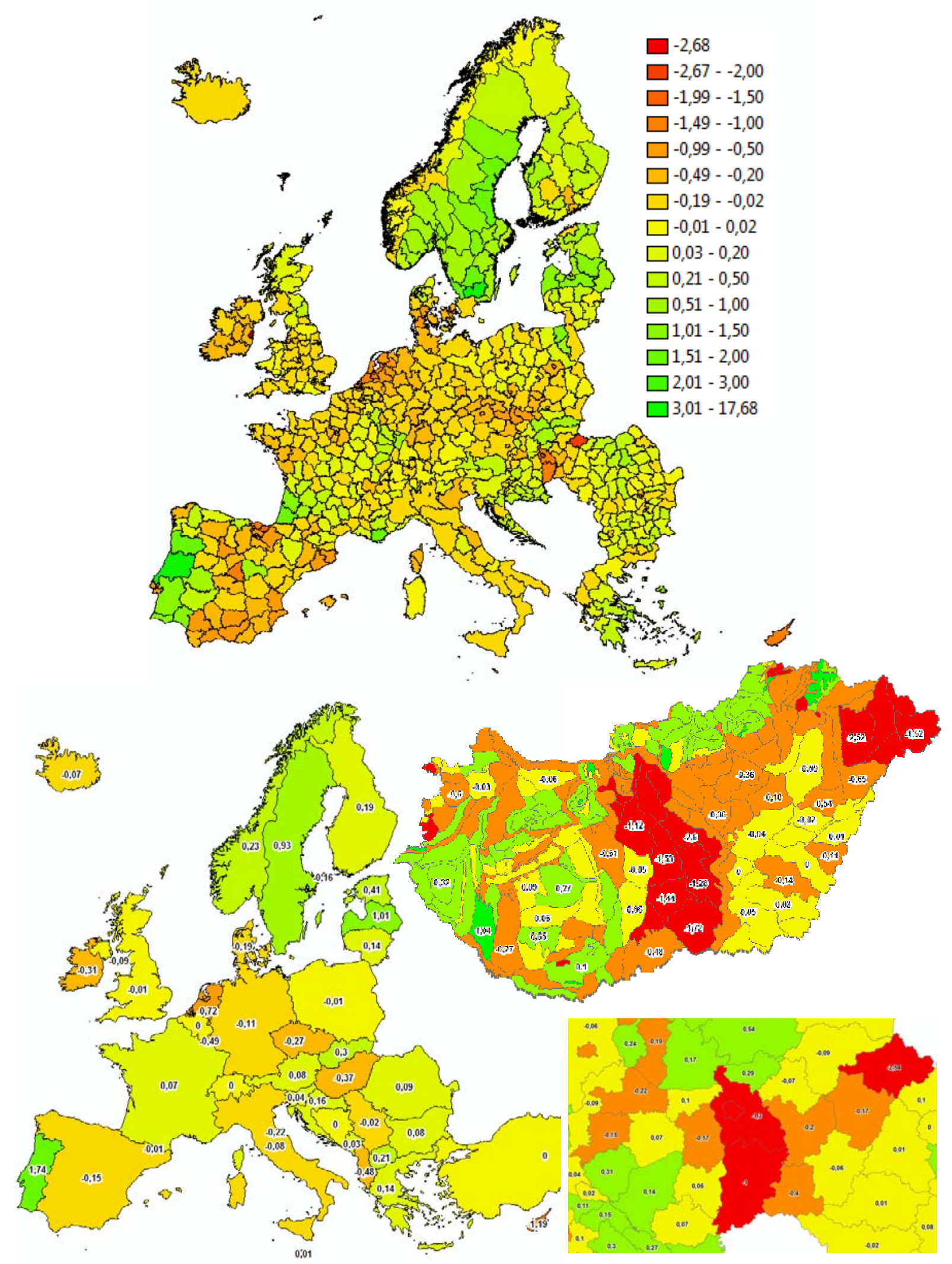

91. ábra A Táj nyitottságának változása 2000 és 2006 időpontok között Európa egyes államaiban $^{22}(\%)$. A Táj nyitottságának változása 2000 és 2006 időszakban Magyarországon (megyékre és kistájakra) A számértékek megmutatják, hogy a vizsgált területegység milyen arányáú (\%) területrészén történt milyen irányú (+/-) nyitottság-változás.

\footnotetext{
${ }^{22}$ Görögorszá gra nem áll rendelkezésre 2006-os adat, ezért ott az 1990-2000 időszakot vettem figyelembe
} 


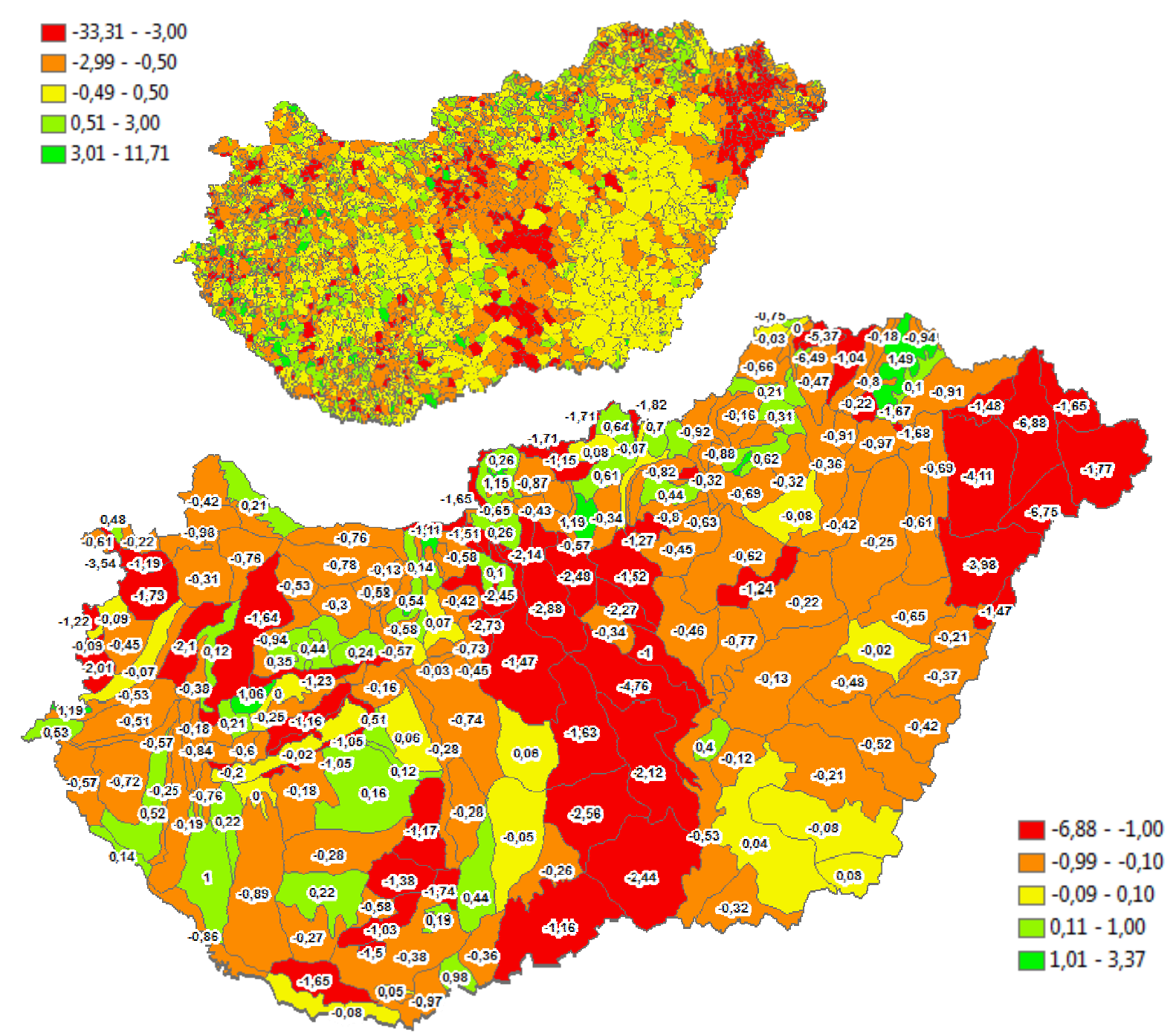

92. ábra A Táj nyitottságának változása 1990 és 2006 időpontok között Magyarországon. A mutató azt jelzi, hogy a tájegység vagy település területének hány százalékán történt változás a táj nyitottságában. A „,-33,3\%” egy település területén azt jelenti, hogy a terület harmadán teljes záródás történt, vagy kétharmadán részleges záródás történt

\section{0. táblázat $A$ „táj nyitottságának változása” indikátor számításának módszere}

CLC 100 adatbázisban előforduló felszínborítás kategóriák jellemzése a meghatározó tájelemek magasságából következő nyitottság szerint. A 0, 0,5 és 1 pontok szorzóként szerepelnek a nyitottságváltozás területének felhasználásakor:

\begin{tabular}{|c|c|c|}
\hline Zárt (0 pont) & Átmeneti (0,5 pont) & Nyitott (1 pont) \\
\hline $\begin{array}{llll}111 & 112 & 121 & 133 \\
311 & 312 & 313 & 323\end{array}$ & $\begin{array}{c}141 \quad 142 \\
221222223 \quad 242 \quad 244 \\
323 \quad 324 \\
412\end{array}$ & 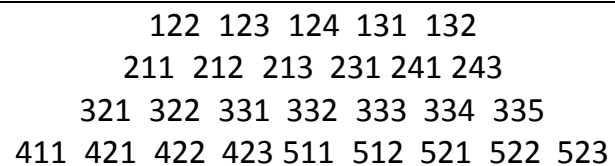 \\
\hline
\end{tabular}

A táj nyitottságának változása indikátor képlete:

$$
\text { VáltCLC * (NyitKódCLC2006 - NyitKódCLC2000) }
$$

\section{TájTer * 100}

Ahol:

VáltCLC $=\mathrm{a}$ felszínborítás-változás területe $\left(\mathrm{km}^{2}\right)$

NyitKódCLC2000 = a korábbi felszínborítás-kategória nyitottság értéke ( 0 és 1 között)

NyitKódCLC2006 = a későbbi felszínborítás-kategória nyitottság értéke ( 0 és 1 között)

TájTer $=$ a tájegység, vagy tájtípus területe $\left(\mathrm{km}^{2}\right)$ 

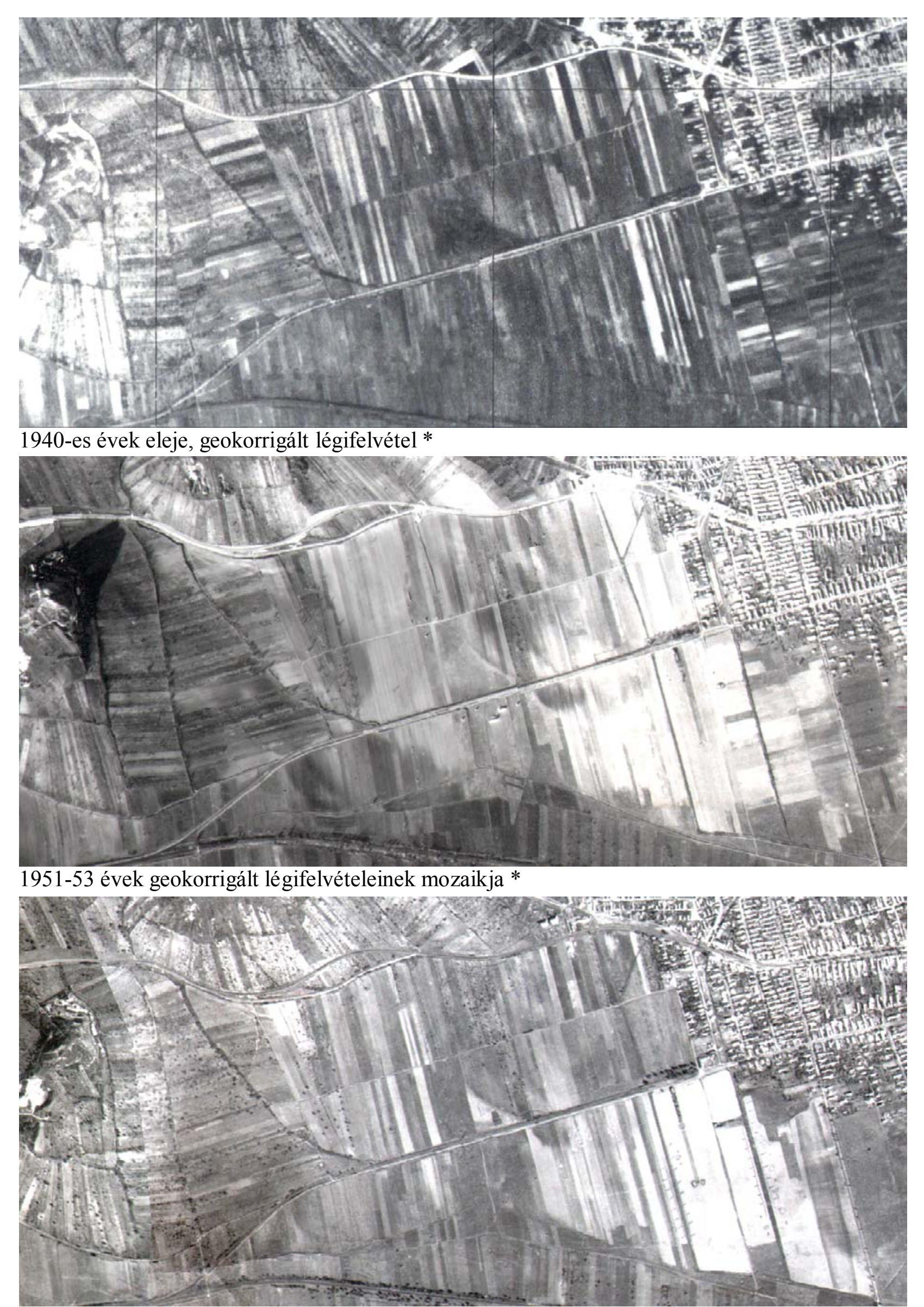

1958-as geokorrigált légifelvételek mozaikja *
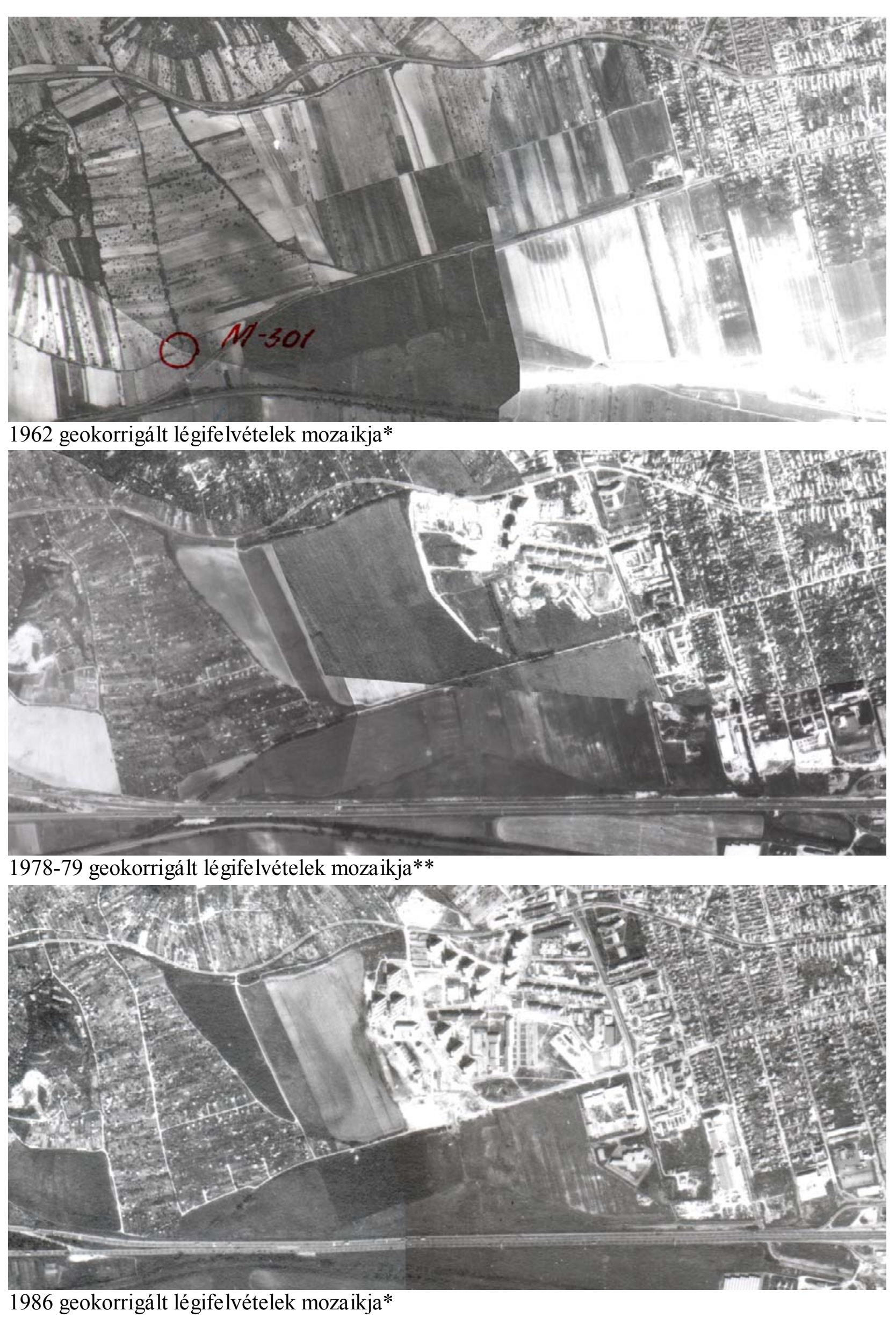


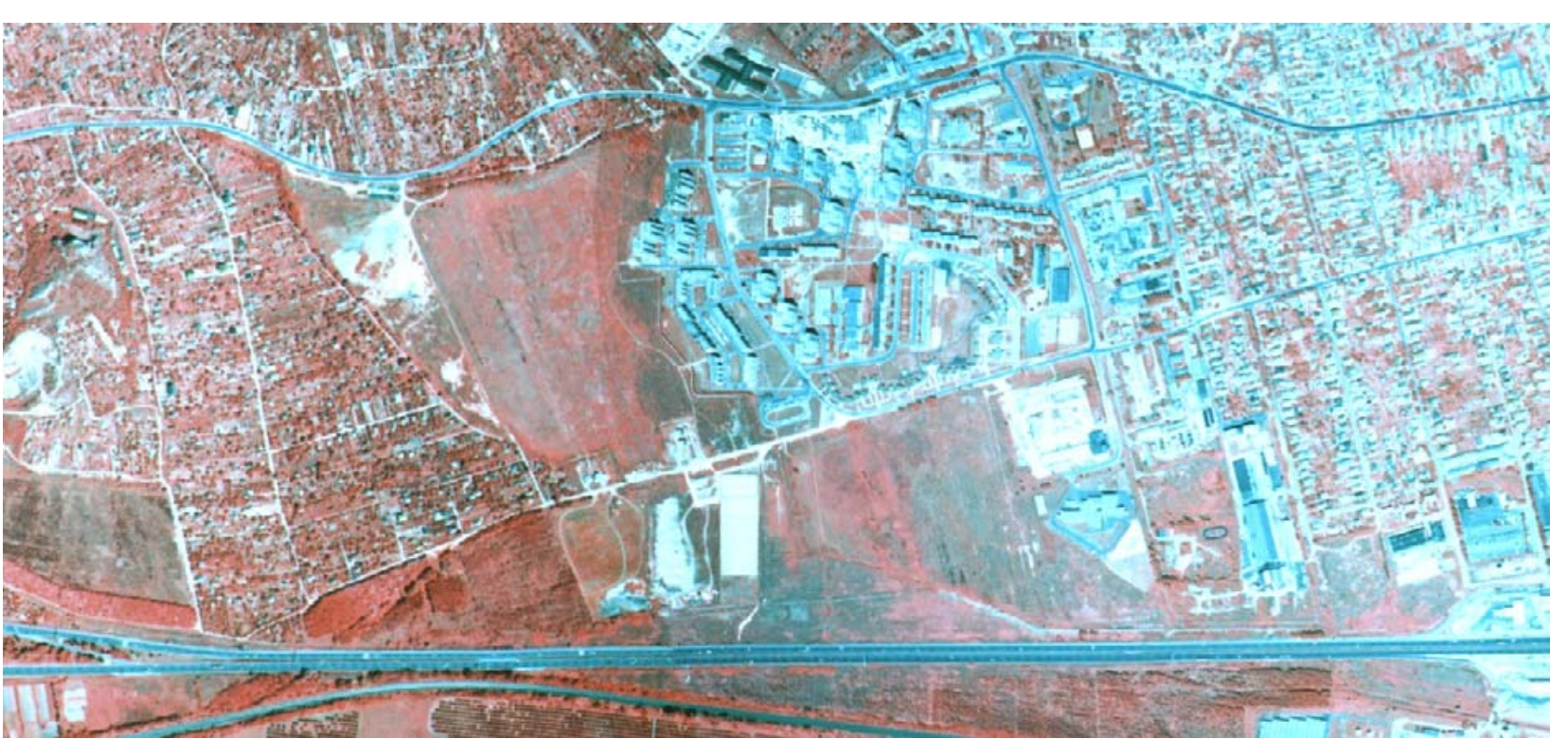

1992 geokorrigált infravörös légifelvételek mozaikja**

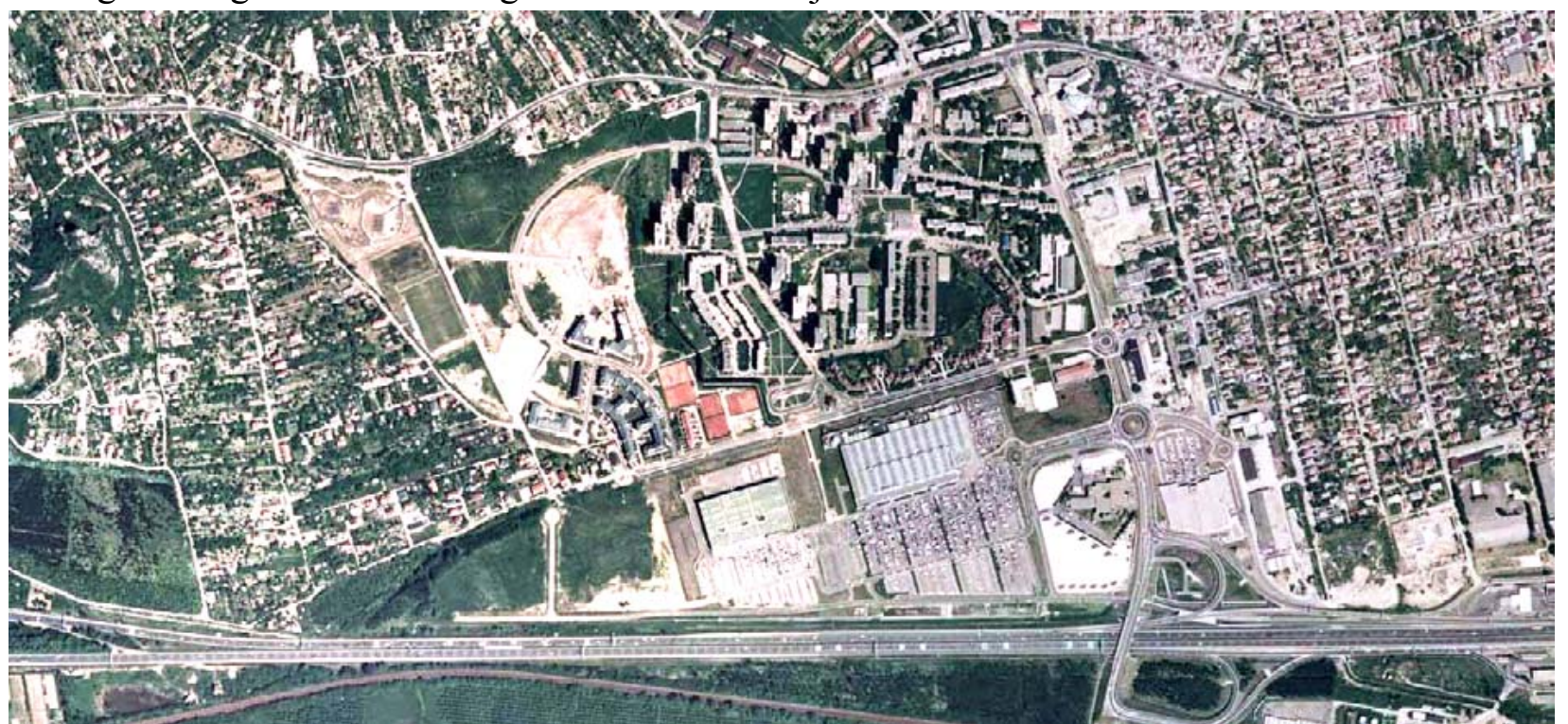
2000 Ortofotó $* *$

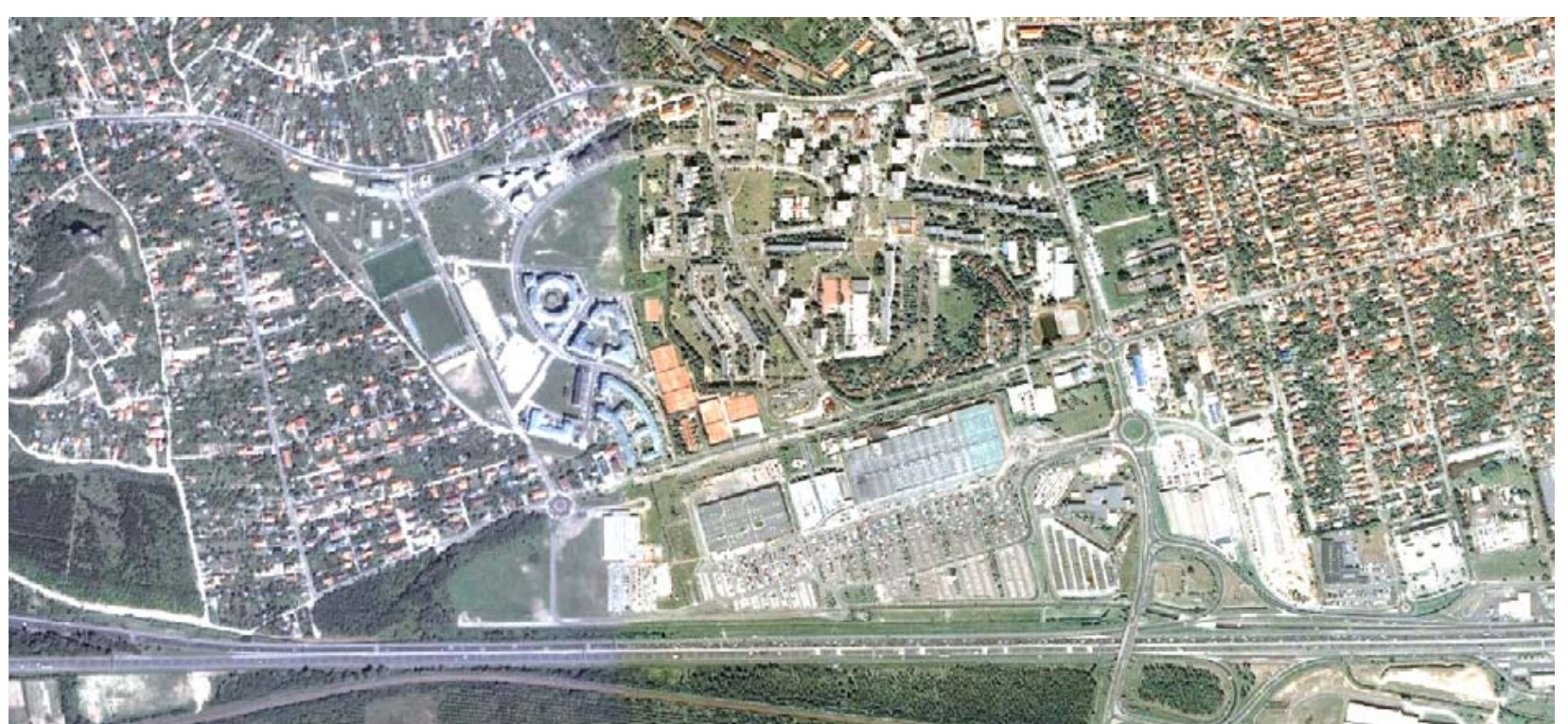

Dive 4

2006-2008 *** Nagyon nagy felbontásúu ürfelvétel

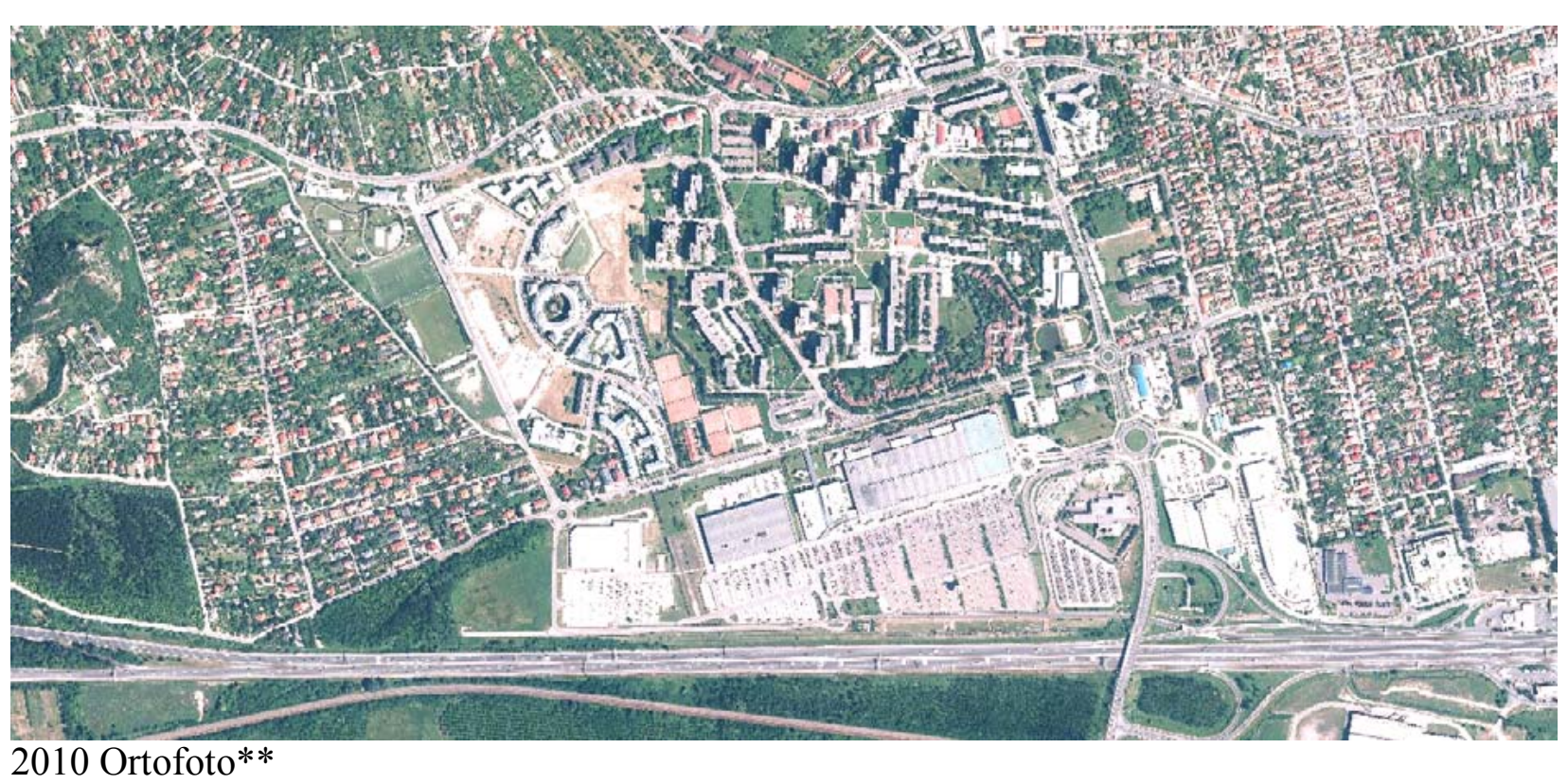

93. ábra Tájielleg változást tanúsító légifelvételek történeti idősora a Budaörsi-medence központi területére 1940-es évektől 2010-ig. (felvételek forrása: * Hadtörténeti Múzeum Térképtára, **Földmérési és Távérzékelési Intézet Achívuma, *** GoogleEarth)

31. táblázat Eltünő és megjelenő tájelemek A Délnyugat-Budakörnyék elővárosiasodô térségében eltúnő és terjedő típusos karakterelemek az 1940-es évek - 2010 időszakban készült légifelvételek és ortofotók vizuális interpretációja alapján.

\begin{tabular}{|c|c|}
\hline Eltúnő vidéki / rurális tájelemek: & Terjedő városi tájelemek: \\
\hline - Szántók, legelők, földutak & - Burkolt utak, autópályák, autóutak \\
\hline - Szölök, gyümölcsösök, kertek & - Lakóterületek (lakótelepek, lakóparkok, családi házak) \\
\hline - Mezőgazdasághoz kötődő épített & - Kereskedelmi, logisztikai célú nagy kiterjedésű \\
\hline tájelemek & építmények \\
\hline (pincék, présházak, magtárak) & \\
\hline
\end{tabular}



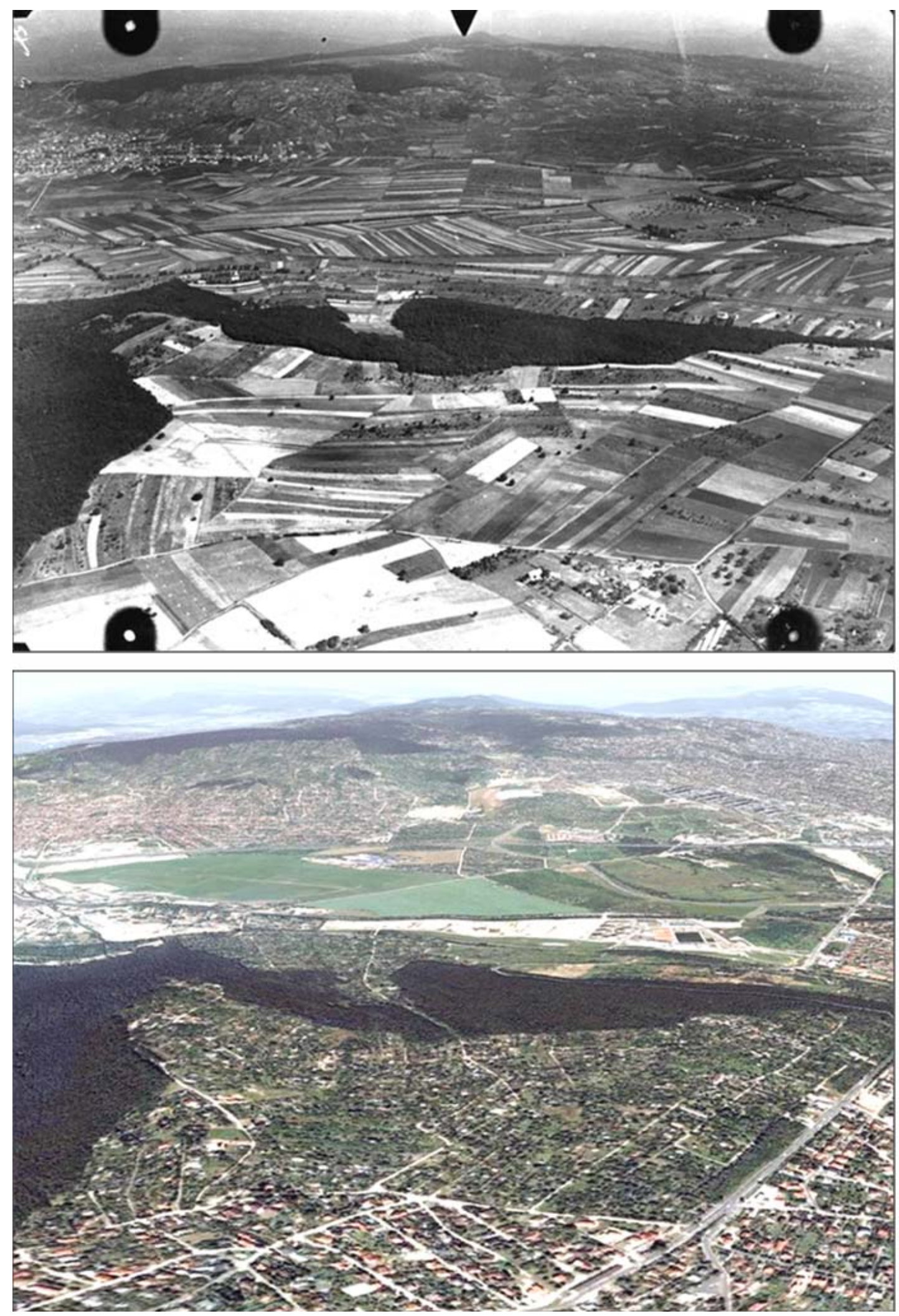

94. ábra A kérdőívezéshez felhasznált képpár az 1920-as évekből és 2008-ból

(Képek forrása: „A” kép: Hadtörténeti Múzeum, Térképtár; „B” kép GoogleEarth) 

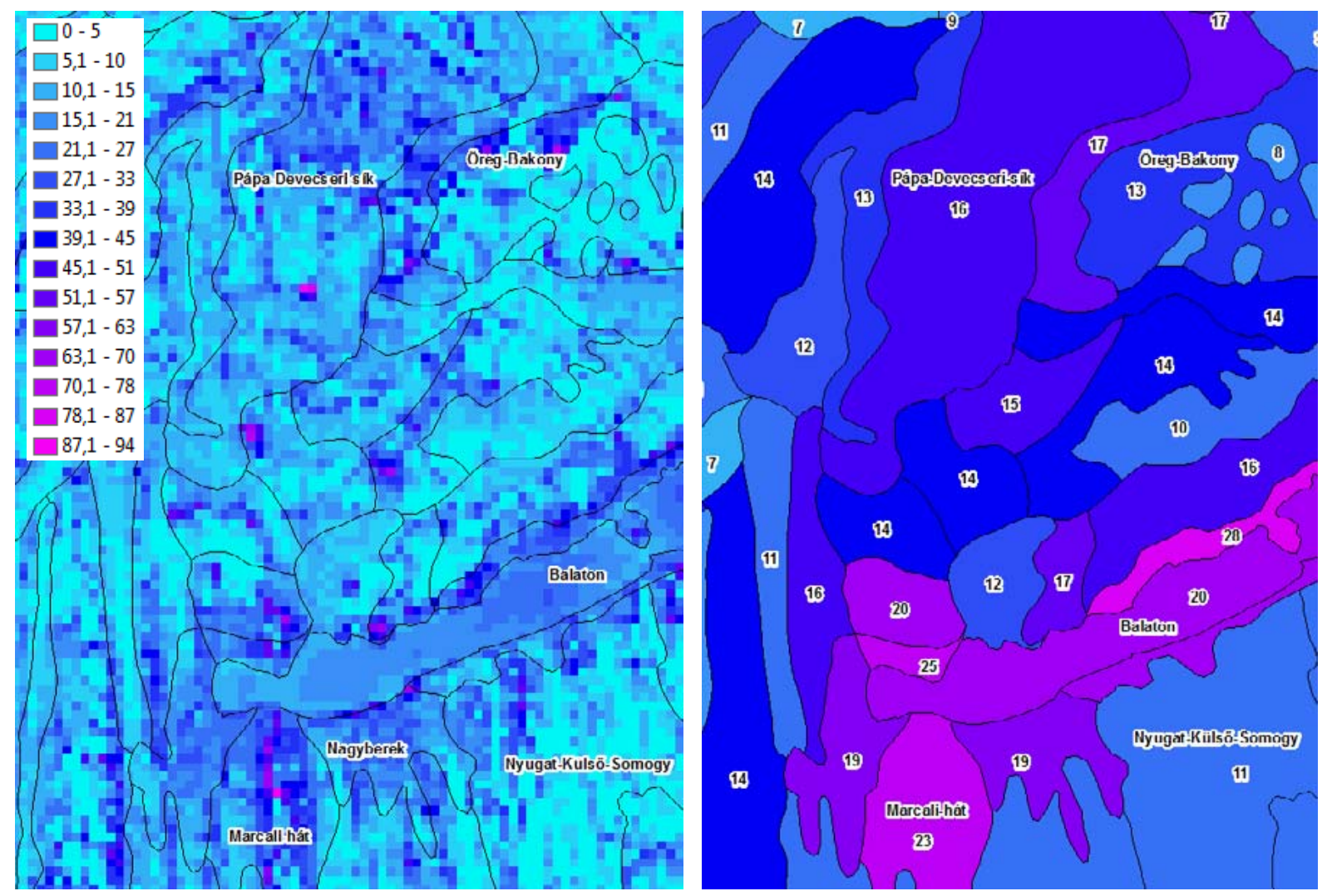

95. ábra Tájrészletek láthatósága a Nagyberek térségében az elméleti láthatósági mutató alapján (\%). A láthatósági mutató megmutatja, hogy a vizsgált tájrészletek milyen arányban (\%-ban) láthatóak a környező területekről. A térkép jól mutatja a Badacsony, a fonyódi Várhegy, a Ság és a Somló $60 \%$-ot meghaladó láthatóságát. Ebben az esetben $1 \mathrm{~km}^{2}$-es tájrészletek $20 \mathrm{~km}$-es körzetében vizsgáltam a láthatóságot és átlagoltam kistájakra (Felhasznlát alapadat: ASTER GDEMv2) 

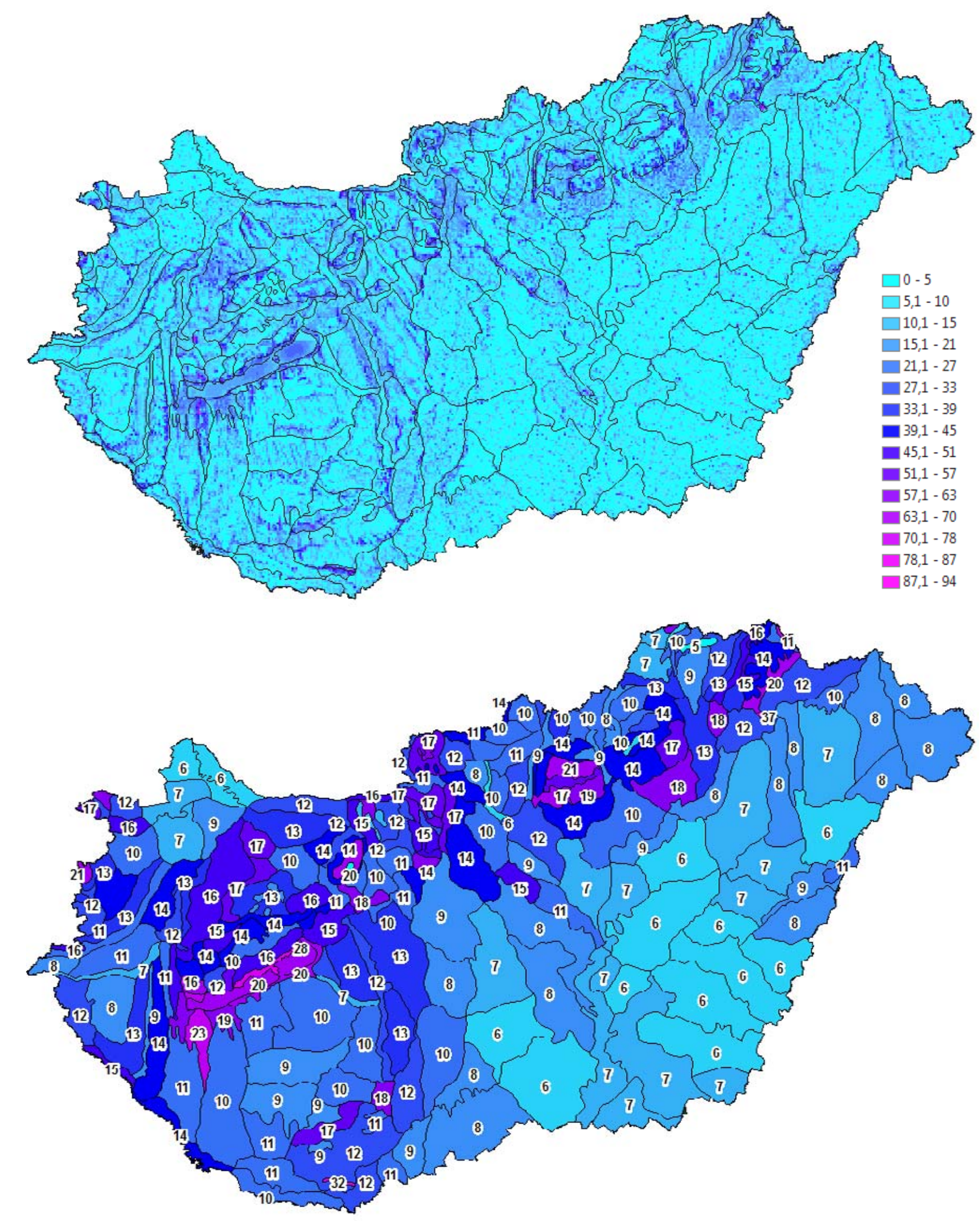

96. ábra Magyarország területén található tájrészletek és kistájainak elméleti láthatósága (\%). A láthatósági mutató megmutatja, hogy a vizsgált tájrészletek milyen arányban (\%-ban) láthatóak a környező területekről. A láthatóság-elemzés paraméterei:

- magassági modell térbeli felbontása: $1 \mathrm{~km}^{2}$

- nézőpontháló nézőpontjainak távolsága: $2,5 \mathrm{~km}$

- látótávolság-maximum: $20 \mathrm{~km}$

- felhasznált alapadatok: ASTER GDEMv2, Magyarország Kistájainak Katasztere
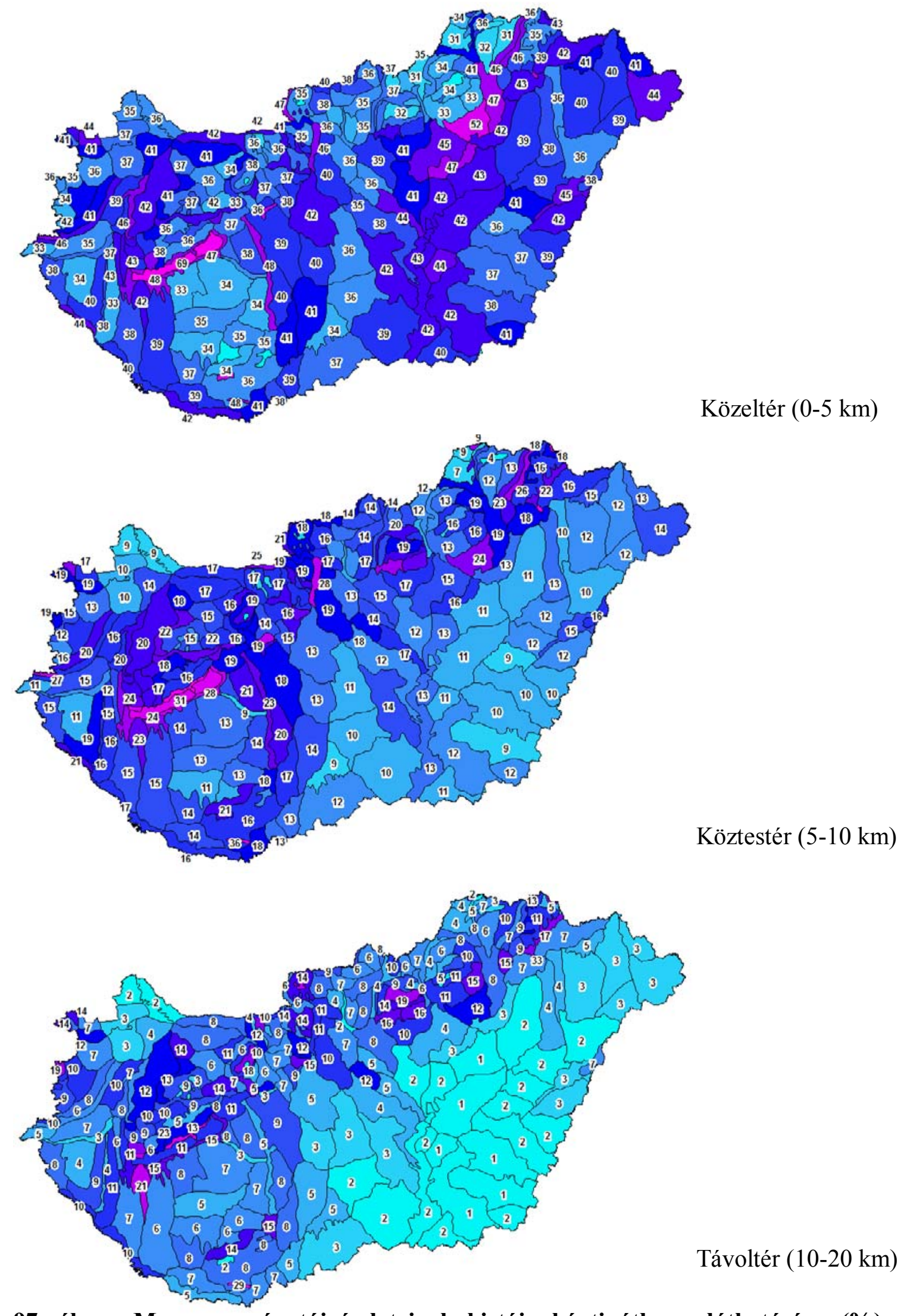

97. ábra Magyarország tájrészleteinek kistájankénti átlagos láthatósága (\%) a közeltérben, köztestérben és távoltérben (felhasznált alapadatok: ASTERGDEMv2 domborzatmodell) 

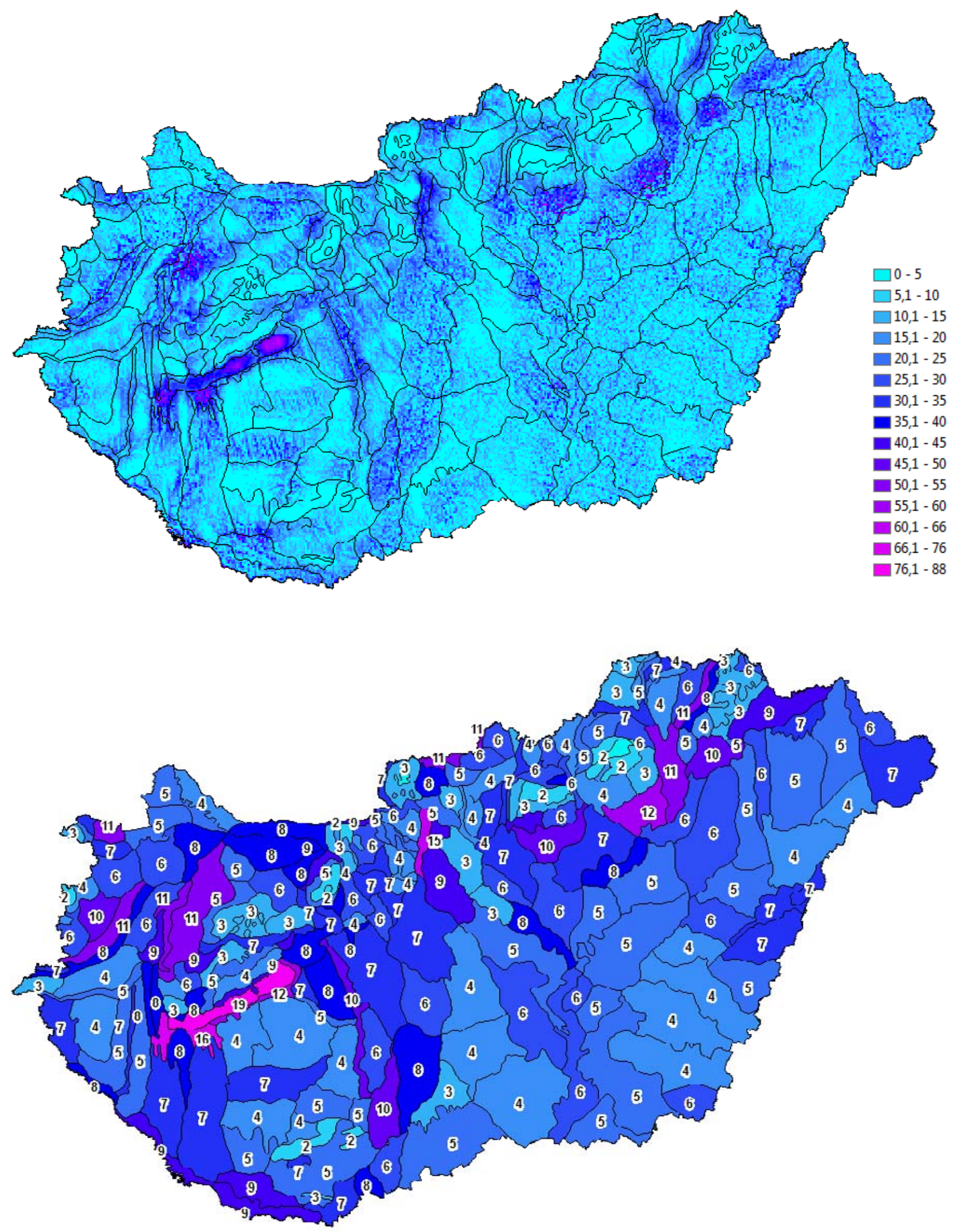

98. ábra Magyarország tájrészleteinek és kistájainak lefelé tekintő elméleti láthatósága. A térkép megmutatja, hogy az egyes tájrészletekre a környező területekröl milyen arányban lehet lefelé rátekinteni. (felhasznált alapadatok: ASTERGDEMv2 domborzatmodell)
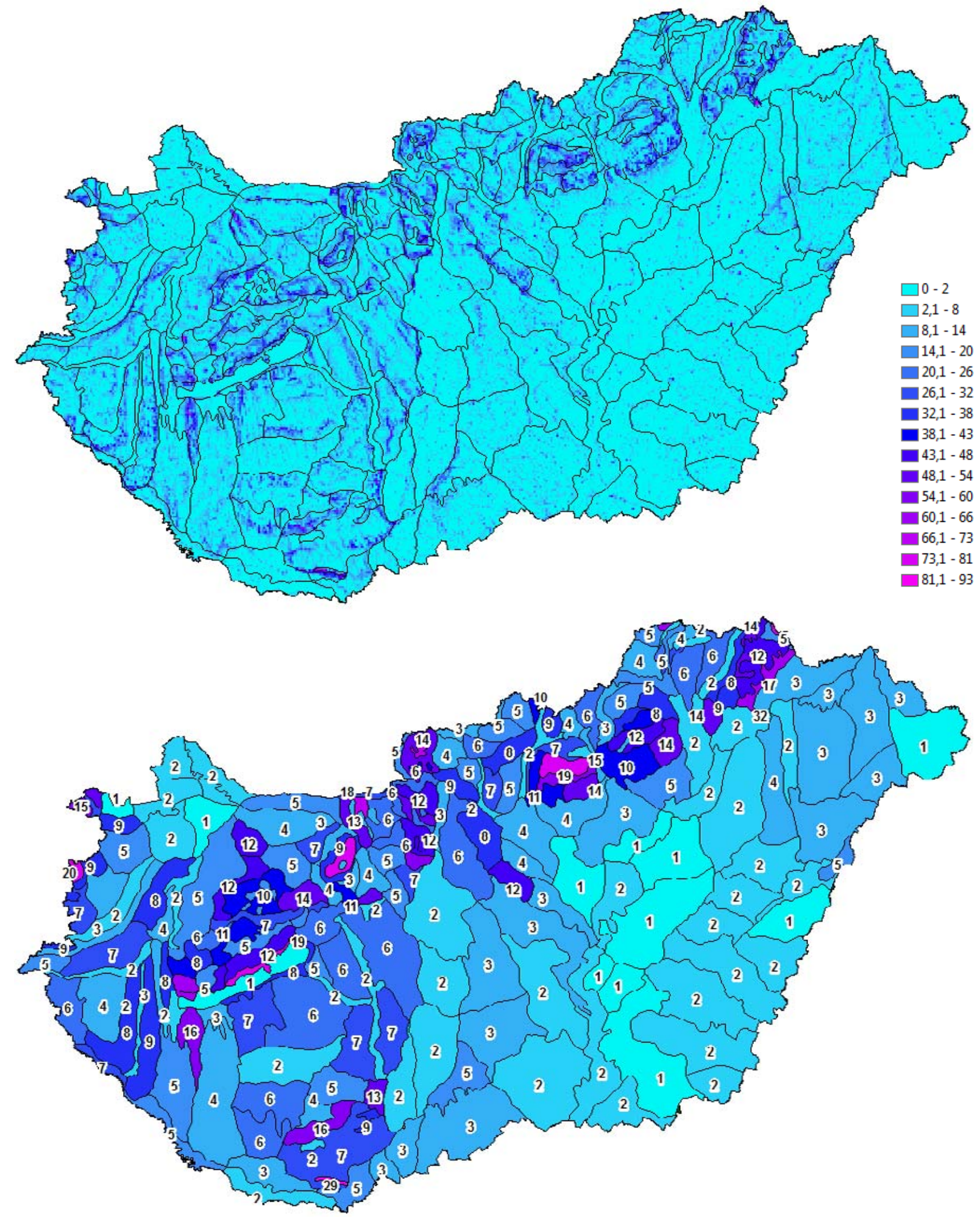

99. ábra Magyarország tájrészleteinek és kistájainak felfelé tekintő elméleti láthatósága. A térkép megmutatja, hogy az egyes tájrészletekre a környező területekről milyen arányban lehet felfelé tekinteni. (felhasznált alapadatok: ASTERGDEMv2 domborzatmodell, $1 \mathrm{~km} 2$-es térbeli felbontással és $2,5 \mathrm{~km}$-enkénti nézőpontokkal) 


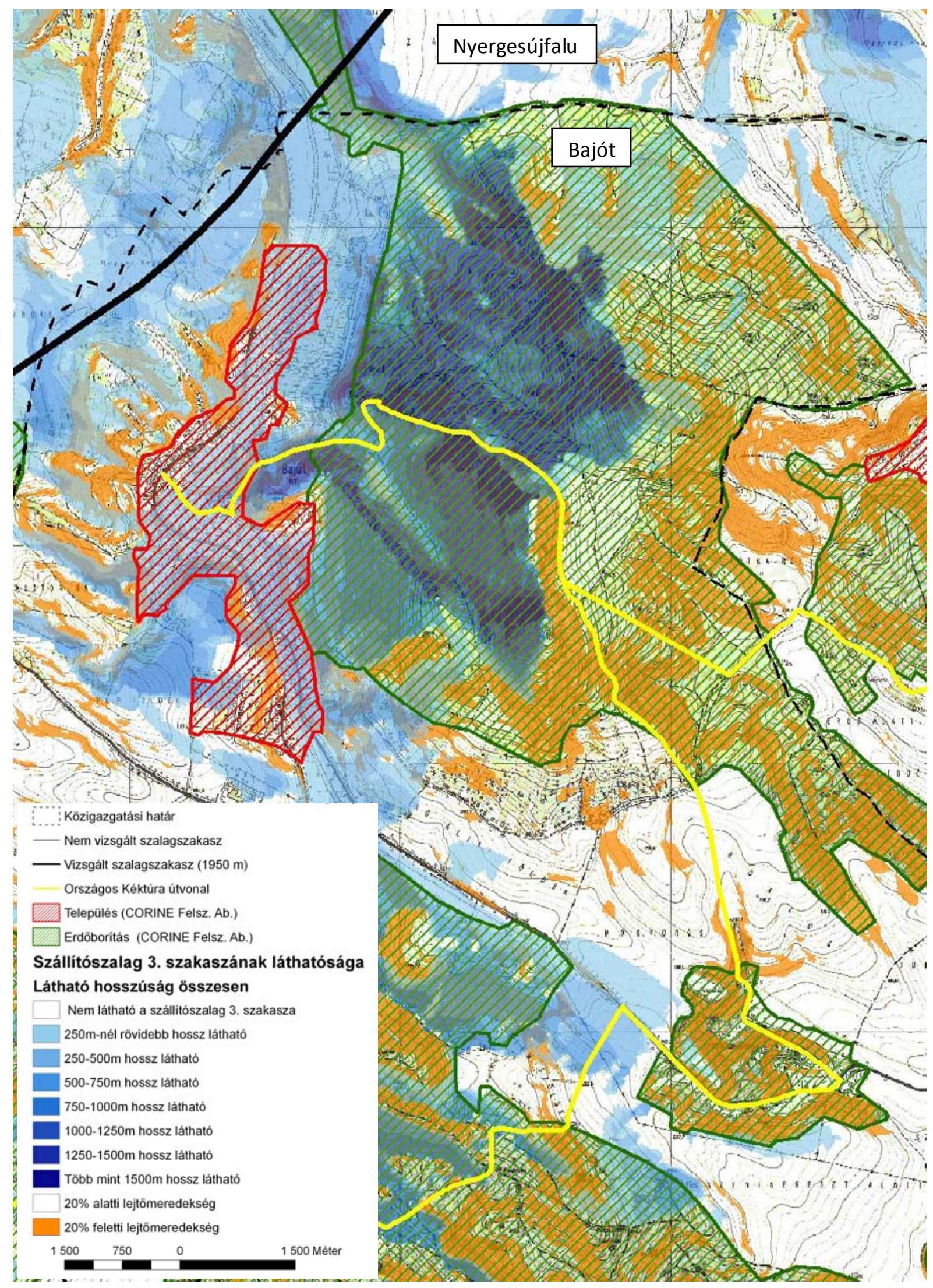

100. ábra A tervezett nyergesújfalui cementgyár szállítószalagjának láthatósága Bajóton. A szalag láthatóságát 50m-enként kijelölt pontjaival elemeztem. A láthatóságfedvény a látható pontok száma alapján határozta meg a látható szalaghosszt 
- Szélerõmũ

Település

Erdő

Szélerőmű nem látható

Szinte a teljes torony látható ( $5 \mathrm{~m}$ feletti rész) Néhány torony látható

Sok torony esetében

A torony fele látható ( $89 \mathrm{~m}$ feletti rész)

$\square$ Nehany torony lathato

Sok torony esetében

\section{Csak a felsō $10 \mathrm{~m}$ látható}

Néhány torony látható

Sok torony esetében
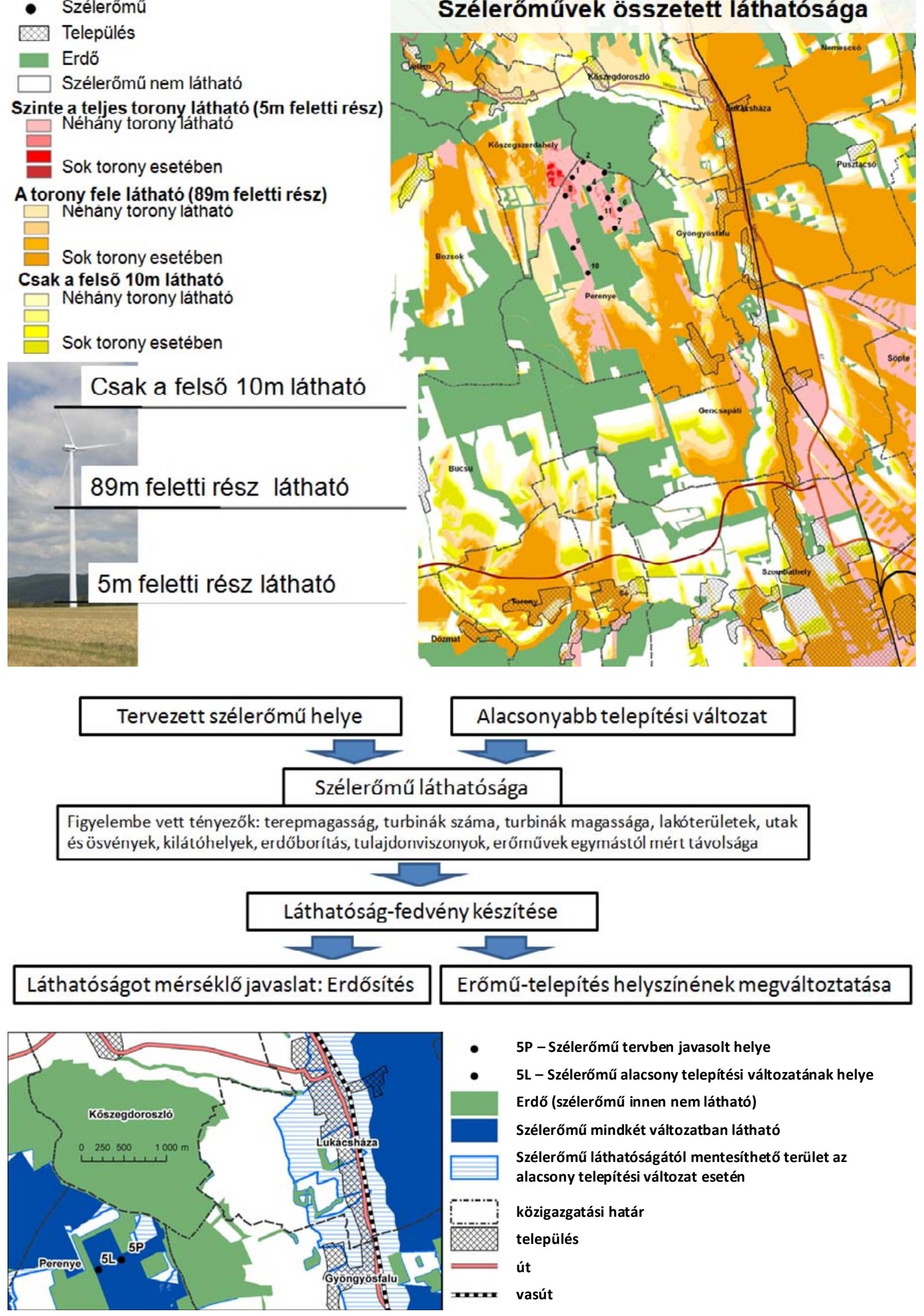

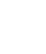




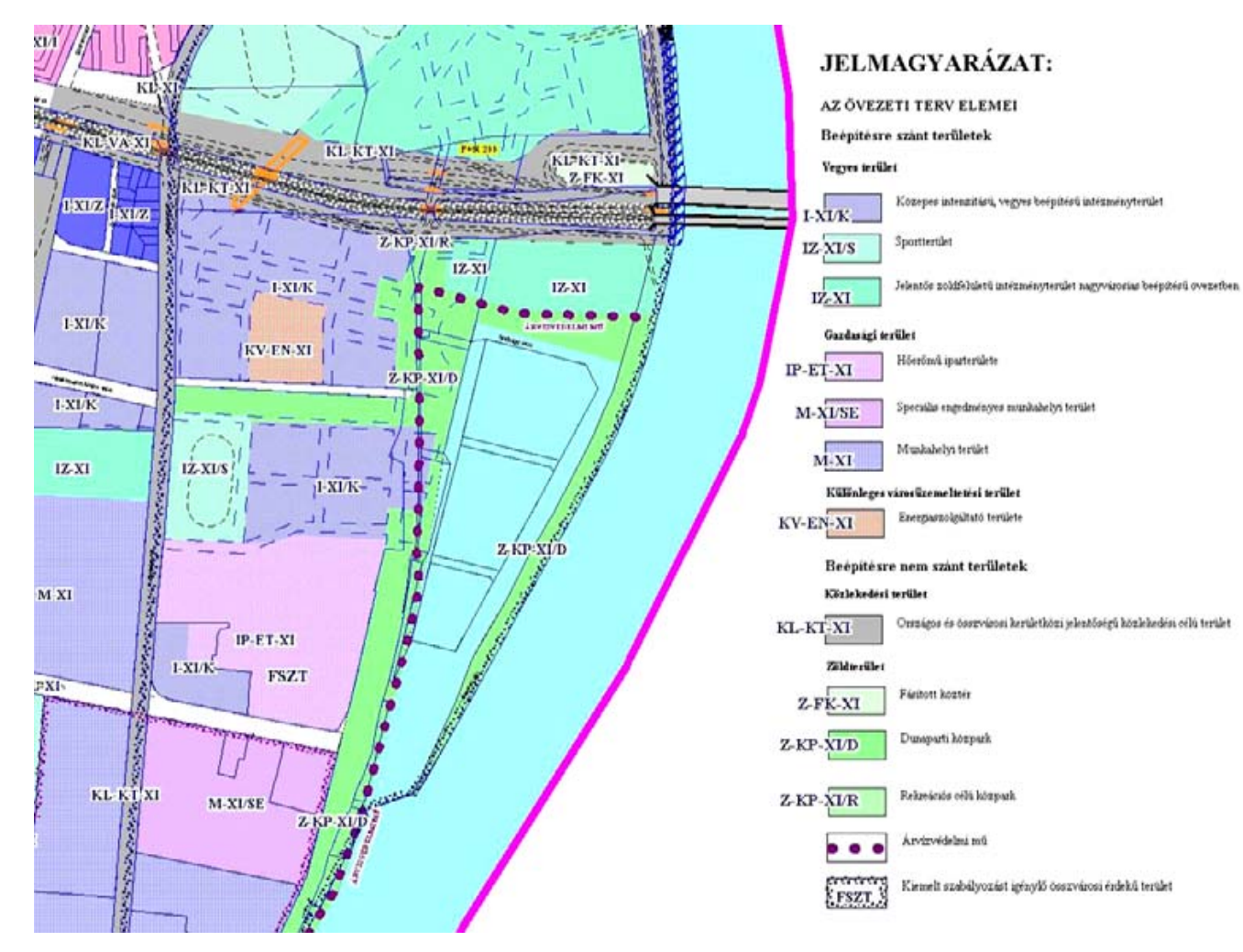

102. ábra Budapest XI. Kerület, KVSZ, RM-1 számú melléklet, Övezeti térkép, 2003
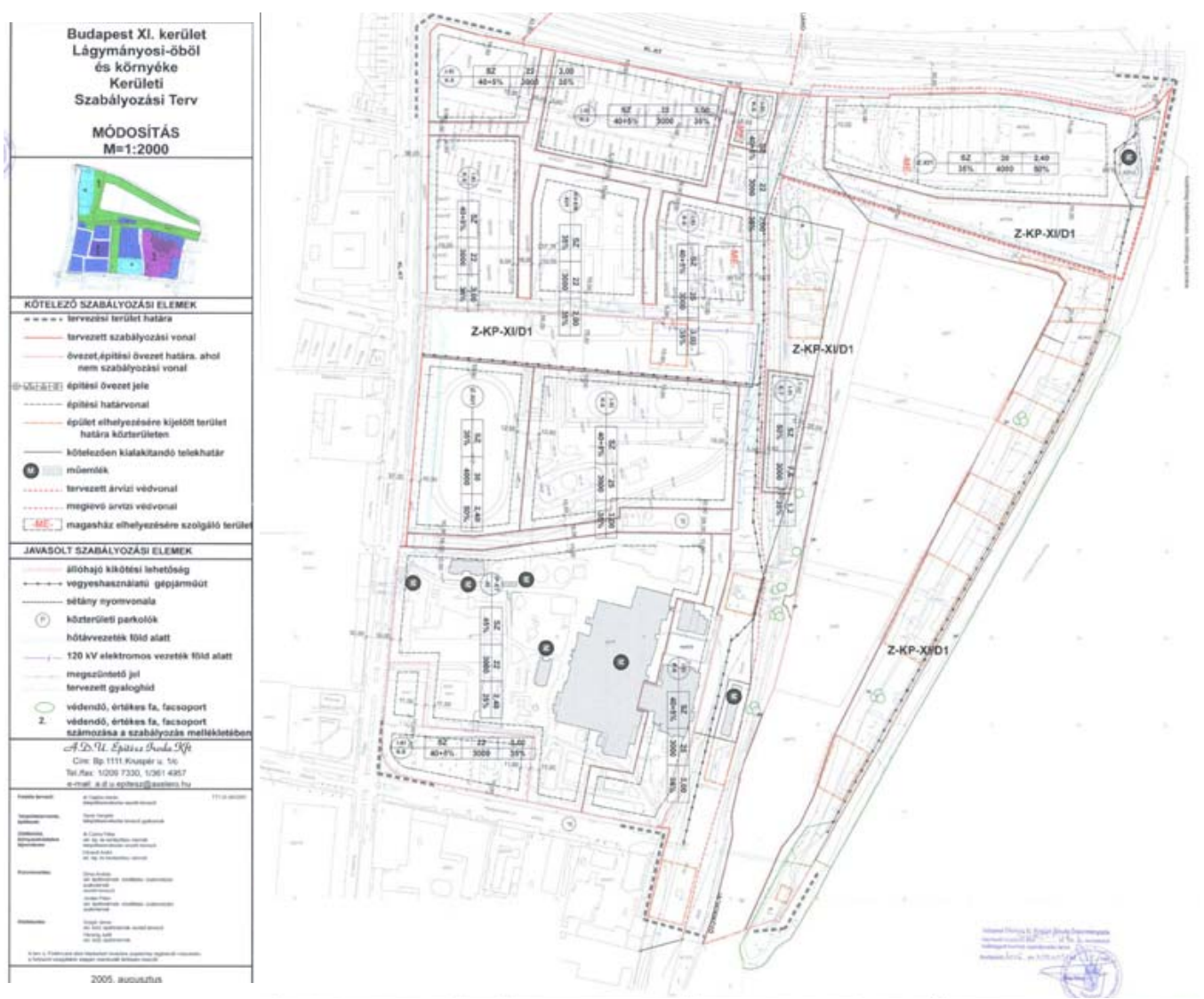

103. ábra A 2003-as Szabályozási terv 2005 augusztusi módosítása szinkronban a kerület 49/2005./X.28./ XI.ÖK számú rendeletével (6. Melléklet)
32. táblázat Budapest Főváros XI. Kerületi Önkormányzat 49/2005./X.28./ XI.ÖK számú rendeletéből

Részlet Budapest Fốváros XI. Kerületi Önkormányzat 49/2005./X.28./ XI.ÖK számú rendeletébốl (Budapest XI. kerület Kerületi Városrendezési és Épitési Szabályzatáról) (egységes szerkezetben 2009. június 10-i hatállyal)

\section{„Budapest Főváros XI. Kerület Újbuda Önkormányzata}

49/2005./X.28./XI.ÖK számú rendelete

a Budapest XI. kerület Kerületi Városrendezési és Építési Szabályzatáról szóló 34/2003./X.21./ XI.Ö K sz. rendeletnek a Budapest XI. kerület, Lágymányosi öböl és környéke (Duna folyam - Hengermalom út - Budafoki út Dombóvári út által határolt terület) kerületi szabályozási tervére vonatkozó módosításáról

Budapest Főváros XI. Kerület Ujbuda Önkormányzatának Képviselö-testülete a helyi önkormányzatokról szóló 1990. évi LXV. törvény 16. § (1) bekezdése, az épített környezet alakitásáról és védelméről szóló módosított 1997. évi LXXVIII. törvény $6 . \$(3)$ bekezdese és a fơvarosra vonatkozo 14 . \&-a fel hatal mazása alapjăn a következo rendeletet alkotja:

A XI. kerület Kerületi Városrendezési és Éṕitési Szabályzatáról szóló 34/2003./X.21./ XI.ÖK sz. rendelet (a továbbiakban KVSZ) 1. § (2) bekezdés a) pontjában az RM-11 sz. melléklet megnevezése helyébe a következö rendelkezés lép: „RM-11 Szabályozási tervlap a Budapest XI. kerület, Lágymányosi öböl és környékére (Duna folyam - Hengermalom út "Budafoki út - Dombóvári út által határolt terület)"

A KVSZ a következö alcímmel és az 50/K. §-sal egészül ki:

$$
\text { ,I-XI/K-5 }
$$

Közepes intenzitású intézményi övezet az Infopark déli részén

$50 / \mathbf{K} . \S$

\begin{tabular}{|c|c|c|c|c|c|c|c|c|c|}
\hline \multirow{2}{*}{$\begin{array}{c}\text { Övezet } \\
\text { jele }\end{array}$} & \multirow{2}{*}{$\begin{array}{c}\text { Kialakítható } \\
\text { legki-sebb } \\
\text { telek-terület } \\
\text { mérete }\end{array}$} & \multirow{2}{*}{$\begin{array}{l}\text { Legki- } \\
\text { sebb } \\
\text { telek- } \\
\text { széles- } \\
\text { ség }\end{array}$} & \multirow{2}{*}{$\begin{array}{l}\text { Beépí- } \\
\text { tési } \\
\text { mód }\end{array}$} & \multirow{2}{*}{$\begin{array}{c}\text { Beépí- } \\
\text { tettség } \\
\text { megen- } \\
\text { gedett } \\
\text { legna- } \\
\text { gyobb } \\
\text { mértéke }\end{array}$} & \multicolumn{2}{|c|}{$\begin{array}{l}\text { Építménymagas- } \\
\text { ság }\end{array}$} & \multirow{2}{*}{$\begin{array}{l}\text { Zöldfelület } \\
\text { legki-sebb } \\
\text { mértéke }\end{array}$} & \multirow{2}{*}{$\begin{array}{c}\text { Terepszint } \\
\text { alatti } \\
\text { beépítés } \\
\text { legna- } \\
\text { gyobb } \\
\text { mértéke }\end{array}$} & \multirow{2}{*}{$\begin{array}{c}\text { Szintterületi } \\
\text { mutató } \\
\text { megengedett } \\
\text { legnagyobb } \\
\text { mértéke }\end{array}$} \\
\hline & & & & & $\begin{array}{l}\text { legki- } \\
\text { sebb }\end{array}$ & $\begin{array}{l}\text { legna- } \\
\text { gyobb }\end{array}$ & & & \\
\hline$\overline{\mathrm{XI} / \mathrm{K}-5}$ & $3000 \mathrm{~m}^{2}$ & $25 \mathrm{~m}$ & $\overline{\mathrm{SZ}}$ & $40 \%$ & $66,0 \mathrm{~m}$ & $22,0 \mathrm{~m}$ & $35 \%$ & $65 \%$ & $\overline{3,0}$ \\
\hline
\end{tabular}

Az övezetben kivételesen megengedhetổ a 45 m építménymagasság, a szabályozási terven jelölt helyeken.

(3) Az építési övezetben elhelyezhetô épületek:

közintézmények épületei

ktatási és kulturális célú épületek

igazgatási épületek és irodaépületek

szolgáltatás, vendéglátás, kiskereskedelem épületei, egy épületen belül legfeljebb $15000 \mathrm{~m}^{2}$ bruttó szintterületig egyéb közösségi szórakoztató épületek

sportépületek

a kutatás-fejlesztés nem üzemi technológiájú építményei

parkolóházak

valamint a felsorolt épületeket kiszolgáló és kiegészitő funkciójú épületek, amennyiben azok terhelési határértéke nem haladja meg az intézményterületekre vonatkozó egyéb jogszabályban rögzített határértékeke. 
(4) Az építési övezetben nem helyezhető el:

önálló ipari épület

önálló raktárépület

üzemanyagtöltő állomás

(5) Az építési övezetben a beépítési mód szabadonálló

beépítettség 5\%-kal növelhetö, ha a földszint nettó területének legalább $65 \%$-a közforgalom számára megnyitott terület vagy közfor gal mú intézmény.

A $150 \mathrm{~m}^{2}$-t meghaladó bruttó beépített alapterületủ épületek minimális építménymagassága 16,0 méter lehet

A zöldfelület mértéke nem csökkenthetỏ. A tetőkert területét sem lehet a zöldfelületbe beszámítani.

9) Épület homlokzata tüzfal nem lehet.

(10) Az elöírt parkolók legalább $80 \%$-át épületek és a terepszint alatt kell elhelyezni

Az övezetben az építés feltétele a Dombóvári út és a vasút alatti - kerületi szabályozási tervben szereplö - a

A készülnie."

5. $\S$

A KVSZ a következö alcímmel és az 50/L. §-sal egészül ki:

Közepes intenzitású intézményi övezet a Lágymányosi öböl partján

50/L. $\S$

Az épitési övezet szabályozási határértéke :

\begin{tabular}{|c|c|c|c|c|c|c|c|c|c|}
\hline \multirow[b]{2}{*}{$\begin{array}{c}\text { Övezet } \\
\text { jele }\end{array}$} & \multirow{2}{*}{$\begin{array}{c}\text { Kialakítható } \\
\text { legkisebb } \\
\text { telekterület } \\
\text { mérete }\end{array}$} & \multirow{2}{*}{$\begin{array}{l}\text { Legki- } \\
\text { sebb } \\
\text { telek- } \\
\text { széles- } \\
\text { ség }\end{array}$} & \multirow[b]{2}{*}{$\begin{array}{l}\text { Beépí- } \\
\text { tési } \\
\text { mód }\end{array}$} & \multirow{2}{*}{$\begin{array}{l}\text { Beépí- } \\
\text { tettség } \\
\text { megen- } \\
\text { gedett } \\
\text { legna- } \\
\text { gyobb } \\
\text { mértéke }\end{array}$} & \multicolumn{2}{|c|}{ Építménymagas-ság } & \multirow{2}{*}{$\begin{array}{c}\text { Zöldfe- } \\
\text { lület } \\
\text { legki- } \\
\text { sebb } \\
\text { mértéke }\end{array}$} & \multirow{2}{*}{$\begin{array}{l}\text { Terep-szint } \\
\text { alatti } \\
\text { beépítés } \\
\text { legna- } \\
\text { gyobb } \\
\text { mértéke }\end{array}$} & \multirow{2}{*}{$\begin{array}{c}\text { Szintte- } \\
\text { rületi } \\
\text { mutató } \\
\text { meg- } \\
\text { enge- } \\
\text { dett } \\
\text { legna- } \\
\text { gyobb } \\
\text { mértéke } \\
\end{array}$} \\
\hline & & & & & $\begin{array}{l}\text { legki- } \\
\text { sebb }\end{array}$ & $\begin{array}{l}\text { legna- } \\
\text { gyobb }\end{array}$ & & & \\
\hline K-6 & $00 \mathrm{~m}^{2}$ & $25 \mathrm{n}$ & & $0 \%$ &,, $0 \mathrm{~m}$ & $5,0 \mathrm{~m}$ & $35 \%$ & $65 \%$ & 3,0 \\
\hline
\end{tabular}

A övezetben kivételesen megengedhetỏ a $45 \mathrm{~m}$ építménymagasság, a szabályozási terven jelölt helyeken.

(3) Az építési övezetben elhel yezhetö épületek:

- közintézmények épületei,

- oktatási és kulturális célú épületek,

- igazgatási épületek és irodaépületek,

- lakóépületek,

- egyéb közösségi szórakoztató épületek,

- sportepuletek,

- kutatás-fejlesztés nem üzemi technológiájú építményei,

- valamint a felsorolt épületeket kiszolgáló és kiegészitő funkciójú épületel

mennyiben azok terhelesi határerteke nem haladja meg az

intézmenyy

(4) Az építési övezetben nem helyezhetỏ e:

- önállóan a szol gáltatás és kereskedelem épületei,

- önálló ipari épület,

- parkolónáz,

- üzemanyagtöltő állomás.

(5) Az építési övezetben a beépítési mód szabadonálló

A lakóépületek elhelyezéséhez előzetes környezetvédelmi vizsgálat szükséges. Csak ott helyezhetỏ el lakóépület, ahol a környezeti feltételek megfelelőek.

A beépitettség 5\%-kal növelhető, ha a földszint nettó területének legalább $65 \%$-a közforgalom számára megnyitott terület vagy közforgalmú intézmény.

A $150 \mathrm{~m}^{2}$-t meghaladó bruttó beépített alapterületủ épületek mini mális építménymagassága 16,0 méter lehet.

Aöldfelulet mértéke nem csōkkentheto. A tetökert területet sem lehet a zöldfelületbe beszámitani.

(10) Expület homlokzata tüzfal nem lehet.

(11) Az előirt parkolók legalább 80\%-át épületek és a terepszint alatt kell elhelyezni."
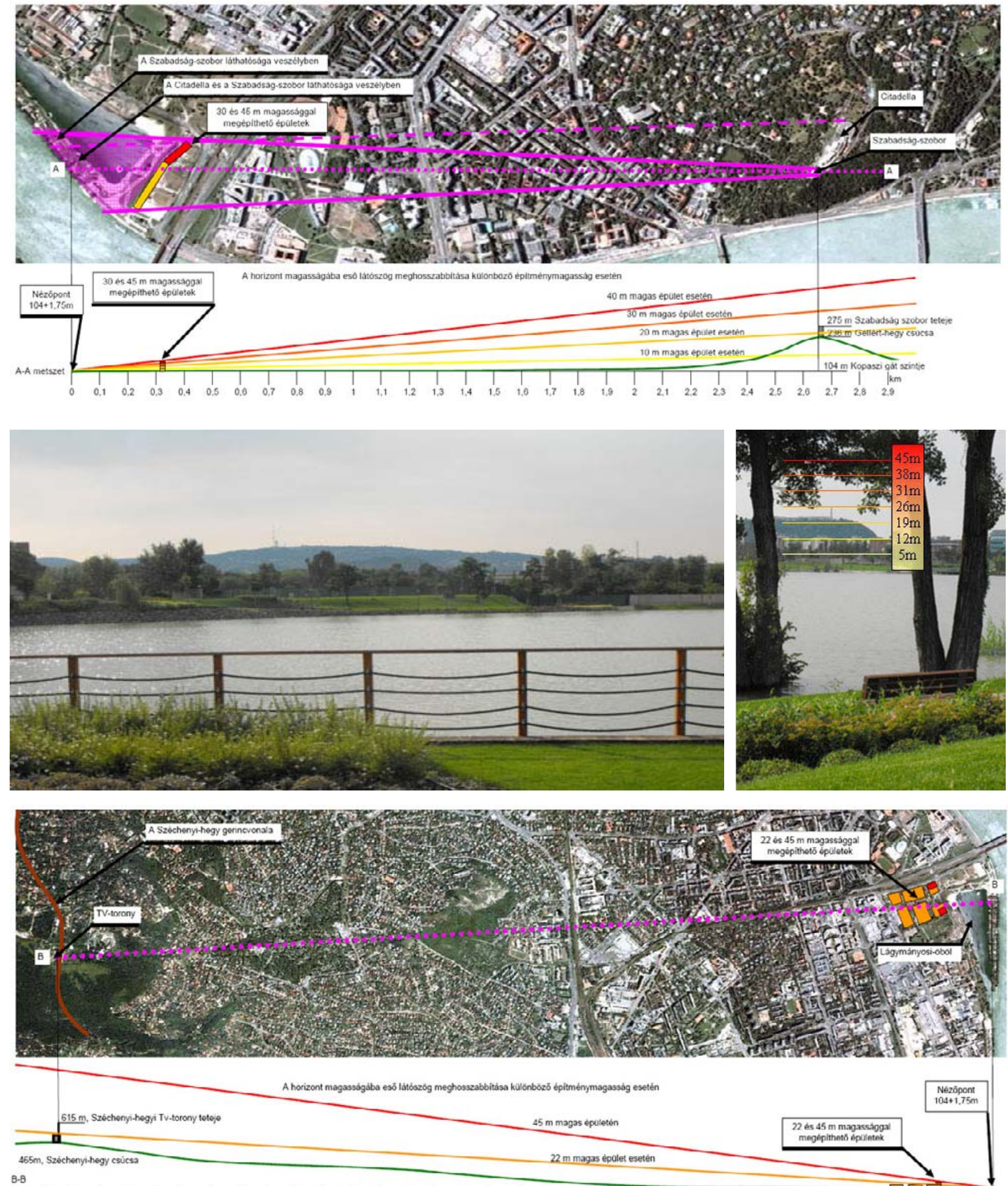

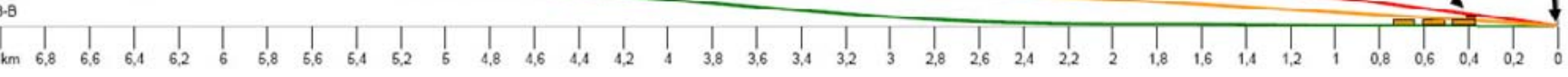

104. ábra A Gellért-hegy és a Szabadság-hegy láthatóságának elemzése a Lágymányosi Öbö Közpark közelébe tervezett épületek eltérö építménymagassága esetén. Az épületek elhelyezése egy szélsőséges esetet ábrázol, amikor az építési vonal által meghatározott területen belül, az öbölhöz legközelebb kerülnek elhelyezésre az épületek, a lehető legszélesebb kialakítással 
33. táblázat Délnyugat-Budakörnyéki mintaterület 9 kilátóhelyének jellemzése ASTER GDEM v2 magassági adatok felhasználásával ${ }^{23}$

\begin{tabular}{|c|c|c|c|c|c|c|c|c|c|c|c|c|c|c|c|c|}
\hline Vizsgált kilátók & \begin{tabular}{|c} 
épitmény azon \\
szintjenek \\
padlómagassága, \\
ahonnan a \\
kilátás nyiliki \\
\end{tabular} & környezet jellemzése & \begin{tabular}{|c} 
környezón \\
terepssinthez \\
becsuilt kilátópont \\
sinitiének \\
magassága \\
\end{tabular} & $\begin{array}{c}\text { környezö } \\
\text { terepsinthez } \\
\text { becsült nézzopont } \\
\text { sizitínek } \\
\text { magassága } \\
\end{array}$ & $\begin{array}{c}\text { Létható } \\
\text { terület } 5 \\
\text { km-en } \\
\text { belül (km2) }\end{array}$ & $\begin{array}{c}\text { Létható } \\
\text { terulutet 20 } \\
\text { km-en } \\
\text { belül (km2) }\end{array}$ & \begin{tabular}{|c|} 
Látható \\
terület 80 \\
km-n \\
belül (km2) \\
\end{tabular} & \begin{tabular}{|c|c} 
Legtávolabbi \\
latbohatar \\
távolsaga $(\mathrm{km})$
\end{tabular} & \begin{tabular}{|c|} 
Legtávo- \\
labbi \\
látóhatár \\
iránya \\
\end{tabular} & $\begin{array}{c}\text { Közeltér } \\
\text { aránya (\%) }\end{array}$ & $\left|\begin{array}{c}\text { Köztestér } \\
\text { aránya }(\%)\end{array}\right|$ & $\begin{array}{c}\text { Távoltér } \\
\text { aránga } \\
(\%)\end{array}$ & $\begin{array}{l}\text { A rélítás domináns } \\
\text { vertikílisis iránya }\end{array}$ & 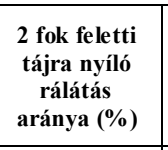 & 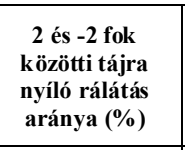 & $\begin{array}{c}-2 \text { fok alattit } \\
\text { taira ynilo } \\
\text { ralitis } \\
\text { aránya (\%) } \\
\end{array}$ \\
\hline $\begin{array}{l}\text { Anna-hegyi kilat́tó } \\
\text { (Tôrókbablint) }\end{array}$ & $\mathrm{kb} 20 \mathrm{~m}$ & erōteleljes $15 \mathrm{~m}$ magas fás szárú növényzet & $5 \mathrm{~m}$ & $6.75 \mathrm{~m}$ & 25,45 & 184,93 & 460,90 & 80km-en túl & ÉK & 6 & 35 & 60 & abszolút letekintő & 0,0 & 97.6 & 2,4 \\
\hline $\begin{array}{l}\text { Citadella (Budapest } 11 . \\
\text { és 1. ker.) }\end{array}$ & $5 \mathrm{~m}$ & $\begin{array}{l}\text { terepszintet vizsgáltam, mert Citadella szerepel a } \\
\text { modellben }\end{array}$ & $5 \mathrm{~m}$ & $6,75 \mathrm{~m}$ & 44,76 & 240,91 & 419,16 & $80 \mathrm{~km}-$ en túl & ÉK & 11 & 47 & 43 & letekintő & 0,2 & 94,5 & 5,4 \\
\hline Csergezán kilátó (Páty) & $18 \mathrm{~m}$ & van fás cseriés növényzet & $12 \mathrm{~m}$ & $13,75 \mathrm{~m}$ & 20,61 & 222,64 & 1183,17 & $80 \mathrm{~km}$-en túl & $\begin{array}{l}\text { ÉK, ÉNy, } \\
\text { D, DK }\end{array}$ & 2 & 17 & 81 & abszolút letekintő & 0,0 & 93,1 & 6,9 \\
\hline Érdi Minaret & $18 \mathrm{~m}$ & sok lakóṕpület veszi körül (4-8m ma gasak & $10 \mathrm{~m}$ & $11,75 \mathrm{~m}$ & 10,46 & 28,20 & 45,20 & 38,9 & $\mathrm{~K}$ & 23 & 39 & 38 & kissé letekintő & 0,5 & 98,7 & 0,9 \\
\hline 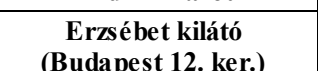 & $23 \mathrm{~m}$ & erón & $13 \mathrm{~m}$ & 145 & 4086 & 7,26 & 1402,45 & $80 \mathrm{~km}-$ en túl & $\begin{array}{l}\text { ÉK,DNy, } \\
\text { D, DK }\end{array}$ & 3 & 21 & 76 & abszolút letekintő & 0.0 & 92,7 & 7,3 \\
\hline Öreghegyi kilátó (Etyek) & $10 \mathrm{~m}$ & nincs jelentösebb növényzet a közelében & $10 \mathrm{~m}$ & $11,75 \mathrm{~m}$ & 11,91 & 110,62 & 144,94 & 68,8 & DK & 8 & 68 & 24 & letekintö & 0,0 & 98,1 & 1,9 \\
\hline $\begin{array}{l}\text { Tétényyi vítzorony } \\
\text { (Budapes 22. ker.) }\end{array}$ & $40 \mathrm{~m}$ & nincs jelentősebb növényż & $40 \mathrm{~m}$ & $41,75 \mathrm{~m}$ & 28,84 & 228,77 & 485,70 & 80km-en túl & ÉK & 6 & 41 & 53 & absz & 0.0 & 97.4 & 26 \\
\hline Viadul & $25 \mathrm{~m}$ & van némi terepváltozatosság ás növényzet is & $15 \mathrm{~m}$ & $16,75 \mathrm{~m}$ & 5,82 & $\frac{220,71}{10,35}$ & 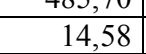 & 37,0 & Eny & 40 & 31 & 29 & \begin{tabular}{|l} 
kissé feltekintö \\
\end{tabular} & 8,8 & 89,3 & 2,0 \\
\hline $\begin{array}{l}\text { Zsámbéki Rontemplom } \\
\text { kertje (Zámbék) }\end{array}$ & $3 \mathrm{~m}$ & nincs jelentősebb növényzet a közelében & $3 \mathrm{~m}$ & $4,75 \mathrm{~m}$ & 9,82 & 60,69 & 62,96 & 23,9 & ÉK & 16 & 81 & 4 & letekintő & 0,6 & 97,5 & 2,0 \\
\hline
\end{tabular}

34. táblázat Délnyugat-Budakörnyéki mintaterület 9 kilátópontjáról feltáruló táj elemzéséhez felhasmált tényezők

\begin{tabular}{|c|c|c|c|c|}
\hline Tényezők a karakteradó láthatóság meghatározásához & Paraméterek & Távolság & Max látószög & Minimum látószög \\
\hline Vertikális látószög tényezö 1 . & -1 fok alatti látószög & 80000 & -1 & -90 \\
\hline Vertikális látószög tényezö 2. & -2 fok alatti látószög & 80000 & -2 & -90 \\
\hline Vertikális látószög tényezö 3. & -3 fok alatti látószög & 80000 & -3 & -90 \\
\hline Vertikális látószög tényezö 4. & & 80000 & -4 & -90 \\
\hline Vertikális látószög tényezö 5 . & -5 fok alatti látószög & 80000 & -5 & \\
\hline Vertikális látószög tényező 6. & -6 fok alatti látószög & 80000 & -6 & -90 \\
\hline Vertikílis látószög tényezö 7 . & 1 fok feletti látószög & 80000 & 90 & \\
\hline Vertikális látószög tényezö 8. & 2 fok feletti látószög & 80000 & 90 & \\
\hline Vertikális látószög tényezö 9. & 3 fok feletti látószög & 80000 & 90 & \\
\hline Vertikális látószög tényezö 10. & 4 fok feletti látószög & 80000 & 90 & \\
\hline Vertikális látószög tényező 11. & 5 fok feletti látószög & 80000 & 90 & \\
\hline Vertikális látószög tényező 12. & 6 fok feletti látószög & 80000 & 90 & \\
\hline Távolság tényező 1. & 0,1 km-es körzetben & 100 & 90 & -90 \\
\hline Távolság tényezö 2. & $0,25 \mathrm{~km}$-es körzetben & 250 & 90 & \\
\hline Távolság tényezö 3. & $0,5 \mathrm{~km}$-es körzetben & 500 & 90 & -90 \\
\hline Távolság tényező 4. & 1 km-es körzetben & 1000 & 90 & -90 \\
\hline Távolság tényező 5. & 2,5 km-es körzetben & 2500 & 90 & -90 \\
\hline Távolság tényező 6. & 5 km-es körzetben & 5000 & 90 & -90 \\
\hline Távolság tényező 7. & 10 km-es körzetben & 10000 & 90 & \\
\hline Távolság tényezö 8. & 20 km-es körzetben & 20000 & 90 & -90 \\
\hline Távolság tényező 9. & 30 km-es körzetben & 30000 & 90 & \\
\hline Távolság tényező 10. & $40 \mathrm{~km}$-es körzetben & 40000 & 90 & -90 \\
\hline Távolság tényezö 11. & $50 \mathrm{~km}$-es körzetben & 50000 & 90 & -90 \\
\hline Távolság tényezö 12. & 60 km-es körzetben & 60000 & 90 & \\
\hline Távolság tényező 13. & 70 km-es körzetben & 70000 & 90 & -90 \\
\hline Távolság tényezö 14. & 80 km-es körzetben & 80000 & 90 & \\
\hline Lejtömeredekség 1. & $0-10 \%$-os meredekség esetén & \multirow{10}{*}{ távolságtól függetlenül } & \multirow{11}{*}{\multicolumn{2}{|c|}{ nem releváns }} \\
\hline Lejtömeredekség 2. & $10-15 \%$-os meredekség esetén & & & \\
\hline Lejtömeredekség 3. & $15-20 \%$-os meredekség esetén & & & \\
\hline Lejtömeredekség 4. & $20-25 \%$-os meredekség esetén & & & \\
\hline Lejtömeredekség 5. & 25-30\%-os meredekség esetén & & & \\
\hline Lejtömeredekség 6. & 30-35 \%-os meredekség esetén & & & \\
\hline Lejtômeredekség 7. & $35-40 \%$-os meredekség esetén & & & \\
\hline Lejtömeredekség 8. & 40-45\%-os meredekség esetén & & & \\
\hline Lejtőmeredekség 9. & 45-50\%-os meredekség esetén & & & \\
\hline Lejtőmeredekség 10. & $50 \%$ feletti meredekség esetén & & & \\
\hline Szembenéző lejtö & Szembenéző lejtó esetén & távolságtól függetlenül & & \\
\hline
\end{tabular}

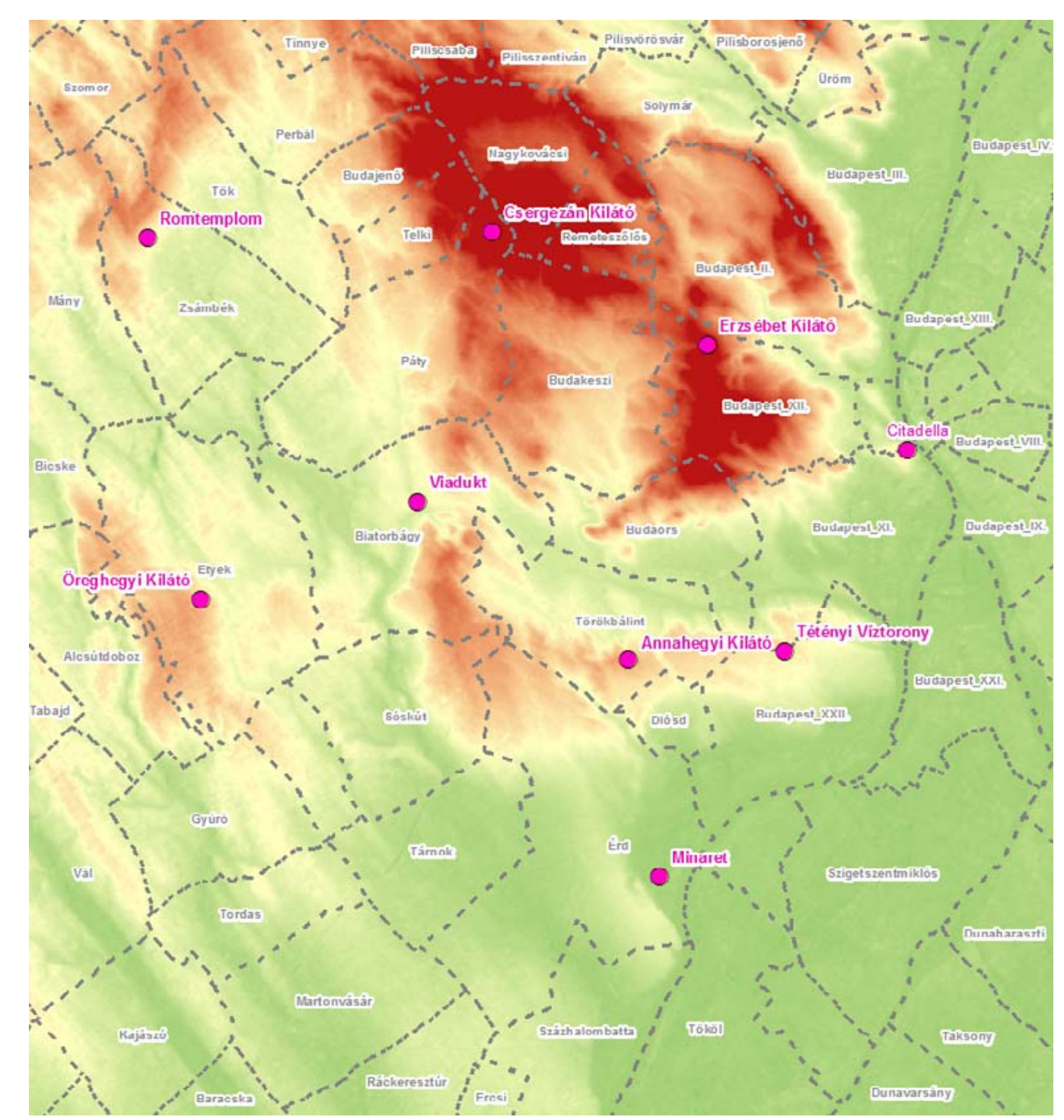

105. ábra A Délnyugat-Budakörnyéki térségben vizsgált kilátóhelyek elhelyezkedése

${ }^{23}$ A szürke cellák tartalma terepi bejárás és felmérés, vagy internetes kutatás eredményeként született 


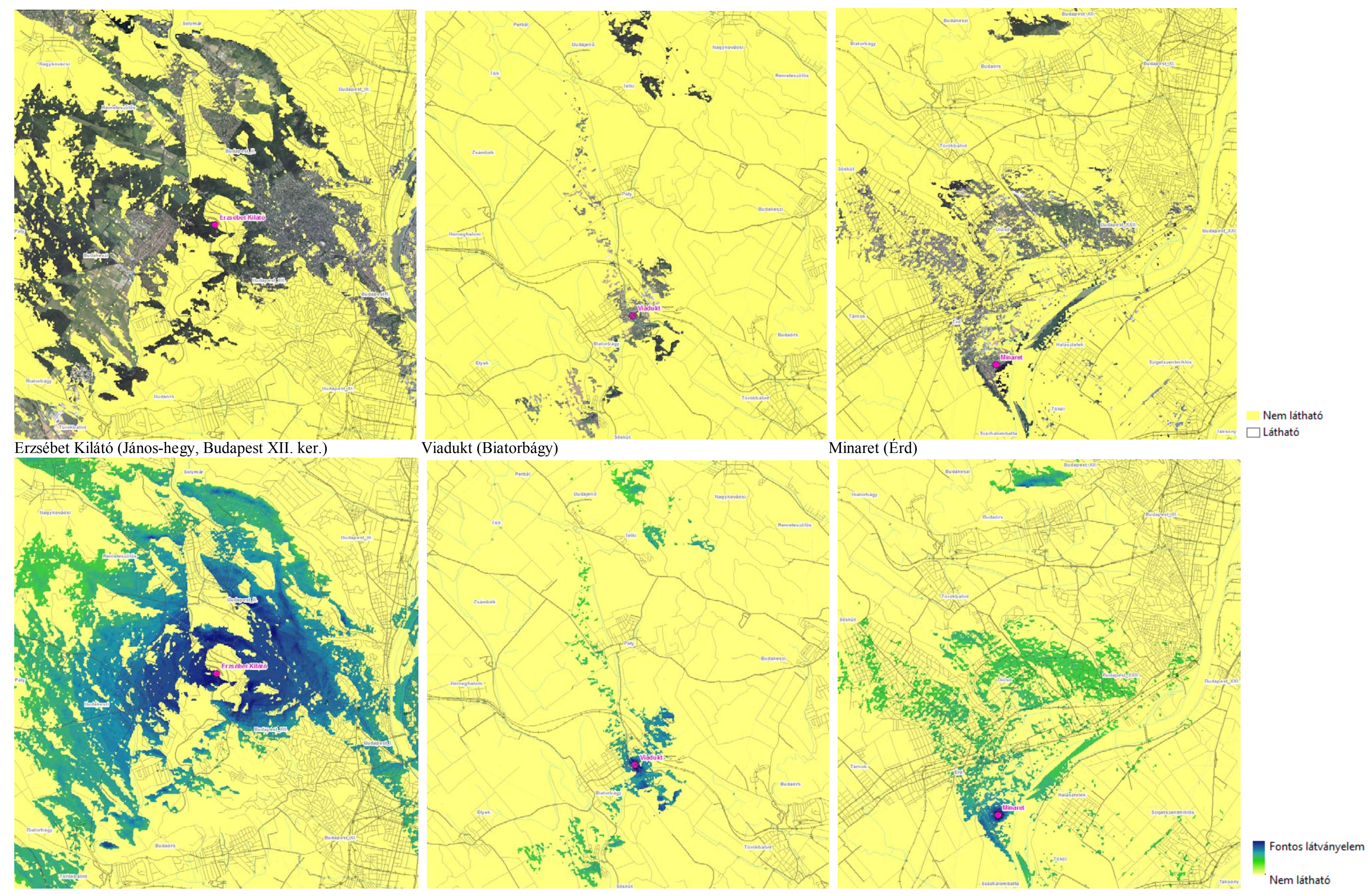

106.a. ábra Egyszerủ kilátás-fedvények és a fontos látványelemek figyelembevételével készült kilátás-fedvények. A terület láthatósága az egyes kilátóhelyekről (felül), és a látványban kulcsfontosságú tájrészletek láthatósága hangsúlyosan kiemelten (alul). 

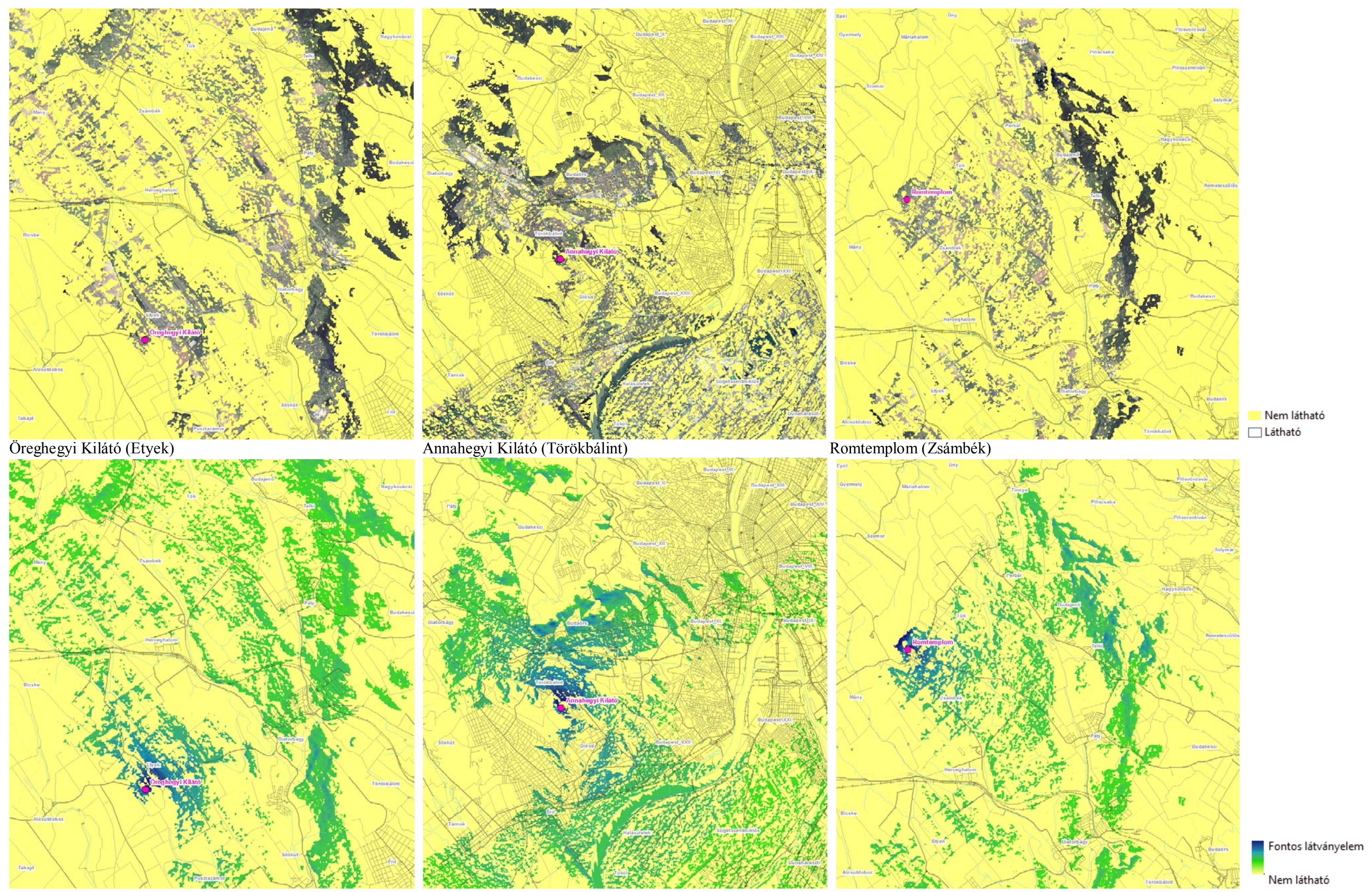

106.b. ábra Egyszerü kilátás-fedvények és a fontos látványelemek figyelembevételével készült kilátás-fedvények. A terület láthatósága az egyes kilátóhelyekröl (felül), és a látványban

kulcsfontosságú tájrészletek láthatósága hangsúlyosan kiemelten (alul). 

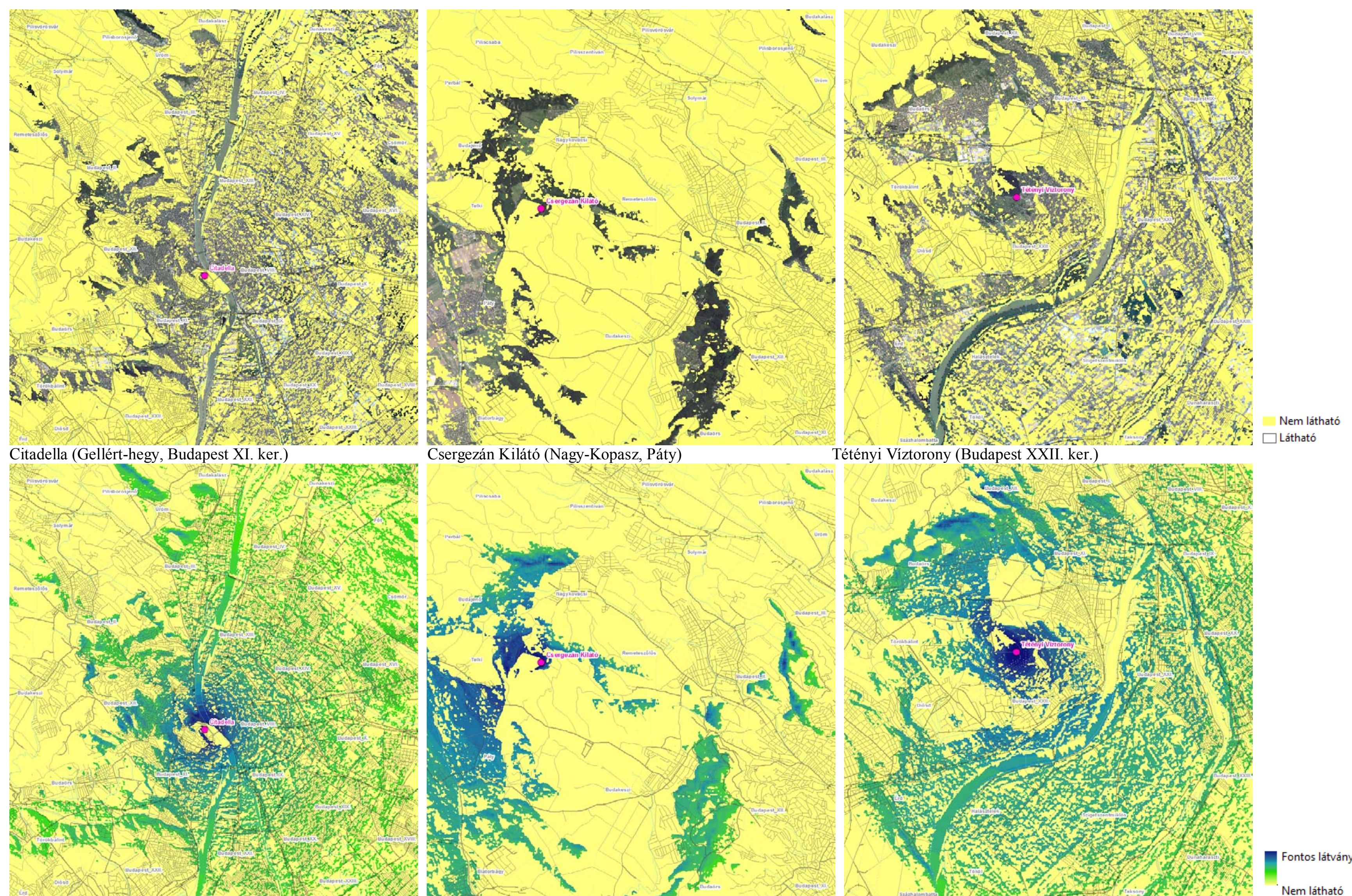
étényi Víztorony (Budapest XXII. ker.)

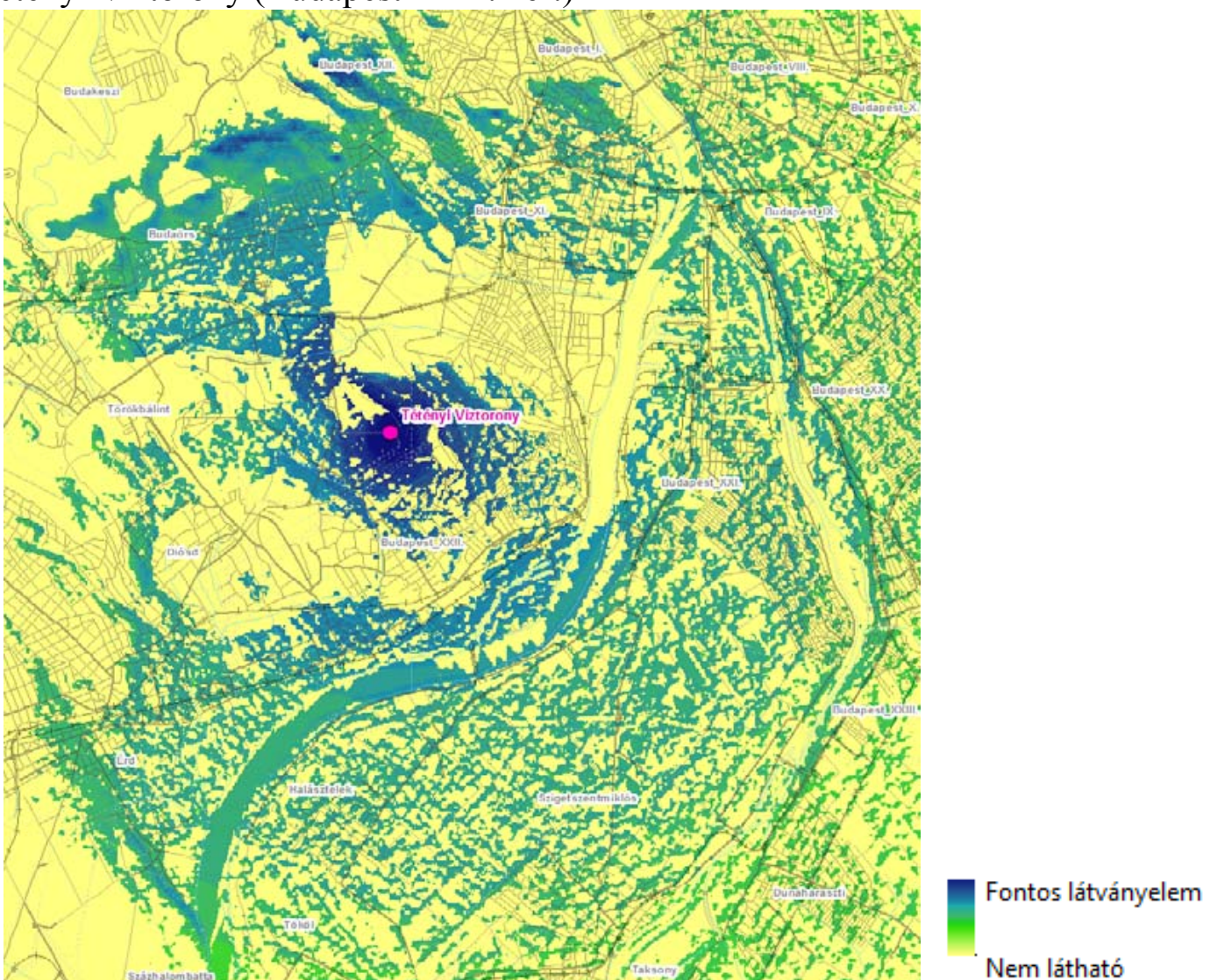

106.c. ábra Egyszerủ kilátás-fedvények és a fontos látványelemek figyelembevételével készültt kilátás-fedvények. A terület láthatósága az egyes kilátóhelyekről (felül), és a látványban kulcsfontosságú tájrészletek láthatósága hangsúlyosan kiemelten (alul). 
1. Kitettség-elemzés

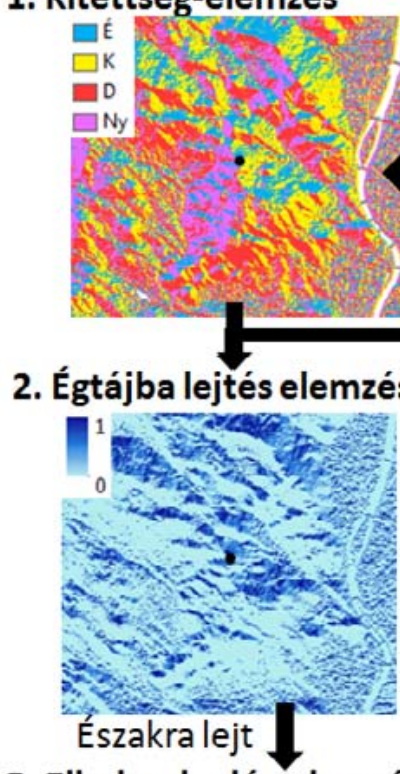

3. Elhelyezkedés-elemzés
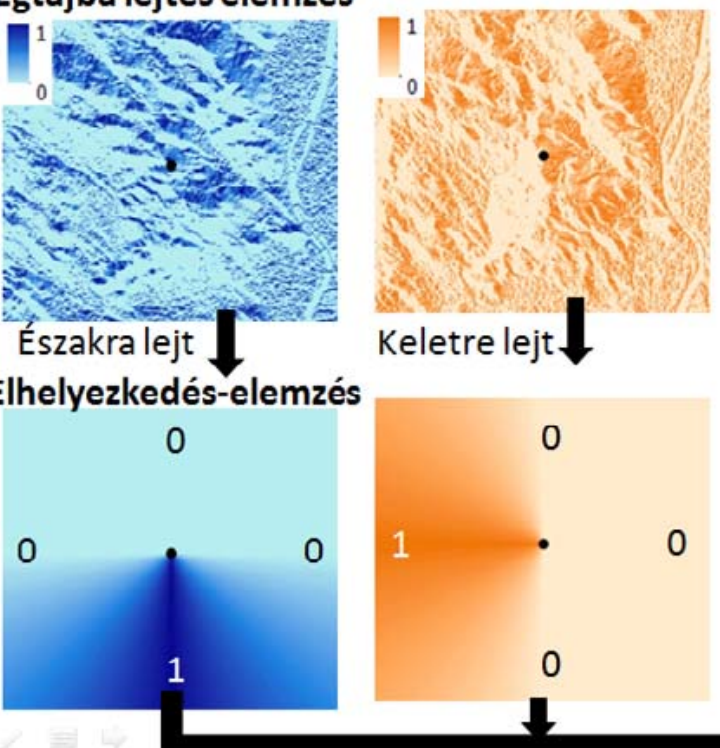

4. Szembenézö lejtő elemzés
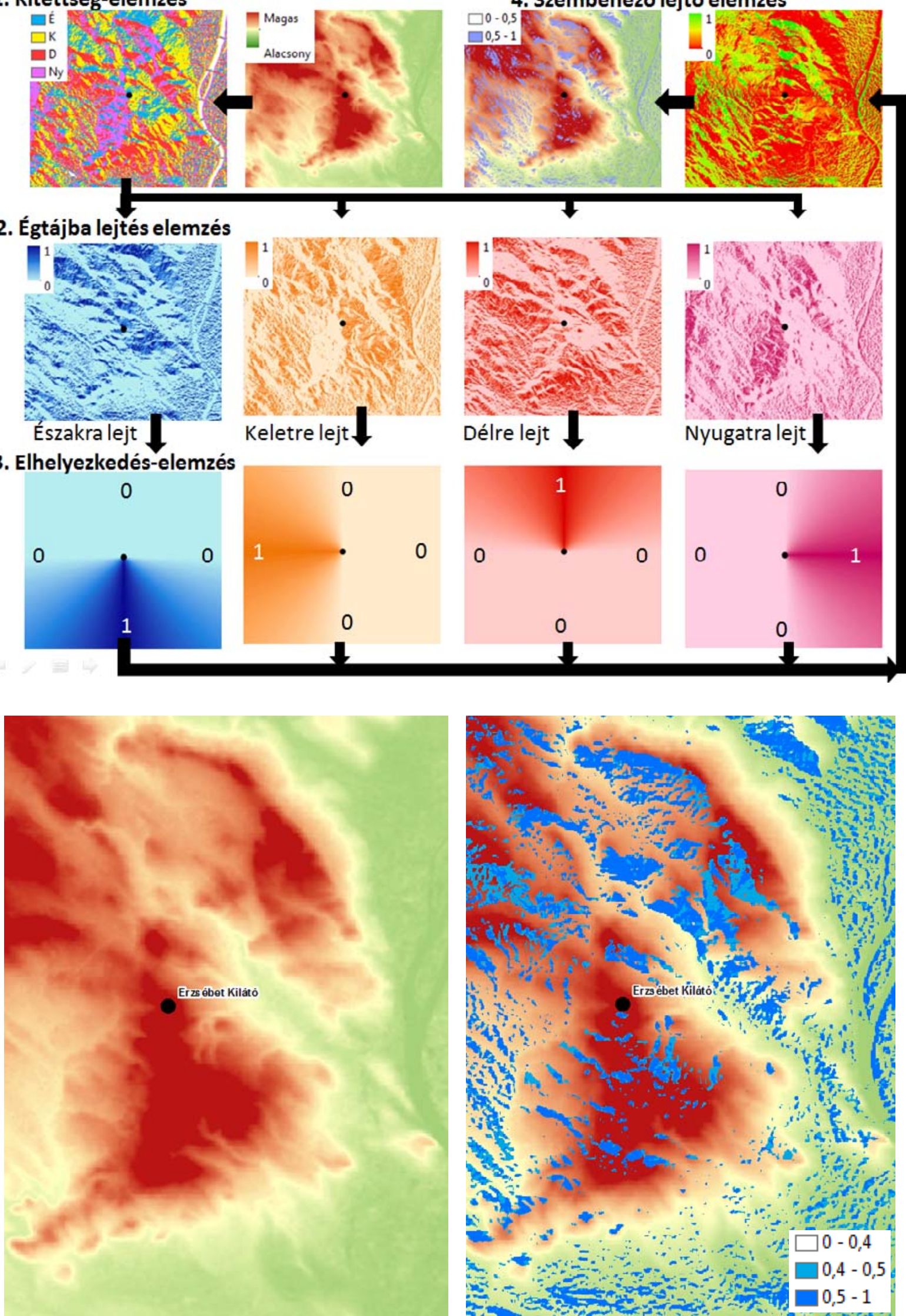

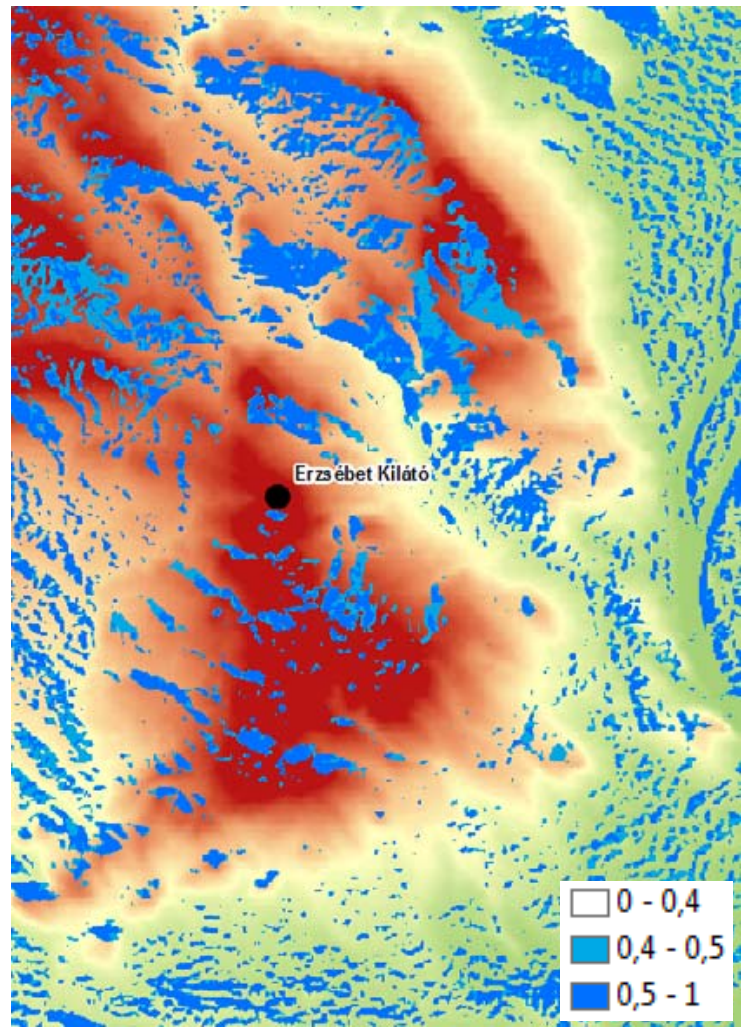

108. ábra Szembenéző lejtők meghatározásához kidolgozott eljárás folyamata. A 0,5 feletti értékek azt jelzik, hogy a lejtők alapvetően szembenéznek a kilátóhellyel. 

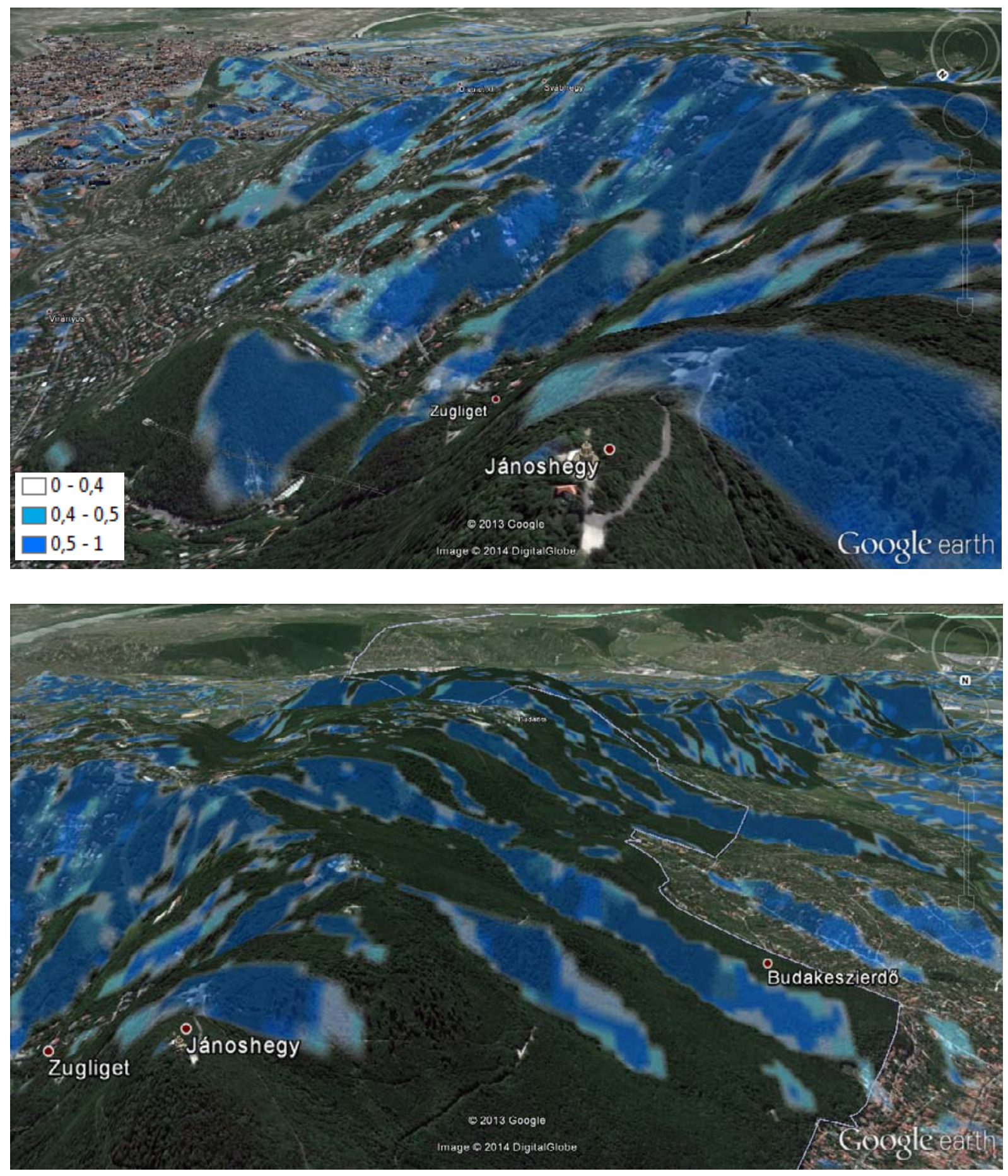

109. ábra A János-hegy kilátóhellyel szembenéző lejtők megjelenítése a GoogleEarth-ön Szembenéző lejtő elemzés eredményeinek 0,5 feletti értékei sötétkékkel, 0,4 feletti értékei világoskékkel. 

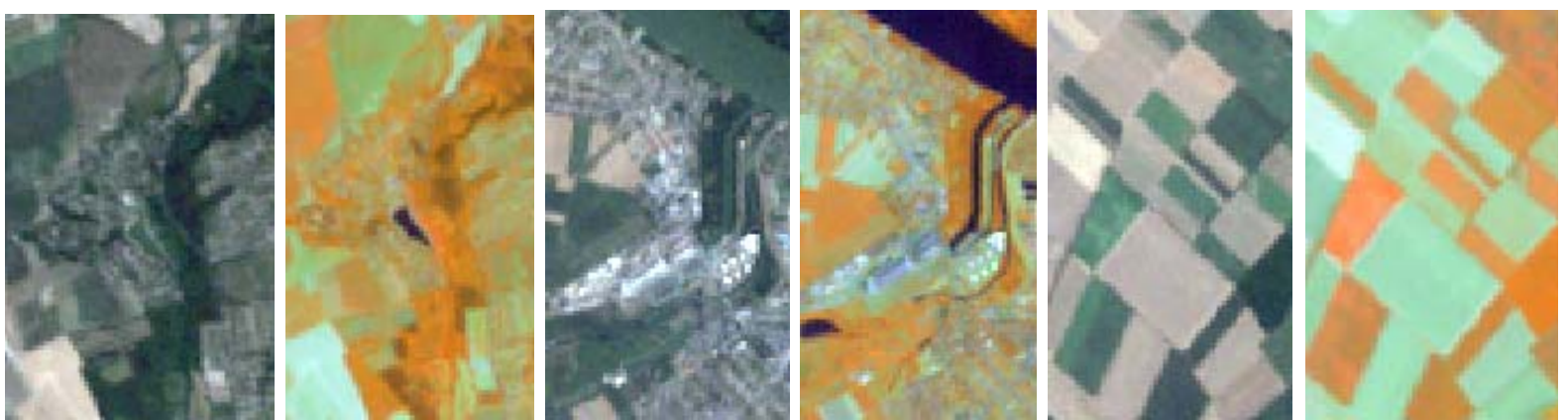

Közepes felbontású ürfelvételek (valós színek 3,2,1 és infra és vörös sávok 4,5,3) (forr.: Landsat 2011 (USGS))
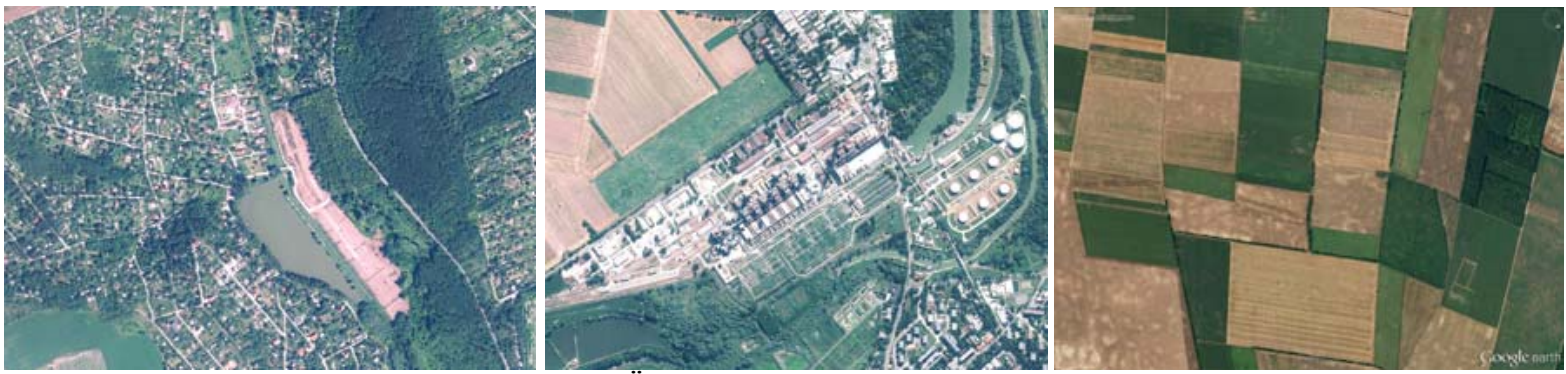

Ortofotók és VHR (Forrás: Ortofotó 2010 (FÖMI) és GoogleEarth 2009)
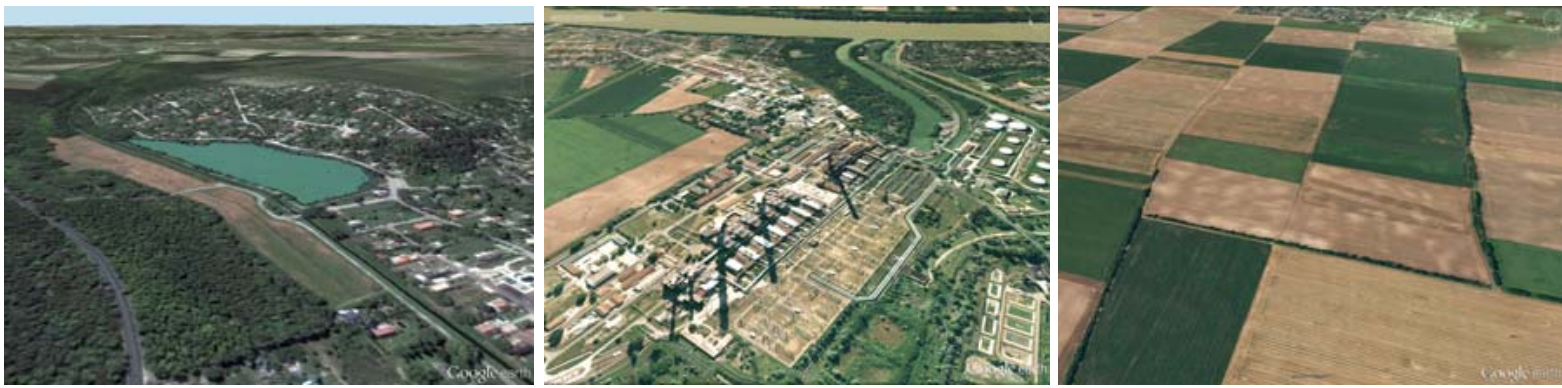

Tájmodellek (domborzatmodell és ortofotó, vagy VHR)
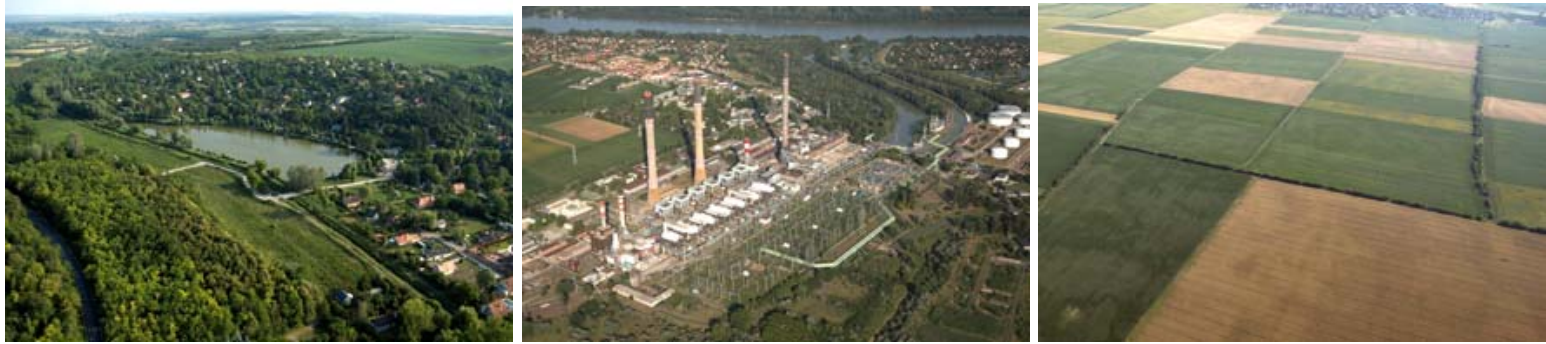

Madártávlati ferde tengelyű légifelvétel (Forrás: Pillangó Siklóernyős Iskola Archívuma 2012)
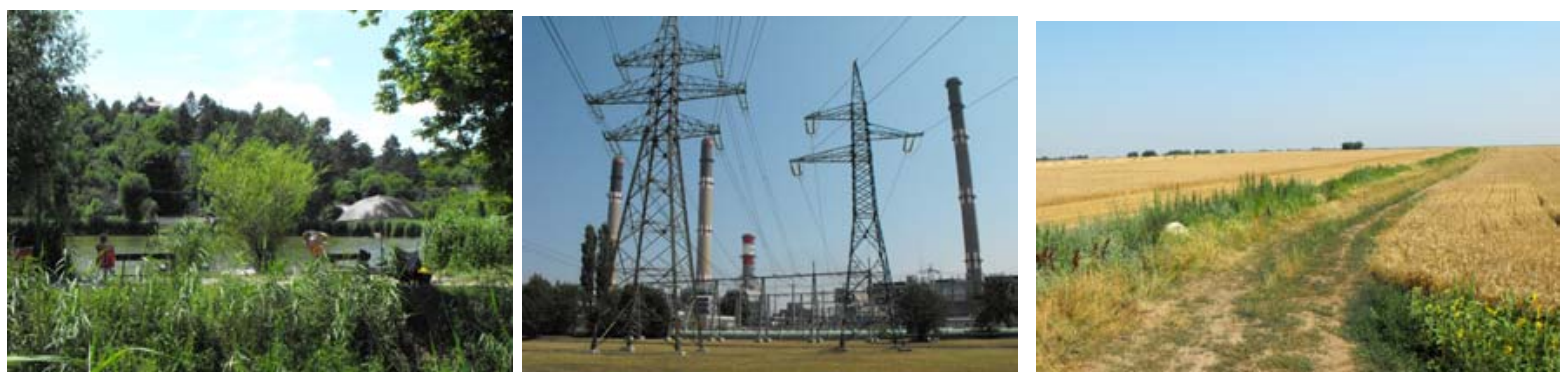

Terepi fényképek

110. ábra Három tájtípus felvételének mintája a 30 fókuszterületből a DélnyugatBudakörnyéki térségből (Üdülőtáj, Ipargazdasági táj, „Szántógazdasági táj”) Helyszínek: Peca-tó Biatorbágyon, hőerőmű Százhalomtattán, szántók Százhalombtta és Ercsi határában. 

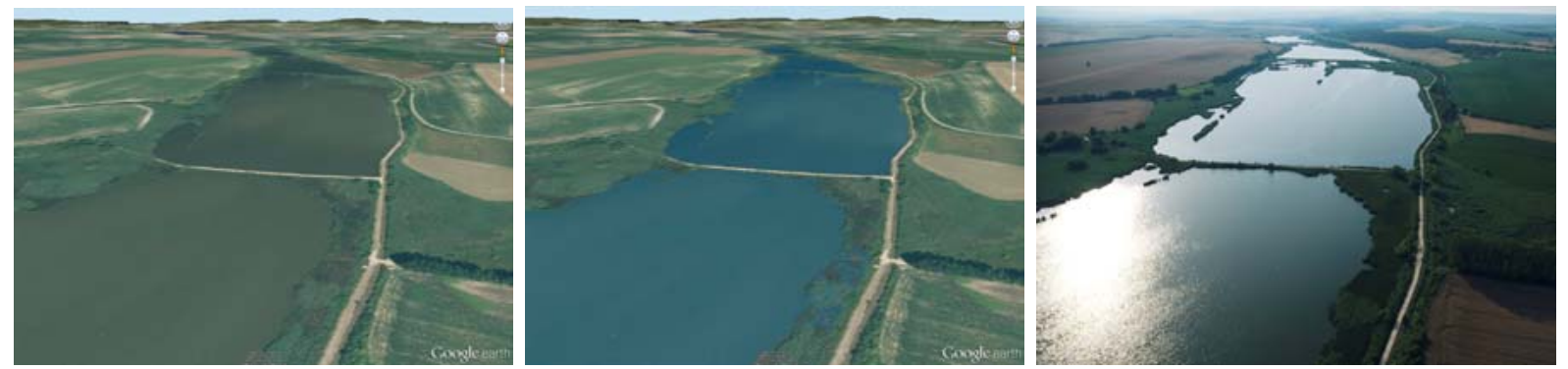

111. ábra A vízfelszínek színének tájjelleg-meghatározó szerepe a felvételeken. A vízfelszín felismerésén nagy mértékben javít a vízfelület „,kékítése” mind a ferde tengelyü, mind a mérőképes felvételek esetében. (Felvételek forrása: FÖMI Orto 2010 a GoogleEarth felületén, és Pillangó Siklóernyős Iskola Archívuma 2012) Helyszínek: halastó Biatorbágyon
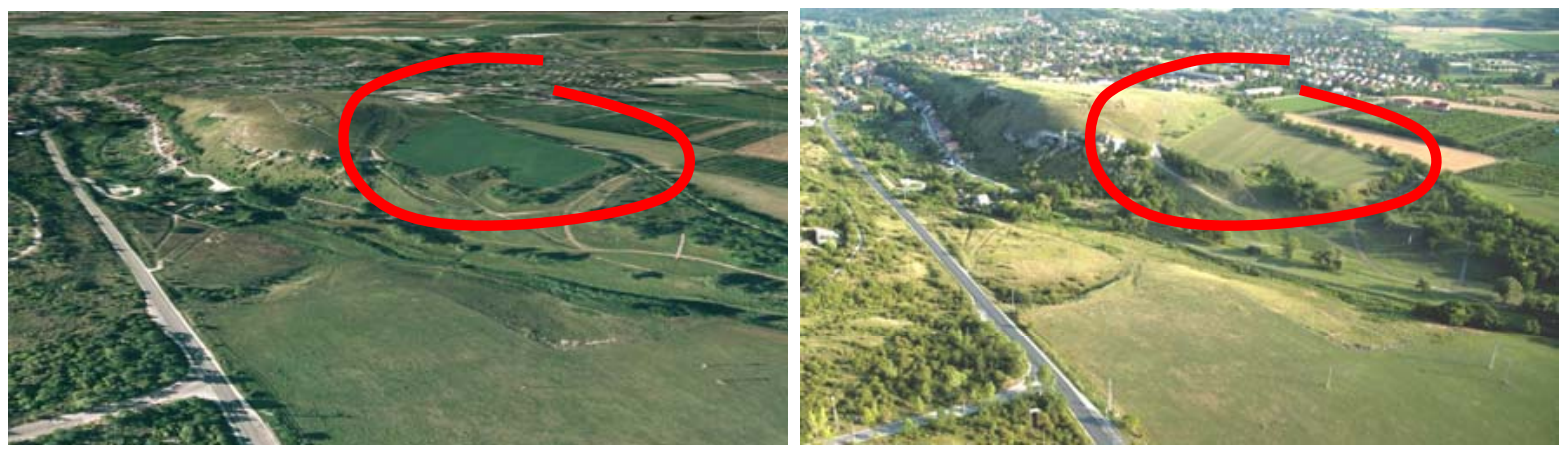

112. ábra Tévesen vízfelszínnek értelmezett kékeszöld kaszálófolt (Felvételek forrása: GoogleEarth és Pillangó Siklóernyős Iskola Archívuma 2012) Helyszín: Kálvária környéke Sóskúton

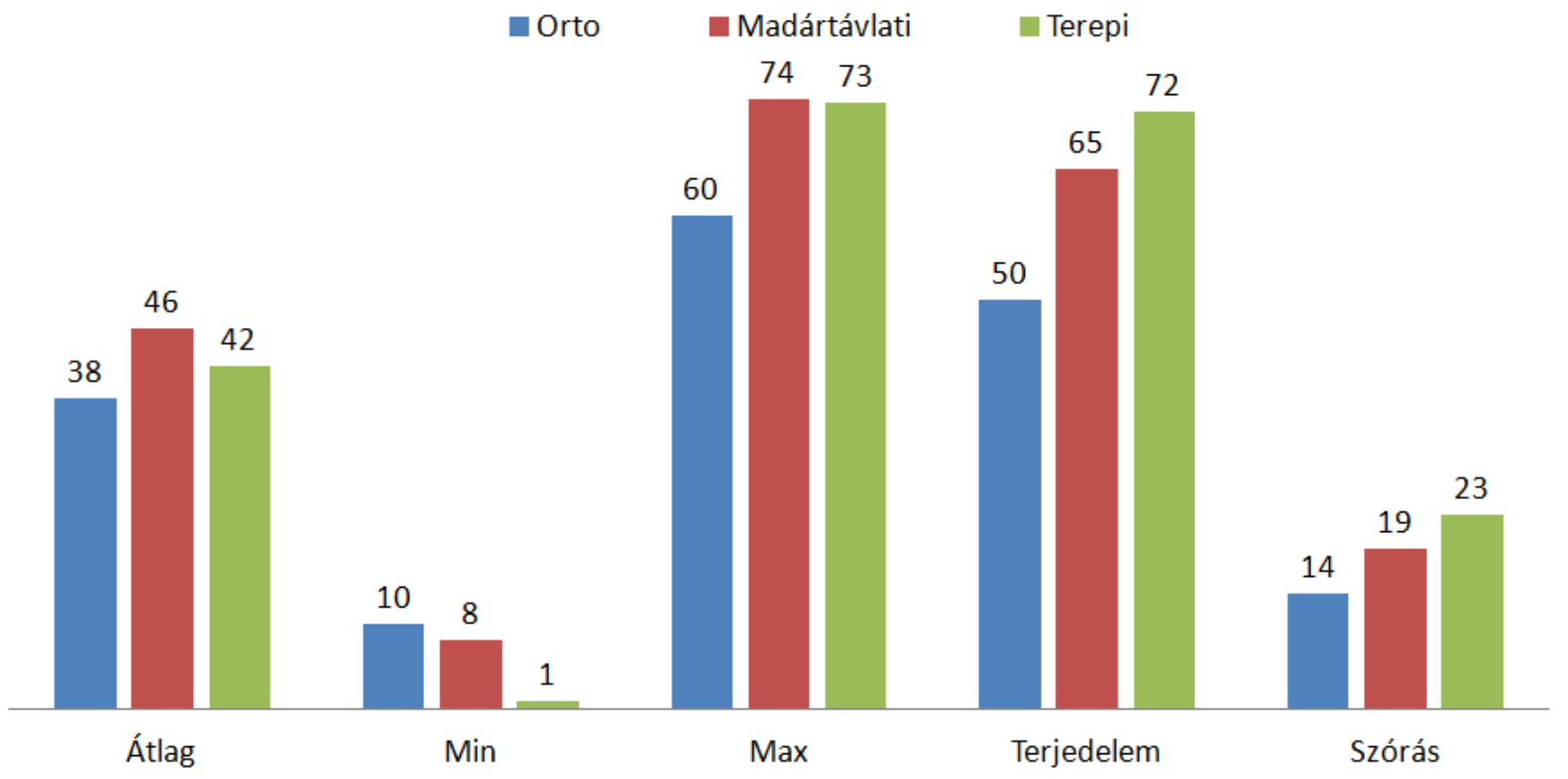

113. ábra A különböző felvételeken megjelenő tájrészletek helyes besorolásának aránya (\%) településekbe, a kérdőívek és interjúk eredménye alapján. 

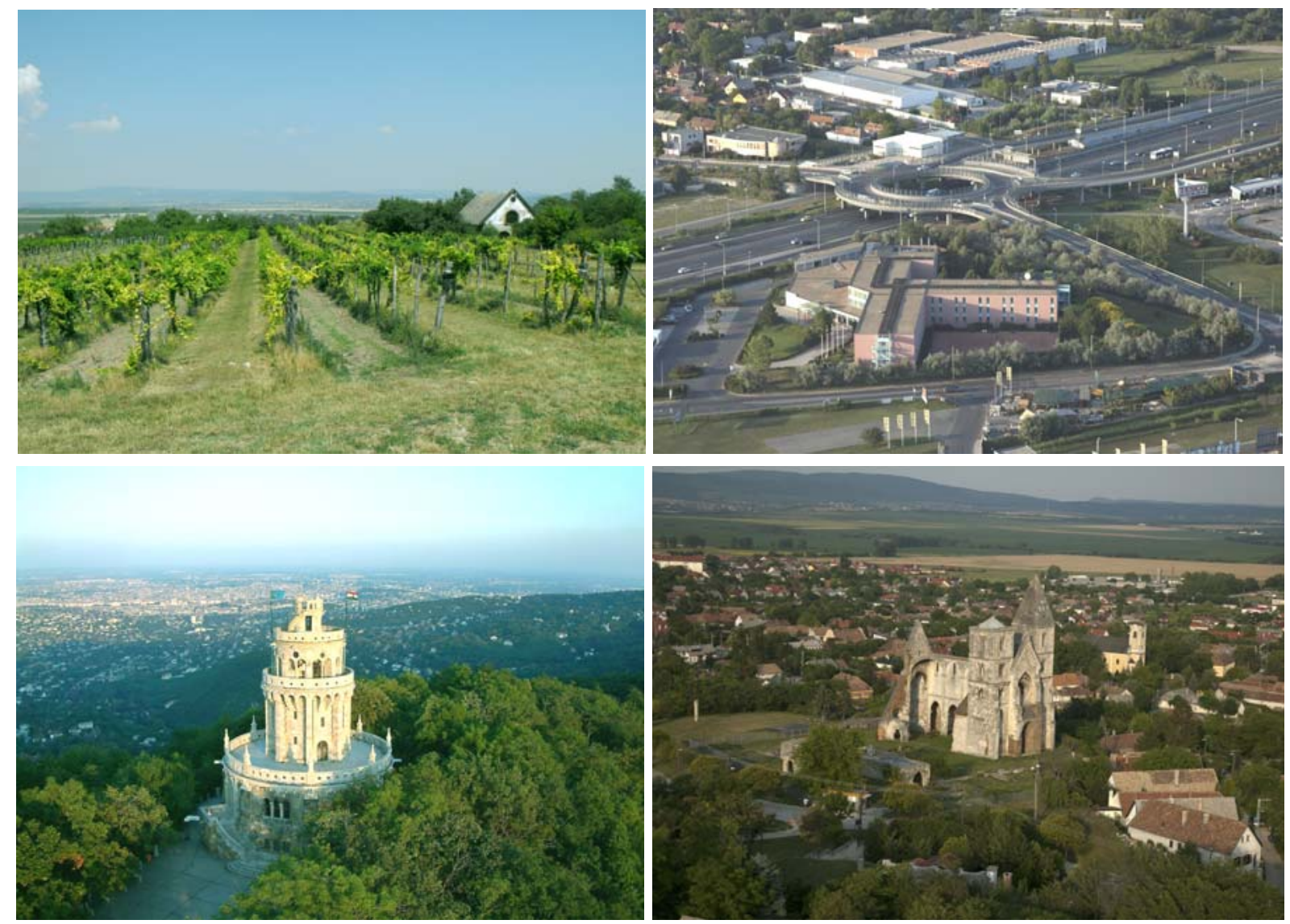

114. ábra A nagy arányban helyes településhez és kistájhoz kapcsolt tájrészletek felvételei. (Bal felső fénykép kivételével a felvételek forrása: Pillangó Siklóernyős Iskola Archívuma 2012) Helyszínek: Prásház és szőlők Etyeken, Autópálya-csomóppont a Budaörsimedencében, Erzsébet-kilátó a Budai-hegyekben, Romtemplom a Zsámbéki medencében.

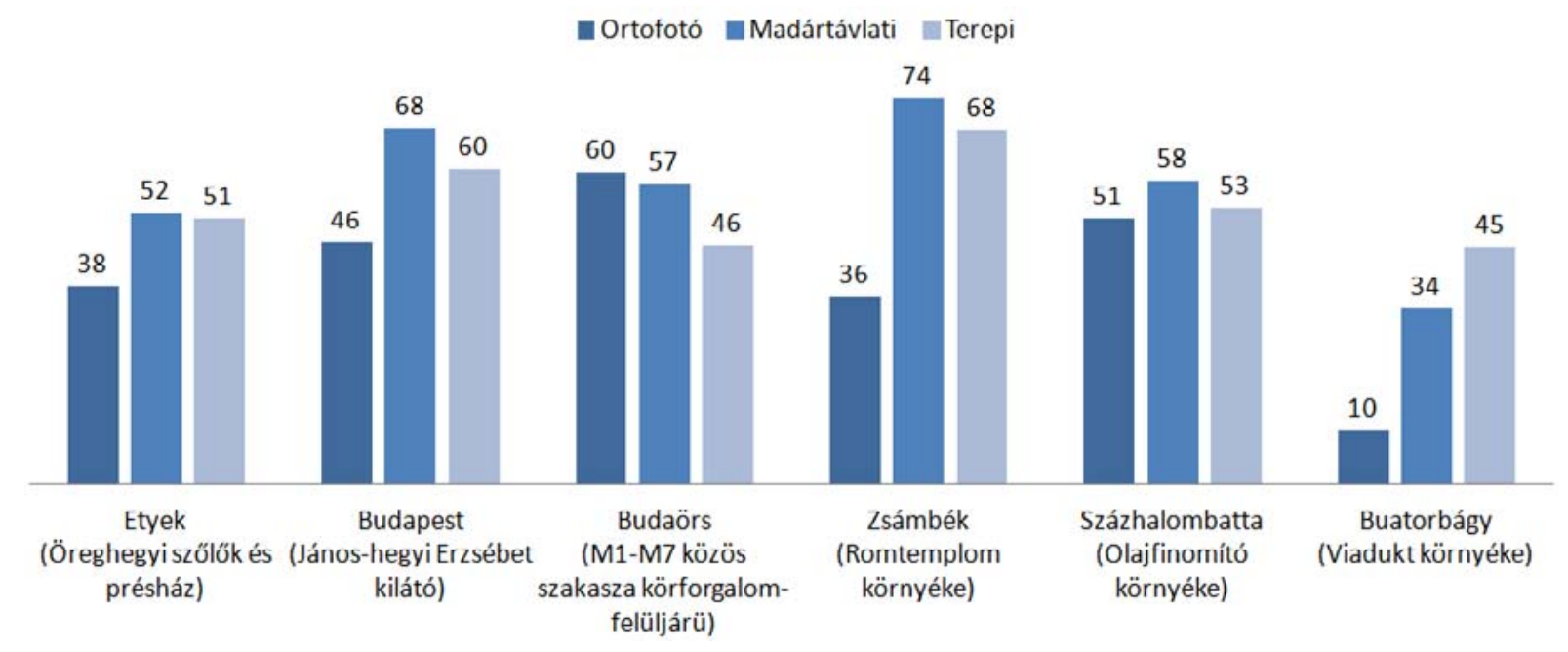

115. ábra A tájrészletek helyes településbe sorolásának aránya (\%), a különbözö felvételeket bemutató kérdőívek és interjúk eredménye alapján. 

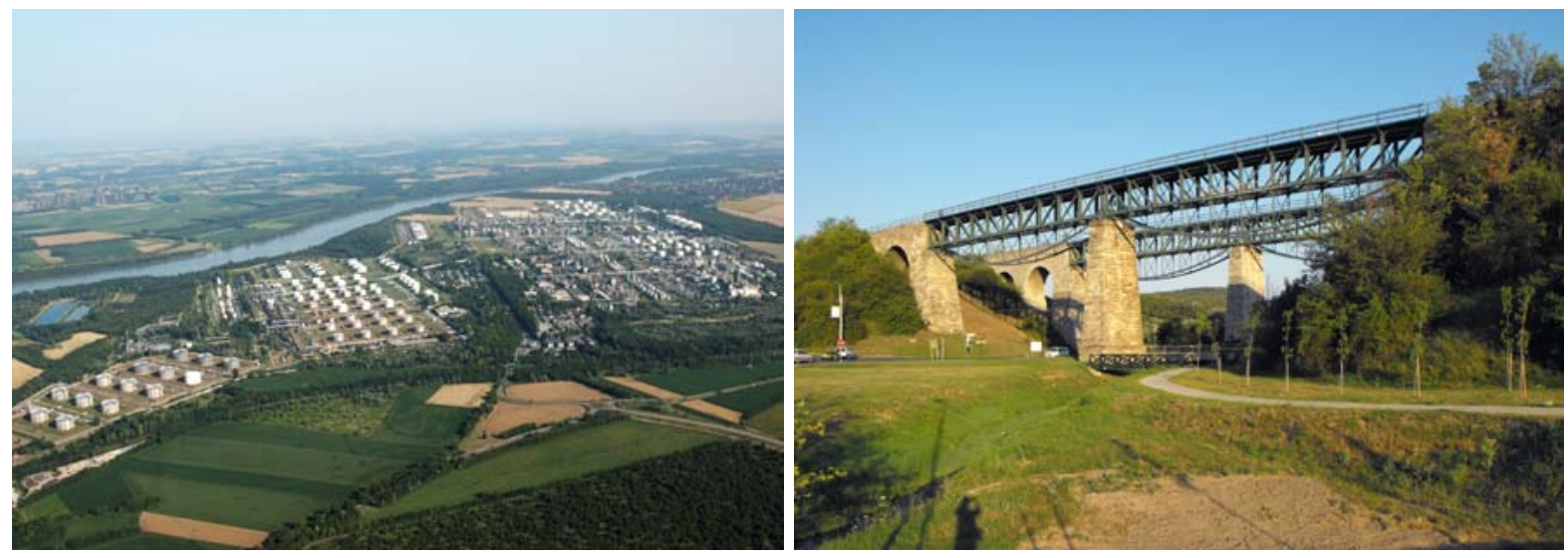

116. ábra A nagy arányban helyesen településhez, de nem megfelelő kistájhoz sorolt helyszínek felvételei (Százhalombatta, olajfinomító, Biatorbágyi Viadukt), de ennek ellenére a tájegységhez kapcsolásuk kevésbé volt sikeres, mert nehezen meghatározható tájegységhez tartoznak, vagy több tájegység határán helyezkednek el. (Érd-Ercsi hátság; Etyeki dombság, Tétényi fennsík, Zsámbéki medence) (Bal oldali felvétel forrása: Pillangó Siklóernyős Iskola Archívuma 2012)

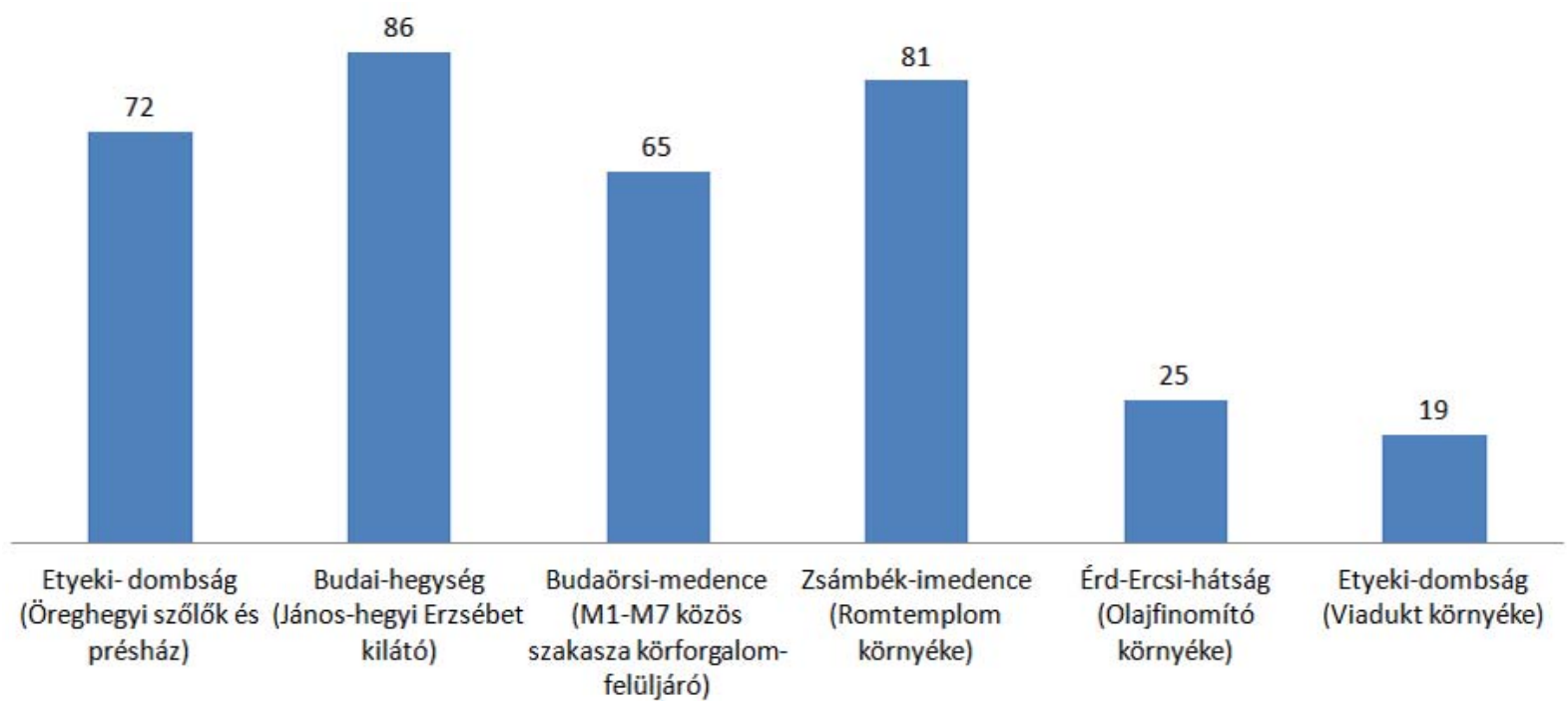

117. ábra A tájrészletek helyes tájegységbe sorolásának aránya (\%), a madártávlati felvételeket bemutató interjúk eredménye alapján. Az interjúalanyok mind Budapest környékén éltek és tudták, hogy Budapest környéki tájrészleteket láthatnak. 

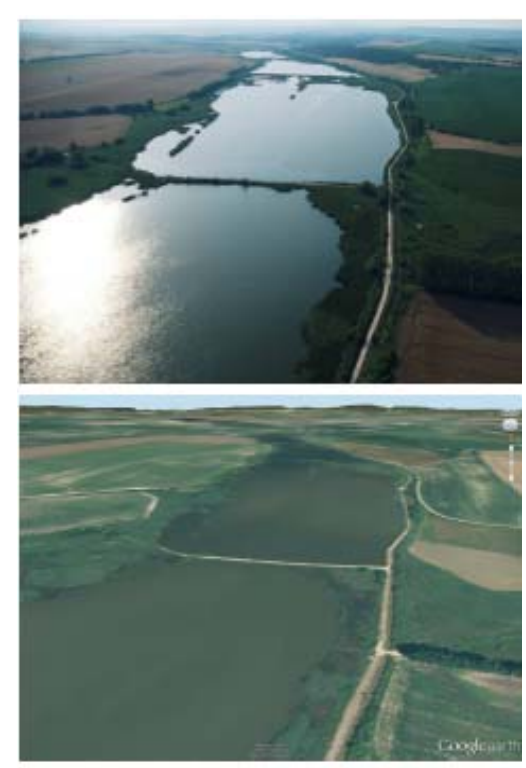

Halastó (Biatorbágy)
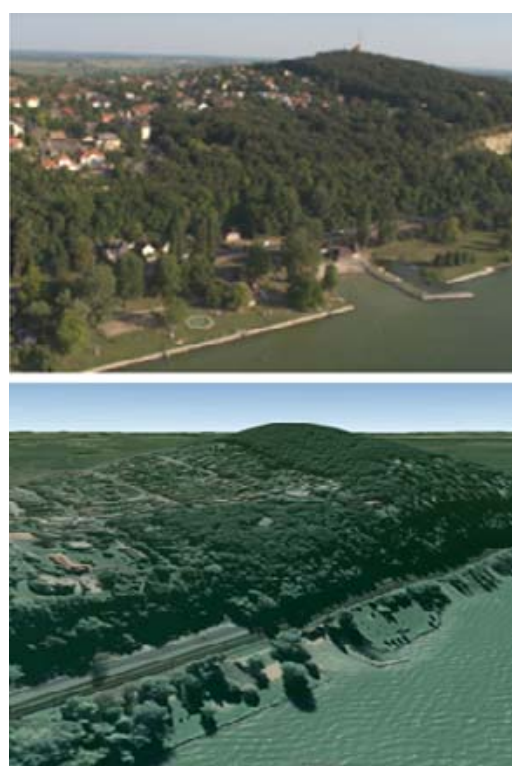

Várhegy (Fonyód)
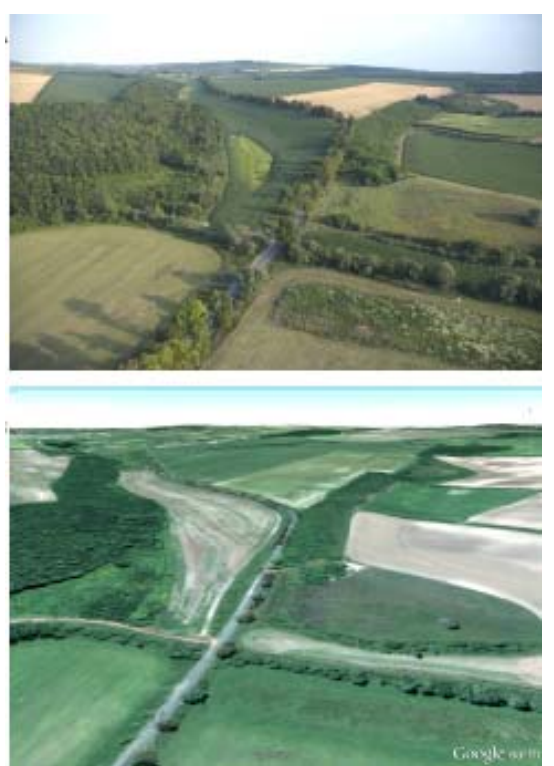

Kettős gesztenyefasor (Etyek)

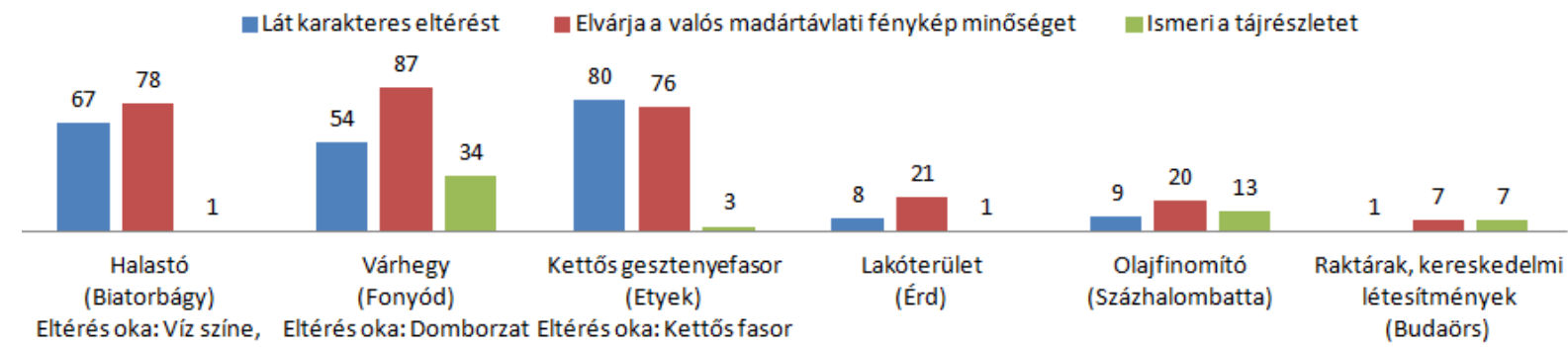

Elés oka:Viz szine, Eltérés oka:Domborzat Elteres oka: Kettốs fasor elnagyoltsága, nem érvényesül
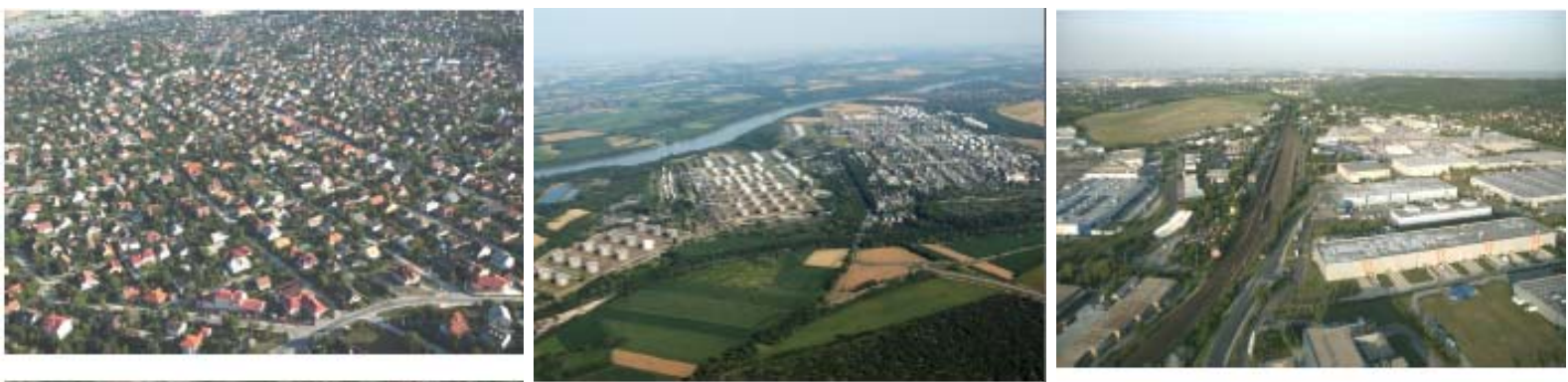

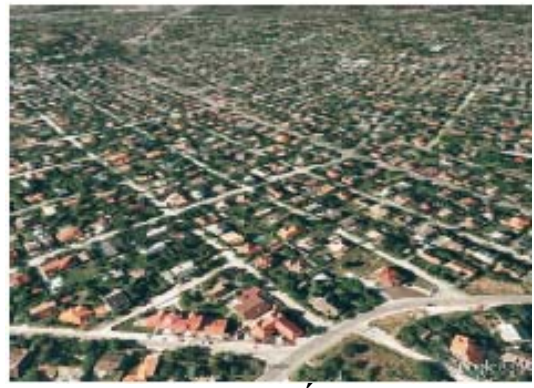

Lakóterület (Érd)

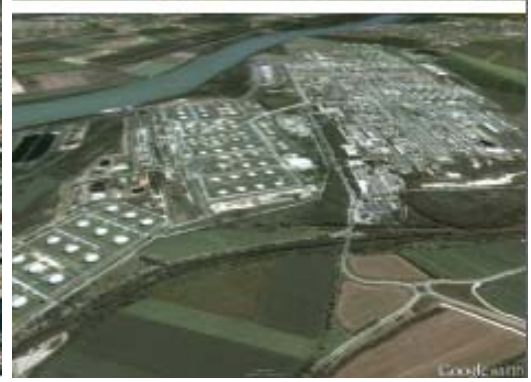

Olajfinomító (Százhalombatta)

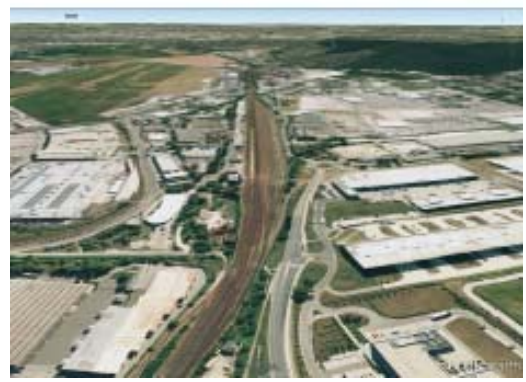

Raktárak (Budaörs)

118. ábra A tájjelegbeli eltérés megítéséle madártávlati fényképek és $2,5 \mathrm{D}$ tájmodellek között. A kérdőívezettek válaszainak arányában (\%). Jelentős jellegbeli eltérések (fent) nem jellegbelinek tekintett eltérések (lent) a madártávlati felvételhez képest a 2,5D tájmodellen. (Felvételek forrása: GoogleEarth és Pillangó Siklóernyős Iskola Archívuma 2012) 

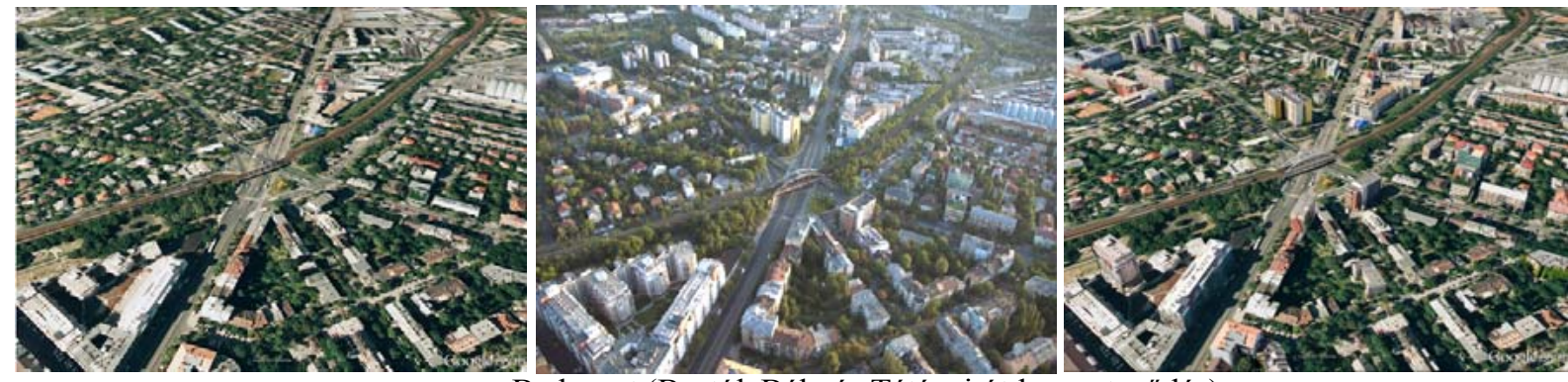

Budapest (Bartók Béla és Tétényi út kereszteződés)
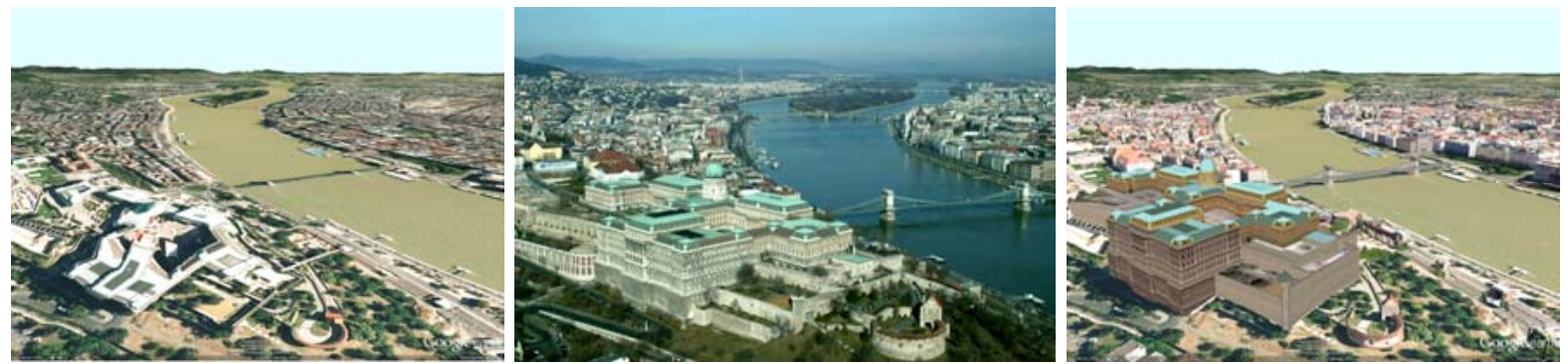

Budapest (Budai Királyi Palota)
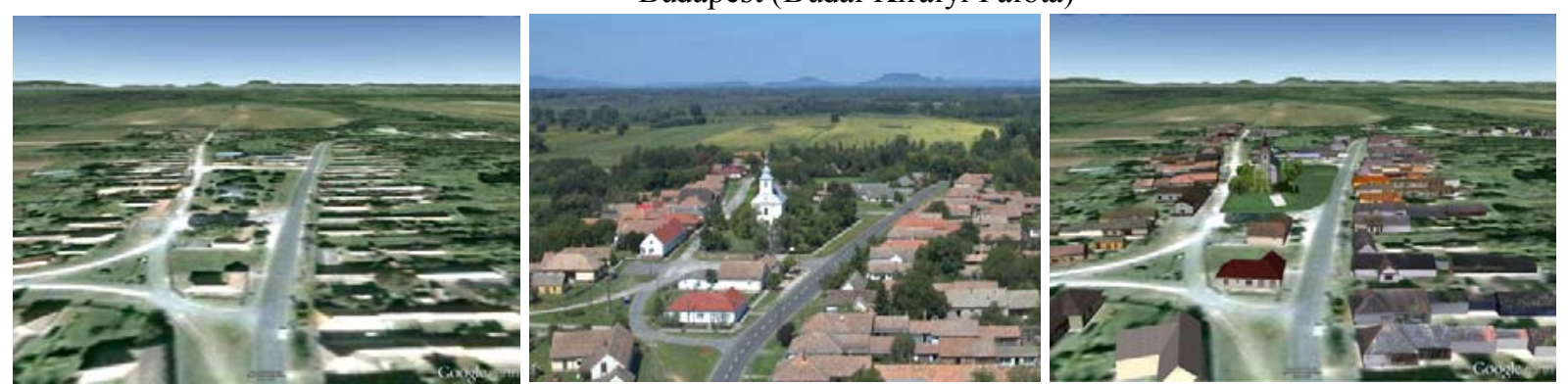

Táska (faluközpont)
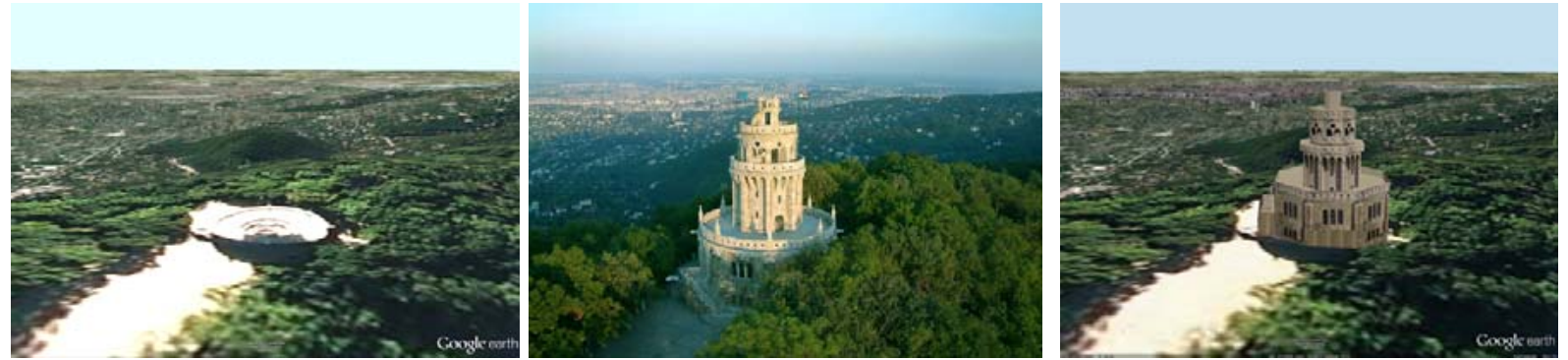

Budapest (János-hegy, Erzsébet-kilátó)

— Lát karakteres eltérést, ha nincs 3 D épület

- Lát karakteres eltérést, ha van 3 D épület akkor is

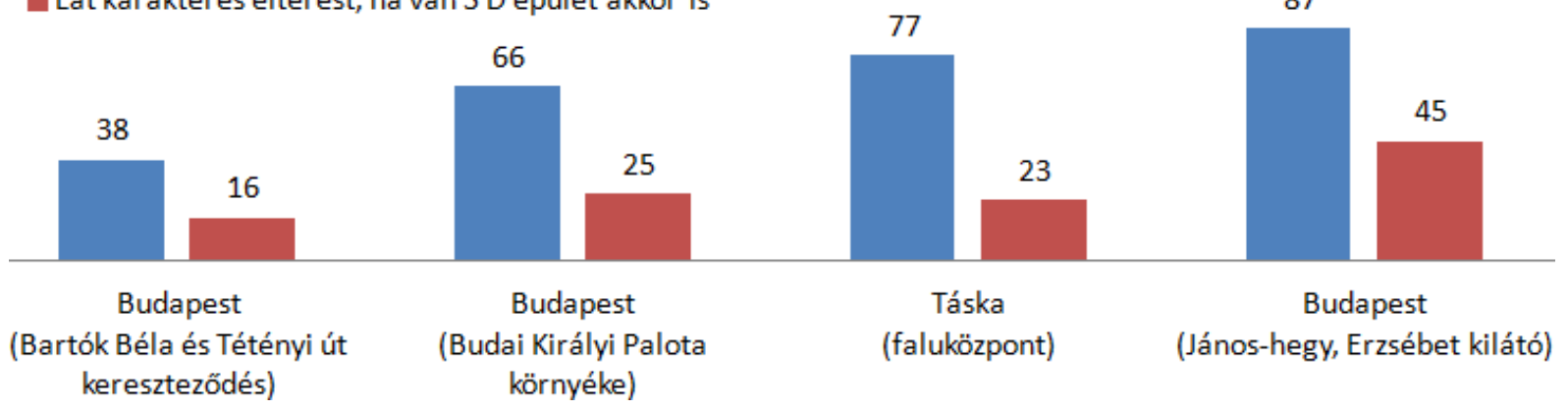

120. ábra A tájjelegbeli eltérés megítéséle madártávlati fényképek és 2,5D és 3D tájmodellek között. A kérdőívezettek válaszainak arányában (\%). A közeli jellegzetes épületek hiányát a válaszadók legalább kátharmada karakterbeli különbségnek vélte, de a fotorealisztikus 3D-modellekkel ezt az arányt 25-45\%-ra lehetett mérsékelni. 

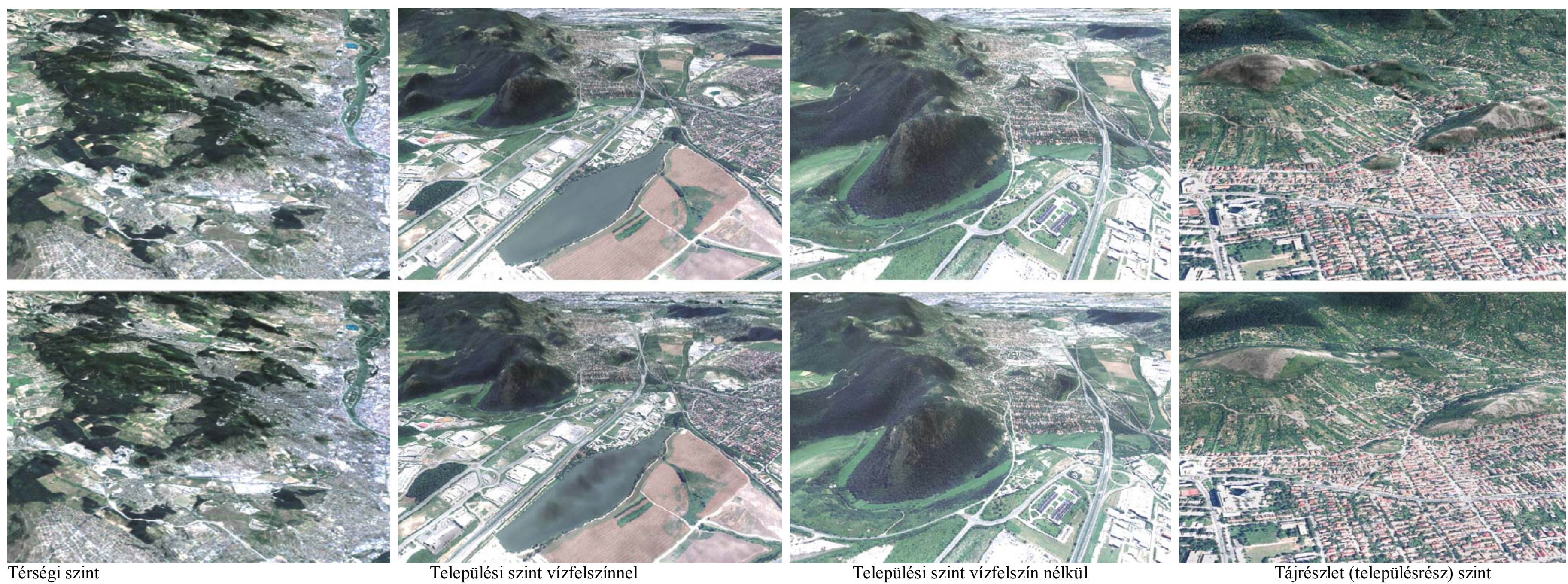

Lát eltérést (\%)

Tájrészlet (településrész) szin

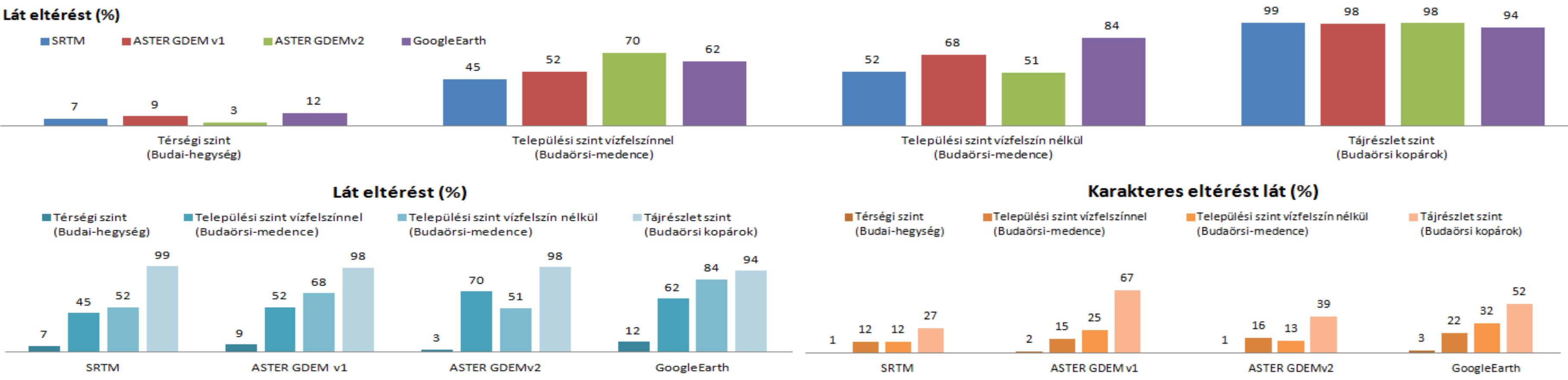

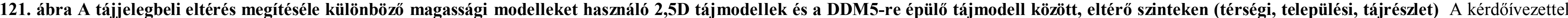
válaszainak aránya (\%). Az ábrán DDM5-re (felső képek) és ASTERGDEMv1 modellekre (alsó képek) épülő tájmodellek szerepelnek mintaként. 


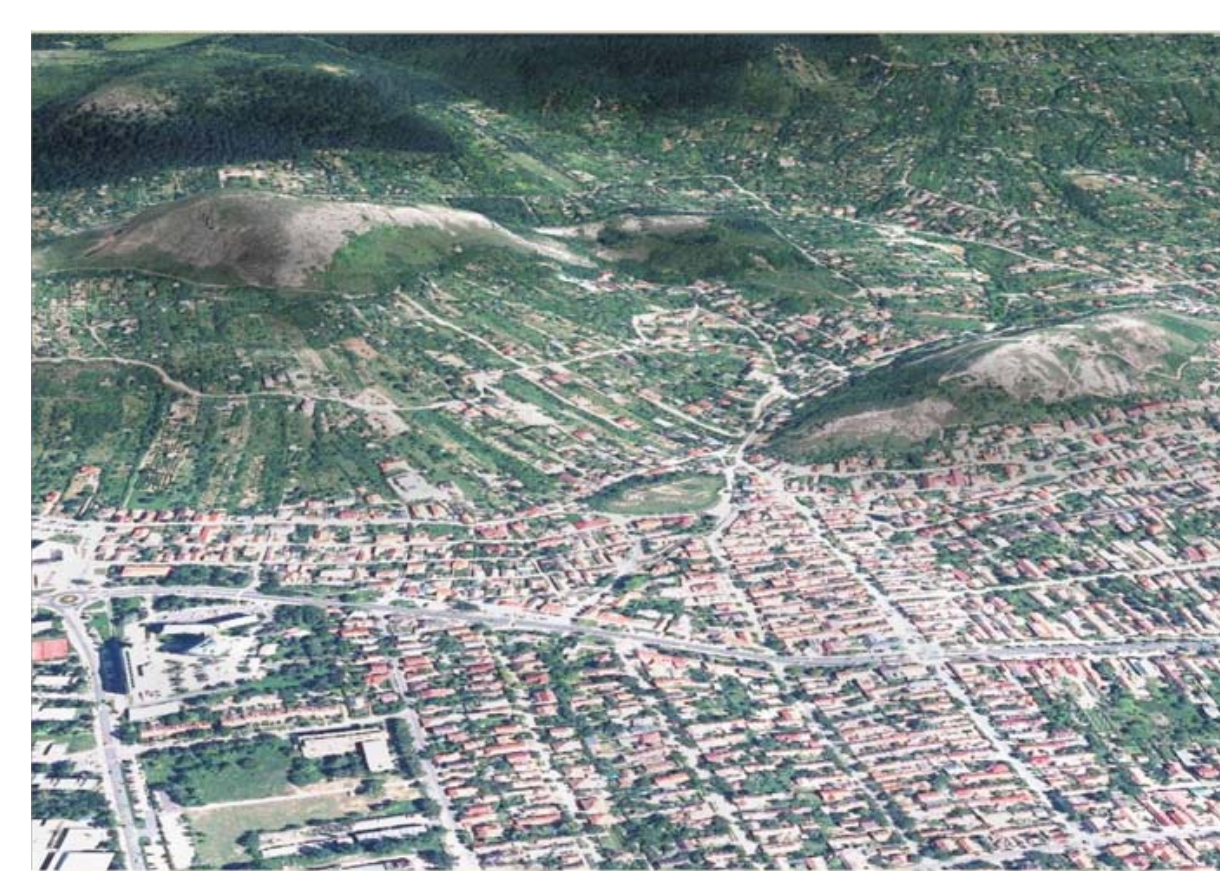

SRTM

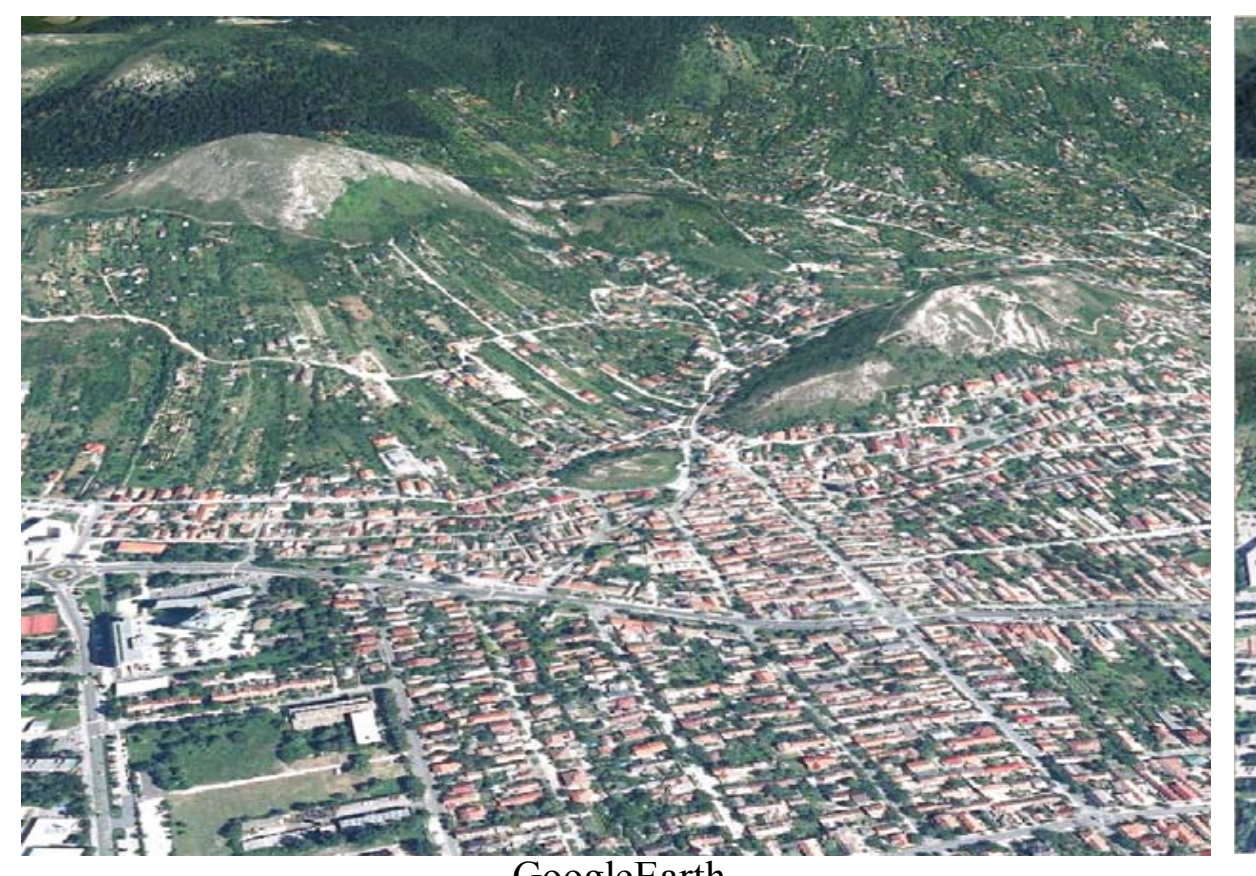

GoogleEarth

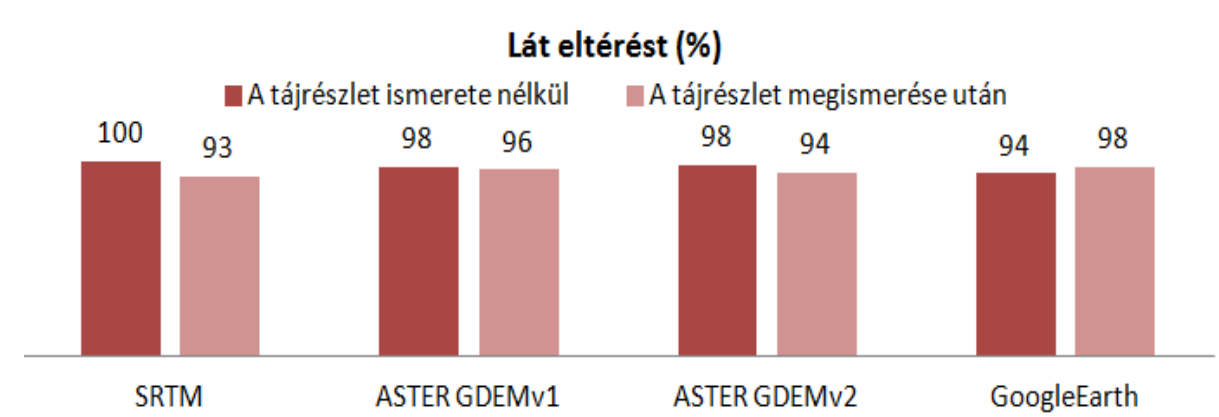

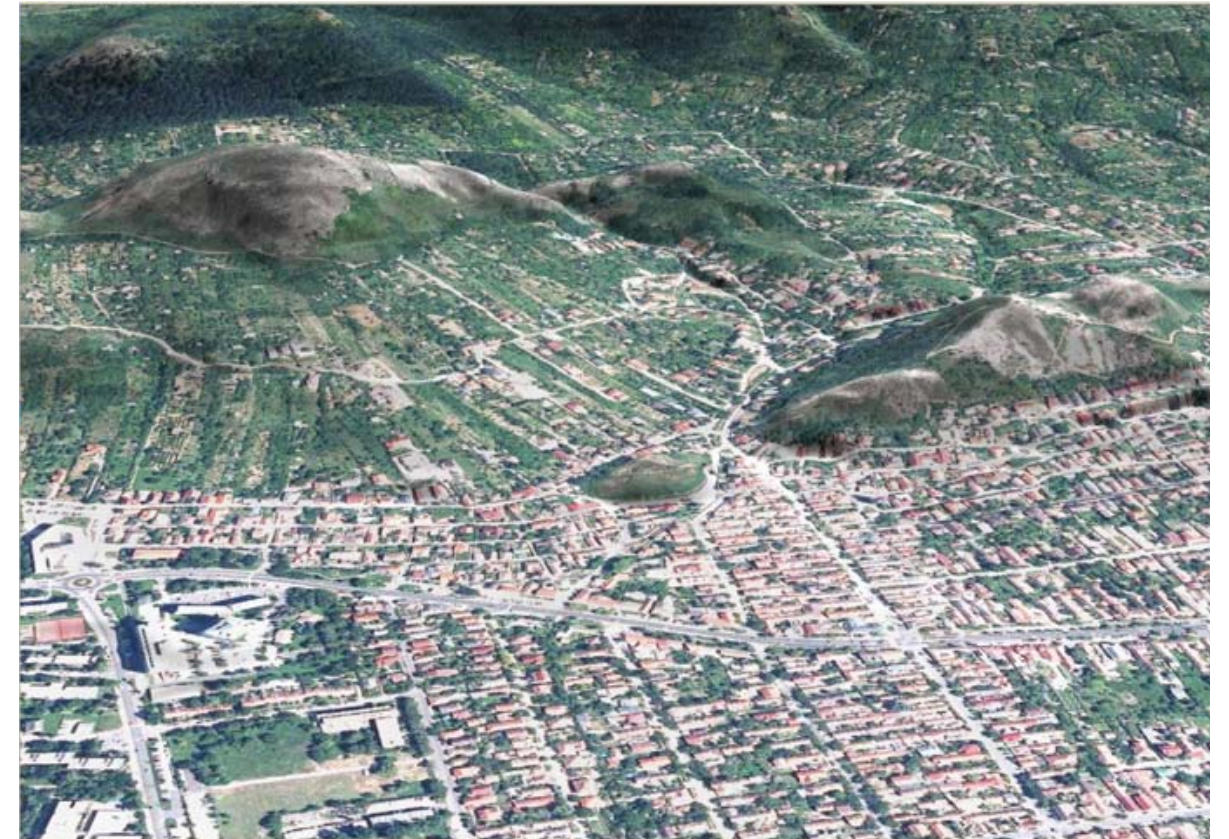

DDM5

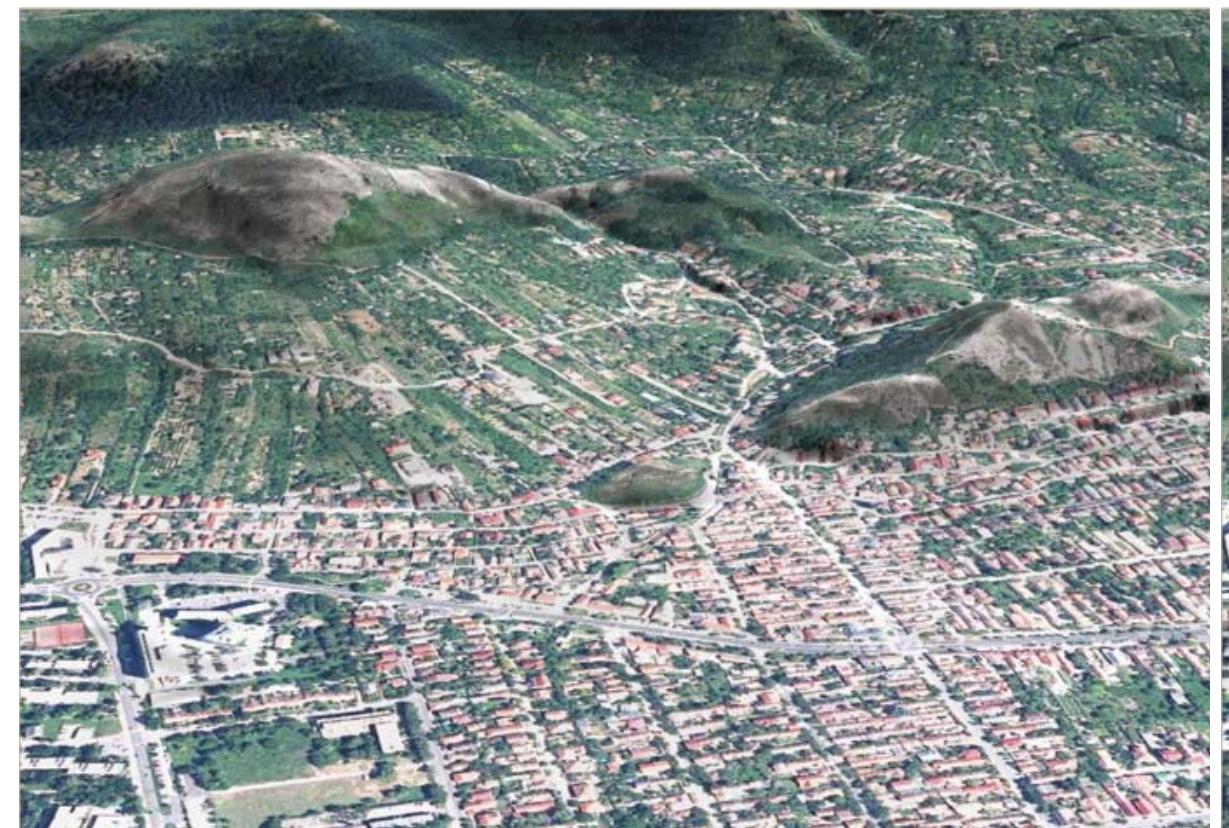

DDM5

Karakteres eltérést lát (\%)

—A tájrészlet ismerete nékül $\quad$-A tájrészlet megismerése után
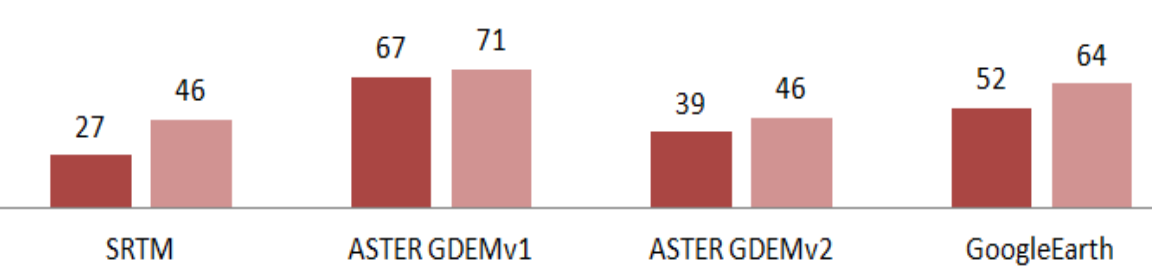

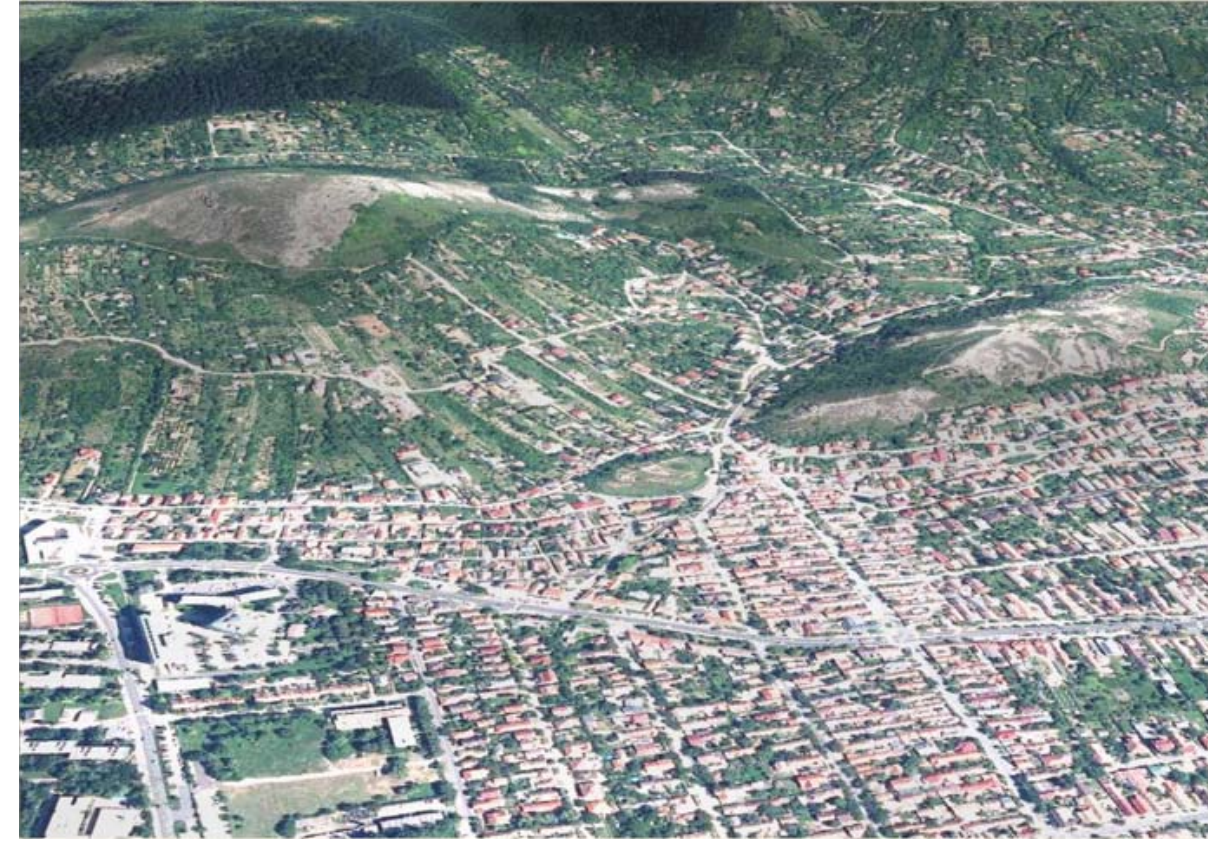

ASTER GDEMv1

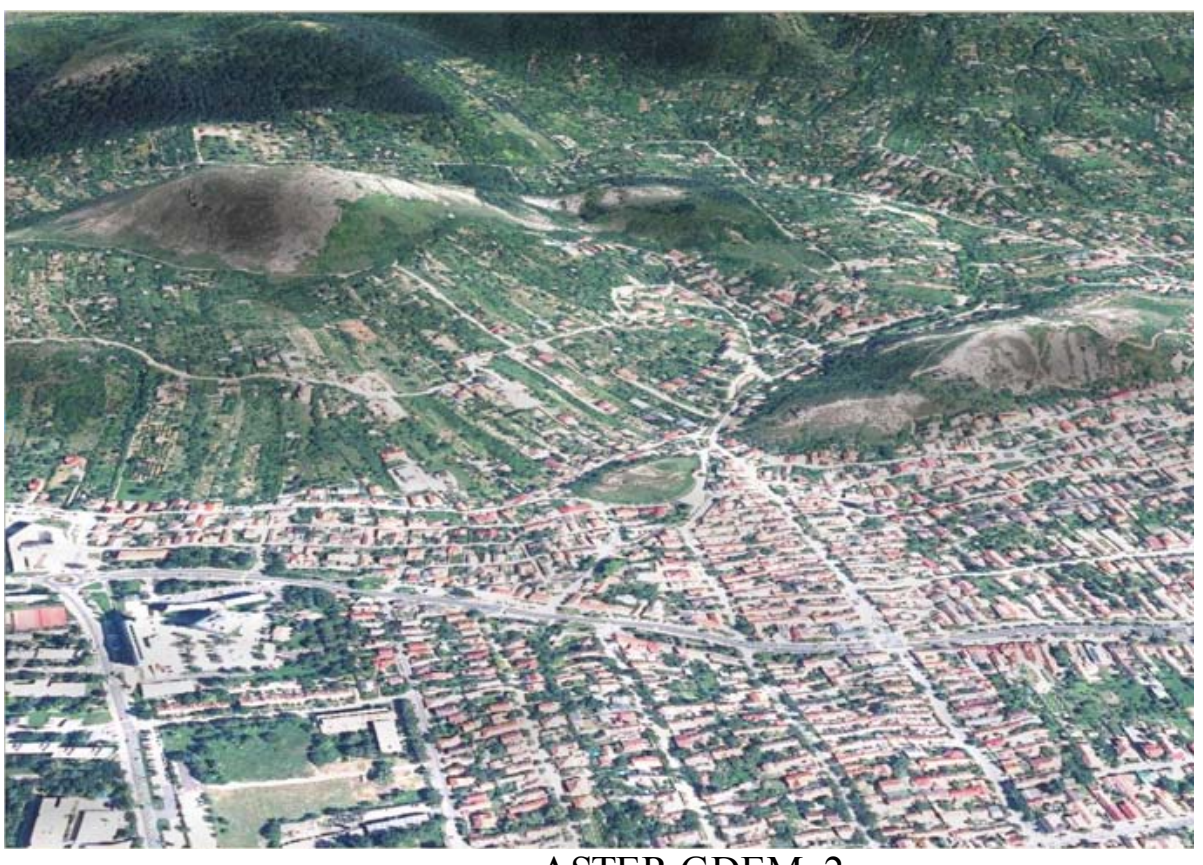

ASTER GDEMv2

Az ingyenes tájmodellt kéri (\%)

A tájrészlet ismeretenékül $\llbracket A$ tájrészlet megismerése után

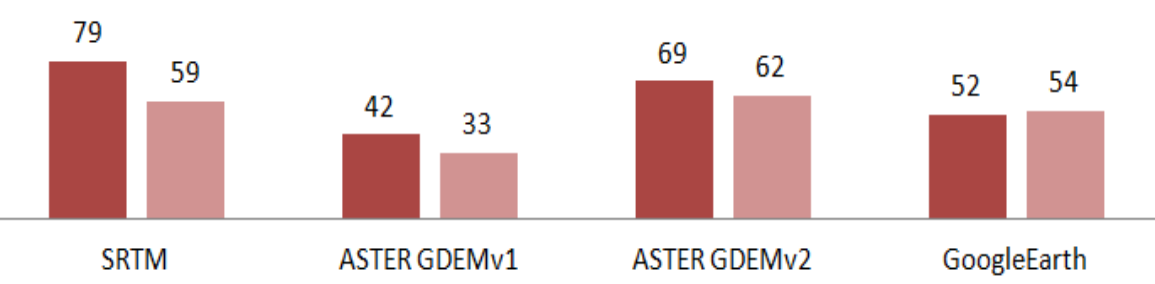

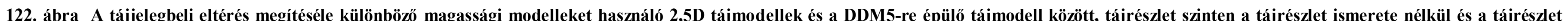
megismerése után. A kérdőívezettek igen válaszainak aránya (\%).

M99 


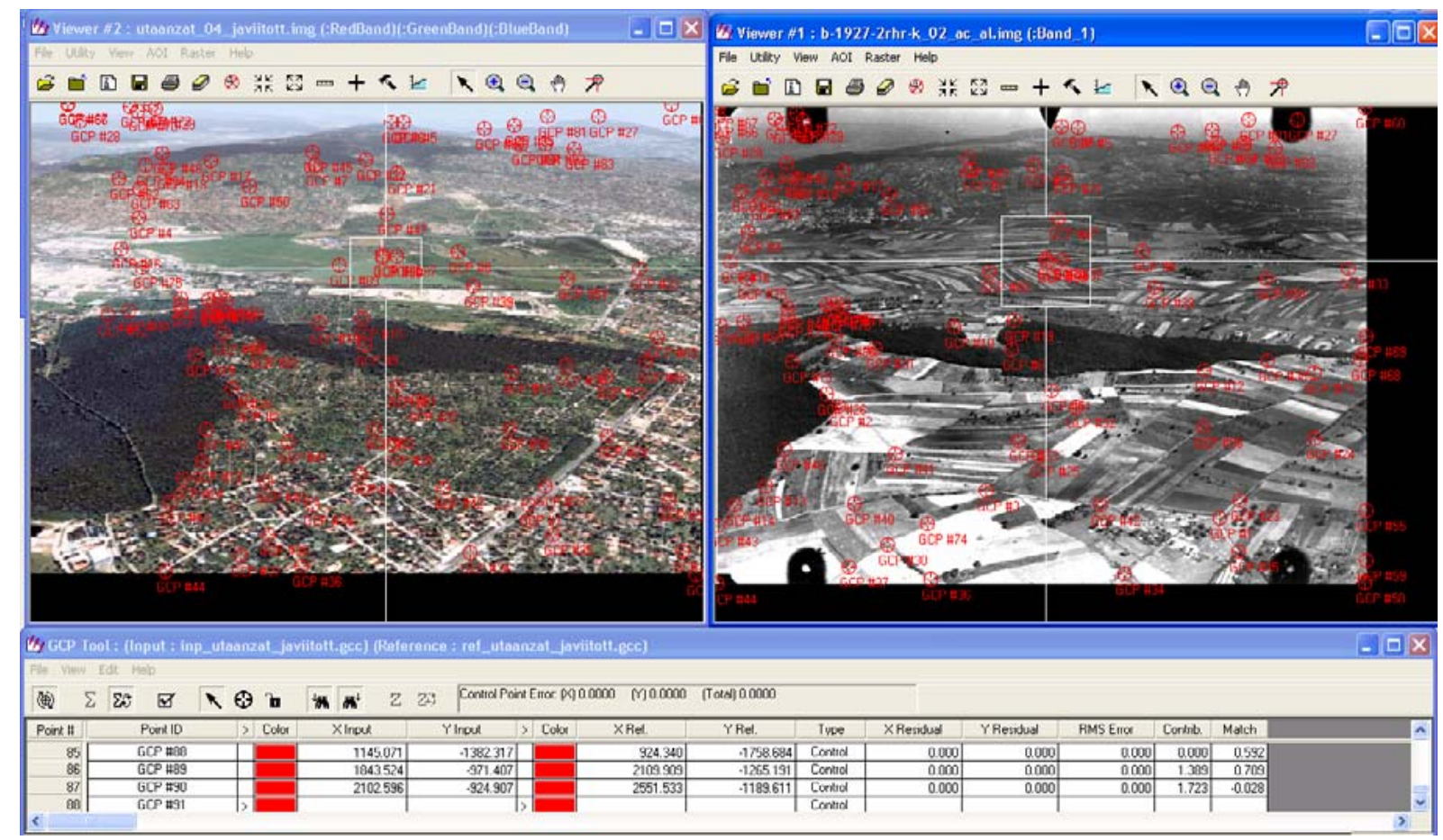

123. ábra Felvételek készítésének, feldolgozásának, igazításának módszere tájjellegváltozás megjelenítésének minőségi animálása érdekében. A tájjelleg változásának megjelenítése érdekében 3.c lépésben meghatározott korrekció ERDAS Imagine-nel. A lépés során megtörténik a 2,5D tájmodellről képként mentett látvány (balra) korrekciója a bázisidőpont madártávlati fényképéhez (jobbra). Egy 1920-as években készített madártávlati légifelvétel és egy 2008-ban készült nagyfelbontású ürfelvétel igazításáról készült munkaközi képriport 


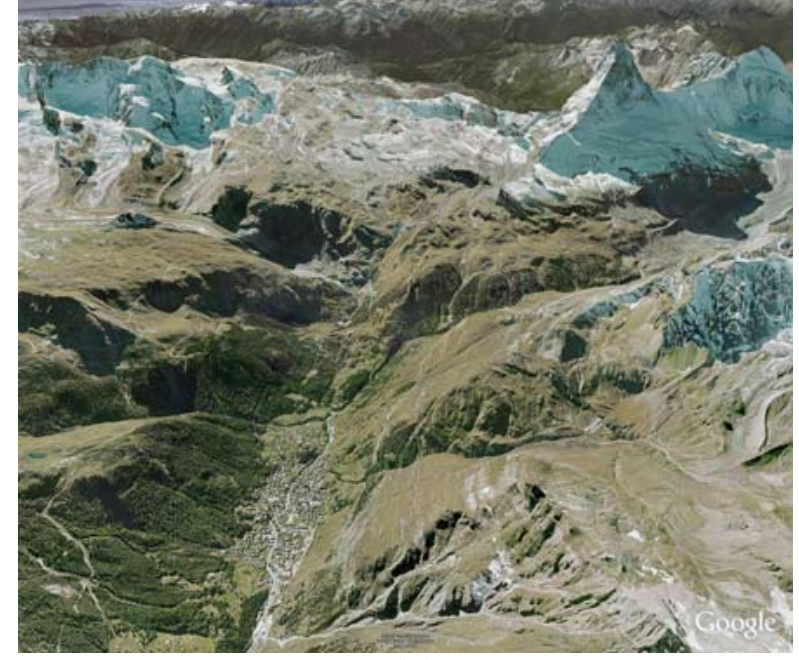

(1)

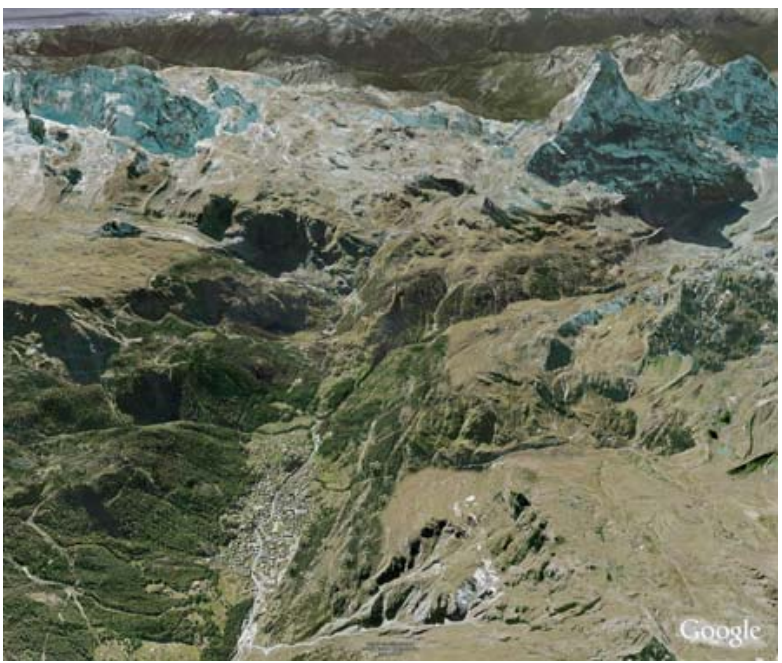

(3)

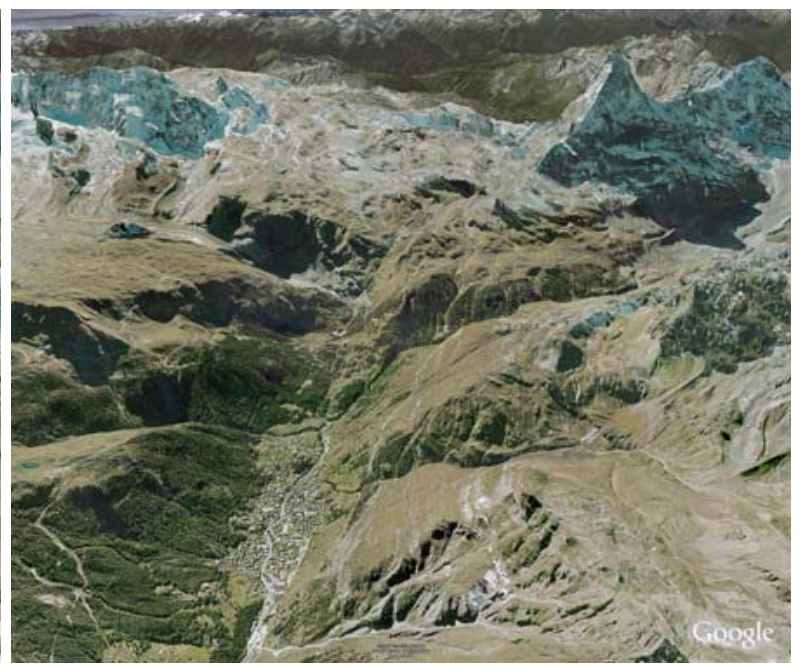

(2)

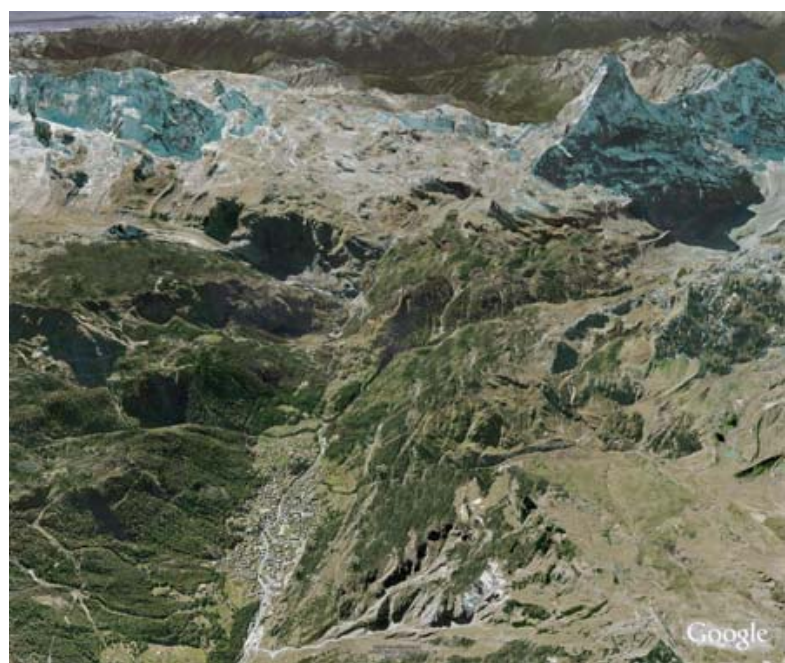

(4)

124. ábra Jövőben várható tájjellegváltozás megjelenítése képszerkesztéssel és mozgóképkészítéssel. Fényképszerkesztő programmal (Photoshop) előállított képsor (1-4), melyek lépésről lépésre az alpesi táj egyik potenciális átalakulási folyamatát jelzik a hófödte csúcsok eltünésével, az erdőhatár változásával a globális éghajlatváltozás egyik lehetséges következményeként Svájcban a Matterhorn csúcsának térségében. (Felhasznált tájmodell forrása: Google Earth) 


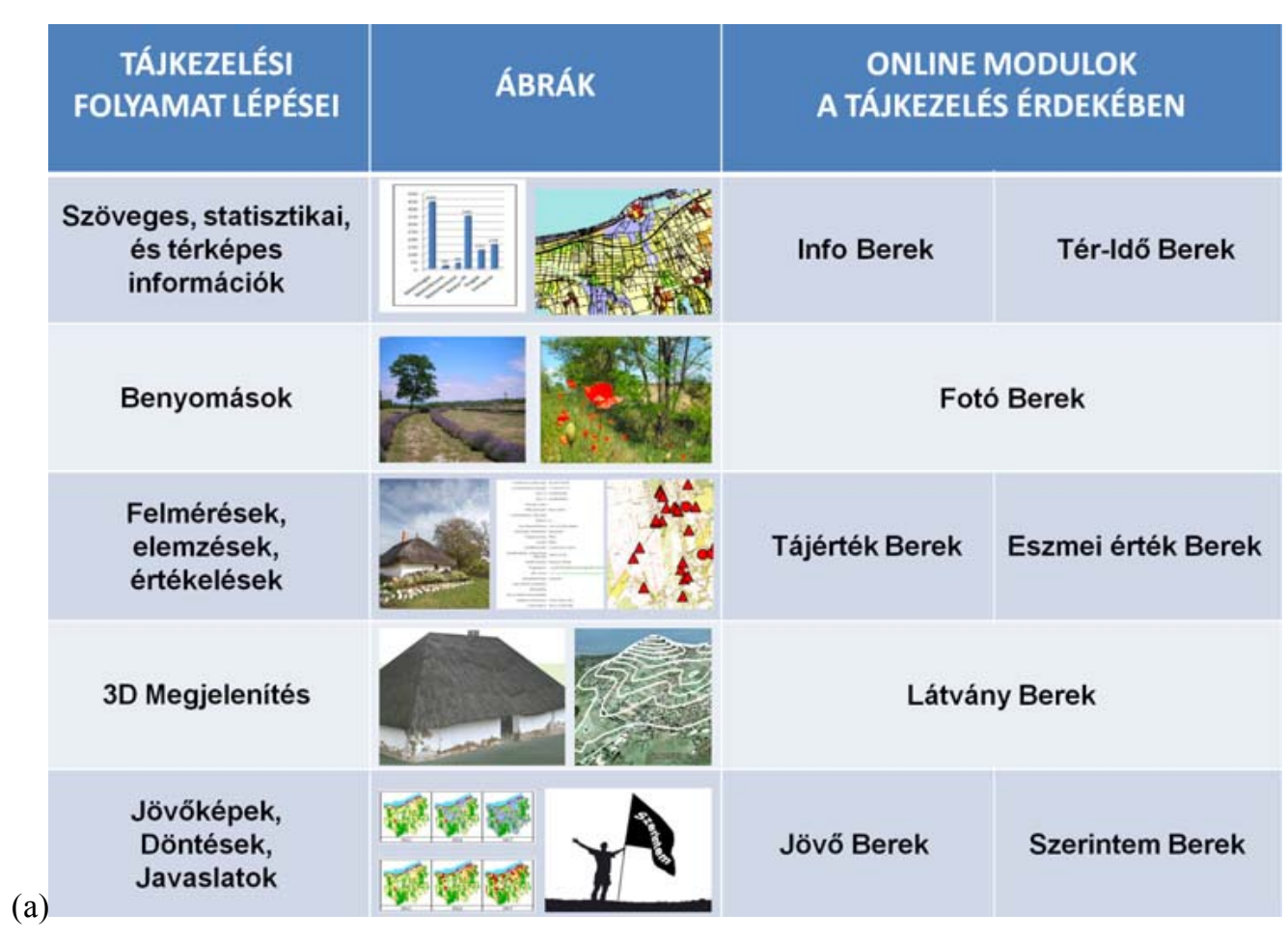

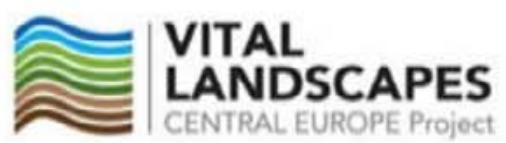

\section{CEETRAP}

ELÖO BEREK

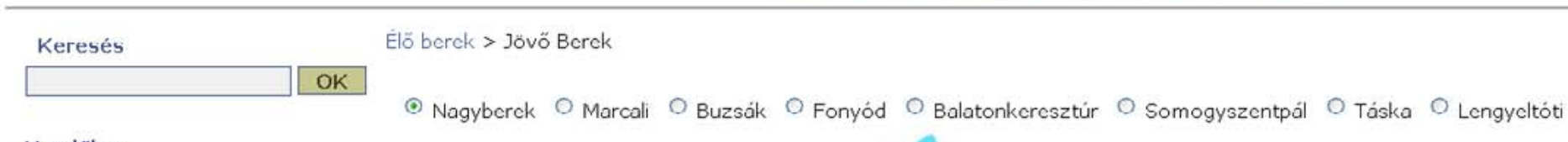

Kezdölap
F́lö Tájak Projekt

Élō Tajak Proj
Info Bcrck

Into Bcrck

Tér-Idö Berek

Iajejrtèk Berek

\begin{tabular}{l} 
Lszmei erték Berck \\
\hline Jovo Berek
\end{tabular}

Jovob Berek
Jovö Berek mükodés
Szerintem Berek

Jövő Berek

ÆiviAL

6. CENTRAL

Tegyelidibutacást a
Naquberébben!!

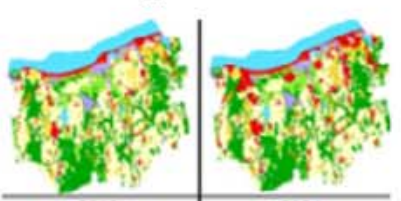

๑ Nagyberck $\bigcirc$ Marcali $\bigcirc$ Buzsák $\bigcirc$ Fonyód $\bigcirc$ Balatonkcrezztúr $\bigcirc$ Somogyszentpál $\bigcirc$ Táska $\bigcirc$ Lengycltóti
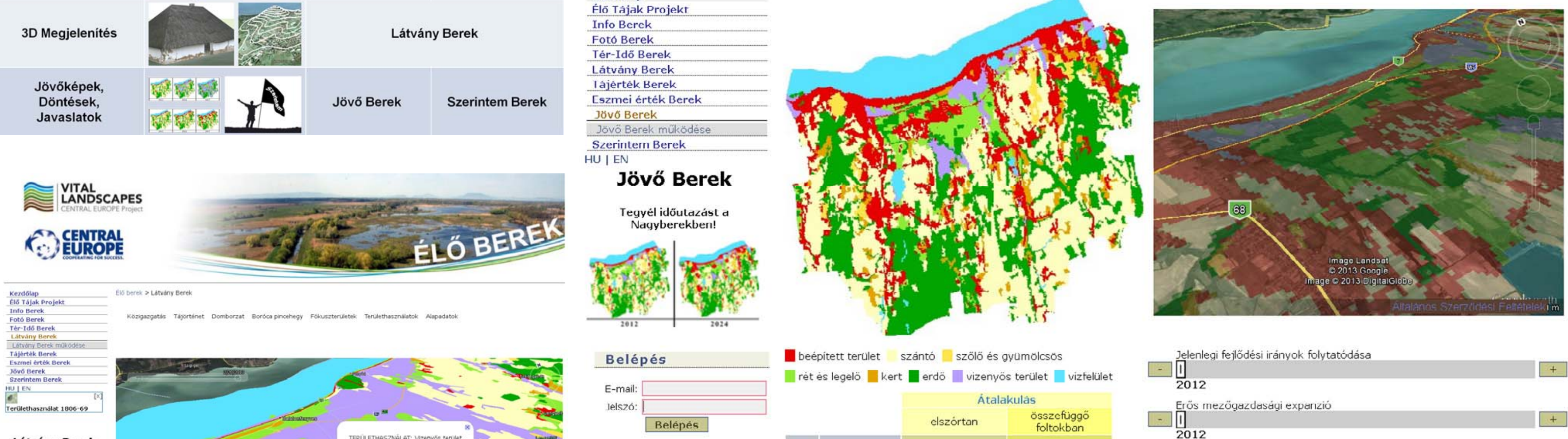

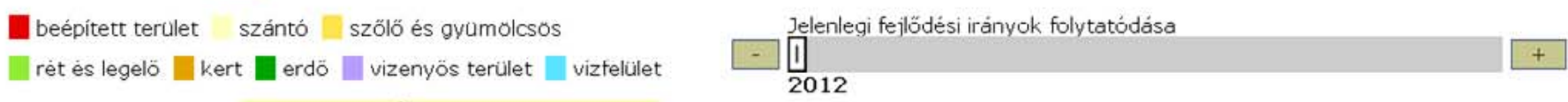

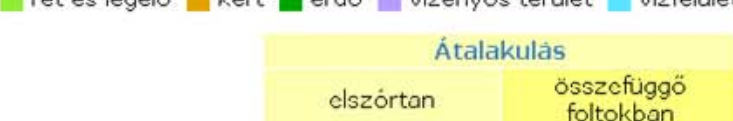

$-\prod_{2012}^{\text {Erös mezögazdaságie expanzió }}$

Regisctráció

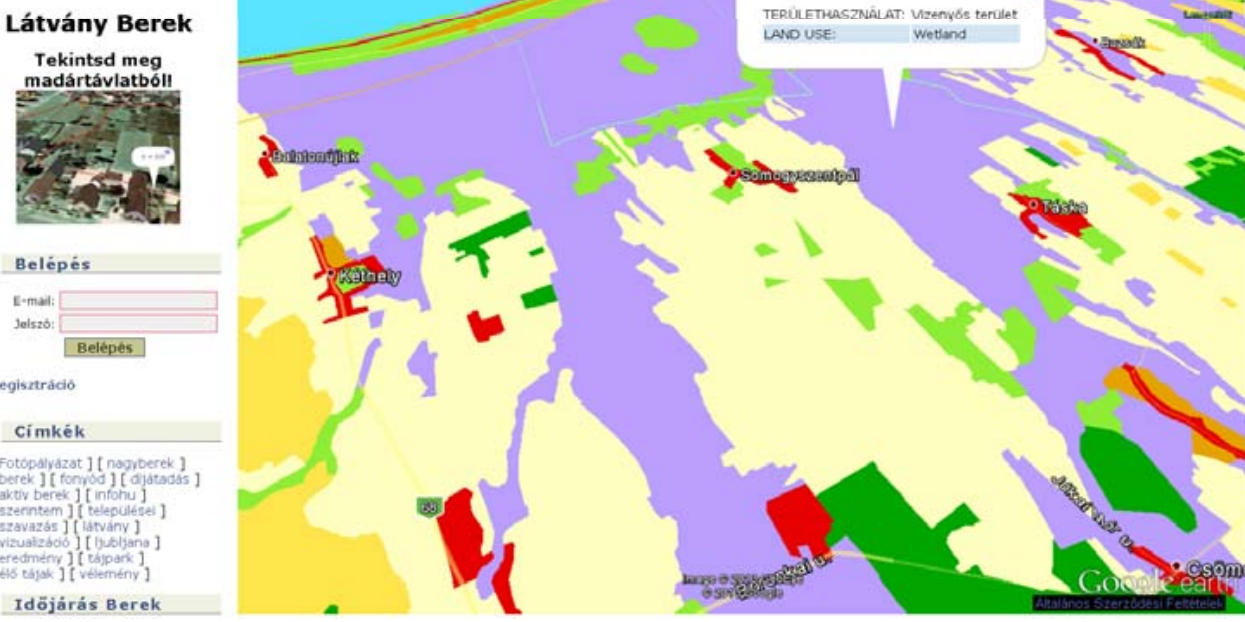

Cím kék
[Fotópályázat] [ berek ]

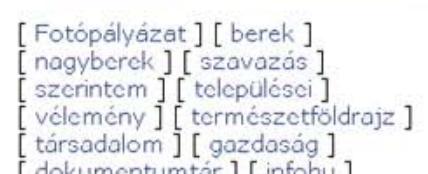

[ tórsadalom ] [ gazdaság ]
$[$ dokummentumtár [ infohu ]
$[$ aktiv berek ] [ dijatadàs ]

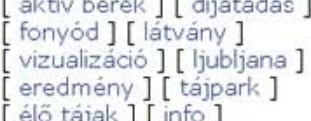

I đổiárác Rarak

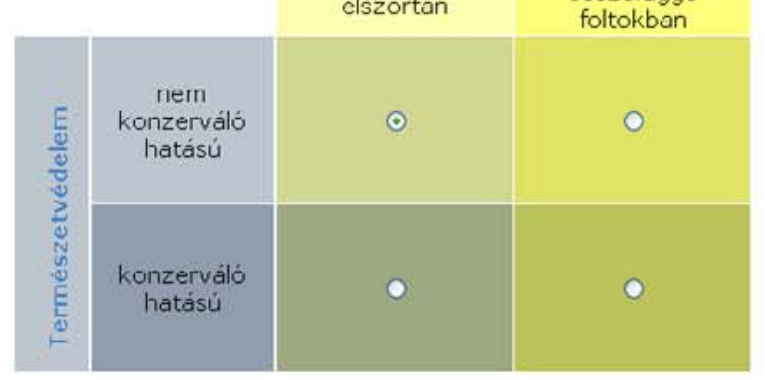

\begin{tabular}{|l|l|} 
Természetes folyamatok fokozódó érvényesulése \\
\hline$-\left.\right|_{2012} ^{\mid++}$
\end{tabular}

Erdŏgazdaság és vadgazdákodás szerepének novekedése

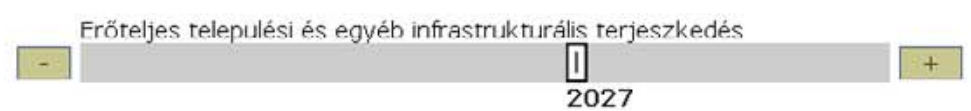

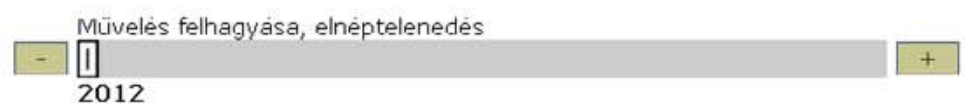

(b)

125. ábra Az Éló Berek weboldal (e-berek.hu) vizualizációs megoldásai. A tájkezelést támogató modulok rendszere (a), Múltbéli terưlethasználatok terrképeit az integralt GoogleEarth plattormon feltuntetơo oldal (Làtvanny Berek) (b), A Jővő̋ Bere modul szcenáriók mentén megjelenített területhasználat-változások GoogleEarth felületen (c) a Nagyberek térségére.

Közremüködők: Kollányi László (projektvezető), Nagy Gergő Gábor (területhasználatok múlttbéli változásainak térképezése),

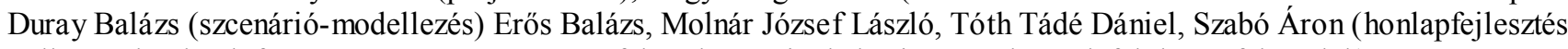
Felhasznált adatok forrása: CLC50 és CLC100 felszínboritási adatbázis, GoogleEarth felület és felvételek) 

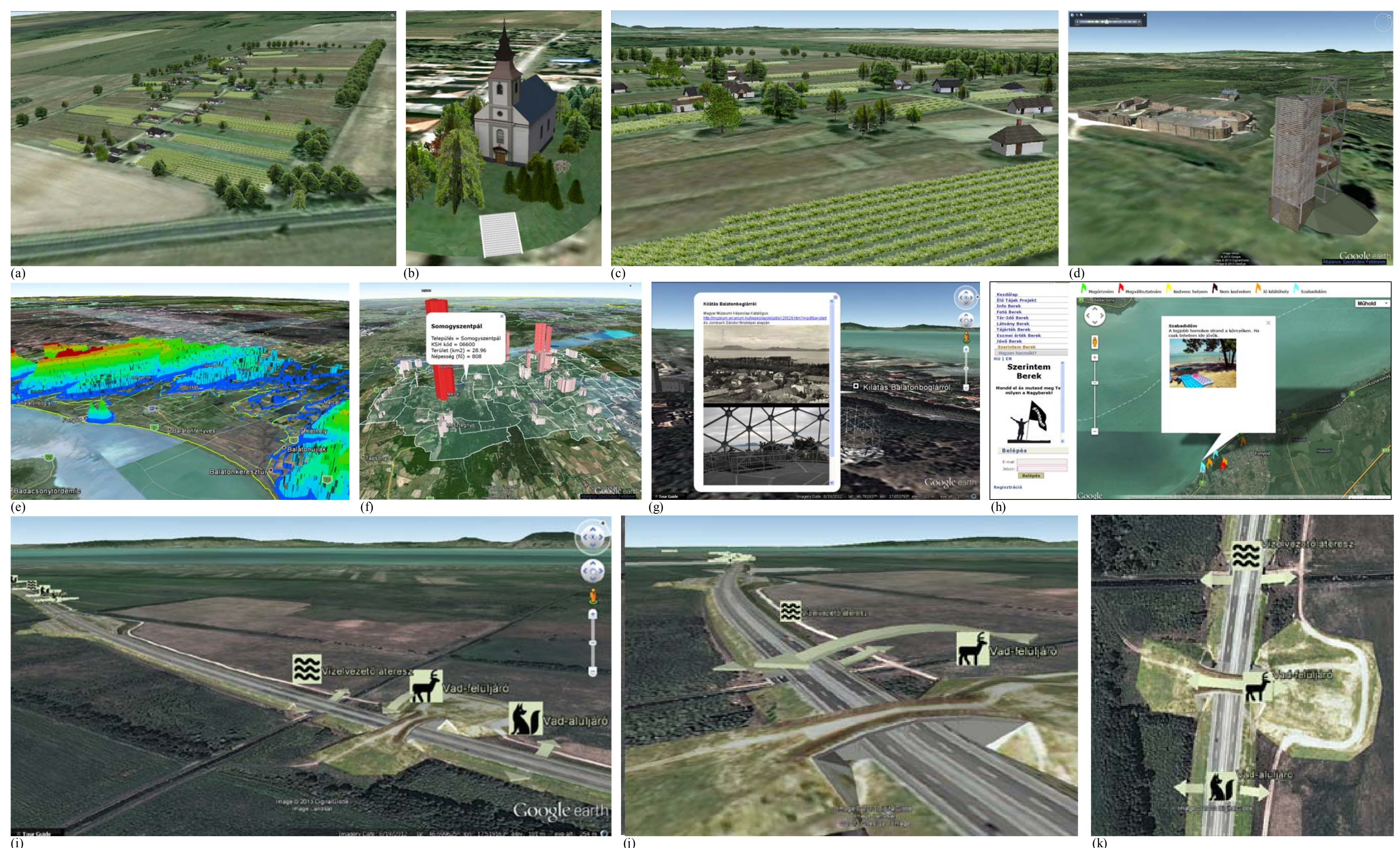

126. ábra Megjelenítési megoldások az Éló Tájak projektben Nagyberek térségére a honlapba integrált GoogleEarth felïleten. Epület és növénymodellezés Táskán (a-c) ès Somogyszentpálon (d). Domborzati és népességi adatok 3D megjelenités a Nagyberek térségében (e-f), Régi és mai látképek összevetése nevezetes helyszineken (g), Szerintem Berek modul a táj

Valamennyi megjelenítéshez GoogleEarth felületet használtunk. Közremüködők: Kollányi László (projektvezetö), Szabò kommentálására (h). Vizualizációk, az autópálya menti létesítmények funkciójának megértetésére (i-k)

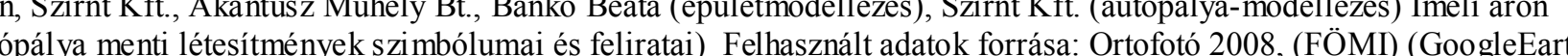
felület és felvételek) 


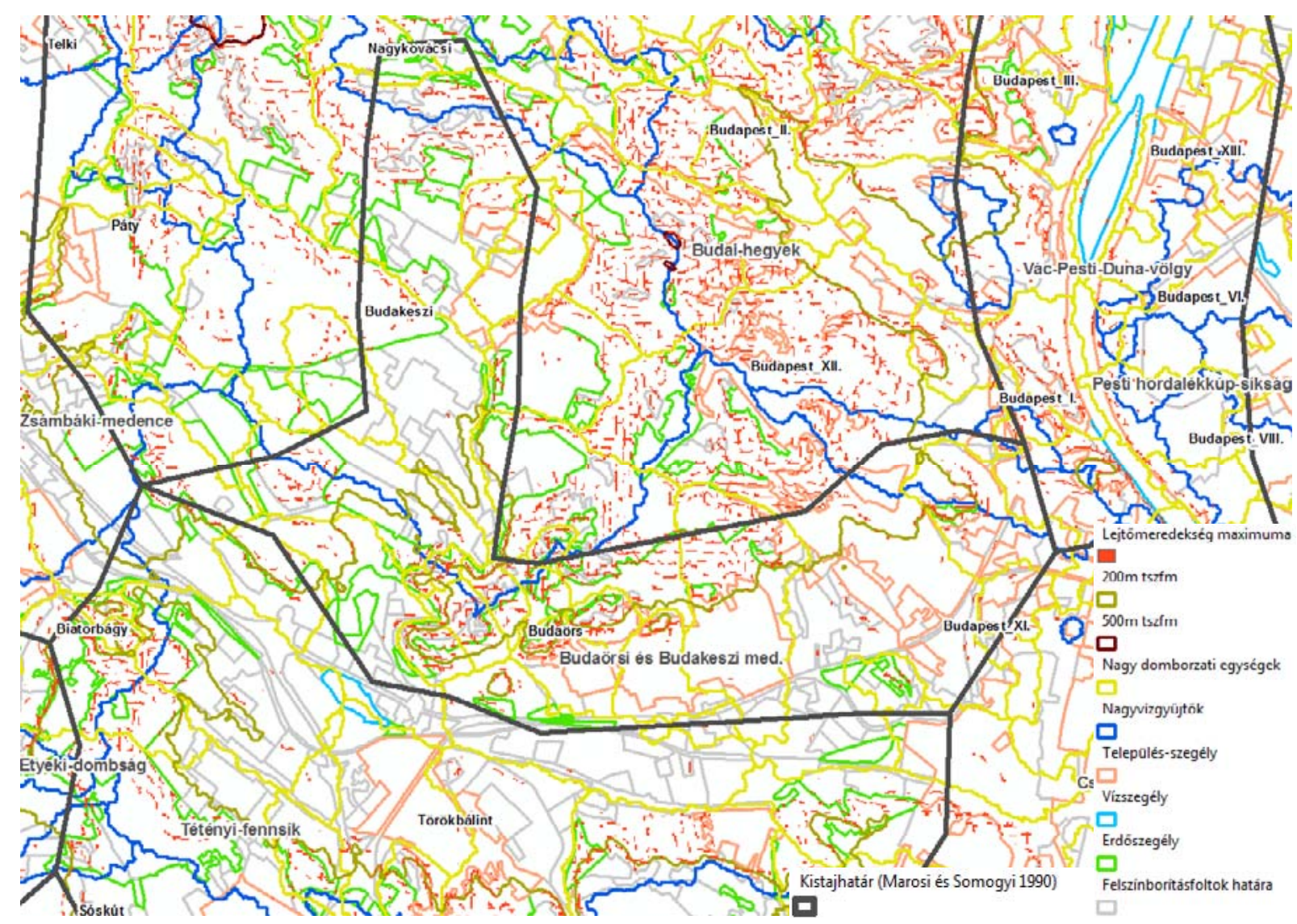

127. ábra A passzív képalkotó távérzékelési adatokkal előállítható potenciális tájhatárvonalak a Budaörsi és Budakeszi-medence térségében. A kistájkataszter szerinti tájhatárok pontosítása érdekében felállított térinformatikai adatbázisban.

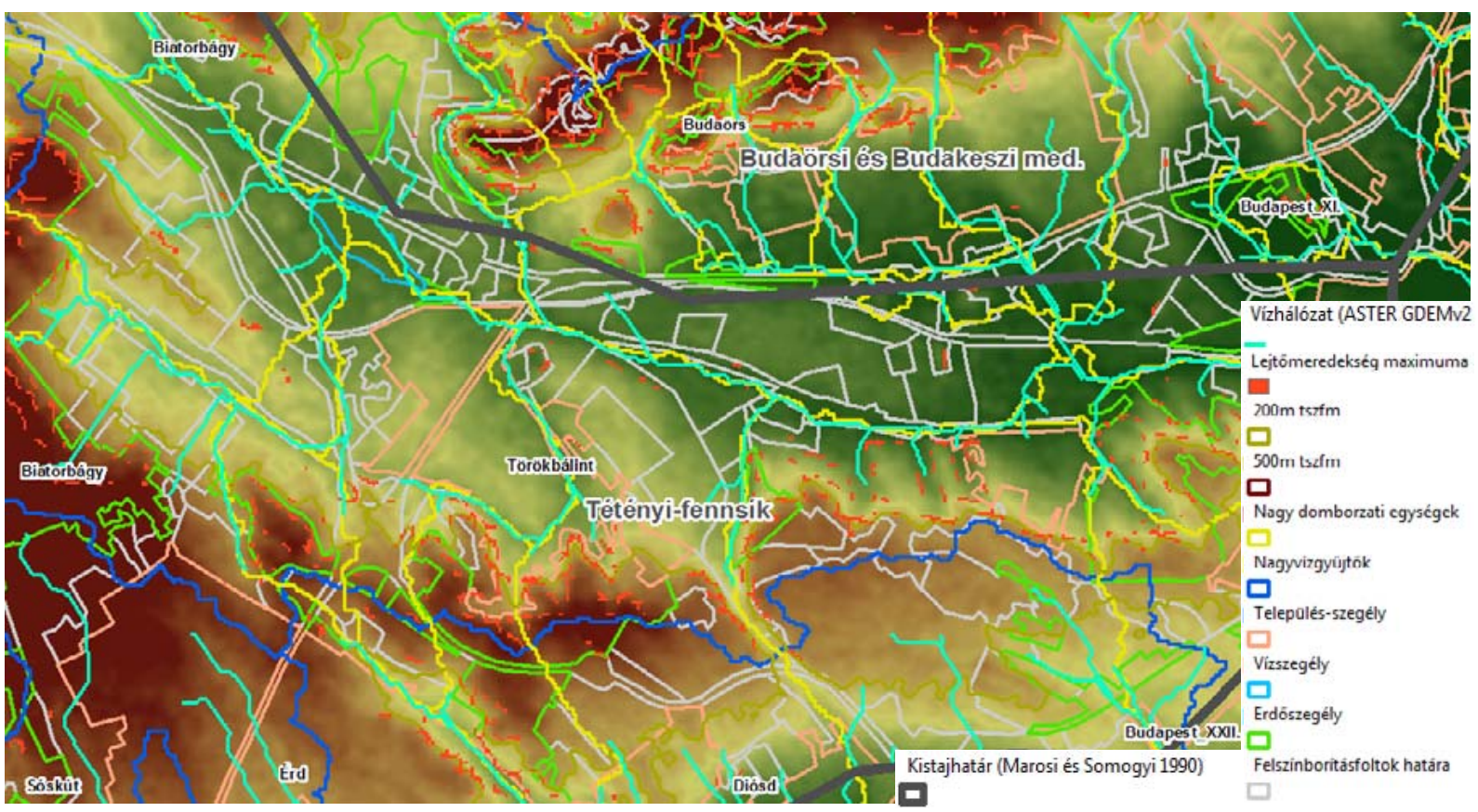

128. ábra Potenciális tájhatárvonalak a domborzati modell elöterében és a meglévő tájhatárok. Látható, hogy a vízfolyás jócskán kívül található a medence kistájkataszterben lehatárolt területén, ami a lehatárolás ponttatlanságát mutatja. 


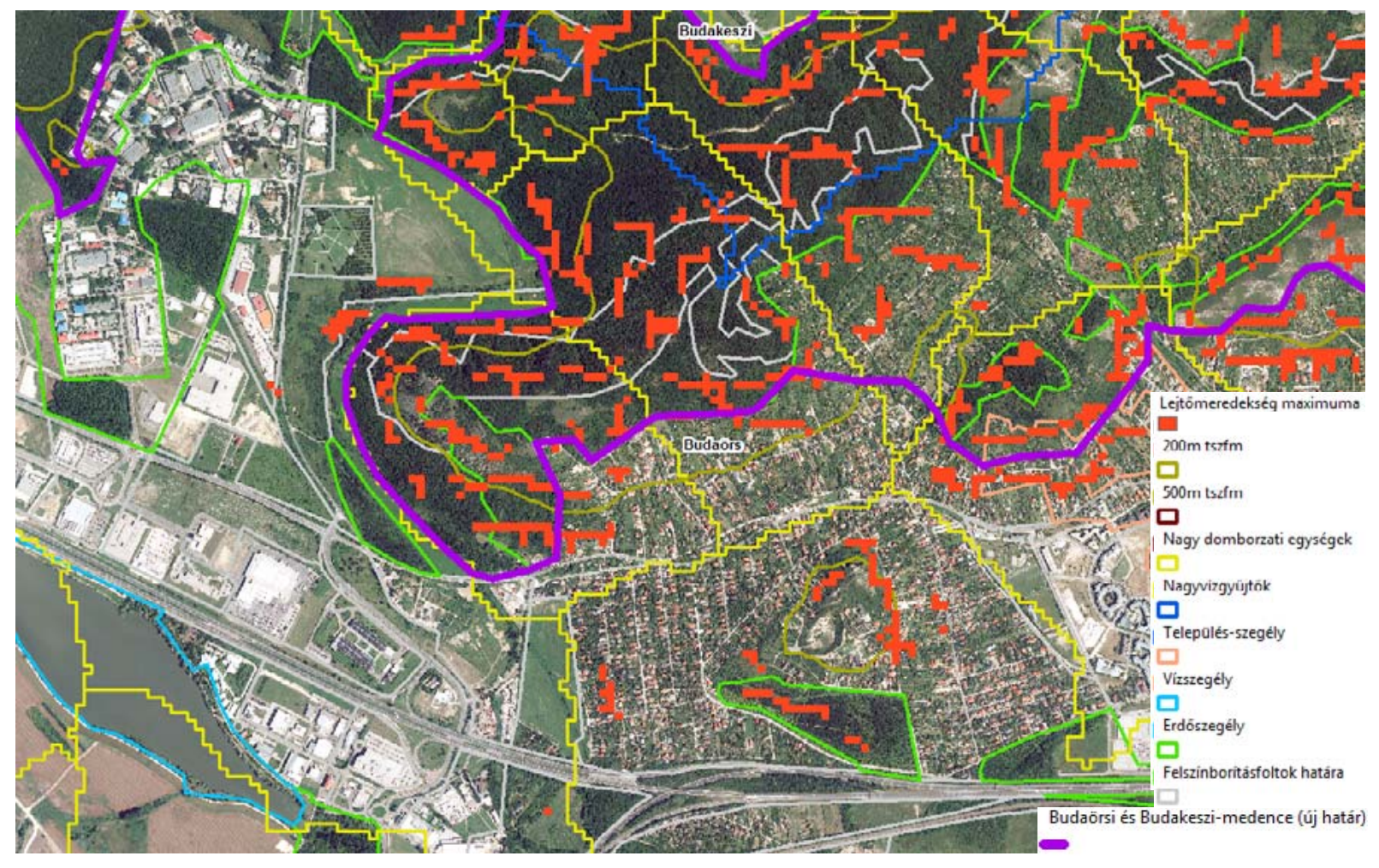

129. ábra A ,határvonal-választó” módszer. Lényege, hogy valamennyi potenciális tájhatárvonal közül az elemző kiválaszthatja a tájkarakter kezelése szempontjából célszerüt.

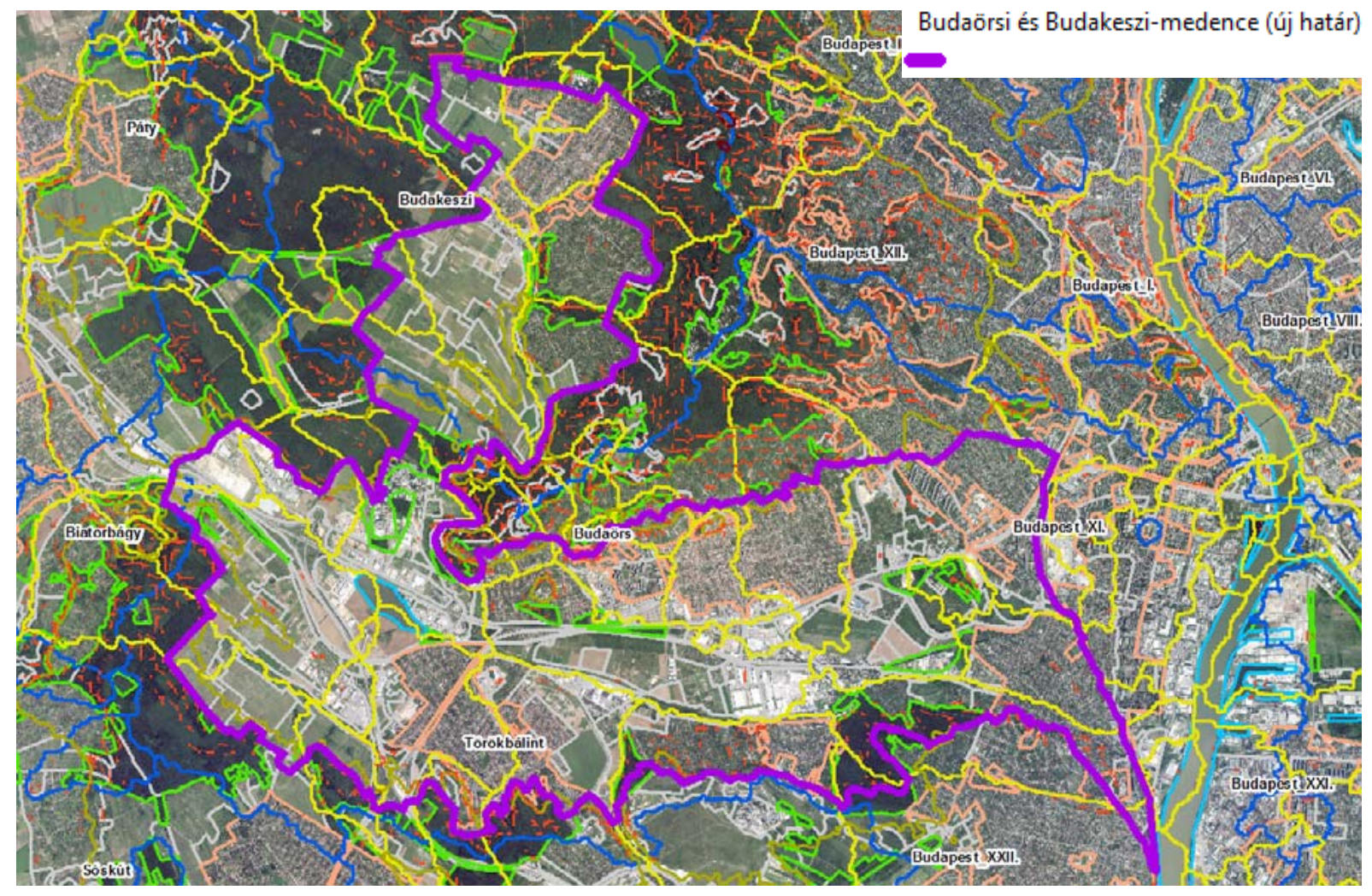

130. ábra A ,határvonal-választó" módszer eredményeként lehatárolt Budaörsi és Budakeszi-medence 


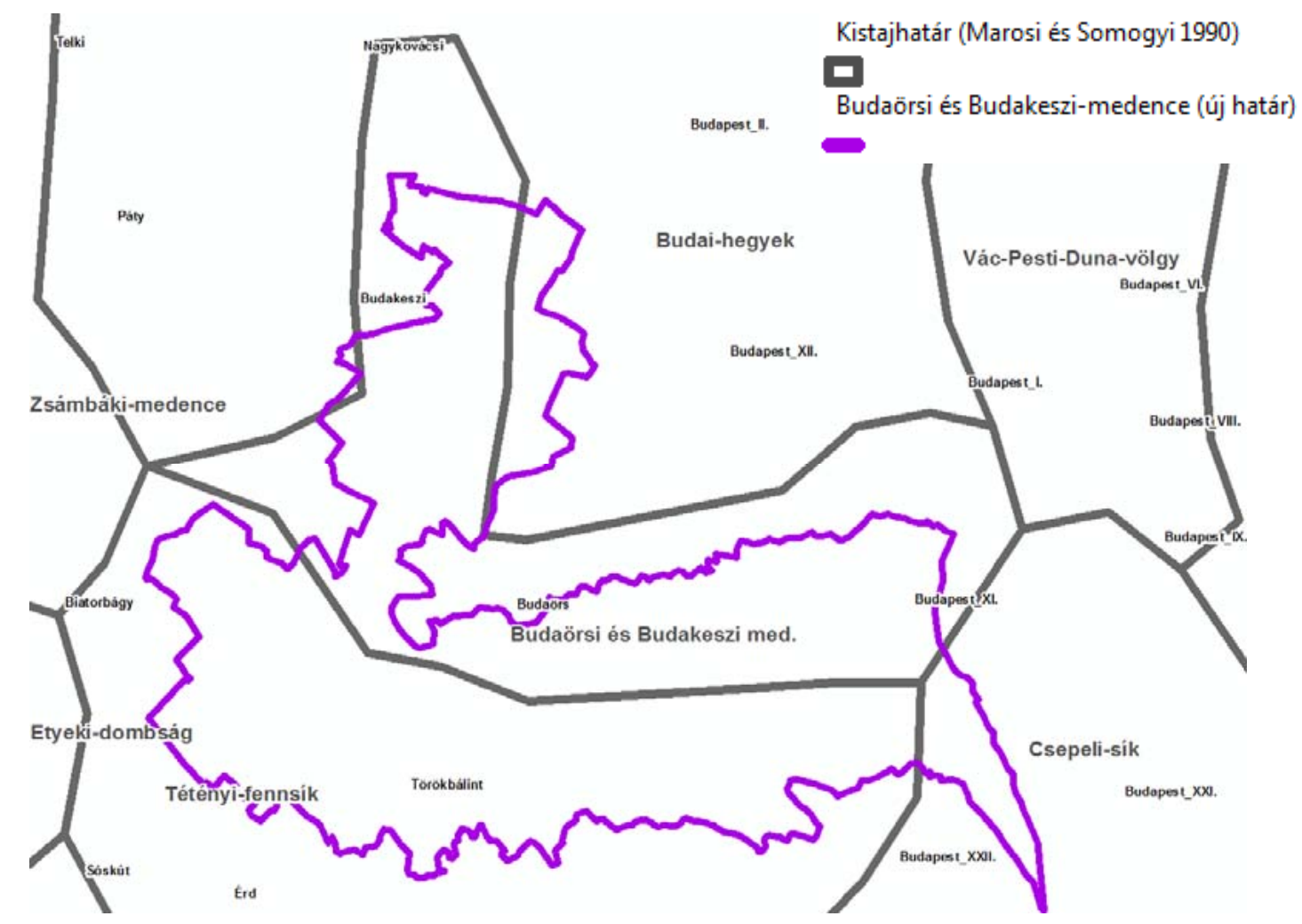

131. ábra Tájhatár pontosítása. A Marosi és Somogyi által 1990-ben definiált tájhatár és a folyamatosan beépülő tájkarakter kezelése szempontjából célszerüen lehatárolt tájhatár a Budaörsi és Budakeszi medencére.

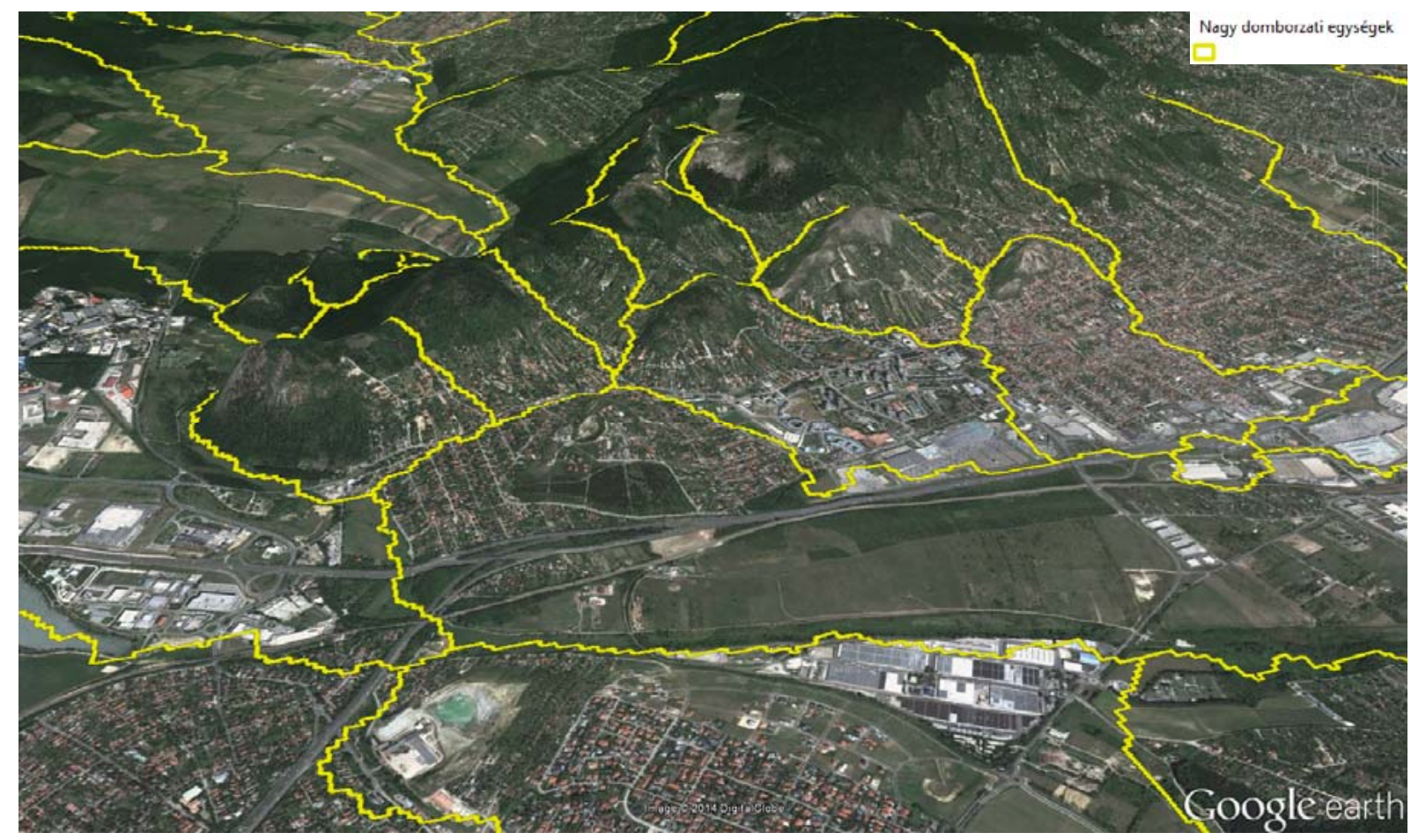

133. ábra A domborulat-határok megjelenítése GoogleEarth-ön (Domborulat-határok képzéséhez felhasznált magassági modell: AsterGDEMv2) 


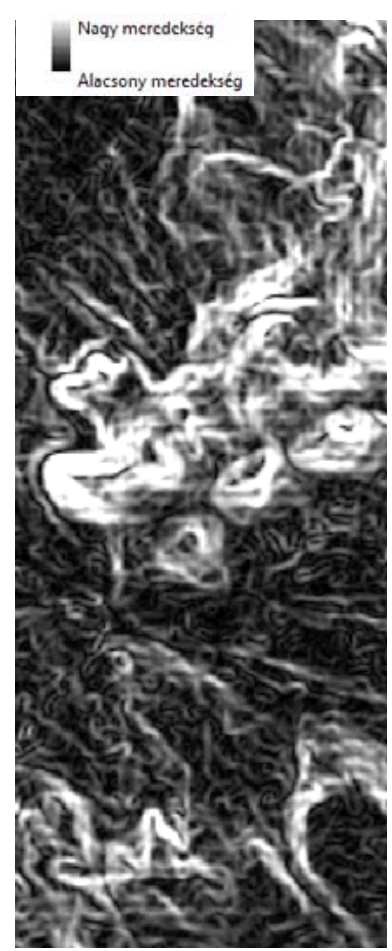

Lejtőmeredekség alapadat

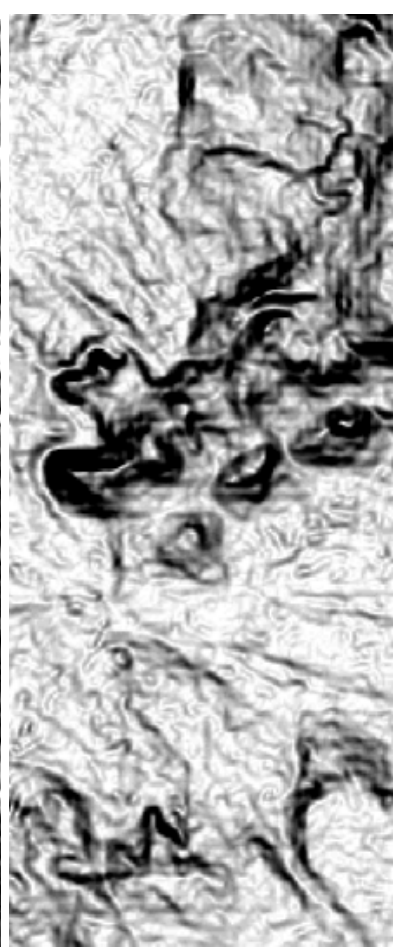

1. lépés

Lejtőmeredekség inverze

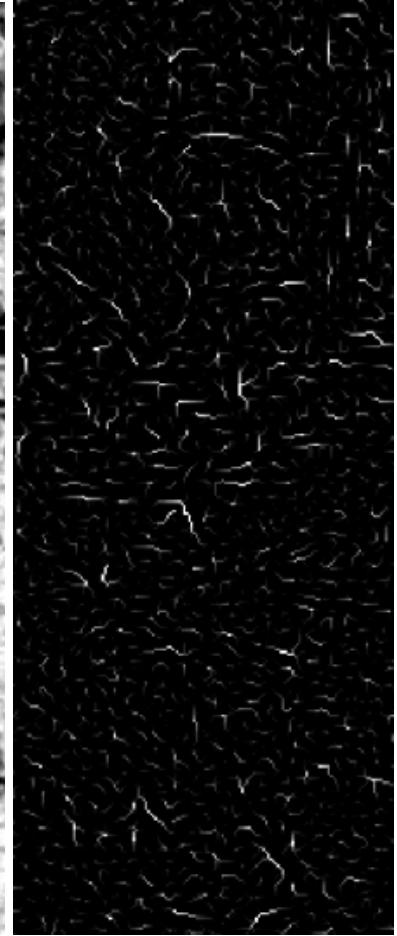

2. lépés

Inverzen számított „vízlefolyás”

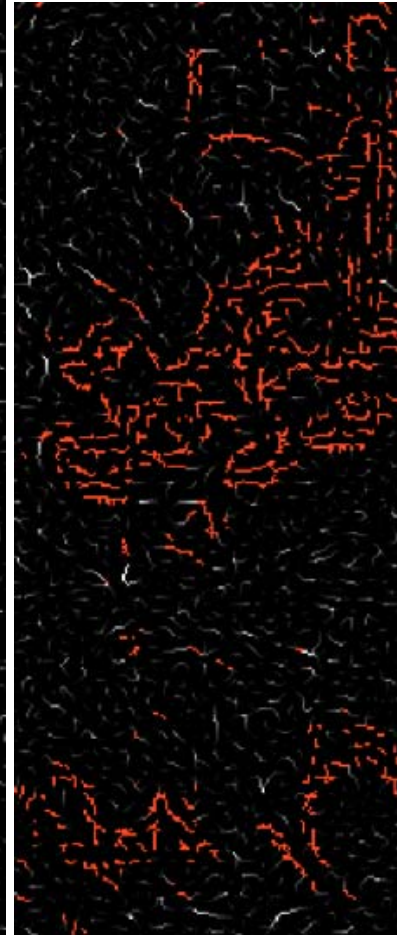

3. lépés

„Vízlefolyás” meredek lejtőn

\section{4. ábra A lejtőmeredekség maximumának meghatározása.}

1. lépés: Lejtőmeredekség inverzének elkészítése $=$ Lejtőmeredekség*(-1)+1000

2. lépés: Vízlefolyás-elemzés a lejtőmeredekség inverzén. (A víz az inverzen ott gyűlik össze ahol az adott lejtőn a legnagyobb a meredekség, mert az inverz lejtőmeredekség adatokat a vízlefolyás-vizsgálat magassági adatnak tekinti.)

3. lépés: A vízlefolyásból csak azokat kell figyelembe venni, ahol a lejtők meredeksége magas volt (pl. 20\% feletti egy dombvidéki területen)

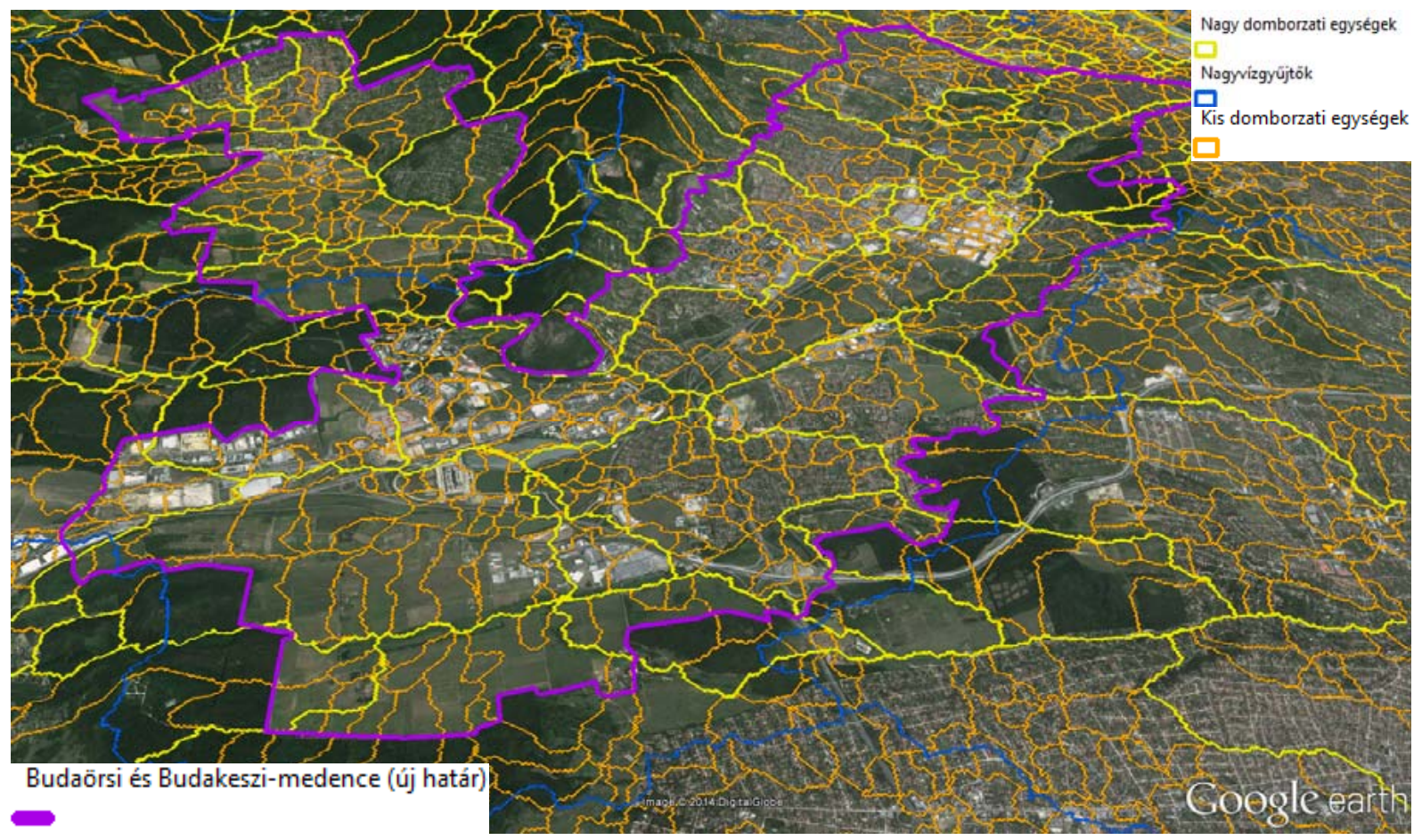

135. ábra Tájegység-lehatárolás eredményei és a felhasznált adatok egy része a GoogleEarth-ön 


\section{2 things to do that will make a reality of the ELC}

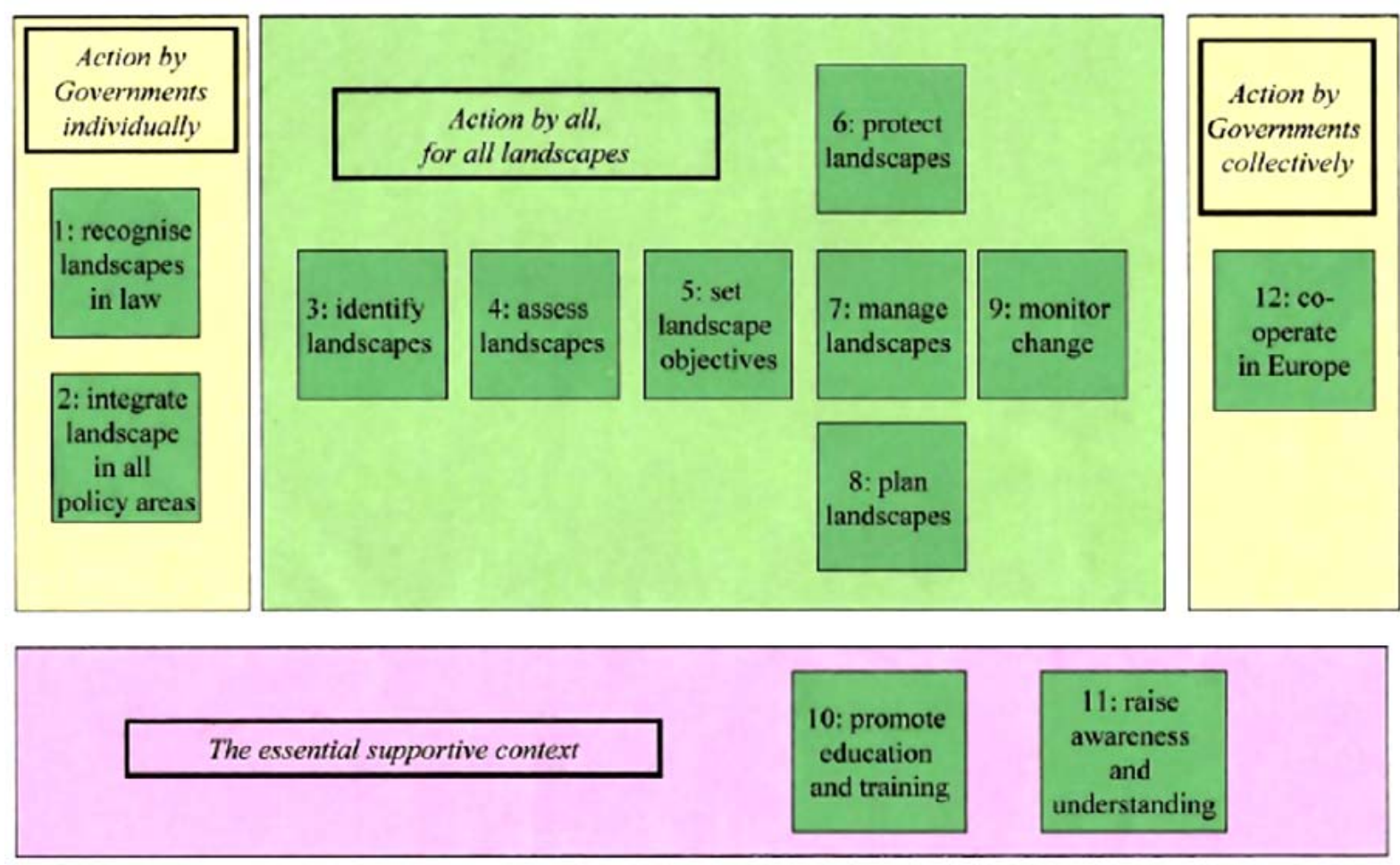

137. ábra Az Európai Táj Egyezmény megvalósításának lépései (SCOTT 2011, 2758) Scott ábrája azt illusztrálja, mit kell tenni annak érdekében, hogy az Európai Táj Egyezményt valóra váltsuk. 


\section{KÖSZÖNETNYILVÁNÍTÁS}

Köszönettel tartozom minden kollégának, aki tanácsával támogatta az értekezés elkészítését. Kiemelten köszönöm témavezetőm, Dr. Kollányi László szakmai ötleteit és támogatását $\mathrm{PhD}$ disszertációm elkészítése során. Köszönöm a Tájépítészeti és Tájökológiai Doktori Iskola valamennyi tanárának tanácsait, külön köszönöm Dr. Csemez Attilának, Dr. Csima Péternek, Dr. Drexler Dórának, Dr. Fábos Gyulának, Gábor Péternek, Dr. Konkoly-Gyuró Évának, Mezősné Dr. Szilágyi Kingának, Ongjerth Richárdnak és Dr. Sallay Ágnesnek, hogy olyan tájkutatási és tájelemzési projektekben vehettem részt, melyek bővítették tapasztalataimat és gyakorlati példákkal gazdagították értekezésemet. Közremüködésem a SENSOR Projektben, a Vital Landscapes Projektben, a TÁMOP Projektben és a TÉKA Projektben rendkívüli mértékben hozzájárult az értekezés elkészítéséhez. A projekteknek köszönhetem szinte valamennyi költséges alapadat, felvétel beszerzését és felhasználását.

Köszönöm a Fábos Alapítványnak, a CEEPUS és ERASMUS programoknak, hogy támogatták külföldi ösztöndíjaimat és ezáltal hozzájárultak ahhoz, hogy irodalomkutatásomat - bőséges szakirodalom áttekintésével, sokféle gyakorlati tapasztalatot gyüjtve folytathassam a Massachusettsi Állami Egyetem Tájépítészeti és Területrendezési Tanszékén az USA-ban, a Belgrádi Egyetem Erdészeti Karán Szerbiában és a finnországi Häme Főiskolán. Köszönetet mondok a Budapesti Corvinus Egyetem Tájtervezési és Területfejlesztési Tanszék valamennyi munkatársának és hallgatójának, továbbá családomnak és barátaimnak a doktori értekezés elkészítéséhez biztosított támogatásukért. 